\title{
Antonio van Diemen : de opkomst van de VOC in Azië Witteveen, W.M.
}

\section{Citation}

Witteveen, W. M. (2011, March 10). Antonio van Diemen : de opkomst van de VOC in Azië. Pallas Publications, Amsterdam. Retrieved from https://hdl.handle.net/1887/16609

Version: $\quad$ Not Applicable (or Unknown)

License: $\quad$ doctoral thesis in the Institutional Repository of the University of Leiden

Downloaded from: $\quad$ https://hdl.handle.net/1887/16609

Note: To cite this publication please use the final published version (if applicable). 
Antonio van Diemen

De opkomst van de VOC in Azië 
Afbeelding omslag: Portret van Antonio van Diemen, anoniem. Rijksmuseum Amsterdam. De baas van Goa, Atlas Van der Helm, Österreichische Nationalbibliothek. Ontwerp omslag: Maedium, Utrecht Ontwerp binnenwerk: The DocWorkers, Almere Index: Ansfried Scheifes, Utrecht

ISBN 9789085550464 e-ISBN 97890485 I 4274 NUR 685

(c) M. Witteveen / Pallas Publications, Amsterdam University Press, 20II

Alle rechten voorbehouden. Niets uit deze uitgave mag worden verveelvoudigd, opgeslagen in een geautomatiseerd gegevensbestand, of openbaar gemaakt, in enige vorm of op enige wijze, hetzij elektronisch, mechanisch, door fotokopieën, opnamen of enige andere manier, zonder voorafgaande schriftelijke toestemming van de uitgever.

Voorzover het maken van kopieën uit deze uitgave is toegestaan op grond van artikel I6B Auteurswet I9I2 $\mathrm{j}^{\circ}$ het Besluit van 20 juni I974, Stb. 35I, zoals gewijzigd bij het Besluit van 23 augustus I985, Stb. 47I en artikel I7 Auteurswet I9I2, dient men de daarvoor wettelijk verschuldigde vergoedingen te voldoen aan de Stichting Reprorecht (Postbus 305I, 2I30 KB Hoofddorp). Voor het overnemen van gedeelte(n) uit deze uitgave in bloemlezingen, readers en andere compilatiewerken (artikel I6 Auteurswet I9I2) dient men zich tot de uitgever te wenden. 


\title{
Antonio van Diemen
}

\author{
De opkomst van de VOC in Azië
}

\section{PROEFSCHRIFT}

\author{
ter verkrijging van \\ de graad van Doctor aan de Universiteit Leiden, \\ op gezag van Rector Magnificus prof.mr. P.F. van der Heijden, \\ volgens besluit van het College voor Promoties \\ te verdedigen op Io maart $201 \mathrm{I}$ \\ klokke I5.00 uur \\ door
}

Willem Menno Witteveen

geboren te Driebergen, in 1954 


\section{Promotiecommissie}

Promotor:

Prof.dr. L.J. Blussé van Oud Alblas

Overige Leden:

Prof.dr. H.W. van der Doel

Prof.dr. F.S. Gaastra

Prof.dr. K.J.P.F.M. Jeurgens

Prof.dr. J. van Goor (Universiteit Utrecht)

Dr. J.J.L. Gommans 


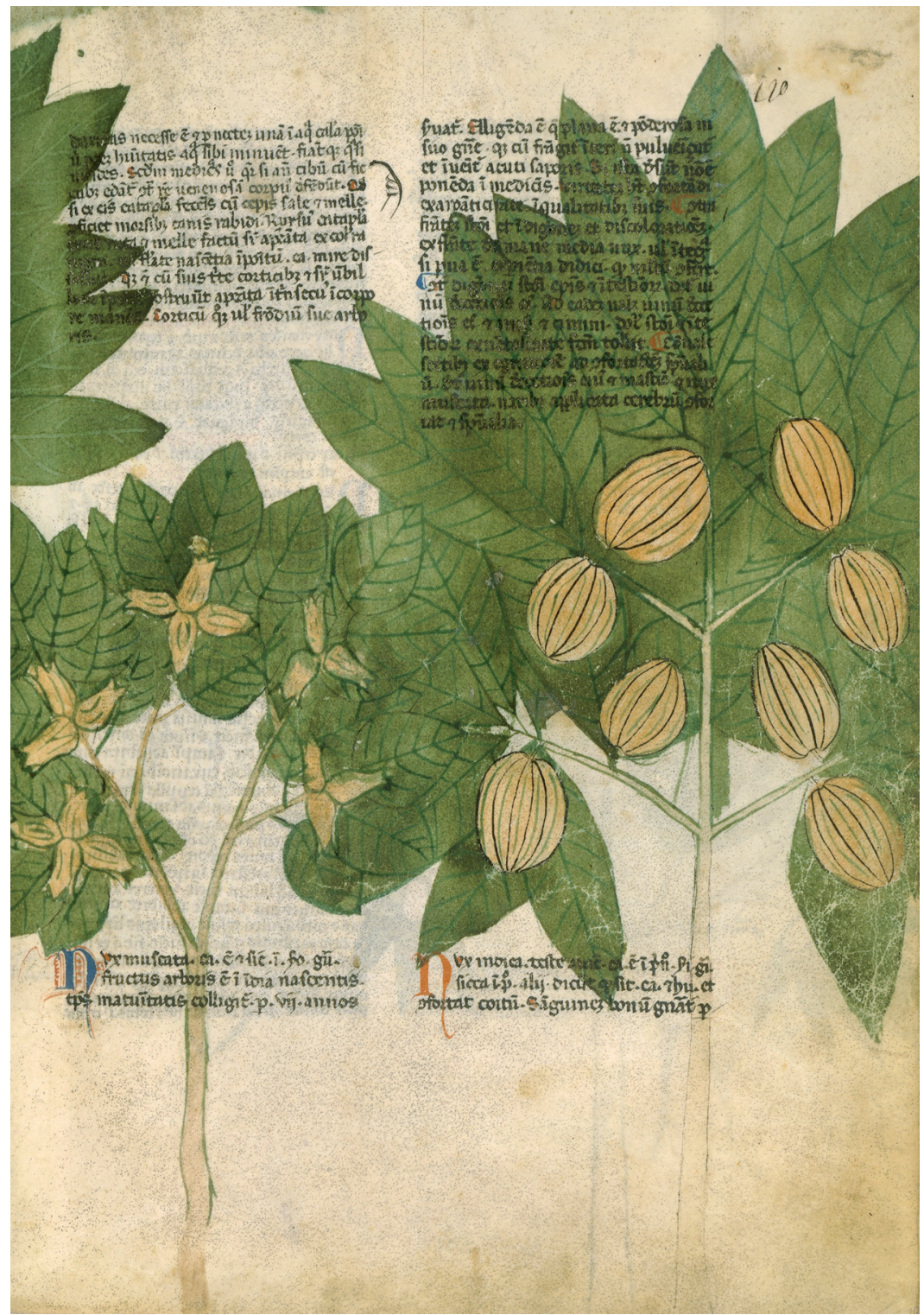

Het was de onweerstaanbare lokroep van de specerijen die de aanzet gaf tot de Europese expansie in Azië. Hier een onschuldige afbeelding van de kostbaarste van allemaal: de muskaatnoot. Bibliothèque National de France. 


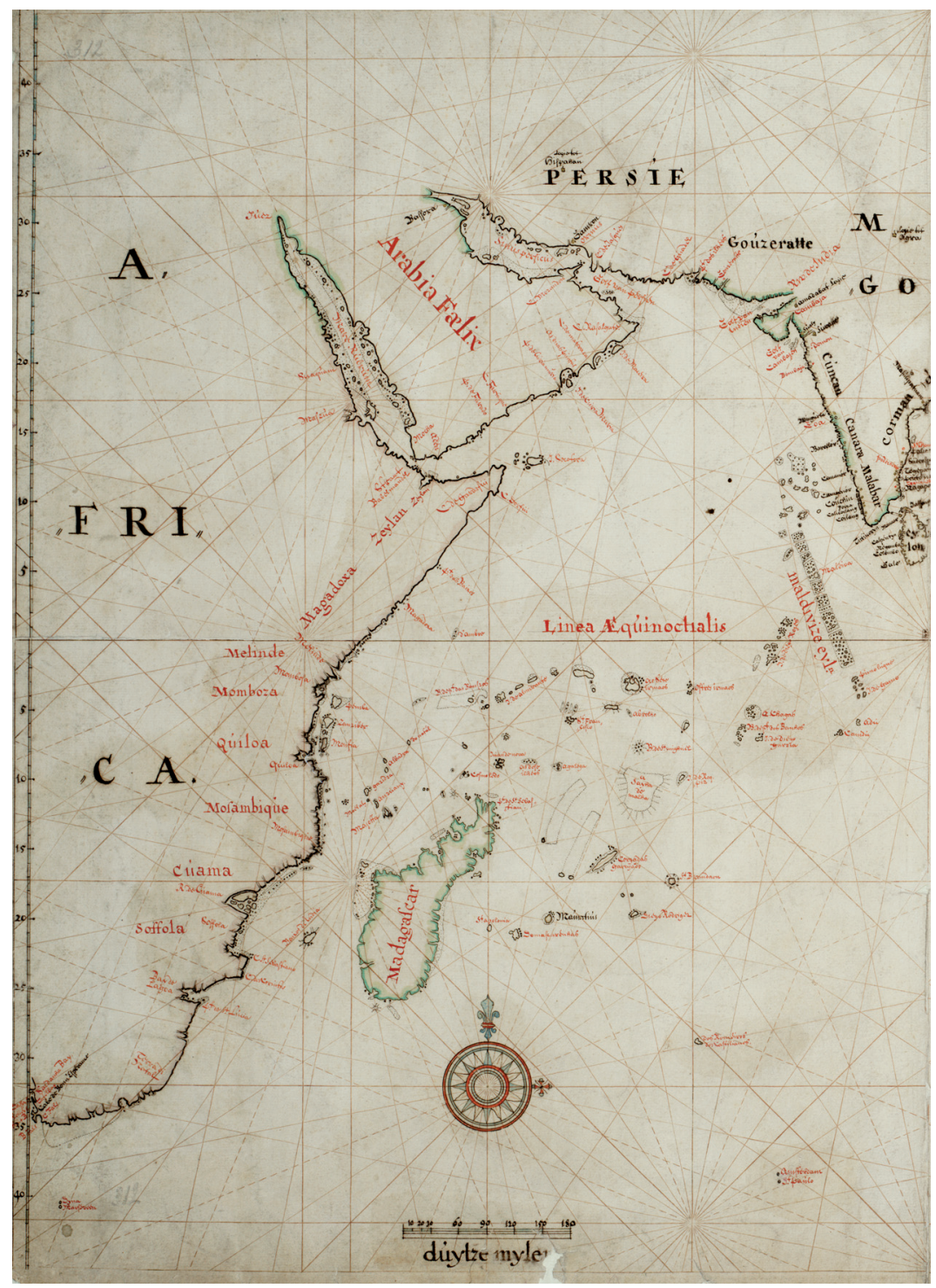

Op deze kaart van Kaap de Goede Hoop tot Japan staan de vestigingen van de VOC in het zwart. Hij stamt uit het laatste kwart van de zeventiende eeuw toen de macht van de VOC op zijn hoogtepunt was. De tocht van Abel Tasman lijkt vergeten. Nationaal Archief Den Haag. 


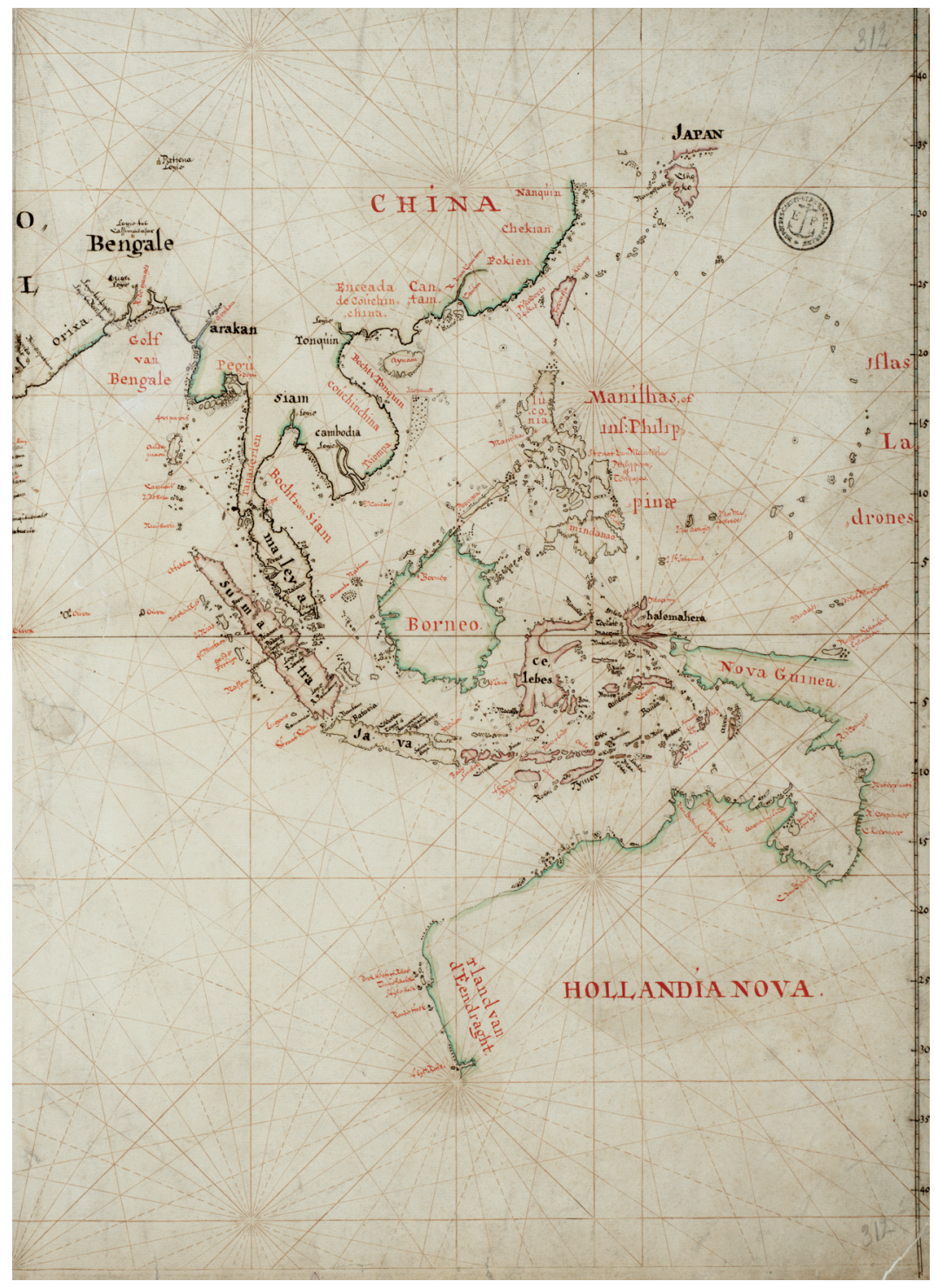




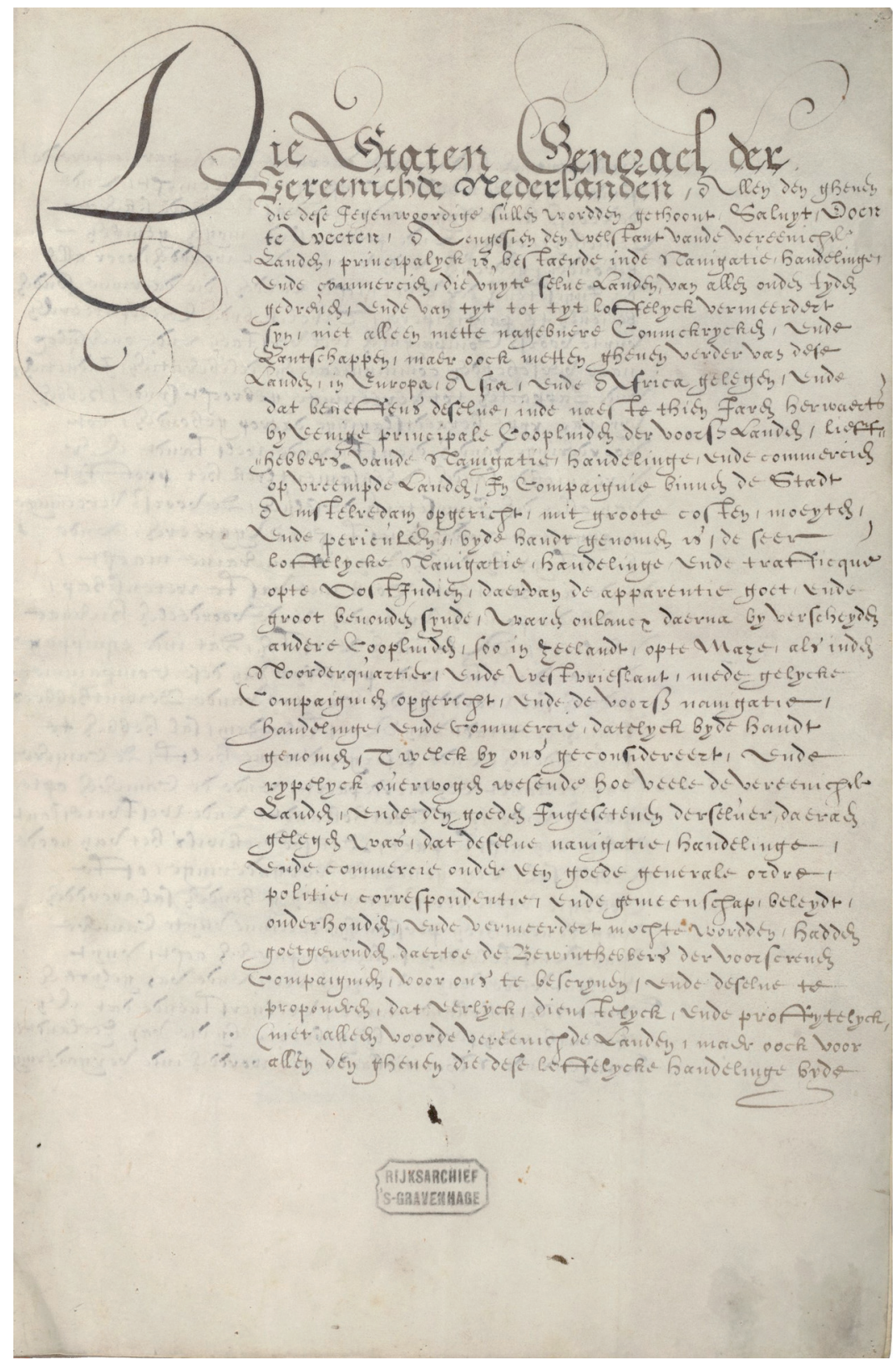

Eerste bladzijde van het Octrooi dat op 20 maart 1602 door de Staten-Generaal aan de VOC werd verleend. In haar enorme octrooigebied mocht de VOC zich als soevereine staat gedragen. Nationaal Archief Den Haag. 


\section{Inhoudsopgave}

Lijst van gouverneurs-generaal in de zeventiende eeuw

Voorwoord

I. Inleiding

2. Proloog: de Tachtigjarige Oorlog als decor

3. Jeugd in Culemborg (1593-1608)

4. Koopman in Amsterdam (I609-I6I6)

5. De lokroep van de specerijen en de oprichting van de VOC

6. Een 'blaeuw oogh' voor de VOC, Cornelis Matelief de Jonge en de strategiewijziging van de VOC in 1608

7. Coen en carrière

8. Een lange sollicitatiebrief, de buitengewone generale missive van I63I

9. Terug in Nederland, oktober I63I-januari I633

Io. Directeur-generaal, juli I633-december 1635

II. Een benoeming op een breukvlak

I2. 'Schaars een behoorlijcken interest'. De winst van de VOC ten tijde van Van Diemen nader bekeken

I3. De vloot van de Compagnie onder Van Diemen

14. 'A tale of two Compagnies'. De concurrentie tussen de EIC en de VOC 
I5. De 'Memorie van Overgave'

I6. De bevestiging van het kruidnagelmonopolie, Ambon en de Molukken

I7. De VOC in de Chinese zee en de kolonisatie van Taiwan

I8. De situatie op Java

I9. De strijd tegen de Portugezen in de Indische Oceaan

2o. De regering van Van Diemen

2I. Overlijden, opvolging en erfenis

22. Nabeschouwing

\section{Bijlagen}

1. Brief van Antonio van Diemen aan de Heren Zeventien van 1 augustus 1619

2. Brief van Antonio van Diemen aan de kamer Amsterdam van 20 november 1629, plus bijlage

3. Twee brieven van 2 en 9 december 1632 van Antonio van Diemen aan de kamer Amsterdam

4. Eerste brief van Antonio van Diemen als gouverneur-generaal van 3 januari 1636 aan de Heren Zeventien

5. Brief van Antonio van Diemen aan de Heren Zeventien van 20 januari 1645 plus aanvulling van 6 februari 1645

6. Beschrijving retourlading 1641 met opbrengsten en winsten

7. Testament van Antonio van Diemen en Maria van Aelst van 4 oktober 1632

8. Testament van Antonio van Diemen van 16 april 1645 
Geraadpleegde archieven

Literatuur

378

Index

Curriculum Vitae

403 


\section{Lijst van gouverneurs-generaal in de zeventiende eeuw}

$\begin{array}{ll}\text { I6Io-I6I4 } & \text { Pieter Both } \\ \text { I6I4-I6I5 } & \text { Gerard Reynst } \\ \text { I6I6-I6I7 } & \text { Laurens Reael } \\ \text { I6I9-I623 } & \text { Jan Pieterszoon Coen } \\ \text { I623-I627 } & \text { Pieter de Carpentier } \\ \text { I627-I629 } & \text { Jan Pieterszoon Coen } \\ \text { I629-I632 } & \text { Jacques Specx } \\ \text { I632-I635 } & \text { Hendrik Brouwer } \\ \text { I636-I645 } & \text { Antonio van Diemen } \\ \text { I645-I650 } & \text { Cornelis van der Lijn } \\ \text { I650-I653 } & \text { Carel Reyniersz } \\ \text { I653-I678 } & \text { Joan Maetsuycker } \\ \text { I678-I68I } & \text { Rijklof van Goens } \\ \text { I68I-I684 } & \text { Cornelis Speelman } \\ \text { I684-I69I } & \text { Johannes Camphuys } \\ \text { I69I-I704 } & \text { Willem van Outhoorn }\end{array}$




\section{Voorwoord}

Het is alweer meer dan twaalf jaar geleden dat ik met mijn gezin door Indonesië reisde. De tocht begon in Jakarta en ging via Ambon naar de Banda-eilanden. Pas veel later kwam ik erachter dat Antonio van Diemen tweemaal dezelfde tocht gemaakt had. Het is de enige reisbestemming van Van Diemen in Azië geweest. Zo hebben hij en ik met een verschil van bijna vier eeuwen evenveel van de archipel gezien. Anders dan in Jakarta en Ambon, zou Van Diemen op Banda nog veel herkend hebben. Het leek alsof een glazen stolp over die kleine afgelegen archipel was gezet, waardoor forten, huizen, kerken en begraafplaatsen bewaard waren gebleven. Helaas is bij de onlusten van 1999 een gedeelte van dit erfgoed verloren gegaan.

Mijn belangstelling voor de VOC werd op Banda definitief gewekt en deze koppelde zich aan de combinatie van mijn studie geschiedenis aan de Leidse universiteit en een werkzaam leven als ondernemer. Ondernemingen spelen een niet meer weg te denken rol in onze maatschappij en de VOC is de belangrijkste voorloper van de moderne naamloze vennootschap. In 2002 mondde de vraag hoe deze eerste vennootschap tot stand was gekomen uit in mijn boekje: Een onderneming van landsbelang, de oprichting van de Verenigde Oost-Indische Compagnie in 1602. Het onderzoek en schrijven smaakten naar meer. De nu voorliggende studie vormt het vervolg hierop.

Zoals velen met en voor mij, vind ook ik de VOC een buitengewoon veelzijdig en boeiend onderwerp. De VOC was het economische boegbeeld van de Gouden Eeuw, maar zij maakte in de eerste decennia van haar bestaan bepaald geen 'zegetocht over knielende golven'. De eerste ontmoeting met Azië verliep ongemakkelijk en elke stap, elke meter moest bevochten worden zowel op het water als op het land, zowel op de Aziaten als op de Europese concurrenten. Het was een harde tijd van sterke karakters en soms ongebreideld opportunisme en in dit opzicht was de VOC een spiegel van de Republiek tijdens de Tachtigjarige Oorlog.

Van niemand minder dan Erasmus is de verrassende levensles: 'Begint eer gij bezint.' Deze is wellicht niet in alle gevallen toepasbaar maar wel op mijn plan een proefschrift te schrijven naast andere dagelijkse bezigheden. Gelukkig ben ik er gewoon aan begonnen. Het was een 
vaak verfrissende retraite. Door zo intensief een klein deel van de geschiedenis te bestuderen krijg ik het gevoel dat ik het heden soms beter begrijp. Juist in de archieven heb ik veel plezier beleefd aan mijn onderzoek. Met het lezen in die oude brieven met dat lastige handschrift en soms prachtige woordgebruik werd voor mij gedeeltelijk de kloof overbrugd die door het verstrijken van zoveel jaren onvermijdelijk is ontstaan tussen het heden en verleden. Wat dat betreft is het toenemend gebruik van film, microfiche of elektronische drager een stap terug.

Bij mijn onderzoek en schrijven heb ik steeds het gevoel gehad dat ik op de schouders van reuzen stond. Er zijn vele wetenschappers (geweest) die decennia achtereen de Nederlandse en West-Europese expansie in Azië hebben onderzocht en beschreven. Het is gelukkig geen gesloten groep en op mijn vragen kreeg ik altijd een uitgebreid en stimulerend antwoord. In vergelijking met hun opgebouwde kennis ben ik een passant, die hoopt door zijn ervaring op andere terreinen toch een bijdrage te kunnen leveren.

Zonder mijn promotor Leonard Blussé zou ik niet aan dit onderzoek begonnen zijn. Gedurende de acht jaar dat ik aan mijn dissertatie heb gewerkt, heb ik kunnen rekenen op zijn steun.

Speciaal dank ik daarnaast Léon van der Hoeven voor zijn hulp bij het genealogisch onderzoek en Cissy Böck voor haar bijzonder adequate aanpak van de redactie. Daarnaast is de belangstelling van mijn vrienden en dochters onontbeerlijk geweest, maar vooral van Wimke, die mij de ruimte heeft gegeven niet alleen om te beginnen, maar vooral ook gestimuleerd heeft om het af te maken. 


\section{$1 \quad$ Inleiding}

'Wie het historisch kenbare ernstig onderzoekt, wie uit feitelijkheden van het verleden tracht te verstaan, hoe dit alles weer zoo gekomen is, zal altijd achter die gewaande noodzakelijkheid stuiten op personen, die iets wilden en zochten te verwezenlijken.'

Johan Huizinga ${ }^{1}$

Op 4 januari I6I8 zeilde het grote VOC-schip 'Mauritius' weg van de rede van Texel voor de lange reis naar Bantam op het eiland Java. ${ }^{2}$ Een van haar tweehonderdvijftig bemanningsleden was aangemonsterd onder de naam Thonis Meeusen. Een valse naam, want in zijn vijfentwintig levensjaren tot dan toe was Thonis Meeusen beter bekend geweest als Anthonie of Antonio van Diemen. Met deze maskerade vluchtte de Amsterdamse koopman Van Diemen weg voor de gevolgen van zijn faillissement.

Op Java slaagde hij erin zijn verleden achter zich te laten. Met toenemend succes maakte hij daar carrière en doorliep hij in dienst van de Compagnie vele rangen. $\mathrm{Na}$ een paar jaar zelfs weer onder zijn eigenlijke naam. In 1636 volgde zijn benoeming tot gouverneur-generaal, de hoogste post van de Verenigde Oostindische Compagnie in Azië, die hij tot zijn dood in I645 zou behouden. Gedurende zijn bewind - Van Diemen was de negende landvoogd - vestigde de VOC haar primaat over de Aziatische zeehandel in het reusachtige gebied van Japan tot de Perzische Golf. Deze hegemonie zou voortduren tot in de achttiende eeuw.

In zijn voor de oorlog verschenen monumentale vijfdelige Geschiedenis van Nederlandsch Indië noemde F.W. Stapel Antonio van Diemen direct na Jan Pieterszoon Coen 'als opbouwer van het rijk van Nederlandover-zee'. ${ }^{3}$ Hij sprak daarbij zijn verbazing uit dat van het leven van Van Diemen geen behoorlijke beschrijving bestond terwijl diens carrière toch in meerdere opzichten markant was geweest. De ingrediënten voor een biografie leken zo aanwezig, maar toch gaf W.Ph. Coolhaas (I899-I98I) in I946 het verzoek tot het schrijven daarvan terug. De figuur van Van Diemen stak zijns inziens niet duidelijk genoeg af tegen diens omgeving. Van Diemen was 'slechts den organisator die zijn bureaux niet of nauwelijks verliet.'4 Ook was volgens Coolhaas over Van Diemen te weinig bekend om aan zijn persoon kleur te geven. Hij con- 
cludeerde: 'Van Diemen blijft een schimachtige figuur, waarvan we de omtrekken niet of slechts zeer vaag kunnen onderscheiden. ${ }^{5}$ Inderdaad bieden de bronnen op het eerste gezicht weinig aanknopingspunten voor een beschrijving van de persoon van Van Diemen. Zo is slechts een handjevol persoonlijke brieven van hem bewaard gebleven en door zijn tijdgenoten is nauwelijks over hem geschreven. Wel zijn er veel relevante stukken van bestuurlijke aard bewaard gebleven.

Was Coolhaas wellicht direct na de Tweede Wereldoorlog, in die woelige tijd in de relatie tussen Nederland en Indonesië, ook van mening dat het niet het juiste moment was voor een biografie over een koloniale empire-builder? Of woog misschien mee dat hij zelf op het punt stond om als landsarchivaris naar Batavia/Jakarta te vertrekken? ${ }^{6}$ Voor mij liggen anno 2010 al deze zaken anders. Niet langer spelen politieke of persoonlijke carrière overwegingen een rol. Maar bovendien blijken in de archieven nog belangrijke aanvullende gegevens over de persoon van Van Diemen terug te vinden die voorheen over het hoofd zijn gezien. De contouren van Van Diemens persoonlijkheid komen daardoor scherper en met meer contrast tot uiting dan de bevindingen van Coolhaas doen vermoeden.

Daarbij is de vraag om een beschrijving van het leven van Van Diemen blijven bestaan zoals in 2004 door Van der Kraan werd benadrukt.?

De levensloop van de VOC als handelsbedrijf is in veel facetten te volgen dankzij het bewaard gebleven en goed ontsloten archief. Er zijn maar weinig ondernemingen geweest met een zo uitgebreid en toegankelijk archief. Het is bijna onmogelijk om bij een bestaande of teloorgegane onderneming in de keuken te kijken, zoals dat kan bij de VOC. Als er al aan geschiedschrijving van bedrijven wordt gedaan, gebeurt dat over het algemeen in opdracht en worden vervolgens de successen breed uitgemeten, terwijl zowel de strijd om de macht binnen de onderneming, als de vele beslissingen die verkeerd zijn uitgepakt, in de marge worden behandeld. Alleen bij een (bijna) faillissement of een grote fraude komen de onappetijtelijke zaken naar voren die normaal onder de vennootschappelijke deken verborgen blijven. Binnen de VOC werden in de lange missiven van en naar Azië het falen van het beleid en de vermeende menselijke tekorten regelmatig aan de orde gesteld. Het begrip VOC-mentaliteit heeft wat mij aangaat een andere betekenis dan er tegenwoordig weleens aan wordt gegeven: de ruwe zeventiendeeeuwse bolsters betrokken bij de VOC hadden maar zelden een blanke pit.

Het welslagen van de VOC stond bij haar oprichting geenszins vast. Het succes liet lang op zich wachten en de oorspronkelijke plannen moesten vrij snel radicaal worden bijgesteld. Het lijkt alsof na het aantreden van Van Diemen in ${ }^{1} 6_{3} 6$ de zaken pas werkelijk op hun plaats 
gingen vallen. Was dit het gevolg van een bewuste lange-termijnstrategie of van de persoonlijke bijdrage van Van Diemen? Vanuit deze invalshoek onderzoek ik twee vragen:

- Wat was de bedrijfsstrategie van de VOC en hoe ontwikkelde die zich in de eerste vijftig jaar?

- In hoeverre was hierbij de rol van Van Diemen een bepalende factor?

Deze twee vragen liggen met een overlapping in elkaars verlengde al was het maar omdat Van Diemen pas een aantal jaren na zijn aankomst in I6I8 in Azië een zichtbare functie ging vervullen.

De studie begint met de jeugd van Van Diemen tegen de achtergrond van de Tachtigjarige Oorlog en zijn onfortuinlijke debuut als koopman in Amsterdam.

Dan volgt een terugblik naar de eerste twee decennia van de VOC. Wat waren de doelstellingen van de Amsterdamse initiatiefnemers van de vaart rond Kaap de Goede Hoop op Azië? Was, na de aanvankelijke successen van de eerste vaarten, de oprichting in I602 van de VOC en de buitengewone structuur daarvan hun bewuste keuze?

Vervolgens komt de crisis aan de orde waarin de Compagnie zes jaar na haar oprichting verzeild raakte. Om deze te boven te komen werd de functie van gouverneur-generaal in het leven geroepen. Pas de vierde landvoogd, Jan Pieterszoon Coen (I587-I629) slaagde er in I6I9 in het rendez-vous Batavia te vestigen vanwaaruit in de twee eeuwen die volgden de Compagnie in Azië bestuurd zou worden.

Aangekomen op Java maakte Van Diemen direct kennis met Coen, de vereerde en verketterde grondlegger van het Nederlandse handelsimperium in Azië. Handelde Coen werkelijk zo eigenmachtig als vaak aangenomen wordt? Stond juist hij aan het begin van de carrière van Van Diemen en dient hij te worden gezien als zijn leermeester? In I629, aan het einde van het leven van Coen was Antonio van Diemen hoog opgeklommen in de hiërarchie van de VOC en bracht de juridische afwikkeling van een beruchte zedenzaak hem in direct conflict met Coen. In deze jaren leverde zijn betrokkenheid bij de besluitvorming van de VOC in Azië hem de nodige vijanden op. Toen hij in 1636 gouverneurgeneraal werd, was hij, anders dan zijn voorgangers, van onderaf omhooggeklommen. Juist door zijn faillissement was hij lotsverbonden met het bedrijf van de VOC in Azië geraakt. Stelde hij zich eenmaal benoemd tot gouverneur-generaal anders op dan zijn voorgangers tegenover de Heren Zeventien? Hoe verhield zijn werkwijze zich tot die van de Portugese ‘verklaarde vijanden' en de Engelse 'geveinsde vrienden'?

In mijn beschrijving van zijn gouverneur-generaalschap zullen diverse thema's aan bod komen. Van Diemen zocht voortdurend de strijd 
met de Portugezen. Koesterde hij een speciale wrok tegen hen of voelde hij zich gedwongen door een commerciële noodzaak? Wat waren dan zijn uitgangspunten voor de handel? Hoe bestierde Van Diemen de stad Batavia? De onder zijn leiding tot stand gekomen Bataviase Statuten zouden tot in de negentiende eeuw als wetboek dienstdoen. Wilde hij net als Coen van Batavia een grote Nederlandse kolonie maken?

Negen jaar, veel langer dan zijn voorgangers, bleef Van Diemen in functie. Zijn erfenis was het systeem van de VOC zoals dat nog 150 jaar zou blijven bestaan met al zijn gebreken en matige winstgevendheid. Het enorme fortuin dat hij en vooral zijn vrouw Maria in Batavia verzamelden, zou na zijn overlijden in Nederland aanleiding geven voor een aantal verrassende rechtszaken waarvan de laatste nog in I736 liep. In de nabeschouwing worden de draden bijeengenomen. Kunnen wij stellen dat, zoals vaak bij grote vennootschappen, ook het beleid van de VOC doortrokken was van persoonlijke ambitie die als ratio werd verpakt?

\section{Noten}

I. Huizinga, J., Geschonden wereld (Haarlem I945) 5.

2. Bruijn, J. R., F. S. Gaastra en I. Schöffer. Dutch-Asiatic shipping in the 17th and 18th centuries II ('s-Gravenhage I979) 40.

3. Stapel F. W., Geschiedenis Van Nederlandsch Indië III. (Amsterdam I938) 24I.

4. Coolhaas, W. P., 'Gegevens over Antonio Van Diemen', Bijdragen tot de Taal- Land- en Volkenkunde van Nederlandsch-Indië ('s-Gravenhage 1946) 77.

5. Ibidem 470.

6. Schutte, G. J., 'Coolhaas, Willem Philippus (1899-1981)', In Biografisch Woordenboek van Nederland. http://www.inghist.nl/Onderzoek/ Projecten/BWN/lemmata/bwn6/coolhaas ('s-Gravenhage, 2008).

7. Kraan, A. van der, 'Anthony van Diemen: from Bankrupt to Governor-General, I593-I645 (Part I)', The Great Circle, Journal of the Australian Association for Maritime History 26/2 (Perth 2004) 2I. 


\section{Proloog: de Tachtigjarige Oorlog als decor}

Tijdens het gehele leven van Antonio van Diemen dreunden op de achtergrond de kanonnen van de Tachtigjarige Oorlog (I568-I648). Er zijn gebeurtenissen, voorvallen, of momenten in de geschiedenis die zo beeldend en verhelderend zijn dat zij houvast geven aan een beter begrip van een heel tijdvak. Voor mij bijvoorbeeld is dat een paar jaar voordat de oorlog begon, die dag in december 1564, toen in Brussel de Raad van State, het hoogste regeringsorgaan van de Nederlanden naast landvoogdes Margareta van Parma, bijeenkwam. De vergadering vond plaats in de imposante raadszaal van het hertogelijk paleis en behandelde de instructie die aan de graaf van Hoorne zou worden meegegeven op zijn reis naar koning Philips II in Madrid om hem namens de Raad persoonlijk de grieven en de problemen van de regering in de $\mathrm{Ne}$ derlanden voor te leggen. Er was een tandeloos concept opgesteld waarmee de aanwezigen een voor een instemden, tot Willem van Oranje als laatste het woord nam. Uren sprak hij aan één stuk. 'Het is tijd,' zo was hij begonnen, 'ronduit te spreken en niets meer te verbloemen, want in de toestand waarin het land thans verkeert, kan het niet langer blijven bestaan.'

Hij sprak over de noodzaak van hervorming van regering en justitie. De uitputting der staatsfinanciën en vooral de snelle voortgang der ketterij. 'De koning dwaalt,' zo besloot hij, 'als hij meent dat Nederland, te midden van landen waar godsdienstvrijheid bestaat, voortdurend de bloedige plakkaten verdragen kan: evenals elders zal men ook hier oogluikend veel moeten toelaten. En hoezeer ik aan het katholieke geloof gehecht ben, ik kan niet goedkeuren dat vorsten over het geweten van hun onderdanen willen heersen en hun de vrijheid van geloof en godsdienst ontnemen."

Zo sprak prins Willem van Oranje, gewezen favoriet van keizer Karel $\mathrm{V}$, stadhouder van Holland, Zeeland en Utrecht, ridder in de Orde van het Gulden Vlies die aan Philips II trouw had gezworen. Een jaar later zou hij zelf tot het protestantse geloof overgaan. Hij trok in die vergadering een compromisloze grens. Het was in feite zijn oorlogsverklaring aan Philips II, koning van Castilië, Aragon, de twee Siciliën enz, enz., de machtigste man ter wereld en bovenal de kampioen van de katholieke kerk. Philips ondertekende zijn brieven met 'Yo el rey', 'Ik de koning'. Er stond niemand tussen hem en zijn god. Onmogelijk kon hij instemmen met het oogluikend toestaan van het protestantse geloof. 
Hij moest de handschoen opnemen en zo begon de Tachtigjarige Oorlog die losbarstte in 1568 en de achtergrond vormde van het leven van Antonio van Diemen.

Willem van Oranje had het juist gezien. Omringd door landen waar godsdienstvrijheid heerste, kon de vervolging van andersdenkenden niet slagen, zelfs niet met het beste leger en de grootste financiële inspanning. De hertog van Alva kwam en ging, de gruwelijke herinnering aan uitgemoorde steden en Bloedraad achterlatend. De hertog van Parma kwam en de splitsing in een noordelijk door protestanten geregeerd en een zuidelijk katholiek Nederland werd een feit na de val van Brussel en Antwerpen in 1585 .

Toen in de jaren direct daarna de protestantse zaak verloren leek, kwam de ommekeer. De Armada werd in 1588 door de Engelsen onder aanvoering van Drake verslagen. De legers van Parma moesten vanaf datzelfde jaar ook in Frankrijk, dus op twee fronten, gaan vechten. Met grote Franse en Engelse steun werd vanuit Holland en Zeeland het offensief ingezet. ${ }^{2}$ De belegerde werd belegeraar.

Eerst werden Holland en Zeeland veilig gesteld. Dat gebeurde in I593, in het geboortejaar van Van Diemen, met de verovering van Geertruidenberg. Door een spectaculaire maandenlange belegering op slechts drie dagmarsen van het grote Spaanse arsenaal in Mechelen verwierf Maurits zijn krijgsroem. De haven van Geertruidenberg was het slot op de vaart op de grote rivieren. Met deze verovering werd 'de Hollandse tuin' gesloten. ${ }^{3}$ Tegelijkertijd werden de Schelde en de Vlaamse kust geblokkeerd, wat een bijzonder belangrijk economisch effect had.

De Hollandse en Zeeuwse handelaren bleven hun goederen ter bevoorrading van de Spaanse troepen naar Vlaanderen en Brabant brengen, maar voortaan wel tegen een zeer hoge prijs. De Spaanse schatkist werd jaar in jaar uit leeg geschraapt om het neerslaan van de opstand te bekostigen. In tachtig jaar werden 2I5 miljoen dukaten, ofwel werd meer dan 600 miljoen gulden, naar Vlaanderen gebracht, meer nog dan er zilver uit de Nieuwe Wereld in Sevilla aankwam. ${ }^{4}$

Naar geen plek in Europa werd ooit zoveel contant geld verscheept als naar het front in de Zuidelijke Nederlanden. Maar nu laafden de Hollandse en Zeeuwse handelaren zich aan het zilver en mede, of misschien wel juist door de handel met de vijand werd de jonge Republiek een rijk land. Het vele geld gaf de Hollandse handelaren een niet te onderschatten voordeel boven hun Engelse concurrenten in de handel in de Baltische Zee en rond de Noordkaap met Rusland. Bij deze handel was de balans negatief voor de Engelsen. De Nederlanders, die het meeste geld hadden, deden de beste zaken. 
Het verklaart ook de route die de eerste Hollandse vloot in 1595 rond Kaap de Goede Hoop naar Oost-Indië voer: rechtstreeks naar de handelsplaats Bantam op Java. Daar konden immers met geld peper en specerijen gekocht worden.

Zagen de Spanjaarden dan niet in dat zij een fantoom najoegen? De onmogelijke queeste van Don Quichotte? Natuurlijk wel. In 1593 na het verlies van Geertruidenberg schreef de Spaanse bevelhebber in de Nederlanden voor het eerst dat het zijns inziens onmogelijk was de opstandige gewesten te veroveren. ${ }^{5}$

Gezichtsverlies, eer en godsdienst verhinderden echter nog tientallen jaren de nederlaag in volle omvang te erkennen. ${ }^{6}$

Door de verovering in 1580 van de Portugese kroon door Philips II waaierde de strijd over zee uit tot in alle uithoeken van de bewoonde wereld. Bewapende Nederlandse koopvaardijschepen voeren naar Amerika en Azië en maakten daar aanspraak op de handel. Het was mede de Hollandse expansie in Azië door de VOC, die de Spanjaarden in I608 naar de onderhandelingstafel bracht.

De onderhandelingen voor het Twaalfjarig Bestand (I609-I62I) waren begonnen met als inzet een volledige vrede. Het struikelblok was de eis van Spaanse kant dat de VOC en de Nederlanders zich uit Azië zouden terugtrekken. De oprichting van een West-Indische Compagnie wilde Van Oldenbarnevelt wel tegenhouden, maar de Spaanse eis om de VOC te ontmantelen maakte van een vredesverdrag een bestand. Tijdens het bestand ging de strijd in Afrika, Azië en Amerika door. Het is ook tijdens het bestand dat de Engelse East India Company (EIC) voldoende geld bijeen kon krijgen waardoor zij enige tijd een serieuze concurrent werd van de VOC. Het is eveneens tijdens het bestand dat de Republiek haast in tweeën scheurde langs de lijnen van geld, geloof, oorlog of vrede. Geld, een onverdraagzaam geloof en oorlog wonnen voor korte tijd.

Het lijkt wel of na afloop van het bestand de machthebbers in de Republiek steeds rationeler handelden en hun Spaanse tegenvoeters steeds minder contact met de werkelijkheid hielden. Een militair en een economisch voorbeeld hiervan. Het eerste is verbeeld op een schilderij van Velasquez. Het is de overgave in I625 van Breda door Justinus van Nassau aan de Italiaanse veldheer in Spaanse dienst, Ambrosio de Spinola. ${ }^{7}$ Het kostbare beleg was voorbeeldig uitgevoerd maar het resultaat was een strategisch nutteloze Pyrrusoverwinning. Het enorme doek voor het nieuwe koninklijke paleis van Philips IV in Madrid was in I635 klaar, één jaar voordat Breda opnieuw van bewind verwisselde. 


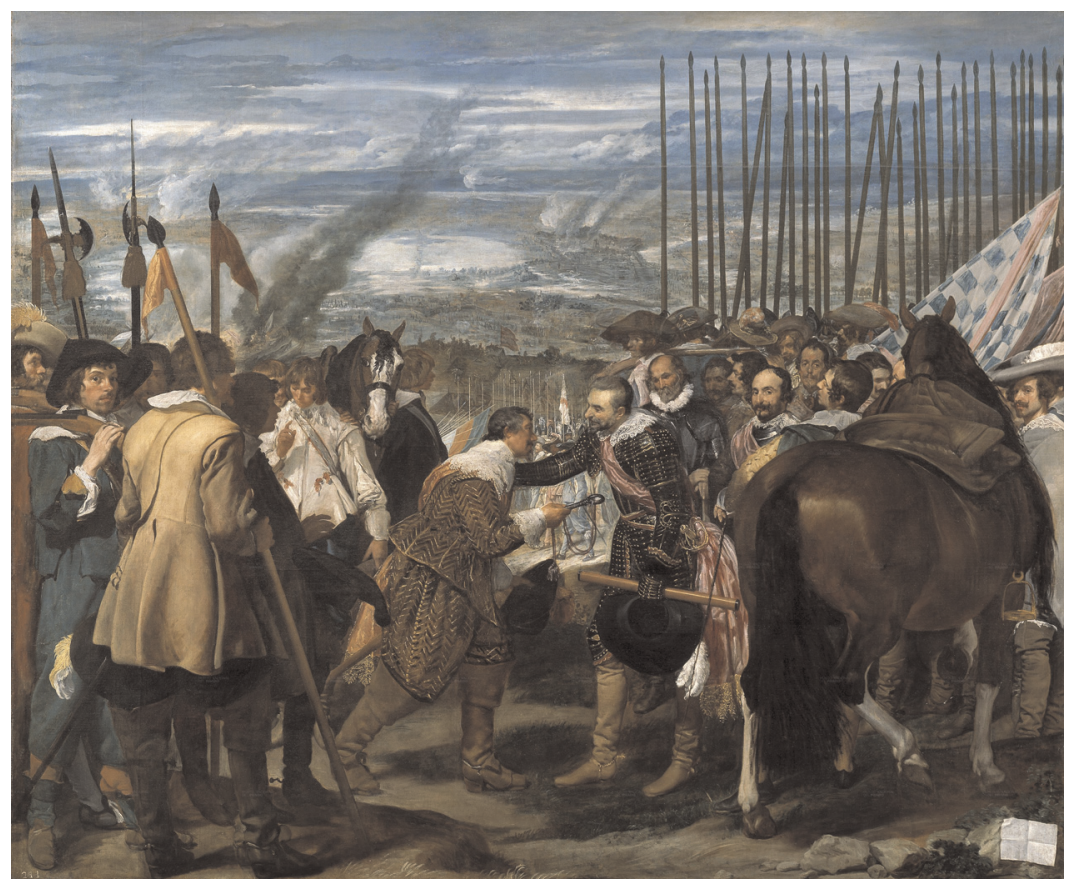

De verovering van Breda door de Spanjaarden in 1625 was een even kostbare als nutteloze overwinning. Bovenstaand meesterwerk van Velasquez was pas in 1635 klaar. Een jaar later zou de stad weer in Staatse handen overgaan. Het was toen duidelijk dat de oorlog in de Nederlanden definitief door de Spanjaarden was verloren. Museo del Prado, Madrid.

Het tweede, economische, voorbeeld laat zien hoeveel de Spanjaarden er in die jaren voor over hadden, en konden hebben om de Nederlandse handel structureel schade toe te brengen, en wel door de aanleg van een kanaal dat vanaf ${ }_{1} 626$ gegraven werd tussen de Rijn en de Maas ter hoogte van Venlo. De bedoeling was om de winstgevende handel van Holland op Duitsland niet alleen af te snijden, maar ook af te buigen naar Antwerpen. Het project werd de Fossa Eugeniana genoemd naar de dochter van Philips II, de populaire landvoogdes van de Zuidelijke Nederlanden, Isabella Maria Eugenia. Het was een geldverslindende onderneming. De kosten liepen op tot ver boven de ro miljoen gulden. Het kanaal was maar liefst 50 kilometer lang en werd door 24 schansen en forten beschermd. In $16_{2} 8$ naderde het zijn voltooiing, maar daar kwam vertraging in, onder meer door de verovering van de zilvervloot door Piet Hein in datzelfde jaar. Na de inname van Venlo door Frederik Hendrik in I632 raakte dit grootse project in vergetelheid. Sinds een 
aantal jaar echter is er een wandelroute langs dit landschappelijk fraaie voorbeeld van overspannen ambitie. ${ }^{8}$

Het Europese strijdtoneel was vanaf I6I8 volop in beweging door het uitbreken van de Dertigjarige Oorlog en de opkomst van Frankrijk als opvolger van Spanje als de machtigste staat in Europa. In het vierde decennium van de zeventiende eeuw werd de Spaanse reus door de Franse kardinaal en regeringsleider de Richelieu van zijn lemen voeten ontdaan. In I640 brak Portugal voor altijd los van de Spaanse kroon en de gelijktijdige revolte in Catalonië kon pas na jaren met de grootste moeite worden bedwongen.

Engeland werd onbestuurbaar en gleed vanaf I640 af naar een burgeroorlog. In de eerste helft van de zeventiende eeuw werkten zo de spelers op het Europese toneel aan alle kanten mee om de Republiek te laten excelleren in de hoofdrol. Nog steeds schitteren de Amsterdamse kooplieden uit die tijd op vele schuttersstukken: trots, arrogant, overmoedig, maar o zo succesvol.

Over de fenomenale opkomst van de Republiek als centrum van de wereldhandel zijn vele boeken geschreven. (Braudel ${ }^{9}$, Van Dillen ${ }^{\text {IO }}$, Gelderblom $^{\mathrm{II}}$, Israel ${ }^{\mathrm{I} 2}$, Lesger ${ }^{\mathrm{I} 3}$, De Vries en Van der Woude $\left.{ }^{\mathrm{I} 4}\right)$. De expansie na 1590 is zo allesomvattend en volledig geweest dat er in de beschrijvingen geen eind lijkt te komen aan de producten waarin de hegemonie werd gevestigd, of het nu ging om hout of zout, kaviaar of kanonnen, walvistraan of wijn, linnen of lijm, kruidnagel of kruit. Over deze feiten bestaat geen discussie.

Wel bestaat een nog steeds veranderend inzicht over de vraag hoe dit mogelijk was. Waren het de eigen economische grondslagen (Van Dillen, De Vries en Van der Woude) of veranderde de toestroom van Antwerpse handelaren en kapitaal het beeld (Gelderblom)? Hoe bepalend was de oorlog met de Zuidelijke Nederlanden en de afsluiting van de Schelde, waardoor Antwerpen buiten spel werd gezet? Hoe belangrijk was de dynamiek van de Amsterdamse koopmansstand en hoe bepalend de geografische ligging van Holland en Amsterdam (Lesger)? De vraag kan ook anders geformuleerd worden: hoe was het mogelijk dat de Hollanders de Engelsen achter zich lieten? Hadden de Engelsen geen op zijn minst gelijkwaardige uitgangspositie? Wat was het verschil? Uit alle gegevens komt naar voren dat de Hollanders over veruit het meeste contant geld konden beschikken. De bron van een belangrijk deel van dat geld waren de Zuidelijke Nederlanden die effectief geblokkeerd werden, maar waarop handel volop werd toegelaten. De handelsbalans was voor het zuiden negatief, wat tot gevolg had dat vandaar veel zilver naar de Republiek stroomde. 
Al was Antwerpen niet meer de grote stapelmarkt van vroeger, toch waren handel en bankwezen er nog steeds van betekenis. Het karakter van Antwerpen veranderde in 1585 na de verovering door Parma. Van wereldse open metropool werd Antwerpen een naar binnen gekeerd bolwerk van de contrareformatie. Het werd echter geen arme stad. Net als de Noordelijke Nederlanden haalde de stad haar profijt uit de oorlog. De Spaanse soldaten die er gelegerd waren, makten hun soldij op in de stad. $^{\text {I5 }}$ Daarnaast bleef Antwerpen in de eerste helft van de zeventiende eeuw het centrum van de Europese luxe industrie. ${ }^{16}$ Pas na de Vrede van Munster in I648 begon het werkelijke verval van Antwerpen. ${ }^{\text {I7 }}$

Er bleef een druk handelsverkeer tussen Antwerpen en Amsterdam bestaan, getuige de vaste beurtvaart tussen beide steden aansluitend bij de beurtvaarten van Antwerpen op Gent, Mechelen en Brussel. In het verkeer met de zuidelijke gewesten werd ook gebruik gemaakt van het transport over land. Hiervoor zorgden te 's-Hertogenbosch gevestigde expediteurs, die agenten in Amsterdam hadden aangesteld. Per schip werden de goederen naar Den Bosch vervoerd en vandaar met karren over zandwegen naar Luik en Verviers. Een andere route leidde via Breda naar Leuven. Wagenaar verhaalde in zijn geschiedenis van Amsterdam hoe de Richelieu in I638 bijna uit zijn vel barstte toen hij hoorde dat Amsterdamse kooplieden vier fluiten beladen met 300.000 pond buskruit, pieken, sabels en musketten naar Antwerpen verscheepten. ${ }^{\text {I8 }}$ Niet voor niets heeft Fernand Braudel gehamerd op het belang van geld als het levensbloed van de handel. Zonder geld stond alles stil.

'The role of precious metals has never seemed more important than in the sixteenth century. Contemporary writers unhesitatingly accord them pride of place and economists of the seventeenth century are even more emphatic. For one, they are "the substance of the people"; another considers "that we draw our living less from traffic in commodities than from gold and silver". And a Venetian speaker goes so far as to say that precious metal, whether gold or silver is "the sinews of all government, it gives it its pulse, its movement, its mind, soul, and it is its essence and its very life [''esser et la vita']... It overcomes all impossibilities, for it is the master, the patron of all: it carries with it the necessity of all things; without it all is weak and without movement".'19

Naar mijn mening dient bij de opkomst van Nederland als rijk land dan ook het vele Spaanse geld betrokken te worden dat via de Zuidelijke Nederlanden in Hollandse handelshanden kwam. De belasting die Amsterdam hief over de in- en uitvoer van goederen, de convoyen en licenten, was een barometer van de handel en deze volgde het ritme van de Tachtigjarige Oorlog: sterke stijging vanaf I590, stagnatie tijdens het 
Twaalfjarig Bestand, sterke stijging na I62I, stabiel tot $\mathrm{I}_{3} \mathrm{3}$, daarna verdere stijging tot boven een miljoen gulden in $\mathrm{I}_{3} 6$, verdere stijging tot I648, waarna een daling optrad. ${ }^{20}$ Dit argument werd recent ook gegeven door Engelse historicus Ormond. Hij stelt in zijn boek The rise of commercial empires. England and the Netherlands in the age of mercantilism, 1650-1770, dat de Hollandse hegemonie in de wereldhandel veel korter zou hebben geduurd dan in de geschiedschrijving wordt aangenomen: deze zou maar 40 jaar (I609-I652) stand hebben gehouden. ${ }^{2 \mathrm{I}}$

De Engelse misten deze contanten en konden daardoor in de landen aan de Oostzee, Rusland en Azië, dus in die gebieden waar de handelsbalans negatief was, niet tegen de Hollanders op. De Hollanders hadden als enigen geen geldtekort. En geld nu was juist het vliegwiel van de spectaculaire expansie. Toen de ambassadeur van Venetië in I602 op bezoek was in Middelburg informeerde hij naar de handelswaar aan boord van de drie grote Oost-Indiëvaarders die gereed lagen om uit te zeilen. Hij kon zijn oren niet geloven 'ne portano altro che denari in reali di Spagna' schreef hij op. Zij hadden als lading alleen maar geld en wel Spaanse realen aan boord. ${ }^{22}$

\section{Noten}

I. Fruin, R., Voorspel Verzamelde geschriften I ('s-Gravenhage I900) 345 .

2. Parker, G., Spain and the Netherlands, 1559-1659: ten studies (London, I990) I79. Throughout early modern times the Netherlands were the 'cockpit of Europe' and almost every European State became involved in the Dutch struggle for independence at some time. Several German princes sent occasional subsidies; Elizabeth of England sent at least fifteen million florins to the Low Countries between I585 and I603; and Henry IV of France sent ten million florins between 1598 and i6ro.

3. Fruin, R., Tien jaren uit den Tachtigjarigen Oorlog, 1588-1598 ('s-Gravenhage I889) I03.

4. Parker, Spain and the Netherlands, 1559-1659, I86. Overshadowing these 'social costs' of the war, however, was the far more debilitating haemorrhage of Spanish treasure and the virtual destruction of the Castilian economy in order to finance the war against the Dutch. But this flexing of Spain's imperial muscles was only achieved at a terrible cost. Philip III was quite correct to claim that more was sent to the Netherlands than arrived legally on the New World treasure fleets. Between I566 and I654, the Military Treasury In the Netherlands received a minimum of 218 million ducats from Castile, while the crown received only I2I million ducats from Indies. 
5. Israel, J. I., The Dutch Republic and the Hispanic world, 1606-1661 (Oxford, I982) I59: I. One pro-truce memorial put to the 'Consejo de Estado' at this time (I623) argued that the Dutch were actually financing the conflict with the funds that Philip remitted to the Netherlands to pay his troops, and which gradually seeped into 'rebel' hands, and that by opting for peace the king would both damage the Republic financially and save Spain from being utterly drained of resources; the same author dealt scathingly with the strategic argument that Flanders was Spain's best 'plaza de armas', asking what sense it really made to concentrate resources at one extremity of the empire leaving the rest devoid of funds.

6. Spain and the Netherlands I559-1659, Ten studies, Geoffrey Parker, London 1979. Why Did the Dutch Revolt Last So Long? 4S" Io. War and Economic Change: the Economic Costs of the Dutch Revolt I78 'The matter may be reduced to two points,' Olivares informed the king: 'religion and reputation'. A remarkable consistency of outlook, which lasted from the I570s until at least the I630s.

7. Het enige buitenechtelijke kind van Willem van Oranje. Justinus ligt begraven in de Hooglandsekerk in Leiden.

8. Pistor, R. G. en H. Smeets, Die Fossa Eugeniana: eine unvollendete Kanalverbindung zwischen Rhein und Maas (Köln I979) RheinlandVerlag www.arcen.nl/arcen+en+omgeving/natuurgebieden/fossa +eugeniana

9. Braudel, F., The Mediterranean and the meditarraneum world in the age of Phillip II. 2e edition, 2 vols. (New York I976).

Io. Dillen, J. G. van., Van rijkdom en regenten; handboek tot de economische en sociale geschiedenis van Nederland tijdens de Republiek ('s-Gravenhage i970).

II. Gelderblom, O., Zuid-Nederlandse kooplieden en de opkomst van de Amsterdamse stapelmarkt (1578-1630) (Hilversum 2000).

I2. Israel, J. I., Dutch primacy in world trade, 1585-1740 (Oxford, New York ig89).

I3. Lesger, C., Handel in Amsterdam ten tijde van de Opstand: kooplieden, commercièele expansie en verandering in de ruimtelijke economie van de Nederlanden, ca. 1550-ca. 1630 (Hilversum 200I).

I4. Vries, J. de en A. van der Woude, Nederland 1500-1815, De eerste ronde van moderne economische groei (Amsterdam 2005).

I5. Stock, J. van der, Antwerpen, verhaal van een metropool in de 16de en 17de eeuw (Antwerpen r993) 63.

16. Stock, van der, Antwerpen, 95.

I7. Ibidem, 95.

I8. Wagenaar, J., Amsterdam, in zijne opkomst, aanwas, geschiedenissen, voorregten, koophandel, gebouwen, kerkenstaat, schoolen, schutterye, gil- 
den en regeeringe, beschreeven door Jan Wagenaar, hystorieschryver der stad 3 delen (Amsterdam I760) 535.

I9. Braudel, F., Capitalism and Material Life, 1400-1800 (Londen I974) 462.

20. Brugmans, P. D. H., Opkomst en bloei van Amsterdam (Amsterdam I9II) II8 e.v.

2I. Ormond, D., The rise of commercial empires. England and the Netherlands in the age of mercantilism, 1650-1770 (2003).

22. Blok, P.J., Relazioni Veneziane. Venetiaansche berichten over de Vereenigde Nederlanden van 1600-1795 Rijks Geschiedkundige Publicatiën 7 ('s-Gravenhage iو०9) 6. 


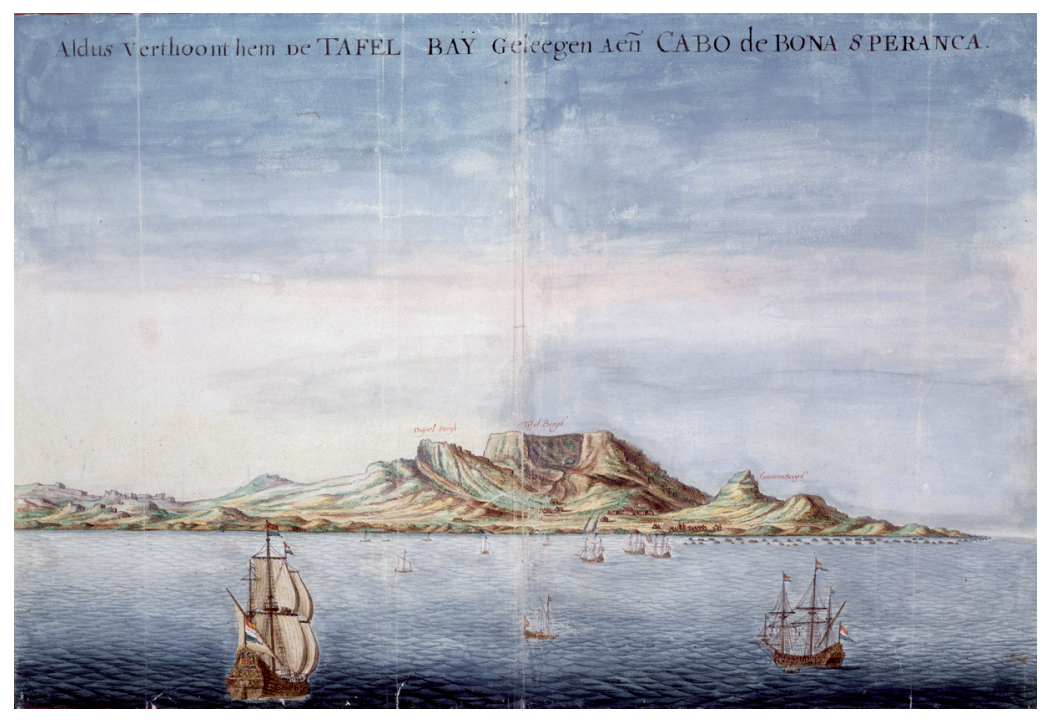

In het kielzog van Antonio van Diemen verliet ook zijn neef Jan van Riebeeck Culemborg. In dienst van de VOC stichtte hij op 6 april 1652 bij Kaap de Goede Hoop de kolonie die de prachtige bijnaam 'De Herberg van Twee Oceanen' kreeg. Nationaal Archief Den Haag. 


\section{Jeugd in Culemborg, 1593-1608}

Antonio van Diemen werd in 1593 geboren in Culemborg. Op zeventiende-eeuwse afbeeldingen ligt Culemborg dromerig aan de zuidoever van de Lek. Jan van Goyen schilderde in gele en bruine pasteltinten wat een reiziger zag die over de weg uit Utrecht bij het veer aankwam: een paar schepen op een rivier voor een groot kasteel, met vaag rechts daarvan een stadje. ${ }^{\mathrm{I}}$ Preciezer toont een ets uit $\mathrm{I}_{220}$ het kasteel aan de rivier met op de achtergrond de stadsmuur op de dijk met daken van huizen erbovenuit stekend. ${ }^{2}$ Een plattegrond van Joan Blaeu uit $1649^{3}$ geeft aan wat door de rivierdijk aan het oog ontrokken werd: een kleine stad met aan de oostkant een groot kasteel. Het stadje bestond uit drie delen: de oude stad rond de markt met het stadhuis en de grote SintBarbarakerk, de nieuwe stad aan de landkant met boerderijen binnen de eenvoudige ommuring en als derde de kleine havenstad aan de Lekdijk.

Met tussen 1500 en I800 een bevolking van rond de 2500 inwoners was Culemborg economisch slechts van lokaal belang. Op de markt in de oude stad werd wekelijks op dinsdag de opbrengst van het omliggende land verkocht. De schippers voeren daarmee en met andere waren over de grote rivieren.

Vanuit militair oogpunt was de ligging van Culemborg tijdens de Tachtigjarig Oorlog ook onbelangrijk. Maar, omdat het grote kasteel de residentie was van een graaf speelde Culemborg ten tijde van de Republiek toch een soms opvallende rol. Als graafschap namelijk vormde Culemborg tussen Linge en Lek een onafhankelijk staatje omringd door de Republiek. De graven benadrukten deze onafhankelijke positie door op hun grondgebied asiel te verlenen aan vervolgden van elders uit de Republiek, waardoor Culemborg de ongunstige reputatie kreeg van vrijplaats voor misdadigers en bankroetiers die tegen betaling van de graaf een acte van vrijgeleide verkregen. ${ }^{4}$ 


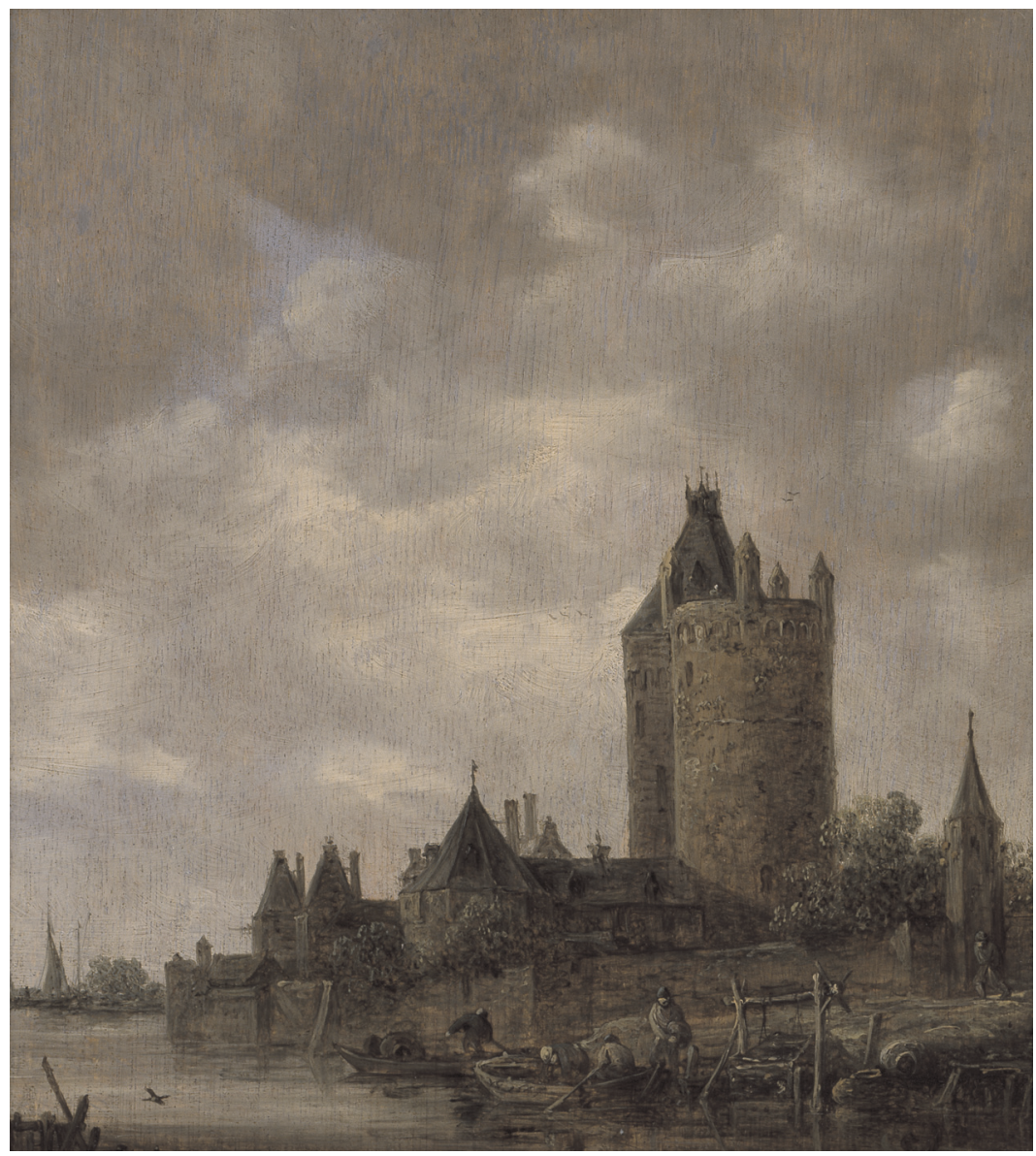

In 1735 werd het grote kasteel van Culemborg afgebroken. Het eens zo rijke graafschap was armlastig geworden en in 1720 door de laatste erfgenaam verkocht aan de Staten van het Kwartier van Nijmegen. Jan van Goyen, Ashmolean museum, Oxford.

Ten tijde van de Opstand was graaf Floris I (I537-I598) geen grote heer zoals Egmont, Hoorne of Oranje dat waren, maar behoorde hij met Bredero, de heer van het nabijgelegen Vianen tot de voornaamsten van de lagere adel. ${ }^{5}$ In de strijd tegen de Spanjaarden speelde hij een bescheiden rol. In april 1566 koos in Floris' paleis te Brussel de opstandige adel de spotnaam 'Geuzen' tot strijdkreet tijdens het diner dat volgde op het aanbieden van het smeekschrift der edelen. In 1567 nam de hertog van Alva zijn intrek in ditzelfde paleis. Een jaar later echter liet hij het tot de grond afbreken. Op een gedenkpilaar ter plekke stond dat dit gebeurd was om de herinnering te vervloeken aan de samenzwering 
die daar had plaatsgevonden tegen de rooms-katholieke kerk en tegen koning Philips II. Graaf Floris zelf werd bij verstek ter dood veroordeeld en al zijn goederen werden verbeurd verklaard. ${ }^{6}$

Eveneens in ${ }_{5} 66$ werd Floris in Culemborg zelf met een smeekschrift geconfronteerd, nu van verontruste katholieken. Zij waren bezorgd over de vrijheid die de protestanten kregen. Zeventig van hen wendden zich tot de graaf met het verzoek de ketterse diensten niet meer oogluikend toe te staan. Onder hen bevond zich ook Anthonisz Meusz, oud-burgemeester van Culemborg en grootvader van Antonio.' De graaf gaf er geen gehoor aan. Hij moedigde daarentegen de 35 beeldenstormers aan die van zaterdag I4 september I566 tot de daaropvolgende woensdag huishielden in de kerken van Culemborg. Een van hen was Lambert Hoevenaer, burgemeester en (van moederszijde) eveneens grootvader van Antonio. ${ }^{8}$ Bij de nadering van het leger van de hertog van Alva vluchtte Floris naar zijn Duitse bezittingen. Ook de Culemborgse beeldenstormers namen de wijk en keerden met de graaf pas in I576 terug in Culemborg. Hoezeer graaf Floris bedrukt werd door het doodvonnis geven zijn laatste woorden weer die luiden dat hij nu verzekerd was niet te zullen sterven in handen van de Spanjaarden.' 9

Zoals in zoveel steden in de Republiek is ook in Culemborg tijdens de Tachtigjarige Oorlog de geloofsstrijd niet op de spits gedreven. Ondanks de gereformeerde gezindheid van de graven is meer dan de helft van de bevolking van Culemborg katholiek gebleven. Scholen en kerkdiensten werden aan de katholieken oogluikend toegestaan.

De magistraten van de stad werden door de graaf benoemd. Daarmee week Culemborg af van het gebruik in de overige steden van de Republiek waar de stadsregering benoemd werd door de vroedschap, die zichzelf weer door coöptatie op sterkte hield.

In het jaar dat Anthonie van Diemen werd geboren, was zijn vader Meus Anthonisz stadsburgemeester, een functie die hij om het jaar wisselde met Lambert Hoevenaer, de vader van Antonio's moeder, Christina. ${ }^{\text {IO }}$ Oom Cornelis was secretaris van de stad en van de graaf. ${ }^{\text {II }}$ Het was een bijzonder uitgebreide familie, waartoe ook Jan van Riebeeck, de stichter van de Kaapkolonie, behoorde. Hij was een neef van Antonio. ${ }^{\text {I2 }}$ Als stadsburgemeester was Antonio's vader verantwoordelijk voor de stadsfinanciën, daarnaast bekleedde hij een aantal minder belangrijke functies. Hij was al rond de vijftig toen hij trouwde. Hij had vanaf zijn achtste jaar vanuit Culemborg veertig jaar lang eerst als knecht en later als schipper over de rivieren gevaren, ${ }^{\mathrm{I} 3}$ voordat hij aan wal wijnhandelaar en wijnwaard werd. Zo leverde hij de avondmaalswijn aan de St.-Barbarakerk. Anthonie was de oudste van vier kinderen, na hem kwamen drie dochters Anna, Elisabeth en Hendrickje. Het gezin woonde in het hartje van de oude stad aan de Oude Vismarkt in het huis dat zijn moeder als bruidschat had meegekregen. Zijn vader kocht 
in I6I3 nog de herberg 't Gulden Hooft aan de markt voor II35 gulden. ${ }^{14}$ Deze herberg staat er nog steeds. Alles wijst erop dat het gezin waarin Antonio opgroeide een goed kleinsteeds leven leidde. Zijn familie speelde een belangrijke rol in Culemborg. De kerkelijke gezindheid van het gezin was protestants en daarin waarschijnlijk remonstrants, zoals ook de graven tot 1618 zouden zijn. ${ }^{15}$ Drie grote gebeurtenissen in Culemborg tijdens Antonio's jeugd hadden alle met de grafelijke familie van doen. Op de dood en de plechtstatige begrafenis van graaf Floris I in 1598 volgde de inhuldiging van graaf Floris II in augustus I599. In april r6o deed graaf Floris II feestelijk zijn officiële intrede binnen de stad, nu met zijn gemalin aan zijn zijde. ${ }^{16}$ Deze plechtigheden waren voorzien van de pracht en praal die de rijke graven zich konden veroorloven. Later maken in Batavia een ridderharnas en een toernooipaard deel uit van het begrafeniscortège van overleden gouverneurs-generaal. Zou dit het gevolg zijn van Antonio's jeugdherinneringen? Wie zal het zeggen.

Culemborg had een Latijnse school en Antonio is hier naar alle waarschijnlijkheid op zesjarige leeftijd voor het eerst naartoe gegaan. De lessen begonnen met een gebed, uitgesproken door de oudste leerling. De lesuren waren van half acht tot negen, van half tien tot elf, van één tot twee en van drie tot half vijf. In de zomer begon men een uur vroeger. Op dinsdagmiddag na twee uur was er geen school omdat het dan markt was. De school telde in I645 zo'n veertig leerlingen, vermoedelijk niet meer dan vijfenveertig jaar daarvoor, in I6oo.

Uit die tijd stamt ook de instructie van de graaf aan de schoolmeester wat onderwezen diende te worden: naast lezen en schrijven, eerst in het Nederlands en daarna in het Latijn diende de opvoeding in de gereformeerde religie ter hand genomen te worden, maar dan wel de remonstrantse of arminiaanse variant.

In I605 werd deze instructie uitgebreid. De schoolmeester, Van Ravenswaeij, werd bevolen voortaan dezelfde boeken te gebruiken als op de beroemde Latijnse school van Utrecht. ${ }^{17}$ Deze band met Utrecht geeft de positie weer die de graaf en de onderwijzer innamen in het religieuze spectrum van die dagen. De Utrechtse school, waar Arminius zelf les had gehad, was een erkende veste van de remonstrantse of arminiaanse stroming in de gereformeerde kerk. Deze stond tegenover de gomaristische of contraremonstrantse stroming. Dit lijkt ons nu wellicht niet van groot belang, maar in de Republiek waren in het eerste tijdvlak van de zeventiende eeuw geloof en politieke richting onlosmakelijk aan elkaar verbonden. Op school zat ook de zoon van de onderwijzer, Johannes van Ravenswaeij, die later predikant van Culemborg werd en trouwde met Antonio's jongste zuster. Rond I605 raakte Antonio's vader in opspraak vanwege een geschil met zijn voormalige knecht Willem van Iseren. De ruzie liep zo hoog op dat beiden door de 
kerkenraad tijdelijk niet tot het avondmaal werden toegelaten. De classis van Gorinchem waar Culemborg onder viel, sprak zich uit ten gunste van Meus Anthonisz, waarop de synode van Delft eraan te pas moest komen om de zaak uit de wereld te helpen. ${ }^{{ }^{8}}$ Het zal de gemoederen van de familie nogal bezig hebben gehouden, maar meer dan de storm in een glas water lijkt het niet te zijn geweest.

Zo groeide Antonio op in een staatkundig buitenbeentje van de Republiek. Naast de pracht en praal van de grafelijke hofhouding uitte zich dat in de hiërarchische structuur. Terwijl in de overige steden van de Republiek de regenten het bestuur vormden en benoemden, was in Culemborg de macht in de handen van de graaf. Van Diemen zelf was naar kleinsteedse begrippen afkomstig uit een gegoede familie van bekwame administrateurs. Op school had hij naast Latijn enige kennis van de humaniora meegekregen. Van gereformeerde huize was hij waarschijnlijk in de arminiaanse richting opgevoed. Als enige zoon leek hij voorbestemd om in de voetsporen te stappen van zijn vader, grootvader en vele familieleden door magistraat te worden in Culemborg. Maar in I609 komen wij de I6-jarige Antonio van Diemen geheel onverwacht tegen als koopman in Amsterdam. Hadden de schippersverhalen van zijn vader bij hem een avontuurlijke snaar geraakt? Het zou ook door het geloof kunnen komen, want terwijl zijn omgeving arminiaans was, ontpopte hij zich in zijn verdere leven als overtuigd contraremonstrant. ${ }^{\mathrm{I9}}$ Wij zullen zijn beweegredenen nooit weten.

\section{Noten}

I. Ashmolean Museum, Van Goyen ref. WA 1962.I7.I5 A973.

2. Rademaker, A., 't Kasteel te Kuilenburg (1620). Rijksmuseum Amsterdam.

3. Johannes Blaeu, Stedenboek, I649.

4. Gijswijt-Hofstra, M., Wijkplaats voor vervolgden. Asielverlening in $\mathrm{Cu}$ lemborg, Vianen, Buren, Leerdam, IJsselstein van de 16de tot eind 18de eeuw (Dieren I984) 244.

5. Fruin, R., 'Het voorspel van den Tachtigjarigen Oorlog' in Verspreide Geschriften I, ('s-Gravenhage I900) 33I.

6. Voet van Oudheusden, A. K. W., Historische beschrijvinge van Culemborg (Utrecht I753).

7. Ibidem $2 \mathrm{I} 6$.

8. Ibidem 2I9.

9. Ibidem 253.

Io. Oud Archief van de Gemeente Culemborg (OAGC), no 2042/ 2043. Regionaal Archief Gelderland, Oud rechterlijk Archief Culemborg (ORA Culemborg) toegang I40/232 f 4I. Testament Lam- 
bert Hoevenaars/ juli I6ı2. Ten onrechte werd tot nu aangenomen dat zijn moeder Elizabeth heette. Dat was zijn grootmoeder.

'Gelijck wij mede by desen legateren geven ende vermaecken aan Christina onse dochter, huysvrouwe van Meus Anthonisz, de beecker genoemt de uyl, legateer daer noch toe die heerschap van haer huys daer sy tegenwoordigt inne woont wat die beter is dan zeshondertgulden ende die lasten die daarop stonden daervoor wil so die te huwelijck gegeven hebben.'

II. De uitgebreide stamboom van Antonio Van Diemen staat in bijlage 9 .

I2. Beltjes, P. J. W., Jan van Riebeeck zijn voor- en nageslacht ('s-Gravenhage I952) 332.

I3. ORA Culemborg, inv.nr. 226, p. IIv, 29 juli I596.

Meus Anthoenisz, oud zeven of 58 jaar, en Jan Alaert Jansz, ongeveer 52 of 53 jaar, eertijds schipper geweest zijnde, verklaren ter verzoeke van Jan Alaerts de Veer, onze mede burger, ten eerste Meus Thoenisz dat hij voortijds met zijn schip en eigen goederen voorbij de tol tot Emmerik is gevaren zonder aan dezelve tol aan te leggen of verlof te halen dan op zijn burger vrijheid voorbij gevaren te zijn en dat op een tijd hij met zijn schip tot Rees is gearresteerd en met recht is aangesproken en enige sententie of verklaring daarvan gegaan zijnde dat daarvan bij de tollenaar van Emmerik of zijn meester binnen Nuijs geappelleerd is en daar nog onbeslist is, voorts sedert aan de vz tol nooit met schip of eigen goed aangelegd of verlof gehaald te hebben dan vrij en ongemolesteerd voorbij gevaren te hebben.

ORA Culemborg, inv.nr. 226, p. 30v, 6 aug. I6oo.

Cornelis Aertsz, Sebastiaen Cornelisz, Dirck Janz, Meus Antoenisz, Gerrijt Cornelisz, Aert Aertsz, Rembout Gerijtsz, Herberen en Dirck Sam Jansz, Pons Jansz, Dirck Beernts, Anthoenis Toenis, verklaring afgelegd op verzoek van Walraven van Muers, in naam en vanwege de regeerders van de stad Wijk bij Duurstede, Cornelis Aertsz, ${ }_{5}$ jaar, Sebastiaen Cornelisz, 63, Dirck Jansz, 64, Meus Antoenis 60 jaar, Gerrijt Cornelisz 60 jaar, Herberen Sam, 42 jaar Dirk Sam Jansz 40 jaar Pons Jansz, 37 jaar, Dirck Beerntsz, oud 28 jaar, Antoenis Toenis, 26 jaar, en Ghijsbert Sebastiaensz, oud 43 jaar, als dat zij lieden als schippers ettelijke malen in Holland en Zeeland en voorts stroom boven en beneden met hun schepen hebben gevaren, waarvan Meus Antoenis sedert dat hij elf jaar oud was en nu omtrent Io jaar geleden verlaten hebben.

I4. RAG ORA Culemborg inv no I59 folio 29.

I5. OAGC inventaris no. 549 en 555 .

I6. Voet van Oudheusden, Historische beschrijvinge van Culemborg, 258. 
I7. Beltjes, P. J. W., 'De Latijnse school in Culemborg' Overgedrukt uit Bijdragen en Mededelingen der Vereniging "Gelre", deel 53, I953.

I8. Acta der provinciale en particuliere synoden in de noordelijke Nederlanden I593-1620 etc deel 3 p 246, 8 augustus i6o6 ibid p 267, I4 augustus 1607.

I9. In zijn generale missive van december I639 schreef Van Diemen dat hij geen Roomse, Lutherse of remonstrantsgezinde secretarissen wilde, waarmee hij zichzelf duidelijk in het contraremonstrantse kamp plaatste (Tiele-Heeres, Bouwstoffen II, 396). 


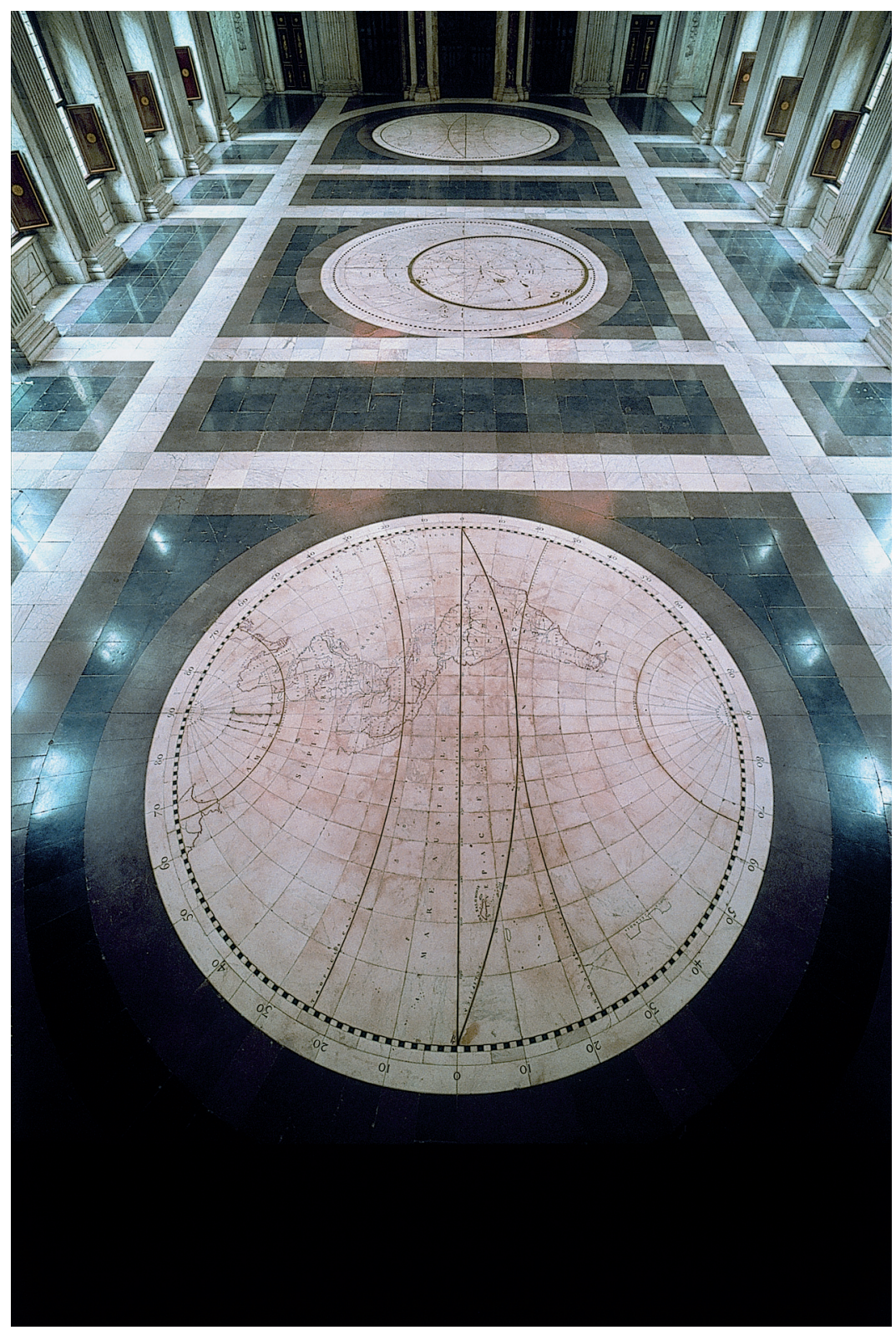

In de grote Burgerzaal van het stadhuis liepen de trotse Amsterdamse magistraten over de wereldhelften en de sterrenhemel. Masters of the Universe. Koninklijk Paleis op de Dam, Amsterdam. 


\section{Koopman in Amsterdam, 1609-1616}

Het onverwachte succes van de Hollandse revolutie tegen de Spaanse Habsburgers, de militaire triomfen van Maurits en Frederik Hendrik en de groei van de handel gaven in de eerste helft van de zeventiende eeuw aan de Republiek vrijheid, macht en rijkdom en aan haar inwoners dat opwekkende, meeslepende gevoel dat voortkomt uit overwinning en zelfvertrouwen. Het waren denkers als Grotius, Descartes en Spinoza die in deze omgeving hun rationele gedachten ontwikkelden, het waren staatslieden als Van Oldenbarnevelt die zelfbewust het Europese toneel betraden en het waren kooplieden in Amsterdam die hun omgeving vormden naar hun inzicht. Zij bouwden welhaast een nieuwe stad, legden de grote meren van Noord-Holland droog en regeerden de wereldhandel. Toen het stadhuis van Amsterdam in I644 afbrandde en er een nieuw gebouwd moest worden, werd dit een ontlading van hun ambitie en trots. Welk gevoel kon anders overheersen bij hun besluit om op de marmeren vloer van de Grote Burgerzaal van het nieuwe stadhuis van Amsterdam de twee wereldhelften groots af te beelden naast de noordelijke sterrenhemel? Zij liepen over de wereld heen: Masters of the Universe. Als nooit tevoren waren de Nederlanders overtuigd van zichzelf.

Amsterdam was in de eerste helft van de zeventiende eeuw een stad van immigranten. Zo kon de stad van 30 duizend inwoners in 1580 groeien tot meer dan roo duizend in I630. ${ }^{\mathrm{I}}$ De stad trok gelukszoekers. En wie vond dat geld gelukkig maakte, ging naar Amsterdam. Zo was daar de eerbiedwaardige koopman en regent Jan Poppen (I545-I6I6) zonder één cent uit het oosten van Duitsland aan komen lopen en zou hij er sterven als de rijkste man van Amsterdam. ${ }^{2}$ Jan Poppen sprong eruit, maar was geen uitzondering. Velen lukte het in Amsterdam van niets weinig te maken, of van een beetje veel. Haar succes maakte Amsterdam tot een ware magneet. Ook de Culemborgse burgemeesterszoon Antonio van Diemen werd erdoor aangetrokken.

In de geschiedschrijving werd tot nu toe aangenomen dat Van Diemen slechts één jaar, in I6I6, in Amsterdam als koopman actief was en dat hij daarbij door een zekere Jan Engels bedrogen buiten zijn schuld failliet ging. De bron van dit verhaal is Van Diemen zelf geweest. ${ }^{3}$ 
Zo schreef Stapel:

'Als zoovele patricierszoons was hij voor den handel bestemd en in ${ }_{16} 6$ vestigde hij zich als koopman te Amsterdam. Daar viel de 23-jarige in handen van zekeren Jan Engels, die hem onder schoonschijnende voorwendselen in speculatieve ondernemingen wist te betrekken, met een noodlottig gevolg. Na een goed jaar moest Anthony zijn faillissement aanvragen, wat hem voor goed van een eervolle carriëre scheen uit te sluiten.'

En Coolhaas:

'In 1616 vestigde hij zich als koopman te Amsterdam waar hij voornamelijk in koloniale waren handelde. Lang heeft het niet geduurd, dat hij daar zaken kon doen: de onervaren jongenman had zich, op aansporing van een minder scrupuleuzen zakenvriend, zekeren Jan Engels, die meende Antonio's duitjes wel in zijn zakken te kunnen krijgen, in speculatieve ondernemingen gestoken. Toen de zaken misliepen, steunde Jan Engels Van Diemen niet, zoodat hij niet aan zijn verplichtingen kon voldoen. 5

Echter, uit de archieven van de stad Amsterdam blijkt een heel ander beeld van de activiteiten van Van Diemen. Hij vestigde zich namelijk al in I609 op I6- of I7-jarige leeftijd als koopman in Amsterdam waar hij introk bij Pieter Jacobs, een koopman met een huis aan de Warmoesstraat. $^{6}$ Of er een verdere band bestaat is onbekend, evenmin of hij kostgeld betaalde, of werkte in dienst van zijn gastheer. ${ }^{7}$ In ieder geval koos hij een goede plek voor zijn activiteiten. Voordat de beurs - naar Londens voorbeeld gebouwd - in I6II geopend werd, deden de kooplui bij mooi weer hun zaken op de Nieuwe Brug en bij slecht weer in de Warmoesstraat op de stoepen en onder de luifels. In de winter kwamen zij samen in de Oude Kerk. ${ }^{8}$

$\mathrm{Nu}$ beperkten de kooplieden zich in die tijd niet tot de handel in reële goederen. Zij waren eveneens bankiers, grond-, wissel- en valutaspeculanten, traden op als assuradeur en gingen daarnaast allerlei weddenschappen aan waarvoor zij in hun boekhouding aparte rekeningen aanhielden. 9 Zeker niet altijd bezaten de handelaren de goederen die zij verkochten, of hadden zij die als koper zelf nodig. Er was dus sprake van veel termijnhandel en daarbij horende speculatie. 


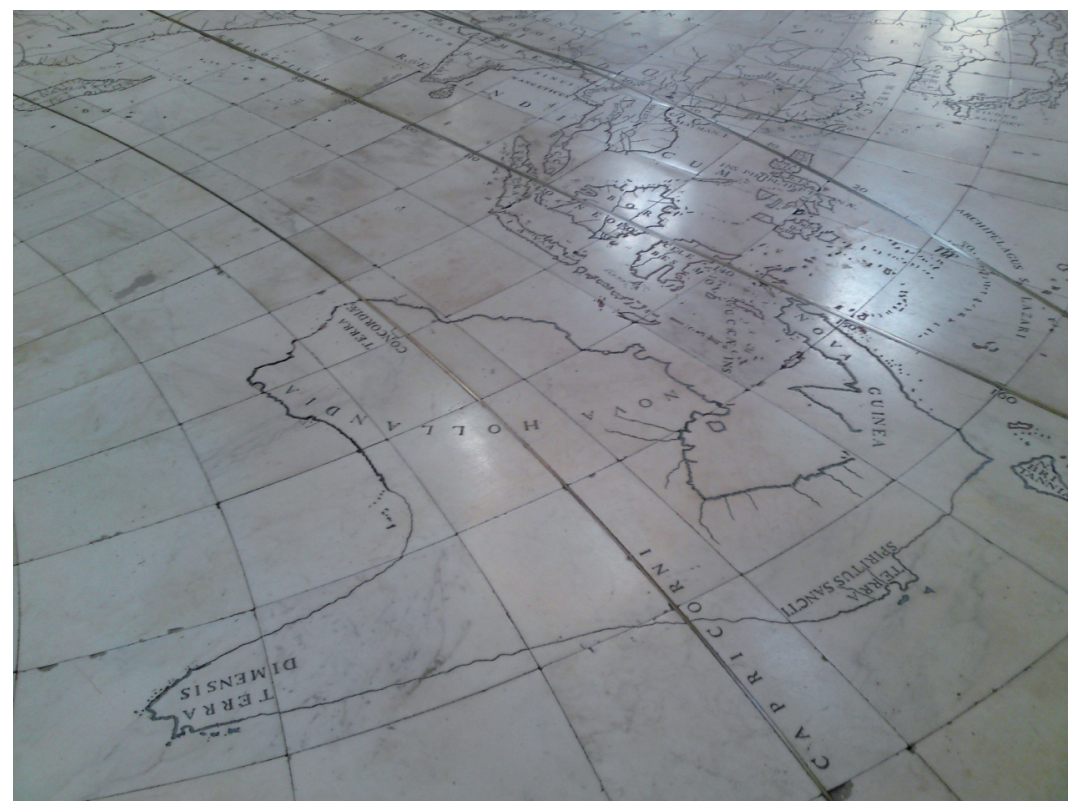

Op de marmeren wereldkaart die op de vloer van de Burgerzaal van het Stadhuis van Amsterdam - nu het Koninklijk Paleis - ligt, staat in het Oostelijk Halfrond het Terra Dimensis afgebeeld. Koninklijk Paleis op de Dam, Amsterdam.

Zo stonden de bekende speculaties in tulpenbollen zeker niet op zichzelf. Speculaties en weddenschappen vormden een onderdeel van de dagelijkse bezigheid van vele kooplieden, zoals dit door de eeuwen heen in alle markten is voorgekomen. ${ }^{\text {IO }}$ Over de uitleg en uitvoerbaarheid van de contracten waren regelmatig meningsverschillen die werden vastgelegd bij een notaris. Zo komen wij voor het eerst ook Antonio van Diemen tegen en wel in een akte van 26 oktober I6o9 bij Notaris J.Fr. Bruyningh. ${ }^{\mathrm{II}}$ Het ging - zo toepasselijk - om een aandeel in de VOC. Volgens de akte hadden Jan Engels en Antonio Van Diemen, kooplieden te Amsterdam aan Aernout van Libergen, ook koopman te Amsterdam door tussenkomst van makelaar Isacq Florian een aandeel van 500 ponden Vlaams in de VOC bij de kamer Amsterdam verkocht op een koers van I3 8 procent te betalen en te leveren na één jaar. Het probleem was dat Van Libergen weigerde het contract te tekenen omdat hij twijfelde aan de gegoedheid van de verkopers. Van Libergen verklaarde dat hij van het begin af aan bij de makelaar borgstelling had vereist en dat hij bij het ontbreken hiervan de overeenkomst voor vervallen verklaarde. 
Het ging dus om een aandeel in de VOC. Echter, de VOC heeft nooit aandelen uitgegeven. Als men werkelijk een VOC-aandeel wilde kopen, dan dienden koper en verkoper naar het kantoor van de VOC te gaan om aldaar in het grootboek de transactie te laten optekenen. Wij zouden nu spreken over een optie of termijnaffaire. Aernout van Libergen kocht het recht om op termijn een aandeel in de VOC te verwerven tegen een vastgestelde koers. Nu wist hij natuurlijk dat de verkopers geen aandeel in de VOC bezaten. Het ging dus om een puur speculatieve transactie waarbij verkopers een koersdaling, en kopers een koersstijging verwachtten. Deze opties werden veel verhandeld op de Amsterdamse beurs. Het bedrag was over het algemeen 500 ponden Vlaams of een veelvoud daarvan.

Hiermee stuiten wij op een ander merkwaardig fenomeen. De 'gulden', waarnaar uiteindelijk alle transacties werden teruggerekend, bestond in werkelijkheid niet. Het was een rekeneenheid. Eén pond Vlaams was omgerekend zes gulden. De koers van de optie was dus 3.000 gulden plus 38 procent dus 4.I40 gulden. Een groot bedrag en wij kunnen ons na bijna vierhonderd jaar de vraag van Van Libergen goed voorstellen of Van Diemen en zijn kompaan voldoende buffer bezaten om grote uitslagen in de koers op te kunnen vangen. Wij mogen ervan uitgaan dat Engels en Van Diemen aan het kortste eind hebben getrokken. Dat was maar goed ook voor hen, want een jaar later was de koers van het aandeel aanzienlijk gestegen. De koers lag toen op I54 procent hetgeen een verlies van 400 gulden zou hebben betekend. In het voorjaar van I6II stond de koers zelfs boven de 200 procent.

Van Diemen was bepaald niet de enige die in 1609 speculeerde op een verdere daling van het VOC-aandeel. Doordat de koers juist steeg, kwam menig speculant - er was zelfs een consortium met grote en bekende namen - in ernstige moeilijkheden en een enkeling ging failliet. $^{\mathrm{I} 2}$

Daarna volgde in juli i6ro een onduidelijk wisselprotest waarin Van Diemen weer optrok met Engels. ${ }^{13}$ Het lijkt erop dat Engels en Van Diemen zich lieten gebruiken door een Antwerpse koopman tegenover een onwillige debiteur. Dit is overigens de laatste keer dat Van Diemen en Engels samen genoemd worden. Daarna wordt het spoor van Engels onduidelijk: was hij in I6I5 de koper van het kleine schip de 'Groene Draeck'? ${ }^{14}$ In ieder geval was hij in I62I nog in leven, toen een koopman die bij hem inwoonde, betrokken was bij een wisselprotest. ${ }^{15}$

Van Diemen komen wij de volgende jaren regelmatig tegen als assuradeur van zeeschepen en hun lading. Het was zoals eerder gezegd is, een activiteit die kooplieden vaak naast hun eigenlijke nering erbij deden. Hoe ging het in zijn werk? Een eigenaar van een schip, of van lading aan boord van een schip verzocht aan een makelaar deze voor hem te doen verzekeren. De eigenaar gaf dan aan de makelaar de naam 
van het schip en de schipper, de waarde van de te verzekeren goederen en de route, kortom alle nodige gegevens. De makelaar ging hiermee vervolgens ter beurze en polste de kooplieden onder welke voorwaarden en voor welk bedrag zij wilden intekenen. Was het bedrag voltekend en waren de voorwaarden akkoord, dan maakte de makelaar de polis op. De premie varieerde per route en ook naar gelang de politieke situatie. Ook hier waren natuurlijk riskante en minder riskante transacties mogelijk. Het waren vaak hele consortia waarbij soms meer dan twintig assuradeurs en kooplieden gezamenlijk een polis vol tekenden.

De assurantiemarkt was in de tijd van Van Diemen van stadswege gereguleerd door de keuren van 3i januari I598 en 27 januari I6I2. De polissen waren voorgedrukt om bedrog te voorkomen en partijen mochten niet van het bepaalde in de keuren afwijken, wat in de praktijk echter toch veelvuldig voorkwam. De courtage van de makelaar bedroeg eenderde procent over het verzekerde bedrag, te voldoen door de verzekeraar en verzekerde ieder voor de helft. De premie moest door de polishouder bij afsluiten van de polis worden voldaan. ${ }^{\mathrm{I} 6}$

Over welke bestemmingen verzekerd konden worden en een indicatie van de premies die de verzekeraars wilden bedingen, is een document uit januari I6I5 bewaard gebleven. ${ }^{\text {I7 }}$ Dit document circuleerde onder de verzekeraars en was opgesteld door Amsterdamse verzekeraars die ontevreden waren over de premies die door de onderlinge concurrentie laag geworden waren. Het document was een voorstel voor vaste afspraken over de premies. Wat het bijzonder maakt, is de lange lijst met maar liefst 95 bestemmingen over heel Europa en ook daarbuiten.

Het geeft aan hoezeer Amsterdam tot handelscentrum was uitgegroeid. De veelheid en variatie van de bestemmingen is indrukwekkend. Van voor de hand liggend tot exotisch. Van Londen naar Holland werd een premie van twee procent voorgesteld, van Constantinopel naar Venetië zes, Van Angola naar Portugal acht, van Archangel naar Venetië negen.

Om het risico te spreiden schreven assuradeurs in op vele polissen. In hun streven de polis rond te krijgen keken de makelaars niet altijd nauwkeurig naar de kredietwaardigheid van de inschrijvers. Onder de personen die in dezelfde tijd als Van Diemen failliet gingen, oefenden velen het assuradeurvak uit. Dat wil niet zeggen dat er alleen maar krabbelaars inschreven. Met Van Diemen tekenden grote en kleine kooplieden. Het aantrekkelijke was dat de premie geheel of gedeeltelijk contant werd voldaan en dat over uitbetalingen doorgaans lang gechicaneerd werd. De verzekeraars hadden dan ook de naam onbetrouwbaar te zijn. ${ }^{\text {I8 }}$ Was er schade, dan diende die onverwijld aan de assuradeurs gemeld te worden met alle belangrijke gegevens. Dat gebeurde over het algemeen via een notaris. Zo zijn wij ook op de hoogte van de assuradeuractiviteiten van Van Diemen. 
Van Diemen tekende voor bedragen tussen de 75 en 250 ponden Vlaams. Het waren veelal Portugese kooplieden van wie hij de lading verzekerde en het waren ook Portugese makelaars die de polissen afsloten.

In de archieven krijgen wij in zoverre een vertekend beeld, omdat wij alleen de zaken terug zien die mis zijn gelopen en Van Diemens activiteiten als handelaar in specerijen bijna geheel aan ons oog ontrokken blijven. Maar zij zijn daarom niet minder instructief. Zo kwam in februari 1613 het schip van schipper Martijn Darisaga aan in Rouen in Frankrijk met een lading wol van de Portugese koopman Mathieu Rodrigues uit Biskaye, dat wil zeggen Noord-Spanje. Bij het uitladen bleek de wol zeer nat, wat schade betekende. ${ }^{\text {I9 }}$ Het was op drie schepen tegelijk dat koopman Rodrigues natte, maar goedverzekerde wol bleek te vervoeren. De negen assuradeurs, waaronder dus Van Diemen, lieten het er niet bij zitten. Zij machtigden de hun goedbekende Adam Ray die in Rouen woonde, de wol voor hen te onderzoeken en sommeerden Rodrigues de wol niet te verkopen tot dit onderzoek was afgelopen. Rodrigues stemde hiermee in en beloofde dit aan zijn zaakwaarnemer in Rouen te schrijven. 'Maar hij vreesde dat al het nodige gebeurd was,' zoals hij aan het consortium schreef. ${ }^{20}$ Geen fraaie kwestie lijkt ons nu nog.

Een paar maanden eerder was onderweg van Brazilië naar Porto het schip 'Nossa Senora de Nasara' door zeerovers gekaapt met aan boord goederen van de Portugese koopman Garcia Gomes Victoria, die in Amsterdam woonde. ${ }^{2 \mathrm{I}}$ Ook betrof het eens goederen, weer voor een Portugese koopman in Amsterdam, die met een schip van Lissabon naar Goa, Cochin of andere plaatsen vervoerd werden, maar in andere schepen dan eerst aangegeven werd. ${ }^{22}$ Dan waren er het schip 'De Jonas' met schade aan de lading opgelopen tussen Guinea en Livorno ${ }^{23}$ en het schip 'De Appelboom' uit Enkhuizen met schade aan de goederen gedurende de reis tussen Lissabon en Livorno. ${ }^{24}$ Wat te denken van een groot consortium dat in mei i6 I4 een slaventransport verzekerde tussen Luanda in Angola en West-Indië en voor de terugreis naar Sevilla goud, zilver of goederen zonder nadere omschrijving? ${ }^{25}$ Het is overigens in deze polis de eerste keer dat wij Van Diemen onder zijn later zelf aangenomen voornaam 'Antonio' tegenkomen, een teken hoezeer hij in Portugese kringen verkeerde. Weer een ander geval betreft een lading aluin in een schip van Constantinopel naar Venetië. ${ }^{26}$ Op I8 maart I6I6 sloeg het noodlot toe voor Van Diemen. Het schip 'De Engel Gabriël' met aan boord een partij diamanten die Van Diemen met slechts één ander had verzekerd, was tussen Lissabon en Duinkerken door zeerovers gekaapt. Van Diemen raakte door dit alles in het nauw. Ook moest hij nog na vier jaar Ioo ponden Vlaams betalen voor de schade van de 'Nossa Senora de Nasara', op I7 augustus I6I6 kon hij daarvan niet meer dan 75 pond voldoen. ${ }^{27}$ 
Bovendien was er op 3 juni een wissel van roo ponden Vlaams op twee maanden voor een andere affaire op hem getrokken, en door hem geaccepteerd. Deze was ongedekt. Na deze twee maanden wilde Van Diemen niet betalen vóór eind oktober. Daar werd geen genoegen mee genomen door de houder van de assignatie, een zekere Cloosterman, die naar Van Diemen toeging. Hierop werd volgens het verslag in de akte Van Diemen kwaad en schreeuwde vanuit zijn deuropening dat hij niet kon betalen vanwege schade geleden 'door assurantie'. Men besloot uiteindelijk toch tot eind oktober te wachten, maar toen Van Diemen nog steeds niet betaalde, werd op го november I6 6 in een akte gesproken van zijn faillissement. ${ }^{28}$

De makelaar Henrico Zacuta royeerde op I3 december I6I6 dertien verzekeringen namens zijn opdrachtgevers, omdat Van Diemen failliet was gegaan en zich als 'bankroetier' gedroeg. ${ }^{29}$ Van Diemen zelf was inmiddels uit Amsterdam vertrokken. Zoals bijna iedere gefailleerde ontvluchtte ook hij de stad. Hij liet niet alleen verzekeringsschulden achter. Bij de kamer van de VOC in Amsterdam en bij koopman Voet stond hij gezamenlijk voor 2.683 gulden en I5 stuivers in de boeken. Later zou blijken dat hij daarnaast bij ons onbekende crediteuren in het krijt stond voor circa 9 duizend gulden. ${ }^{30}$ Eenmaal weer in goeden doen zou Van Diemen schrijven over 'mijn ongelegenheyt', die blijkbaar een schuld van ongeveer I2.000 gulden had veroorzaakt. ${ }^{\text {I }}$ Van Diemen week uit naar zijn ouderlijk huis. Buiten het grondgebied van de Republiek was hij daar onbereikbaar voor zijn schuldeisers. Niet iedereen was die jaren welkom in Culemborg. De graaf weigerde twee jaar later aan de aanhangers van Van Oldenbarnevelt asiel. De vluchtende hofpredikant Uitenbogaert schreef daarbij: 'Ik ben geen banqueroutier, noch die ijemandt hebbe te cort gedaen in 't minste.'32

Hoe indertijd in Amsterdam tegen een faillissement werd aangekeken, blijkt uit verscheidene passages van Bredero's Spaanschen Brabander, die in I6I7 verscheen. Bredero onderscheidde twee soorten bankroetiers: de moedwillige oplichter en degene die door ongeluk werd getroffen. Zoals in het stuk enerzijds gezegd wordt:

'En speelden hy Bankerot sonder noot, ic sou hem hangen dat ' $k$ de macht hat. (vs. 368-69)

Maar aan de andere kant

'Dat een mensch tot een ongeluc komt door een ander, of door ongeval op Zee,

Of door ander avontuer, daer heb ick seker melyden mee.' (vs. 372-73) 
Ophanging bij de Nieuwe Brug was sedert I53I de straf die in Amsterdam bij faillissement kon worden uitgesproken. Interessant is dat Brederode en zijn publiek goed op de hoogte waren van de bijzondere status van Culemborg. Zo schreef hij in de Klucht van de Koe (1612):

'Hoe duyvel souwenset maken met de Banckeroetiers? Die 't so byster en grof de Mienteman ontstelen, En om een Haver-stro eens Haes-op na Kuylenburgh spelen, Doch Keyser Karel die stelden daer tegen een keur; Dat men sulcke Dieven sou hangen in haar eygen Deur. (VI. 40-44)

Deze keur werd door Karel V uitgevaardigd op 7 oktober I53I en later bevestigd bij het Eewich Edict van 4 oktober I540. Volgens het Groot Placaet-Boeck behoorde het tot de taak van de rechters te procederen ende doen procederen tegens de voorsz Banckerouten ende Fugitiven, ende die te doen pugnieren ende brengen ter doot mette koorde'. ${ }^{33}$

Van Diemen probeerde naar eigen zeggen vanuit Culemborg een jaar lang te redden wat er te redden viel, maar dat bleek onbegonnen werk. Hij zou daarbij aangeboden hebben om in dienst te treden van de VOC om met zijn verdiensten als koopman zijn schulden weg te werken, maar dit werd hem geweigerd.

Uiteindelijk waagde hij het erop onder valse naam aan te monsteren op het schip 'Mauritius' van de kamer van Amsterdam: 'Thonis Meeusen uit Utrecht als soldaat in de rang van vaandrig voor acht gulden in de maand'. Wanneer dat op de gebruikelijke manier is gegaan dan moet hij dat persoonlijk tegenover twee bewindhebbers een maand of twee voor zijn werkelijke vertrek in het Oostindisch Huis aan de Kloveniersburgwal in het hartje van Amsterdam gedaan hebben.

Dat hij uitgerekend in Amsterdam waar hem wellicht de doodstraf boven het hoofd hing, aanmonsterde zonder enige steun of protectie, is maar moeilijk te geloven. Hij was immers bekend in Amsterdam. De latere stadssecretaris Boudewijn Cortenhoeff noemde hem nog in I630 'mijn goede speciale vriend en speelgenoot'. ${ }^{34}$ Cortenhoeff was een van de voormannen van de contraremonstranten. In een hekel-dicht van Vondel was hij 'Kortenboeff een kornuit van Reintje de Vos, achter wie niemand minder schuilging dan Reinier Pauw, de machtige oprichter van de VOC. Uit de latere correspondentie over Van Diemen blijkt dat ook de bewindhebbers in Amsterdam aan hulp van vrienden dachten. ${ }^{35}$ Ook Van Diemen zelf hintte later op bescherming van hoger hand. Coolhaas dacht dat Van Diemen op steun kon rekenen van Graaf Floris II, maar van enig contact van vader of zoon met hem blijkt niets. ${ }^{36}$

In het stadhuis van Amsterdam, nu het koninklijk paleis, is een afbeelding te vinden van Icarus die uit de lucht ter aarde stort. Hij is gebeeldhouwd boven de ingang van de faillissementskamer of 'desolate 
boedelskamer', die sedert 1643 de faillissementen in Amsterdam afhandelde. De loslatende vleugels van Icarus geven de vrije val aan waarin iemand terechtkomt die niet meer aan zijn verplichtingen kan voldoen. In de versierde rand boven Icarus zijn een lege geldkist, kapotte beurzen, gescheurde papieren en ratten afgebeeld.

Het heimelijke vertrek van Van Diemen uit Amsterdam heeft dertig jaar later een onwaarschijnlijk gevolg gekregen dat is afgebeeld in een van de twee wereldhelften op de marmeren vloer in het stadhuis die ik aan het begin van dit hoofdstuk beschreef. In de oostelijke wereld helft is het Terra Dimensis ingelegd, Van Diemens Land, wij kennen het nu als Tasmanië.

Juist op deze vloer is zijn naam vereeuwigd. Geen andere Nederlander viel die eer te beurt.

De indiensttreding bij de VOC was een noodsprong. Hij had zich tot dan waarschijnlijk nooit verder gewaagd dan Holland en Zeeland, maar trad nu de wereld binnen van de machtige Verenigde Oostindische Compagnie.

\section{Noten}

I. Brugmans H., Opkomst en bloei van Amsterdam (Amsterdam I9II), I07. 'In I6ro werd door den Venetiaanschen gezant Contarini het getal der inwoners van Amsterdam geschat op 50.000. ...Amsterdam telde in December I630 ruim II5.000 zielen of "hoofden", zoals Wagenaar zegt.'

2. Elias, J. E., De vroedschap van Amsterdam, 1578-1795 (Haarlem I903) 286.

3. NA, Archief VOC, Overgekomen brieven en papieren uit Indië aan de Heren XVII en de kamer Amsterdam nr Io69, (voortaan NA VOC Io69 OBP) f 447, 5 augustus i6ig.

4. Stapel, F. W., Geschiedenis Van Nederlandsch Indië III, 24I.

5. Coolhaas, 'Gegevens over Antonio Van Diemen', 472.

6. GAA Not.Arch. 379 fol. 596. Nots.: Jacob \& Nicolaes Jacobs. /J.E. Elias, De Vroedschap van Amsterdam I, 8o.

7. Er woonden in die tijd meer Van Diemens in Amsterdam, maar zij waren geen familie van Antonio. Het betrof hier een Antwerpse familie, die aan het einde van de zestiende eeuw zich in Amsterdam had gevestigd.

8. Le Moine De L'espine, J., De koophandel van Amsterdam, naar alle gewesten des werelds 2 delen (Rotterdam I763) 47.

9. Have, O. ten, De leer van het boekhouden in de Nederlanden tijdens de zevetiende en achttiende eeuw (Delft I933) I6. 
Io. Kindleberger, C. P. en R. Z. Aliber, Manias, panics, and crashes: a history of financial crises (Hoboken, N.J., 2005).

II. GAA Not.Arch. iI7 f 8I, Nots. J.Fr.Bruyningh.

I2. Dillen, J. G. van, 'Isaac Le Maire en de handel in actiën der OostIndische Compagnie', Economisch-Historisch Jaarboek I6 ('s-Gravenhage, I930) I-I65.

I3. GAA Not. Arch. iIg f I59 en I59v, Nots. J.Fr.Bruyningh.

I4. GAA Not.Arch. 378, f 684 Nots. Nic. Jacobs.

I5. GAA Not. Arch. 735 f 3, nots. H. Bruyningh.

I6. Vergouwen, J. P., De geschiedenis der Makelaardij in Assurantiën hier te lande tot 1813 ('s-Gravenhage I945) 33-42. Noorderkerk, H., Handvesten der stad Amstelredam 4 delen. (Amsterdam I748) 653 en Io62.

I7. GAA Archief verzekeringswezen N 33.90.04

I8. Dooren de Jong, E. L. G. den, 'De practijk der Amsterdamsche zeeverzekering in de I7de eeuw', Het Verzekerings-Archief ('s-Gravenhage I927) I3.

I9. GAA Not.Arch. 253 reg. I2, f 38 v. Nots. Jacob Meerhout, 2 maart IGI3.

20. GAA Not.Arch. I3I f.I II, IIv. Not. J.F.Bruyningh.

2I. GAA Not Arch. 375 f 498 Nots. Nicolaes Jacobs iI september i6ı2.

22. GAA Not.Arch. I29 f I96 v, I97. Nots. J. Fr. Bruyningh, I8 januari IGI3.

23. GAA Not.Arch. 258 f 83 Nots Jacob Meerhout 28 januari i6I4.

24. GAA Not.Arch. 258 f 87 Nots. Jacob Meerhout I6I4 29 maart.

25. GAA Not.Arch. 254 f I88, I88v. Nots.Jacob Meerhout 22 mei I6I4.

26. GAA Not.Arch. $254 \mathrm{f}$ 30I Nots.Jacob Meerhout 4 augustus I6I5.

27. GAA Not.Arch. 667 omslag 24, f 43, 43v Nots. Jan Warnaertsz. 8 december 1632 .

28. GAA Not.Arch. 254 f 43I, 43IV, 432, 432v Nots. Jacob Meerhout 7 augustus I6I7.

29. GAA Not.Arch. 622 f 64v-65, Nots. Sibrant Cornelisz. i3 dec. i6i6.

30. NA VOC OBP Iog8 544-546 Brief Van Diemen aan Pieter de Carpentiermet afrekening uit Batavia dd 20 novemberı629.

3I. Ibidem.

32. AHGC 695 .

33. Groot Placaet-Boeck I, 3I5.

34. Valentijn, F. Oud en nieuw Oost-Indiën IV (Dordrecht I724) 29I.

35. NA VOC 313 fol.246, afgedrukt in H. T. Colenbrander, Jan Pieterz. Coen, bescheiden omtrent zijn bedrijf in Indië 7 delen ('s-Gravenhage I9I9-I923), 400.

36. Coolhaas, 'Gegevens over het leven van Antonio van Diemen', 485. 


\section{De lokroep van de specerijen en de oprichting van de VOC}

Tegenwoordig kunnen we ons nauwelijks meer de kracht verbeelden van de geurige verleiding waaraan Europa zich willig overgaf aan het einde van de middeleeuwen. Dante schreef rond I300 in de Inferno van zijn Divina Comedia als een van de eersten over de in zwang gekomen kostbare gewoonte om Oosterse specerijen in het eten te gebruiken. In Europa groeide de vraag, en specerijen werden onmisbare ingrediënten in maaltijden, dranken en medicijnen van niet alleen de adel, maar ook van de opkomende middenklasse in de steden. Hoe snel het gebruik was ingeburgerd, is te lezen in een manuscript uit $\mathrm{I} 393$ getiteld Le Ménagier de Paris waarin de ingrediënten en recepten voor een feestmaal werden opgesomd. Peper, nootmuskaat, foelie, kruidnagel en kaneel werden in forse hoeveelheden voorgeschreven met de prijzen erbij die hiervoor op de markten en in de winkels van Parijs gerekend werden. ${ }^{\mathrm{I}}$ Specerijen waren een betaalbare luxe geworden en daarmee ideale handelswaar, vooral omdat zij zich makkelijk over grote afstanden lieten vervoeren.

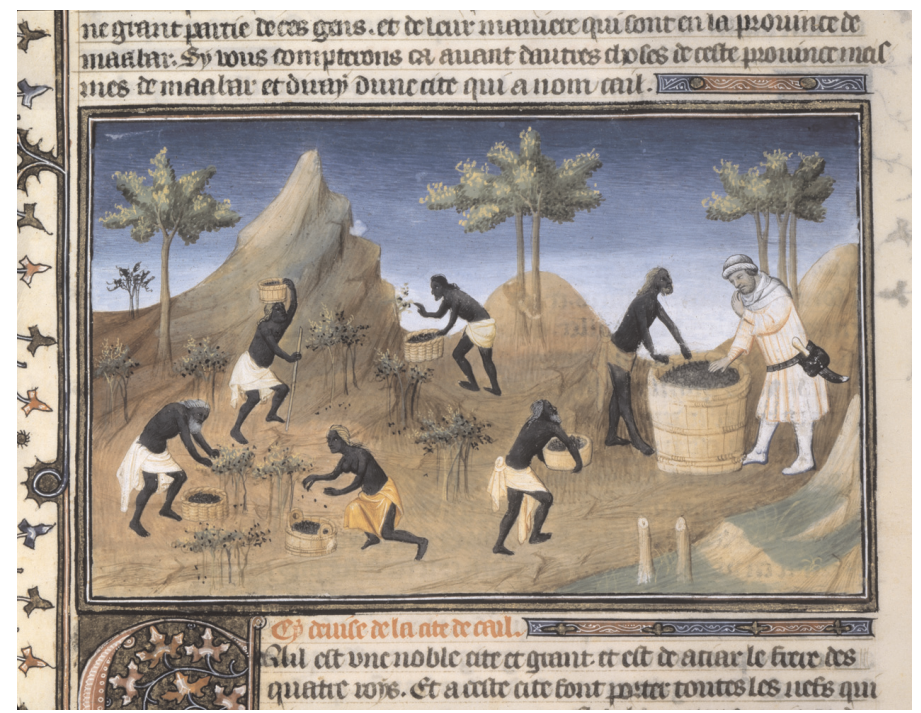

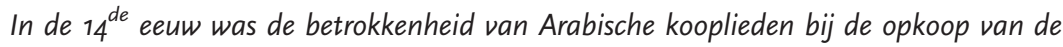
peper bekender dan de peperoogst zelf. Bibliothèque National de France, Parijs. 


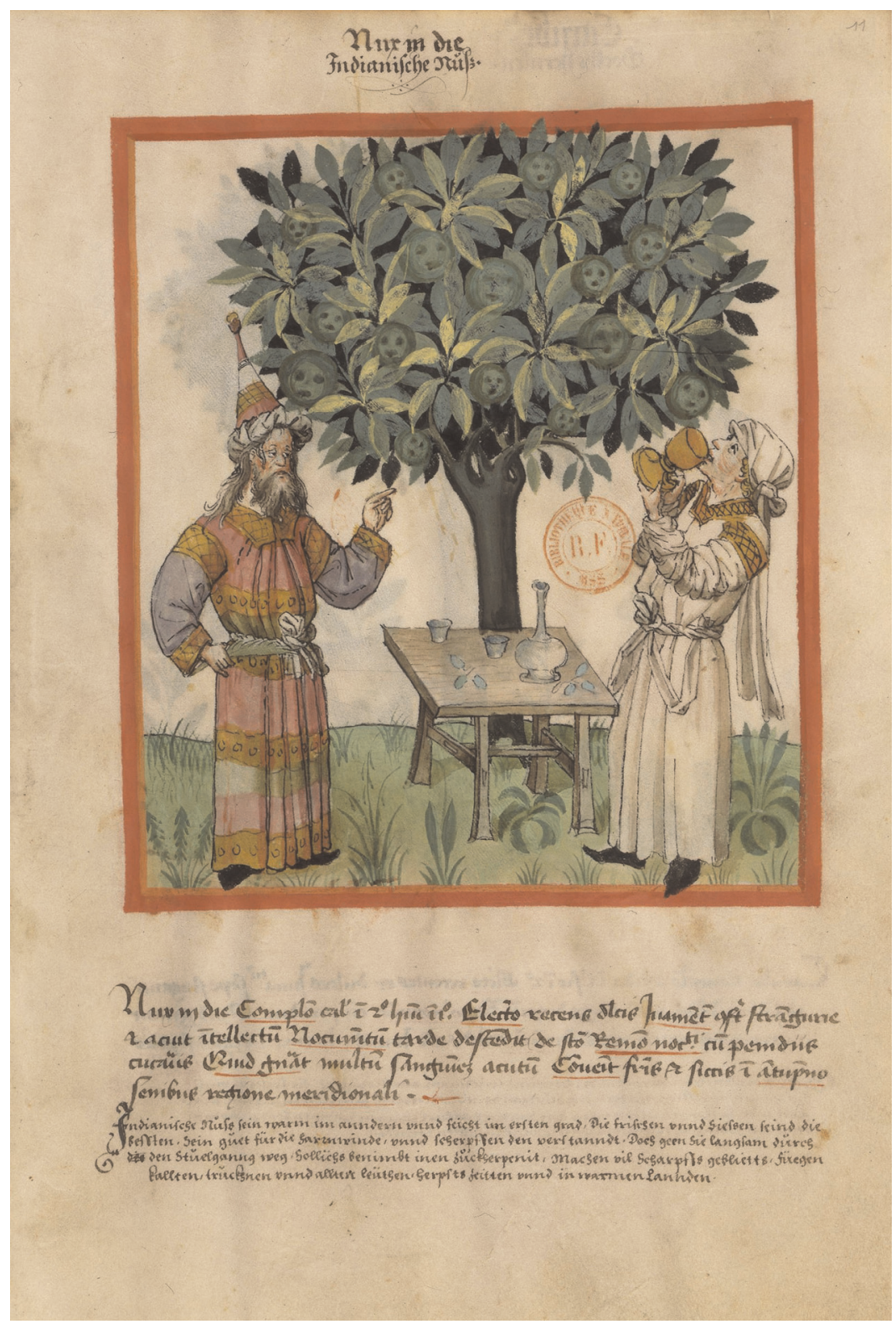

Hoe mystiek de specerijen waren, blijkt uit deze 14de-eeuwse fantasie over de nootmuskaat. Een levend wezen aan een boom die door een tovenaar geoogst werd. Bibliothèque National de France, Parijs. 
Met deze begeerte groeide de handel. De gevolgen daarvan waren groot. Zo werd de islam in de veertiende en vijftiende eeuw in het kielzog van de islamitische handelaren op de specerij-eilanden in de Indonesische Archipel geïntroduceerd. En, was niet de belangrijkste drijfveer achter de ontdekkingsreizen over de oceanen de wens van de Portugezen en de Spanjaarden om rechtsreeks naar deze legendarische eilanden te varen? Hierover schreef op 24 juni I474 de Florentijnse humanist en geograaf Paolo dal Pozzo Toscanelli een brief aan een hoveling van de Portugese koning waarin hij uitlegde dat de aarde rond was en dat daarom over de oceaan naar het westen zeilend de kortste weg zou zijn naar de specerij-eilanden in de Oriënt. Deze brief werd richtsnoer bij Columbus' ontdekkingsreizen over de Atlantische Oceaan. Het zou daarbij echter blijken dat Toscanelli zich nogal verrekend had in de afstand en dat, voordat men wist dat men bewoners ontmoette van een tot dan toe onbekend continent ze al de naam Indianen hadden gekregen. $^{2}$

De Portugees Bartolomeus Diaz rondde in I486 als eerste Kaap de Goede Hoop waardoor hij de Indische Oceaan op kon varen. Over deze ontzagwekkende prestatie schreef de Italiaanse handelaar Piero Vaglienti nuchter dat het grootste belang hiervan zijns inziens was dat de specerijen die tot dan toe Europa via het Midden-Oosten bereikten voortaan uit Lissabon zouden komen. Dat zou een zware slag betekenen voor de Turken en de Venetianen. ${ }^{3}$

Bizar, maar illustratief, is het verhaal van edelen uit Gascogne die rond ${ }_{5} 66$ al hun bezittingen verkochten en zich aan het hoofd stelden van achthonderd man om een kapersnest op de westkust van Afrika te stichten. De buit, zo stelden zij zich voor, zou bestaan uit Portugese schepen die jaarlijks rijkbeladen met specerijen uit India langs zeilden. Natuurlijk liep dit avontuur anders en dramatisch af. ${ }^{4}$

En wat te denken van de tweede vloot die in 1598 uit Amsterdam naar Oost-Indië zeilde? Vier van de acht schepen keerden al na vijftien maanden terug met een lading specerijen goed voor een winst van ruim twee miljoen gulden, meer dan drie keer de inleg van de initiatiefnemers. Ongekende kapitalen voor de toenmalige Hollandse kooplieden. In dit perspectief moet het streven gezien worden van vooral de Amsterdamse handelaren om het monopolie van de handel in specerijen te veroveren. Een hogere inzet was moeilijk denkbaar. Hiervoor werd in I602 de Verenigde Oostindische Compagnie (VOC) opgericht.

'De organisatie van de VOC in de Republiek is reeds vele malen beschreven. Toch valt er ook hier niet aan te ontkomen om althans in hoofdlijnen de bestuursstructuur te schetsen', zo begon Gaastra in I989 het eerste hoofdstuk van zijn Bewind en beleid bij de VOC van 1672-1702. ${ }^{5}$ Het aantal van deze beschrijvingen is in de twee decennia daarna alleen maar gegroeid, met een kleine explosie rond 2002, 400 
jaar na de oprichting van de VOC. En ook de nu voorliggende studie zal ermee beginnen. Niet zozeer om opnieuw een overzicht te geven van die merkwaardige structuur met aan het hoofd een college van zeventien heren, maar om nader in te gaan op een viertal vragen die voor deze studie relevant zijn: waarom werd de VOC in I6o2 opgericht, wie had de macht, waarom kregen de aandeelhouders geen zeggenschap en waar kwam de in haar tijd bijzondere structuur vandaan?

Natuurlijk zijn deze vragen in de literatuur aan bod geweest, maar de gegeven antwoorden verschillen op een aantal punten van de resultaten van mijn eigen onderzoek. Het maakt deze inleiding hopelijk interessanter voor de lezer, want ik tart hiermee de conclusie die Enthoven in de zomer van 2007 trok bij zijn recensies van De geoctrooieerde compagnie, de VOC en WIC als voorlopers van de naamloze vennootschap en de verzamelbundel VOC 1602-2002, 400 Years of Company Law. Enthoven stelde: 'Afsluitend kan ik me niet anders dan aansluiten bij de conclusies van Gaastra in 2005. Het meeste is nu wel over de VOC gezegd, zeker als handelsfirma. Bij het lopende en komende onderzoek in de VOC-archieven zal de Compagnie naar de achtergrond wijken en zal de Aziatische geschiedenis voorop komen te staan. ${ }^{6}$

Dat ooit het laatste woord over de VOC als vennootschap geschreven zal worden, denk ik overigens niet. De geschiedenis van de VOC is van belang niet alleen voor de beschrijving van de Nederlandse en Europese expansie, maar ook voor de economische wereldgeschiedenis. Er is misschien wel enige overdrijving in de volgende uitspraak uit I9II van de latere Nobelprijswinnaar Murray waarmee hij de naamloze vennootschap op een voetstuk plaatste: 'I weigh my words when I say that in my judgment the limited liability corporation is the greatest single discovery of modern times ... . Even steam and electricity are far less important than the limited liability corporation, and they would be reduced to comparative impotence without it." Mede door het gegeven dat internationaal de primeur onomstreden aan de VOC wordt gegeven, zal de belangstelling voor de VOC als vennootschap wel blijvend zijn. ${ }^{8}$

Er is in de historiografie het nodige geschreven over de motieven van de Amsterdamse kooplieden om aan het einde van de zestiende eeuw de handel op Azië over zee te beginnen toen de kennis en de middelen daartoe beschikbaar kwamen. Zoals Gaastra in zijn standaardwerk over de VOC deze bondig samenvatte, waren het volgens de diverse schrijvers zowel negatieve - men werd buitengesloten - als positieve - het aanbod van specerijen bleef ver achter bij de vraag. ${ }^{9}$ Of zoals Fruin stelde: 'Zo hebben wij ons waarlijk niet te verwonderen, dat de Hollanders de wedstrijd gaan wagen, veeleer dat zij die zolang hadden ontweken. ${ }^{\text {,o }}$

Volgens Van Dillen was de directe aanleiding niet een belemmering van de vaart tussen Nederland en het Iberisch schiereiland. Juist de ge- 
slaagde poging van Philips II om de Nederlanders uit te sluiten van de specerij- en peperhandel door in I59I een contract met een internationaal consortium te sluiten waardoor deze handel aan Amsterdam voorbij ging, was waarschijnlijk de reden, waarom de Amsterdamse kooplieden na een zorgvuldige voorbereiding besloten zelf naar Indië te varen. ${ }^{\text {II }}$ In deze laatste zienswijze worden wij door de bronnen op een bijzondere wijze ondersteund. Het archief van het scheepvaartmuseum te Amsterdam herbergt een bijzondere bundel papieren uit I594 die professor Warnsinck in I936 daar vond en die hij 'De wetenschappelijke voorbereiding van de eerste scheepvaart naar Oost-Indië' doopte. ${ }^{\text {I2 }}$ De bundel bevat de diverse informatie waarop de Amsterdamse handelaren hun beslissing baseerden om die eerste vaart uit te rusten. Zo zijn er stukken over de te varen route in een memorie van de beroemde predikant en geograaf Plancius, een brief van Jan Huygen van Linschoten uit Goa, uitgebreide marktinformatie en nog meer. Maar voor ons onderwerp springt er één stuk uit vanwege de bevlogen visie over de doelstellingen van de initiatiefnemers. De schrijver had het over de stad Bantam op Java, of zoals hij zei 'Sunda'. Hij onderkende het strategisch belang van deze plaats waar de Portugezen weinig invloed hadden. De specerijen uit Banda en de Molukken werden hier verhandeld met Indiërs, Turken en Chinezen: hier zou men een handelsplaats kunnen maken 'gelijck Antwerpen plach te wesen tusschen die Noort-Landen, Spaigne end Italien', maar dan tussen Europa, India en China met greep op de specerijen. De koning van Bantam zou men met geld en goede contracten moeten paaien en 'Lichtelicken souden wij connen verwerven, dat niemant anders van deze landen mocht daer comen hanteren (handelen-w), dan die die het eerste contract hadde gemaect so dat alle dese navigatie ons zoude toebehooren' en dan zou het mogelijk zijn 'die stapel, die te Venetyen ende Marsilien is, in deze landen te brengen, soo dat men 't peper ven hyr tot Italien, Vranckrijck ende Duytslandt zoude voeren. ${ }^{\text {I3 }}$

Mijn verbazing blijft over het feit dat nog voordat één Hollands schip de Kaap was gerond, of voordat één Nederlander voet aan wal had gezet op Java, niet alleen al op een Europees monopolie in de specerijen werd gemikt, maar dat ook al het plan was geboren een belangrijke handelsvestiging op Java bij de Straat Sunda op te zetten. Deze dubbele doelstelling bleef de kern van de strategie van de VOC. Het buitengewone is niet alleen dat zo vroeg zo'n ambitieuze strategie werd ontwikkeld, maar dat deze in haar simpele hoofdlijnen later ook nog voor Coen en Van Diemen zou blijven gelden. Het was een doortastende, maar ook een bijzonder agressieve aanpak.

Terwijl de eerste vloot uit Amsterdam op Indië (I595-I597) de kosten nauwelijks goedmaakte, werd de tweede scheepvaart (I598-I599) op Indië uit Amsterdam zoals eerder gezegd is, een weergaloos commercieel succes. Het gevolg was dat in Europa de specerijhandel op zijn kop 
werd gezet. Tot dan toe liep de aanvoer van specerijen via Lissabon of de grote karavaanroutes die eindigden in Alexandrië en Aleppo. Toen in december 1599 het bericht van het ongehoorde Hollandse succes doordrong in Aleppo, dachten de handelaren van de Engelse Levant Company eerst dat het een flauwe grap was waaraan een ervaren handelaar geen geloof behoorde te hechten. De berichtgever 'is known to jest' zo schreef de ene Engelse handelaar aan de andere. Maar toen het waar bleek te zijn, brak paniek uit. De Britse agent William Aldrich overzag direct de gevolgen en schreef: 'This trading to the Indies have clean overthrown our dealings to Aleppo, as by experience we shall see. ${ }^{\text {"4 } 4}$ Volgens een andere agent was iedereen in Aleppo 'fearfull of spices', niemand durfde hierin te handelen door het Hollandse succes. Terecht noemde Steensgaard het 'een revolutie. ${ }^{15}$ In 1599 werd het zwaartepunt van de specerijhandel in Europa verplaatst naar Amsterdam.

Zo snel als hun succes was, zo snel ontstonden ook problemen voor de Amsterdamse handelaren. In de literatuur wordt vaak ten onrechte de concurrentie door elders in de Republiek opgerichte compagnieën voor de vaart op Indië als voornaamste daarvan genoemd. Dit beeld is met name opgeroepen in de eerste beschrijving van de oprichting van de VOC door Van der Chijs in het midden van de negentiende eeuw en deze zienswijze heeft tot nu stand gehouden. ${ }^{16}$ Het dient mijns inziens afgezwakt te worden. Voor de oprichting van de VOC in 1602 waren 64 schepen uit de Republiek naar Azië gevaren, waarvan 44 afkomstig uit Amsterdam. Van deze 64 schepen waren 25 teruggekeerd in 1602 , en wel 20 die vertrokken waren uit Amsterdam, 4 uit Zeeland en één uit Rotterdam. ${ }^{17}$ De vier Zeeuwse schepen die in de zomer van i60o teruggekeerd waren, deden dat met kleine lading. Het Rotterdamse schip was het enig overgeblevene van de vloot waarmee Olivier van Noort rond de wereld was gevaren. Deze tocht staat geboekstaafd als 'een heldendaad', maar door de verliezen bedroefden sy alle haere reeders die abandonnaerde alle 't schip ende goet voor 't volck. ${ }^{18} 8$

In september I6oo schreef de immer goed geïnformeerde ambassadeur van Frankrijk in de Republiek, de Buzanval, over de dat jaar teruggekeerde schepen in Zeeland en Holland dat veel schepen veilig teruggekeerd waren 'mais c'est avec divers succès. Tous les navires de Hollande (het gaat hier alleen over Amsterdamse schepen -w) c'est à dire dix ou douze, $y$ ont bien fait leurs affaires et en sont retournez riches; mais les quatres de Zellande, les deux de Moucheron ont mal rencontré. ${ }^{\text {I9 }}$ Opvallend is in dit verband ook dat twee Amsterdamse vloten die elkaar op de rede van Bantam troffen op 29 november I60o een afspraak maakten om voor gezamenlijke rekening peper in te kopen. ${ }^{20}$

Zeker, binnenlandse concurrentie dreigde voor de Amsterdammers, maar was nog niet manifest aanwezig. De Engelse handelaren van de 
Levant Company hadden op 3I december I6oo het octrooi voor de oprichting van de East India Company (EIC) verkregen. Deze zou een geduchte concurrent van de Nederlanders worden.

De grootste dreiging kwam van het antwoord dat door de Portugezen en de Spanjaarden op bevel van Philips II werd voorbereid op de Hollandse invasie van de Aziatische wateren. In het grote Portugese fort Malakka werd een vloot bijeen gebracht om de Nederlanders uit Java en de Molukken te verdrijven. Het was de Amsterdammers duidelijk dat slag geleverd zou moeten worden en daarnaast eigen forten in Azië nodig zouden zijn om de zo snel verworven positie te kunnen behouden. ${ }^{2 \text { I }}$ Daarbij kwam dat steeds meer kapitaal van de eerste initiatiefnemers vast zat in de inmiddels jaarlijkse vloten vanuit Amsterdam. Bedroeg in I595 de inleg voor de eerste vloot nog 290 duizend gulden, in I6oI was dit bedrag opgelopen tot I,7 miljoen gulden ${ }^{22}$. Zoals bleek uit de felle memories van de Amsterdamse kooplieden aan de Staten van Holland en daarna aan de Staten-Generaal, moest volgens hen de handel op Azië op andere leest geschoeid worden. Anders gezegd: de Amsterdammers wilden hun greep op de handel behouden, maar daarbij hun eigen investering terugbrengen. De machtige Amsterdamse kooplieden dwongen daarbij staatssteun voor hun onderneming af. Maar de opvatting dat de VOC op initiatief van de Staten-Generaal en met name van Van Oldenbarnevelt werd opgericht, is mijns inziens bepaald onjuist. ${ }^{23} \mathrm{De}$ macht binnen de VOC was stevig in Amsterdamse handen en zou daar ook blijven. Ook in de tijd van Coen en Van Diemen werden de beslissingen over de VOC in Amsterdam genomen.

De vloten die voor de oprichting van de VOC vanuit Amsterdam waren uitgerust, leverden winsten op van vaak meer dan tweehonderd procent. $^{24}$ Aan de participanten van de VOC zou in later jaren nooit zoveel dividend worden uitgekeerd.

Op 20 maart I602 werd het octrooi voor de VOC in de Staten-Generaal vastgesteld. De Franse ambassadeur in Nederland gaf als commentaar 'dat er een staat in de staat was gecreëerd'. Daarmee raakte hij als eerste de kern die de econoom Schumpeter in het begin van de twintigste eeuw in grote ondernemingen onderkende toen hij deze met koninkrijken vergeleek. ${ }^{25}$ Die opvatting echode in de stelling van Terpstra die het karakter van de VOC omschreef als eerder een staat buiten de staat dan een staat in de staat. ${ }^{26}$ Datzelfde deed bewindhebber Coenraad van Beuningen in $\mathrm{I} 684$ toen hij opmerkte dat de VOC zowel een handelsonderneming als een staat was. Hoe autonoom men zich ging voelen, bleek in I644 toen de Heren Zeventien tegenover de StatenGeneraal verklaarden dat zij de bezittingen van de VOC konden verkopen aan wie zij wilden, ook al zou dat aan de koning van Spanje zijn. ${ }^{27}$ Het octrooi en de geschiedenis van de VOC laten zich ook zo lezen. 
Tussen Kaap de Goede Hoop en Kaap Hoorn gedroeg de VOC zich soeverein: de VOC handelde, vocht en veroverde.

De inschrijving op het kapitaal van de VOC was een succes. Zij sloot op 3I augustus I602 om middernacht en leverde een bedrag op van bijna 6,5 miljoen gulden, waarbij met name opvalt dat de inleg van de Amsterdamse bewindhebbers van het eerste uur met steeds ongeveer 20 duizend gulden relatief klein was. De activiteiten van de VOC in Nederland werden verdeeld over zes zogenoemde kamers, waarbij die van Amsterdam de helft te doen kreeg, Zeeland een kwart en de vier kamers in de kleine Hollandse steden Delft, Rotterdam, Enkhuizen en Hoorn ieder een zestiende deel (art.I). De directie kwam in handen van het college van de Heren Zeventien dat bij gewone meerderheid van stemmen kon beslissen. De Heren Zeventien werden gekozen uit de zestig bewindhebbers die de directie voerden in de verschillende kamers. De kamer Amsterdam, waar meer dan de helft van het kapitaal was ingelegd, leverde voor de Heren Zeventien acht bewindhebbers, de kamer Zeeland vier en de kamers Rotterdam, Delft, Enkhuizen en Hoorn elk één. Bij tourbeurt werd de zeventiende benoemd door een van de kamers buiten Amsterdam. (art. 2). In het octrooi was vastgelegd dat de kamers gehouden waren de besluiten van de Heren Zeventien uit te voeren. (art. 3). Tevens werd voorzien in een gezamenlijke boekhouding. Na verloop van tien jaar zou de rekening daarvan worden opgemaakt. Aandeelhouders zou het dan vrij staan uit te treden met hun kapitaal en eventuele winst. (art. I4). De aansprakelijkheid van de VOC voor haar schulden en de beperking van de aansprakelijkheid van de bewindhebbers en daarmee ook van de participanten werd vastgelegd. (art. 42). Daarnaast werden de winstrechten van de participanten bepaald (art. I7) met de regeling van de overdraagbaarheid van de participaties, zoals deze is vastgelegd in het register van de respectieve kamers. Zo werd avant la lettre voldaan aan de vijf basisvoorwaarden die vierhonderd jaar later in de juridische leerboeken van de Harvard Lawschool aan een moderne onderneming worden gesteld:

- Rechtspersoonlijkheid

- Centrale directie

- Beperkte aansprakelijkheid voor de investeerders

- Overdraagbaarheid van aandelen

- Eigendomsrechten van de investeerder ${ }^{28}$

Kortom, de structuur van de VOC was een baanbrekende institutionele innovatie. De zwakke stee in deze opvatting is echter het wel zeer beperkte eigendomsrecht van de investeerders. Zij kregen bij de oprichting een winstrecht, maar geen enkele invloed op de benoemingen van de bewindhebbers. Recent is bij dit manco stilgestaan door Den Heijer en Frentrop ${ }^{29,30}$ die net als Steensgaard eerder ${ }^{3 \mathrm{I}}$ ) dit terecht koppelden 
aan artikel I4 van het octrooi. Daarin staat dat na tien jaar de rekening moest worden opgemaakt waarna het de participanten vrij zou staan uitkering te eisen van hun ingelegde gelden met eventuele winst. Met andere woorden, van permanent kapitaal, een voorwaarde voor rechtspersoonlijkheid, was aanvankelijk geen sprake. Volgens Frentrop en Steensgaard ontwikkelde de VOC zich gaandeweg, haast bij toeval, tot een vennootschap omdat afgezien werd van die tussentijdse afrekening. ${ }^{32}$ Er zou volgens hen geen sprake zijn geweest van een bewust beleid dat leidde tot de bijzondere structuur van de VOC. Den Heijer stelt in dit verband: 'Tussen de ondernemingsvorm van de voor-compagnieen en die van de VOC met de tienjarige rekening bestonden nauwelijks verschillen.'33 En Steensgaard: 'The fundamental issue behind the features sketched above was the creation of a permanent capital. Even though the $V O C$ is not the first instance of permanent, anonymous capital in history, the notion was certainly out of the ordinary at the time. The eventual permanence of the capital subscribed in 1602 was not anticipated by the founders of the company, and it was not the result of a deliberate company policy aiming at what we might consider a more modern economic organisation. Rather it was a side effect of a number of practical decisions made in the first ten or twenty years of the company's existence. 34

Tegen deze opvatting van een geleidelijk ontstaan van de ondernemingsvorm van VOC pleit een memorie van de hand van een Amsterdamse bewindhebber. ${ }^{35}$ Deze kan gedateerd worden op februari I602, dus juist voordat het octrooi op 20 maart werd verleend, maar nadat medio januari I602 het concept van het octrooi van de VOC door Reinier Pauw aan de Staten-Generaal was aangeboden. In dat concept vroegen de kooplieden om een octrooi voor vijftig jaar. Al snel daarna werd duidelijk dat een dergelijke lange looptijd op bezwaren zou stuiten, waarschijnlijk bij de vertegenwoordigers van de niet-betrokken steden. In deze memorie kwamen uitvoerig aan de orde de vraag van de wenselijke looptijd van het octrooi en de gevolgen van een kortere of langere looptijd. Zij geeft daarmee een boeiende blik in de gedachtegang van de betrokken kooplieden over de verwachtingen die zij van de nieuwe opzet hadden en de wijze waarop die bestuurd diende te worden. Zelfs geeft zij de richting aan waar wij het antwoord kunnen vinden op de oude vraag waar nu die nieuwe ondernemingsvorm vandaan kwam.

In genoemde memorie werd ten eerste gesteld dat 'een tydelijck en gelimiteerd octroy' afdoende zou zijn als de kooplieden voornemens waren op Azië te blijven handelen zoals zij dat tot dan gedaan hadden, namelijk met heen en weer varende vloten. $\mathrm{Na}$ afloop van een reis werd immers steeds afgerekend.

Maar juist doordat men forten en eigen handelsplaatsen wilde vestigen was een lange looptijd geboden. Immers voortaan zou de kost voor de baat uitgaan. Men voorzag een 'penibel zwaerder en langk' proces 
waardoor het wel een generatie zou kunnen gaan duren eer de vruchten van de inspanning geplukt zouden kunnen worden. Een afrekening na tien jaar was dus ondenkbaar. De roerende zaken kon men waarderen, maar het waarderen van de onroerende goederen in Oost-Indië, de forten, magazijnen en pakhuizen was immers onmogelijk: 'Laet ick alle computisten en rekenmeesters overleggen, oft selve doenlijck is,' [...] 'die van ongehoorde dingen en ongesiende panden en verbeeteringe wijt van der handt in de orientaelse indien en elders sullen oordelen gelijck de blinde van de couleuren.' 'Bovendien,' zo vervolgde de schrijver, 'was het toch bekend dat de eerste tien jaar de meeste kosten zouden moeten dragen.' Tegen het verwijt dat hierdoor aan niet-participanten de toegang tot de VOC ontzegd zou worden stelde hij dat, hoe profijtelijk de Compagnie ook zou zijn er altijd lieden waren die hun participatie wensten te verkopen. 'Sijnde waerachtig dat tot alle tijden het derde part van de werelt te coop staet.' Dit is een belangrijk inzicht, want hiermee wordt de kracht van de structuur van een beursgenoteerde vennootschap aangegeven. Er is namelijk sprake van een dubbele liquiditeit. De onderneming kan permanent over vermogen beschikken, terwijl de aandeelhouder zijn bezit in de onderneming steeds op de markt te gelde kan maken. Professor Lowenstein noemde dit terecht 'an act of magic' ${ }^{36}$

De VOC diende wel jaarlijks haar balans en winst- en verliesrekening te maken om tot een gefundeerde waardering voor koper en verkoper te kunnen komen en periodiek moesten nieuwe bewindhebbers door de participanten worden gekozen. De schrijver van de memorie concludeerde daarom dat 'de thien jaerige openinge en admissie geheel onnoodich en ongefondeert is.' Uit een en ander blijkt dat men wel degelijk bewust koos voor de vernieuwende ondernemingsvorm die de VOC was. Men was doordrongen van de noodzaak van permanent kapitaal en dat leidde bij de oprichting van de VOC tot een bijzondere structuur.

Zoals de memorieschrijver al voorzag, is de afrekening na tien jaar er niet gekomen. De bewindhebbers kregen steun van de Staten-Generaal toen zij weigerden hieraan te voldoen. Het hoefde volgens hen niet, omdat de koers van het aandeel boven de uitgiftekoers lag, dus wie wilde, kon winst nemen. ${ }^{37}$ Het gevolg voor de invloed van de participanten was verstrekkend. De bewindhebbers dienden namelijk gedurende de gehele looptijd van de eerste tienjarige rekening aan te blijven en konden daardoor verantwoordelijk gehouden worden bij die afrekening voor de gang van zaken over deze periode. Maar door het verdampen van de einddatum verviel deze zware vorm van toezicht geheel en sloeg deze juist door naar het andere uiterste, namelijk naar het geheel ontbreken van toezicht. Het winstrecht was het enige recht dat bleef, maar het recht van de participanten op inzage in de boeken en enige vorm van invloed op de benoeming van de bewindhebbers ontbrak. Bij de verlenging van het octrooi in $\mathrm{I}_{2} 3$ is dit manco gedeeltelijk verholpen, 
maar niet zo doortastend als oorspronkelijk in de memorie werd voorgesteld.

Door historici is natuurlijk al aandacht besteed aan de herkomst van de ondernemingsvorm van de VOC. Vaak wordt daarvoor naar het zuiden gekeken, namelijk naar Antwerpen en naar Italiaanse steden waar toentertijd verder ontwikkelde ondernemingsvormen bestonden dan in het in dit opzicht jonge Amsterdam. ${ }^{38,39}$ De antwoorden zijn steeds onbevredigend gebleken, want de VOC lijkt juist door haar permanent vermogen en overdraagbaarheid van aandelen zonder precedent. Dat is wellicht niet helemaal zo. Door de Staten van Holland en West-Friesland werd na lange beraadslagingen in 1596 het octrooi verleend voor de inpoldering van de Zijpe. Om deze Noord-Hollandse binnenzee met een oppervlakte van maar liefst zeventig vierkante kilometer van een zeedijk te voorzien waren grote investeringen nodig en zou het rendement jaren op zich laten wachten. Amsterdamse kooplieden en financiers richtten hiervoor een samenwerkingsverband op met een onbeperkte looptijd.

Het werd een reusachtige onderneming en in 1597 werkten drieduizend man met duizend paarden aan het maken van de dijken en de afwateringen. Deze poldervennootschappen waren dus ook langjarige ondernemingen waarvoor een octrooi werd verkregen en waarvan de aandelen konden worden verkocht. Dit was de ondernemingsvorm die de Amsterdamse kooplieden kenden, omdat zij daar zelf in investeerden. Pieter Pauw, de broer van VOC-oprichter Reinier Pauw was rentmeester van de Zijpe en voorzitter van het college van hoofdingelanden, het hoogste bestuur van de polder. Van Oldenbarnevelt zelf belegde in de Zijpe.

In zijn studie over de Zijpe concludeerde Belonje: 'Wij zien de Zijpe georganiseerd als een soort verenigingsvorm, in meer of mindere mate met publiekrechtelijke functies toegerust, steunende op het publiek gezag, doch van dat gezag vrijwel geheel onafhankelijk. ${ }^{40}$

Het ontstaan van deze ondernemingsvorm voor de lange termijn laat zich wellicht verklaren doordat de geslaagde bedijking van 1597 voorafgegaan werd door een drietal mislukte pogingen. De eerste begon op basis van een octrooi dat door keizer Karel V in I552 was verleend ${ }^{4 \mathrm{I}}$ en werd gefinancierd door kooplieden uit Antwerpen, Brussel en Leuven. De opzet is interessant, want 'Men verkreeg autonomie onder de voorwaarde van een sterk preventief toezicht. Op typische wijze geeft de regering van de Zijpe in deze periode een voorbeeld van het centraliseringsideaal van den Bourgondisch-Oostenrijkschen staat.' $4^{2}$ Bij de uiteindelijke inpoldering in I597 bleef de autonomie, maar was het centrale toezicht uit Brussel verdwenen. Ziedaar de structuur waarmee de oprichters van de VOC goed bekend waren en die bewust of onbewust grote gelijkenis vertoonde met de grondslag voor de inrichting van de VOC. 


\section{Noten}

I. Krondl, M., De smaak van de verovering: Venetië, Lissabon, Amsterdam en de strijd om de specerijen (Amsterdam 2008) en http://www. pbm.com/ lindahl/menagier/

2. Vignaud, H., La lettre et la carte de Toscanelli sur la route des Indes par l'ouest, adressées en 1474 au portugais Fernam Martins et transmises plus tard à Christophe Colomb: étude critique sur l'authenticité et la valeur de ces documents et sur les sources des idées cosmographiques de Colomb: suivie des divers textes de la lettre de I474 avec trad., ann. et facs. (Parijs I903), 26I en T. Goldstein, 'Geography in Fifteenth Century Florence', in: J. Parkers (ed) Merchants and Scholars (Minneapolis I965) 4.

3. Goldstein, T., 'Geography in Fifteenth Century Florence', in: J. Parkers (ed) Merchants and Scholars (Minneapolis I965) I6.

4. Heers, J., 'Le role des capitaux internationaux dans les voyages de découvertes aux xv et xvi siècles', in: F. Fernandez-Armestos (ed), The European opportunity (Aldershot I995) 279.

5. Gaastra, F. S., Bewind en beleid bij de VOC. De financiële en commerciële politiek van de bewindhebbers, 1672-1702 (Zutphen I989) 22.

6. Recensie in Bijdragen en mededelingen betreffende de geschiedenis der Nederlanden (BMNG) deel I22-2 (2007) 278.

7. Fletcher, W. M., Cyclopedia of the law of private corporations (Chicago IgI7) I.

8. Micklethwait, J. en A. Wooldridge. The company: a short history of a revolutionary idea (New York 2003) 28.

9. Gaastra, F. S., De geschiedenis van de VOC (Zutphen, I99I) I5.

Io. Fruin, Tien jaren uit den Tachtigjarigen Oorlog, I62.

II. Dillen, van, Van rijkdom en regenten, Io8.

I2. Warnsinck, J. C. M., De wetenschappelijke voorbereiding van onze eerste schipvaart naar Oost-Indie ('s-Gravenhage I936).

I3. Bibliotheek Scheepvaartmuseum Amsterdam signatuur A IV 2243 a 'Artikelen betreffende de voorbereiding van de Eerste Schipvaart naar Oost-Indië'.

I4. Chaudhuri, K. N., The English East India Company; the study of an early joint-stock company, 1600-1640 (London I965) II en I2. Foster, W., The travels of John Sanderson in the Levant, 1584-1602, with his autobiography and selections from his correspondence (London I93I) I90.

I5. Steensgaard, N., The Asian trade revolution of the seventeenth century: the East India companies and the decline of the caravan trade (Chicago I974).

I6. Chijs, J. A. van der, Geschiedenis der stichting van de Vereenigde O.I. compagnie en der maatregelen van de Nederlandsche regering betref- 
fende de vaart op Oost-Indie, welke aan deze stichting voorafgingen (Leiden I857). 2. verm. druk (Leiden I857).

I7. Bruin, Dutch-Asiatic Shipping II en III, de eerste 64 scheepvaarten.

I8. IJzerman, J. W., De Reis om de Wereld door Olivier van Noort, 2 dln ('s-Gravenhage I926).

I9. Lettres et négotiacations de Paul Choart, seigneur de Buzanval, ambassadeur ordinaire de Henri IV en Hollande. Anneé I6oo , G.G. Vreede (Utrecht I853) I2I.

20. Rietbergen, P. J. A. N., De Eerste Landvoogd Pieter Both (1586-1615) Gouverneur-generaal van Nederlands-Indië (1609-1614) (Zutphen i987) 60.

21. De door Fruin aangehaalde 'instructie' van de Staten Generaal aan de VOC om oorlogschepen naar Azië te sturen om het gevecht met de Portugezen en Spanjaarden aan te gaan dateerde uit i6o6. De Heren Zeventien hadden een dergelijke aanmoediging niet nodig. Ook zonder deze opdracht waren de Nederlanders vanaf i6oo als kapers van Portugese schepen in Azië actief. Fruin, Verzameld werk III, 377. Een onuitgegeven werk van Hugo de Groot.

22. Dam, van, Beschrijvinghe I, Ie deel, I6.

23. Gaastra, Geschiedenis van de VOC, I9.

24. Dam, van, Beschrijvinghe I, Ie deel, 27.

25. Schumpeter, J. A., The theory of economic development. An inquiry into Profits, Capital, Credit, Interest, and the business cycle (Cambridge, Massachusetts I96I) I92.

26. Dillen, J. G. van, Van rijkdom en regenten (Den Haag I970) I27.

27. Potter Adams, J., One's company, three's a crowd : metropolitan statebuilding and east indies merchant companies in the early modern Netherlands, France and England, 1600-1800 (Wisconsin I990) 73.

28. Kraakman, E. A., The Anatomy of Corporate Law: a comparative and functional approach (Oxford 2009).

29. Heijer, H. J., den, De geoctrooieerde compagnie. De VOC en de WIC als voorlopers van de naamloze vennootschap, Ars Notariatus I28 (Deventer 2005).

30. Frentrop, P. Ondernemingen en hun aandeelhouders, corporate governance 1602-2002 (Amsterdam 2002).

3I. Steensgaard, N., 'The Dutch East India Company as an institutional innovation', in: M. Aymards (ed) Dutch capitalism and world capitalism (Cambridge i982) 235-257.

32. Steensgaard, N., 'The Dutch East India Company as an institutional innovation', in: M. Aymards (ed) Dutch capitalism and world capitalism (Cambridge I982), 238 en P. Frentrop, Ondernemingen en hun aandeelhouders, corporate governance 1602-2002 (Amsterdam 2002), 87.

33. Heijer, den, De geoctrooieerde compagnie, 66. 
34. Steensgaard, 'Dutch East India Company as an institutional innovation', 238.

35. NA Archief Van Oldenbarnevelt 3082.4 afgedrukt in M.Witteveen, Een onderneming van Landsbelang (Amsterdam 2002).

36. Lowenstein, L., What's wrong with Wall Street: short-term gain and the absentee shareholder (Reading I988) 90-9I.

37. Korte, J. P. de, De jaarlijkse financiële verantwoording in de VOC (Leiden i984) 5.

38. Mansvelt, W. M. F., Rechtsvorm en geldelijk beheer bij de Oost-Indische Compagnie (Amsterdam, I922) II2.

39. Heijden, E. J. J. van der, De ontwikkeling van de naamlooze vennootschap in Nederland vò̀r de codificatie (Amsterdam i908).

40. Belonje, J., De Zijpe en Hazepolder, De ontwikkeling van een waterschap in Holland's Noorderkwartier (Leiden I933) I78.

4I. Ibidem 6 .

42. Ibidem 23. 


\section{Een 'blauew oogh' voor de VOC, Cornelis Matelief de Jonge en de strategiewijziging van de VOC in 1608}

Bij de oprichting van de VOC werden de risico's van de nieuwe onderneming over veel aandeelhouders gespreid. En dat die risico's groot waren, bleek bij de terugkeer van de tweede vloot van de VOC in I6o8. Op maandag I september van dat jaar liep de Oranje, het vlaggenschip van die vloot, de rede van Wielingen voor Vlissingen binnen. Daags daarvoor nog had de schipper in Portland aan de Engelse zuidkust veertig zeelui moeten aanmonsteren om de Oranje veilig naar Zeeland te kunnen brengen, de eigen bemanning was daar te ziek en te uitgeput voor geweest. ${ }^{\text {I }}$ Het was het einde van een reis die drie jaar, drie maanden en twintig dagen had geduurd.

Nadat de ankers waren uitgeworpen, verliet admiraal Cornelis Matelief de Jonge het schip als een gedesillusioneerd man. De tocht van de grote vloot die onder zijn leiding uit de Republiek om Kaap de Goede Hoop naar Azië was uitgezeild, was een mislukking geworden. De lading viel tegen en het doel de specerijhandel te beheersen was eerder verder weg geraakt dan dichterbij gekomen. Matelief besefte dat hierdoor de VOC zes jaar na haar oprichting, in een crisis was geraakt die haar voortbestaan mogelijk bedreigde. Door Gaastra in zijn overzichtswerk De Geschiedenis van de VOC ${ }^{2}$ en door Rietbergen in De eerste landvoogd Pieter Both ${ }^{3}$ wordt aan deze beginepisode van de VOC aandacht besteed, en ook in het kader van deze studie is die belangrijk om nader uit te diepen.

Het doel van de VOC was gericht op het monopolie in de lucratieve handel in Oosterse specerijen. Maar, wat was bij haar oprichting het plan van de kooplieden en hoe werd dit plan uitgevoerd? Wat ging daarbij fout en waardoor, welke oplossingen werden aangedragen en door wie, en hoe reageerden de Heren Zeventien daarop?

\section{Het businessplan van de VOC}

Tegenwoordig maken startende ondernemingen bijna allemaal een zogenoemd businessplan, waarin het doel, het benodigde kapitaal, de beoogde activiteiten en de benodigde bedrijfsmiddelen beschreven worden met daaraan gekoppeld de rendementsverwachting, de organisatie, de 
ervaring op het te betreden terrein van de directie in spe en, last but not least, de te verwachten concurrentie.

Als wij vanuit dit hedendaags perspectief kijken naar het begin van de VOC, dan laat zich uit de beschikbare gegevens het volgende plan destilleren. De VOC werd opgericht met als voornaamste doel de handel in kostbare specerijen zoals nootmuskaat, foelie en kruidnagel wereldwijd te monopoliseren. Deze handel zou worden aangevuld met vooral peper en ook andere Aziatische goederen waarin een monopolie niet direct mogelijk was. Hiertoe zou jaarlijks in de Republiek een vloot uitgerust worden die naar de productiegebieden in Oost-Indië zou zeilen: voor de peper naar Bantam op Java en voor nootmuskaat, foelie en kruidnagel naar de Molukken en de daar dichtbij gelegen kleine Banda Archipel. Het was de bedoeling de Molukken en Banda met eigen forten te beheersen.

Natuurlijk beseften de Heren Zeventien dat hiervoor de positie van de Portugezen, die immers al bijna een eeuw lang in Azië deze handel beheersten, met geweld moest worden aangetast. Daarom moesten de in Oost-Indië gelegen kleine Portugese forten veroverd worden. Als dat gebeurd was, zou de positie van de VOC worden geconsolideerd met de verovering van de Portugese vesting Malakka. Juist dit handelsfort was van het grootste belang door zijn bijzonder strategische ligging in de keten van Portugese vestigingen in Azië. Het bezit van Malakka was de sleutel tot enerzijds de handel in de Indonesische Archipel en anderzijds tot de handel met en tussen China, Japan en India.

In I602 werd door de aandeelhouders aan de vennootschap het grote vermogen van meer dan zes miljoen gulden ter beschikking gesteld. Dit geld werd in ruim drie jaar in termijnen in de kas van de VOC gestort en was voldoende om drie grote vloten naar Oost-Indië uit te rusten. Gerekend werd met een reisduur van maximaal drie jaar voor een vaart van de Republiek naar Oost-Indië en weer terug. De gedachte was dat als de schepen van de eerste vloot terugkeerden, de opbrengst van de lading voldoende zou zijn om én dividend uit te keren aan de aandeelhouders én een volgende, tegen die tijd vierde, vloot uit te rusten. Zo zouden dan drie vloten onderweg zijn. De winsten van de eerdere vaarten uit Amsterdam hadden, op de eerste moeizame tocht in I595 na, steeds veel meer dan Ioo procent bedragen, dus over het rendement maakte men zich geen zorgen.

Aan de organisatie van de VOC in de Republiek was bij de oprichting van de Compagnie veel aandacht besteed. Onder leiding van de Amsterdamse kooplieden ontstond in de Republiek een slagvaardige structuur met als hoogste bestuursorgaan de Heren Zeventien en de zes kamers in die handelssteden van Holland en Zeeland die tevoren al dan niet actief waren geweest in de vaart op Oost-Indië. ${ }^{4}$ Alle aanwezige kennis en ervaring waren zo binnen de VOC gebundeld. Het 
octrooi van de VOC verbood bovendien concurrentie door derden in de Republiek.

De organisatie van de VOC in Azië zou bestaan uit forten en handelsposten die jaarlijks door schepen werden bezocht om de daar verzamelde koopwaar aan boord te nemen en natuurlijk ook deze forten en handelsposten opnieuw van mensen, geld en handelsgoederen te voorzien. Daarnaast zou er steeds een aantal schepen in Azië blijven om de vestigingen bescherming te kunnen bieden. Het was niet de bedoeling dat de VOC een eigen hoofdvestiging in Azië zou stichten anders dan door verovering van de Portugese vesting Malakka.

Vermeden bij de eerste tochten van I595 tot en met I602 de voorlopers van de VOC zoveel mogelijk de strijd tegen de Portugezen en dreven zij handel aangevuld met kaapvaart, de opdracht aan de eerste vloten van de VOC daarentegen luidde juist dat naast handeldrijven de machtspositie van de Portugezen in Azië moest worden aangetast. Tegelijkertijd moest ertegen gewaakt worden dat de Engelsen en Fransen in Banda en de Molukken vaste voet aan de grond zouden krijgen.

In grote lijnen was dit het plan dat strookte met de ervaringen die waren opgedaan in de vorige tochten.

\section{De tocht van Matelief 1605-1608, oftewel de weerbarstige praktijk}

De admiraal van de tweede vloot van de VOC, Cornelis Matelief, werd in 1570 in Rotterdam geboren als zoon van zijn naamgenoot Cornelis Matelief. Sindsdien hadden zij achter hun naam 'de Jonge' respectievelijk 'de Oude' staan. 'De Oude' was een welvarende koopman in Rotterdam en 'de Jonge' trad in zijn voetsporen. De laatste had, naar uit zijn nagelaten geschriften blijkt, een gedegen opleiding genoten, waarna hij enige jaren koopman was in Rotterdam, Amsterdam en Lissabon.

In I602 werd hij een van de bewindvoerders van de kamer van de VOC in Rotterdam.

Als de VOC niet in I602 was opgericht, zou Cornelis Matelief de admiraal zijn geworden van slechts twee schepen die in I602 uit Rotterdam naar Azië zouden zeilen, en niet van elf. Hij moest geduld hebben, en zijn geduld werd beloond: in I605 werd hij benoemd tot admiraal van de tweede VOC-vloot naar Azië. De uitrusting van de elf zwaarbewapende schepen had het voor die tijd enorme bedrag van bijna twee miljoen gulden gekost. De verwachtingen waren navenant hoog gespannen. De bemanning van de schepen, in de verslagen met boekhoudkundige kilheid aangeduid als 'eters', was 1357 koppen groot. 


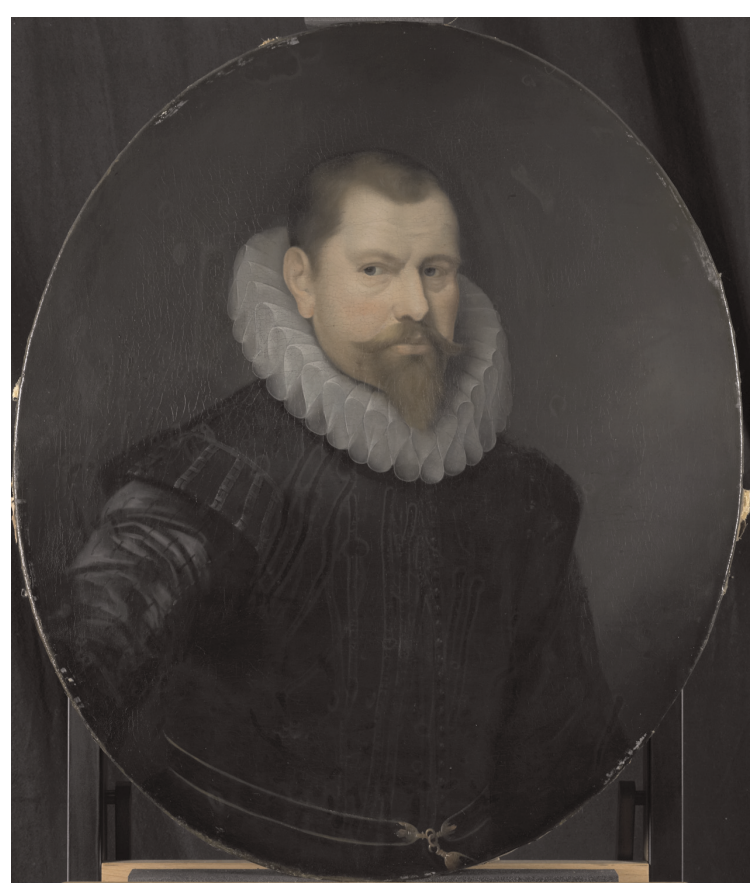

'Matelief doet zich voor als een man in de bloei des levens, met een uiterlijk van sterken lichaamsbouw en vaste gezondheid. Zijn voorkomen is beschaafder, dan wij ons van een oud zeeman zouden voorstellen of van een koopman, die is opgegroeid in gestadigen omgang met varenslui. De zeemansknevel en impérial, fijn en blond, zet er eenige vlugheid aan bij. Maar de gunstige indruk, dien hij op den aanschouwer maakt, verhindert niet waar te nemen, dat de blauwe oogen eenigszins schuins rechts naar beneden kijken alsof de eigenaar op zijne hoede is, en gereed tot een uitval.' Rijksmuseum Amsterdam.

Op de heenreis kwam de vloot van Matelief in januari I6o6 aan op de rede van Mauritius, het toen nog onbewoonde dodo- en ebbenhouteiland midden in de Indische Oceaan. Daar trof hij bij toeval twee VOCschepen met aan boord Steven van der Haghen, admiraal van de eerste vloot van de VOC. De twee admiraals overlegden uitvoerig en Matelief werd zo uit de eerste hand op de hoogte gesteld van de situatie in Azië en de uitkomst van de reis van Van der Haghen. De tocht van Van der Haghen was op het oog een succes geworden. Hij was in december I603 uit de Republiek vertrokken. Nadat zijn vloot eerst de Portugezen in hun forten bij Mozambique en Goa van afstand had beschoten, had Van der Haghen ook een treffen met de Portugese vloot bij Goa niet opgezocht en was hij via Bantam op Java naar de Molukken gezeild, waar hij bijna zonder slag of stoot eerst het kleine Portugese fort op Ambon 
had veroverd en vervolgens met geluk het grotere Portugese fort op het eiland Tidore. De voorraad buskruit van dat fort was tijdens de beschieting door Van der Haghens vloot ontploft, waardoor het verwoeste fort makkelijk in de handen van de Hollanders was gevallen. Hierdoor waren de Portugezen uit de Molukken verdreven. Zodra Van der Haghen vervolgens zijn schepen had volgeladen, was hij weer op de terugvaart naar de Republiek gegaan en ontmoette zo op de rede van Mauritius zijn collega Matelief.

$\mathrm{Nu}$ had Matelief van de Heren Zeventien geheime instructies meegekregen die helaas verloren zijn gegaan. Naar alle waarschijnlijkheid heeft in deze instructies gestaan dat, als Van der Haghen daar niet aan toegekomen was, Matelief op zijn beurt moest proberen Malakka te veroveren. Over de bezetting van de vesting Malakka en het gevaar dat de Portugese vloot vormde, ging een groot deel van het gesprek tussen de beide admiraals.

Matelief zeilde daarop in februari I606 met zijn vloot rechtstreeks van Mauritius naar Johor, een vorstendom vlakbij Malakka, waar hij in maart aankwam. De sultan van Johor was een verklaarde vijand van de Portugezen, daarom verwachtten de Hollanders dat hij hen zou helpen in de strijd tegen de Portugezen in Malakka. Matelief was namelijk bepaald niet zeker van de manier waarop hij de Portugezen het beste kon aanpakken.

In het verslag van zijn reis worden Mateliefs twijfels beschreven. Zo wist hij dat in Goa, de hoofdstad van het Portugese rijk in Azië, een vloot gereed lag om in augustus, na het einde van de moesson, via Malakka naar de Indonesische-Archipel te varen. Moest hij dan toch in de maanden daarvoor nog een poging wagen het sterke Malakka na een beleg al dan niet stormenderhand te veroveren? En kon hij daarbij rekenen op de steun van de sultan van Johor? En kon hij zeker zijn van zijn eigen mannen?

$\mathrm{Na}$ veel beraad werd in april toch met het beleg van Malakka begonnen. De bemanning deed mee nadat hun een deel van de buit in het vooruitzicht was gesteld. Het beleg verliep moeizaam, zoals in het reisverhaal werd geschetst:

'Omtrent dese tijt hadde den admirael veel sieck volcks, want sij moesten om de andere nacht waken en het regende dickwijls also dat de trencheen (de loopgraven voor Malakka-w) onder water stonden. De Malyen die hielden haer buiten schoot ende en waren in de trencheen niet te krijghen, waerdoor den Admirael daghelijcks volck nae voort moest senden ende weder vers volck in haer plaets doen komen. Sulcks datter schepen waren die 25, 30 ja 35 siecken en gequetsesten hadden. Liet men dan ergens sijn geweer liggen, de Malyen hadden het wech ende daer was gheen ordre op te stellen want het volck moest dan wa- 
ken, dan weder arbeyden. Ende wat den Admirael over de Malyen klaegde, de man was nimmermeer te vinden. 't Is wel te gissen datter oock menigh roer ende sabel in den Arack ghevlogen $z$, maer men konde 't volck evenwel over sulcks niet straffen, want sy seyden datse haer gestolen waren terwijle dat sy arbeyden. Het Arack drincken gingh so schrickelijck onder haere in swange, dat het gheen mensch en soude gelooven. Nimmermeer en quam de Admirael over wech of vont droncken volck, soo dat hy dickwils des nachts moest op staen om nuchter volck in de trencheen te brenghen, daer altemet gheen 10 nuchtere personen in en waren. 't Welck indien de vyande geweten hadde soude haer somtijts als honden geslagen hebben. Evenwel en wasser geen ordre in te stellen noch remedie toe te vinden, 6

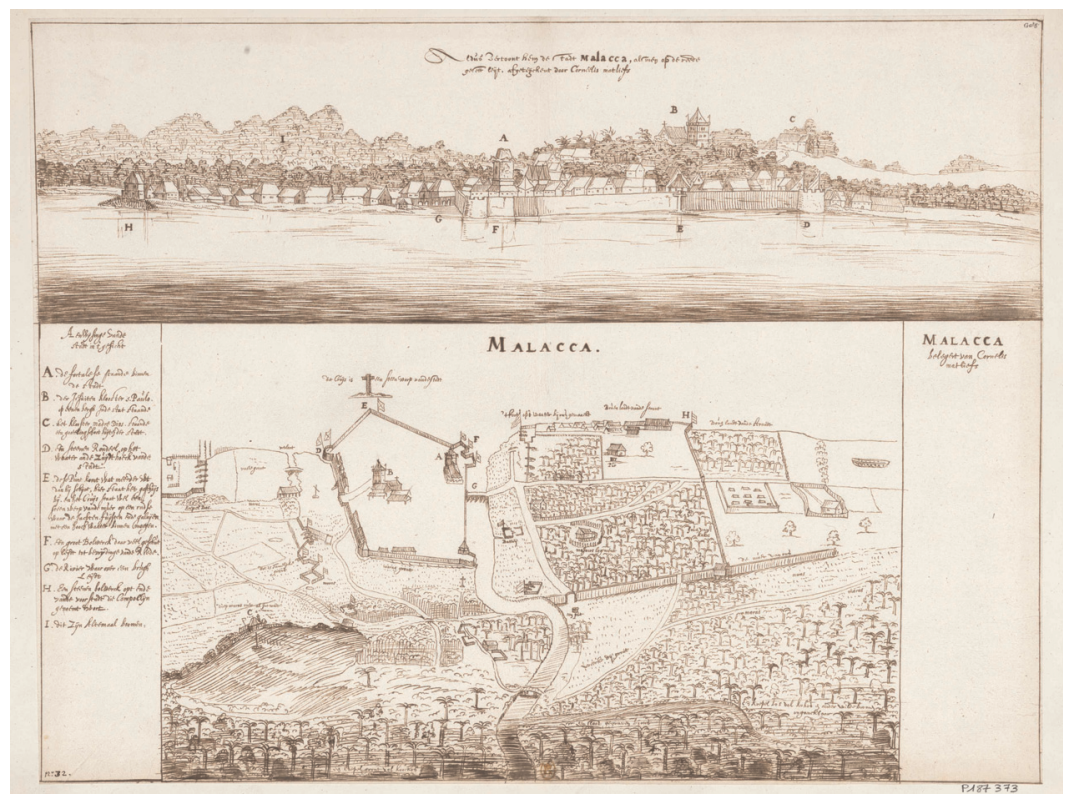

Dezelfde nauwkeurigheid waarmee Matelief zijn memories schreef, vinden wij terug in deze bijzondere 'aftekening' van zijn hand van het beleg van Malakka in 1606. Bibliothèque National de France, Parijs.

Zonder steun van de sultan van Johor, die zich, anders dan de Hollanders verwacht hadden, met zijn manschappen bijna geheel afzijdig hield, was het beleg een onbegonnen zaak en het werd ijlings opgebroken toen het bericht kwam van de nadering van de Portugese armada. Deze vloot bestond uit zestien galjoenen, vier galeien en een twintigtal kleinere schepen. De galjoenen waren wat omvang betreft te vergelijken 
met de Nederlandse schepen. De bewapening was echter minder, maar de bemanning van de gehele vloot was veel groter, in totaal circa zesduizend koppen, waarvan de helft Portugezen.

Op I8 augustus I6o6 raakten de vloten slaags. De tactieken waren geheel verschillend. De Hollanders wilden met hun superieure scheepsartillerie de Portugese schepen tot zinken brengen. De Portugese admiraal daarentegen, had de instructie de Nederlandse vloot te vernietigen door schepen te enteren en vervolgens, als verovering niet direct lukte, zowel het eigen als het vijandige schip in brand te steken. Daarbij was de redenering dat de Nederlanders met hun schepen ook hun handel zouden verliezen, terwijl de Portugezen één schip meer of minder niet zouden missen. Die dag slaagde de laatste tactiek ten dele: twee Nederlandse en Portugese schepen verbrandden zij aan zij. Het Portugese vlaggenschip was door de kanonnen van het Nederlandse admiraalsschip Oranje zwaar beschadigd, maar het werd, toen het de vlag al had gestreken, door een gelukkige zeestroming naar veiliger wateren gevoerd.

Daags daarna vond nog een ontmoeting op afstand plaats. In de nacht van de $23^{\text {ste }}$ op de $24^{\text {ste }}$ augustus ondernam de Portugese vloot een verrassingsaanval op de Nederlandse schepen, wat voor de Hollanders maar net goed afliep. Op de $25^{\text {ste }}$ augustus raakten de vloten vervolgens elkander uit het zicht toen de Portugezen naar Malakka voeren en de Hollanders voor de wind naar Johor vluchtten, waar zij I3 september aankwamen. Daar lapte Matelief zijn schepen op en werden de bodems van de schepen van aangroeisel ontdaan om hun wendbaarheid te vergroten, want daaraan had het in het gevecht ontbroken.

Begin oktober bereikte Matelief het nieuws dat de Portugese vloot zich voor konvooitaken in tweeën had gedeeld. Daarop zeilde Matelief zijn vloot omzichtig naar de rede van Malakka waar inderdaad maar zes grote schepen en één klein Portugees schip te zien waren, waaronder de schepen die in de vorige strijd door de kanonskogels het zwaarst waren toegetakeld. $\mathrm{Nu}$ kon de Nederlandse vloot tot de aanval overgaan. Maar liefst vier Portugese schepen werden in brand gestoken. Een paar regels kruitdamp uit het verslag van het gevecht van 22 oktober I606:
'Middeler tijt raekte de vice admirael int schip Amsterdam een Portu- gees namelijk 't Galjoen St. Simaon, aen boort en terstond noch een aen d'andere zijde, waer tegen kwam weders de Swarte Leeuw die den portugees chargeerde. En daarop smeet Mauritius den Portugees mede aan boort so dat sy t'samen den brant daerin kregen en hij verbrande met volck en al."

Meer dan 500 Portugezen kwamen die dag om het leven. Toen enkelen uit het Hollandse volk het brandende galjoen 'Santa Cruz' plunderden, vatte de kruitkamer vlam en in een vreselijke explosie werd het schip 
uit elkaar gereten. De 75 plunderaars kwamen allen om. Daags daarna zagen de Hollanders de drie overgebleven schepen gehavend onder de wal voor anker liggen, waarop ze besloten ook deze schepen in brand te schieten. Maar de Portugezen waren hen voor en bliezen de schepen zelf op. Zo behaalde Matelief weliswaar een klinkende overwinning op zee, maar bleef Malakka stevig in Portugese handen.

Vervolgens zeilde Matelief met zijn vloot naar de ingang van Straat Malakka waar hij op een beschutte plaats de resterende Portugese schepen voor anker aantrof. In de tweede week van december I606 kwam het weer tot schermutselingen tussen de twee vloten, maar daar bleef het bij. Een overwinning bleef uit. Later sprak Matelief van een unieke kans om de Portugese zeemacht in Azië te vernietigen. Zijn instructies echter, zouden hem daarvan weerhouden hebben. Uit het reisverslag kriigt men daarentegen eerder de indruk dat Matelief het niet aangedurfd had de Portugezen in hun sterke positie aan te vallen. In ieder geval voer hij de $20^{\text {ste }}$ december door naar Bantam om te verversen en lading te verkrijgen. Drie schepen van zijn vloot met aan boord zieken en gewonden, had hij daarvoor al de opdracht gegeven om lading te zoeken in Atjeh of elders en daarna naar het vaderland terug te zeilen. Twee van deze schepen kwamen in mei I608 in Nederland aan. Het derde bleef in Azië.

Direct na de aankomst van de vloot in Bantam was het toch al niet grote gezag dat Matelief en de schippers over de bemanning hadden, tijdelijk geheel verdwenen:

'maer so haest sy lant onder voeten hadden waren se niet weder 'tscheep te kryghen (...) Speelden overal de beest, drinkende 't lijf vol Arack (...) De admirael liep selve 't eene hups uyt 't andere in maer de menichte was soo groot dat als hy se uyt het eene huys smeet sy terstond weder in 't ander liepen sonder dat hy haer daerom dorst te straffen'.

Uiteindelijk moet toch een mate van orde hersteld zijn, want in februari I607 voer Matelief met zijn vloot van dan nog slechts zes schepen, van Bantam langs de oostkust van Java naar Ambon. Daar vernam hij van Frederik Houtman, gouverneur van het fort Victoria ongunstig nieuws. Nadat Van der Haghen de Portugezen uit Ternate had verdreven, slaagden de Spanjaarden er vanuit het nabij gelegen Tidore op hun beurt in op Ternate voet aan de grond te krijgen. Zij opereerden vanuit Manilla op de Philippijnen en bleken in de Molukken in de jaren die volgden, geduchtere tegenstanders van de Nederlanders dan de Portugezen waren geweest.

Om het tij te keren voer Matelief daarop met zijn vloot naar het eiland Makian in de buurt van Ternate, waarnaar de Ternataanse vorst zijn toevlucht had genomen. Matelief nam zich voor Ternate te herove- 
ren met diens steun. Zoals eerder bij Malakka hielden nu de Ternatanen zich zoveel mogelijk afzijdig bij deze poging die, de inspanningen van Matelief ten spijt, maar gedeeltelijk slaagde.

De bouw van een nieuw fort op Ternate vormde hierbij een bijzonder frustrerende episode. In het reisverslag wordt geschreven hoe de beschaafde en voorzichtige admiraal, door een muitende bemanning en door de onbetrouwbaarheid van de Ternataanse bondgenoten 'bijnaest van syn sinnen gebracht' zwaaiend met 'een kort Japons sabelken' op de omwalling van het fort in wording een ultieme poging deed het werk voortgang te laten vinden. Toen het fort gedeeltelijk af was, legerde hij aldaar een kleine bezettingsmacht en zette met vier schepen zeil naar China.

In de volgende jaren bleef de positie van de VOC op de Molukken precair tegenover de Spanjaarden. Mede, zo schreef de eerste commandant van het fort dat door Matelief was gebouwd: 'omdat den Admirael Matelief de slapende heeft wakker gemaakt.' Overigens 'een fort' was in het begin misschien een wat te groot woord, en gemakkelijk had het kleine garnizoen het niet, zoals dezelfde commandant verder schreef: 'somma te cortste geseyt, den admirael (Matelief-w) liet ons seer elendigh hier.' 9

Na de nodige avonturen en uiteindelijk op de vlucht voor de Portugezen keerde Matelief in het najaar van $\mathrm{I} 607$ onverrichter zake uit China terug in Bantam. Hij verklaarde zijn falen als gevolg van de tegenstrijdigheid van zijn instructies. Zo schreef hij voor zijn vertrek uit Bantam aan zijn opvolger, admiraal Van der Caerden: 'Daerom, indien men een soldaet ende een coopman in een persoon wil hebben, $t$ 'is verloren arbeit.' ${ }^{\text {'o }}$

De derde vloot van de VOC, onder de drieste Paulus van der Caerden, was in januari I6o8 na ruim een jaar varen in Bantam aangekomen. Van der Caerden had veel tijd verdaan met een mislukte aanslag op de Portugese vesting in Mozambique. Voorzichtigheid en terughoudendheid konden hem niet verweten worden. Nog in hetzelfde jaar werd hij in de Molukken door de Spanjaarden gevangen genomen. Hij werd losgekocht, maar korte tijd later viel hij wederom in Spaanse handen. Als gevangene sjouwde hij stenen voor de fortificaties en stierf in Manilla.

Matelief zeilde terug naar de Republiek, waar hij in september I6o8 aankwam. Het resultaat van zijn tocht was pover en ook de vooruitzichten van de derde en vierde vloot waren op hun best onzeker te noemen. De uitvoering van het oorspronkelijke plan van de VOC was niet gelukt. Matelief besefte dat in Azië een totaal andere aanpak nodig was en deed in zijn memories dan ook voorstellen daartoe. 


\section{De memories van Matelief}

Tijdens zijn tocht van de Molukken naar China in I607 nam Matelief voor het eerst de tijd zijn gedachten 'op den Staet ende handel van Indien' aan het papier toe te vertrouwen. ${ }^{\text {II }}$

Het zijn deze en de daarop volgende 'discoursen' die hij na zijn terugkeer in de Republiek schreef, die Matelief tot zo'n interessante figuur in de geschiedenis van de VOC maken. Hij analyseerde en droeg suggesties tot verbetering aan op basis van zijn ervaring en inzichten ter plaatse. Ondanks de tegenslagen schreef hij nooit dat de doelstelling van de VOC, het monopolie in de specerijen, niet haalbaar was. Dat het doel niet bereikt werd, lag volgens hem aan de manier waarop de VOC zich in Azië organiseerde.

In zijn memorie die hij nog in Azië schreef, constateerde hij ten eerste dat de Portugezen in Goa en de Spanjaarden in Manilla een 'vast fondament' hadden. Dat gaf aan hen een grote voorsprong op de Hollanders.

'Daerom, willen wij hier in Indien iets vruchtbaers doen soo moeten wij oock sien een plaets te krijghen, daer wij uit Hollant komende onse uitspanning hebben. Waerdoor ons veel profyten sullen komen, vooreerst de ververssinge voor ons volck ende schepen ende ten anderen aenwas van reputatie bij de Indiaensche vorsten.'

Vervolgens beschreef hij de handel en de producten, met name de specerijen. Elk product had zo zijn eigen aanpak. Een monopolie op peper was vooral vanwege de Engelse en de Portugese concurrentie niet te krijgen. Het sluiten van een contract met de vorst van Bantam waarbij Europese mededingers zouden worden uitgesloten, leek Matelief een weinig solide oplossing, hoeveel de Hollanders er ook voor zouden willen betalen. Maar in de Molukken lagen de kaarten anders: 'Om alle de handel in nooten en foelie in onse handen te krijghen, daer is naer mijn oordeel wel raet toe', zo meende hij. Matelief stelde voor dit te doen in verbond met de vorst van Makassar die met Hollandse hulp Banda zou kunnen veroveren, waarna aan de VOC het monopolie gegund zou worden. Het verwerven van een monopolie in kruidnagelen zou ingewikkelder zijn. Maar als Malakka eenmaal veroverd was, dan was daarmee voor de Portugezen de weg naar de Molukken afgesneden. En ook de Spanjaarden zouden dan verdreven kunnen worden.

Een ander belangrijk aspect was de intra-Aziatische handel. Als de VOC hieraan zou kunnen deelnemen, zou dat de kosten van de specerijen kunnen drukken. Met name de handel in geweven katoenen vanuit de Indiase Coromandelkust op de Molukken en Java was volgens Matelief van het grootste belang, 'want dese landen moeten die kleetjens 
hebben, het zij dan wat se oock kosten'. Ook hiervoor was, evenals voor de handel op China, het bezit van Malakka de sleutel. Hij sloot af met:

'Uyt dit discours mach men sien van wat importantie dat Malacca is. Daerom dient daer wel een blauew oogh om gewaeght, want wy moeten toch een vaste plaets in Oost-Indien hebben dewelke hoeveel se kosten soude eer se soo bequaem soude weesen als Malacca, mach men considereren'.

Tot zover zijn gedachtevorming op reis in Azië.

Na zijn terugkomst in de Republiek deed Matelief mondeling zijn relaas aan de Heren Zeventien, de Staten-Generaal en prins Maurits. In oktober en november van i6o8 schreef hij een tweetal lange discoursen over de moeizame staat van de Oost-Indische handel. Hij richtte deze aan de Heren Zeventien en aan de advocaat van de VOC, Hugo de Groot. ${ }^{\text {I2 }}$ Matelief werkte in deze memories zijn eerdere punten verder uit en paste deze aan nieuw verworven inzichten aan. Zo stelde hij in deze memories eerst vast dat volgens hem de Portugese vijand te vast verankerd was in Azië om te mogen verwachten dat die 'op een corte sprongh' verdreven zou kunnen worden. Hij herhaalde daarom zijn stelling die wij al kennen: er moest in Azië een centraal punt komen.

'Vooreerst ende all moeten wy in India een rendez vous ofte gemeene plaets verkiesen, alwaer alle schepen uyt dese landen recht op aen mochten coomen.'

Maar waar?

Matelief had zijn mening over Malakka herzien. Behalve dat de verovering een grote 'swaerigheyt' zou geven, was Malakka door de moesson maar een gedeelte van het jaar per schip bereikbaar. Dicht bij de Straat Sunda tussen Java en Sumatra was de ligging gunstiger. Het machtige Bantam viel af om vooral politieke redenen. Eigenlijk kwam, zo concludeerde Matelief, maar één plek werkelijk in aanmerking 'daerom soude mijn advys voort beste wesen, dat men met de koninck van Jakarta sage te handelen (...) te mogen een fortressen bouwen.' In deze hoofdplaats zou een 'commandeur' met voldoende autoriteit moeten resideren, 'want myn heeren (de Heren Zeventien-w) sullen hyer op verdacht wesen dat het tot groot schandael van onse saecke is, datter geen autoriteyt in India is (...) want nu doet elck wat hy wil ende niemant is straffe ofte correctie onderworpen.' Deze commandeur zou moeten kunnen handelen als waren de Heren Zeventien zelve in Azië.

Zoals hierboven al aan de orde is gekomen, onderkende Matelief als koopman het grote belang van de intra-Aziatische handel. De VOC zou 
zijns inziens vanuit de hoofdplaats bij Jakarta dienen te varen van Japan tot Ceylon en India aan toe.

'Men saude moeten de humeuren, conditieen ende macht van alle coningen in Oost-India aansien en elck nae syn qualiteyt tracteren, want den eenen is ons dienstich met syn havenen ende landen, den anderen met syn waren, weder eenighe met hare macht ende auctoriteyt, 'twelck wy elck ons mosten toeeygenen nae dat wy souden connen en raedsaem vinden.'

Vanwege het specerijmonopolie vormden de Molukken en de kleine Banda-Archipel een uitzondering. Met name Banda dat 'te beter onder de Heeren Staten soude moghen brengen,' maar wel behendig om geen jalouzie te kweken bij de omliggende koningen, 'want het eiland Banda is soo veel gout waert als het groot is.' Vervolgens ontvouwde hij opnieuw het plan voor de verovering van Banda met de hulp van de koning van Makassar. Maar daarmee hoefde men niet tevreden zijn: 'Nu volgen de Molucas, daer wat meer swaereigheyt (dan Banda-w) soude vallen die te conquesteren, doch is niet ondoenlyck naer myn oordeel.'

Wel was het naar de mening van Matelief noodzakelijk dat Malakka tandeloos gemaakt werd, anders zouden de specerijen altijd via die weg op de markt kunnen komen en zou voortdurend een aanval van de Portugezen langs die route te verwachten zijn.

De Portugezen en Spanjaarden waren natuurlijk de echte vijanden, maar als concurrenten voor de handel in Azië beschouwde Matelief de Engelsen en Fransen niet minder gevaarlijk. Het stak hem dat deze dankzij de VOC handel konden drijven. Matelief constateerde bitter dat 'sy de schapen en wy de verckens scheren,' omdat de Hollanders de kosten van de forten en van de strijd tegen de Spanjaarden en Portugezen alleen droegen.

Dit waren de voornaamste punten uit de memories van Matelief.

\section{De reactie van de Heren Zeventien}

De Heren Zeventien reageerden op de kritiek en suggesties van Matelief met opmerkelijke flexibiliteit en instemming. In het kort gezegd, namen zij de belangrijkste aanbevelingen over om het bestuursvacuüm in Azië op te vullen. Reeds het volgende jaar, in november I609, bekrachtigden de Staten-Generaal de benoeming door de Heren Zeventien van Pieter Both tot eerste gouverneur-generaal van de VOC in Azië: 'Eene cloecke persoone van goede fame,' zoals in de resolutie van de Heren Zeventien staat te lezen. ${ }^{\mathrm{I}}$ Hiermee werd de grondslag gelegd voor het centrale gezag van de VOC in Azië. 
Both kreeg de instructie een centraal punt, het rendez-vous, te vestigen. Weliswaar ging de voorkeur voor de locatie daarbij niet naar Java uit, maar naar het grondgebied van het vorstendom Johor in de straat van Malakka, waar op de medewerking van de vorst werd gerekend. Banda en de Molukken bleven 'het voornaemste wit' waarop in opdracht van de Heren Zeventien moest worden geschoten.

Met deze besluitvorming kwam er tenminste een begin van stabiliteit en continuïteit van beleid. Desondanks hing in de tien jaren die volgden, het lot van de VOC in Azië een aantal malen aan een zijden draad. De Spanjaarden waren meer dan eens in de gelegenheid de Nederlanders uit de Molukken te verdrijven, maar misten uiteindelijk de kracht in deze verste hoek van hun wereldrijk toe te slaan. Het is, zoals Rietbergen in zijn biografie schrijft over de eerste landvoogd Pieter Both, diens verdienste geweest dat de macht van de Portugezen en de Spanjaarden in die regio definitief werd gebroken. ${ }^{\text {I4 }}$

Het monopolie op Banda leek ook bepaald niet zeker. Zo schreef Matelief in december I6I3 aan Hugo de Groot over de situatie rond Banda: 'De saecke van Banda hebbe ick voor verloren geacht, dewijll ick gelooffde dat de Engelse haer souden voegen met de Bandanezen. "I5 Dat leek ook meerdere malen te gebeuren wanneer de Engelsen de Bandanezen ondersteunden in hun verzet tegen de Nederlanders die met geweld en forten hun macht over de eilanden wilden consolideren. Uiteindelijk werd de Banda-Archipel in I62I door Jan Pieterszoon Coen veroverd, niet omzichtig zoals Matelief gesuggereerd had, maar met grof geweld.

De ongewisse toestand van de VOC in Azië duurde in wezen tot de stichting van Batavia door Jan Pieterszoon Coen in I6 I9. In de Republiek kwam rond i6ıo de crisis natuurlijk vooral op financiële wijze naar voren. De vierde vloot van de VOC bestond uit maar zeven schepen en voor de uitrusting moest een half miljoen gulden geleend worden. In de koers van de aandelen of actien zoals zij toen genoemd werden kwam ook de klad. Ook in de ogen van de belegger had Mateliefs tocht weinig goeds gebracht in de vorm van koopmanschappen of buit. De hooggespannen verwachtingen moesten worden bijgesteld, zoals Matelief schreef in januari I609: 'men sal eenen heelen anderen voet nemen als men tot noch toe heeft gedaen' bij de waardering van de aandelen en het te verwachten rendement. ${ }^{\mathrm{I}}$ Het eerste dividend kon pas in I6II worden uitgekeerd. Het is tijdens het Bestand dat de Compagnie een beroep moest doen op de Staten-Generaal voor hulp. Het argument hierbij was dat in Azië en vooral de Molukken de strijd tegen de Spanjaarden en Portugezen immers doorging. De Staten-Generaal gingen tot ondersteuning over en van I6Io tot I6I7 zou de subsidie I,7 miljoen gulden bedragen, die voor de helft in de vorm van een korting op de convoyen, de belasting die over de in- en uitvoergoederen werd geheven en voor de helft in contanten werd vastgesteld. ${ }^{\text {I7 }}$ 
De rol van Matelief was in wezen uitgespeeld nadat hij zijn memories had geschreven. Zoals uit zijn latere brieven blijkt, liet hij het OostIndische avontuur niet los, al was het alleen maar omdat hij bewindhebber werd van de kamer van Rotterdam. In I6o9 verzeilde hij ook nog eens in een voor hem hoogst onaangename discussie met de Heren Zeventien over zijn beloning. Werd eerst besloten aan de admiraal Matelief voor zijn 'dienst in Oost Indie te presenteren eene schone gouden keten met eene medaille daeraen ende eene vergult rapier ende poignaert weerdig ten somme van tweehondert ponde vlaems, ${ }^{, 18}$ al gauw ontstond onenigheid tussen diezelfde heren en Matelief over de provisie (gage) die aan Matelief was toegezegd. Blijkens de notulen van de vergaderingen van de Heren Zeventien werd hij aan het lijntje gehouden. In augustus I6Io werd hem een laatste aanbod gedaan door de kamer van Rotterdam, onder de dreigende mededeling dat, als dat niet aanvaard werd door Matelief, de zaak dan maar aan de rechter moest worden voorgelegd. Uit de notulen van de Staten-Generaal blijkt overigens dat regelmatig hooglopende ruzie ontstond over afrekening met de admiraals van de vloten. Verscheidene zaken werden ter arbitrage aan de StatenGeneraal voorgelegd.

Hoe de afrekening met de Heren Zeventien is afgelopen, heb ik niet meer kunnen achterhalen, maar naar tevredenheid van Matelief was die zeker niet. Dat blijkt uit de brief die hij op 3 maart I6I6 aan Hugo de Groot richtte. Daarin schreef hij: 'het schijnt dat Indië de plaag heeft dat alle degenen die daar gaan bij thuiskomst half bedorven worden door degenen die zij gediend hebben, ${ }^{\prime \prime} 9$ om daarna de zijns inziens schandelijke wijze te beschrijven waarop niet alleen de Hollandse, maar ook de Portugese bevelhebbers door de magistraten in Holland, dan wel Portugal werden behandeld. Hugo de Groot schreef in de kantlijn 'quade belooningen van die in Indien gedient hebben.'

Hoewel 'quaad beloont' door de Heren Zeventien, klom Matelief wel op in de rangen van de Rotterdamse magistraten, en werd hij in I6I8 een van de burgemeesters van de stad Rotterdam. Namens deze stad werd hij in I625 zelfs benoemd in de Staten-Generaal. Daar heeft hij overigens slechts één keer een vergadering bijgewoond. In I627 liet hij weten drie maanden afwezig te zullen zijn, omdat hij voor particuliere zaken via Amsterdam naar Warschau diende te reizen. Hij zou niet meer terugkeren in de Staten-Generaal.

Op I7 oktober I632 overleed Matelief te Rotterdam. Hij was 62 jaar oud en liet geen gezin achter. Hij werd begraven in de Laurenskerk, waar zijn grote grafsteen tot de restauratie van de kerk gelegen heeft. $\mathrm{Na}$ enig speurwerk vond ik een paar jaar geleden deze steen terug bij de ingang van de opslagplaats van de Rotterdamse Historische Musea gelegen aan het fabrieksterrein de Metaalhof in Rotterdam. De steen was gebarsten en werd bijeen gehouden door een dikke plak beton. Uit 
een van de spleten groeide een jonge els. Het grafschrift was bijna geheel onleesbaar geworden. Met moeite viel als enige het woord 'Malacca' te lezen. Het hele grafschrift luidde als volgt:

\author{
Cornelis Matelief de Jonge \\ Die Malacca heeft besprongen \\ 's Konings vloot gebracht te schant \\ 9 Galioenen genomen en verbrant. \\ De Ternatanen waren verdreven \\ Wederom haer lant in gegeven \\ Was aldaer Admirael \\ En hier State Generael \\ Oock Burgemeester deser stede \\ Raet en vroedschap mede \\ Is den 17 October 1632 overleden \\ En alhier begraven in vreden ${ }^{20}$
}

\title{
Conclusie
}

Toen in r6o8 bleek hoe wankel de positie van de VOC in Azië was, moesten de Heren Zeventien de bakens verzetten. Matelief vond dat voor het behalen van succes vooral de organisatie in Azië moest worden verbeterd. De door Matelief aangedragen oplossingen hiertoe werden verrassend snel overgenomen. $\mathrm{Al}$ in I609 werd de door Matelief voorgestelde centrale machthebber in Azië benoemd in de figuur van de eerste gouverneur-generaal, Pieter Both.

Ook de noodzaak van een hoofdvestiging in Indië werd onderkend, maar dat was makkelijker gezegd dan gedaan. Pas tien jaar later werd Batavia door Jan Pieterszoon Coen gesticht op de plek die door Matelief was aangewezen.

De verovering van de Banda-Archipel en delen van de Molukken was volgens Matelief onvermijdelijk. Ook deze strijd kreeg zijn bloedig verloop. Daarnaast werd het belang voor de VOC van de intra-Aziatische handel door Matelief erkend.

Matelief toonde zich in zijn daden wellicht geen groot admiraal, maar wel één met visie. Hij had bij de poging om Malakka te veroveren, achteraf door hem als onmogelijke opgave bestempeld, een 'blauew oogh' opgelopen en dat zette hem aan het denken. Zo heeft Matelief in zijn memories het pragmatische richtsnoer gegeven waarlangs de VOC zich in Oost-Indië in de eerste helft van de zeventiende eeuw kon ontwikkelen, en wat zij in de praktijk ook gedaan heeft.

Matelief is nu zo goed als uit onze herinnering verdwenen, zijn memories zijn slechts bij een enkeling bekend. Geen straat of steeg is ooit 
naar hem vernoemd, zijn grafsteen is in kommervolle staat, maar toch... sigarenfabriek D'Olifant uit Kampen brengt een voortreffelijk tuitknakje met Sumatraans dekblad op de markt onder de naam 'Matelief. Desgevraagd schreef een medewerkster mij dat D'Olifant deze naam gekozen heeft als eerbetoon aan de VOC en haar 'gevreesde admiraal' Matelief.

Fama fumi: zo gaat de roem van Matelief nog dagelijks in rook op.

\section{Noten}

I. Hartgens, J., Journael, ende historische verhael van de treffelijcke Reyse gedaen naer Oost-Indien, ende China, met elf Schepen. Door den Manhaften Admirael Cornelis Matelief de Jonge. Uyt-gevaren in de Jare 1605. En wat haer in de volgende Jaren 1606. 1607. ende 1608 wedervaren is. Een seer Vreemde en Wonderlijcke Reyse (Amsterdam I648) I4I.

2. Gaastra, Geschiedenis van de VOC, 39.

3. Rietbergen, P. J. A. N., De Eerste Landvoogd Pieter Both (1586 -1615) Gouverneur-generaal van Nederlands-Indië (1609-1614) 2 delen, Werken uitgegeven door de Linschoten-Vereniging deel 86 en 87 (Zutphen i987).

4. Witteveen, M., Een onderneming van landsbelang: de oprichting van de Verenigde Oost-Indische Compagnie in 1602 (Amsterdam 2002) 42.

5. Frederiks, J. G., 'Cornelis Cornelisz Matelieff de Jonge en zijn geslacht', Rotterdamsche Historie Bladen (Rotterdam I87I) 2I8.

6. Hartgens, Journael, 23.

7. Ibidem 39.

8. Ibidem 54 .

9. De Jonge, Opkomst III, 228.

Io. Ibidem 233.

II. Hartgens, Journael, 73.

I2. Frederiks, Rotterdamsche Historie Bladen, bijlage G, 237.

13. NA VOC 1.04 .03 besluiten folio 49.

I4. Rietbergen, De Eerste Landvoogd Pieter Both, I24.

I5. Groot, H. de, Briefwisseling van Hugo Grotius I ('s-Gravenhage I928) 285 .

I6. Frederiks, Rotterdamsche Historie Bladen, I98.

I7. Dam, van, Beschrijuinge van de Oostindische Compagnie I deel twee, 494.

I8. NA VOC Iоo Resoluties Heren Zeventien f. 42 I3 maart I609.

I9. Groot, de, Briefwisseling van Hugo Grotius, I, 503.

20. Frederiks, Rotterdamsche Historie Bladen, 233. 


\section{Coen en carrière}

'Il est très difficile de connaître un homme dont ses flatteurs ont dit tant de bien, et ses ennemis tant de mal'. Voltaire

Toen Antonio van Diemen onder zijn schuilnaam op 23 augustus I6I8 voet aan wal zette in Jakarta, was dat aan het begin van de dramatische en gewelddadige periode die samenviel met het eerste gouverneur-generaalschap van Jan Pieterszoon Coen (I6I9-I623). Coen verkeerde juist in een merkwaardige tussenfase: hij had in april zijn benoeming tot gouverneur-generaal uit Nederland ontvangen, maar hij moest wachten op de gunstige moessonwinden om naar de dienstdoende gouverneurgeneraal Reael in de Molukken te zeilen om daar het ambt van hem over te nemen. Dat zou pas eind december van dat jaar het geval zijn.

$\mathrm{Nu}$ was Coen officieel nog directeur-generaal en als zodanig verantwoordelijk voor de handel van de VOC in Azië. Daarvoor verbleef hij in de VOC-loge te Jakarta, waar sinds enkele maanden de administratie van de VOC in Azië zetelde. De Compagnie was namelijk in maart I6ı8 naar Jakarta verhuisd vanuit het nabijgelegen Bantam. Coen was vast van plan om van Jakarta de hoofdplaats van de VOC in Azië te maken.

Het was Coens gewoonte om persoonlijk kennis te maken met de opvarenden van de schepen die uit Nederland aankwamen. Een ontmoeting die voor Van Diemen bijzonder fortuinlijk zou blijken. Coen benoemde hem onmiddellijk tot assistent op de secretarie. Hoe is deze stap te verklaren? Ten eerste was er gebrek aan goed personeel voor ongeveer elke functie, zoals Coen meermalen luid en duidelijk aan de Heren Zeventien geschreven had. Van Diemen had niet de kwalificaties van een beroepssoldaat, maar wel ervaring in de handel en de administratie die daarbij hoorde. Wellicht had hij zijn vaardigheid met de pen aan boord ten toon gespreid door het schrijven van verzoekschriften voor ongeletterde soldaten, zoals Valentijn vermoedde. ${ }^{\mathrm{I}}$ Of was het Coens grote mensenkennis - hiervoor lof toegezwaaid door Coolhaas - die Van Diemen 'ontdekte'? ${ }^{2}$ Of was Antonio zelf met een mondelinge of schriftelijke aanbeveling op Coen afgestapt? 
In ieder geval was hij vaandrig af en werd hij belast met het bijhouden van de generale boekhouding op de secretarie in een van de haaks op elkaar staande grote verstevigde stenen huizen die toen de vestiging van de VOC in Jakarta vormden. Deze huizen, Maurits en Nassau, stonden op de rechteroever vlak bij de monding van de rivier, de Tjiliwoeng. Op de andere oever van de ongeveer vijftig meter brede rivier lag de loge van de Engelsen en een paar honderd meter stroomopwaarts lag de kraton van de vorst van Jakarta, een Javaanse nederzetting zonder verdedigingswerken. Alles bij elkaar een klein bewoond plekje aan de kust, omringd door dichte jungle. Kaaimannen maakten de rivier onveilig zoals tijgers dat nog lang zouden doen in het omliggende oerwoud.

Eén week later, op 30 augustus, namen Coen en zijn Raad het besluit de twee huizen om te bouwen tot een klein fort. ${ }^{3}$ Dit was de opmaat voor de gewelddadige vestiging van Batavia, de soevereine hoofdplaats van de VOC in Azië. Van Diemen werd meegesleept in de maalstroom van gebeurtenissen die in de maanden daarop volgde en die door Coen in gang werd gezet.

Jan Pieterszoon Coen is ongetwijfeld de meest omstreden figuur uit de geschiedenis van de VOC. Dat bleek opnieuw in 2002 toen op grootse wijze werd 'gevierd' dat de VOC vier eeuwen daarvoor was opgericht. In de twee boeken die de grote overzichtstentoonstellingen begeleidden, werd natuurlijk ook over Coen geschreven. In het ene werd Coen op afstand gezet: 'Coen stond een zeer militante koers voor. (...) Dit bracht hem in voortdurend conflict met de Heren XVII, die de handelsdoelen van de Compagnie veelal met minder gewelddadige en kostbare methodes wilden bereiken. ${ }^{4}$ In het andere was de nuance ver te zoeken: 'In zowel Indonesië als Nederland is Coen het symbool van alles wat bruut, slecht en fout was aan de Compagnie. ${ }^{5}$

Dit zwarte beeld van Coen is niet maatgevend voor wat de afgelopen anderhalve eeuw over hem geschreven is. Voordat de Nederlandse schrijvers aan bod komen, laat ik eerst een van de weinige buitenlanders die over Coen hebben geschreven, aan het woord. Het citaat stamt uit het einde van de negentiende eeuw:

'Coen stands out from among all men of European race in Asia of his day, a statesman of the clearest vision, and an administrator of the firmest hand, halfway between the Portuguese Alburquerque in the sixteenth century and the French Dupleix or the English Warren Hastings in the eightteenth. But he could not rise above the morals of his age and his strong personality during a double tenure of office impressed the stamp of a cruel age on the colonial system of his country. His crime, or misfortune, was that he stereotyped in Dutch India the dis- 
regard for human suffering which brutalised Europe during the Thirty Years War.' 6

In Nederland daarentegen wordt in de geschiedschrijving een dergelijke afstandelijkheid niet ingenomen over Coen. Te beginnen rond I860 met de opgang van de ethische politiek in Indië. Jhr. mr. J.K.J de Jonge, de rijksarchivaris die zich als een der eersten verdiepte in de geschiedenis van de VOC, schreef in I862:

'In dit opzicht stond de zachtmoedige Arminiaan, Reael, op een veel hooger zedelijk en staatkundig standpunt dan de scherphoekige Gomaristen, de bewindhebbers, zijne meesters, dan Jan P. Coen, zijn opvolger, die, om het monopolie der Compagnie te bewaren, zelfs voor eene geheele ontvolking van de Banda-eilanden niet zijn teruggedeinsd, en eigen naam en die der Nederlandsche natie, in dat gedeelte van den Archipel, met een schier onuitwischbare bloedvlek hebben beklad.'7

Busken Huet bewonderde Coen om zijn daadkracht zoals hij in I878 schreef

'in zijne soort een voortreffelijk man ..., schrander en ernstig, ingetogen en dapper, ondernemend en de volharding zelf,' maar ook 'Coen was koopman, diplomaat, wetgever, generaal en stedehouder, maar het lot misgunde hem zich ook een mens te tonen. 8

De historicus Van der Chijs onderstreepte dit in I886 in zijn boek De vestiging van het Nederlandsch gezag over de Banda-eilanden:

'Waare voor Coen niet reeds een standbeeld opgerigt, ik betwijfel of zulks nog zoude verrijzen. Aan zijnen naam kleeft bloed.' 9

Overigens vergiste Van der Chijs zich. Er bestond weldegelijk een plan voor een nieuw standbeeld en dat werd op 30 mei I893 in Hoorn onthuld na een gloedvolle toespraak van dr. Schaepman, de katholieke voorman van zijn tijd. De criticasters van Coen verweet hij 'zelfbehagelijke kleinheid'. ${ }^{\text {Io }}$

In de jaren dertig van de vorige eeuw leken de verdedigers van Coen het pleit te winnen. De gezaghebbende historicus dr. H.T. Colenbrander schreef in I934 aan het slot van zijn biografie over Coen:

'(Coen ... ) te doen kennen is het doel van mijn schrijven geweest. Niet, hem te verschoonen: de schaduwzijden van karakter 
en gedrag meen ik te hebben vertoond. Zwaar is de verantwoordelijkheid, moeilijk het werk, groot het gevaar van wie macht begeeren. Macht vestigt zich nooit zonder onmacht te breken en daarbij wonden te slaan. Wij, die slechts te heelen hebben, mogen nimmer vergeten, dat zonder de held dezer bladzijden Nederlandsch-Indië niet zou bestaan. Door het een taak op de schouders te leggen waarvan hij noch den omvang meten noch de toekomstige ontwikkeling beseffen kon, maar die de onze niet zou zijn geworden zonder zijn initiatief, heeft hij het leven van het Nederlandsche volk verruimd; noodzakelijke voorwaarde, opdat het zou kunnen worden veredeld. Zoo wij door hem ook smaad dragen, wij kunnen dien uitwisschen, en beschoolmeesteren hem niet. In hem brak, om zijn eigen woorden te bezigen "naar alle kanten wasdom uit", ook naar zijden die wij niet bewonderen. Ware daarom de wasdom beter uitgebleven, of versmoord? Niemand die waarlijk leefde, zegt ja. De enkele lettergreep van 's mans naam is onder de zeer zeldzame die in Nederlandsch geslacht na geslacht eene trilling te weeg brengen: Coen. ${ }^{\text {II }}$

Bij de herdenking van zijn $350^{\text {ste }}$ geboortedag in I937 werd Coen op seculiere wijze heilig verklaard. Eerst in de Nieuwe Rotterdamse Courant op 8 januari I937, de dag na het huwelijk van Juliana en Bernard, door prof. dr L. Knappert, die over Coen schreef:

'(...) bij uitstek kundig, onvermoeid en van rusteloze toewijding (...) was hem dat geniaal-profetische geschonken, die goddelijke gave, waardoor uitverkorenen zien wat nog niet is en bouwen aan wat zij vastelijk gelooven dat komen zal.'

En zo ging het vele kolommen door. De feitelijke herdenking vond plaats op I februari i937: Hoorn eerde zijn 'Grooten zoon'. De herdenking van Coen moest een nationale herdenking zijn. Werkelijk iedereen deed mee. Minister-president dr. H. Colijn was voorzitter van het erecomité, waarin naast vier oud-gouverneurs-generaal en degene in functie, voorts zitting hadden de voorzitters van de Eerste en Tweede Kamer, de vice-voorzitter van de Raad van State, de rectores magnifici van de Indische universiteiten te Utrecht en Leiden, de commissaris van de Koningin van Noord-Holland en de president-directeuren van de Nederlansche Handel Maatschappij en van de belangrijkste lucht- en scheepvaartmaatschappijen. De koninklijke familie ontbrak op de dag zelve omdat het jonge paar op huwelijksreis was en koningin Wilhelmina in het buitenland uitrustte van de vermoeienissen van het huwelijk. Burgemeester Leemhorst zette de toon als volgt: 
'Coen's nagedachtenis verdient een andere bejegening dan haar ten deel valt van hen, binnen wier engen gezichtskring slechts valt wat hij heeft misdaan ... en wien ten eenenmale ontgaan die prachtige eigenschappen, die hem hebben doen zijn, wat hij voor ons geweest is en dien hem hebben doen volbrengen, wat hij ons heeft nagelaten.' ${ }^{2}$

Daarna sprak Colijn een rede uit, waarin hij Coen eerde: 'want we kunnen hem noemen een licht te midden van veel duisternis.'

Zijn daden tegen Bandanezen moesten volgens Colijn gezien worden in het karakter van de calvinistische strijd tegen de Spanjaarden. 'Dan vinden we zelfs een verschoonend en verzachtend woord voor handelingen, die, gemeten met den maatstaf van later tijd, scherpe afkeuring zouden verdienen'. Colijn sloot zijn rede als volgt af: “'dispereert niet...." zoo klinkt zijn woord; wanhoop niet ook al stuwen de golven van moeiten en zorgen tegen $U$ op. Die woorden zijn niet aan tijd of plaats gebonden. Ze werden geuit in den aanvang der $I 7^{\text {de }}$ eeuw, ze gelden óók voor onzen tijd. Ze hadden betrekking op den arbeid in Indië, ze hebben gelijke beteekenis voor het Moederland. Deze man spreekt tot ons eeuwen nadat hij gestorven is.

Hij eischt iets van ons: hij wil dat wij zijn voorbeeld zullen volgen in opofferingsgezindheid, in kloekheid, in zorgvuldig beraad, als het er om gaat de zaak van het vaderland en die van "groter Nederland" te dienen.

Zo zou hij verlangd hebben dat zijn nagedachtenis zou worden geeerd. En in die stemming herdenken wij zijn 350sten geboortedag, daarbij niet vergetend, dat het de Almachtige God is Die in het leven van een volk mannen als Coen roept om Zijn wil op aarde te volbrengen. $^{\text {I3 }}$

In zijn geloof stond Colijn dicht bij Coen.

In de periode na de dekolonisatie van Indonesië werd het stiller rond Coen. In I962 omschreef Meilink-Roelofsz in haar grote studie Asian Trade and European Influence in the Indonesian Archipelago between 1500 and about 1630 Coen als de - wellicht overijverige - uitvoerder van de bevelen van de Heren Zeventien. Van een werkelijk conflict met hen zou geen sprake zijn geweest. ${ }^{\mathrm{I}}$ Als er in de jaren daarna over Coen werd geschreven, was dat vaak in verband met de wreedheid van de volkerenmoord op Banda. ${ }^{\text {I5 }}$

Een latere korte studie die over Coen verschenen is, is van de hand van R.J. Spruyt, de voormalige directeur van het West-Fries Museum in Coens geboortestad Hoorn. Het werd geschreven ter gelegenheid van Coens $400^{\text {ste }}$ geboortedag in I987. Hoewel het de bedoeling was 'Coens daden in dienst van de VOC aan een kritische beschouwing te onder- 
werpen' bleef deze auteur aan de oppervlakte. Zo schreef hij: 'De Heren XVII namen telkens aanstoot aan de felle kritiek van hun Compagniedienaar. Ze slikten echter veel, omdat zij wisten dat Coen niet alleen een goed bestuurder en koopman was, maar vooral omdat hij behoorde tot de weinige mensen die niet corrupt waren.' ${ }^{\text {I6 }}$

Hoe het beeld van Coen thans geworden is, blijkt uit de citaten van de in 2002 verschenen boeken. Luc Panhuysen deed daar in 2009 in het Historisch Nieuwsblad nog een schepje bovenop: 'De Heren XVII keken met walging naar Coens bloedbesmeurde handen, maar deden zich wel te goed aan de rijkdommen die hij hielp binnenhalen'. ${ }^{\text {I7 }}$

Coen is in de geschiedschrijving hoe langer hoe losser van zijn omgeving en van zijn tijd komen te staan. Hierdoor is geleidelijk het beeld ontstaan dat Coen individueel, niet alleen fysiek, maar ook intellectueel verantwoordelijk was voor het beleid van de VOC tijdens zijn bewind. Hij wordt daardoor zoals Colenbrander al schreef 'buiten de maat' gesteld. ${ }^{\text {I8 }}$ Hoewel door het aanwijzen van een zondebok politiek een hete aardappel correct op de rand van het bord geschoven wordt, doet zo'n voorstelling aan de geschiedenis geen recht. Want, was Coen nu wel of niet voortdurend in conflict met het bestuur van de VOC in de Republiek? Wat was de invloed van de politieke situatie in Amsterdam en de Republiek voor het voorgestane beleid?

Daarnaast is door de controverse rond Coen een groot dilemma waarvoor de VOC zich geplaatst zag direct na de vestiging van Batavia, onderbelicht gebleven: de vraag of Batavia moest uitgroeien tot een zo groot mogelijke Nederlandse kolonie, of juist tot een zo zuinig mogelijke bemande hoofdvestiging van de VOC in Azië.

\section{J.P.Coen in kort bestek}

Jan Pieterszoon Coen werd op 8 januari 1587 in Hoorn geboren ${ }^{\text {I9 }}$ en op II januari 1587 in de gereformeerde kerk aldaar ten doop gehouden door zijn ouders Pieter Willems Coen en Geert Jansdochter Mol. ${ }^{20}$ Jan had een jongere zuster, Aefgen. De vader van Pieter Willems, Willem Coenes, had zich eerder vanuit het nabij gelegen Twisk in Hoorn gevestigd.

In I568, het jaar van de aankomst van de hertog van Alva met zijn leger in de Nederlanden, vluchtte hij waarschijnlijk met zijn familie zoals velen om geloofsredenen naar Emden in Noord Duitsland. ${ }^{2 \mathrm{I}}$ Hoorn verklaarde zich in 1572 voor de opstand en de familie keerde weer terug in Hoorn.

Het gezin van Pieter Willems Coen woonde in de Mallegomsteeg, vlak bij de oude haven van Hoorn. Van de oorspronkelijke bebouwing van de Mallegomsteeg is niets bewaard gebleven. Overigens zette dit 
'Mallegom' de historicus Gerretson op het verkeerde been: hij leidde eruit af dat deze Pieter Willems voer op Malaga, door de Straat van Gibraltar en dus een van de eerste straatvaarders was. Hij vergistte zich. Over de zakelijke activiteiten van Pieter Willems Coen is vrij veel terug te vinden in het Hoorns archief waaruit blijkt dat hij geen 'straatvaarder' was, maar een 'Spaensvaerder'. ${ }^{22}$ Hij huurde scheepsruimte die hij bevrachtte met onder andere rogge naar het in zuid-Portugal gelegen Faro om vervolgens een retourvracht zout rechtstreeks naar de Baltische zee te laten varen. ${ }^{23}$ Regelmatig, of wellicht altijd voer hij met het gecharterde schip mee. In I600 werd hij bedlegerig en overleed rond maart 1602,47 jaar oud. $^{24}$

Vlak na zijn vaders overlijden ging de jonge Jan Pieterszoon in de leer bij het handelshuis van Justus Pescatore in Rome, waar hij in ieder geval voortreffelijk boekhouden leerde op de toentertijd nieuwe Italiaanse manier, dat wil zeggen dubbelboekhouden met een balans en aparte winst- en verliesrekening zoals dat sinds die tijd eigenlijk niet meer is veranderd. Deze uitstap was minder merkwaardig voor een calvinist dan die nu wellicht lijkt. Pescatore staat namelijk voor de in oorsprong Vlaamse calvinistische familie De Visscher. Deze had net als de familie Coen haar toevlucht gezocht in Emden, waarna zij zich vestigde niet alleen in Rome, maar ook in Amsterdam en Hoorn. Buitenlandse calvinisten liepen in Rome geen gevaar door de Inquisitie gevangen genomen te worden. ${ }^{25}$

Nadat hij in Hoorn teruggekeerd was, vertrok Jan Pieterszoon Coen in december 1607 in de rang van onderkoopman voor de VOC naar Azië. Dit was op de vierde vloot van de VOC die met een omvang van negen schepen onder commando stond van de onfortuinlijke admiraal Pieter Willemsz Verhoeff. De Staten-Generaal rustten twee van de schepen op hun kosten uit. Op deze vloot bevonden zich ook Piet Hein en de latere gouverneur-generaal Jacques Specx. Verhoeff kreeg twee instructies mee. Eén openbare, die de nadruk legde op de handel en één geheime, die de nadruk legde op de strijd tegen de Portugezen in Mozambique, Goa, Malakka en de Molukken.

In Bantam aangekomen, kreeg Verhoeff nog een derde nagezonden instructie. Deze had betrekking op de gevolgen van het naderende Twaalfjarige Bestand. Hij moest zoveel mogelijk plaatsen bezetten en contracten afsluiten, omdat na de afkondiging van het bestand de invloedssfeer van de VOC in Azië bepaald zou worden door de forten en de exclusieve handelscontracten. Dit zogenaamde uti possidetis-principe zou in Azië gelden vanaf één jaar na sluiting van het bestand in Europa.

In bewoordingen waarin duidelijk afkeer tegen een wapenstilstand doorklonk, schreven de bewindhebbers hierover: 
'De eylanden van Banda en de Moluques is het principaalste wit, waernaer wy schieten' [...] 'deselve soekende met tractaet ofte met geweld aen de Comp. te verbinden vóór den 1sten september 1609 ofte eerder, oock op elck land een klein fortres opwerpende met eenich krijghsvolck besettende ${ }^{26}$

Van een bestand zoals in Europa zou overigens in Azië geen sprake blijken te zijn.

Gehoor gevend aan zijn laatste instructie wilde Verhoeff een fort bouwen op het Banda-eiland Neira. Onder het mom van onderhandelingen onder welke voorwaarden de bouw zou plaatsvinden, werd Verhoeff op 22 mei I6o9 door de Bandanezen in de val gelokt en met zo'n 40 anderen overvallen en vermoord. Zoals Valentijn schreef:

'Men vont den zeevoogt zonder hoofd, en met 29 wonden deerlyk aan zyn einde gebragt. ${ }^{27}$

In I6ıг keerde Coen in Nederland terug en het jaar daarop vertrok hij weer naar Oost-Indië, nu als opperkoopman en commandeur van twee schepen. In I6I3 werd hij door de eerste gouverneur-generaal, Both, benoemd tot boekhouder-generaal van alle kantoren in Indië en directeur van de kantoren van de VOC in Bantam en Jakarta. In die jaren legde Coen de grondslag voor de administratie van de VOC in Azië.

Op r januari I6I4 schreef hij een lang 'discours' over 'den Nederlantsche Indischen staet' aan de bewindhebbers in Nederland ${ }^{28}$, waarin hij duidelijk verder ging dan Matelief in zijn memories van I608. Hij week weliswaar niet af van diens denkbeelden, maar voegde daaraan toe, dat, om de macht van de VOC in Azië te verankeren, deze zich verder in dezelfde richting moest ontwikkelen als de Portugezen dat gedaan hadden: ondersteund met veel schepen en geld zouden Nederlandse koloniën gevestigd moeten worden.

Eveneens in I6I4 werd Coen door de nieuwe gouverneur-generaal Reynst benoemd tot lid van de Raad van Indië en directeur-generaal van alle kantoren van de VOC in Azië. Gerrit Reynst was admiraal geweest van de vloot die in I600 vanuit Amsterdam naar Indië was gevaren en vanaf I602 bewindhebber bij de kamer van de VOC in Amsterdam. Hij kwam uit dezelfde calvinistische hoek als Coen, wat blijkt uit het gegeven dat hij in I6I3 getuige was geweest bij de doop van de kleinzoon van Reinier Pauw. ${ }^{29}$ Ook was Reynst de zwager van de gereformeerde Amsterdamse burgemeester Witsen. ${ }^{30}$

Toen Reynst in I6r6 plotseling overleed, werd Laurens Reael, de toenmalige gouverneur van de Molukken, door de Raad van Indië geko- 
zen om Reynst op te volgen. De geleerde Amsterdamse regent Reael zou echter niet lang in functie blijven. De contraremonstrantse fractie had namelijk juist in Amsterdam de macht aan zich getrokken en de verkiezing van de bij uitstek remonstrantse Reael moet een schok geweest zijn. Hij werd onmiddellijk teruggeroepen. ${ }^{3 \mathrm{I}}$

Op 30 april I6I8 ontving de toen 3I-jarige Coen het bericht van zijn benoeming tot gouverneur-generaal. Gedurende zijn eerste gouverneur-generaalschap (I6I9-I623) richtte hij zich op de vestiging van een hoofdplaats voor de VOC in Azië en op het veiligstellen van het specerij-monopolie in Banda en de Molukken. Dit was niet mogelijk zonder confrontatie met de Engelsen, Javanen, Molukkers en Bandanezen. Steeds vond Coen de middelen waarover hij kon beschikken voor de uitvoering van zijn taak veel te beperkt, daarover schreef hij op 29 september I6ı8 de volgende bekende passage:

'Derhalve bidde andermael seer demoedelijck, dat de heeren metten eersten herwarts aen gelieven te senden groote menighte van volck, menighte van schepen ende groote somma gelt, met alderley nootlijckheden. Dit doende sal alles wel gelucken; soo niet, sal't U.E. berouwen. Dispereert niet, ontsiet uwe vyanden niet, daer en is ter werelt niet dat ons can hinderen noch deeren, want Godt met ons is; en trect de voorgaende mislagen in geen consquentie, want daer can in Indien wat groots verricht ende daer connen tegelijck jaerlicx groote rijcke retoeren gesonden worden. 32

Coens latere roem rust mede op zijn groots taalgebruik.

Coen was niet zomaar al op de jonge leeftijd van 28 jaar in I6I5 directeur-generaal geworden. Hij genoot het volle vertrouwen van de Heren Zeventien en werd meer nog dan de gouverneur-generaal rechtstreeks aangeschreven. De Heren Zeventien verwachtten daden van hem. Die daden kwamen er. Hoezeer daarbij het gebruik van geweld werd ingecalculeerd, blijkt uit onderstaande fragmenten van hun brieven aan Coen.

In I6I5 over Banda:

'Wy zouden nu geraden vinden (...) dat men nu deselve onse forcen en schepen mochte gebruycken omme yets groots tot affbreuck van den vyand tedaarmede uut te mogen richten ende de Bandanesen te vermeesteren, de principale uut te doen roeyen ende verjagen, ende 't land liever met heydenen wederom te doen peupleren. ${ }^{33}$ 
In zijn discours van I6I4 was Coen zelf minder vergaand. De Bandanezen moesten volgens Coen wel met de wapenen 'ten onder gebracht worden', 'doch niet tierannichlijck, maer eenighe wel rigoreuselijck. ${ }^{34}$

In november I6I7 schreven de Heren Zeventien aan Coen:

'Wy vinden noodich U.E. als in 't eerste ende in 't middelste soo oock in 't leste van dese onse brieven andermael ten hoochsten te recommanderen het principael hoofftpoinct van onsen handel, dat is dat men niet alleenlijck de Chinesen, Javanen, Clingen, Maleyen ende andere vreemde natien, maer oock insonderheyt d'Engelse, Francoisen ende andere wie se oock sijn, die ons den handel in de Moluques, Banda ende andere plaetsen, daer wy forten ende contracten hebben, sullen soeken te verderven, sal sien daeruyt te houden ende ten dien eynde (naer eenige vriendelijcke waerschouwinge ende vermaningen vermogens onse vorige ordre, in de copien hierby gevoecht), den middel van wapenen daertegens te gebruycken ende haerlieder met gewelt te doen vertrecken, sonder daerinne langer te simuleren offte civiliseren gelijck als voor desen gedaen is, alsoo de verder conniventie de ruine van de Compagnie soude medebrengen (...). ${ }^{35}$

Met name de Engelse dreiging was bepaald niet fictief. Zoals uit de notulen van de vergaderingen van de directors van de East India Company blijkt, was het in I6I5 hun bedoeling 'to boldly brake into the Spice Islands and to attempt both Banda and Amboyna'. ${ }^{6}$

De Heren Zeventien prezen ook de even harde als dodelijke hand van gouverneur Speult bij de uitoefening van zijn gezag op Ambon. Deze zou nagevolgd moeten worden

'om daerdoor te verseeckeren voor onse Compagnie de vruchten van naegelen, nooten ende foelie, die soo somnelijcken ende op soo een swaere ende costelijcke conditie (...) ons alleene sijn verbonden, opdat d'inwoonderen mogen leeren gehoorsaamen ende eyndetlijck affectie dragen. ${ }^{37}$

Met kennis van deze brieven zal Coen zich in die jaren waarschijnlijk nooit hebben afgevraagd of zijn meesters in patria anders dachten over het gebruik van geweld dan hijzelf.

\section{De vestiging van het rendez-vous}

De stichting van Batavia is ongetwijfeld de belangrijkste gebeurtenis geweest in de geschiedenis van de VOC. In veel brieven van de Heren Zeventien aan Coen tussen I6I4 en I6I8 werd over de vestiging van een 
hoofdplaats in Azië, het rendez-vous, geschreven. Alle betrokkenen wisten dat het een hachelijke onderneming zou zijn. Het is in die stukken prachtig te zien hoe de Heren Zeventien een aantal jaren heen en weer werden geslingerd tussen moed en vrees en worstelden met het formuleren van de instructie aan Coen. In hoeverre handelde hij binnen de instructies die hem werden gegeven?

Om te beginnen een fragment uit de brief aan Coen van november I6I4:

'Wy hebben by desen brieven den heer Gouverneur (gouverneur-generaal Reynst, die op de Molukken resideerde-w) ten hoochsten gerecommandeert de verkiesinge van een rendez vous in de Strate van Sunda, om aldaer mettertijt eene colonie te planten volgens de resolutie van de leste vergaderinge van de Seventhiene, daervan wy hiernevens de copye senden, verhopende dat ghy daerin nevens d'andere Raden in Indien met alle voorsichtichheyt sult helpen raeden ende de saecke dirigeren, dat sulcx met de minst ongunste ende vooral sonder eenige schade ofte verlies onser goederen (als voor deesen) ten effecte gebracht sal werden. Wy sullen daerop ende op de particuliere aanwysing van de bequamste plaetsen ofte eylanden in de voorsz. Strate van Sunda U.E. advijs verwachten, daertoe ghy U.E. neerstelijck op alle gelegentheden ende commoditeyten derselver meucht informeren ende ons particulierlijck over schrijven. ${ }^{38}$

$\mathrm{Nu}$ niet bepaald een vrijbrief aan Coen om zijn gang te gaan.

Een halfjaar later was de toon daarentegen veel beslister:

'Wy hebben U.E. voor desen hooghlijck gerecommandeert het verkiesen en versekeren van een rendez vous (...) maer hoe deselve bevonden off watter verders in gedaen is, hebben nog niet vernomen. 39

Coen schreef zijn rapport waarin hij na diverse afwegingen de voorkeur gaf aan Jakarta als vestigingsplaats, zoals Matelief in 1608 ook al had gedaan.

Intussen echter was in I6I7 Joris van Spilbergen teruggekeerd in de Republiek, nadat hij in opdracht van de VOC met een vloot de wereld had rondgevaren. Op Java had hij met Coen overlegd. Blijkbaar plaatste Van Spilbergen de nodige kanttekeningen bij de keuze voor Jakarta en de angst sloeg de Heren Zeventien om het hart:

'Maer aengaende het (...) incorporeren van seeckere aldaer by U.E. gelegen plaetsen om tot een rendez vous te maecken, daervan ons den voorsz. Spilbergen van uwerlieden wege mede particuliere openinge heeft gedaen, 't selve vinden wy van grooten bedencken ende perijckel, 
hoe men soodanige plaetse tegens een soodanich machtich en peupleus volck souden kunnen maintineren,'

om verder in de brief nogmaals te benadrukken dat de heren een dergelijke onderneming 'seer bedenckelijck en vol perickels' vonden om te vervolgen 'soodat ghylieden, aleer sulcx te beginnen, wel rypelijck ende wyselijck niet alleen het begin, maer oock het succes ende 't geheele gevolch van een soo swaere saecke met den anderen hebt t'overleggen'. ${ }^{\circ}$

Weer een halfjaar later hervonden de Heren echter hun moed en kreeg Coen de vrije hand. Na overleg met 'de Hooch Mogende Heeren Staten-Generael ende syne princelijcke Exellentie' (Maurits-w) gaven zij hun zegen aan een vestiging bij Jakarta. Nadat zij nog geschreven hadden dat de beslissing gesteund werd 'oock van den heer advocaet van 't Landt (Van Oldenbarnevelt-w) ende andere voorneme persoonen van qualiteyt ende van state hier te lande' en de uitvoering nu ook werkelijk moest gebeuren 'soo willen wy U.E.andermael gerecommandeert hebben (gelyck wy oock by onse voorgaende gedaen hebben) dat ghylieden (...) hoe eer hoe liever de sake by der handt wil nemenende en ten effecte sien te brengen'. Om ten overvloede te vermanen 'dat het werck nu doch eens sonder veel meer over ende weder schryvens (daermede veel tijts verlooren werdt) in conformité met onse vorige ordre' zo snel mogelijk, maar wel voorzichtig moest worden uitgevoerd. ${ }^{4 \mathrm{I}}$

In I6r8 gaven zij Coen nogmaals volledige steun

'ende dat ghylieden de plaetse soodanich ende soo bequaem vindt als ons deselve hier wort aangepresen ende by U.E. in de leste brieven werdt beschreven, willen wy uwelieden gerecommandeert hebben (gelijck als oock by de generaele vergaderinge van de Seventhiene geschreven is), de saecke sonder eenigh langer dilaey ofte versuym byderhand te nemen, sonder eenige goede occasien, die daertoe mochte presenteren, voorby te laten gaen'. ${ }^{42}$

Deze boodschap bereikte Coen in Jakarta in juli I6ı8 per schip dat de toepasselijke naam 'Zeewolf' droeg. De heren gingen er zelfs toe over een ontwerp voor een fort door Simon Stevin mee te sturen. Meer aanmoediging had Coen niet nodig en in de laatste maanden van I6I8 kwam hij in actie.

De jarenlange rivaliteit tussen de Engelse East India Company (EIC) en de VOC kreeg aan einde van het jaar i6ı8 een gewelddadig karakter. In de Molukken namen de Nederlanders een tweetal Engelse schepen in beslag en op de rede van Bantam deden de Engelsen hetzelfde met het Nederlandse schip 'de Swarte Leeuw'. Doordat de Engelsen buiten verwachting voor de rede van Jakarta over meer schepen konden beschik- 
ken dan de VOC, kwam Coen in de problemen. Na een behoedzame confrontatie tussen de vloten trok Coen zich in de eerste dagen van I6I9 met zijn scheepsmacht terug naar de Molukken om versterkingen te halen. Het fortje met een bezetting van tweehonderdvijftig man vrijwel zonder ammunitie, werd belegerd door de Jakatranen en de Engelsen. Aanvankelijk leek de situatie hopeloos en op 3i januari i6 I9 besloot men dan ook zich over te geven. De akte van overgave werd mede door Thonis Meeusen ondertekend. ${ }^{43}$ Door onenigheid tussen Bantammers en Jakatranen en terughoudendheid van de Engelsen bleek overgave echter voorbarig. Het fortje hield stand en van een belegering was daarna weldra geen sprake meer.

In mei keerde Coen - nu wel officieel gouverneur-generaal - met een grote vloot terug. Op 30 mei landde hij met meer dan duizend man, ruimde de verlaten stellingen van de belegeraars uit de weg en veroverde Jakarta en de omliggende landen. Zij werden souverein bezit en Jakarta, later omgedoopt tot Batavia, werd de hoofdvestiging van de VOC. ${ }^{44}$ Met de bouw van Batavia kon worden begonnen.

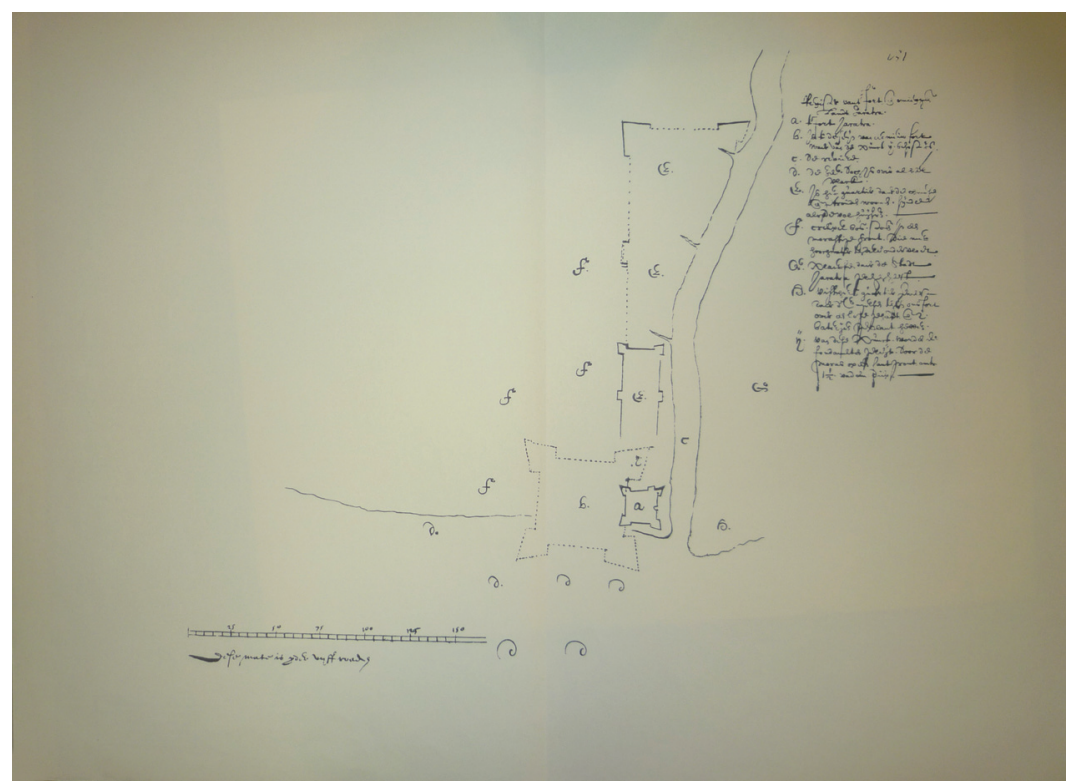

Plattegrond voor het kasteel van Batavia van de hand van Jan Pieterszoon Coen. Het werd een kopie van het kasteel van Jülich (Gulick) zoals dat door Simon Stevin was opgemeten en als voorbeeld naar Coen was opgestuurd. Langs de punten mat het 400 bij 400 meter. 'Doe het groot of doe het niet' was een uitspraak van Coen. Nationaal Archief Den Haag. 
Vervolgens liet Coen zijn vloot los op de Engelsen en veroverde, vaak met geweld, in korte tijd niet minder dan zeven schepen. De Raad van Indië onder leiding van Coen veroordeelde de hogere functionarissen die overgave op I februari hadden ondertekend met ontzetting uit hun ambt en een geldboete. Maar aan de lagere compagniedienaren, waaronder Thonis Meeusen, werd gratie verleend.

$\mathrm{Na}$ het beleg bleek dat een aantal assistenten zich compagniegoederen had toegeëigend, onder de namen van hen treffen we de naam van Thonis Meeusen niet aan.

De Heren Zeventien schreven aan Coen over het gepasseerde 'also wy ten hoochsten verblijt sijn geweest te verstaen de goede en geluckige uytcompste' die dan misschien gedurende het beleg 'meer door geluck als door beleydt' in handen van de Compagnie was gebleven.

De Heren Zeventien bevestigden Jakarta als het rendez-vous: 'als sijnde dezelve plaetse ende het land daerontrent gelegen geconquesteert ende gewonnen in een goede, oprechte ende welgefondeerde oorlooge, die wy nootsaeckelijck tot onser defentie hebben moeten aennemen. ${ }^{45}$

$\mathrm{Nu}$ de verovering een feit was kon met de stichting van het rendezvous worden begonnen. In zijn verwachtingen over de toekomst van Jakarta schreef Coen: 'Soo sal Jakarta de treffelijckste plaetse van gants Indien werden, ende seer haest sal hier de stapel van de gantsche Indischen handel zijn, want de plaetse daertoe seer wel gelegen ende seer bequam is. ${ }^{46}$

Dat was precies 25 jaar nadat in I594, bij de voorbereiding van de eerste vaart van de Hollanders naar Oost-Indië, voor het eerst geschreven werd over een Hollands stadje op Java aan de Straat Sunda: 'Daar zou kunnen verrijzen "een modelplaetze gelijck Antwerpen placht te wesen (...) oft gelijck Venegien is tusschen die van Oosten ende Westen". 47

Niet op de hoogte van deze ontwikkelingen in de Oost sloten op i7 juli I6ı9 de Engelse en Nederlandse Oost-Indische Compagnieën een verdrag waarbij de Engelsen recht kregen op één derde van de opbrengst van het specerij-monopolie, mits zij de kosten mede droegen. Op 27 maart I620 kreeg Coen dit bericht. Hij was natuurlijk op de hoogte geweest van onderhandelingen, maar had uit een vorige missive begrepen dat zij zouden worden afgebroken. Hij was verbijsterd.

Op II mei van dat jaar schreef hij hierover aan de Heren Zeventien:

'Lachen d' Engelsen tot danckbaerheyt, soo is den arbeyt niet verlooren. Grooten danck zijn zy U.E. schuldigh, want hadden haerselven met recht uut Indien geholpen, ende heeren hebben hun daer weder middenin geseth. Meenen zy het recht en wel, sal 't wel weesen; maer weederom quaet willende, hebt ghylieden, is het te duchten, 't serpent in de bosem geseth. Wy bekennen, dat het de knecht niet en roert, wat 
de meester doet, maer evenwel doet ons gemeen gebreck (gelijck de zotten) spreecken; niet om dese vereeninge te bestraffen, want ons kennelijcken is, hoeveel den staet der Vereenichde Nederlanden ten hoochsten aen de goede vrientschap, correspondentie ende vereeninge van de croone van Engelandt gelegen is. Maer U.E. is onder correctie al te haestich geweest. Ende waeromme d'Engelsen een derde van de nagelen, noten en foelye vergunt is, connen niet wel begrypen. Niet een sandeken van 't strandt hadden zy in de Molluccos, Anboyna noch Banda te pretendeeren. ${ }^{4} 8$

Naar te verwachten was, ging de samenwerking met de Engelsen niet van harte, dat gold voor beide zijden overigens. Na een paar jaar hield deze dan ook weer op.

Tot slot de vraag of de Heren Zeventien geen aanstoot namen aan de aanmatigende toon van Coen in zijn brieven. Een interessant wisselend beeld laat zich dienaangaande zien. Was de toon in $\mathrm{I} 6 \mathrm{I} 6$ vergoelijkend naar Coen:

'U.E. goeden yver tot het meeste profijt ende voordeel van de Compagnie ende den goede moet ende courage (...) doen ons lichtelijck vergeten de passie ende hevige propoosten by U.E tegens ons in syne brieven gebruyckt, soodat het onnodich was, deselve by dese leste brieven t'excuseren, want van soodanighe trouwhertige dienaers lichtelijcks yets sulcks te verdragen is. ${ }^{\prime} 4$

In I622 echter, ging de wind uit een heel andere hoek waaien. De bewindhebbers hadden genoeg van Coens overgrote woorden: bevinden $w y$, dat U.E. sijt clagende over diverse poincten, jaa, eenige derswelcken met sulcke vrymoedicheyt in woorden syt extenderende, die alle maet, regel ende discretie te buyten gaet..$^{50}$

Het gegeven dat er in de periode I6I5 tot I62I in ieder geval geen controverse bestond tussen Coen en de Heren Zeventien is op zichzelf een belangrijke conclusie.

Het voorgaande toont aan dat Coen de uitvoerder was van het beleid zoals dat uitdrukkelijk werd geformuleerd door de Heren Zeventien, inclusief het gebruik van geweld. Ook als persoon wist men wat voor karakter en figuur men had benoemd in Indië.

Waar dus tevoren het gebruik van geweld werd gestimuleerd, werd het in I622 afgeremd zoals blijkt uit het oordeel van de Heren Zeventien over de verovering van Banda: 
'Die van Banda hebben een harde straffe over hare voorgaende moorderye, bontbreckinge en andere ontrouwicheden, tegen de onse buyten reden begaen, geleden, 't welck wy achten vry wat schricks ende andere tot exempel sal dienen. Laet het een ende genoegh wesen. Wy hadden wel gewenst, dattet met gematichder middelen hadde connen beslist werden. Sy hebben haer voorgaende trouloosheyt dier genoegh betaelt. 't Sal wel soo geseyt is, ontsagh, maer geen gunst baren. Die'r veel doet vresen, moet veel vresen. De geslagen wonde moet men met alle sachticheyt soeken te verbinden, doch sich wel wachten, in geen nieuw perickel te vervallen. ${ }^{5 \mathrm{I}}$

Om deze verandering in de waardering van Coen te kunnen volgen, moeten wij deze spiegelen aan de eerdere harde afwijzing van het beleid van Coens voorganger, Laurens Reael. Hem werd slapte verweten. Aan Coen werd daarover in de periode van I6I5 tot I6I8 regelmatig geschreven in niet mis te verstane toon: 'Voorder hebben wy met onlust verstaen' en in het vervolg kreeg Reael dan een stevige veeg uit de pan. ${ }^{52}$ Dit gebeurde haast in elke brief omdat veel ' (...) by den commandeur Real tot nadeel van de Compagnie was verandert. ${ }^{53}$

Toen Coen in I6I7 tot gouverneur-generaal werd benoemd, kreeg hij instructie Reael onmiddellijk naar huis te zenden:

'Real (...) met d'eersten schepen sult overseynden, sonder eenichsins te gedoogen dat hy aldaer langer soude blyven, om vele pregnante redenen ende consideration ons daertoe mouverende, die wy niet geraden vinden hierby te voegen. ${ }^{54}$

\section{De invloed van de gebeurtenissen in de Republiek op het beleid van de VOC in de jaren 1615-1621}

Via de instructies van de Heren Zeventien bestond een direct verband tussen het voorgestane beleid van de VOC en de gebeurtenissen in de Republiek in de jaren I6I5 tot I62I. Want de eerdere volmondige steun en de latere koele toon van de aan Coen gerichte brieven in deze periode, alsmede de manier waarop Reael werd aangepakt, kwamen niet uit de lucht vallen, maar vormden een weerspiegeling van het verloop van de strijd om de macht, zowel in de stadsregering van Amsterdam als in de Republiek.

Hier nu komen wij met een grote sprong op de beslissende rol van enerzijds de machtige Amsterdamse koopman en regent Reinier Pauw (I564-I636) met zijn medestanders in de strijd tussen de contraremonstranten of gomaristen en prins Maurits en anderzijds de remonstranten of arminianen en Van Oldenbarnevelt. De steun van de gomarist 
Pauw aan Maurits droeg in belangrijke mate bij aan de overwinning van Maurits op Van Oldenbarnevelt. De positie van Reael wordt ons duidelijk als wij weten dat hij de zwager was van Arminius.

Om meer begrip te krijgen van de militante calvinistische stroming waarvan Coen en Pauw deel uitmaakten, moeten wij diep graven en teruggaan naar de beeldenstorm en de jaren erna. In 1566 gloorde de triomf van de aanhangers van het nieuwe geloof, maar de komst van Alva dreef hen op de vlucht. Enkele duizenden bannelingen uit de noordelijke provincies trokken naar Emden in Noord-Duitsland. Van hieruit konden de gevluchte kooplieden onder hen hun Baltische hout- en graanhandel voortzetten. Zij waren niet met zo velen, en hadden ook nog niet hetzelfde gedachtegoed. Pas in de jaren van ballingschap in Emden vormde zich het noord-Nederlandse calvinisme. In Emden stond de moederkerk, waarvan de inscriptie in de poort van de grote kerk in Emden nog getuigt: 'Gods kerck vervolgt, verdreven, heft God hyr trost gegeven.' 55

Het waren bange jaren voor de bannelingen. In I568 versloeg Alva bij Jemmingen, op slechts tien kilometer van Emden, het leger van Lodewijk van Nassau genadeloos en trok hij op tot voor de poorten van deze stad vanwaar hij zich onverwacht weer terug trok. Het jaar daarop heerste pest in Emden, velen verloren het leven. In I57I werd een geuzenvloot in de haven van Emden door een Spaans-Nederlandse vloot overrompeld en werden meer dan honderd opvarenden in het zicht van de stadswallen ter dood gebracht.

Onder deze dreigingen voelden de vluchtelingen zich door God verkozen het ware geloof van de ondergang te redden. In Emden waar men buiten het stadsbestuur stond, verkreeg de kerkenraad zijn streng gezag over de zeden. Elke afwijking van de leer werd fel bestreden. Dit werd bevestigd door de eerste Nationale Synode die in I57I in Emden werd gehouden. Naar Emden vluchtte onder anderen de vader van Jan Pieterszoon Coen, maar ook die van Reinier Pauw en de vader van de latere tegenstrever van deze twee, Laurens Reael. Zoals gezegd: men kende elkaar. In Emden stond de oude Reael een gematigde koers voor, zoals ook zijn zoon dat later zou doen. Zijn lijfspreuk liefde vermacht al' gaf zijn positie aan.

Terug in de Republiek namen de bannelingen van weleer vooral in Amsterdam de macht over. Hun dadendrang was enorm en letterlijk onbegrensd. In de aanloop naar het Twaalfjarig Bestand begon niet alleen de verwijdering tussen Maurits en Van Oldenbarnevelt zich af te tekenen, maar ook die tussen Van Oldenbarnevelt en de Amsterdamse kooplieden. De laatsten vonden het bestand slecht voor de handel. Bijzonder fel werd de strijd tussen de twee partijen. Geloof, economie en politiek werden erin aan elkaar gekoppeld. Een strijd die uiteindelijk zou leiden tot de onthoofding van Van Oldenbarnevelt en bijna tot een 
burgeroorlog. Reinier Pauw was de voorzitter van de rechtbank die Van Oldenbarnevelt schuldig bevond. Elias heeft in zijn boek over de vroedschap van Amsterdam deze machtsstrijd meesterlijk beschreven. ${ }^{56}$

Voor ons is hierin van belang dat in de eerste vergadering van de Heren Zeventien in I602 Pauw werd benoemd tot 'continuelijck president' en dat hij in I6I3 terugtrad om zich meer te kunnen wijden aan de politiek. Zijn nauwe band met de VOC bleef echter bestaan. Pauw en de zijnen waren in Amsterdam aan de macht tussen I6I3 en I62r. Als relatief onschuldig voorbeeld van hoe diep deze macht ingreep, dient de aanstelling van Hessel Gerritsz in de functie van kaartenmaker van de VOC. In IGI7 werd hij, omdat hij een gomarist was, in deze functie voor het leven benoemd. Zijn leermeester, Willem Blaeu, zou eigenlijk veel meer voor deze functie in aanmerking zijn gekomen, maar Blaeu was arminiaan. Dankzij ingrijpen van Laurens Reael werd Blaeu in I633 na de dood van Gerritsz tot diens opvolger benoemd. ${ }^{57}$

Minder onschuldig was het verdrag tussen de EIC en de VOC van I6I9 waartegen Coen zo gekant was en dat zijns inziens haaks stond op het belang van de VOC in Azië. Gaastra schreef hierover dat dit verdrag werd afgesloten met het oog op het aflopen van het bestand in I62I. ${ }^{58}$ In diens opvatting was het een tactische manoeuvre van de Heren Zeventien, waarmee de Nederlanders hun voorsprong consolideerden en de Engelsen aan banden legden, terwijl de uitkomst van de onderneming van Coen die zou uitmonden in de stichting van Batavia, nog geenszins duidelijk was. Daarnaast werd zo de dreiging weggenomen dat de Engelsen zich zouden verenigen met de Spanjaarden, Fransen of Denen tegen de Nederlanders.

Toch schreef MacLeod in zijn De Oost-Indische Compagnie als zeemogendheid in Azië hierover: 'Het is verwonderlijk, dat de Bewindhebbers in zulk een tractaat hebben kunnen toestemmen. ${ }^{59}$ En de Engelse koopman Thomas Mun rekende zich in zijn discours al rijk met de inkomsten van het Engelse deel. ${ }^{60}$ Er was, denk ik, dan ook meer aan de hand. Het traktaat met de Engelsen werd afgesloten in juni I6I9 op het hoogtepunt van de macht van Reinier Pauw, burgemeester van Amsterdam en voornaamste steunpilaar van Maurits in zijn strijd met Van Oldenbarnevelt.

Buiten de geloofskwestie was de buitenlandse politieke strategie van de Republiek het grote geschilpunt. Moest men kiezen voor Frankrijk en een voortzetting van het bestand zoals Van Oldenbarnevelt voorstond, of voor Engeland als bondgenoot tegen de Spanjaarden en hervatting van de strijd, waarvoor Maurits koos? 


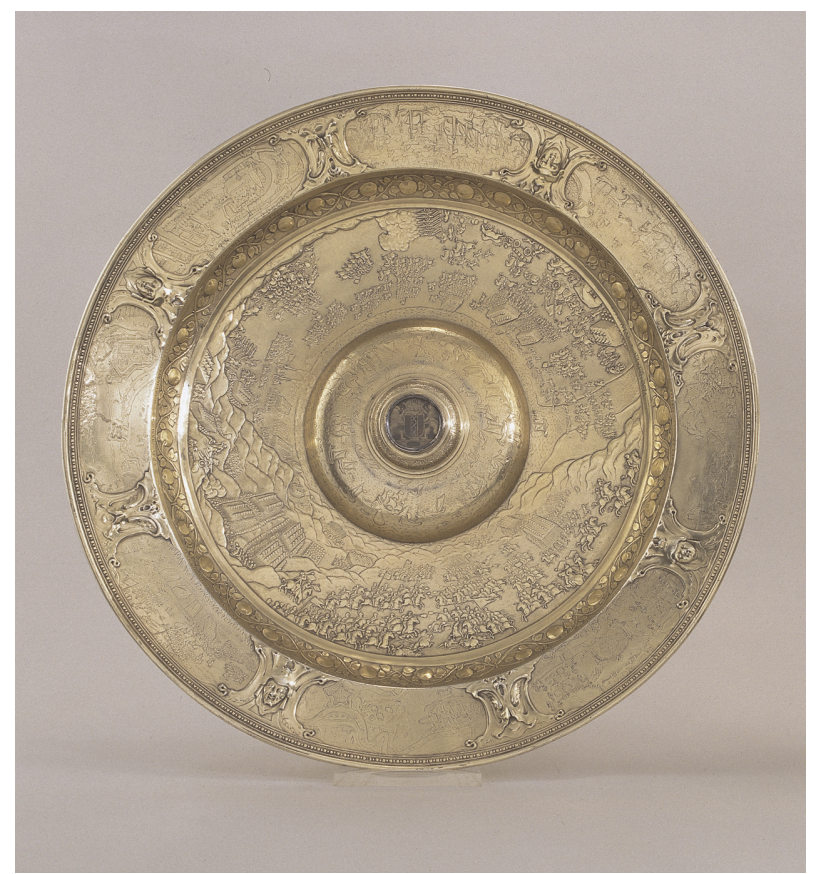

Zelden kwamen kunst en geschiedenis zo dicht bij elkaar als in de schitterende vergulde schaal waarop de overwinningen van Prins Maurits in reliëf en perspectief zijn afgebeeld. In 1616 kreeg hij ter ere van zijn bezoek aan Amsterdam dit geschenk uit handen van burgemeester Reinier Pauw. Het gezamenlijk belang is duidelijk: hervatting van de oorlog zou krijgsroem aan de veldheer en handelswinsten voor de kooplieden brengen. Rijksmuseum Amsterdam.

Het brandpunt in I6r9 werd de calvinistische Duitse keurvorst Fredrik $\mathrm{V}$ van de Palts, schoonzoon van de Engelse koning en neef van Maurits. Hij stond aan het hoofd van de Protestantse Unie die de rechten van de protestanten in het Keizerrijk moest beschermen en werd in I6I9 door de opstandige protestantsen in Bohemen tot koning gekozen. Hij regeerde slechts enkele maanden en verloor de slag op de Witte Berg. Zo werd hij bekend als de Winterkoning, omdat hij slechts één winter regeerde. Hij vluchtte naar de Republiek. Tegen de achtergrond van deze poging alle protestantse krachten tegen de Habsburgse macht te verenigen, zie ik het verdrag tussen de EIC en de VOC. Maurits en Pauw vonden elkaar vooral in het doel de oorlog koste wat het kost weer te laten losbarsten en probeerden uit alle macht Engeland hierbij aan hun zijde te krijgen. De VOC was daarmee tijdelijk verworden tot een pion op een groot schaakbord. ${ }^{61}$ 
In het perspectief van de gebeurtenissen in Amsterdam en de Republiek is Coen te plaatsen. Bij de VOC voerde hij het beleid uit dat door Pauw en de zijnen was bedacht, zoals dat door anderen gebeurde bij de oprichting van de West-Indische Compagnie, in de Staten van Holland, in de Staten-Generaal en in de vroedschap van Amsterdam. Toen Pauw in I62I aan macht verloor, was dit direct merkbaar aan de toon van de Heren Zeventien in de brieven aan Coen. Hoe uitgesproken en gepassioneerd Coen ook was, hij plaatste zich in zijn daden nimmer buiten de orde. Ook nadat in I62I de 'waggelmutsen' onder de Amsterdamse regenten van partij waren gewisseld waarmee ze de val van Pauw in het stadsbestuur teweeg hadden gebracht en zijn greep op de VOC hadden gebroken, bleef Coen gezagsgetrouw aan zijn nieuwe meesters in patria, hoewel die zijn beleid in Azië afwezen.

\section{Een snelle carrière voor Van Diemen}

Als eerste Nederlander maakte Jan Huygen van Linschoten in 1584 op een Portugees schip de zeiltocht rond Kaap de Goede Hoop naar India. Zijn afschuw over deze ervaring klinkt na vier eeuwen nog door in de brief die hij hierover uit Goa naar huis schreef: '(men) vaart acht maanden en ziet niets dan water, lucht en verdriet.' ${ }^{62}$

Zo zijn er veel verhalen over de lange vaak moeizame zeiltocht tussen Nederland en Azië. Niet dat er onderweg vaak schipbreuk geleden werd, dat kwam bij de VOC in de hele zeventiende eeuw betrekkelijk weinig voor. Het bekende lot van de in brand geraakte 'Nieuw Hoorn' onder schipper Bontekoe die in I6r8 vertrok of het ijselijke verhaal van de 'Batavia' die in I629 voor de kust van Australië schipbreuk leed, vormden uitzonderingen. Het waren vooral ziekte en gebrek die hun tol eisten. Ook de 'Mauritius', het schip waarmee Van Diemen naar de Oost zou reizen, zou een reis vol ontberingen tegemoet gaan. En dat zou, eenmaal aangekomen in Azië, voor de opvarenden niet veel anders zijn. Hoewel weinigen zich in Azië wilden vestigen, keerde toch slechts één op de drie behouden in de Republiek terug. Veeleer door ziekten dan door geweld waren de twee anderen gestorven.

De VOC liet in Amsterdam omroepen wanneer het tijd was voor de bemanning om scheep te gaan. Waarschijnlijk heeft op zo'n oproep ook Thonis Meeusen in december I6I7 eerst zijn kist met bagage naar een lichter gebracht die bij de Montelbaanstoren afgemeerd lag, om zich daarna te laten inschrijven in het Oost-Indisch huis aan de Kloveniersburgwal. ${ }^{6}$ Vervolgens moet hij dan met het andere scheepsvolk gevaren zijn naar de Oost-Indiëvaarder 'Mauritius' die op de rede van Texel gereed lag voor de tocht naar Bantam. Met een bemanning van tweehonderdvijftig man zou het schip de tocht alleen ondernemen. 
Voor kapitein Leendert Jakobsz was dit zijn tweede reis met de 'Mauritius'. Hij moest wachten op gunstige wind en hoog water om op 4 januari I6I8 over de drempel tussen Texel en Den Helder naar de Noordzee uit te kunnen varen. De 'Mauritius' was een van de grootste schepen van de VOC met een lengte van ongeveer 200 voet. Het schip stak 22 voet diep en was zo'n 60 voet breed. De hoogste van de drie masten mat I70 voet. Het was een imposante verschijning met zijn enorme ankers, zeilen en tuigage. Zoals alle VOC-retourschepen was de 'Mauritius' zwaar bewapend en ongelofelijk sterk gebouwd. Het schip kon een lading van 800 lasten vervoeren, ongeveer i6oo ton. ${ }^{64}$

Opperkoopman Willem Jansz heeft in een tweetal korte briefjes aan de Amsterdamse kamer van de VOC gerapporteerd over het verloop van de reis. Na het vertrek op 4 januari I6I8 had het schip last gehad van tegenwind met stormen uit het westen en zuiden. Daarbij was op I3 februari de fokkenmast verloren gegaan, waarna koers gezet was naar de Kaap Verdische Eilanden. Daar was de mast van de grote sloep met planken versterkt op de plaats van de fokkenmast gezet. De tocht werd voortgezet en op 8 juni werd Kaap de Goede Hoop gepasseerd. Voortgestuwd door de westelijke winden bereikte de 'Mauritius' op 3I juli de westkust van Australië, waar aan wal werd gegaan om vers water te halen. Op het strand waren voetsporen van mensen gezien, maar verder was geen teken van leven bespeurd.

Na een reis van bijna acht maanden passeerde de 'Mauritius' op 22 augustus Bantam en ging een dag later bij Jakarta voor anker. Er waren tijdens de reis 4I personen 'meest aan scheurbuik' overleden. Dat zouden er in de dagen daarna 50 worden. Welgeteld één regel werd aan hen gewijd. Het welzijn van de bemanning was onbelangrijk, een voetnoot aan het einde van een geslaagde reis. ${ }^{65}$

Aan boord was ook Philips Lucasz in de rang van assistent koopman. Hij zou net als Antonio snel carrière maken en een vertrouweling van Van Diemen worden. De aan den lijve ondervonden slechte omstandigheden van de bemanning hebben een diepe indruk op Van Diemen achtergelaten. Later zou hij zelf regelmatig hameren op de noodzaak van goed en gezond eten voor de bemanning.

Toen dus op 23 augustus I6I8 Antonio van Diemen onder zijn schuilnaam Thonis Meeusen blijkbaar gezond en wel, voet aan wal zette in Jakarta, was dat aan het begin van het eerste gouverneur-generaalschap van Jan Pieterszoon Coen.

\section{Van Diemen ontmaskerd, maar zonder gevolgen}

Alsof het beleg en de stichting van Batavia geen vuurdoop genoeg waren voor Van Diemen, werd zijn positie in de maanden daarna op an- 
dere wijze bedreigd. In Nederland was zijn vertrek namelijk niet lang onopgemerkt gebleven. Nauwelijks drie maanden na zijn dubieuze aftocht werd gouverneur-generaal Jan Pieterszoon Coen gewaarschuwd voor Van Diemen. In de brief van de Heren Zeventien die meeging aan boord van het eerstvolgende schip na het vertrek van Van Diemen werd een lange passage aan hem gewijd. De inhoud loog er niet om:

'Wy en kunnen niet laten U. E. by desen te waerschouwen, alsoo onder de soldaten, door recommandatie van goede vrienden, ofte oock by onbekende namen, sommaels eenige gedebaucheerde quanten met onse schepen der waerts gesonden werden, die ofte alhier -gefailleert sijn ofte hun anderszins groflick hebben verloopen- ende evenwel daer kommende, 't sy deur de goede hand die se in 't schryven mogen hebben als oock door d' ervarentheyt in der coopmanschap, ofte in eenige andere kunsten ende scientien, by U. E., by eenige vice-gouverneurs op de forten ofte coopluyden op onse comptoiren (van haerlieder hier te lande bedreven fouten ofte ongeregelt leven geen kennisse hebbende), mids haerlieden capaciteyt ende dat sy hem aldaer souden wel weten aen te doen ende schoon voor te geven, tot grooten ondienst, schade ende schande van de Compagnie tot de bedieninge van eenige ampten op de respective comptoiren ofte andere voorneme plaetsen souden mogen gepromoveert werden; dat wy oversulcks ten hoochsten noodich achten. dat ghy lieden op alle onse forten, comptoiren code andre plaetsen alle behoorlijcke ordre stelt, dat [ghy] soodanige voor soldaten 't sy adelborsten ofte in eenige andere krijghsdiensten overcommende persoonen, sonder onse expresse ordre ende naerder advijs, ofte tenminsten van de cameren daer se uytgevaren sijn, tot geene zodanige ampten, bysonder in den coophandel, en sult advanceren, maer alleenlick in eenige hooger krijghsampten, naerdat sylieden deur hun comportement ende goed leven sullen meriteren, sonder hunlieden nochtans eenige onse effeckten, contanten ofte coopmanschappen te vertrouwen, ofteonder hunlieder gewelt ende administratie te stellen, opdat se aldaer met onse goederen niet en leven gelijck se alhier met hare eyge ende met haerder ouderen ende vrinden goederen gedaen mogen hebben. Van deser soorte is eene Anthony van Diemen onlangs binnen Amsterdam gefailleert, die hem, soo wy verstaen, onder den naem van Thonis Meeusen van Utrecht onder de soldaten op het schip Mauritius heeft op-doen schryven ende a1soo voor onbekent heeft meynen $t^{\prime}$ schepe te gaen, apparentelijck om in Indien met der tijt, deur faveur ofte andersints, op eenige onse cantoiren te geraecken, daerom ghylieden tegens syne ende sijnsgelijcken voornemen ende pratijcken overal goede ordre dient te stellen. ${ }^{, 66}$ 
Op 5 augustus I6I9 antwoordde Coen hierop aan de Heren Zeventien in dezelfde brief waarin hij de geslaagde verovering van Jakarta mededeelde met de volgende prachtige passage:

'Om de beste (dienaren) hier te verkiesen, doen wy ons beste dan, dan worden zoowel ick als U. E. bedrogen; want het is quaat van qua iets goets te maecken: Ongelijck meerder keure is het in Nederlandt dan hier. Wy worden somtijts genootsaect te gebruycken lieden, daer selffs te vooren cleene hoope van hebben dan wat sullen hier doen? de noot breect wett. 't is waer en billijck dat U.E. haer goederen vertrouwen moogen die het haer gelieft, maer een mensche, die gevallen is ende geerne opstaen soude, sal men die onderhouden? Die gedebausscheert sijn geweest connen met de penne wel gebruyct worden, sonder dat men haer daeromme U.E. middelen vertrouwe. ${ }^{, 67}$

Was Coen door de brief uit Nederland achter de ware identiteit van Van Diemen gekomen, of kende hij deze al? In ieder geval had Van Diemen in de maanden daarvoor zijn nut kunnen bewijzen. Coen nam klaarblijkelijk genoegen met de verklaring van Van Diemen en was bereid hem te steunen. Van Diemen schreef onder zijn eigen naam ook zelf aan de bewindhebbers in Amsterdam een uitvoerige brief. Dat lijkt merkwaardig, tenzij Coen toch niet geheel zeker van zijn zaak was geweest. Zouden in de brief immers grove onwaarheden gestaan hebben over de werkelijke reden van Van Diemens vlucht, dan zou daar zeker vanuit de Republiek op gereageerd worden. De brief is gedateerd op I augustus I6I9, dus enige dagen vóór de brief van Coen. Het is een belangrijk biografisch document eis in zijn geheel in de bijlagen opgenomen.

In zijn brief schrijft Van Diemen dat hij in dienst van de VOC was getreden met alleen maar goede bedoelingen: 'Tot profijt van de generaele Compagnie, contentement van mijn crediteuren, t'mijnder eere, ende tot verdriet van mijn benijders.'

Dat hij niet onder zijn eigen naam scheep was gegaan was 'wt oorsaecke, dat vrese hadde den naem van Antonio van Diemen meer in Indiën bekent was als den parsoon selfts, ende niet om UEd. $t^{\prime}$ abuseeren oft voor onbekend $t^{\prime}$ scheepe door te gaen.' Hij had zich immers daags voor de afvaart aan de Amsterdamse bewindhebber Hendrick Brouwer bekend gemaakt. Vervolgens schoof Van Diemen de schuld van zijn faillissement geheel in de schoenen van Jan Engels: 'Jan Engels is d'eenigh oorsaecke van myn ruinne ende verderff, die sy Godt myn getuyche'. 68

Zoals wij hebben kunnen zien uit de bronnen over zijn verblijf in Amsterdam doet Van Diemen de waarheid nogal geweld aan door de schuld van zijn faillissement geheel in de schoenen van Jan Engels te schuiven. Maar goed, als Van Diemen naar eigen zeggen zelf geen 
blaam trof, moest een zondebok worden gevonden om enigszins geloofwaardig te blijven.

Opvallend is dat hij zich voor zijn vertrek bij bewindhebber Hendrick Brouwer bekendgemaakt had. Brouwer zou later gouverneur-generaal worden en door Van Diemen zelf worden opgevolgd. Deze ontmoeting zou mede Van Diemens latere onvoorwaardelijke steun aan Brouwer kunnen verklaren tegenover de harde kritiek op diens beleid door de Heren Zeventien. In het oog springt ook de zin in de brief over een ons onbekende beschermheer die zich het lot van Antonio zou hebben aangetrokken. Coolhaas dacht dat deze via graaf Floris II van Culemborg prins Maurits zelve zou kunnen zijn geweest, maar dat lijkt mij onwaarschijnlijk. Graaf Floris was in die tijd namelijk zelf in politieke problemen gekomen omdat hij pas laat Maurits ging steunen tegen Van Oldenbarnevelt. Ik denk dat een eventuele beschermheer eerder gezocht moet worden in de contraremonstrantse kring rond Reinier Pauw, waartoe ook Boudewijn Cortenhoeff behoorde. Deze laatste noemde Van Diemen later 'zijn speelgenoot'. Bij wie was de maskerade verder nog bekend? Buiten Coen waarschijnlijk ook bij de raden van Indië die immers de brieven naar Nederland mede ondertekenden en wellicht bij zijn directe collega's op de boekhouding. Het zou nog enige jaren duren voordat Antonio weer zijn eigen naam ging voeren.

Zoals wij zullen zien, belemmerde dit alles zijn carrière in Batavia geenszins. Op 2 oktober I6I9 - precies twee maanden later - kreeg assistent Thonis Meeusen zijn eerste salarisverhoging, en wel een verdubbeling tot twintig gulden in de maand. ${ }^{69}$

Over deze en volgende promoties schreef Valentijn dat Coen niemand anders kon vinden dan Van Diemen om de generale boeken bij te houden: 'Eenigen tijd daar na wierd men om een algemeen Boekhouder verlegen, en men raakte hierontrent zoo in het naauw, dat men zich genoodzaakt vond met de trom te laten rond slaan, om te zien, ofer iemand onder de Soldaten, of onder de andere borsten was, die zijn dienst daar toe wilde aanbieden.' Men vond 'er geen dan hem alleen' (Van Diemen-w), die 'er toe bequaam was, gelyk hy ook zijnen dienst niet alleen aanbood, maar dat ampt zoo wel tot genoegen van zyn oppergebieders waarnam, dat hy daar op ten eersten Koopman, en kort daar na algemeen Boekhouder wierd. ${ }^{70}$

Van Diemen werkte op de plek die het administratieve hart vormde van de VOC: de secretarie en de boekhouding in het kasteel van Batavia. Alle bewegingen van schepen, goederen en mensen in dienst van de VOC werden hier vastgelegd. Als een schip op de rede aankwam, werden de meegezonden brieven gelezen en ingeschreven, de cognossementen in ontvangst genomen en vergeleken met de lading die werd gelost. De scheepsboeken werden gecontroleerd en overgeschreven. 
De bemanning werd wellicht verspreid over forten en andere schepen. Het schip zelf werd opgeknapt en opnieuw uitgezonden.

Steeds werd alles vastgelegd en de winst of het verlies berekend. Geen schip vertrok zonder instructie of brieven voor de koopman die als opperhoofd in een haven de loge beheerde. Zo ging dat voor alle schepen van de VOC en voor elke vestiging. Hier, in het kasteel van Batavia werd de administratie van de VOC gevoerd en het ongelofelijke archief gevormd dat er soms na eeuwen nog uitziet alsof het pas geschreven is.

In Van Diemens tijd was het leven van de 'pennisten' hard. Om half zes op en als zij hun 'handen en aengesicht' hadden gewassen om zes uur 's ochtends beginnen en staande aan de lessenaars tot zes uur 's avonds doorschrijven met een half uur pauze voor het ontbijt en twee uur voor het noenmaal. Was er veel werk, dan gingen om zes uur de kaarsen aan. Twee of drie 'borsten van de pen' sliepen samen op een klein kamertje in een van de zolders van de gebouwen in het kasteel. Zij mochten alleen op woensdag- en zondagmiddag buiten het kasteel komen. De straffen voor luiheid of overtredingen waren streng. In het grote werk over Oud-Batavia staat hierover:

'Werd over hun vlijt geklaagd, of overnachtten zij buiten het kasteel, dan werden hunne collega's opgecommandeerd om met eene houten kolf hun zitvlak te bewerken; dat heette 'moirioneeren'. Ofwel men klonk hen eenige dagen met een ketting aan hunne schrijftafel vast, of ook, men plantte hen op schildwacht met een ijzeren stormhoed, waar bij wijze van versiering een kanonskogel was aangebroacht. In den loop van den dag werd dan de helm natuurlijk gloeiend heet van de zon, en het is gebeurd dat de schildwacht er dood bij neerviel. ${ }^{\text {गI }}$

Van Diemen werd belast met het bijhouden van de 'generaele boucken', dat wil zeggen de consolidatie van de gegevens in een algemeen financieel overzicht. Hij kon dit blijkbaar goed met zijn verleden als koopman. Veel concurrentie zal hij wel niet gehad hebben. Het was klerkenwerk. Kooplieden met ervaring wilden veelal worden uitgezonden naar de vestigingen van de VOC buiten Batavia waar de kans op persoonlijk gewin groot was. Maar als klerk was er in de beginjaren van de VOC uitzicht op promotie.

Van Diemen woonde in het kasteel in aanbouw, zoals in die jaren alles in Batavia in aanbouw was. Veel mensen woonden er verder overigens niet: Nederlanders, Chinezen en slaven, maar bijna geen Javanen. Bij elkaar misschien een paar duizend mensen. Op I2 januari I62I werd 'Antonio Meusen oft Van Diemen' bevorderd tot onderkoopman met een salaris van vijftig gulden in de maand. 'ten aensiene van sijnne 
goede comportementen ende extraordinarie diensten daarinne hy geemployeert ende dagelijcx gebruyct wort. ${ }^{72}$

Een datum die significant is voor de goede verhouding die bestond tussen Coen en Van Diemen, want één dag later, op I3 januari, vertrok Coen met een grote vloot van Batavia naar de Banda-Archipel om daar aangekomen het monopolie in foelie en nootmuskaat op zeer bloedige wijze te verzekeren. Met geweld had de VOC vanaf haar oprichting geprobeerd deze kleine eilanden te veroveren. De rechtvaardiging hiervoor was dat de Bandanezen de met de VOC gesloten overeenkomsten voor exclusieve levering aan de VOC van muskaatnoten en foelie niet nakwamen. Vanaf i6ıо waren twee van de vijf eilanden die samen deze archipel vormden, in het bezit van de VOC. Pogingen om ook de overige eilanden te veroveren, waren mislukt.

Het doel van Coen was niet anders dan dat van zijn voorgangers. Hij weigerde op Ambon met de Bandanezen te onderhandelen over nieuwe contracten. In maart werd het grootste eiland Lontor aangevallen. In de daarop volgende maanden werden de eilanden systematisch ontvolkt. Op gruwelijke wijze werden 44 gevangengenomen Bandanese hoofden op last van Coen na een schijnproces ter dood gebracht. Duizenden Bandanezen stierven. De archipel werd herbevolkt door gewezen VOCdienaren, 'perkeniers' die met medewerking van slaven de muskaatnotencultuur gingen voortzetten.

In I622 komen wij Anthonio Meusz tegen als lid van een commissie die orde moest scheppen in de boekhouding van de VOC-factorij op het Japanse Hirado. Opperkoopman Jacques Specx had deze in zo'n wanorde achtergelaten, dat niemand daar wijs uit kon worden 'alsoo vele in sijnne memorie nog bestondt dat in geen schriften vermelt was.' Het bleek mee te vallen en na enige dagen werk waren de boeken weer op orde. ${ }^{73}$

Op 3I januari I623, in de laatste resolutie van Coen voor zijn vertrek naar Nederland werd Van Diemen onder zijn eigen naam bevorderd tot opperkoopman. Uit deze resolutie sprak onmiskenbaar de waardering voor goed en betrouwbaar werk.

'Anthony Meusz van Diemen, uytgevaeren anno 1617 met 't schip Mauritius, jegenwoordigh by den E. heer Generael omtrent 3 1/2 jaer met een goet vernoegen tot houden van de generaele boucken gebruyct ende synen tijt in Augusto voorleden geexpireert geweest sijnde, wert de novo wederom aengenomen de Compagnie van nu aff noch dry jaeren in qualite van oppercoopman in 't lant te dienen onder een tractement van $f$ go ter maent, die naer expiratie van sijnnen tijt sal genieten. ${ }^{74}$ 


\section{Coen terug naar de Republiek}

Op I februari i623 keerde Coen terug naar de Republiek om daar zijn plan, een grote Nederlandse kolonie in Batavia te stichten, persoonlijk te presenteren en goedgekeurd te krijgen. Om de gewenste stroom kolonisten middelen van bestaan te geven, zou de VOC een groot deel van de intra-Aziatische handel aan deze vrije burgers moeten overlaten.

Bij het vertrek werd op voorspraak van Coen zijn rechterhand Pieter de Carpentier door de Raad van Indië, verkozen tot zijn opvolger als gouverneur-generaal. Ook met De Carpentier had Van Diemen een goede verstandhouding.

Van Diemen zelf begon langzamerhand een zichtbare rol te spelen binnen de VOC. Coolhaas vermoedde bijvoorbeeld dat Van Diemen na het vertrek van Coen verantwoordelijk was voor het opstellen van de belangrijke jaarlijkse verslagen aan de Heren Zeventien over het wedervaren van de VOC in Azië. Deze zogenoemde generale missiven gaven een overzicht van de activiteiten van de VOC in het octrooigebied. ${ }^{75}$

De volgende stap in zijn loopbaan maakte Van Diemen op 28 maart I624. Op die dag werd Anthony Meeusz, 'oppercoopman en boekhouder van de generale rekeningen', benoemd tot lid van de Raad van Defensie. ${ }^{76}$ Dit was een gezamenlijk orgaan van de EIC en de VOC waarin beide zouden samenwerken in de strijd tegen de Portugezen en de Spanjaarden. Door de voortdurende rivaliteit bestond deze raad echter alleen nog op papier. Van grotere betekenis voor Van Diemens snelle stijging in de VOC-hiërarchie is dat vanaf die datum in maart ${ }^{6} 624$ alle resoluties van de gouverneur-generaal en de Raad van Indië door Van Diemen onder zijn eigen naam mede ondertekend werden.

Niet lang daarna - op I8 november I624 - volgde de grootste stap toen 'Wert goetgevonden den persoon van Anthonio van Diemen, oppercoopman ende boeckhouder van de Generaele Rekeningen van Indien tot Raet van Indien te benoemen' en wel voor een 'tractement van tweehondert en vijfentwintigh gulden ter maent. ${ }^{77}$ In vijf jaar was Van Diemen opgeklommen tot de hoogste rang van de VOC na de gouverneur-generaal.

De Heren Zeventien bekrachtigden deze benoeming op I5 april I625. Hieruit blijkt dat deze stap waarschijnlijk door De Carpentier en Coen gezamenlijk is voorbereid, want de Bataviase resolutie zou pas in november I625 in Amsterdam aankomen. ${ }^{78}$

$\mathrm{Na}$ deze stappen in zijn carrière werden vanuit de loges en de factorijen voor het eerst rechtstreeks brieven aan Van Diemen gericht. Van zijn eigen eerste brief in functie aan de Heren Zeventien straalt nog steeds de precisie en de trots af. ${ }^{79}$

Door zijn vooraanstaande positie krijgen wij al lezend in de dagregisters van Batavia meer kijk op de positie van Van Diemen in Batavia. Zo behandelde hij samen met Specx de lange reeks handelsgeschillen met 
de Engelsen. Waar het kon, zetten de twee naties elkaar de voet dwars. Uit 1626 is een sprekend voorbeeld hiervan de lotgevallen van de Italiaan Juan Maria Moretti, een van de vele gelukszoekers die over land of zee naar Azië waren getrokken.

Moretti zeilde in opdracht van De Carpentier naar Makassar om kruidnagelen te kopen voor de Compagnie en nieuws te vergaren. Makassar was in oorlog met de Nederlanders en de belangrijkste vrijplaats waar Engelsen, Portugezen, Spanjaarden en Denen specerijen uit de Molukken konden kopen. Daarnaast konden de Portugezen via Makassar de verbinding in stand houden tussen Goa enerzijds en Manila en Macao anderzijds als de Straat van Malakka geblokkeerd werd door de Nederlanders.

Bij aankomst op Makassar werd Moretti door misleiding gevangen genomen door de Engelse president van de loge aldaar. Moretti werd ruw behandeld en in een blok vastgezet. Zijn schip en lading werden aan de Spanjaarden verkocht en hijzelf werd in gevangenschap aan de Portugezen overgeleverd, waarna zijn bemanning werd teruggezonden naar Batavia. ${ }^{80}$ De Italiaan ontsnapte, maar werd op de markt achtervolgd door vier Engelsen met lansen. Op het nippertje werd hij uit hun handen gered door Spanjaarden die dachten dat het een landgenoot betrof. Toen dat niet zo bleek te zijn, werd Moretti door hen weer uitgeleverd aan de Portugezen. Dit werd de koning van Makassar te gortig en hij beval de vrijlating van de Italiaan, die terugkeerde naar Batavia.

Aldaar werd natuurlijk genoegdoening gevraagd aan de Engelsen door de Italiaan en de Nederlanders. Op 20 oktober 1626 ging de president van de Engelse loge op audiëntie bij de gouverneur-generaal en zijn raden, waaronder Van Diemen en Specx. Hij ontkende in deze zaak ook maar enige opdracht gegeven te hebben en insinueerde dat Moretti een kwade reputatie bezat. Er werd besloten de zaak 'vreundelijk' af te handelen door gecommitteerden van beide zijden.

De eerste sessie daartoe vond plaats op 5 november. Specx en Van Diemen gingen naar de Engelse loge waar zij te horen kregen dat de Italiaan aan de Engelsen in Makassar meer verschuldigd was dan van hem was afgenomen, en voorts dat de Engelsen in Batavia niet aansprakelijk gesteld konden worden voor de daden van de loge in Makassar. ${ }^{8 \mathrm{I}}$

Zo kon dat voor de Nederlanders niet voortgaan en bij twee vonnissen op respectievelijk 6 en 30 maart I627 werden de Engelsen door de Nederlandse rechtbank in Batavia veroordeeld tot het betalen van vijfenzeventighonderd realen voor de geleden schade. De Engelsen weigerden te betalen, waarna Specx en Van Diemen op I5 april met een gewapend gevolg verhaal gingen halen Het ging er heftig aan toe. Natuurlijk wilden de Engelsen niet betalen en weigerden de toegang tot de loge. Daarop forceerden de Nederlanders de toegang tot het pakhuis en namen vijf kistjes Japans zilver mee. De Engelsen waren des duivels. 
De tevredenheid over de eigen actie straalt af van de beschrijving door de Nederlanders van het vertrek uit de loge: 'synde voorts voor ons afscheyt d'Engelsche logie d' opgeslagene deuren vant packuys ende t' geforceerde slot van dien alles wederom behoorlyck, ende in voorige forme herstelt. ${ }^{82}$ Niet lang daarna zouden de Engelsen hun loge in Batavia opbreken. Na een mislukte poging op een van de eilandjes in de Straat van Sunda een eigen fort te bouwen, vestigden zij zich in Bantam.

\section{Coen voor de tweede maal gouverneur-generaal}

Ondertussen werd Coen bij zijn terugkeer in de Republiek in I623 geconfronteerd met de slechte financiële toestand van de VOC. Door hoge schulden, tegenvallende winsten en laag dividend kregen de bewindhebbers veel kritiek van de participanten te verwerken. Tegen Coen zelf circuleerde een fel pamflet waarvan indertijd de auteur onbekend was, maar dat later is toegeschreven aan Artus Gijsels, die in dienst van de VOC onder Reael was opgeklommen tot opperkoopman op Ambon. Tussen vele verwijten typeerde hij Coen als 'dol, rasent en uutsinnigh'. ${ }_{3}$ Dit weerhield Coen er niet van zijn plan met kracht en verve uit te dragen om van Batavia een grote kolonie te maken met vrije burgers die leefden van de intra-Aziatische handel. Want, juist door de forten in Batavia, Banda en de Molukken te laten beschermen door vrije burgers in plaats van soldaten zou de Compagnie verlost zijn van de hoge kosten die de garnizoenen met zich mee brachten. En, door zich daarnaast te concentreren op de vaart tussen Azië en Nederland zou de Compagnie van veel kosten bevrijd worden en zelfs veel inkomsten verkrijgen door belasting te heffen op de intra-Aziatische handel. Na lange beraadslagingen werd dit radicale voorstel op I7 oktober I624 door de Heren Zeventien aangenomen. ${ }^{84}$ Direct diezelfde dag schreef Coen een ingetogen juichende brief naar Indië over deze besluiten. ${ }^{85}$

Hoe Coen zijn toekomst zag, blijkt uit de vorstelijke portretten die hij liet maken van hemzelf en zijn jonge vrouw: zoals de Portugese vice-koning in Goa resideerde, zou hij dat doen in Batavia. Overigens is in dit verband de mening interessant van Sir Francis Bacon naar aanleiding van het faillissement van de Virginia Company in I624. Deze compagnie was opgezet om tabakplantages te exploïteren. Bacon gaf gehoor aan de heersende opvatting dat de leiders van koloniën 'be rather noblemen and gentle men then merchants; for they (the merchants) look ever to their present gain. ${ }^{86}$ 


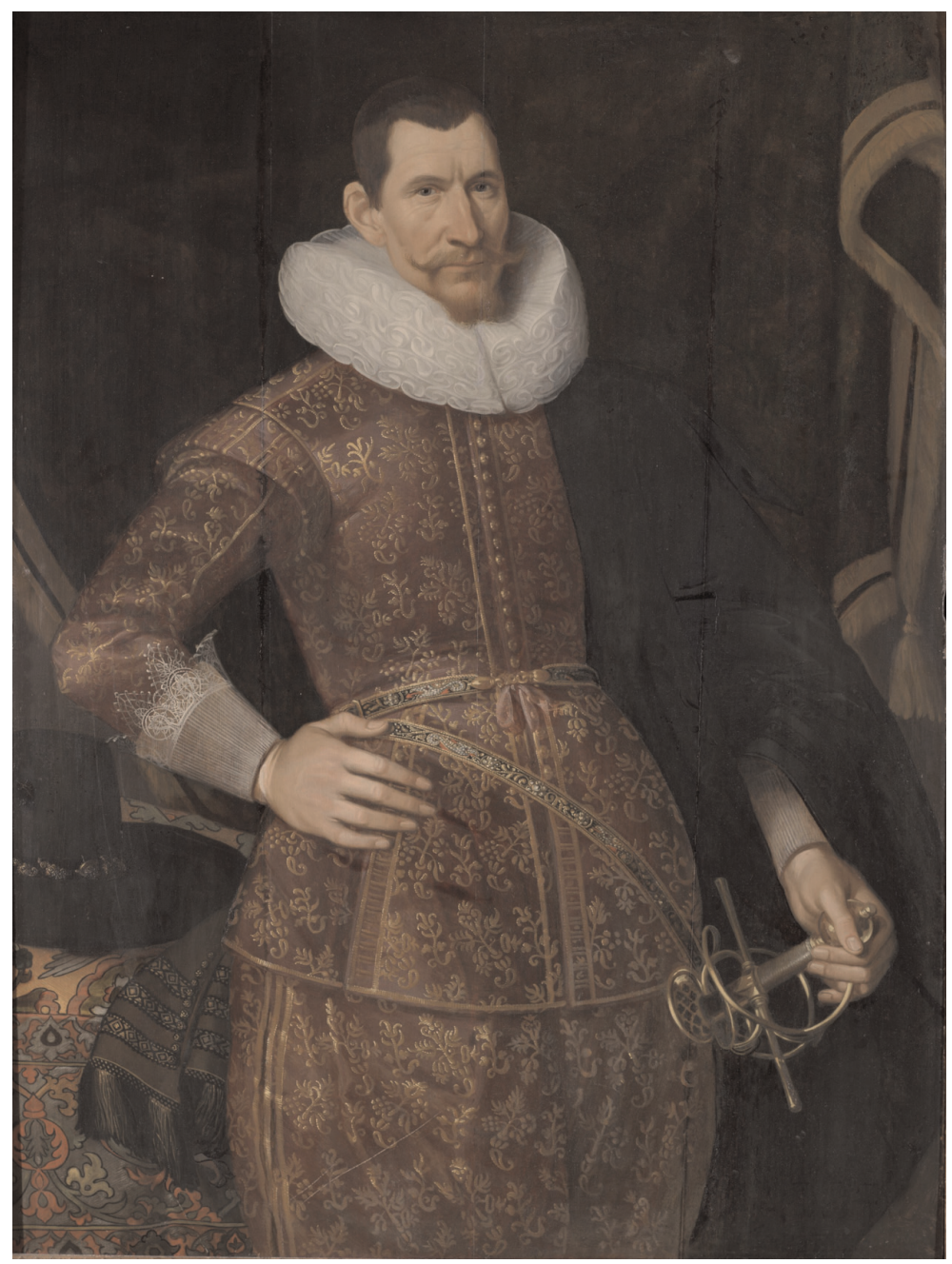

Jan Pieterszoon Coen wilde van Batavia een semi-autonome kolonie maken waarover hij zou heersen als een vorst. Op dit portret straalt hij die ambitie uit. Westfries Museum, Hoorn.

Intussen was Coen herbenoemd tot gouverneur-generaal en hij wilde naar Batavia om het nieuwe beleid uit te voeren. In februari I625 gebeurde echter iets onverwachts. De machtige Engelse ambassadeur in Nederland, Sir Dudley Carleton klaagde Coen bij de Staten-Generaal aan wegens schending van het verdrag uit i6I9 tussen de Engelse en Nederlandse Compagnieën. Schriftelijk werd geëist dat hij 'streng ge- 
straft behoorde te worden'. ${ }^{87}$ De hernieuwde verslechtering van de verhoudingen was het gevolg van de beruchte Ambonese moordzaak van I623. Op onduidelijke gronden werden op Ambon elf Engelse kooplieden door de Nederlandse gouverneur aldaar verdacht van verraad. Nadat door marteling bekentenissen waren verkregen, volgde een summier proces waarin over hen de doodstraf werd uitgesproken, waarna vervolgens het vonnis ten uitvoer werd gebracht. Decennia later nog zou deze infameuze zaak door de Engelsen aangehaald worden telkens als er een conflict was met de Nederlanders. De Engelsen zagen Coen als degene die 'de fundamenten heeft geleyt van alle offencien' 88 tegen de Engelsen. Zij wilden voorkomen dat hij opnieuw naar Indië werd uitgezonden. Onder druk van de Staten-Generaal stemden de bewindhebbers toe in het verzoek Coen niet terug te laten gaan.

Ondertussen namen de Engelsen wel een drietal retourschepen in beslag.

Met toestemming van de Heren Zeventien ging Coen toch in het voorjaar van I627 alsnog heimelijk scheep. Men was blijkbaar niet bang voor verdere represailles. De reden daarvoor was spectaculair. Koning Karel I van Engeland (I626-I648) verkeerde voortdurend in geldnood en onderhandelde achter de rug van de EIC om met de VOC over teruggave van de drie schepen. In I628 gaf hij zijn kroonjuwelen in onderpand aan de VOC tegenover een forse lening. De schepen werden daarop vrijgegeven. ${ }^{89}$

Intussen was het inzicht van de bewindhebbers gewijzigd ten aanzien van de voorstellen van Coen, ze kwamen er geheel op terug, maar pas nadat Coen was vertrokken. In een opvallend korte brief van io augustus I627 aan gouverneur-generaal en raden werd bevolen de handel in Indië niet open te stellen en alles bij het oude te houden: 'Soo is't, dat wij U.E. op 't serieuste verbieden eenige openingen van den vrijen handel in Indien te gedoogen ofte toe te staen. '9० Was dit een afrekening onder invloed van Reael? Het lijkt mogelijk. Colenbrander was ervan overtuigd. ${ }^{9 \mathrm{I}}$

Dit zwalkende beleid heeft gevolgen gehad voor het functioneren van de VOC in Azië. Vooruitlopend op het definitieve besluit was al een gedeelte van de handel vrijgegeven. Coen, noch zijn opvolger Specx zou de vrije handel voor zover die reeds was vrijgegeven, terugdraaien. Daarnaast waren op instigatie van Coen bestuurders voor de kolonie uitgezonden in hoge functies, maar zonder eerdere ervaring in Azië. Ook dat zou ontwrichtend werken.

Het was onverwacht voor De Carpentier en de raden van Indië toen Coen in september ${ }^{6} 627$ in Batavia aan wal stapte om ten tweede male het gouverneur-generaalschap op zich te nemen (I627-I629). Dit keer geen grootse plannen of gewaagde expedities meer. Dat kwam mede doordat in deze paar jaar de problemen zelf Coen opzochten. 
Batavia werd namelijk in 1628 en 1629 tweemaal van augustus tot oktober aan de landzijde belegerd door een groot Javaans leger van de vorst van Mataram. Deze krijgszuchtige heerser had vrijwel geheel Java veroverd op Bantam en Batavia na. De aanvallen werden zonder moeite gepareerd. Door de onvermoeibare arbeid van met name De Carpentier waren kasteel en stad de voorafgaande jaren dermate versterkt dat de verdediging tegen een groot, maar ongeregeld leger geen al te grote problemen gaf. De handel, die geheel over zee ging, werd er nauwelijks door verstoord zoals Van Diemen in een brief opmerkte..$^{22}$

Een paar maanden voor de tweede belegering, in juni I629, speelde de beruchte affaire van Sara Specx en Pieter Cortenhoeff. De nasleep zou de sfeer in Batavia de daarop volgende jaren in ongunstige zin bepalen. Voor ons is van belang dat in deze spraakmakende zaak Coen en Van Diemen tegenover elkaar kwamen te staan. Wat was er aan de hand?

In het huis van Coen woonde de twaalfjarige Sara, de dochter van Jacques Specx bij een Japanse vrouw, die hij in I627 bij zijn vertrek naar Nederland in Coens zorg had achtergelaten. In het huis van Van Diemen had Pieter Cortenhoeff gewoond voordat hij vaandrig werd. Pieter was de zoon bij een Arakanse vrouw van de in compagniedienst overleden Jacob Cortenhoeff, de neef van Boudewijn Cortenhoeff, de stadssecretaris van Amsterdam met wie Van Diemen in Amsterdam nauw bevriend was geraakt. Van Diemen was in Batavia executeur-testamentair van Jacob Cortenhoeff geworden.

In Coens huis nu werd Sara in bed aangetroffen met Pieter Cortenhoeff. Coen raakte door deze losbandigheid buiten zinnen van woede en wilde beiden onmiddellijk laten doden. Toen hij hiervan werd weerhouden door Vlack, Van Diemen en Van den Heuvel riep hij woedend uit dat hij 'wel merckte dat men al te samen een deel hoerenjagers waren ende dat hij sijn spillen wel mochte packen soo men malcanderen niet anders wilde voorstaen. ${ }^{93}$ Op aandrang van anderen vond er nog iets van een rechtszaak plaats.

Het wrede vonnis luidde uiteindelijk dat Pieter Cortenhoeff werd onthoofd en Sara werd gegeseld terwijl zij naar de executie keek. Genade werd niet gegeven. Het vonnis werd ondertekend door Coen en zijn zwager Pieter Vlack, voorzitter van de Raad van Justitie. Van Diemen als het derde lid van die Raad weigerde het vonnis te ondertekenen. Hij zag niet in waarom Pieter zoveel zwaarder gestraft moest worden dan Sara.

Het voorval heeft de relatie tussen Coen en Van Diemen verstoord of zoals hij zelf later schreef: 'daerover oock in de ongunste van den Generael Coen saelr. geraeckt. ${ }^{94}$ Voor Van Diemen was de zaak niet af. Tien jaar later nog schreef Van Diemen in een brief aan de Heren Zeventien vet en groot geschreven 'Notoire Leugen' over de hernieuwde aantijging uit 
de koker van Van den Heuvel dat hij met het vonnis zou hebben ingestemd.

Ook in Nederland werd de zaak opgemerkt. In I637 berispte Jacob 'vadertje' Cats Coen met moraliserende dichtregels.95 Slauerhoff schreef over de affaire een toneelstuk, waarvan de opvoering na drie eeuwen nog een gevoelige snaar bleek te raken. In 1948 verbood de Amsterdamse burgemeester D'Ailly de opvoering van het 'ploertig stuk' op het boekenbal op grond van artikel 22I van de gemeentewet omdat het de openbare orde zou bedreigen. Op 30 mei 1969 werd een fragment door de VPRO opgevoerd ter herdenking van de stichting van Batavia 350 jaar daarvoor en in I986 werd het stuk eindelijk in zijn geheel opgevoerd met Ton Lutz in de rol van Coen. ${ }^{96}$ Slauerhoff legde aan het drama ten grondslag dat Coen heimelijk zelf Sara begeerd had.

In augustus ${ }^{6} 629$ begon het tweede beleg van Batavia. Toen in september de loopgraven de stadswallen op één punt dicht waren genaderd, werd tot een grote uitval besloten. ${ }^{97}$ Van Diemen werd aan het hoofd gesteld van een van de twee groepen die de aanval zouden uitvoeren. Het was voorzover wij weten de enige keer dat Van Diemen lijfelijk bij krijgsgeweld was betrokken. Van Diemen schreef hierover aan De Carpentier:

'Den 17en nadat d'heer Generael Coen persoonlijck de ronde ende des vijants wercken hadde besichticht, de selve omtrent Bommel ende Weesp in soodanige gestaltenisse vindende, soo daer niet tegen wird gedaen, den vijant apparaent de selve afsneijden ende ons onbruijck maecken zoude, wird daervoor goetgevonden als per resolutie van 17 en 18 de september 1629 blijct gemelte werck aen te tasten ende in brant te steecken. Omtrent 350 man werden bedectelijck in de reduyten gebracht. Des achternoens als den Zeewint begont te waije zijn wt ijder reduijt gevallen 25 a 30 bootsgesellen met branders die gesecondeert worden met 60 cloecke soldaten, 30 japanders ende maredijckers, daerop dat de chineesen mede quamen aenmarcheren. Den vijant hielt sterck teegen maer wird met gewelt van schieten ende werpen van granaten gedwongen te retireren. De wercken geraeckten in brant. Den vijandt hielt in zijn groot werck stal, daerop niet geattenteert wirde, veel peicken Critsen, met een metale bas wirt daer verovert. $\mathrm{Na}$ men verstaet verloor den vijant tusschen de 200 a 300 man. Die van Bantam rapporteren wel van 500 dooden, Wij cregen daer soo Nederlanders, Chineesen, Japanders als Mardijckers in de 30 gequetste, geen presente dooden. Van dese gequetste zijn geen vier overleden.

Soo haest d'onse retireerde ende den wint wat tijtelijck aft nam als ordinarij, quam den vijant wt, doende alle devoir om den brant te blussen ende zijn doode te bergen. Cregen 't vuer, niettegenstaende daer 
dapper op wert gesargeert wt, zoodat den brant inde werkcken tegen over Bommel weijnich schade had gedaen, bij Weesp was veel hout verbrant ende duerde tot avont als wanneer grooten regen ophanden quam die alles voorts bluste. ${ }^{98}$

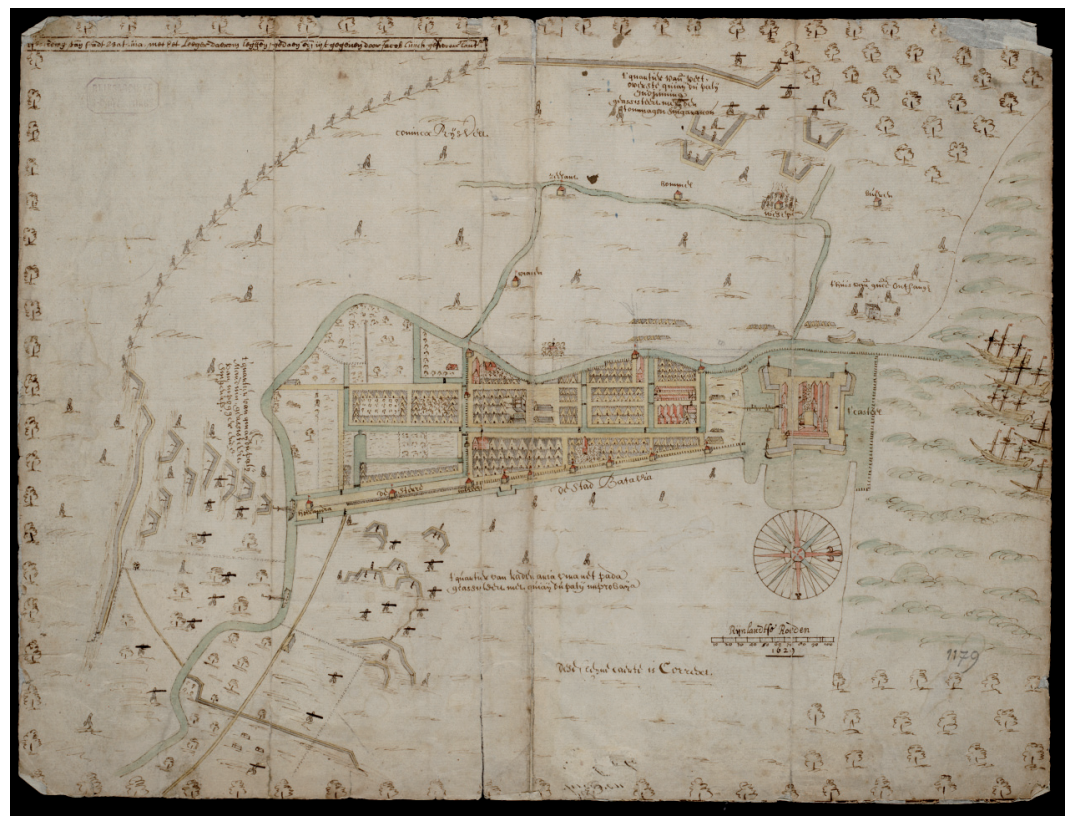

Batavia werd in 1629 belegerd. Het redout Weesp wordt op deze kaart nog bedreigd door de Javanen. Het werd ontzet door de hierboven beschreven uitval onder leiding van Van Diemen. Nationaal Archief, Den Haag.

Het besluit tot de uitval was de laatste resolutie van Coen voor zijn dood. Getuigde het van wrok dat Coen de onervaren Van Diemen de uitval liet leiden? Op diezelfde i8de september bereikte Batavia het bericht dat Jacques Specx, de vader van Sara, als admiraal van de vloot uit Nederland voor Bantam was aangekomen. Twee dagen later op 20 september I629 overleed Coen plotseling, waarschijnlijk aan cholera en wellicht, zoals Valentijn en Van Dam schreven, geschokt door de aankomst van Specx. Merkwaardig genoeg is nooit gedacht aan vergiftiging door een van zijn vijanden. Het lot wilde dat Coen drie dagen voor zijn dood zelf vader was geworden van een dochter.

Van Diemen schreef het ooggetuigeverslag van het overlijden van Coen. Het kwam voor iedereen plotseling en vooral voor Coen zelve. 's Middags was hij nog actief geweest en had hertelijck aen taeffel gegeten'. Hij verscheen echter niet bij het avondgebed nadat hij 'omtrent se- 
ven uren was gaen liggen'. Van Diemen vergezeld door de raad van Indië, Johan Raemburch, ging daarna polshoogte nemen. Zij onderkenden onmiddellijk de ernst van de ziekte en ontboden de arts Bontius. Deze zag dat Coen de volgende ochtend niet zou halen. Vanuit zijn ziekbed vertrouwde Coen de zorg voor zijn vrouw en dochter toe aan zijn zwager Vlack. Daarna wilde Coen gebruikmaken van zijn prerogatief om zijn opvolger aan te wijzen. Hij 'belaste gemelte Heurnius (de predikant die er natuurlijk bij was-W) de naem ('twelck d'heer Vlack was) in gesloten missive na zijn overlijden d'aenwesende raden van India ter hant te stellen, daernae riep ons, d'heer Vlack ende Raemburch te samen int corte verhaelende d'ordre aenden predicant Heurnius gelaten. Wij verstonden wel sijn Edele, alleen tot soo absolute dispositie niet was gequalificeert, maer insiende sijn swackheijt vonden niet geraden daer tegen te contesteren, onlangs daerna ende gelijck boven geseijt is heeft sijn Edele den geest gegeven, hebbende gans weijnich woorden gebruijct, selfts niet tegen zijn huijsvrouw die omtrent een ure voor zijn bedde sadt, 't Schijnt dat de sieckte zijn Edele soodanich overviel geen lust noch crachten hadde zich meer met wereltse saecken te moijen. Wij zijn van opinie soo d'heer Generael niet aengemaent hadden, dat noch van 't een nocht ander souden gesproocken hebben, selfts sijn huijsvrouw niet hebben laeten waerschouwen. Soo doende en woelende als sijn Edele bij zijn leven is geweest, immer soo stil, zich met geen saecke ter werelt moijende is zijn wteijnde geweest. 99

Waarschijnlijk is Coen aan cholera overleden, de snelle uitputting en shock passen in het soms zeer agressieve ziektebeeld. ${ }^{\text {Io० }}$

Coens keuze voor Vlack als zijn opvolger paste anders dan Van Diemen deed voorkomen, wel degelijk binnen zijn instructie. Dit was het voorrecht dat aan de gouverneur-generaal in I6I7 was gegeven om te voorkomen dat weer een ongewenste opvolging zou plaatsvinden. Immers na het overlijden van Reynst in I6I5 was Reael zeer tegen de wens van de Heren Zeventien tot zijn opvolger verkozen. ${ }^{\text {Ior }}$ Mede door ingrijpen van Van Diemen werd verhinderd dat Pieter Vlack gouverneur-generaal werd. De keuze van Specx, uitgezonden als eerste raad van Indië, als opvolger van Coen werd bij stemming door de Raad van Indië bepaald, nadat men besloten had de keuze van Coen voor zijn zwager Vlack voor één stem te laten meetellen.

'Den predikant Heurnius volgens d'ordre van d'heer Generael Coen zaliger levert sijn besloten missive aen den Raet over. Den Raedt de dispositie van zijn Edele verstaen ende deselve in deliberatie geleijt hebbende, conde niet verstaen sijn Edele geaucthoriseert was soo finalijck op 't Generaele Gouverno te mogen disponeren, maer dat men daerinne volgens den teneur van Artijckelbrief in de meninghe van heeren maiores behoorden ende mosten handelen. Weshalve voor alleer ge- 
melte geslooten missive wird geopent, gearresteert is, dat men d'absolute dispositie van d'heer Coen zaliger niet voirder in consequentie sal trecken als voor een stem ten behoeve van den persoon in de missive gementioneert als per resolutie in dato 24 september nader blijct. ${ }^{\text {,O2 } 2}$

Een doortastende aanpak mede uit eigenbelang, want zoals zou blijken had Van Diemen van de kant van Pieter Vlack weinig goeds te verwachten.

\section{De aanval op Van Diemen}

Eigenlijk wilde Van Diemen naar Nederland terugkeren nadat hij bij Coen in ongenade was gevallen en hij de schulden uit zijn faillissement in het najaar van I629 had afgedaan. De afwikkeling van zijn schulden had hij toevertrouwd aan De Carpentier, toen deze na zijn gouverneurgeneraalschap terugkeerde naar de Republiek, waar hij bewindhebber voor de kamer van Amsterdam werd.

Wij kunnen volgen hoe de schulden werden voldaan. Ten eerste berichtte De Carpentier op 20 december I628 aan Van Diemen dat zijn tegoed in de boeken van de Compagnie achtduizend gulden bedroeg. Dit bedrag resteerde nadat zijn schuld was verrekend aan de kamer van Amsterdam in samenhang met het verschuldigde van circa achtentwintighonderd gulden aan de Amsterdamse koopman Voet, tevens bewindhebber. Van Diemen schreef hierop op 30 november I629 aan de kamer van Amsterdam dat hij een aanzienlijk hoger bedrag van de VOC verwachtte. Hij had namelijk door een boekhouder laten bepalen dat hij in de loop der jaren voor zijn onderhoud in Batavia een bedrag van iets minder dan vijftienhonderd gulden uit de kas van de Compagnie had opgenomen. Daarnaast was hij nu zestig maanden raad van Indië. Drie in die rang in ${ }^{6} 625$ uitgezonden heren kregen bij hun aanstelling een gage van tussen de driehonderdvijfenzeventig en zeshonderd gulden in de maand. Hij verwachtte natuurlijk een dergelijke vergoeding met terugwerkende kracht op zijn rekening te krijgen. In ieder geval verzocht hij om zonder 'scrupule' ten laste van die rekening acht à tienduizend gulden aan de heer De Carpentier ter hand te stellen om zijn 'ongelegenheyt' met zijn crediteuren in Amsterdam te vereffenen. ${ }^{\text {I03 }}$

Van Diemens voornemen om terug te keren naar Nederland kwam pas een jaar later tot uitvoer. Gezien zijn ter zake deskundigheid vond Specx het onverantwoord om zijn directeur-generaal met de retourvloot van januari I630 te laten gaan. Dit had als onverwacht gevolg dat Van Diemen, van zijn schulden ontdaan, zich vrij voelde in het huwelijk te treden met Maria van Aelst. 
Toen Maria in januari I630 met Anthonie huwde, was zij een rijke weduwe van rond de vijfentwintig jaar oud. Wanneer Maria in Indië was aangekomen, is onbekend. Op haar jeugdige leeftijd was zij in I629 voor de tweede maal weduwe geworden. Haar eerste echtgenoot, opperkoopman Johan Liberer, trouwde zij in Batavia in maart $\mathrm{I}_{2} 6 \mathrm{6}$. Na zijn dood was zij in juli I628 hertrouwd met Bartholomeus Havicksz Kunst. Deze was eerder opperkoopman geweest in dienst van de VOC, maar had in ${ }^{6} 627$ ontslag genomen uit compagniedienst en zich in Batavia als vrijburger gevestigd. Hij werd daar onder meer president van de weesmeesteren. Uit deze functie werd hij ontslagen, omdat hij een erfenis die bestemd was voor de minderjarige kinderen van een overleden koopman, had uitgekeerd aan de nieuwe echtgenoot van de weduwe van deze koopman. Hoe het ook zij, Kunst overleed in september I629 tezelfder tijd als Coen. Maria bleef bepaald niet onbemiddeld achter. Haar huis met goederen verkocht zij na haar huwelijk met Van Diemen voor achtennegentighonderd realen(ongeveer vijfentwintigduizend gulden) aan de directeur van de Deense Oost-Indische Compagnie, Roland Crappe.

Rond I630 broeide het in Batavia. De steun van Van Diemen aan Specx tegen Vlack bracht hem in een kwetsbaarder positie dan voorheen. Er waren aan de top van de VOC in Azië verschillende kampen ontstaan. Als er een zwakke leiding is, zijn aanvaringen om elkaar eruit te werken haast voorspelbaar. De aanval op Van Diemen kwam van Vlack, die daarbij geholpen werd door Van den Heuvel en Nuyts.

Van Diemen schreef hierover aan Specx:

'Mijn Heer hoe hun de Heeren Pieter Vlacq ende Pieter Nuijts met den gewesen Avocaet fiscael Mr. Anthonij van den Heuvel eenen ruijmen tijt geleden samen hebben gevoecht omme mij waert mogelijk voor alle de weerelt odieus te maecken, van ontrouwe ende valscheden te beschuldigen ende voor een meijnedich dienaer te doen passeren, is UEd ende den rest kennelijck ende blijct bij de resolutie van den gen april laets.

Waerom ende wat dese Heeren heeft gemoveert mij met loode schoenen laten te gaen, soo gants onvruntl. proceduren tegen mij te houden mitsgaders mij te becladden met alsulcken ongehoorde valscheden ende notoire leugenen can niet wel bevroeden, te meer mij wel verseeckert houde, haer noch niemant oijt oorsaecke daertoe hebben gegeven. Godt Almachtich een hater der leugenen ende een voorstander vande vroomen dese complotterij verdrietende, sent onder hun den geest der verwarringe ende beweeght den gewesen advocaet fiscael Mr. Anthonij van den Heuvel soodanich dat hij den Gen April passato tot mijnen huijse gecomen ende mij aldaer openingh van saecken heeft gedaen als namentlijck. 'I04 
Antonie van den Heuvel was een geschoolde jurist die als aanklager toentertijd heette die functie die van fiscaal - rechtszaken in Batavia voorbereidde. Volgens Van Diemen was de 'pokdalige fiscaal ${ }^{\text {, } 05}$ een gevaar, omdat hij naast onbetrouwbaar ook intelligent was. Hij was speciaal door de Heren Zeventien in I625 uitgezonden om de privéhandel van compagniedienaren te bestrijden. Daarbij was hem een derde van de opgelegde boetes toegezegd.

Pieter Nuyts was in 1625 in de hoge positie van raad van Indië uitgezonden. In die functie spreidde hij een mengeling van arrogantie en incompetentie ten toon. Als gevolg van zijn optreden als gouverneur van Taiwan werd de positie van de VOC in Japan in gevaar gebracht, hierom was hij nog door Coen teruggeroepen. Door Specx aangesproken op zijn gedrag, antwoordde Nuyts dat hij in India niet was gecoomen om hoij te eeten. ${ }^{106}$

Van Diemen werd door dit drietal beschuldigd van handel voor eigen rekening. $\mathrm{Nu}$ was dit het meestvoorkomende vergrijp bij de VOC van hoog tot laag, waarvoor de geëigende straf was om buiten rang en zonder gage naar Nederland te worden teruggestuurd. Het verhaal kwam op 6 april i63o aan het rollen op de merkwaardige manier waar Van Diemen geen redelijke verklaring voor kon vinden.

Van Diemen zou, zo luidde de aantijging, arak smokkelen naar Banda en kleedjes naar Bantam. Waarschijnlijk geheel tegen de verwachting van Van den Heuvel in confronteerde Van Diemen nog dezelfde middag Vlack en Nuyts met deze beschuldigingen aan zijn adres. Zij ontkenden alles en verklaarden dat zij slechts gehoor hadden gegeven aan de verklaringen van Van den Heuvel. Naast handel voor eigen rekening, zo werd nu gezegd, zou Van Diemen overigens ook delen in opgelegde boetes. Van Diemen legde de zaak de volgende dag voor aan Specx.

Op 9 april I630 werd Van den Heuvel, Nuyts en Vlack in een uitgebreide vergadering van gouverneur-generaal en Raad van Indië om uitleg gevraagd. Een conclusie kon niet getrokken worden, omdat de drie elkaar beschuldigden en tegenspraken. 'Wat confusie daer gehoort wird hoe den fiscael d'Heren Vlacq ende Nuijts beschuldigde, hoe de gemelte heeren alles loochende' was een ieder die daar aanwezig was, bekend, zo schreef Van Diemen. Aan Van den Heuvel werd de opdracht gegeven een schriftelijke verantwoording van zijn gedrag te geven omdat hij aanleiding had geven 'tot misvertrouwen van de hoochste authoriteijt ende de gequalificeerde persoonen van desen staet tot ophitsingh reciproquelijck tegen malcanderen te brengen, zouckende door een schisma te veroorsaecken.' Deze verantwoording gaf zoals te verwachten viel, slechts beperkt inzicht. Wat wel gebeurde, was dat Van den Heuvel op 8 mei uit zijn ambt werd ontzet en dat een dag later Pieter Nuyts in arrest werd gesteld voor zijn wanbeleid als gouverneur van Taiwan, met name jegens Japanse handelaren. Ter genoegdoening hiervoor werd Nuijts aan de Japanse authori- 
teiten uitgeleverd, waarna hij vervolgens een aantal jaren in Japanse gevangenschap zou doorbrengen.

Voor Van Diemen was dit nog niet voldoende. Hij wilde van alle blaam gezuiverd worden. Toen Specx ondanks zijn verzoek de zaak liet liggen, nam hijzelf het initiatief. Op I5 oktober I630 schreef Van Diemen een lange memorie aan Specx waarin hij de beschuldigingen een voor een weerlegde. ${ }^{107}$ Op 7 november werd de zaak opnieuw in de Raad van Indië behandeld, die voor de gelegenheid versterkt werd met drie leden van de Raad van Jusititie. Van den Heuvel beweerde nu dat hij nooit Van Diemen had beschuldigd, 'maar ter contrarie wel geseght als de Hr. Van Diemen naer huys gaet de Compagnie een trouw dienaer in Indien missen sal.' Vlack verklaarde 'rondelijck, dat soo lange syn E. met de heer van Diemen omgegaen heeft, noijt int minste eenich naer bedencken van particuliere ofte ontrouwe handelinge van gemelte Heer van Diemen gehadt te hebben.' Alles had volgens hem 'alleenlijck hun oorspronck genomen ... wt valsch bedrijff van Van den Heuvel. ${ }^{108}$

Deze laatste kon rekenen op zijn vrienden in Nederland. In augustus I630 was hij door de Heren Zeventien tot buitengewoon raad van Indië benoemd. Nadat zij in oktober I63I van het gebeurde hadden vernomen, werd hij op 23 november I63I door hen in zijn ambt van fiscaal hersteld. Aan de wraak van Van Diemen zou Van den Heuvel echter niet ontkomen.

Ondertussen wilde Van Diemen nog steeds terug naar Nederland. Dit keer werd zijn verzoek ingewilligd en werd hij benoemd tot commandeur van de retourvloot van zeven schepen die in maart I63I van de rede van Batavia wegvoer met een lading met een inkoopwaarde van anderhalf miljoen gulden.

Dat onder Specx de administratie verslofte, had tot gevolg dat dit de enige retourvloot was die Batavia ooit verliet zonder een door de gouverneur-generaal en raden getekende en voltooide generale missive. Deze was bij het vertrek nog maar gedeeltelijk gereed, ondanks het feit dat de vloot enige maanden later dan de bedoeling was geweest, vertrok. Van Diemen zou de missive tijdens de reis op zee afmaken. Dat deze belangrijkste brief van het jaar niet klaar was, gaf aan Van Diemen een bijzonder podium. Voor het eerst bracht hij zijn gedachten over het reilen en zeilen van de VOC in Azië onder woorden en kon hij deze rechtstreeks richten aan de Heren Zeventien. Nog geen veertien jaar na zijn vlucht keerde hij getrouwd en als bemiddeld man terug naar Nederland. En niet zomaar. Hij was de commandant van een rijkbeladen vloot. Hij had drie belegeringen van Batavia overleefd en evenzovele aanvallen op zijn persoonlijke integriteit. Om Bredero's lijfspreuk aan te halen: 't Kan verkeren.'

Zie bijlagen i en 2, brieven van Van Diemen (I6I9 en I629). 


\section{Noten}

I. Valentijn, Oud en nieuw Oost-Indiën (Dordrecht I624) 294.

2. Coolhaas, 'Gegevens over het leven van Antonio van Diemen', 475.

3. Colenbrander, H. T., Jan Pieterz.Coen, bescheiden omtrent zijn bedrijf in Indië III ('s-Gravenhage I9I9-I923) 973.

4. Zandvliet, K., De Nederlandse ontmoeting met Azië, 1600-1950 (Zwolle 2002) 80.

5. Akveld, J. en E.M. Jacobs, De kleurrijke wereld van de VOC, Nationaal Jubileumboek VOC 1602-2002 (Bussum 2002) II3.

6. Hunter, W. W. en P. E. Roberts, A history of British India (New York I966) 375 .

7. Jonge, de, Opkomst III.

8. Busken Huet, C., Litterarische fantasiën en kritieken Deel 5 (Haarlem I878).

9. Chijs, J. A. van der, De vestiging van het Nederlandsche gezag over de Banda-eilanden (1599-1621) ('s-Gravenhage I886) I59.

Io. Schaepman, H. J. A. M., Jan Pieterszoon Coen, rede uitgesproken te Hoorn op 30 mei 1893 ('s-Gravenhage I893) 9.

II. Colenbrander, H. T., Jan Pietersz. Coen, levensbeschrijving ('s-Gravenhage r934) 448.

I2. Leemhorst, H. C., Plechtige herdenking van Jan Pieterszoon Coen (Hoorn i937).

13. Colijn, D. H., Dispereert niet....., Rede ter herdenking van den 35osten geboortedag van Jan Pietrsz. Coen uitgesproken te Hoorn den 1sten Februari 1937 (Amsterdam I937) 22.

I4. Meilink-Roelofsz, M. A. P., Asian trade and European influence in the Indonesian archipelago between 1500 and about 1630 ('s-Gravenhage i962) 207.

I5. Berg, J. van der, Het verloren volk: een geschiedenis van de Banda-eilanden. ('s-Gravenhage I995).

I6. Spruit, R., J.P. Coen: dagen en daden in dienst van de VOC. (Houten I987).

I7. Panhuysen, L., Historisch Nieuwsblad nr Io, december 2009, 33.

I8. Colenbrander, Jan Pietersz. Coen, levensbeschrijving. I.

I9. Velius, T., Chroniick van Hoorn, daer in verhaelt werden des selven stadts eerste begin, opcomen, en gedenckweerdige geschiedenissen, tot op den jare 1630 ... / Oversien, verbetert, en eensdeels op 't nieu beschreven, deur D. Velius, Dr. in de medecijnen tot Hoorn (Hoorn I630) 357.

20. Het is de heer A. Merens geweest die verder onderzoek naar Coens ouders heeft gedaan, waarvan de bevindingen gedeeltelijk zijn gepubliceerd door Gerretson - verzamelde werken 4 blz. 20I, 203 als bijlage bij zijn 'Coens eerherstel'. Het archief van Merens met 
zijn aantekeningen over Coen is bewaard gebleven in het provinciaal archief van Noord-Holland in Haarlem.

2I. Pater, J. C. H. de, Jan Pieterszoon Coen en Indië in zijn tijd ('s-Gravenhage I948) 5 .

22. Archief Hoorn, Not. arch No 205I fol 37.

23. Archief Hoorn Not. arch no 2037 fol 299 I3 augustus I593.

24. Archief Hoorn Not. Arch 204I f 6I en Not. Arch 2050 fol I78.

25. Colenbrander, Jan Pietersz. Coen, levensbeschrijving, 4; verwijst naar $\mathrm{K}$. Heeringa, Bronnen tot de geschiedenis van den Levantschen handel I, 99, ro9.

26. NA VOC 3I5 Brief Zeventien brief 29 maart I608.

27. Valentijn, Oud en nieuw Oost-Indiën III 2e deel, 78 Bandaasche Zaaken.

28. Colenbrander, Jan Pietersz. Coen, levensbeschrijving, 45I-472.

29. Elias, De vroedschap van Amsterdam I, 20I.

30. Ibidem I, LXV.

3I. Colenbrander, Jan Pietersz. Coen, bescheiden omtrent zijn bedrijf in Indië, IV, 377, Brief XVII 25 oktober I6I7.

32. Colenbrander, Jan Pietersz. Coen, bescheiden omtrent zijn bedrijf in Indië, I, 399.

33. Ibidem IV 307, Heren Zeventien aan Coen, 30 april I6I5.

34. Colenbrander, Jan Pietersz. Coen, levensbeschrijving, 454.

35. Colenbrander, Jan Pietersz. Coen, bescheiden omtrent zijn bedrijf in Indië, IV, 332, I5 nov. I6I5.

36. Calendar of State Papers,I6I5, par. 972/1078.

37. Colenbrander, Jan Pietersz. Coen, bescheiden omtrent zijn bedrijf in Indië, IV, 444.

38. Ibidem 288, 2I november I6I4.

39. Ibidem 313, 6 mei I6I5.

40. Ibidem 378 en 382,25 oktober I6I7.

4I. Ibidem 398, I0 april I6เ8.

42. Ibidem 393 .

43. Coolhaas, Gegevens over Antonio van Diemen, 478.

44. Haan, F. de, Oud Batavia 2 delen (Bandoeng I935) 26.

45. Colenbrander, Jan Pietersz. Coen, bescheiden omtrent zijn bedrijf in Indië, IV, 443-445.

46. Colenbrander, Jan Pietersz. Coen, bescheiden omtrent zijn bedrijf in Indië, I 526, Coen 22 januari I620.

47. Bibliotheek Scheepvaartmuseum Amsterdam signatuur A IV 2243 a Artikelen betreffende de voorbereiding van de Eerste Schipvaart naar Oost-Indië.

48. Colenbrander, Jan Pietersz. Coen, bescheiden omtrent zijn bedrijf in Indië, I 543.

49. Ibidem IV, 398. 
50. Ibidem IV, $55^{2}$.

51. Ibidem IV, 549, I4 april I622.

52. Ibidem IV, 307.

53. Ibidem IV, 3I9.

54. Ibidem IV, 377.

55. Pettegree, A., Emden and the Dutch revolt: exile and the development of reformed Protestantism (Oxford I992).

56. Elias, De vroedschap van Amsterdam, 1578-1795. Haarlem,: V. Loosjes. $2 \mathrm{v}$.

57. Zandvliet, K., Mapping for money: maps, plans, and topographic paintings and their role in Dutch overseas expansion during the 16th and 17th centuries (Amsterdam I998) hoofdstukken 5 en 7.

58. Gaastra, Geschiedenis van de VOC, 40.

59. Macleod, N., De Oost-Indische compagnie als zeemogendheid in Azië I (Rijswijk, I927) 260.

6o. Mun, T., A discourse of trade. Herdruk I969 (London/Amsterdam, I62I-I969) 28.

6I. Deursen, A. T. van, Maurits van Nassau 1567-1625: de winnaar die faalde (Amsterdam 2000) 284.

62. Warnsinck, De wetenschappelijke voorbereiding.

Brief Van Linschoten in Bibliotheek Scheepvaartmuseum Amsterdam signatuur A IV 2243 a Artikelen betreffende de voorbereiding van de Eerste Schipvaart naar Oost-Indië.

63. Roeper, V. de en R. van Gelder, In dienst van de Compagnie: leven bij de VOC in honderd getuigenissen (1602-1799) (Amsterdam 2002) 39.

64. Vos, W., Batavia, de herbouw van een Oostindiëvaarder Vol. I. (Almere I990).

65. NA VOC ıо68, f.358.359, Copie en originele missiven van Willem Janszoon aen de camer Amsterdam in datis 28 Maert I6I8 (reede van Cabo Verde) en 6 October I6r8 (te Bantam).

66. Colenbrander, Jan Pietersz. Coen, bescheiden omtrent zijn bedrijf in Indië, IV 400.

67. Ibidem I, 48I.

68. NA VOC OBP Io69, f. 447.

69. NA VOC. OBP I070 v 2 oktober i6i9.

70. Valentijn, Oud en nieuw Oost-Indiën. IV, 294.

7I. Haan, de, Oud Batavia I (Bandoeng I935) I50.

72. NA VOC OBP Iо73, f. 36, resolutie I2 januari I62I.

73. NA VOC OBP Io76 f. 260,6 maart I622.

74. Colenbrander, Jan Pietersz. Coen, bescheiden omtrent zijn bedrijf in Indië, III 960.

75. Coolhaas, W. P., Generale missiven van gouverneurs-generaal en raden aan de Heren XVII der Verenigde Oostindische Compagnie ('s-Gravenhage I960) Inleiding. 
76. Coolhaas, Gegevens over Antonio van Diemen, 487.

77. NA VOC OBP 1082, Res i8 nov i624.

78. Coolhaas, Gegevens over Antonio van Diemen, 488/ J. Bruin, Dutch Asiatic Shipping, III, 26.

79. NA VOC OBP IO82 of Io83, direct na nov I624.

80. Heeres, J. E., Dagh-register gehouden int Casteel Batavia vant passerende daer ter plaetse als over geheel Nederlandts-India anno 1624-1629 ('s-Gravenhage I896) 278, 30 augustus I626.

8I. Ibidem 294.

82. Ibidem 309-3I3.

83. Colenbrander, Jan Pietersz. Coen, bescheiden omtrent zijn bedrijf in Indië, IV ('s-Gravenhage I922) 333.

84. Ibidem 646 .

85. Ibidem 654 .

86. Brenner, R., Merchants and revolution: commercial change, political conflict, and London's overseas traders, I550-1653 (Princeton 1993) Io6.

87. Colenbrander, Jan Pietersz. Coen, bescheiden omtrent zijn bedrijf in Indië, IV ('s-Gravenhage 1922) 655.

88. Ibidem 665 .

89. Booth, A. en A. Merens, Een dienaer der Oost-indische compagnie te London in 1629 ('s-Gravenhage I942) I2-I4.

90. Colenbrander, Jan Pietersz. Coen, bescheiden omtrent zijn bedrijf in Indië, IV ('s-Gravenhage I922) 708.

91. Colenbrander, Jan Pietersz. Coen, bescheiden omtrent zijn bedrijf in Indië, IV ('s-Gravenhage I922) 377.

92. NA VOC OBP $1097 \mathrm{f}$ 489-524, Originele missive van Antonio van Diemen aen Pieter de Carpentier of bewinthebberen tot Amsterdam, gedateerd 30 November I629 met een aanhang van io en I5 December.

93. Gerretson, F. C., Coens eerherstel (Amsterdam I944) I22.

94. NA VOC OBP II28 f 325-357 originele missive van den gouverneur generaal Antonio van Diemen aen bewinthebberen in dato Io Januarij I639.

95. Jacob Cats, Aenmerckingen over onstelde sochters, Alle de werken II (Amsterdam I7I2) I24.

96. Slauerhoff, J., Jan Pietersz. Coen, drama in elf taferelen met een inleiding door Ronald Brouwer ('s-Gravenhage 1986) 24.

97. Colenbrander, Jan Pietersz. Coen, bescheiden omtrent zijn bedrijf in Indië, IV ('s-Gravenhage I922) 430.

98. NA VOC OBP I097 489-524, Originele missive van Antonio van Diemen aen Pieter de Carpentier of bewinthebberen tot Amsterdam, gedateerd 30 November I629 met een aanhang van Io en I5 December. 
99. Ibidem.

I00. In its extreme manifestation, cholera is one of the most rapidly fatal illnesses known. A healthy person may become hypotensive within an hour of the onset of symptoms and may die within 2-3 hours if no treatment is provided. More commonly, the disease progresses from the first liquid stool to shock in 4-I2 hours, with death following in I8 hours to several days. (bron http://textbookofbacteriology.net/cholera.html).

ıог. Colenbrander, Jan Pietersz. Coen, bescheiden omtrent zijn bedrijf in Indië, IV 385, brief XVII 25 October I6I7.

I02. NA VOC OBP 1097 489-524, Originele missive van Antonio van Diemen aen Pieter de Carpentier of bewinthebberen tot Amsterdam, gedateerd 30 November I629 met een aanhang van io en I5 December.

I03. Ibidem.

I04. NA VOC OBP ıІо०, 38-4I, Copie missive van Antonio van Diemen aen den gouverneur generaal Jacques Specx in dato I5 October I630.

I05. Valentijn, Oud en nieuw Oost-Indiën. IV (Dordrecht I724) 29 I.

ıo6. Coolhaas, W. P., 'Een Indisch verslag uit I63I, van de hand van Antonio van Diemen', Bijdragen en mededelingen betreffende de geschiedenis der Nederlanden 65 ('s-Gravenhage I946) 82.

ı07. NA VOC OBP ııoo f 38-4I, Copie missive van Antonio van Diemen aen den gouverneur generaal Jacques Specx in dato I5 October 1630 .

Io8. Coolhaas, Gegevens over Antonio van Diemen, 5 I6. 


\section{Een lange sollicitatiebrief, de buitengewone generale missive van 1631}

Met elke retourvloot die uit Batavia naar Nederland vertrok, ging een door de gouverneur-generaal en raden ondertekende lange brief mee, de zogenoemde 'generale missive', waarin een uitgebreid overzicht gegeven werd van de staat van de VOC in haar octrooigebied. De opbouw van deze jaarlijkse generale missive was steeds eenzelfde. Eerst werden de aangekomen en vertrekkende schepen vermeld om te vervolgen met een uitgebreid overzicht van de gebeurtenissen in het octrooigebied, waarbij in dit tijdvak begonnen werd in Perzië, om vervolgens met de wijzers van de klok mee, via India, Maleisië naar China, Formosa en Japan door naar de Molukken en Banda te eindigen in Batavia op Java. De missive werd door een secretaris opgesteld aan de hand van de brieven die in de loop van het jaar uit de diverse kantoren werden ontvangen, gekoppeld aan de interpretatie van de beschreven gebeurtenissen door het hoofdkwartier in Batavia. Vervolgens werd de brief ondertekend door de gouverneur-generaal en de raden van Indië waarna de post scheep ging naar het vaderland. Het is duidelijk dat in I63I Van Diemen zelf de secretaris was. ${ }^{\mathrm{I}}$

In bijna twee eeuwen zou op deze regel één uitzondering zijn. Namelijk, toen op 7 maart I63I de vloot twee maanden later dan gepland was geweest, vertrok, was de generale missive niet af. Het eerste gedeelte eindigde op het $46^{\text {ste }}$ folio met de woorden:

'Ed. Heeren! Den tijt van depecheren der schepen alreede seer verloopen zijnde mits gaders dagelijckx verwachtende retouren ende advysen van de cust van China als Jappan niet en verschijnen, ende dat d 'Heer Generael eenige dagen aen sijn oude quale vant graveel seer indispoost geweest is, hebben goedgevonden desen te abbrieveren ende door den Ed Hr. Van Diemen onderwegen op de reyse te laten suppleren, daer toe sijn Ed alle noodige pampieren ende advijsen mede gegheven zijnde."

Door Coolhaas werd aangenomen dat deze uitzondering op de regel kwam omdat gouverneur-generaal Specx een broertje dood had aan administratieve zaken en dit corvee gaarne aan Van Diemen overliet om in rust op zee af te maken. ${ }^{3} \mathrm{Ik}$ denk dat de werkelijke reden een andere 
zou kunnen zijn en gezocht kan worden in de slechte onderlinge verhoudingen in de top van de VOC in Azië.

Het eerste deel, in Batavia geschreven, werd namelijk gezamenlijk ondertekend door gouverneur-generaal Specx, en de raden van Indië Vlack, Van Diemen en Van der Burgh. Specx en Van Diemen hadden beiden goede redenen om met Vlack af te willen rekenen, een delicate zaak, want Vlack was na Specx wel de hoogste in rang. Van Diemen zou daar in het vervolg van de generale missive de ruimte voor krijgen, én nemen. Bijkomend voor Van Diemen was dat hij buiten het zicht van derden zonder verdere verantwoording kon mededelen dat zijn vrouw en hij voor meer dan 50.000 gulden in wissels en diamanten met zich mee namen.

Wat dit tweede deel van deze generale missive zo bijzonder maakt, is dat alle andere generale missiven werden geschreven onder de verantwoordelijkheid van de zittende gouverneur-generaal en daarmee uiteraard een uitleg en verdediging van het gevoerde beleid waren. Van Diemen was daarentegen voor het oog belangeloos en hoefde niets toe te dekken als hij dat niet wilde. Voor het eerst bracht hij zijn gedachten over het reilen en zeilen van de VOC in Azië onder woorden en kon deze rechtstreeks richten aan de Heren Zeventien.

Het is boeiend de twee delen van deze generale missive van I63I met elkaar te vergelijken. Het verschil in toon is opvallend. In het eerste, in Batavia geschreven, gedeelte komt een bedrijf naar voren dat sterk werd beïnvloed door gebeurtenissen die buiten zijn macht lagen. Tegenslagen waren bijkans onafwendbaar en zelden het gevolg van het beleid van compagniedienaren. Of het nu de peperhandel in Sumatra was waar de Engelsen de markt bedierven ${ }^{4}$, de suikerinkoop in Bengalen waar het seizoen tegen zat ${ }^{5}$, de gierige en inhalige gouverneur van Suratte ${ }^{6}$, of de oorlogvoerende Groot Mogol waardoor minder salpeter kon worden ingekocht. ${ }^{7}$ En ook de doorlopende strijd met de Portugezen was de oorzaak van tegenvallers. Natuurlijk werden ook compagniedienaren schuldig bevonden aan particuliere handel, maar steeds zonder namen te noemen. Eén uitzondering hierop vormden twee heren: Nuyts en Van den Heuvel. Uitzonderlijk dat twee hoge compagniedienaren van hoge rang gevangengezet werden. De toedracht is al eerder besproken en was ook in de generale missive toegelicht, let wel zonder de verwikkelingen rond de vermeende particuliere handel van Van Diemen te vermelden. De afsluiting van de weeklacht over Nuyts en Van den Heuvel is prachtig:

'Ondertusschen Uw Edhn versoeckende, dat sulcken spitsvinnighe ende overlange bekende warvogels in toecomende moghen geexcuseert werden in Compgs dienst herrewaerts te senden. ${ }^{8}$ 
Het was hierdoor niet zozeer een beleidsbrief, als wel een excuusbrief geworden. De VOC in Azië draaide niet goed, maar dat lag maar in beperkte mate aan de mannen die aan het roer stonden van de organisatie.

In het tweede gedeelte dat door Van Diemen werd geschreven tijdens de oversteek van de Indische Oceaan, kwam een ander beeld naar voren. Dit gedeelte was af op 7 juni, vlak voordat de vloot onder zijn commando Kaap de Goede Hoop zou ronden. Het besloeg 64 aan beide kanten beschreven foliobladen, die in druk verschenen meer dan 200 pagina's tekst opleverden. ${ }^{9}$ Volgens Valentijn was Van Diemen 'een ongemeen gaauw en schrander man, die een schoone pen voerde en een heerlijcke stijl in 't opstellen van zijn zaken had.' 'Le style est l'homme même' zoals Buffon in de achttiende eeuw vaststelde. ${ }^{\text {II }}$ De op zee geschreven generale missive van I63I vormt daarmee dan ook een karakterschets van Van Diemen. Bemiddeld en zonder eindverantwoordelijkheid of meelezers kon hij schrijven wat hij vond en wilde.

Wat voor figuur komt uit deze generale missive naar voren? Het is duidelijk dat Van Diemen schreef met autoriteit gebaseerd op grote kennis van zaken en overzicht. Details betreffen vooral de handel, indien nodig met verwijzingen naar de bijgaande correspondentie. Het zijn vooral afstandelijke, in onze ogen kille analyses. Het vele menselijk lijden is volstrekt ondergeschikt aan de positie van de VOC. Hij schreef helder en bij tijd en wijle beeldend. Het beeld dat Van Diemen opriep, is subtiel opgebouwd en staat haaks op de conclusies van het eerste deel: van de traditionele vijanden, de Portugezen en de Spanjaarden, was geen groot gevaar meer te duchten. Ook de Engelse concurrenten waren zo goed als van het toneel verdwenen. De aanvallen van de Javaanse vorst op Batavia waren krachteloos en zouden dat blijven.

Waarom ging het dan toch niet echt goed? Het waren juist menselijke zwakte en ondoordachte beslissingen geweest die de macht van de Compagnie van binnenuit bedreigden. Menigeen werd door Van Diemen te kijk gezet. Hij schreef over 'de twee schadelijke kankers' binnen de organisatie van de VOC in Azië: de vele koopmannen voor wie geen werk was en degenen die het particulier boven het algemeen stelden. ${ }^{\text {I2 }}$ Vijanden had hij genoeg in eigen kamp en in de brief nam Van Diemen de gelegenheid om met hen af te rekenen, terwijl vrienden juist een steun in de rug kregen. Specx werd niet genoemd, maar het is duidelijk dat hij volgens Van Diemen niet voor zijn taak berekend was.

De oorzaak van de tegenslagen lag dus niet aan de buitenwereld, maar aan de kwaliteit van de hogere functionarissen van de VOC zelf: elke keer werden man en paard genoemd. Al op het derde folio was Pieter Vlack aan de beurt. Hij had 'een groote faulte gecommitteerd' bij het bevel over een kleine vloot voor de kust van Sumatra. Om daarover te constateren: 'door slecht en quaat beleijtt wortt den dienst van de Compa, 
in veele saecken meermalen verachttert. ${ }^{\mathrm{I} 3}$ Ook Pieter Nuyts kwam uitvoerig aan bod. Hij zou tegen gouverneur-generaal Specx ronduit gezegd hebben dat hij niet naar India was gekomen 'om hooi te eten'. Waarop Van Diemen verzuchtte: 'Had hij maar in Middelburg vette tarwe te eten gekregen en was hij maar nooit naar India gekomen, wat zou de Compagnie daarmee een voortreffelijke dienst zijn bewezen. "I4

De vijanden van Van Diemen kregen er zo stuk voor stuk van langs. Maar ook de anderen waren eigenlijk niet competent genoeg. Er was volgens Van Diemen in Indië niemand bekwaam genoeg om de hoogste ambten te vervullen.

Was er dan ook niemand die wist hoe het wel moest? Een retorische vraag. Van Diemen gaf praktische aanwijzingen hoe de problemen opgelost konden worden, maar dan moest er wel eerst schoon schip gemaakt worden onder het hogere compagniepersoneel.

Wij lezen het verslag van een intelligente, analytisch ingestelde, ambitieuze en wellicht wrokkige man, die zich bewust was van zijn gehoor dat bang was voor kosten, grote risico's en steeds, overigens terecht, bezorgd over de vele manieren waarop buiten de boeken van de VOC het personeel in Azië de zakken vulde ten eigen bate.

$\mathrm{Hij}$, de man die zelf in Batavia van onderop begonnen was, had een hekel aan op voorspraak benoemde functionarissen. Men diende personen met een lage militaire rang naar Batavia te laten gaan, dan stond het aan de bestuurders aldaar vrij een keuze te maken wie verder op kon klimmen, en wie niet. Wie kon anders uit eigen ervaring schrijven: 'trouw cloeck en eiverich volck zall in India well voort geraecken. ${ }^{15}$ Deze indirecte verwijzing naar zijn eigen carrière zal de lezers niet ontgaan zijn.

Een duidelijk voorbeeld is de situatie rond de kruidnagelen op de Molukken. 'Het monopolie van de VOC bestond,' zo schreef Van Diemen 'slechts op papier'. Veel handel lekte weg via handelaren die naar de Molukken voeren vanuit Makassar (het tegenwoordige Ujong Pandang), gelegen halverwege de Molukken en Java. In Makassar werden deze kruidnagelen dan opgekocht door Aziatische handelaren en Engelsen, Portugezen, Fransen of Denen. Van de in Makassar verhandelde hoeveelheden en prijzen was men in Batavia overigens nauwkeurig op de hoogte.

Hoe dit nu op te lossen? Een in Batavia voorgestelde optie was om Makassar te verwoesten. Daar voelde Van Diemen niets voor, een riskante militaire operatie die waarschijnlijk geen effect zou hebben omdat de handelaren makkelijk een andere haven konden vinden op Borneo of Java. Immers 'niet anders als den nagelreuck treckt den coopman derwaerts' en die zou daardoor niet verdwijnen. ${ }^{16}$

De gouverneur op de Molukken stelde voor aldaar permanent meer schepen aan te houden en daarnaast grotere garnizoenen op de forten 
in de Molukken. Volgens Van Diemen was dat een kostbare en slechts halve oplossing. Sterker nog, de garnizoenen waren volgens hem al te groot.

Hij stelde zelf het volgende voor. Door de regentijd op Java kon Batavia maar vier maanden per jaar door Mataram worden aangevallen, zoals in I628 en I629 was gebleken. De rest van het jaar was het grote garnizoen aldaar dan ook niet nodig. Daar kwam bij dat de vloot die voor de rede van Batavia lag, door de moesson een halfjaar niet voorbij Sumatra kon varen, maar dan juist wel naar de Molukken. Zijns inziens kon daarom het beste één goed bemande vloot jaarlijks naar de Molukken zeilen om de schepen van de Makassaren te vernietigen en de dorpen die het monopolie ontdoken, onder gezag te brengen. De handhaving van het monopolie zou daardoor binnen handbereik komen.

Dit moet de Heren Zeventien als muziek in de oren geklonken hebben.

Een bijzonder heikel punt echter, was de situatie rond de voorwaarden waaronder handel voor eigen rekening van burgers en compagniedienaren was toegestaan. Zoals hierboven beschreven werd, wilde Coen Batavia ontwikkelen tot een echte volksplanting. Om de bevolking middelen van bestaan te geven zou het grotendeels vrijgeven van de Aziatische handel door de VOC noodzakelijk zijn. Dit beleid werd eerst ingezet en vervolgens weer teruggedraaid. Dat ging zeker niet vanzelf. In oktober I630 was met het schip 'Egmond' hiertoe een expliciete order van de Heren Zeventien in Batavia aangekomen. In januari I63I werd er een plakkaat over opgesteld. ${ }^{\mathrm{I7}}$ Maar gouverneur en raden vonden dit bevel veel te ver gaan en weigerden er uitvoering aan te geven. Het zou naar hun mening Batavia ontwrichten. Van Diemen stelde dat de Heren Zeventien de consequentie van hun besluit niet konden overzien en gaf een aantal veranderingen in overweging. ${ }^{\text {I8 }}$ Deze weigering van Specx om uitvoering te geven aan een expliciete aanwijzing zou hem zijn baan kosten. Werd hem in I630 nog bevestiging van zijn rang als gouverneur-generaal toegezegd, binnen een maand na de aankomst van Van Diemen in Amsterdam werd Hendrick Brouwer als zijn opvolger benoemd.

Dat de privéhandel van compagniedienaren een gegeven was dat voor de Heren Zeventien onverteerbaar, maar in wezen onuitroeibaar was, bleek al uit een brief van Both uit I6ı2. Both meende dat als iedere hogere compagniedienaar die zich schuldig had gemaakt aan handel ten eigen bate, naar Nederland zou worden teruggezonden, er weinigen zouden overblijven. ${ }^{\text {I9 }}$ De kans op snelle rijkdom was immers vaak de voornaamste drijfveer voor iemand om dienst te nemen bij de VOC.

Van Diemen repte in zijn lange brief met geen woord over de expansie van de VOC in Azië ten koste van de Portugezen, zoals die later onder zijn leiding tot stand zou komen, en waardoor hij beroemd zou 
worden. Oorlog was kostbaar en deze plannen - zo hij die toen al had zouden wellicht op dat moment niet in goede aarde gevallen zijn in Amsterdam.

De man die dit alles schreef, wilde weer terug naar Batavia. Gezien het matige optreden van Specx en de onbetrouwbaarheid van diens ondergeschikten werd de gedachtevorming van de Heren Zeventien ook die kant op gedwongen: onder leiding van Van Diemen zou het met de VOC in Azië goed komen.

\section{Noten}

I. Dat was Van Diemen waarschijnlijk al vanaf het overlijden van Coen in september I629. Ongeveer tezelfdertijd vertrok de toenmalige secretaris Antonio del Court naar Perzië en werd na het vetrek van Van Diemen in I63I Dirck van der Lee als zodanig benoemd (Coolhaas Indisch verslag blz 7) Ook zijn de Generale Missive van december ${ }^{6} 629$ en de particuliere brief van Van Diemen aan De Carpentier in hele stukken bijna identiek.

2. Coolhaas, Een Indisch verslag uit I63I, 8.

3. Ibidem.

4. Coolhaas, Generale missiven van gouverneurs-generaal I, 282 en 299.

5. Ibidem 292.

6. Ibidem 286.

7. Ibidem 287.

8. Ibidem 30I.

9. Ibidem.

Io. Valentijn, Oud en nieuw Oost-Indiën. IV 293.

II. Georges-Louis leclerc de Buffon (I707-I788) http://www.britannica. com/EBchecked/topic/165345/Discours-sur-le-style

I2. Coolhaas, Een Indisch verslag uit I631, ig6

I3. Ibidem 26 .

I4. Ibidem 82.

I5. Ibidem 196 .

I6. Ibidem I52.

I7. Chijs, J. A. van der, Nederlandsch-Indisch Plakkaatboek 1602-1811 I7 delen ('s-Gravenhage, I885-1900), I 254.

I8. Coolhaas, Een Indisch verslag uit I63I, I98.

19. Dam, van, Beschrijvinge III, 393. 


\section{$9 \quad$ Terug in Nederland, oktober 1631-januari 1633}

Op 9 oktober I63I ging de vloot waarover Van Diemen het commando voerde, voor anker op de rede van Texel. Na bijna veertien jaar keerde hij terug in Nederland, 38 jaar oud. Hij had zijn schulden afgelost en was getrouwd met een rijke vrouw. Voelde hij opluchting of triomf? Was er sprake van een emotioneel weerzien met zijn familie? Hoe lag dat bij Maria? Wij zullen het nooit weten. Wel kunnen wij in de archieven zijn bewegingen tijdens zijn verblijf in Nederland volgen. Het zou overigens maar veertien maanden duren voor hij in Texel weer scheep zou gaan naar Batavia.

Toen Van Diemen in I6I7 Nederland verliet, was dat aan de vooravond van de val van Van Oldenbarnevelt en de poging van de fanatieke contraremonstranten om met Engeland de kern van een Europese protestantse alliantie te vormen die de strijd zou moeten aangaan met de katholieke Habsburgers. Na het fiasco van deze strategie en de hervatting van de strijd met de Spanjaarden was de Republiek lange tijd militair en economisch in het defensief gedrongen. Men besefte aan Spaanse kant weliswaar dat verovering van de Republiek niet meer mogelijk was, maar alles werd in het werk gesteld om het prestige en de kracht van de Republiek te breken. Zo werd Breda in I625 na een even voorbeeldig als kostbaar beleg door de veldheer De Spinola veroverd.

De Europese verhoudingen beleefden II november i630 op de beroemde journée des dupes een ommekeer. Aan het begin van deze dag sprak Lodewijk XIII van Frankrijk zich uit voor de partij van Maria de Medici, zijn imposante moeder, en daarmee voor een katholieke alliantie met de Habsburgers in Spanje en Oostenrijk tegen de protestantse naties. Later op die dag echter, veranderde hij van mening en koos naar zou blijken definitief - voor de politiek van zijn Eerste Minister, de Richelieu, die juist van mening was dat Frankrijk zich met alle middelen moest verdedigen tegen de vermeende Habsburgse omsingeling.

Maria de Medici ging daarop in ballingschap, zij zou haar zoon nooit weerzien. Haar grootste medestander maarschalk Louis de Marillac werd gearresteerd. De Richelieu orkestreerde een schijnproces waarin de Marillac ter dood werd veroordeeld en onthoofd werd. Niet alleen in de Republiek was politiek dus een 'halszaak'. 
Het Europese toneel zou vervolgens tot na $6_{40}$ bepaald worden door de haast persoonlijke worsteling tussen de kardinaal-hertog de Richelieu aan Franse kant en de graaf-hertog Olivares, de Eerste Minister van Philps IV, aan Spaanse kant.

Doordat de Spaanse aandacht in die jaren naar de Franse grenzen werd verlegd, viel de militaire druk op Nederland deels weg. ${ }^{\mathrm{I}-3}$ Hier maakte de Republiek goed gebruik van. In I632 werd de campagne van Frederik Hendrik bekroond met de sensationele verovering van Maastricht op 23 augustus. De Zuidelijke Nederlanden reageerden geschokt en snel daarna werden vanuit Brussel onderhandelingen geopend om de oorlog te beëindigen. Deze onderhandelingen begonnen in november in Den Haag. In de Republiek heerste diepe verdeeldheid over de wenselijkheid van vrede. Zeeland, Friesland en Groningen waren tegen, evenals de contraremonstrantse steden in Holland, maar het belangrijke Amsterdam leek voorstander. ${ }^{4}$

In deze periode van nieuw elan en politieke onduidelijkheid kwam Van Diemen terug. De aankomst van de retourvloot werd routineus afgehandeld. Voordat iemand aan wal mocht, kwam een bewindhebber van de kamer van Amsterdam met helpers aan boord die alle verslagen en cognossementen in ontvangst nam. De lading en de inhoud van de persoonlijke bezittingen werden gecontroleerd en daarna vrijgegeven.

Van Diemen en zijn vrouw gingen naar Amsterdam, waar hij al op I6 oktober in de vergadering van de kamer van Amsterdam mondeling verslag deed. ${ }^{5} \mathrm{Hij}$ zal de conclusie van zijn generale missive hebben onderstreept dat de situatie in Batavia aan de top van de VOC onhoudbaar was geworden. Voor de bewindhebbers werd hiermee een gevoel dat reeds bestond, bevestigd. De conclusie werd getrokken dat Specx onmiddellijk vervangen moest worden, maar dat een vervanger als gouverneur-generaal niet binnen het hogere personeel voorhanden was. Er moest een gouverneur-generaal komen die met gezag de orde kon herstellen.

Aangezien de kamer van Amsterdam altijd de gouverneur-generaal leverde, werd daar naar een kandidaat gezocht. Er waren twee kandidaten die beiden bewindhebber waren en op Indische ervaring konden bogen: de voormalige gouverneur-generaal Pieter de Carpentier en de oudgediende Hendrick Brouwer. De eerstgenoemde bleek niet beschikbaar te zijn, waarmee de keuze op Brouwer viel. ${ }^{6}$

Later in de maand oktober maakte Van Diemen in gezelschap van een bewindhebber zijn opwachting bij de Staten-Generaal en prins Frederik Hendrik in Den Haag. Het was een plichtpleging, want voor hen was een apart verslag opgesteld dat optimistisch van toon was en waarin de vuile was werd binnengehouden. ${ }^{7}$ 
In Amsterdam voldeed Van Diemen vervolgens aan drie Portugese kooplieden de laatste openstaande schulden uit zijn faillissement. ${ }^{8}$ Het was bij elkaar nog zo'n twaalfhonderd gulden.

Hoewel Descartes op 30 april van dat jaar nog in een lange brief aan een vriend had geschreven hoe verstandig een mens eraan deed 'se retirer à Amsterdam' zoals hij zelf gedaan had, omdat iedereen in deze stad zo druk was met geld verdienen of uitgeven dat je je ongehinderd aan de studie of andere bezigheden kon wijden, was Van Diemen in die stad bepaald niet op zoek naar rust. De door hem geschreven generale missive was doorspekt met persoonlijke ambitie, bijna een sollicitatiebrief.

Maria en Antonio reisden in november door naar Culemborg, waar hij getuige was bij de doop van zijn neefje Antonio, maar een huis werd daar niet gekocht. ${ }^{9}$ In Culemborg woonde ook de moeder van Maria, die na het overlijden van haar eerste echtgenoot gehuwd was met Cornelis de Keyser, oud-burgemeester van Culemborg. Maria en Antonio maakten in Culemborg hun testament dat ons inzicht geeft in de vermogenspositie van het echtpaar. De aanhef van zo'n zeventiende-eeuws testament is mooi:

'In de names des Heeres Amen, wij Antoni van Diemen ende Maria Aelst maecken condt, dat wij aenmerckende de brosheijt der menselijcke nature die niets seckerder onderworpen is dan de doot en niets onseckerder dan de wijse derselve, wille daeromme van onse tijtelijcke goederen ons bij Godt almachtich verleent ende noch te verleenen disponeeren alleer wij door de doot daervan geprevenieert worden, hebben ingestelt gemaeckt ende gewilt desen onsen testamente ende vuytterste wille verclaeren 'tgeene hiernae volcht. ${ }^{10}$

Het verschil in vermogen tussen de beide echtelieden was groot. Waar Antonio zijn zusters steeds drieduizend gulden toebedacht, had Maria het over enkele tienduizenden guldens voor haar ouders en broer. Maria was gefortuneerd uit Batavia teruggekeerd, maar Antonio zeker niet. Die vermogensscheiding zou ook blijven. Toen Van Diemen later gouverneur-generaal was, liet hij enkele malen bedragen van dertigduizend gulden of meer door de Heren Zeventien uitbetalen aan zijn zwager Pieter de Gruyter. Na de dood van Antonio maakte Maria daar geen aanspraak op.

In Nederland was Van Diemen voortdurend met de VOC bezig. Zo zien we dat hij eind november in Middelburg alweer de vergadering van de Heren Zeventien bijwoonde. Hij werd daar meerdere malen gevraagd 'om zijn goede adviezen'. Ook werd daar met terugwerkende kracht zijn salaris als raad van Indië vastgesteld op 400 gulden per maand en kreeg hij een 'verering' - bonus zouden wij tegenwoordig zeg- 
gen - van 2500 gulden in de vorm van een gouden ketting of desgewenst in contanten. Zoals gezegd is, trad hij ook op als executeur-testamentair voor de vader van de ongelukkige Pieter Cortenhoeff. ${ }^{\text {II }}$

Van Diemens oordeel over de incompetentie van vele hoge functionarissen van de VOC in Azië weerklonk in de precieze instructie die Brouwer meekreeg om met harde maatregelen de corruptie te bestrijden. De Heren zaten duidelijk in hun maag met de manier waarop Specx moest worden teruggeroepen. Het was een delicate aangelegenheid en op eenzelfde manier als tegenwoordig Raden van Commissarissen wel eens om de hete brei heen blijven draaien totdat een aanvaardbare formulering is gevonden, kwam hiervoor uiteindelijk ook een eenvoudige en elegante oplossing: Specx had het bewind in september I629 na het overlijden van Coen overgenomen. Normaal gold een benoeming voor drie jaren en tegen de tijd dat Brouwer in Batavia zou aankomen, zouden die precies verstreken zijn. Voor de vorm was er zo geen sprake van ontslag, maar van reguliere aflossing. Het punt dat Specx nooit officieel benoemd was als gouverneur-generaal, werd omzeild. ${ }^{\text {I2 }}$

Het belangrijkste besluit van deze vergadering was om (nogmaals) de handel door particulieren in Indië bijna overal te verbieden en dit verbod 'ten rigoreusten' te handhaven. ${ }^{13}$ Daarnaast moesten 'alle ledige onnutte dienaeren waerover in't vervolge van de generaele missive seer geclaeght wort en meest de cost niet waert en sijn' naar Nederland worden teruggestuurd. ${ }^{\mathrm{I}}$

In maart I632 was Van Diemen weer bij de vergadering van de Heren Zeventien aanwezig. Zozeer werd zijn mening op prijs gesteld dat werd gewacht met de beraadslagingen over de handel op bijvoorbeeld Suratte en Perzië tot hij kon worden geraadpleegd. Op zijn voorstel werd de voor het volgende jaar 'geëiste' hoeveelheid peper uit Batavia belangrijk verhoogd en ook op zijn voorstel werd besloten zes bewapende jachten te bouwen. ${ }^{15} \mathrm{Hij}$ werd hier, of vlak daarna gepolst of hij met de komende vloot in de rang van directeur-generaal wilde uitvaren.

Uit het veelvuldig raadplegen van Van Diemen blijkt dat een merkwaardige situatie ontstaan was binnen de VOC in Nederland. Enerzijds wilde men vanuit Nederland de greep op het bedrijf in Azië vergroten, anderzijds erkende men dat de kennis daarvoor ontbrak. Deze kloof zou alleen maar groter worden. Toen na ${ }_{1} 6_{3} 6$ eerst Reael en later De Carpentier van het toneel verdwenen waren, zou er geen bewindhebber meer zijn die zelf in Azië was geweest.

Het is onduidelijk of Van Diemen ooit overwogen heeft niet terug te gaan naar Batavia. In ieder geval kostte het geen aanwijsbare overtuigingskracht om hem weer dienst te laten nemen bij de VOC. Hij werd uitgezonden als directeur-generaal, de hoogste functionaris na de gouverneur-generaal met de bedoeling om na afloop van de driejaartermijn 
van Brouwer diens opvolger te worden. ${ }^{\mathrm{I}}$ Over de voorwaarden werd een contract gemaakt, dat helaas verloren is gegaan.

Voor Van Diemen ontstond ruimte voor patronage en zo zou er familie met hem mee reizen. Zo waren daar de broer van Maria, Arend van Aelst in de rang van luitenant, met zijn vrouw en drie zonen. Samen scheepten zij gelijk in met een volle neef van Antonio, Bartholomeus de Gruyter, zoon van zijn oudste zuster en Pieter de Gruyter en tot slot voer ook zijn Culemborgse achterneef Gerrit van Harn mee. In I639 zou ook uit Culemborg nog zijn neef Jan van Riebeeck volgen in de rang van onder-chirurgijn. Hij was, de latere stichter van de Kaapkolonie in Batavia. Als secretaris van de vloot werd een protegé, Salomon Sweers, aangesteld. Ten overvloede werd in de vergadering van de Heren Zeventien van november I632 vastgelegd dat Antonio van Diemen als 'commandeur van de eerstvolgende vloot' zou uitvaren. ${ }^{\text {I7 }}$

Eind november I632 vertrok het gezelschap naar Texel om scheep te gaan. Van Diemen zag op tegen de reis. Hij werd in de eerste week van december ziek en moest naar de wal terugkeren. In die gesteldheid schreef hij een tweetal brieven aan de kamer van Amsterdam. De inhoud van deze brieven is van groot belang om de strategie van Van Diemen als gouverneur-generaal later, te begrijpen. Dit des te meer omdat deze brieven tot nu toe onbekend waren. Hun vindplaats is ongebruikelijk en bij de grote inventarisatie van het VOC-archief zijn zij over het hoofd gezien. Zij bevinden zich in het archief van de kamer Zeeland achter de resoluties van de vergadering van de Heren Zeventien die in de herfst van I632 in Middelburg was gehouden. ${ }^{\mathrm{I} 8}$

De eerste brief schreef hij op 2 december, waarin hij inging op de vrije burgerij in Batavia en de noodzaak om deze van goede schepen te voorzien voor hun eigen handel, voor zover hun nog vrije handel was toegestaan. Hij stelde voor in Nederland een drietal fluiten voor hen te bouwen. Op zich een opmerkelijk verzoek, omdat het tijdens de afgelopen vergaderingen van de Heren Zeventien juist een thema was geweest om de handel van de vrije burgers bijkans ondoenlijk te maken, wat geresulteerd had in een expliciete instructie aan Brouwer hierover.

De tweede brief was van een geheel ander kaliber en daar was alle reden voor. Op 4 december had niemand minder dan de raadspensionaris Adriaan Pauw een brief aan de Heren Zeventien geschreven. Daarin informeerde hij in het kader van de besprekingen die in Den Haag begonnen waren, expliciet naar hun opvatting over een eventueel bestand. Dit zou immers ook van kracht worden in Azië. Blijkbaar is deze brief of een samenvatting daarvan onmiddellijk per koerier doorgestuurd naar Van Diemen met het verzoek om een reactie. Die kwam op 9 december en liet niets aan helderheid te wensen over. Een bestand in Azië zou volgens Van Diemen niets minder dan een ramp zijn voor de Compagnie. 
Hij was van mening dat bij een wapenstilstand met de Portugezen de VOC bijna overal in Azië haar positie zou verliezen aan Portugese handelaren: 'Sij sijn bastant als van ons niet getroubleert wordende de Compagnie hare gantse handel in India infructueus te maken. Van rijcke en goede borgerije die alles weten op te soucken en te door snuffelen zijn zij beter als wij voorsien.'

En, 'want de portugees zal ons altijt bij vredige handel vercloecken dat wil ick geerne bekennen.'

Alleen een vrije burgerij zou deze concurrentie het hoofd kunnen bieden. Zijn conclusie luidde dan ook dat de oorlog tegen de Portugezen zo lang mogelijk voortgezet moest worden. Met een verwijzing naar de vredesonderhandelingen die in november in Den Haag begonnen waren, moedigde hij de bewindhebbers hiertoe op dramatische wijze aan: 'Houdt mijn heeren 't sweert inde handt, het sal u niet rouwen.'

Vlak voor zijn vertrek liet Van Diemen het achterste van zijn tong zien. Om te kunnen overleven moest de VOC de Portugezen in Azië verslaan. In deze tweede brief geeft Van Diemen de reden van de verbeten strijd die hij als gouverneur-generaal tegen de Portugezen zou voeren. In vergelijking met een Portugese handelaar was de VOC log en kostbaar. Als de keuze niet werd gemaakt voor de eigen vrije burgers om in de intra-Aziatische handel deel te nemen, moesten de Portugezen definitief verslagen zijn voordat een wapenstilstand werd gesloten.

Zijn waarschuwing zou effect sorteren. Op 2I december schreven de Heren Zeventien aan 'de weledel Hoogmogende Heeren', de Staten-Generaal dus. In deze brief werd het standpunt van Van Diemen overgenomen, weliswaar zonder de duidelijke redenen die hij had aangegeven. Dat was te gevoelige informatie.

Een bestand, zo schreven de Heren, moest worden afgewezen niet alleen omdat de 'tractaten met de Aziatische potentaten' een verandering van de staat van oorlog in de weg stonden, maar vooral omdat het ging 'omme verscheijdene hoogwichtige consideratien het geheel welvaren van de Compagnie concernerende, de welcke de penne niet wel vertrout moghen werden. Niet en soude moghen toegelaten werden eenighe handelinghe met onse vijanden aen te gaen, als die strecken tot totale ruijne van de Compagnie.'I9

Samen met 'zijn' generale missive kunnen wij ons op grond hiervan een helder beeld vormen van de strategie die Van Diemen als gouverneur-generaal voor ogen stond. Kort samengevat, ging het hem om het kruidnagelmonopolie op de Molukken en de strijd tegen de Portugezen. Tijdens zijn reis naar Nederland en zijn verblijf aldaar had hij zijn plan getrokken. 


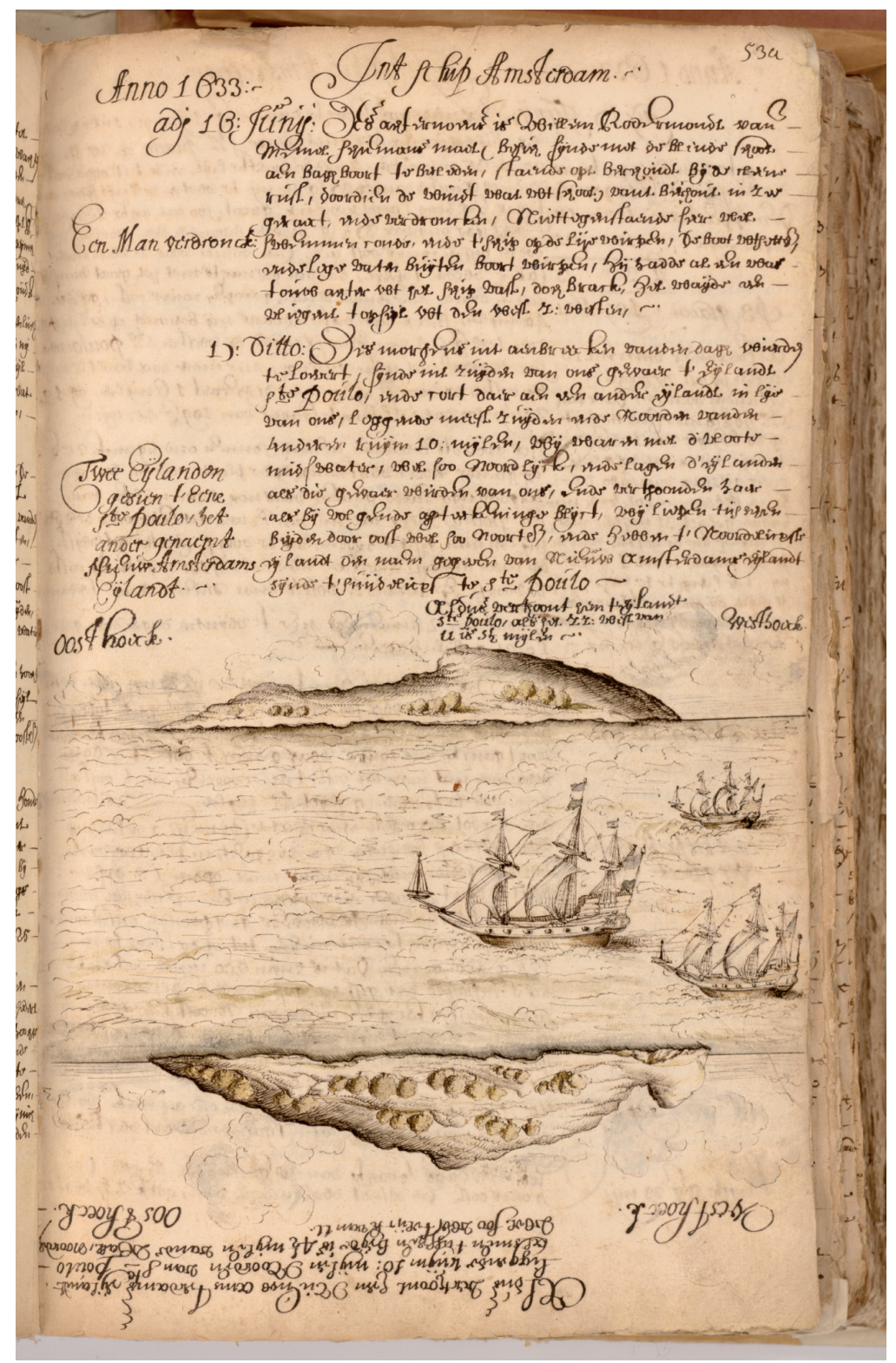

Dit is de enige ons bekende tekening van de hand van Van Diemen. Het charmante is dat je je kunt voorstellen hoe hij gezeten op het dek van zijn vlaggenschip, deze bladzijde van zijn verslag op zijn kop hield en zijn stoel naar de andere reling schoof om het reliëf van het tweede eiland te schetsen. Nationaal Archief, Den Haag. 
Van zijn tweede zeereis naar Indië heeft Van Diemen een verslag gemaakt. De tocht begon in december i632 met zoveel tegenwind dat na vier dagen de Schelde werd binnengelopen. Daar kwam de moeder van Maria nog twee weken aan boord. Op 28 januari $\mathrm{i} 633$ werd de reis hervat. Kort daarna werd de vloot door een nieuwe storm overvallen en moest beschutting gezocht worden in de luwte van het eiland Wight. Daarna verliep de tocht voorspoedig en snel. Binnen vijf maanden werd de rede van Batavia bereikt. Op de Indische Oceaan werden twee eilanden die niet eerder door Nederlanders beschreven waren, aangedaan. De niet onverdienstelijke tekening van de eilandjes Amsterdam en St. Paul in het verslag is naar alle waarschijnlijkheid van de hand van Van Diemen.

Opvallend is de manier waarop op de gezondheid van de bemanning werd gelet. Van Diemen was er trots op dat maar acht man van de ruim dertienhonderd tijdens de reis waren gestorven, van wie ook nog eens drie doordat zij over boord waren geslagen. Door fruit en goed eten was bij aankomst in Batavia op de hele vloot niet één man ziek. ${ }^{20}$

Deze zorg van Van Diemen voor de bemanning vond bepaald niet altijd navolging. In de generale missive van I639 opende Van Diemen sarcastisch dat hij met de jongste vloot meer man had aangekregen dan hij had gedacht, hoewel er van de 909 uitgevaren zielen 136 tijdens de reis waren gestorven door gebrek aan vers voedsel. ${ }^{2 \mathrm{I}}$

\section{Noten}

I. Blucher, F. Richelieu (Paris 2003).

2. Elliott, J. H., The Count-Duke of Olivares: the statesman in an age of decline (New Haven I986).

3. Elliott, J. H., Richelieu and Olivares (Cambridge I984).

4. Israel, J. I., The Dutch Republic: its rise, greatness and fall, 1477-1806 (Oxford I995) 465-523.

5. Coolhaas, Gegevens over Antonio van Diemen, 5I7.

6. NA VOC 7346 Kopie resoluties vergadering Vergadering Heren XVII, maart 1632 , punt 3 .

7. NA VOC OBP rog9 f 78-86. 'copie missive van Antonio van Diemen aen den prince van Orangiën nopende het wedervaren der Oost-Indische Comp. van December I629 tot en met 9 Maert I63I onder Sint Helena ten ancker gekomen, gedateerd I3 Juli r63r.'

8. GAA Not. Arch. 667 map 25, folio 4IV-43V Nots. Jan Warnaertsz.

9. Zie bijlage 8. In zijn testament liet Van diemen aan zijn ten doop gehouden neefje 500 gulden na. 
IO. RAG ORA Culemborg inv. nr. 233 f I32V-I34V. Testament Van Diemen/Aelst.

II. NA VOC 7342, 'punten van beschrijving' voor de vergaderingen van de Heren XVII, november i63I.

I2. NA VOC 7342, 'punten van beschrijving van de vergaderingen van de Heren XVII, november I63I punt 4 en NA VOC 7346 kopie-resoluties van de vergaderingen van de Heren XVII maart i632 punt 3.

I3. NA VOC 7342, 'punten van beschrijving' voor de vergaderingen van de Heren november i63I punt I9.

I4. Ibidem, punt 20.

I5. NA VOC 7346 kopie-resoluties van de vergaderingen van de Heren XVII, maart 1632.

I6. NA VOC 7346 kopie-resoluties van de vergaderingen van de Heren XVII, 27 september I632.

I7. Ibidem punt $\mathrm{I} 4$.

I8. NA VOC 7346 kopie-resoluties van de vergaderingen van de Heren XVII achter de resoluties van de najaarsvergadering van I632.

I9. NA VOC 7346 kopie-resoluties van de vergaderingen van de Heren XVII achter de resoluties van de najaarsvergadering van ${ }_{1} 632$.

20. NA VOC OBP IIIo f 515-540 Daghregister van den commandeur Antonio Diemen gehouden op den schepe Amsterdam van io December I632 tot 2I Julij I633.

2I. Coolhaas, Generale missiven van gouverneurs-generaal, II, 90. 8 januari 1640 . 


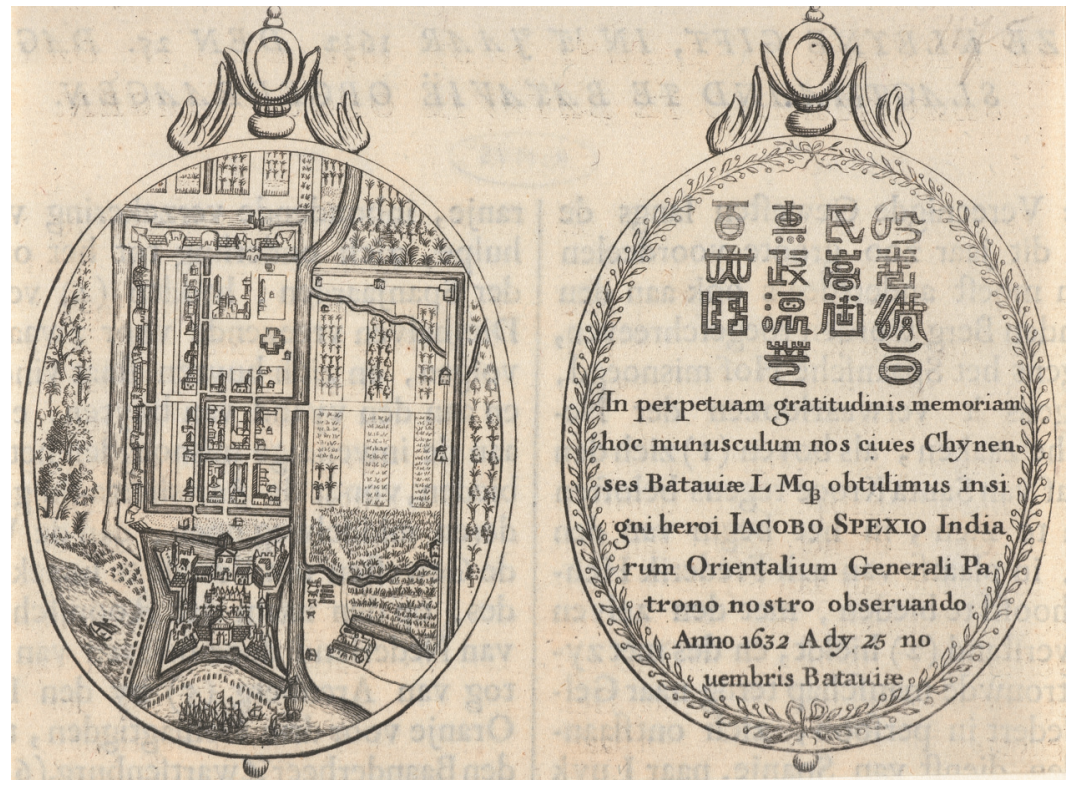

Bij zijn vertrek in 1632 kreeg Jacques Specx van de Chinese gemeenschap deze zilveren penning als dank voor het vele werk dat hij had aanbesteed. Batavia werd gebouwd door slaven en Chinezen. Rijksmuseum Amsterdam. 


\section{Directeur-generaal, juli 1633-december 1635}

Nadat op II juli I633 Java in zicht was gekomen, ging op 20 juli de vloot op de rede van Batavia voor anker. Eerder een thuiskomst, dan een aankomst voor Van Diemen. Hij werd door gouverneur-generaal Brouwer hartelijk en officieel verwelkomd. Brouwer kwam persoonlijk met zijn sloep Maria en Antonio van boord halen. Ook Philips Lucasz was daarbij. Hij was in I6r8 op hetzelfde schip als Van Diemen uitgevaren en was net als hij vanuit een lage rang opgeklommen tot raad van Indië. Toen het gezelschap aan land kwam, stond een compagnie soldaten in het gelid Van Diemen op te wachten en voor het eerst werden voor hem saluutschoten afgevuurd. Het echtpaar ging bij Brouwer logeren in de gouverneurswoning van het Kasteel totdat directeur-generaal Pieter Vlack zijn naastgelegen woning voor Van Diemen had ontruimd. ${ }^{\mathrm{I}}$

Daags na zijn aankomst stuurde Van Diemen een brief naar de Heren Zeventien waarin hij zijn grote waardering voor het door Brouwer gevoerde beleid uitsprak. Hij schreef dat hij alles in veel betere staat aantrof dan hij bij zijn vertrek in I63I had achtergelaten. De handel liep goed en tegen de particuliere handel van compagniedienaren werd 'sonder eenighe ooghluijckinghe' van hoog tot laag opgetreden. ${ }^{2}$

Brouwer van zijn kant stak de loftrompet over Van Diemen in een post scriptum onder de generale missive van 8 januari I635, waarin hij schreef:

'Voor de goede hulpe, die UEd. mij in de persoon van den heer Antoni Van Diemen hebben gelieven toe te synden ben UE seer hoochlijcken bedanckende, ende verclare oock dat sonder deselve het werck niet wel machtich soude wesen. Doch met de vruchten van die missen egeen hulpe altoos van de vertrockene van hier, als de wercken uytwijsen. Gemelten Heere Van Diemen is seer arbeytsaem, wercks voorderaer, vijant van te verachteren, seer opmerckende, vriendelijkck, eertrachtende respectabel, respect dragende ende met alle goede ordre seer menageerende, soodat UE. aen hem hebbe een dienaer naer wenschen.' 


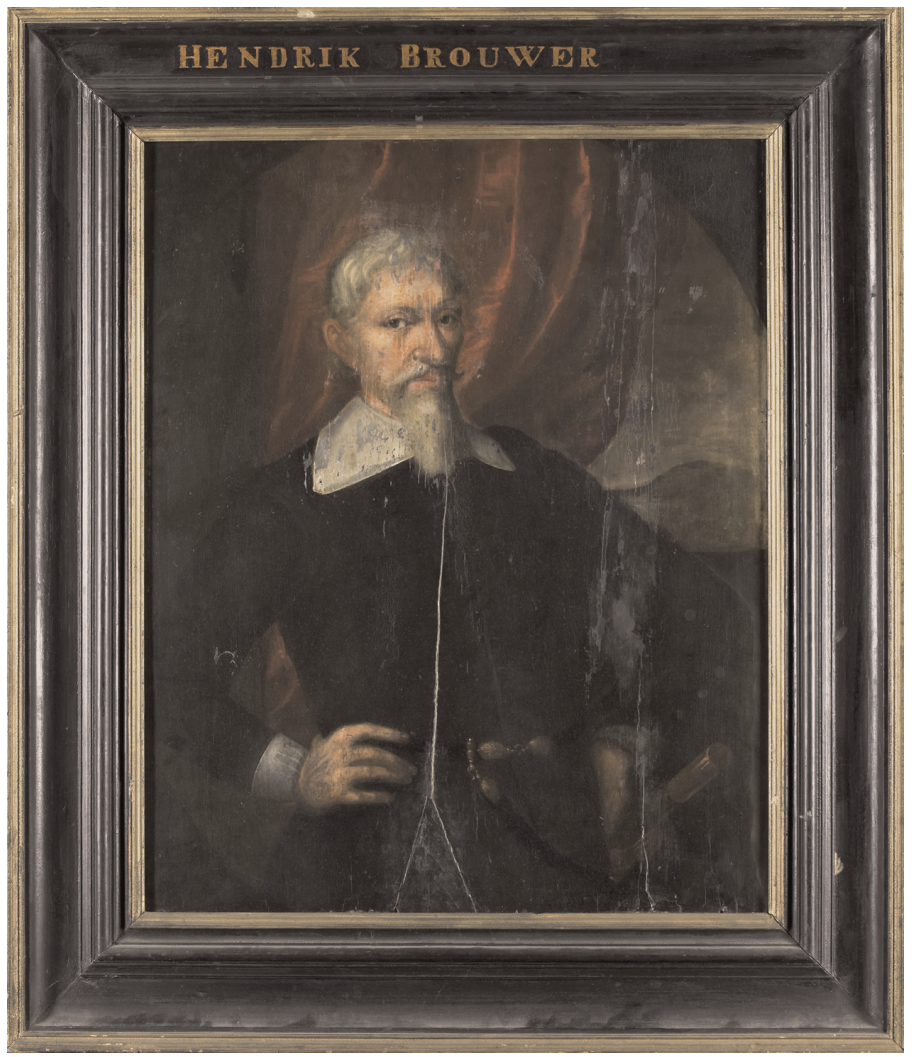

Hendrik Brouwer legde de grondslagen voor de expansie van de VOC in Azië door zijn opvolger Antonio van Diemen. Rijksmuseum Amsterdam.

Deze jaren opereerde Van Diemen in de schaduw van Brouwer, die hij door dik en dun steunde. Het was immers Brouwer geweest die in I6 8 wellicht als enige op de hoogte was geweest van het vertrek van Van Diemen naar Indië onder een valse naam. Voor zover ik weet is ook Van Diemen de enige geweest die vriendelijke woorden aan het bewind van Brouwer heeft gewijd. Brouwer bezat een onbuigzame calvinistische moraal. Valentijn vond dat hij op zijn portret eruit zag als een predikant en ook in werkelijkheid was hij strak in de leer. ${ }^{4}$

Zijn tragiek was dat hij wellicht de enige onkreukbare gouverneur-generaal is geweest en terecht of ten onrechte iedereen om hem heen verdacht linksom of rechtsom betrokken te zijn bij handel voor eigen rekening. Die achterdocht liep als een rode draad door de instructie die hij bij zijn vertrek had meegekregen en tekende voor zijn beleid.

Brouwer had de opdracht met harde hand de misstanden recht te zetten die onder Coen en Specx waren ontstaan. Het zou de laatste poging 
van de bewindhebbers in Nederland zijn om greep te krijgen op de organisatie van de VOC in Azië. Deze poging echter verwerd tot een karikatuur en eindigde met een ernstige beschadiging van Brouwers reputatie.

Bij zijn heenreis in $\mathrm{I}_{32}$ liet Brouwer bij Kaap de Goede Hoop 2500 particuliere brieven openen om onoirbare zaken op het spoor te komen. ${ }^{5}$ Toen hij eenmaal in Batavia aangekomen was, werden op zijn instigatie van hoog tot laag compagniedienaren uit hun functie ontzet en in zijn ogen onnutte dienaren werden naar het vaderland teruggestuurd. Niemand werd gespaard. Zelfs Specx ontving na zijn vertrek een brief van Brouwer waarin deze hem aansprak op vermeende handel voor eigen rekening. Specx reageerde woedend op deze aantijging. ${ }^{6}$ Waarschijnlijk was de beschuldiging terecht, gezien de staat die hij terug in Nederland voerde in het huis 'Met den Dubbele Arend' aan de Keizersgracht I4I in Amsterdam. ${ }^{7}$

Hoe weinig zachtzinnig onder leiding van Brouwer te werk werd gegaan, ondervond Arent Gardenijs aan den lijve. Gardenijs was in I625 als assistent uitgevaren en had snel carrière gemaakt, ${ }^{8}$ die in een stroomversnelling was gekomen toen hij in maart 1632 , net als eerder Philips Lucasz, in Batavia een meegereisde zuster van de vrouw van gouverneur-generaal Specx huwde. ${ }^{9}$ Bij de aankomst van Brouwer in Batavia was Gardenijs net vertrokken om zijn ambt als gouverneur en directeur voor de VOC in fort Gelria op de kust van Coromandel te aanvaarden. In Nederland werd hij beschuldigd van 'quade gangen' en particuliere handel en er was besloten tegen hem op te treden. Gardenijs had namelijk het jaar daarvoor een wissel voor tienduizend gulden naar zijn vader gezonden. Een bedrag dat hij nimmer eerlijk verdiend kon hebben. Op 22 september ${ }^{6} 632$ werd dan ook een jacht uitgezonden speciaal om Gardenijs en zijn vrouw op te halen. Dat gebeurde, waarbij zelfs de ringen en andere juwelen van zijn echtgenote in beslag werden genomen en Gardenijs haast als een gevangene werd opgebracht. In Batavia werd hij op 3I december I632 door de Raad van Justitie veroordeeld om zonder tractement naar Holland te worden teruggestuurd. ${ }^{\text {IO }}$ Zijn goederen werden in beslag genomen ${ }^{\text {II }}$ en in januari ${ }^{6} 633$ vertrok hij naar Nederland. Hoe weinig deze actie uiteindelijk om het lijf had, bleek twee jaar later toen Gardenijs weer in dienst trad bij de VOC. Zijn vrouw kreeg een bedrag van zesduizend gulden en het echtpaar vertrok opnieuw naar Batavia op de vloot die onder het gezag stond van zijn zwager Lucasz. ${ }^{\text {I2 }}$ )

De harde aanpak van Brouwer zou leiden tot een aanzwellende stroom van klachten bij de Heren Zeventien.

In navolging van zijn instructie had Brouwer op 22 september I632, de dag na zijn aankomst in Batavia, het plakkaat op de beperking van de handel door vrijburgers uitgevaardigd. Door deze verordening werd 
het beleid dat Coen tien jaar daarvoor had ingezet, namelijk om de intra-Aziatische handel grotendeels vrij te geven, vrijwel volledig teruggedraaid. Zoals de Heren Zeventien een jaar later schreven, zou voortaan de Compagnie op 'de vetste weiden' grazen. ${ }^{\text {I3 }}$

De discussie over de eventuele vorming van kolonies bevolkt met vrije burgers zou nog niet ten einde zijn, maar het idee om het stelsel van de VOC om te vormen tot een koloniaal systeem naar Portugees voorbeeld, was onuitvoerbaar geworden omdat de VOC juist de handel geheel aan zich trok. Voor de vrije burgers bleven hierdoor onvoldoende mogelijkheden over om geld te verdienen. ${ }^{\text {I4 }}$

In de lijn van zijn eigen sobere levensstijl probeerde Brouwer elk uiterlijk vertoon uit te bannen. Opzichtige kleding werd geweerd en de koets van de Compagnie waarmee plezierritjes werden gemaakt, werd op last van Brouwer uit elkaar gehaald en in een pakhuis op het kasteel opgeslagen. ${ }^{\mathrm{I}}$ Zo maakte Brouwer zich zowel in Amsterdam als Batavia weinig geliefd.

Ook op een ander onderdeel werd het beleid van Brouwer afgekeurd. Dit betrof de hernieuwde oorlog met Bantam. Deze had te maken met de zeer beperkte naleving van het kruidnagelmonopolie van de VOC. Jaarlijks voeren schepen vanuit Bantam naar de Molukken om kruidnagelen in te kopen. Om deze stroom in te dammen blokkeerde de VOC in I633 de haven van Bantam en maakte zij in de Molukken jacht op de Bantamse vaartuigen, hervatting van de oorlog dus. Nu hadden de twee belegeringen de vraag over de verdedigbaarheid van Batavia weer doen opleven. Brouwer herinnerde in een brief de Heren er nog aan dat hijzelf voorstander was geweest van de vestiging van het rendez-vous op een kleiner eiland. ${ }^{16}$ Hoewel met Mataram de oorlog weliswaar op een laag pitje stond, was met Bantam erbij bijna heel Java weer in strijd met de VOC. Dit makte in de ogen van de Heren Zeventien de positie van Batavia onnodig kwetsbaar.

De brieven vanuit Nederland aan Brouwer werden hoe langer hoe geïrriteerder van toon: 'Wij verclaren Ue dat ons al dat overhoop halen van oorlogen niet en gevalt, 't welck meer verachteringhe als bevoordeelinge van compagnies affairen brengen sal. ${ }^{\text {'77 }}$ Hij kon geen goed meer doen.

Uit de brieven die uit Nederland werden gestuurd, sprak ook zorg over de winstgevendheid van de VOC die gekoppeld werd aan de hoge schuldenlast die de VOC met zich mee torste. De oudste balansgegevens van de VOC dateren uit ${ }^{6} 638$ en tonen een grote schuld van ruim elf miljoen gulden in Nederland. ${ }^{\text {I8 }}$

Wat de stemming tegenover Brouwer ook niet verbeterd zal hebben, was het magere retour dat in december ${ }^{1} 634$ werd afgezonden. ${ }^{\text {I9 }}$

Tot slot werd Laurens Reael in I634 president van de Heren Zeventien en deze had met Brouwer nog een oude rekening te vereffenen. Brouwer had namelijk in I6I7 bij zijn terugkeer in Nederland het beleid 
van Reael, die toen gouverneur-generaal was, afgekeurd. Het was duidelijk dat de arminiaan Reael en de contraremonstrant Brouwer tegenpolen van elkaar waren. Brouwer bleef lange tijd de beleefdheid zelve en antwoordde geduldig op de bemerkingen uit Nederland. Hij had zich naar eigen inzicht tot het uiterste ingespannen en zich daarbij voortreffelijk van zijn taak gekweten. Hij was erin geslaagd om kleine brieven, goede tijdingen en grote retouren' naar Nederland te zenden, ${ }^{2 \circ}$ en inderdaad, de winstgevendheid van de VOC was in drie jaar sterk verbeterd. De bewindhebbers zouden er volgens Brouwer goed aan gedaan hebben als zij minder geloof zouden hebben gehecht aan de verhalen vol haat, smaad, afgunst en minachting' die over de Indische regering werden verspreid. $^{2 \mathrm{I}}$

Een bijkomende reden was dat de brieven uit Nederland gewoontegetrouw bij aankomst direct werden voorgelezen in de vergadering van de Raad van Indië. Iedereen was dus op de hoogte van de kritiek. De aanval op Brouwer betekende daarmee ook een aantasting van diens autoriteit als gouverneur-generaal.

In oktober $\mathrm{I}_{32}$ hadden de Heren Zeventien nog geschreven: 'Onze order moet uw wet en regel zijn. Uw discoursen en meededelingen om ons te dienen van advies en om onze orders daarop te verwachten. ${ }^{, 2}$

Nota bene door Brouwer, die als bewindhebber was uitgezonden om hun autoriteit te bevestigen, werd de tafel omgedraaid.

In december 1635 , aan het einde van zijn ambtsperiode, was de maat voor Brouwer vol. In een bijzondere brief verweerde hij zich tegen de aantijgingen en rechtvaardigde hij zijn handelen. Deze brief ging buiten de gebruikelijk generale missive om en werd naast Brouwer ondertekend door Van Diemen en de raad van Indië, Van den Burch. Zij voelden zich gedrieën verantwoordelijk voor dit door de Heren Zeventien zozeer afgekeurde beleid. De overige drie raden van Indië ondertekenden wel de gewone generale missive.

Genoemde brief werd in het publiek briefboek van de Raad van Indië neergelegd. Dit antwoord was zodanig fel van toon en de bewindhebbers in Nederland werden er zodanig incompetent in afgeschilderd dat het de lezers in Batavia onmiddellijk duidelijk was dat de gouverneurgeneraal voor de zijns inziens onheuse aantijgingen uit Nederland niet wilde wijken.

De eerste zinsneden van de brief zijn veelzeggend en de moeite van het lezen meer dan waard. Zij zijn indertijd niet in de grote uitgave van de generale missiven opgenomen. De toon is zelfbewust en arrogant in zijn nauwelijks ingehouden woede. Deze verhulde echter niet de heldere boodschap: de bewindhebbers in Nederland waren door de grote afstand en het gebrek aan ervaring niet in staat een oordeel te vellen over het in Indië gevoerde beleid, laat staan daar anders dan in algemene zin richtlijnen over uit te vaardigen: 
Edele hoogheleerde Erntfeste voorsienige ende seer discrete heeren, Bij ons Generaele Missive geteeckent bij den Generael ende alle de presente ordinaire ende extraordinaire Raeden van India, werden niet alleen beantwoord de brieven der heeren seventhiene van den $3^{\text {de }}$ september 1634, maer werd $U$ ed daernevens oock aengeschreven allen' $t$ geene men heeft connen begrijpen nodight te sijn om $U$ ed te adviseren waer aen ons refereren.

Desen geschiedt alleen bij ons onderteeckende om $U$ e te dienen met naerder, claerder ende bondiger redenen over gepasseerde saecken in Indien onder ons Regereinghe daervan $U$ ed thoonen groot misnoegen te hebben ende d'andere heeren niet responsabel voorcomen wesen alsoo in haere absentie geschiet sijn.

Wij en sijn soo vermeten, glorieus, noch te laetdunckende niet dat wij soodanige opinie van onse regeringe souden hebben dat er niet en souden kunnen voorvallen eenige saecken, die post facto naer de uijtcompste en het succes, souden connen berispt werden, door de hooge: wijsheijt der heeren seventhiene, versterckt met de voorbedachte deliberatien van de sestigh heeren bewinthebberen der ses respectijve Oostindische Cameren, ende geassisteert met het advijs der heeren hooftparticipanten etcetera. Want wij Henrick Brouwer, Antonio van Diemen ende Johan van der Burgh bekennen ons swackheden, imperfectien ende andere menschelijcke defecten van herten gaerne.

Maer wij verclaeren voor den almaghtigen, voor de Generaele Oostindische comp ende voor alle die geene die ons doen magh aengaen, dat wij niet en aspireren als naer de bevoorderinghe van des Comp. hooghste ende meeste welvaeren, naer den inhout onser Eeds. soo wij andermael seggen, dat de wercken uijtwijsen.

Daerom oock de eeuwige Godt dancken, dat hij des Comp. saecke onder deselve ons Regieringe soo blijckelijck ende overvloetelijck segent, dat egeene tijden voordesen bij d'onse te geleijcken sijn, daerover wij ons oock beloont hadden schriften vol vrundelijcke wijsgevingen ende geluckige toewenschingen van $U$ ed toecomen.

Dogh alsoo wij bevinden dat $U$ ed eenige poincten heel spits ende pinnigh gelieven te berispen als oft daer merckelijcke erreuren waren begaen, datter de Comp. seer grooten ondienst door ware toegecomen ende dat bij ons eijgen sinnicheijd ende oock gunst voor reden waere geprefereert.

Soo vinden ons gedwongen alle deselve met de naervolgende naeckte, claere ende opreghte waerheijden te absolveren ende ons opreght goet ende vroom voornemen te justificeren. Comen dan ter materie. ${ }^{23}$

In het vervolg werd niet alleen het eigen beleid gerechtvaardigd, maar werden ook de opeenvolgende tegenstrijdige instructies van de Heren Zeventien in een reeks opgesomd. Natuurlijk werd ook met personen 
afgerekend, met voorop de gewezen fiscaal Anthony van den Heuvel die aan 'veele menschelijcke defecten onderworpen' was.

Ook werd de vraag gesteld of de Heren Zeventien werkelijk vonden dat niet meer moest worden opgetreden tegen figuren als Gijsbert Lodesteyn.

Deze burgemeesterszoon uit Delft was onder Coen aangeworven en was door hem op zevenentwintig jarige leeftijd benoemd tot gouverneur van de Molukken. Hij dronk, dobbelde en hield 'publyckelijcken een bijsit' die hij 'opproncte'. Daarnaast pakte ook zijn beleid ten nadele van de VOC uit. Brouwer had hem teruggeroepen en een maand bij zich in huis genomen. Ondanks de slechte berichten hadden de Heren Zeventien Lodesteyn vanwege zijn verwantschap met bewindhebbers van de kamer van Delft benoemd tot raad van Indië, maar Brouwer had dit tegengehouden. In Batavia was Lodesteyn ziek geworden. Na eerst nog 'twee dagen in de camer van des Generaels huijsvrouwe' gelegen te hebben, was hij kort daarna overleden. ${ }^{24}$

Waarop, zo vroeg Brouwer zich af, werd zijn beleid afgekeurd?

Het was nog meer een persoonlijke brief van Brouwer dan de toon al doet vermoeden. Het blijkt namelijk uit de archieven dat hij geantedateerd is. Brouwer schreef de brief nadat hij uit Batavia was vertrokken. Blijkbaar hadden Van der Burgh en Van Diemen hem een aantal handtekeningen meegegeven op een blanco vel. Van Diemen kreeg zijn exemplaar vanaf Robbeneiland bij de Kaap toegestuurd. Zoals Brouwer schreef:

'Hiernevens sende aen Ued de gecollationeerde copie van de particuliere missive aen de Heeren 17 geschreven jongst door mij ingestelt ende geteekent bij mij Ued en en d heer Johan van den Burgh tot beantwoordinge ende jusitficatie ven eenige poincten van misnoegen derselver heeren die Ued sal gelieven op sijn datum int generael copieboeck te doen stellen ende insereren volgens ons voornemen ende den inhoudt derselve missive die versuijmt is Ued te behandigen voor vertreck. ${ }^{25}$

Dit verweer mocht Brouwer bij terugkomst in Nederland niet baten. Hij was bij de VOC persona non grata geworden. Een nieuwe benoeming tot bewindhebber van de VOC, waar hij nog vast op rekende, zou hij niet meer krijgen. Uit geldnood of eerzucht nam hij in 1642 dienst bij de WIC en zeilde als commandeur van een vloot rond Kaap Hoorn om de Spaanse bezittingen op de westkust van Zuid-Amerika aan te vallen. Een jaar later stierf hij voor de kust van Chili waar hij begraven werd op een eiland dat naar hem zou worden vernoemd: Brouwershaven. 
Hendrick Brouwer was niet van harte teruggegaan naar Nederland. Op I5 augustus 1634 had hij aan de Heren Zeventien om verlenging met één jaar van zijn termijn als gouverneur-generaal verzocht, maar deze brief was via Suratte en daarna met een Engels schip pas in Nederland aangekomen, nadat in april I635 de brief waarin hij werd teruggeroepen, al was verzonden.

In hun antwoord op zijn verzoek gaven de Heren Zeventien overigens aan Brouwer wel de ruimte om pas met de retourvloot van het volgende jaar naar Nederland terug te komen en verzochten hem om in ieder geval aan te blijven als Van Diemen voor zijn vertrek mocht zijn overleden. Deze brief kwam echter pas in juli 1636 in Batavia aan, dus toen Brouwer net in Nederland aan wal was gestapt en Van Diemen al een halfjaar gouverneur-generaal was. ${ }^{26}$

Van Diemen zou op een andere manier leiding geven aan de het bedrijf van de VOC in Azië.

\section{Noten}

I. NA VOC OBP IIIO f 5I5-540. Daghregister van den commandeur Antonio Diemen gehouden op den schepe Amsterdam van Io December I632 tot 2I Julij I633.

2. NA VOC OBP ıııо, f 49I-492 Brief van Diemen dd I4 augustus I633.

3. Coolhaas, Gegevens over Antonio van Diemen, 524.

4. Valentijn, Oud en nieuw Oost-Indiën, IV, 292.

5. MacLeod, De Oost-Indische compagnie als zeemogendheid in Azië, II, I.

6. NA VOC OBP IIo8 f 6ı5-6ı6. Copie missive van Jaques Specx uijt de Tafelbaeij aen gouverneur generael Brouwer tot Batavia in dato 24 Maert I633.

7. Coolhaas, W. P., Het huis 'De Dubbele Arend' Het huis Keizersgracht 141 thans 'Van Riebeeckhuis' genaamd, nu daar een halve eeuw gearbeid is voor de culturele en economische betrekkingen met Zuid-Afrika (Amsterdam i973) 39. Boedel beschrijving Specx.

8. NA I.04.23 'Klapper Van Delden,' waar op kaartjes in alfabetische volgorde gegevens zijn verzameld over honderden Compagniesdienaren.

9. NA VOC OBP IIO4 $\mathrm{f}$ i8.

Io. MacLeod, De Oost-Indische compagnie als zeemogendheid in Azië, II, 9 .

II. Heeres, J. E., Dagh-register gehouden int Casteel Batavia vant passerende daer ter plaetse als over geheel Nederlandts-India anno 1632, 3I december 1632 . 
I2. NA VOC 3I5 Kopieboek van de uitgaande missiven, instructies en andere papieren van de Heren XVII en de kamer Amsterdam. Besluit XVII 5 februari I635, Brief XVII aan GG en raden 2I april I635.

I3. Jonge, de, Opkomst, II, CV. Missive Heren XVII aan gouverneur-generaal en raden, dd i9 sept 1633 .

I4. Jonge, de, Opkomst, II, 2I8 en 2I9. Brouwer aan HH XVII 27 december 1634 .

I5. De Jonge, Opkomst, II, I97. Brouwer aan HH XVII I2 december I632.

I6. Coolhaas, Generale Missiven, I, 42I.

I7. NA VOC 316, Kopieboek van de uitgaande missiven, instructies en andere papieren van de Heren XVII en de kamer Amsterdam. f 67 $2 \mathrm{I}$ april $\mathrm{I} 635$.

I8. Korte, de, De jaarlijkse financiële verantwoording in de VOC, Bijlage A.

I9. Coolhaas, Generale Missiven, I, 457. 27 december I634.

20. Jonge, de, Opkomst, II, 220. GG en raden 4 januari ${ }_{16} 6$.

2I. Ibidem.

22. Jonge, de, Opkomst, V, XCVII. Heren XVII aan Specx 4 oktober 1632.

23. NA VOC OBP ııь6, f ı96-206 Originele particuliere missive van den gouverneur generael Henrick Brouwer, Anthonio van Diemen en Jan van der Burch aen de heeren zeventiene in dato 3I December I635.

24. Coolhaas, Generale Missiven, I, 49I-506.

25. NA I.Io.78 Collectie Sweers no 3 folio I-22.

26. NA VOC 3I6 f 74. Heren XVII aan gg en raden, I3 september I635. 


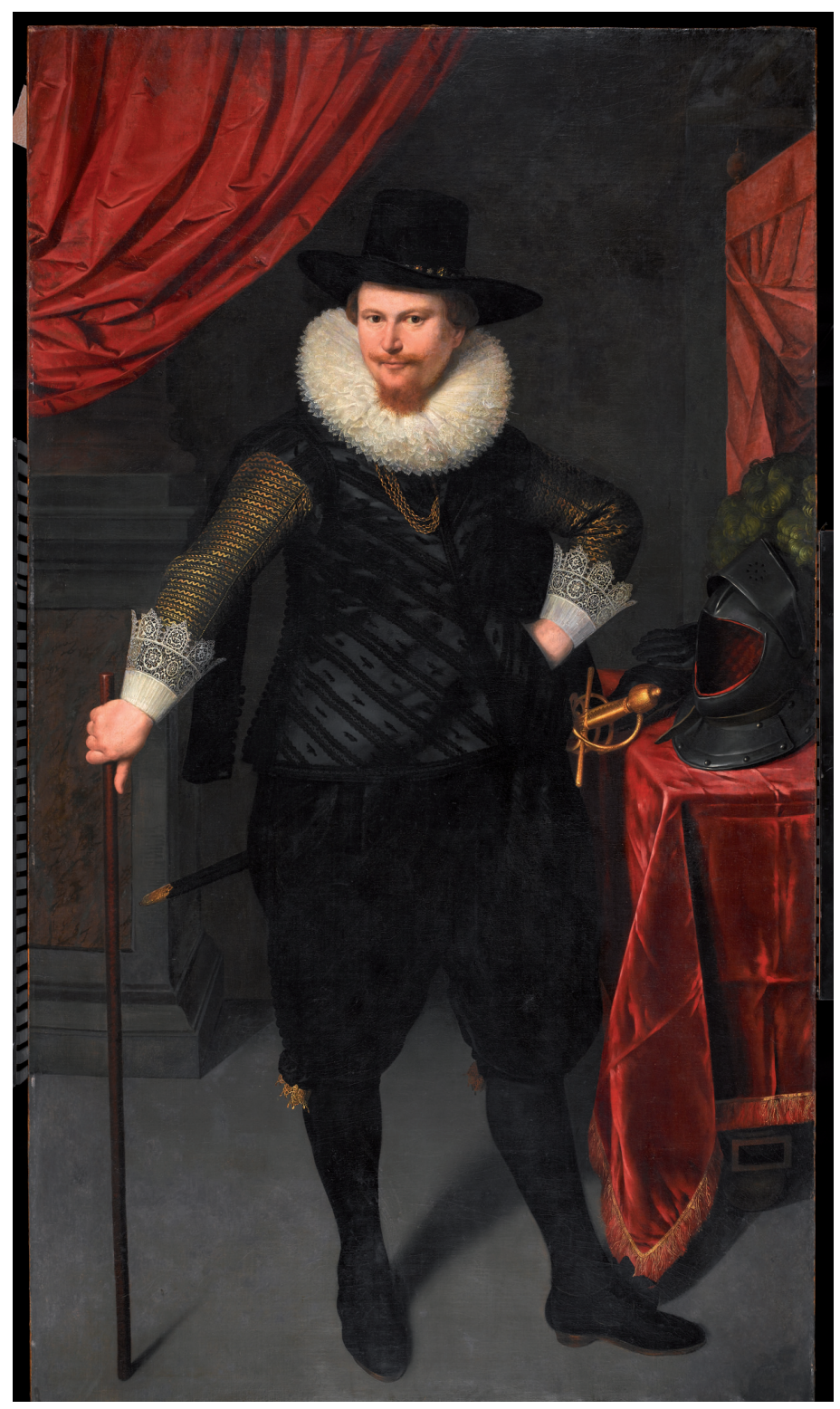

Laurens Reael draagt op dit elegante portret de geschenken die hij van de Heren Zeventien bij zijn terugkeer in Holland kreeg. De zware gouden ketting zien wij terug in het portret van Philips Lucasz (pag. 179) en het zwaard bij Jan Pieterszoon Coen en Antonio van Diemen (pag. 106 en 148). Bij het aantreden van Van Diemen was Reael president van de Heren Zeventien. Hij zou een jaar later aan de pest overlijden. Rijksmuseum Amsterdam. 


\section{Een benoeming op een breukvlak}

In het recente verleden toen op het Nationaal Archief in Den Haag nog de originele ingebonden briefboeken van de VOC ter inzage werden gegeven, was bij het omslaan van de bladzijden een enkele keer het zachte ruisende geluid te horen van zandkorrels die over papier gleden. Dat zand was door een klerk eeuwen daarvoor in Batavia tegen het vlekken over de nog natte inkt gestrooid. Het beeld van de klerken voor hun lessenaar staand in de secretarie van het kasteel doemde op. Dit onverwachte geluid dat tastbaar achterbleef, gaf aan de onderzoeker de historische sensatie dat eeuwen overbrugd kunnen worden. Een enkeling verzamelde dan ook deze korrels in een gekoesterd zakje. Op indirecte wijze blijkt zo echter ook dat de brieven uit Batavia niet altijd in Nederland werden gelezen. Wie een keer de duizenden dikke gebundelde briefboeken in lange rijen heeft zien staan, krijgt daar begrip voor. De bewindhebbers in Nederland werden eens per jaar in juni of juli bij de aankomst van de retourvloot onder informatie bedolven.

Ook Van Diemen, die als klerk in Batavia begonnen was, stuurde lange brieven. De eerste generale missive die in december 1636 onder zijn verantwoordelijkheid werd verzonden, telde maar liefst 287 aan twee kanten beschreven foliovellen. ${ }^{\mathrm{I}}$ Leesvoer voor dagen. Daarbij werd dan nog in kopie de complete correspondentie gevoegd die met de kantoren in Azië was gevoerd en natuurlijk de omvangrijke boekhouding van schepen, ladingen en personeel. Er zouden onder verantwoordelijkheid van Van Diemen nog acht van deze missiven met bijlagen volgen. Vanuit Nederland werd door de Heren Zeventien en de kamer Amsterdam geantwoord, deze brieven waren veel korter en zelden met bijlagen. Dezelfde negen jaren beslaan vanuit de Republiek bij elkaar slechts een kleine vijfhonderd foliovellen. ${ }^{2}$

Deze correspondentie vormt de voornaamste bron voor de beschrijving van het bewind en het beleid van Van Diemen, maar is niet de enige. Met name Portugese en Engelse bronnen en de literatuur die hierop is gebaseerd, geven een belangrijke aanvulling. 


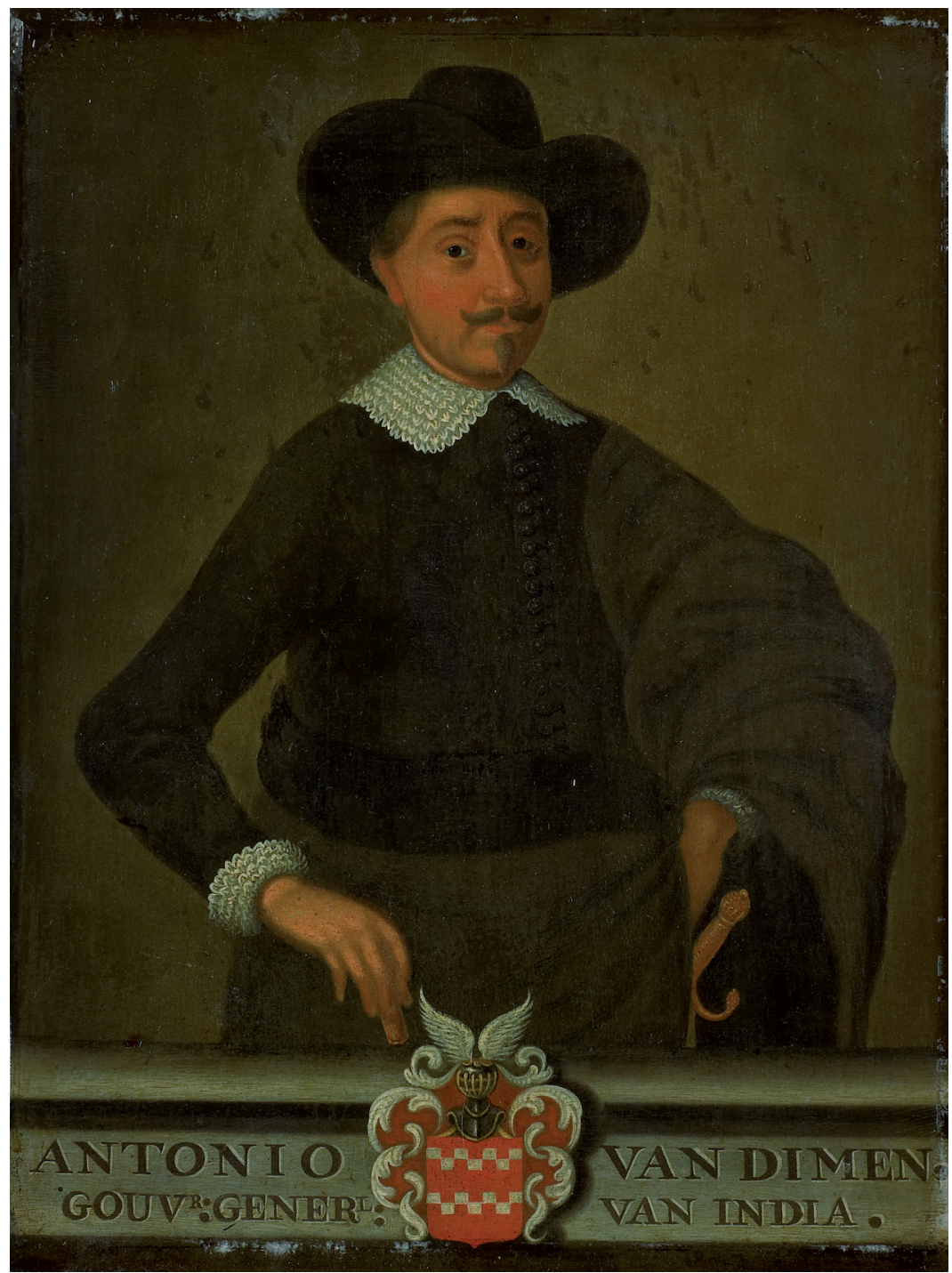

'Zeer fris, byzonder rood, wat rond en kort van wezen, doch zeer levendig van gezicht, hoewel hij aan 't linker oog een ongemak scheen te hebben' zo beschreef Valentijn Van Diemen. Rijksmuseum Amsterdam. 
Van Diemen was 43 jaar oud toen hij in ${ }_{1} 636$ werd benoemd en hij zou negen jaar gouverneur-generaal blijven, veel langer dan zijn voorgangers. Door zijn merkwaardige carrière was Van Diemens lot veel meer dan dat van zijn voorgangers verbonden met het bedrijf van de VOC in Azië. In de periode van zijn gouverneurschap ontstond een trendbreuk die zich doorzette in de relatie tussen de bewindhebbers in Nederland en de regering in Batavia, meer algemeen in de band die de bewindhebbers hadden met het bedrijf van de VOC. In Azië en Nederland was sprake van een verandering die uitmondde in wat een regime change genoemd kan worden.

Anders dan Coolhaas deed vermoeden kunnen wij in veel hiervan de sturende hand van Van Diemen zien. Onder zijn bewind veranderde het aanzien van de Compagnie in Azië. Over de ontwikkeling van de VOC had Van Diemen bij zijn aantreden duidelijke ideeën en vastomlijnde plannen. Door de krachtige uitvoering die hij hieraan gaf, kwam de VOC in een nieuwe fase terecht. Zo staat ook in de monumentale vijfdelige geschiedenis van Nederlands Indië:

'Met Van Diemen begint het grote tijdperk van expansie der compagnie, dat, met korte onderbreking door enkele minder vooraanstaande figuren, zou doorlopen over Maetsuycker en Van Goens tot en met Speelman. Naar onze meening is Van Diemen van het genoemde viertal de grootste; als opbouwer van het rijk van Nederland-over-zee komt hij onmiddellijk na Coen.' 3

Het 'hoe' van deze expansie is in (deel)studies regelmatig aan bod gekomen, over het 'waarom' is echter veel minder geschreven.

Met zijn aantreden, of misschien beter gezegd na het vertrek van de sobere Brouwer veranderde ook de sfeer aan de top van de VOC in Batavia. Het lijkt erop dat dit niet zozeer door Van Diemen zelf kwam, als wel door zijn vrouw Maria. Zij was zelfbewust, jong, nog geen dertig jaar oud, en door haar eerdere huwelijken en eigen handel steenrijk. Zij zou de eerste grande dame van Batavia worden. De 'Mevrouw Generaelse' die achter de schermen aan veel touwtjes trok.

Op I januari I636 was het zover. Gouverneur-generaal Hendrick Brouwer legde zijn functie neer en Antonio van Diemen legde zijn handen in die van Brouwer waarna hij als diens opvolger werd ingezworen. De sobere ceremonie vond plaats voor het gouvernementsgebouw in het kasteel van Batavia. Op het brede bordes stonden Brouwer en Van Diemen omringd door de leden van de Raad van Indië. Op het Paradeplein ervoor stonden de compagniedienaren verzameld. Eerst ontsloeg Brouwer de aanwezigen van de eed van trouw die zij aan hem gedaan hadden. Vervolgens droeg hij het ambt over aan Van Diemen. Daarna werd 
Van Diemen door de aanwezige raden van Indië geïnstalleerd en werd ten slotte de eed van trouw aan hem afgelegd. Van Diemen werd de negende gouverneur-generaal van de VOC, en zou dat ruim negen jaar blijven, zes jaar langer dan zijn voorgangers. Zelf schreef Van Diemen daags daarna aan de Heren Zeventien hierover:

'Ende gelijck $U$ ed hebben gelieven, achtervolgens uwe brieven van commissie ende surogantie mijn persoon als Gouverneur generael over des comp's standt in d'Oostindien t'eligeren en te promoveren, soo zijn ingevolge van dien op den eerste desers, nadat den heere gouverneur Generael Brouwer al voorens alle persoonen onder U ed gehoorsaemheijt resorterende ende tot Batavia sijnde, van den eet der getrouwicheijt, aen sijne E gedaen, hadde onslagen ende desselfs Ampt aen mij geresigneert, publickelijck ende in den beste forme door sijne geseijde $E$ ende de heeren Raden van India int Generale Gouverne g'investigeert, als Gouverneur Generael voor de Gemeente g'authoriseert, daervoor erkent ende aengenomen.'

In het dagregister dat werd bijgehouden in Batavia ontbreken jammer genoeg de eerste dagen van ${ }_{1} 636$ zodat wij het zonder verdere beschrijving van de gebeurtenis moeten doen. Wel werden om de machtswisseling luister bij te zetten gevangenen vrijgelaten en daags daarna werd naar 'Bataviase wyse' een vast- en bededag gehouden 'om den Heere te danken voor alle syne menichvuldige weldaden' en een behouden vaart van de retourvloot. ${ }^{4}$

De eed die Van Diemen zelf aflegde, bestond uit een voor de hand liggende persoonlijke instructie voor de gouverneur-generaal waar deze zich aan diende te houden om zichzelf en zijn bewind van alle blaam vrij te houden. Zo mocht hij geen handel voor zichzelf drijven, alleen 'de vroomste, getrouwste en ervarenste' personen benoemen, zonder acht te slaan op vriend- of vijandschap, en particuliere handel moest hij tegengaan. Het machtsmiddel van de Heren stond in de laatste regels van de eed namelijk 'dat hij bij missive van Bewindhebbers, bij zes of meer dezelve onderteekend, uit Indië gerevoceerd zijnde, en 't zelve advijs ontvangen hebbende, met de eerste herwaarts komende schepen naar Holland of Zeeland zal komen. 5

Tot het aantreden van Van Diemen probeerden de Heren Zeventien de benoeming van de gouverneur-generaal vanuit Nederland te regelen. Dat was een moeilijke en vaak onmogelijke opgave gebleken. In I6o9 had de benoeming van de eerste gouverneur-generaal, Pieter Both, zich geheel in Nederland afgespeeld. Voor zijn vertrek legde Both niet alleen een eed van trouw af aan de VOC, maar ook aan de Staten-Generaal en was zijn benoeming zelfs bekrachtigd door de stadhouder. 


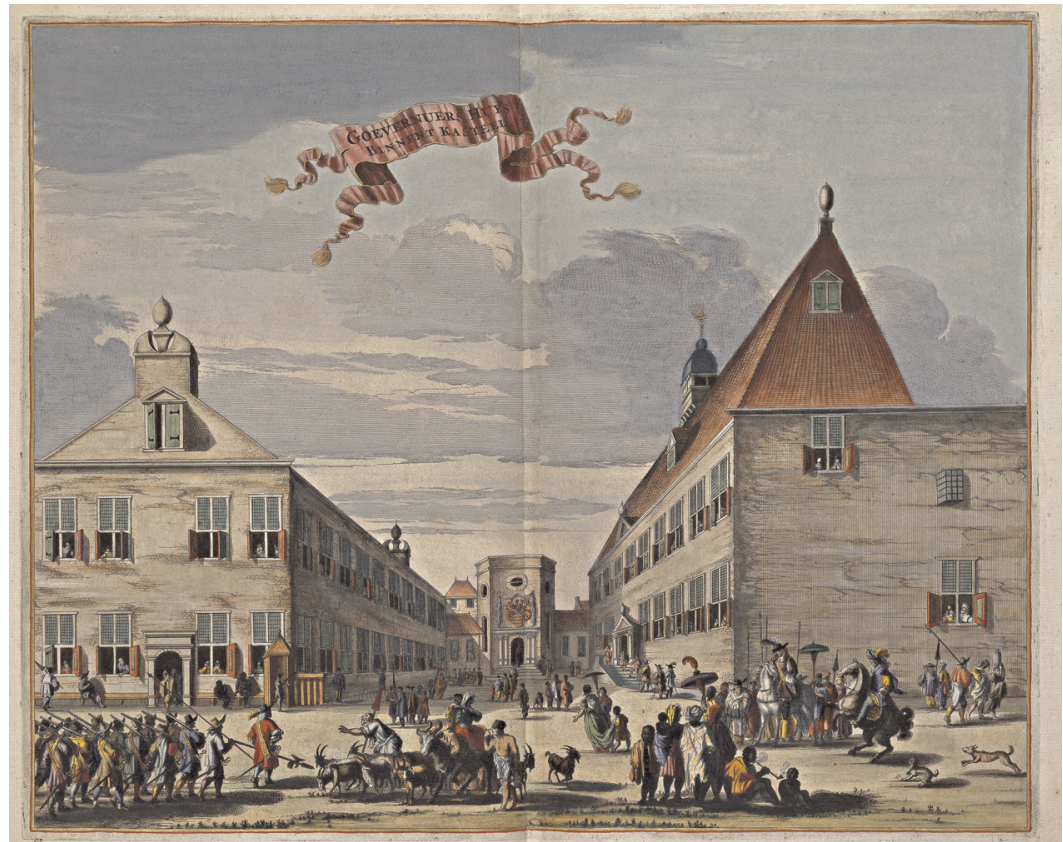

Het hart van de VOC in Azië was het huis in het Kasteel waarin de gouverneur-generaal resideerde. Op de achtergrond de kasteelkerk waarvan Van Diemen de eerste steen legde. Koninklijke Bibliotheek, Den Haag.

Na Both volgde in I6 3 Gerrit Reynst dezelfde officiële route. Hij overleed echter vroegtijdig, in december I6I5, in Bantam. Als zijn opvolger werd door de Raad van Indië, Laurens Reael, de gouverneur van de VOC in de Molukken gekozen. Zijn persoon was echter om politieke redenen onaanvaardbaar voor de Heren Zeventien en hij werd teruggeroepen zodra het bericht van zijn verkiezing in Nederland bekend werd. In zijn plaats benoemden zij Jan Pieterszoon Coen, die reeds in Azië was. De tirannie van de afstand had tot gevolg dat Reael bijna drieënhalf jaar in functie zou blijven voordat Coen in maart I6rg het gezag van hem kon overnemen.

Bij het vertrek van Coen uit Batavia in $\mathrm{I}_{2} 3$ werd door de Raad van Indië op voordracht van Coen Pieter De Carpentier tot zijn opvolger gekozen. Deze benoeming werd achteraf bekrachtigd door de Heren Zeventien. Toen Coen in I627 ten tweede male als gouverneur-generaal aantrad, was zijn benoeming, zoals wij gezien hebben, rommelig verlopen. Bij zijn plotseling overlijden in I629 werd Jacques Specx tegen de instructie van de Heren Zeventien en tegen de laatste wil van Coen door de Raad van Indië verkozen. Net als bij Reael grepen de Heren Zeventien in, ditmaal mede op instigatie van Van Diemen. Specx werd te- 
ruggeroepen en in $\mathrm{I}_{32}$ opgevolgd door Hendrick Brouwer. Hij zou de laatste gouverneur-generaal van de VOC zijn in ruim een eeuw die in die kwaliteit vanuit Nederland vertrok. Van Diemen was in Indië toen hij vanuit Nederland werd benoemd. En al zijn zeventiende-eeuwse opvolgers waren al in Indië toen zij verkozen werden door de Raad van Indië, of in een enkel geval benoemd door de Heren Zeventien. Het was hierbij steeds de directeur-generaal die de gouverneur-generaal opvolgde. De eerste gouverneur-generaal die na Brouwer in die functie vanuit Nederland vertrok, zou Van Imhoff zijn in I743.

Naar het voorbeeld van de Portugese onderkoning in Goa werden de gouverneurs-generaal tot de benoeming van Van Diemen steeds voor een periode van drie jaar aangesteld. Door diverse omstandigheden was geen van zijn voorgangers langer dan drie jaar aangebleven. Van Diemen zou de eerste zijn wiens aanstelling werd verlengd, zelfs tweemaal, zodat hij uiteindelijk ruim negen jaar als gouverneur-generaal zou aanblijven.

In vergelijking met Brouwers benoeming verliep die van Van Diemen informeel. In februari I633 stuurde de kamer van Amsterdam een brief naar de kamer van Zeeland waarin werd voorgesteld een brief naar Batavia te sturen waarin werd vastgelegd dat Van Diemen in geval van Brouwers overlijden deze moest opvolgen. Op de vorige vergadering van de Heren Zeventien was dit punt al genoegzaam besproken, zo schreef de kamer van Amsterdam, vandaar dat zij de advocaat alvast een commissie voor Van Diemen hadden laten opstellen, die werd bijgesloten. De kamer van Zeeland werd vriendelijk verzocht die mede te ondertekenen en terug te sturen, dan zou deze zo spoedig mogelijk naar Batavia worden verzonden. ${ }^{6}$ Deze procedure werd gekozen om te voorkomen dat weer een ongewenste persoon als Reael of Specx tot gouverneur-generaal zou worden verkozen.

Toen Brouwers benoeming niet werd verlengd, volstond door deze aanwijzing een eenvoudige zinsnede in de reguliere brief aan gouverneur-generaal en raden. Hierin werd medegedeeld dat Brouwer met de eerstvolgende vloot naar Nederland scheep moest gaan en dat Van Diemen in zijn plaats diende te treden. Dit bericht bereikte Batavia in september I635. ${ }^{7}$ Deze gang van zaken weerspiegelde de verandering in de manier waarop de VOC werd bestuurd.

Deze omslag is terug te lezen in de verslagen van de vergaderingen van de Heren Zeventien. In I632 was men tijdens de vergadering vooral druk met de bepaling van het beleid in Azië. In I636 kwam dit natuurlijk ook aan de orde, maar meer als reactie en niet meer als richtlijn. In de vergadering van augustus I64I was de inhoud verder naar de achtergrond verdwenen. Het is onduidelijk of, en zo ja, wie van de bewindhebbers de brieven nog in hun geheel las. Zij hadden het vooral druk met de verkoop van de retourgoederen. 
De beantwoording werd grotendeels overgelaten aan de advocaat van de kamer van Amsterdam. Op de eerste vergaderdag van de Heren Zeventien werd aan hem opgedragen:

'Omme nae lecture van brieven met de jongste schepen uit Oost India gecomen te doen enstellen en arresteren de brieven in antwoorde derwaerts gerequireerdt en de specialeijck op de poincten waer op het advijs van dese vergaderinge door den gouverneur generaal en raden van India versocht wert, omme hun te dienen tot gouverno. ${ }^{8}$

Deze antwoorden waren na een tweetal weken gereed en werden sterk samengevat mondeling besproken, waarna ze ongewijzigd vastgesteld werden.

'Bij de vergaderinge geresumeert sijnde de minute van de brieven aende Gouverneur Generael en raeden van India ingestelt is goetgevonden d'selve soo te arresteren, omme te doen grosseren en met de Schepen de Tijger en Nassau in Texel leggende voor aftseijlen naer Battavia gesonden te werden.' 9

Deze door klerken uitgewerkte brieven die vanuit Nederland aan Van Diemen werden gericht, kregen hierdoor een plichtmatig karakter. Zij werden bureaucratisch van toon en gingen steeds meer over boekhoudkundige onvolkomenheden, verkeerd verpakte retourgoederen en klachten over de handel voor eigen rekening en de daarmee verdiende kapitalen. Niet langer door specifieke richtlijnen, maar meer door algemene bemerkingen en als reactie achteraf op de vaak verregaande besluiten en dramatische gebeurtenissen in Azië werd getracht de leiding in Batavia tegenspel te bieden.

De toenmalige advocaat van de kamer van Amsterdam, Dirk Pruys, kreeg zo een steeds belangrijker rol. ${ }^{\mathrm{IO}} \mathrm{Hij}$ werd advocaat in $\mathrm{I}_{632} \mathrm{en}$

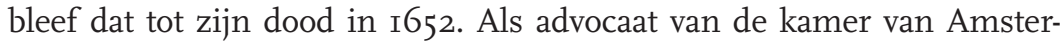
dam bereidde hij niet alleen de vergaderingen van de Heren Zeventien voor, maar ook de antwoorden en instructies die naar Batavia werden gezonden. Hij werd steeds meer de algemeen-directeur van het bedrijf van de VOC in Nederland.

Rond I635, veertig jaar na de eerste vaart op Indië, was in Amsterdam het bijzondere van de VOC eraf. Zo schreef Wagenaar een eeuw later in zijn Amsterdamse stadsgeschiedenis wel over de tulpenmania van 1636 en het opnieuw uitbreken van de pest een jaar later, de ruzies met Haarlem en Enkhuizen, het bezoek van Maria de Medici in I638, en de moeizame verhouding met Frederik Hendrik. De VOC echter kwam slechts ter sprake in haar weigering met de noodlijdende WIC 
samen te gaan, of als er problemen waren bij de octrooiverlenging in I643. ${ }^{\mathrm{II}}$ De VOC werd business as usual.

Nadat in september $1_{3} 6$ Laurens Reael zijn laatste vergadering van de Heren Zeventien had voorgezeten, was in de kamer van Amsterdam als bewindhebber met eigen ervaring in Indië daarna alleen nog Pieter de Carpentier over en na diens terugtreden zou er niemand met die ervaring meer zijn. Ook raakte men in Nederland onbekend met de mannen die aan het hoofd van de VOC in Azië stonden. In hun brief van 22 december I640 stelden de bewindhebbers van de kamer van Amsterdam vast dat behalve de gouverneur-generaal en de directeur-generaal van de raad van Indië 'niemandt persoonlijck oft oock door publiecke correspondentie met brieven hier bekendt is'. ${ }^{\text {I2 }}$ Het zou nog verder gaan: Johan Maetsuycker, die in I653 door de Raad van Indië tot gouverneur-generaal werd gekozen en dat meer dan twee decennia zou blijven, was al in $6_{3} 6$, dus bijna twintig jaar daarvoor, uit Nederland vertrokken. En, zoals de bewindhebbers onbekend waren met hem, was hij dat met de bewindhebbers.

Er was nog een verandering. Bij hun benoeming door de Heren Zeventien kregen Both, Reynst, Coen en Brouwer uitgebreide instructies mee, maar deze ontbraken bij Van Diemen. Bij de aanstelling van Brouwer legden de Heren Zeventien nog vast dat Brouwer: 'voorts alles te doen, sijn ampt en officie aangaande, volgende de generale en particuliere instructiën, hem gegeven ende nogh te geven. ${ }^{\mathrm{I} 3}$

Bovendien was de instructie aan Brouwer bijzonder gedetailleerd geweest. Zij telde 96 punten, waarnaar de gouverneur-generaal Brouwer en de raden van Indië 'zich zullen hebben te reguleren'. ${ }^{\text {I4 }}$ Ondanks de grote onvrede met het beleid van Brouwer ontbrak een instructie voor Van Diemen om aan te geven wat hij anders moest doen.

De organisatie van de VOC in Nederland en daarbij als belangrijkste de kamer van Amsterdam legde zich na het bestuurlijk echec van het bewind van Brouwer neer bij het besef dat zij niet alleen slechts beperkte invloed kon uitoefenen op de gang van zaken van de VOC in Indië, maar ook dat zij dat niet moest willen anders dan op brede hoofdlijnen.

Uiteindelijk vond dit zijn weerslag in de instructies die in 1650 - dus vijf jaar na de dood van Van Diemen - voor gouverneur-generaal Reiniersz werden opgesteld. Met recht stond op het voorblad dat het een 'Generale instructie' was die diende 'tot meerder welvaren en prosperiteit'. ${ }^{\text {'5 }}$ Deze instructie was zo algemeen van aard dat zij ongewijzigd tot I808 van kracht kon blijven, dus tot na het faillissement in I799 van de VOC zelf.

Ook op het terrein van benoemingen vond deze verandering haar weerslag. Het uitzenden vanuit Nederland van mannen zonder Indische ervaring voor de hoge functies in Azië, zoals vooral tijdens Coen was 
gebeurd, raakte in onbruik. In I640 schreven de Heren Zeventien over deze verandering dat 'wij hier meer en meer bevinden dat de principaele bedieningen in India door ervaren personen de welcke van trap tot trap opgeclommen sijn en geen nieuwelingen behoren te worden waergenomen en bedient te werden." $\mathrm{\text {IC }}$

In nog een ander opzicht groeiden de directie van de VOC in Nederland en die in Azië uit elkaar. De bewindhebbers waren niet meer de ondernemers van de eerste generatie, maar waren hun zonen die zich ontpopten als gezeten regenten. Reinier Pauw, de oprichter van de VOC, was begonnen als handelaar in hout en zout, maar hoe anders stond zijn zoon Adriaan Pauw (I585-1653) in de wereld. Hij werd in I6I8 bewindhebber, volgde in I637 Laurens Reael op als president van de Heren Zeventien en trad in I64I als bewindhebber af. Adriaan Pauw woonde sinds $\mathrm{I} 627$ in Den Haag of op zijn prachtige slot in Heemstede. Hij bekleedde een veelheid aan functies: pensionaris van de stad Amsterdam (I6II-I627), eerste en presiderende raad en rekenmeester van de domeinen van Holland en West-Friesland en zo maar door. Daarnaast reisde hij meerdere malen voor langere tijd als gezant naar Londen en Parijs. De geschiedenisboeken haalde hij omdat hij tweemaal raadspensionaris was, de belangrijkste openbare functie in de Republiek, en leider van de Nederlandse delegatie bij de vredesonderhandelingen in Munster. Niet iemand die zich werkelijk verdiept zal hebben in de correspondentie van de VOC. ${ }^{\mathrm{I}}$ Hij had geen band met de self made men in Batavia.

Natuurlijk waren niet alle bewindhebbers als Adriaan Pauw, maar 'bewindhebber' werd wel een baantje, een goed betaalde sinecure, zoals commissariaten dat veelal zijn bij de hedendaagse naamloze vennootschappen. Het echte werk werd overgelaten aan de advocaat van de VOC en zijn staf. Zo vond de benoeming van Van Diemen plaats op een breukvlak in de bestuurlijke ontwikkeling van de VOC.

Zonder specifieke instructie nam Van Diemen direct alle ruimte die hem geboden werd. Dat deed hij op 3 januari ${ }_{1} 636$ in een persoonlijke brief aan de Heren Zeventien. De brief is knap van opbouw. Van Diemen begon met uitvoerig lof aan Brouwer toe te zwaaien. Hij schreef dat naar zijn mening de Heren Zeventien diens aanstelling als gouverneur-generaal hadden behoren te verlengen gezien zijn voortreffelijke staat van dienst. Van Diemen zelf zou daar ook 'volcomen genoegen' mee hebben gehad.

Wij hebben gezien hoe hard de kritiek op Brouwer en het door hem gevoerde beleid in de laatste brieven uit Nederland was. Het antwoord daarop van Brouwer en mede ondertekend door Van Diemen, dat nota bene mee zou reizen met Brouwer naar Nederland, was een bijzonder felle verdediging van datzelfde beleid geweest. In zijn brief legde Van 
Diemen daar nog nadruk op. Hij bleef pal achter Brouwer staan en stelde dat hij diens beleid onverkort zou blijven uitvoeren.

'Belangende $U$ ed Indische standt soo de regeringe, den Oorloge, commercie als andersints concernerende, mitsgaders 't passerende in $U$ ed affaire tsedert onse jongste advuijsen aen $U$ ed afgesonden, insgelijcx t'gene voornemens sijn in toecomende met de hulpe Godes tot verseeckering, vergrooting ende verbeteringe desselfs aen te leggen wert $U$ ed bij onsen Generale Missive distinctlijcken geschreven ende grondich vertoont. Sulx dat mij geheelijcke aen den ingesonde derselver missive gedrage, gelijck oock ben doende ende mij referere tot de rapporten die den heere Generael Brouwer met lieft bij $U$ ed gecomen wesende tot welstandt van de Generale Comp sal doen. Hebbende gemelte heere soo grondige kennisse van d'Indische saecken int generael dat met recht den Indische Phoenix genoemd mach werden. U ed voijders gans vrundtlijck versoeckende in andtwoorde deser onser advuijsen ons met uwen goeden raet, last ende ordre sulx te seconderen dat alles ten beste van de Comp aengeleijt ende na $U$ ed goede intentie alhier int werck gestelt ende wtgevoert mach werden. ${ }^{\text {II }}$

Je moet maar durven degenen door wie je net benoemd bent, zo te kapittelen. Maar Van Diemen moest wel speelruimte creëren wilde hij zijn grootse plannen ten uitvoer kunnen brengen. Dat hij zich wilde bewijzen, blijkt ook uit het verzoek dat hij via de bewindhebbers richtte tot zijn zwager Pieter de Gruyter, namelijk om voor zijn rekening een aandeel van drieduizend gulden in de VOC te kopen. Dat bedrag was geen toeval. Het greep terug op de transactie waarmee hij in 1609 in Amsterdam zijn loopbaan als koopman begon die zo onfortuinlijk zou eindigen. Dat Van Diemen geen behoefte aan bevelen uit Nederland had, klonk door in de afsluiting van zijn brief:

'Den Alwijsen, altegenwoordigen, Almachtigen ende Goedertiren Godt, gelieve ons bij te woonen met sijne Geest: des breetst, omme onsen doen, actien en directien alomme soodanich te bestieren ende te begeven dat alles mach strecken tot grootmaeckinghe sijnes $H$ naem, welvaert ende reputatie onse lieven vaderlandts, afbreuck onser vijanden, welstandt van de Generaele Comp, proffijt ende contentement van de participanten en tot mijne Eere int bijsondere.'

Vooral die laatste zes woorden... en geen woord over zijn hiërarchische verhouding tot de Heren Zeventien. Als koopman in Amsterdam had hij aan de vrijheid geproefd die zelfstandigheid en onafhankelijkheid met zich brengen en die een ondergeschikte functie, hoe eervol ook, niet kan geven. Na zijn faillissement in I6ı6 was deze drang naar vrij- 
heid ondergronds gegaan, maar die zou toen hij eenmaal gouverneurgeneraal was, weer een belangrijke rol spelen. Het geeft ook het grote verschil weer tussen Coen en Van Diemen. Coen was uiteindelijk een creatuur van de contraremonstrantse machthebbers van de Compagnie en hij voerde al dan niet met tegenzin het beleid uit dat in Amsterdam werd geformuleerd en goedgekeurd. Dat lag anders bij Van Diemen: hij maakte het beleid in Azië en voerde dat uit met of zonder instemming uit Nederland.

De bewindhebbers in Nederland probeerden in hun eerste brieven aan Van Diemen de verhoudingen te herstellen die aan het einde van de periode Brouwer onder zware druk waren komen te staan. Met een omweg haalden zij bakzeil. ' $U$ zult ongetwijfeld nu wel zien dat wij grote redenen hadden ons over de veranderingen gedaan onder het vorige gouvernement te beklagen,' zo schreven zij om te vervolgen dat de toon te fel geworden was van beide zijden. Dat zou nu voorbij moeten zijn 'opdat onze correspondentie door onderling respect (ieder in zijn rol) meer en meer ten dienste van de souvereine Compagnie en profijt der Participanten gevoerd zal worden. ' 19

Deze 'verbeterde' sfeer zou niet lang standhouden. Dat kon ook haast niet vanwege bijvoorbeeld enerzijds de voortdurende irritatie over de onvermijdelijk gebrekkige boekhouding, de winsten die altijd bij de grote plannen achterbleven, de handel voor eigen rekening en anderzijds de gevoeligheid van Van Diemen voor elke inmenging in het door hem gevoerde beleid.

Zeker de eerste jaren bemoeide men zich vanuit Nederland nauwelijks met de lopende handelszaken. In september I638 schreef men:

'Wij zijn te verre van anderen gelegen omme zodanige correspondentie int stuck van negotie te houden als wel vereischen zouden en daeromme Ue weijsheijt en goedt beleijt alles ten principaele de negotie aengaende toevertrouwt werdt.' 20

Dat lag anders bij de grote plannen voor expansie die zij jaarlijks te lezen kregen, zeker omdat de winsten steeds maar achterbleven bij de verwachtingen. Men ondersteunde Van Diemens strijd tegen de Portugezen omdat die goed was voor de handel, maar bijvoorbeeld het plan om alle indigo van Lahore in handen te krijgen, werd krachtig ontraden, omdat dergelijke ondernemingen zelden slagen 'want die het al soecken gemeenelijck het al verliest. ${ }^{2 \mathrm{I}}$

Het werd een terugkerend thema:

'ende de indische werelt is voor ons te groodt omme die alleen te possideren ende het landt hier te kleijn'; 
't is dan wel hoogh teijt dat wij eenmaal soo wijs werden omme ons aen macht van schepen en volck soo niet vergapen, dat ons eijgen huijs vergeten schoon te maecken ${ }^{\text {22 }}$;

en, 'onse concepten moeten so verre niet lopen, op presuppoosten van profijten die ons soude toecomen als den handel in de werelt alleen hadden. ${ }^{23}$

Van Diemen zelf vond zijn plannen 'geen imaginatien off casteelen in de lucht, maer gefondeerde concepten, daeraen des Compagnies welstandt dependeert.'24 'A man of action has more illusions than a dreamer' typeerde Oscar Wilde trefzeker twee eeuwen later de oorsprong van deze dadendrang.

Daarnaast was er ook voortdurend wat aan de hand met degenen die uit Azië waren teruggekeerd.

'Wij connen niet naelaten Ued t'adviseren dat deese vergaderinge niet tegenstaend haer hoogwichtighe occupatien en besognes doorgaens geoccupeert is geweest met pretentien van particuliere persoonen jongsten uijt India gecomen. ${ }^{25}$

Over de vele steken boven en onder water met betrekking tot de particuliere handel is een bloemlezing op zijn plaats:

't Is wonder dat d'onse geen nieuwe partije diamanten hebben connen becomen, daer die nogthans bij particuliere veel overgebracht werden. ${ }^{26}$

'Ued ordre op verscheijde particuliere saecken behaegt ons wel, dan wij bemercken dat Ue placcaet op het overvoeren van particuliere haer goederen niet seer gevolcht wert, alsoo cort nae 't aencomen der schepen alle winckels van alderhande Indische manifacturen, porceleijnen en rariteijten bevinden voorsien te wesen.' (3I6: 306 brief I7, II september 1640 )

'waerinne wij van tijt tot tijt soodanige excessen bevinden dat sommige perticuliere geheele Cages met goederen en vrij meer als oijt een gouverneur generael uijt India comende mede brengen. ${ }^{27}$

De langste litanie over de particuliere handel die onder de hoogste dienaren van de Compagnie zou floreren, was meer dan één foliopagina lang naar aanleiding van een niet nader genoemde persoon, waarschijnlijk Salomon Sweers, die een wissel van 75.000 gulden had laten overkomen voor zijn familie. ${ }^{28}$

Elke kritiek wierp Van Diemen ver van zich. Bijvoorbeeld in december I639: 'Echter versoucken gantsch vreundelijck Ued ons niet ten onrechten 
gelieft te taxeren, opdat in respect ende couragie tot dienst van Ued geanimeert blijven. ${ }^{29}$

In zijn brief van I2 december I64I aan de Heren Zeventien ging hij onder het kopje 'progressen onder generael Van Diemens Gouverno' veel verder:

'Dese Ued aengetogen missive van 11 september 1640 hebben met groote opmerckinge ende niet minder verwonderinge gelezen, vermits allen 't halve in dezelve over onse advysen doen ende directie seer misnoeght schynt te wesen. Syn in onse vorige missive soo circumspect niet, als de Hoogheyt van Ued achtbaerheyt, die ons te gebieden hebben, meriteert, gedenckt t'selve eenelyck uyt sucht tot compagnies besten, maer niet tot vilipendie van Ue tendeert. Ued kennen den instelder des brieffs ende weet van soo trotsen humeur niet gedreven wordt. Wy hebben geseyt, gelyck by desen confirmeren dat ons de saken van India vertrouwt moeten worden ende daerover geen ordre mogen inwachten, soo de compagnie dienst doen sullen. Ued is den waeromme namentlyck dat de tyt sulx niet lydt bekent. De volckeren deser landen ende 't den derseler syn oock soo variabel dat by gevolch ins eygen resolutien ende advysen schynen te contradiceren, daeruyt dan tegemoet wort gevoert, dat wy ons schryven soude resumeren; echter vertrouwen by aldien Ued de saken soo bloodt voorquamen als d'aenwesende Uwe dienaren in India, deselve sien ende tasten, ander geweten ende contentement soudt hebben...Coomen ons dese reprochen van alle kanten toe, als God de sake soo merckelyck gelieft te segenen, wat hebben wy te verwachten byaldien het tegendeel ('t welck de Almachtige genadeleyck verhoede) ons quame te treffen. Nu! Wy sullen dit, als comende van ons meerder en die te gehoorsamen hebben, patienteleyck tot onderrichtinge opnemen ende daerover in geen vorder contentie treden. ${ }^{30}$

En dat terwijl de Heren Zeventien juist over de hoge toon van de vorige snedige brief van Van Diemen geschreven hadden: 'waerinne Ue penne al wat verre gaet buijten de limieten van behoorlijck respect deze vergaderinge toekomende. ${ }^{3 \mathrm{I}}$

Ook daadwerkelijk gingen de wegen uiteen. De Heren Zeventien wilden het eiland Mauritius bezetten om te voorkomen dat de Fransen dat zouden doen. Toen Van Diemen dat geen goed plan vond zetten de Heren Zeventien hun zin door op een buitengewone wijze. Er werd in I638 rechtstreeks een schip met een kleine bezettingsmacht vanuit Nederland naar Mauritius gezonden. Door al het ebbenhout op het eiland te kappen en te verkopen zouden de kosten laag zijn en het zijn aantrekkelijkheid voor andere naties verliezen, zo verdedigden zij hun ongewone stap tegenover Van Diemen. ${ }^{32}$ 
Het gevolg was dat de organisatie van de VOC in Azië overtuigd van haar eigen gelijk, hoe langer hoe meer een eigen leven ging leiden. Zo schreef Van Diemen aan de gouverneur van Malakka over in zijn ogen ontrechte kritiek van de Heren Zeventien:

'Connen niet bedencken, uijt welcke hooffde dese swaermoedighe advijsen oorsprong nemen ende dat hun onse directie off ten minsten advijsen niet al te wel gevallen, doch trecken t'zelve weijnich aen, meenen in onse maximen te volherden ende deselven met Godes gratie ten dienste van de Compagnie uijt te voeren. ${ }^{33}$

Zo ver waren de bewindhebbers in Nederland verwijderd van de uitdagingen waar het Aziatisch bedrijf zich volgens Van Diemen voor gesteld zag, dat zij zijn gedachtegang en agenda maar nauwelijks konden volgen. Hoezeer dat soms uit elkaar liep, blijkt uit de geïrriteerde zinsnede uit hun brief van I2 april I640: 'alsof $u E$ alle ende hier geen kennisse van saacken hadden.' Het waren blaffende honden die elkaar niet konden bijten. In een eerdere periode zou Van Diemen wellicht teruggeroepen zijn, maar nergens blijkt dat zo'n stap is overwogen. In I638 en I64I ontving Van Diemen zelfs bijzonder vriendelijk gestelde brieven uit Nederland, waarin hem werd verzocht of hij zijn benoeming wilde verlengen. Van Diemen antwoordde positief hierop, waarna hij vanuit Nederland hartelijk werd gefeliciteerd. ${ }^{34}$ Op het laatste verzoek had hij geantwoord dat hij eind 1643 naar Nederland wilde terugkeren. In eerste instantie werd dat voor I644 vastgesteld, maar in augustus I643 werd hem dringend verzocht toch tot $\mathrm{I} 645$ aan te blijven gezien de moeilijkheden rond de octrooiverlenging en het komende bestand met de Portugezen. ${ }^{35}$

Het maxime dat nog aan Specx werd geschreven: 'Onze order moet $u w$ wet en regel zijn. Uw discoursen en meededelingen om ons te dienen van advies en om onze orders daarop te verwachten ${ }^{36}$ had onder Van Diemen zijn betekenis in Batavia verloren. Ook Brouwer schreef zelf nog in december I634: 'aan Ued. staat het gebieden en aan ons het gehoorsaamen'. In de relatie was de positie van Batavia niet meer ondergeschikt aan die van Amsterdam. Onderlinge afhankelijkheid bleef bestaan: de reden van bestaan van de VOC in de Republiek waren de retourschepen met hun lading enerzijds en anderzijds kon de VOC in Azië niet op eigen benen staan. Zij verwachtte immers jaarlijks schepen met manschappen en geld uit de Republiek. 


\section{Noten}

I. NA VOC OBP III9 fI-20I Originele generale missive van den gouverneur-generaal Antonio van Diemen en raad te Batavia aan de edele heeren zeventhien van de Nederlandse Oost-Indische compagnie in dato 28 December ${ }^{6} 636$ en NA VOC OBP II22 f I-287 Originele generale missive van den gouverneur-generaal Antonio van Diemen en raad te Batavia aan de edele heeren zeventhien van de Nederlandse Oost-Indische compagnie in dato 9 December I637.

2. NA VOC Kopieboek van de uitgaande missiven, instructies en andere papieren van de Heren XVII en de kamer Amsterdam.inventaris nr 3I6 en 3I7.

3. Stapel, Geschiedenis van Nederlandsch Indië, III, 24I.

4. Jonge, de, Opkomst, V, 225. Generale Missive 4 januari I636.

5. Mijer, P., Verzameling van instructiën, ordonnanciën en reglementen voor de regering van Nederlandsch Indië, vastgesteld in de jaren 1609, $1617,1632,1650,1807,1815,1818,1827,1830$ en 1836, met de ontwerpen der Staats-commissie van 1803 en historische aanteekeningen (Batavia I848) en Van Dam, Beschrijvinge, III, 530.

6. Dam, van, Beschrijvinge, III, 58I ev.

7. NA VOC $3 \mathrm{I} 6 \mathrm{f} 64$.

8. NA VOC 7346, Kopie resoluties van de ordinaris en extraordinaris vergaderingen van de Heren Zeventien van augustus I64I.

9. Ibidem.

Iо. Dam, van, Beschrijvinge, I, eerste deel. 272.

II. Wagenaar, Amsterdam, I, 53I-545.

I2. NA VOC 316, 315 22 dec i640.

13. Dam, van, Beschrijvinge, III, 577.

I4. Mijer, Verzameling van instructiën, 47.

I5. Ibidem 7I.

I6. NA VOC 3I6 f3II. Brief Heren XVII i8 september i640.

I7. Elias, De vroedschap van Amsterdam, I, I92.

I8. NA VOC OBP III6 f 207-209. Originele missive van Anthonio van Diemen aen de heeren bewinthebberen ter camer van Amsterdam in dato 3 Januarij I636. Hele brief in bijlage.

I9. NA VOC 316 f i29. Brief Heren XVII 24 september ${ }_{6} 636$.

20. NA VOC 316 f 204. Brief Heren XVII i6 september I638.

2I. NA VOC 3I6 f 20I. Brief Heren XVII i6 september I638.

22. NA VOC 316 f 299. Brief Heren XVII iI september I640.

23. NA VOC $3 \mathrm{I} 6 \mathrm{f} 4 \mathrm{I} 7$. Brief Heren XVII 3I augustus I643.

24. NA VOC II34 f 20-58. Copie generale missive van gouverneur generael Anthonio van Diemen aende heeren bewindhebberen 
vande vereenigde Oost-Indische compagnie ter camer tot Amsterdam in Casteel Batavia desen 8 Januarij anno I64I.

25. NA VOV 316 f 225. Brief Heren XVII i6 september i638.

26. NA VOC 316 f 2I2, Brief Heren XVII I6 september I638.

27. NA VOC $3 \mathrm{I} 6 \mathrm{f}$ I72. Brief kamer Amsterdam I december i637.

28. NA VOC 3 I7 $\mathrm{f}$ I7. Brief Heren XVII 2I september I644.

29. Coolhaas, Gegevens over Antonio van Diemen, 527.

30. NA VOC OBP II35 I-98 Originele generale missive van den gouverneur generaal Anthonio van Diemen en raden van India aan de heeren zeventhiene van de Oostindische compagnie te Amsterdam in dato I2 December I64I. Bovenstaande afgedrukt in Coolhaas, gegevens blz 527 .

3I. NA VOC 316 f 300. Brief Heren XVII in september i640.

32. Coolhaas, Generale Missiven, 728, 28 dec I638; NA VOC 316, 265 I4 maart I639.

33. afgedrukt in Coolhaas, Gegevens over Antonio van Diemen, 528 .

34. NA VOC 316 f 222 december I637, f 227, i5 september I638/9 september I639/23 oktober I639 f 334 I5 maart I64I, f 39925 september 1642 .

35. NA VOC $316 \mathrm{f}_{422}$. Brief Heren XVII 3I augustus I643.

36. Heren XVI aan Specx 4 oktober I632: afgedrukt in De Jonge, Opkomst, V, XCVII. 


\section{2 'Schaars een behoorlijcken interest', de winst van de VOC ten tijde van Van Diemen nader bekeken}

Er is de afgelopen decennia een stortvloed aan literatuur over ondernemers en ondernemingen verschenen. Achter vaak onheilspellend klinkende titels als Barbarians at the Gate ${ }^{\mathrm{I}}$, The Predator's Ball ${ }^{2}$ of De Prooi ${ }^{3}$ wordt in al dan niet stoere taal de economische realiteit weergegeven waaraan alle ondernemingen van klein tot groot onderworpen zijn: continuïteit en winstgevendheid mogen nimmer als vanzelfsprekend worden verondersteld. Een van mijn favorieten uit deze categorie draagt de weinig sentimentele titel Life and Death on the Corporate Battlefield, How Companies Win, Lose, Survive ${ }^{4}$. Het boek geeft vele voorbeelden hoe directies in de onzekerheid van de markt met wisselend succes hun bedrijf positioneerden en onvolledig geïnformeerd moesten besluiten welk gevecht zij op de markt met wie, wanneer en, het moeilijkst, waarom aangingen. Ook de VOC zou in dit beeld hebben gepast. Op eenzelfde manier als de Amerikaanse robber barons aan het einde van de negentiende eeuw, wilde de Compagnie in het begin van de zeventiende eeuw alles en iedereen uitschakelen die haar bedreigde of in de weg stond. Alle middelen waren geoorloofd. Net zoals bij het ontstaan van de zakelijke imperia van Rockefeller, Morgan en Carnegie lagen ook bij de Compagnie aan beslissingen met vaak verstrekkende gevolgen geen rationele kostencalculaties ten grondslag, geen afgewogen besluitvorming door een bureaucratische moloch, maar de wil om te winnen en een primaire drijfveer: als je je bedreigd voelt, is de keuze vluchten of vechten. Ben je sterk, dan trek je ten strijde. Zo ook de Compagnie. Nadat de rookwolken waren opgetrokken, bleek pas of de winst was toegenomen of verminderd. Maar om die winst draaide het uiteindelijk wel.

In de literatuur is het beeld van de winstgevendheid van de VOC in de zeventiende eeuw diffuus. In het overzichtwerk van Gaastra wordt een gezond positief resultaat haast als uitgangspunt verondersteld. ${ }^{5}$ Zo algemeen is dit ingeslopen dat Schutte in zijn inleiding over de hervormde kerk in Indië tijdens de VOC schreef: 'Lange tijd was de Compagnie ook 's wereld grootste en meest succesvolle multinational. ${ }^{6}$ Hoewel op de betekenis van het begrip multinational in het geval van de VOC wel wat valt af te dingen, lijkt op deze toon een discussie overbodig. Dit sluit echter maar gedeeltelijk aan bij de eerdere constatering 
die Glamann maakte in zijn baanbrekende Dutch-Asiatic trade 1620-1740 namelijk dat 'The profit of the Dutch-Asiatic trade was moderate as compared with the receipts won by the Dutch by shipping and commerce in Europe. ${ }^{7}$ Van Veen sluit hierbij aan, maar markeerde juist na de moeizame eerste decennia met het aantreden van Van Diemen in ${ }_{1} 6_{3} 6$ een positieve ommekeer in de winstgevendheid van de Compagnie. ${ }^{8}$

De Engelse EIC stelde daarentegen in $\mathrm{I}_{37}$ in een uitvoerig memorandum dat de Nederlanders genoegen namen met kleine winsten, of soms zelfs verlies om hun concurrenten, en dan met name de Engelsen, weg te houden uit Azië. ${ }^{9}$ Dat klinkt ook door in de brief van de kamer van Amsterdam van I2 april I640 naar Batavia, waarin gesteld werd dat de Indische handel voor 'vreemde natiën' onaantrekkelijk gemaakt moest worden, ook al betekende dit dat sommige goederen duur in Azië moesten worden ingekocht en goedkoop in Europa verkocht, 'om jegens haer cladden en goetcoop geven ende omme int cort te seggen moet haer handel door d'onse met handel gedoot werden gelijck onder coopluijden gepractiseert wert. ${ }^{\text {'I }}$

Om de winstgevendheid van de Compagnie ten tijde van Van Diemen te doorgronden moeten wij een zo goed mogelijk inzicht krijgen in de betekenis van peper, kruidnagelen, nootmuskaat, foelie en al die andere Aziatische goederen voor de winst van de VOC in Nederland en daarnaast het belang voor die winst van de intra-Aziatische handel onderzoeken. ${ }^{\text {II }}$ Want hoe zat het met de soliditeit van de winst van de VOC? Maakte Van Diemen zich daar terecht zorgen over? Kortom, wat was de economische realiteit van de Compagnie?

Wie zich tegenwoordig een mening wil vormen over een bedrijf, pakt het jaarverslag erbij, waarin directie en toezichthouders inzicht aan aandeelhouders geven over het reilen en zeilen van de onderneming. De immer optimistische tekst moet natuurlijk met gezonde achterdocht worden gelezen, maar een jaarverslag geeft over het algemeen een redelijk inzicht in de doelstellingen, activiteiten, soliditeit en winstgevendheid van een onderneming. Zo'n opening van zaken heeft de VOC in haar bestaan niet gegeven. Dat wil niet zeggen dat zij daartoe ten tijde van Van Diemen niet gedeeltelijk toe in staat zou zijn geweest.

In de zeventiende eeuw stond in de Republiek het boekhouden over het algemeen op een hoog niveau. Zo was het Italiaans of dubbelboekhouden vanaf het einde van de zestiende eeuw een afgerond en bekend systeem. Dit blijkt ook uit de vele zeventiende-eeuwse leerboeken waarin vaak met vragen en antwoorden de methode van het Italiaans of dubbelboekhouden werd uitgelegd en onderwezen. ${ }^{\mathrm{I2}}$ Heden ten dage worden in wezen nog op dezelfde manier door vennootschappen de balans en de winst- en verliesrekening opgemaakt. Er waren in het begin van de zeventiende eeuw verschillende schrijvers die heel specifiek de admi- 
nistratie van de VOC in hun leerboeken hebben behandeld. ${ }^{\mathrm{I}, \mathrm{I} 4}$ Het is dus niet door gebrek aan kennis toentertijd dat de boekhouding van de VOC voor het oog van de hedendaagse onderzoeker merkwaardig is ingericht.

Waardoor dan wel? Het bedrijf in Nederland en dat in Azië zijn in de boeken volledig van elkaar gescheiden. Hierbij ontbreken op de balans in Nederland het ingelegde kapitaal en ook de heen en weer varende schepen tussen Nederland en Batavia met hun ladingen. ${ }^{15}$ Deze op het eerste gezicht onlogische scheiding kwam doordat de boekhouding van de VOC in Nederland was gebaseerd op die van de eerste scheepsreizen van Amsterdam naar Azië door de voorlopers van de VOC. Deze werden als volgt ingericht: de participanten vormden een compagnie, legden geld in waarvan schepen en goederen werden gekocht om in Azië handel te gaan voeren, met natuurlijk ook de zorg voor de aangemonsterde bemanning. Als leider van de expeditie werden een schipper voor de koers en een meereizende koopman voor de handel benoemd. De compagnie handelde dus niet met een bepaalde partij goederen, maar met een reis, de 'voyagie'. De winst die gemaakt werd, bestond uit het verschil van de kosten van de 'voyagie' en de opbrengst na verkoop van de retourlading. De winst werd na afloop aan de participanten uitgekeerd en de rekening gesloten. Er werd in de boekhouding dus niet van uitgegaan dat geld en goederen in Azië zouden achterblijven. Het was per reis een doosje waar één keer wat werd ingestopt en waaruit na afloop werd uitgedeeld tot het leeg was. ${ }^{\mathrm{I}}$ $\mathrm{Op}$ zich was dit een bijzonder heldere en effectieve methode.

Hoewel de VOC anders dan deze voorcompagnieën grote bezittingen in Azië verwierf en vaak tientallen schepen met lading heen en weer liet varen, is de boekhoudmethode ten tijde van de Compagnie niet gewijzigd. Deze inrichting van de boeken kwam dus niet doordat de boekhoudkundige kennis of methoden ontoereikend waren in het begin van de zeventiende eeuw, maar uit de macht der gewoonte.

Daarnaast waren er ook goede redenen om het bedrijf in Azië niet samen te voegen met dat in Nederland. De grote afstanden en de tijd die de informatie tussen beide onderweg was, vormden op zich al een beletsel. Hoe zouden in Nederland goederen, forten en schepen in Azië gewaardeerd moeten worden? Het zou zijn alsof een blinde moest oordelen over de kleuren, bedacht men al voor de oprichting.

Daarnaast was de Aziatische boekhouding notoir onbetrouwbaar gebleken.

Aan het einde van de zeventiende eeuw is een poging gewaagd om de bedrijven samen te voegen. Op papier zou dit een uitkomst hebben kunnen zijn. Echter, door tal van praktische problemen werd die poging al gestaakt nog voor de uitvoering ter hand kon worden genomen. ${ }^{\text {I7 }}$ Het gevolg was dat de boekhouding nimmer een getrouw beeld van de ver- 
mogenssituatie van de VOC kon gegeven. Wel gaf zij inzicht in het behaalde resultaat in de Republiek en de ruimte die jaarlijks geboden werd om dividend uit te keren en nieuwe schepen met lading uit te rusten. Als richtsnoer hiervoor voldeed deze methodiek.

Hoe een bedrijf zichzelf cijfermatig inricht, is een weerslag van de manier waarop de leiding van een bedrijf naar haar onderneming kijkt. Bij de VOC betekende dit voor de periode die wij bekijken, dat de belangstelling van de Heren Zeventien vooral gericht was op de verkoopwaarde van de retourgoederen.

Bij zijn benoeming wensten de heren bewindhebbers Van Diemen alleen toe, 'dat de handel van India onder Uw edele Gouverno en directie meer en meer ten dienst van 't Vaderland en profijt van de gemene Participanten mag floreren en gezegend zijn. ${ }^{18}$

Het was een kort stukje, maar het maakte wel duidelijk waar het bij de VOC uiteindelijk om draaide. De Compagnie was per slot een handelsbedrijf.

Vanuit de Republiek gezien was de VOC dus een overzichtelijk bedrijf: jaarlijks werden schepen met geld, goederen en bemanning uitgestuurd naar Batavia en jaarlijks kwam in de zomer een vloot retour met goederen. In Batavia werden deze goederen op kostprijs gewaardeerd. In Nederland daarentegen richtte men zich voornamelijk op de verkoopwaarde.

De samenstelling van de retourlading gebeurde aan de hand van de zogenaamde 'eisch van patria' waarin gespecificeerd werd hoeveel specerijen, peper, textiel enz. werden verwacht vanuit Azië. Voor peper en de specerijen was de vraag gebaseerd op een inschatting van de omvang van de Europese markt. Door de ervaring wijs geworden had men hier een goed beeld van. Zo bedroeg de marktvraag in de zeventiende eeuw voor peper ongeveer 7 miljoen pond per jaar en ook voor de overige specerijen waren dit soort kengetallen bekend. ${ }^{\text {I9 }}$

In de periode van Van Diemen bestond de retourlading bij verkoop grofweg voor één derde uit peper, en voor één derde uit gezamenlijk kruidnagelen, nootmuskaat en foelie. Andere grotere posten waren ruwe zijde en de verfstof indigo. Ongeveer één tiende was samengesteld uit allerlei (stuk)goederen als diamanten, grijze amber, porselein, textiel, suiker, kaneel, gember en overige goederen met vaak in onze oren exotisch klinkende namen als 'drakenbloed'. ${ }^{20}$

$\mathrm{Na}$ de verkoop in Nederland zorgden deze goederen voor een voldoende batig saldo waaruit met het teruggekeerde personeel kon worden afgerekend, de uitrusting van een nieuwe vloot bekostigd en rente over de schulden betaald. Tot het aantreden van Van Diemen werd onregelmatig een dividend in geld of kruidnagelen uitgekeerd aan de aandeelhouders. ${ }^{2 \mathrm{I}}$ 
$x 1$ miljoen gulden

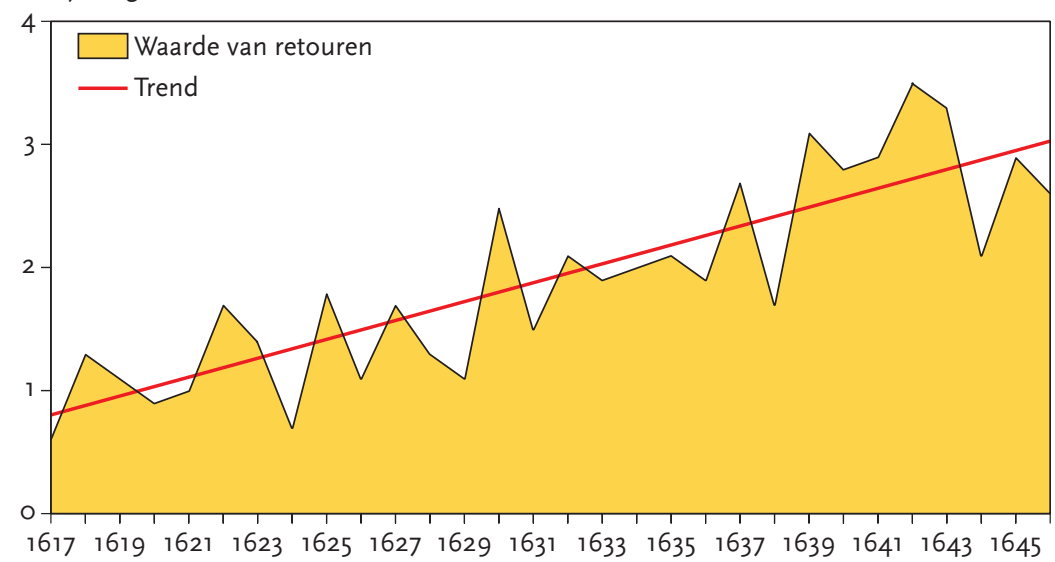

waarde volgens opgave Dutch Asiatic Shipping II ( $x 1$ miljoen)

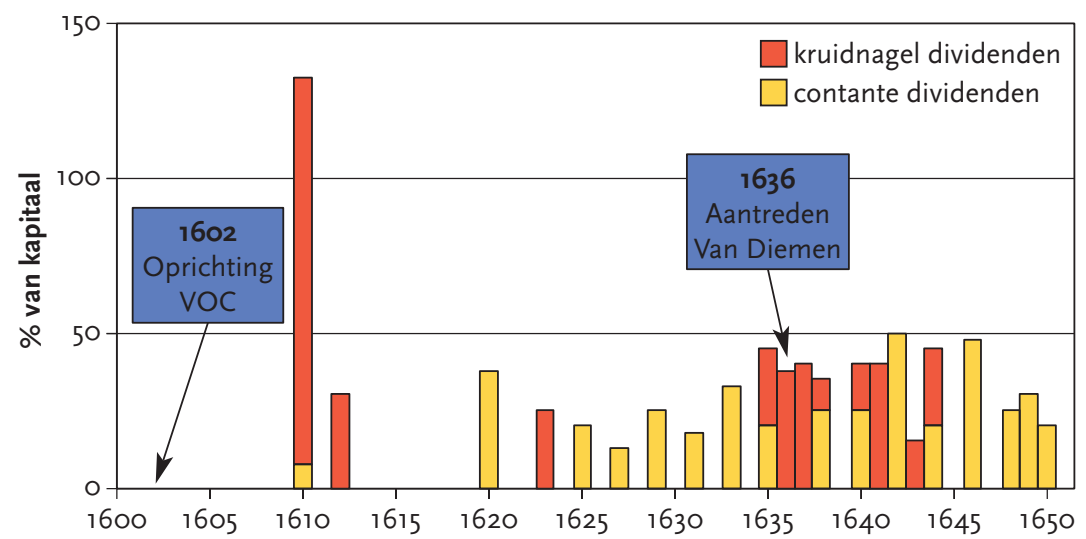

Uitkering van dividenden in percentage van het kapitaal van de VOC. Een dividend van bijvoorbeeld 20 procent correspondeert dus met 1,3 miljoen gulden.

*In 1611 werd het dividend in nootmuskaat en foelie uitgekeerd. Bron: Van Dam I, 454. 
Een verschuiving ten opzichte van de Portugese tijd tot I6oo is dat peper van kostbare specerij tot bulkgoed werd door de grote productie en de overcapaciteit aan scheepsruimte van de Engelsen en de Nederlanders, zoals Matelief in 1609 al beschreef. ${ }^{22}$ De hoge prijs in Europa voor I6oo laat zich verklaren uit de hoge tollen en vervoerskosten tezamen met beperkte vervoerscapaciteit. Peper was overigens onontbeerlijk voor de VOC in Nederland, omdat deze van de uit Azië verscheepte goederen de meest courante was. Er was een contante markt voor. Terwijl veel andere goederen op termijn verkocht werden, rekenden de opkopers van de peper direct met de VOC af. ${ }^{23}$

$\mathrm{Na}$ het werk van Glamann en De Korte zijn op dit terrein geen grote studies meer verricht. ${ }^{24,25}$ Door gebrek aan gegevens en de, door tijdgenoten vaak aangegeven, onbetrouwbaarheid van de wel bewaard gebleven cijfers met name uit Azië, is uiteindelijk niet meer dan een schatting mogelijk. Maar wij moeten hier toch een poging toe wagen, om een beter begrip te krijgen van het beleid dat door Van Diemen werd ingezet. Het vele vechten stond immers steeds in dienst van de handel.

Wij zullen hiervoor eerst de financiële afwikkeling van de retourlading die in I64I in Nederland aankwam, onder de loep nemen.

Zoals uit onderstaand staatje blijkt, was de inkoopwaarde van de retouren in de loop der tijd belangrijk gestegen. Van gemiddeld I,3 miljoen gulden voor de periode van $\mathrm{I}_{2} 20$ tot $\mathrm{I} 629$ was die in de jaren daarna gestegen tot gemiddeld 2 miljoen gulden, om onder Van Diemen op te klimmen tot bijna 3 miljoen gulden. De retourlading van I64I was met een inkoopwaarde van 2,9 miljoen gulden voor deze periode een gemiddeld retour.

Ontwikkeling van de inkoopwaarde van de retouren in miljoenen guldens.

\section{Het retour van 1641 nader bekeken}

'Ondertusschen staan wij hier te lande soo, dat de schoorsteen (so men zegt) van de Indische retouren roocken moet. ${ }^{26}$

Om begrip te krijgen van de waarde en opbouw van een retourlading nemen wij er één onder de loep De gegevens van vóór I640 zijn onvoldoende om een beeld te kunnen krijgen van de verkopen. Daarom is gekozen voor de lading van de negen retourschepen die in juli I64I in Nederland aankwamen, nadat die in december I640 uit Batavia waren vertrokken. ${ }^{27}$ Door de ladinglijsten met de inkoopwaarden naast de verkoopopbrengsten te leggen aangevuld met gegevens over schulden en 
voorraden, kunnen wij een redelijke indruk krijgen van de situatie van het bedrijf in Nederland. Het geeft een interessant beeld.

Zoals Van Diemen in zijn begeleidende brief al had geconstateerd, was het een goed en makkelijk te verkopen retour. In augustus I64I kwamen de Heren Zeventien in Middelburg bijeen om de verkoop van de goederen in goede banen te leiden. (Zie bijlage 6.)

Het ging hen erom zo snel mogelijk zo veel mogelijk te verkopen om de lopende kosten en de equipage voor het volgend seizoen te kunnen financieren. Hierbij was de opbrengst van de peper met name belangrijk omdat 'van de courte provenuen van de peperhandel altijd staat op onze volgende equipage gemaekt wordt. ${ }^{28}$

De grootste posten waren peper, specerijen en ruwe zijde. In één oogopslag wordt het grote belang van de specerijen duidelijk: de winst van meer dan duizend procent op foelie en 5 duizend procent op nootmuskaat maken nog steeds indruk. Samen met de verkochte peper en zijde vormden zij 80 procent van de opbrengst. Het dividend van 25 procent voor de aandeelhouders werd in de vorm van kruidnagelen uitgekeerd. In de praktijk betekende dit dat de kruidnagelen onder de marktprijs werden verkocht voor rekening en risico van de aandeelhouders. Dit deed men om de Engelse EIC die nog steeds veel kruidnagelen in Londen verkocht, dwars te zitten.

Alle andere goederen werden telkens aan een syndicaat of individuele koopman verkocht. Er was meer zijde binnengekomen dan verkocht kon worden, waarop besloten werd deze met tussenpozen op de markt te brengen. ${ }^{29}$ Op de losse goederen liepen de winsten enorm uiteen. Het was vraag en aanbod, die bijvoorbeeld bij de suiker tegenviel 'vermits de overvloedighe toevoer uijt Brasil'30, maar Van Dam kon er zich nog zestig jaar later over verbazen dat de tweede kwaliteit kaneel die voor iets meer dan één stuiver per pond was ingekocht, voor meer dan 2 gulden werd verkocht. ${ }^{3 \mathrm{I}}$ Daarbij werd ook rekening gehouden met de zogenaamde 'laccagie', de verzamelnaam voor alle verlies of bederf van de goederen tijdens de reis. Deze kon oplopen tot één vijfde bij kruidnagelen. ${ }^{32}$ Bij één soort indigo bleek de lading voornamelijk uit aarde te bestaan waar de VOC-koopman, naar men vermoedde, zelf de hand in had gehad:

'Hoe schandelijck d'onse in den ontvanck van den Indigo haer laeten bedriegen en vuijle aerde voor Indigo in de handt steecken. 't Welck immers door pure achteloosheijt veroorsaackt wert, oft oock wel dat d'onse en de mooren malcander verstaen en haer particulier daeronder soecken.'33

In de staat van april $\mathrm{I}_{42} 2$ zijn alle transacties afgewikkeld. De totale verkoopopbrengst van de goederen was uitgekomen op net 6,5 miljoen 
gulden, exclusief het kruidnageldividend. Hiertegenover stonden kosten van 6,7 miljoen aan zogenaamde equipagekosten. Het betrof hier alle kosten die in Nederland werden gemaakt, dus de betaalde gages aan het teruggekeerde personeel, de bouw en uitreding van de schepen naar Azië, de goederen, het goud en zilver dat werd overgestuurd en alle kosten van het bedrijf in Nederland. Verder waren de voorraden peper en specerijen met 8 ton gestegen tot 7,2 miljoen en de debiteuren met een half miljoen tot I,I miljoen. Het bedrag van de uitstaande schuld van de VOC was toegenomen met ruim een ton tot 9,4 miljoen gulden. ${ }^{34}$

Dit was niet het hele verhaal, want één retourschip, 'de Haarlem', was door een storm in de Indische Oceaan ver afgedreven en zou uiteindelijk pas een jaar later met de nieuwe retourvloot in Nederland aankomen.

Het jaar daarop, I643, zou voor de participanten een van de beste jaren uit de geschiedenis van de VOC zijn. Er kwam een groot retour met een waarde van 3,5 miljoen gulden. Aangevuld met de lading van 350 duizend gulden van 'de Haarlem' werd voor I2,5 miljoen goederen verhandeld. Bewindhebbers besloten met deze goede gang van zaken een dividend uit te keren van 50 procent contant en 15 procent in kruidnagelen.

Van Diemens strategie leek eindelijk de beloofde vruchten af te werpen. Om dat effect nog meer te vergroten, werd maar liefst één miljoen extra in contanten naar Batavia verzonden. Hiermee zouden de schulden in Azië afgelost kunnen worden, waardoor de kosten permanent belangrijk verlaagd zouden worden. Ook het kruidnagelmonopolie werd in Europa eindelijk effectief. I644 was het laatste jaar dat een dividend in kruidnagelen werd uitgekeerd. ${ }^{35}$ Toch bracht het zo nagestreefde monopolie niet direct de hoge winsten die ervan verwacht werden.

De echte kater zou in de jaren daarna volgen toen de markt overvoerd raakte en de kosten in Indië niet daalden.

Als wij de dividenduitkeringen van de eerste helft van de zeventiende eeuw op een rij zien, valt op dat in de periode van Van Diemen relatief veel aan aandeelhouders is uitgekeerd. Toch is, ook naar huidige maatstaven, de winstgevendheid van de VOC laag geweest. Neem bijvoorbeeld iemand die een verstandige voorvader heeft gehad die bij de oprichting van Koninklijke Olie in mei I89o een aandeel van duizend gulden had gekocht en dit papier had gekoesterd. Hij zou in de eerste honderd jaar tot 1988 een koersstijging van ruim 3 miljoen gulden naast een dividend van 2 miljoen gulden hebben kunnen bijschrijven. ${ }^{36}$ De VOC was veel, maar ook voor haar tijd geen kampioen 'winstmaken'. De groei van het bedrijf en de grotere waarde van de retouren vertaalden zich niet in hogere winsten, maar in een verdere toename van de kosten. De verkoopwinsten oogden op zich hoog, maar boden te weinig compensatie voor de trage omloopsnelheid van het kapitaal en de 
hoge interne transactiekosten. Daarvan waren de bewindhebbers zich natuurlijk bewust. Op is april I64I schreven zij naar Batavia hierover:

'Want soo lange men van hier noch mocht continueren contanten nae India te senden, sullen de Participanten de rechte proffijte van dien handel niet trecken, alsoo de equipagien, interesse en lopende lasten hier te lande 't meerendeel van de incomende retouren consumeren ende dan weijnigh voor den participanten omme uijt te deelen resteert. ${ }^{37}$

Twee jaar later constateerden zij opnieuw om dezelfde redenen 'dat voor de participanten weijnighe overschiet. ${ }^{38}$

In I644 noemden zijzelf in een memorie het rendement voor aandeelhouders vanaf de oprichting 'schaars een behoorlijcken interest'. ${ }^{39} \mathrm{Ze}-$ ker als dit afgezet werd tegen de koers van de VOC-aandelen, die in die tijd boven de 300 procent lag, was het rendement mager. Doordat de dividend uitkering steeds regelmatiger werd, ondersteunde die de koers van het aandeel. Het werd daarmee een veilige belegging, maar niet één waarvan iemand rijk kon worden.

Over de vermogenssituatie waren de bewindhebbers ook niet gerust. In I630 probeerde de kamer van Amsterdam tevergeefs een dividendvoorstel tegen te houden om eerst een gedeelte af te lossen van de grote schulden waarmee de VOC belast was. ${ }^{40}$ Het bleef een terugkerend thema, maar het aflossen van de schuld zou een voornemen blijven, dat nooit werd uitgevoerd. Er werden wel aanzetten toe gemaakt en in I669 werd zelfs besloten jaarlijks één miljoen gulden af te lossen voordat het dividend werd vastgesteld, maar ook dit werd na een jaar weer losgelaten. Van een dividendpolitiek die gekoppeld was aan de winst, zou bij de VOC geen sprake zijn. Als de winst te laag was, werd geld geleend om het dividend te kunnen betalen. Het is tekenend dat de bewindhebbers in $\mathrm{I}_{32}$ besloten tot het principe van een vast dividend van 12 procent te vermeerderen of te verminderen al naar gelang de opbrengst van de retouren en dat het dividend altijd eerder werd vastgesteld dan dat die opbrengst bekend was. Druk van aandeelhouders blijkt aldus een fenomeen dat zo oud is als de eerste naamloze vennootschap en waaraan de bestuurders van de VOC die steeds losser stonden van het werkelijke bedrijf, steeds gemakkelijker toegaven.

Voor de Republiek lag het belang van de VOC vooral in de grote economische activiteit die zij met zich mee bracht. De kooplieden maakten hun winsten uit de wederverkoop in Europa en die handel versterkte de leidende rol van Amsterdam als commercieel centrum van Europa. Ook de bouw en de uitrusting van de schepen was jaarlijks een grote onderneming. 
Voor ons is van belang dat in Nederland het vermogen van de Compagnie niet meegroeide met de onderneming. Er was nauwelijks een buffer aanwezig en door de steeds verder stijgende hoge vaste lasten werd het bedrijf weinig flexibel. Als de inkoopkosten van de retouren zouden stijgen, kon dit op de markt niet worden doorberekend en zou de winst onder druk komen. Dit was de onzekerheid waarmee Van Diemen zich geconfronteerd zag.

\section{Melkkoeien en verliesmakers: de opbouw van de winst van de VOC in Azië}

Voor het bedrijf in Azië werd wel jaarlijks een geconsolideerde winsten verliesrekening gemaakt. Deze werd door Coen in $\mathrm{I}_{6} \mathrm{I}_{3}$ ingevoerd. De verschillende vestigingen in Azië leverden jaarlijks daartoe hun boeken in bij het hoofd 'comptoir', dat wil zeggen Bantam tot IGIg en daarna Batavia. Daar vond de consolidatie plaats waarop de verhouding in rekening courant tot de kamers in de Republiek werd samengevat onder het hoofdje 'de heren Mayoors', de fictieve boekhoudkundige eenheid van de VOC in de Republiek. Deze boekhouding was echter even uitgebreid als onbetrouwbaar. Wel gaf zij een beeld van de winst of het verlies dat het bedrijf in Azië jaarlijks maakte. ${ }^{4 \mathrm{I}}$

In hun eerste brief aan Van Diemen van 24 september ${ }^{2} 6_{3} 6$ gaven de Heren in Nederland aan weinig vertrouwen te stellen in de jongste generale boeken die uit Indië waren aangekomen. Men hoopte voortaan op een boekhouding 'onthouden van alle termen die naer flatteringhe of adulatie smaecken. ${ }^{42}$

Helpen deed het niet. Zo werd Van Diemen in haast elke brief uit Nederland gemaand de boeken beter bij te houden: 'In somma wij bevinden oock de boucken in genere soo qualijck gecopieert, dat wij niet en connen weten oft daer vast op te mogen gaen. ${ }^{24}$

Een jaar later ging het om de 'scheeps en logieboucken' en in september I638 werd het Indisch gouvernement 'pure sloffigheit' verweten waarvoor geen excuus was ${ }^{44}$, om later te verzuchten: 'Neempt toch dit stuck na zijn meriten en importantie eens ter herten en zouct een eerstrachtiger persoon uijt. 45

Het mocht niet baten. Van Dam schreef in zijn grote werk in I70I: 'In vorige tyden heeft men met het maecken van den staat van de Compagnie in Indien seer slordigh te werck gegaan, sodanigh dat men sigh daarop gantsch niet konde verlaten,' om even later te constateren dat dit gebeurde 'ongetwijffelijck met die insighte om de heeren Bewindthebberen in velen blint te houden. ${ }^{46}$

Volgens Meilink-Roelofsz was het daarbij ook zo dat de hoeveelheid en complexiteit van de boekhouding in Batavia de 'pennisten', zoals de 
schrijvers genoemd werden, te boven ging. Er ontstond volgens haar een 'heilloze verwarring'. 47

Van deze boekhouding die in het kasteel van Batavia in de zeventiende eeuw werd bijgehouden, is niets bewaard gebleven en de kerngegevens zijn maar gedeeltelijk terug te vinden in de correspondentie. Toch geven deze enige houvast om toch een globaal beeld te kunnen geven van de intra-Aziatische handel van de VOC en de rol die de diverse kantoren daarin speelden.

Het bedrijf in Azië kocht op basis van de vraag uit Nederland de retourladingen in, de zogenaamde 'eisch van patria'. Het bijna onoverkomelijke probleem voor de Europeanen was dat goederen van Europese makelij in Azië nauwelijks aftrek vonden, buiten exoten als kwikzilver en bloedkoraal. De Aziaten waren alleen maar geïnteresseerd in zilver en goud. Edel metaal, geld dus, was in Azië aanzienlijk meer waard dan in Nederland, zoals de grote renteverschillen aangaven die de Compagnie op leningen moest betalen in Amsterdam of in Suratte: 6 procent tegen 18 procent of meer.

Zoals Matelief en met name Coen als richtsnoer hadden gegeven, moest, om de kosten van de retouren laag te houden, ook in Azië handel gedreven worden. Gezien de matige winstgevendheid van de VOC in Nederland was de winst op de intra-Aziatische handel ten tijde van Van Diemen dus essentieel voor de continuïteit van de Compagnie.

$\mathrm{Nu}$ waren de kantoren op de specerijeilanden steeds verlieslatend door de hoge kosten die de handhaving van het monopolie met zich mee brachten en ook de Sumatraanse peperhavens leverden weinig winst op. En Batavia speelde op zijn best quitte, zodat de winst in Azië behaald moest worden in de havens die toegang gaven tot de grote Aziatische rijken in Perzië, India, China en Japan. ${ }^{48}$ Zoals Van Diemen schreef, waren dit de beoogde 'melkkoeien'. ${ }^{49}$ Alleen daar waren in principe de markten omvangrijk genoeg om grote omzetten met goede marges te kunnen maken. Dit was zeker geen eenvoudige zaak, niet alleen omdat de trotse Compagnie zich moest zien te handhaven naast het lokale gezag en concurrenten moest dulden, maar ook omdat binnenlandse gebeurtenissen en (burger)oorlogen de continuïteit van de handel onzeker maakten. Van Diemen reserveerde naar eigen zeggen daarom zijn meest ervaren directeuren voor de kantoren in Suratte, Perzië, Coromandel, Taiwan en Japan. ${ }^{\circ}$ Het vaste land van China bleef voor de Compagnie gesloten.

Het ritme van de handel in Azië werd bepaald door de seizoensgebonden winden, de moesson. Door hun voorspelbaarheid konden ver van elkaar gelegen streken door zeehandel met elkaar verbonden worden. ${ }^{\text {I }}$ Chaudhuri, de biograaf van de EIC, beschreef prachtig waar het hierover ging: 
'The two European East India companies discovered within a decade that the whole Indian Ocean had a structural unity created by the periodic rhythm of the monsoon winds and by economic interdependence between one region and another. Cotton textiles from the coast of Coromandel in India were vital for the purchase of pepper and spices in the Indonesian archipelago. Precious metals imported from the Middle East, East Africa, and Japan supplied monetary liquidity without which the rich and powerful centralised empires in Asia could not have functioned properly. This awareness of a vast integrated network of trade and finance in turn induced the bureaucratic companies to follow the natural contours of the commercial geography and design a coordinated system of operations stretching from the Red Sea and the Persian Gulf to the South China Sea. ${ }^{22}$

Het patroon van de Aziatische handel van de Compagnie ontwikkelde zich weliswaar langs gebaande zeepaden, maar die weefden zich een ingewikkeld web.

De eerste scheepvaarten van de Nederlanders gingen naar Bantam en de specerijeilanden om met geld rechtstreeks peper en specerijen in te kopen. Daaraan werd als eerste de Indiase textielhandel vast gekoppeld. De Indonesische archipel kleedde zich van oudsher in de katoenen 'kleedjes' van de Coromandelkust en uit Gujarat in ruil voor peper, specerijen en zilver. Tegelijkertijd werd de Chinese Zee eraan toegevoegd en later, verder naar het westen volgden de belangrijke havens Suratte in India en Gamron in Perzië.

Rond de jaarwisseling vertrokken de schepen vanuit Batavia naar de binnengewesten - Banda, Ambon en de Molukken - om daarvandaan uiterlijk in juli terug te keren. In juni voeren de schepen voor de Coromandelkust weg om voor oktober weer op de weg terug te zijn. In juni begon ook de reis naar Taiwan en Japan en die schepen keerden in januari terug. In juli en augustus vertrokken de schepen vanuit Batavia naar Goa, Suratte en Gamron in de Arabische Zee waar zij in oktober aankwamen om er in april weer van terug te keren. De jaarlijkse retourvloot naar Nederland vertrok tussen november en januari. En zo voeren met het ritme van de seizoenen de schepen van Batavia naar hun verre bestemmingen en weer terug.

De groei van de intra-Aziatische handel bracht onverwachte financiële problemen met zich mee. In Suratte werden de indigo en de katoenen 'lijnwaten' met gedeeltelijke vooruitbetaling ingekocht, waardoor zij bijzonder kapitaalsintensief waren. Volgens Van Diemen betekende dit dat hiervoor eigenlijk een 'dubbel kapitaal' beschikbaar moest zijn. ${ }^{53}$ Het alternatief was lokaal geld lenen dat alleen kon tegen tarieven van soms 2 procent per maand. Door deze 'canckerende interessen' ging steeds een groot deel van de winsten 'in roock' op. ${ }^{54}$ Goede raad was 
duur en om deze leningen zo snel mogelijk af te lossen vond Van Diemen het geraden schepen beladen met zilver rechtstreeks vanuit Taiwan en Japan door de Straat van Malakka naar Coromandel en vooral Suratte te zenden. ${ }^{55}$ In de concurrentie zouden de Engelsen en andere handelaren dan het nakijken hebben. Van Diemen schreef naar Nederland dat immers 'de sterckste beursen staen de victorie te behouden. ${ }^{56}$

Voor het jaar ${ }_{16} 63$ zijn de gegevens van de omvang en winstgevendheid van de intra-Aziatische handel van de VOC ten tijde van Van Diemen redelijk te benaderen. Wij worden hierbij geholpen door een bewaard gebleven brief die Philips Lucasz in december I6 38 in het geheim schreef aan zijn zwager Jacques Specx. Eerstgenoemde was in Batavia directeur-generaal, vertrouweling en plaatsvervanger van Van Diemen. In de brief werd uitvoerig en precies de financiële situatie van de VOC in haar octrooigebied beschreven met als doel te kunnen bepalen of de koers van de aandelen van de VOC te hoog of te laag was gezien de winsten die in Azië waren gemaakt. Het doel was handel of speculatie in aandelen VOC met voorkennis! Gezien de enorme winst die dat jaar behaald was in Japan en die in Nederland vooralsnog onbekend was, zou de koers van het aandeel zeker stijgen, zo meende Lucasz. Het betreft een pikant geval, want Specx was na zijn gouverneur-generaalschap bij de VOC bewindhebber bij de WIC geworden. Deze twee compagnieën hadden een ongemakkelijke relatie en beide hielden elkaar angstvallig in de gaten. ${ }^{57}$

In december I638 schatte Van Diemen zelf dat 'De inlandse handel door geheel India door de Compagnie met niet min als met 80 tonnen fons [8 miljoen gulden] can levendigh en naer behoren waergenomen worden, daermede d'Indische ongelden, sijnde $181 / 2$ tonnen ende een retour voor Nederlant, alhier waerdigh dertigh tonnen can ingewonnen worden. ${ }^{58}$

Dit kapitaal zou volgens Van Diemen permanent aan de handel in Azië ter beschikking moeten staan. De omvang van de intra-Aziatische handel is moeilijk te schatten. Het totaal aan handelsgoederen op de kantoren was gezamenlijk meer dan Io miljoen gulden. Het lijkt dat dit ook het minimum van de jaarlijkse handel was. Op de grote vestigingen werd jaarlijks meer dan een miljoen omgezet. Japan was tussen I635 en I640 in een uitzonderlijke situatie. De export naar Hirado was in die jaren groter dan naar Nederland. Dit resulteerde in een brutomarge van een kleine 4 miljoen gulden, waar na aftrek van kosten rond één miljoen als winst van overbleef. ${ }^{59}$ De omzet van de VOC in Azië was dus duidelijk groter dan die in Nederland. Niet verbazingwekkend laat dit ook zien dat de marge op de handel in Azië voor de VOC lager lag dan in Europa. De concurrentie was groter en de afstanden waren korter. Gedeeltelijk kwam dit ook omdat de Compagnie in India en Perzië veel van haar goederen op termijn kocht, dus leende. De rente die hierover verschuldigd was, was hoog: tussen de I en 2 procent per maand. Deze 
rentelast was in de loop der jaren steeds opgelopen en verminderde de winst op de intra-Aziatische handel dusdanig dat deze regelmatig de 'cancerende interessen' werd genoemd. ${ }^{60}$ Omdat het geld lenen in Nederland maar 6 procent per jaar kostte aan de Compagnie, ging men er die jaren toe over meer schulden in Nederland in de boeken te nemen en extra goud en zilver naar Azië te zenden om de leningen aldaar af te lossen. ${ }^{\text {II }}$ Vooral met de winsten van de Japanse handel hoopte men na een aantal jaren schuldenvrij te zijn. Het ging erom dat Perzië en India uit de schulden kwamen: 't welck ons eenig doelwit moet sijn'. ${ }^{62}$

Van Diemen kreeg mede steun voor zijn beleid vanwege zijn toezegging dat dit op afzienbare termijn zou gebeuren, hetgeen de Heren Zeventien als volgt benadrukten: 'Het is een groote saecke $u E$ ons beloven, dat alle quartieren van India anno $16_{41}$ buijten belastinge sullen staen. ${ }^{63}$

Door de tegenvallende ontwikkelingen in Japan en elders zou dit echter niet het geval blijken te zijn.

Hoe belangrijk nootmuskaat en foelie waren voor de VOC blijkt eens te meer uit incidentele gegevens uit Suratte waar deze specerijen met een winst van duizend procent werden verkocht. ${ }^{64}$

Voor ons is een opsomming van de kosten en baten per kantoor interessant. Het bevestigt het beeld van de winst van de kantoren in Japan, India en Perzië. De winst over I638 was in Japan enorm groot geweest, terwijl de winsten in India en Perzië volgens Van Diemen tegenvielen. ${ }^{65}$ De jaarlijkse verschuivingen konden bijzonder groot zijn. 
Winst en verlies van de Compagnie in Azië in 1637/38

In guldens

t comptoir in Cambodja

t comptoir in Taijouhan

t comptoir in Jambi

t comptoir in Siam

t comptoir in Firando in Jappan

t comptoir Suratte

t comptoir Banda

t comptoir Coromandel

t comptoir in Persia

t comptoir in Amboina

$\mathrm{t}$ comptoir in Wingurla

t comptoir Attchin

t comptoir in Maccassar

Voyagie naer Solor en Timor

Voyagie naer de Westcust van Sumatra

Voyagie naer Palimbang

Voyagie naer Queda en Pera

t comptoir in Batavia

Generaelen tocht naer Amboina

t comptoir in Mollucas

Resultaat voor rente

Betaalde rente over schulden opbrengsten kosten resultaat

$\begin{array}{rrr}62.055 & 8.376 & 53.679 \\ 203.321 & 217.645 & -14.324 \\ 70.345 & 10.326 & 60.019 \\ 30.127 & 11.752 & 18.375 \\ 2.450 .000 & 75.000 & 2.375 .000 \\ 206.630 & 22.080 & 184.550 \\ 89.617 & 117.478 & -27.861 \\ 283.000 & 87.927 & 195.073 \\ 285.487 & 50.464 & 235.023 \\ 73.779 & 111.170 & -37.391 \\ 61.036 & 17.871 & 43.165 \\ 13.797 & 1.648 & 12.149 \\ 10.272 & 2.509 & 7.763 \\ 3.596 & 2.798 & 798 \\ 69.861 & 1.579 & 68.282 \\ 17.960 & 0 & 17.960 \\ 2.924 & 0 & 2.924 \\ 727.104 & 845.214 & -118.110 \\ 0 & 38.722 & -38.722 \\ 106.179 & 218.713 & -112.534 \\ & & \\ 4.767 .090 & 1.841 .272 & 2.925 .818\end{array}$

$18 \%$ over 2,5 miljoen

$-450.000$

2.475 .818

2.475 .818

Winst 
Verkorte balans van de Compagnie in Azië per ultimo I638

In guldens

Debet

Goederen aanwezig in

t comptoir in Batavia

Comptanten in Batavia

t comptoir in Amboina

t comptoir Banda

t comptoir in Mollucas

t comptoir in Firando

in Jappan

$\mathrm{t}$ comptoir in Taijouhan

t comptoir in Cambodja

t comptoir in Siam

$\mathrm{t}$ comptoir in Jambi

t comptoir Suratte

t comptoir in Persia

$\mathrm{t}$ comptoir in Wingurla

t comptoir Attchin

t comptoir in Maccassar

Voyagie naer Solor en Timor

Voyagie naer de Westcust

van Sumatra

Voyagie naer Palimbang

Voyagie naerQueda en Pera

t comptoir Coromandel

Voagie naar Arrakan

Voyagie naer Malabar

Voyagie naer Mocha

Voagie naer Ceylon

Totaal goederen

Afgegeven Victualien,

ammunitie, gereedschappen

Winst 1638

\section{Credit}

4.283.414 Vermogen

24.512

339.583

255.385

279.400

807.432

Af te zenden

2.664.231 Retouren

178.108

149.008

286.997

125.616

83.576

0

15.708

36.157

27.245

68.785

Verliezen

op zee

325.808
3.500 .000

8.067 .337

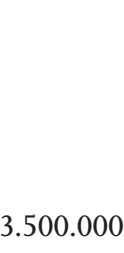

32.931

767.308

25.874

110.341

51.157

5.377

10.618 .145

$-1.200 .000$

2.475 .000

II. 893.145

\section{Totaal}

NB: op deze wat onregelmatige balans ontbreken de geleende gelden ad 2,5

miljoen in Suratte en Perzië. Deze werden waarschijnlijk aldaar gesaldeerd, wat de lage bedragen voor deze twee vestigingen verklaart. Batavia is inclusief het af te zenden retour. Ook ontbreekt een waardering van de schepen en de onroerende goederen als huizen en forten. 


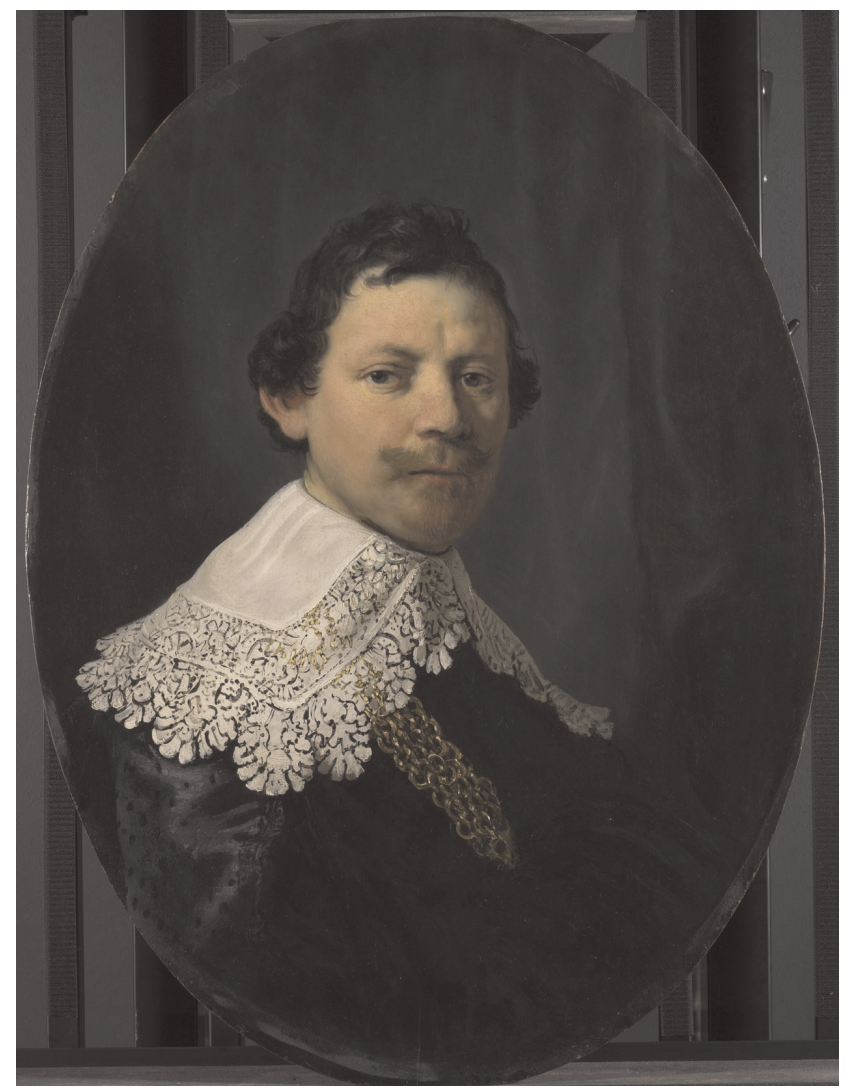

Op dit portret van de hand van Rembrandt uit 1634 draagt Philips Lucasz de gouden ketting waarmee hij als commandant van de retourvloot door de Heren Zeventien was vereerd. National Gallery, Londen.

In zijn brief gaf Lucasz ook een bedrag van ruim 8 miljoen als waarde van de Indische effecten. Van Diemen berekende in I64I opnieuw eenzelfde waarde en constateerde dat dit kapitaal tot zijn spijt de afgelopen jaren nauwelijks was toegenomen. Hij voorzag dat hierin geen verbetering zou optreden tenzij de Japanse handel met hulp van de 'Almogende' tot zijn voormalige 'florissante stand' zou komen. Deze moeizame winstgevendheid maakt de vasthoudendheid begrijpelijk waarmee werd gehoopt op grote winsten uit Japan toen de Portugezen daar hun sterke positie verloren.

In januari I639 schreef Van Diemen nog zorgelijk: 'De canckerende interesten, de rijcke retouren die jaerlijcks overzenden ende de vergroting van 
Compagnies commercie in India houden ons allerwege soo schraal, dat bijna buyten posture geraecken'.66

Maar toch werd na de enorme winst in $\mathrm{I}_{6} 8$ in 1639 daar 4 miljoen gulden geïnvesteerd in de hoop dat 'nae deze geen contant meer voor India van UEd sal worden versocht' en dat de compagnie haar schulden in India zou aflossen. ${ }^{67}$

Het zou een ijdele hoop blijken te zijn. De Japanse winsten vielen vanaf ${ }^{6} 639$ veel lager uit en bedroegen tot ${ }^{6} 650$ gemiddeld 600 duizend gulden per jaar. Het Japanse kantoor bleef daarmee het meest winstgevende kantoor van de Compagnie, maar het bracht niet de winst waarop gehoopt was. De handel met Japan was daarnaast van groot belang omdat tot 1670 als retourlading uit Japan vooral zilver werd geëxporteerd. Buiten de hierboven genoemde uitschieter in $\mathrm{I} 637$ bedroeg die tot $\mathrm{I}_{50}$ jaarlijks gemiddeld circa I,5 miljoen gulden, dus meer dan aan zilver uit Nederland werd gezonden. In de laatste jaren had goud de plaats van zilver ingenomen. Deze stroom zou langzaam minder worden en in I680 abrupt eindigen, waarna aan de cruciale rol van Japan in het handelsnetwerk van de Compagnie een einde kwam. ${ }^{68}$

Tabel Jaarlijkse gemiddelde export van zilver en goud door de VOC uit Japan, 1621-1699. In guldens

\begin{tabular}{|c|c|c|}
\hline Jaren & zilver & goud \\
\hline $1621-1624$ & 157.924 & \\
\hline $1628-1632$ & - & \\
\hline $1633-1636$ & 921.044 & \\
\hline 1637 & 3.029 .550 & \\
\hline $1640-1649$ & 1.518 .871 & \\
\hline $1650-1659$ & 1.315 .121 & 406,092 \\
\hline $1660-1669$ & 1.048 .821 & 1.151 .148 \\
\hline $1670-1679$ & & 263.667 \\
\hline $1680-1699$ & & \\
\hline
\end{tabular}

Uit: O.Prakash, The Dutch East India Company and the Economy of Bengal 1630-1720, 20.

Gedurende het hele bestaan van de VOC bleven contanten vanuit Nederland nodig om lading in te kopen voor verkoop in de Republiek. Steeds weer verdampten de gedachte winsten door veranderende omstandigheden, maar vooral ook door de voortdurend stijgende kosten die de handhaving van het monopolie in de fijne specerijen en de territoriale uitbreiding in Taiwan, Malakka en Ceylon met zich mee zouden brengen.

Daarbij kwam de vennootschappelijke structuur die door haar ingebouwde kracht verandering in de weg stond en het vrijgeven van de 
Aziatische handel aan particuliere kooplieden tot een onmogelijkheid maakte. Het was juist deze overkoepelende vennootschappelijke structuur geweest die de VOC de overhand had gegeven op de Portugezen en de Engelsen, maar die verwerd tot een keurslijf.

Voor ons is vooralsnog van belang dat, door de beschikbare gegevens de constatering van Van Diemen ondersteund wordt dat de winst van de VOC zowel in Nederland als Azië relatief laag en kwetsbaar was.

Terwijl de winst van de VOC uiteindelijk in Nederland neersloeg, bestond de eigenlijke omzet van de VOC uit die van het bedrijf in Nederland plus die van dat in Azië. Zoals wij zagen, was de Aziatische omzet duidelijk hoger dan die in Nederland en onontbeerlijk om de hoge kosten van het bedrijf goed te maken. De winst als marge van de totale omzet was dus lager dan alleen op de Nederlandse gegevens zou kunnen worden verondersteld. Zoals de Heren Zeventien nog in I643 schreven waren de jaarlijkse kosten van de 'grote huishoudinghe' zeker, maar de winsten daarentegen onzeker. ${ }^{69}$ Dit maakte de Compagnie niet tot een marginaal bedrijf, maar zij was bij het aantreden van Van Diemen ook niet zonder risico. Het kapitaal was lager en de winst kwetsbaarder dan van een grote vennootschap na ruim dertig jaar verwacht mocht worden. Door de expansie van de Compagnie die volgde onder Van Diemen en zijn opvolgers, verankerde de VOC de winst in Azië en zou de Indische tak van de Compagnie sterk genoeg worden zijn om lange tijd op de steeds veranderde marktomstandigheden te kunnen inspelen. Zo zou tot het einde van de zeventiende eeuw de intra-Aziatische handel van de Compagnie winstgevend blijven. ${ }^{70} \mathrm{Na}{ }^{\circ} 690$ stegen de kosten echter sterker waardoor de inkomsten van de VOC in Azië lager werden dan de kosten en dat ook zouden blijven.

Door de sterk gegroeide vraag naar Aziatische goederen in Europa was het volume van de handel daar inmiddels dusdanig toegenomen en parallel daaraan de handelswinsten van de Compagnie in Nederland, dat hiermee in de achttiende eeuw de verliezen in Azië konden worden goed gemaakt. Maar kapitaal dat gelijke tred hield met de gestegen omzet, werd niet opgebouwd. De kapitaalsstructuur bleef twee eeuwen vrijwel ongewijzigd. Er was ook lang geen reden tot werkelijke zorg geweest.

In I78I legde echter de Vierde Engelse Oorlog deze zwakke stee van de Compagnie genadeloos bloot. Een buffer ontbrak om de verliezen van de door de Engelsen gekaapte retourschepen te dragen. De Compagnie zou deze klap niet meer te boven komen. ${ }^{7 \mathrm{I}}$

Het is overigens de vraag of dit met zo'n buffer wel het geval zou kunnen zijn geweest. Het was eerder een wijziging in het Europese politieke en militaire krachtenveld die de Compagnie de das om deed. Engeland was ter zee oppermachtig geworden. Britannia ruled the waves, zoals de Compagnie dat meer dan een eeuw in Azië had gedaan. 


\section{Noten}

I. Burrough, B. en J. Helyar. Barbarians at the gate: the fall of RJR Nabisco (New York I990).

2. Bruck, C., The Predators'Ball: the inside story of Drexel Burnham and the rise of the junk bond raiders (New York I989).

3. Smit, J., De Prooi, blinde trots breekt ABN Amro (Amsterdam 2008).

4. Solman, P. en T. Friedman, Life and death on the corporate battlefield: how companies win, lose, survive (New York I982).

5. Gaastra, Geschiedenis van de VOC, I33.

6. Schutte, G. J., Het Indisch Sion, De Gereformeerde Kerk onder de Verenigde Oost-Indische Compagnie (Hilversum 2002) Ten Geleide ongenummerd.

7. Glamann, K., Dutch-Asiatic Trade, 1620-1740 (Kopenhagen I958) II.

8. Veen, E. van, Decay or defeat? An inquiry into the Portuguese decline in Asia, 1580-1645 (Leiden 2000) I63.

9. Sainsbury, E. B. en W. Foster, A calendar of the court minutes etc. of the East India company, 1635-1639 (Oxford I907) 271. Memorandum gedateerd mei 1637 daarin samengevat uit Public records Office East india vol iv B, Nos 39, 39I, 40, 40I, 4I.

Iо. NA VOC 3I6, f 290 Kopieboek van de uitgaande missiven, instructies en andere papieren van de Heren XVII en de kamer Amsterdam. Kamer Amsterdam i2 april I640.

II. In de literatuur is soms een onduidelijk beeld ontstaan over het belang van de fijne specerijen voor de VOC in de eerste helft van de I7de eeuw. Zie Furber, 52 en 235 .

I2. Have, ten, De leer van het boekhouden in de Nederlanden tijdens de zeventiende en achtiende eeuw (Delft I933).

I3. Ibidem 232.

I4. In de begin periode zijn dit Hendrick Waninghen van Campen: Tresoor van 't Italiaens boekhouden, enz. Amsterdam I609 met een uitbreiding in I629. Hierin gaat hij in een drietal hoofdstukken in op de boekhouding van de VOC. Hij onderkende daarin dat in de republiek de verschillende kamers verschillende boekhoudmethodes hanteerden en zijn leerling Buingha maakt een aanvulling in zijn "corte instructie om Boeck te houden voor commijsen, onder. commijsen ofte adsistenten. die hun ten dienst van de Vereenigde Oost-Indische Compagnie sullen willen begeven." uit I636. Hij behandelde met name de boekhouding in Azië. Deze was veel ingewikkelder, omdat de aan en verkopen moesten worden omgerekend in de lokale valuta." "Om Boeck te houden voor Commijsen, varende voor een Compagnie, als de Compagnie van Oost-Indien, heeft men van noode vier Boecken, als een Memoriael. een Goeder-Boeck met een Journael ende Schuldt Boeck, hou- 
dende het Memoriaal ende Goeder Boeck in sulcken geldt als daer te Lande gaet. Ende het Journael ende Schuldt Boeck in sulcken geldt, als hier te Lande gaet." (Noot Geciteerd in Ten Have blz 237 Hendrick van Waninghen van Campen, bewerkt door Johannes Buinghma, Tresoor van het Italiaens boeckhouden, Amsterdam I629, Willem Jansz Stam.

I5. Korte, J. P. de, De jaarlijkse financiële verantwoording in de VOC, I2.

I6. Have, ten, De leer van het boekhouden, I4/I5.

I7. Dam, van, Beschrijvinge, I eerste deel, schema Hudde, XXXIV XXXVIII.

I8. NA VOC 3i6, f 70. 2I april i635.

I9. Glamann, Dutch-Asiatic Trade, 74.

20. Drakenbloed is een bloedrode harssoort, getrokken uit de vruchten van de Calamus draco, een rotansoort. Tegenwoordig wordt deze kleurstof nog gebruikt als kleurmiddel in meubelmakerspolitoer.

2I. Glamann, Dutch-Asiatic trade, I3 en I4.

22. Frederiks, Cornelis Cornelisz Matelieff de Jonge, 310.

23. vgl instructie Brouwer art 83, in P. Mijer, Verzameling van instructiën, 66.

24. Glamann, Dutch-Asiatic trade (Kopenhagen I958).

25. Korte, J. P. de, De jaarlijkse financiële verantwoording in de VOC (Leiden I984).

26. NA VOC $316 \mathrm{f}$ I3I brief I7 24 september $\mathrm{I}_{3} 6$

27. Een tiende retourschip, de Haarlem, raakte bij Mauritius in een orkaan verzeild en zou pas een jaar later met de volgende retourvloot in Nederland aankomen. Bruin, Dutch Asiatic Shipping III, 45

28. NA VOC 316 f i3r. Brief Heren XVII 24 september ${ }_{6} 636$.

29. Dam, van, Beschrijvinge, I, tweede deel, I96.

30. NA VOC 316 f $267 \mathrm{v}$.

3I. Dam, van, Beschrijvinge, I, tweede deel, I96.

32. Ibidem.

33. NA VOC 316 f 315. Kamer Amsterdam 22 december I640 en ook 3I6 f 340. Heren XVII 5 september I64I.

34. Korte, J. P. de, De jaarlijkse financiële verantwoording in de VOC, bijlage A, staatje met balans.

35. Knaap, G. J., 'Kruidnagelen en Christenen: de Verenigde Oost-Indische Compagnie en de bevolking van Ambon 1656-1696', Verhandelingen van het Koninklijk Instituut voor Taal-, Land- en Volkenkunde 2I2. (Leiden, 2004) 35 (Gebaseerd op D.K.Basset English trade in Celebes I6I2-I667, in Journal of the Malayan Branch of the Royal Asiatic Society 31: I-39, I958. Te vinden in de bibliotheek van de $\mathrm{VU})$

36. Gabriëls, H., Koninklijke Olie: de eerste honderd jaar 1890 - 1990 ('sGravenhage I990) 225 . 
37. NA VOC 316 f 37 I.

38. NA VOC $3 \mathrm{I} 6 \mathrm{f} 408$.

39. Dam, van, Beschrijvinge, I tweede deel, 5I5.

40. Heer, C. de, Bijdrage tot de Financiëele geschiedenis der Oost-Indische Compagnie ('s-Gravenhage I929). 5I/ Van Dam, Beschrijving, I, 4I7

4I. Er werd een geconsolideerde balans gemaakt. Deze was uitermate onpraktisch omdat de gemaakte kosten en winsten jaar op jaar werden geactiveerd en gepassiveerd. Hierdoor ontstond een enorm balans, die als richtsnoer voor de waardebepaling van de bezittingen van de VOC in Azië geen betekenis meer had.

42. NA VOC $3 \mathrm{I} 6 \mathrm{Ff}$ I3I

43. NA VOC $3 \mathrm{I} 6 \mathrm{f}$ i75. Kamer Amsterdam aan gg en raden december I637.

44. NA VOC 316, f 204 . I6 sept I638.

45. NA VOC $3 \mathrm{I} 6$ f $222 \mathrm{v}$.

46. Dam, van, Beschrijvinge, III, 333-336.

47. Meilink-Roelofsz, M. A. P., 'Hoe rationeel was de organisatie van de Nederlandse Oost-Indische Compagnie?', Economisch en sociaalhistorisch jaarboek 44 (I982) I84.

48. Gaastra, Bewind en Beleid, 78. In de tabel met de 'staatsrekening van Indië van 28 februari I68I' is eenzelfde onderscheid tussen winstgevende en verlieslatende kantoren.

49. Coolhaas, Generale Missiven, II, I52, I2 december I64I.

50. Coolhaas, Generale Missiven, II, I52, I2 december I64I.

5I. Jacobs, E. M., Koopman in Azië (Zutphen 2000) I4.

52. Chaudhuri, K. N., Trade and civilisation in the Indian Ocean: an economic history from the rise of Islam to 1750 (Cambridge I985) 83.

53. Coolhaas, Generale Missiven, I, 6I7, 9 december I637; H.W. van Santen, De Verenigde Oost-Indische Compagnie in Gujarat en Hindustan, 1620-1660 (Leiden I982) 39)

54. Coolhaas, Generale Missiven, I, 6609 december I637

55. Ibidem.

56. Coolhaas, Generale Missiven, I, 674, 22 december 1638

57. NA I.I0.78 Archief Sweers, Specx etc band i f I95-I99.

58. Coolhaas, Generale Missiven, I, 738.

59. Korte, de, De Jaarlijkse Financiële Verantwoording, 3I. Van Santen, De VOC in Gujarat en Hindustan, 32-33, Tabel I. Hierin wordt een gemiddelde export alleen uit Suratte berekend tussen I635 en I644 van gemiddeld I miljoen gulden.

6o. NA VOC 3I6 f 2I8, I6 september I638 en NA VOC 3I6 f 284, 8 december 1639 .

6r. NA VOC 3I6 f 262v, i2 september I639.

62. NA VOC 316 f 306, I2 april I640.

63. NA VOC 316 f 326 , I5 maart i64I. 
64. NA VOC II56 f 871.

65. Coolhaas, Generale Missiven, I, 22 december I638, 675.

66. Coolhaas, Generale Missiven, II, 37, I2 jan I639.

67. Coolhaas, Generale Missiven, I, 738 en NA VOC Iı33 GG en Raden dd 3I januari I64I fi6v.

68. Prakash, O., The Dutch East Asia Company and the Economy of Bengal 1630-1720 (New Jersey i985) 20 ev.

69. NA VOC 3I6, 4I3, 3I augustus I643.

70. Korte, de, De Jaarlijkse Financiële Verantwoording, 32.

7I. Gaastra, Geschiedenis van de VOC, I67. 


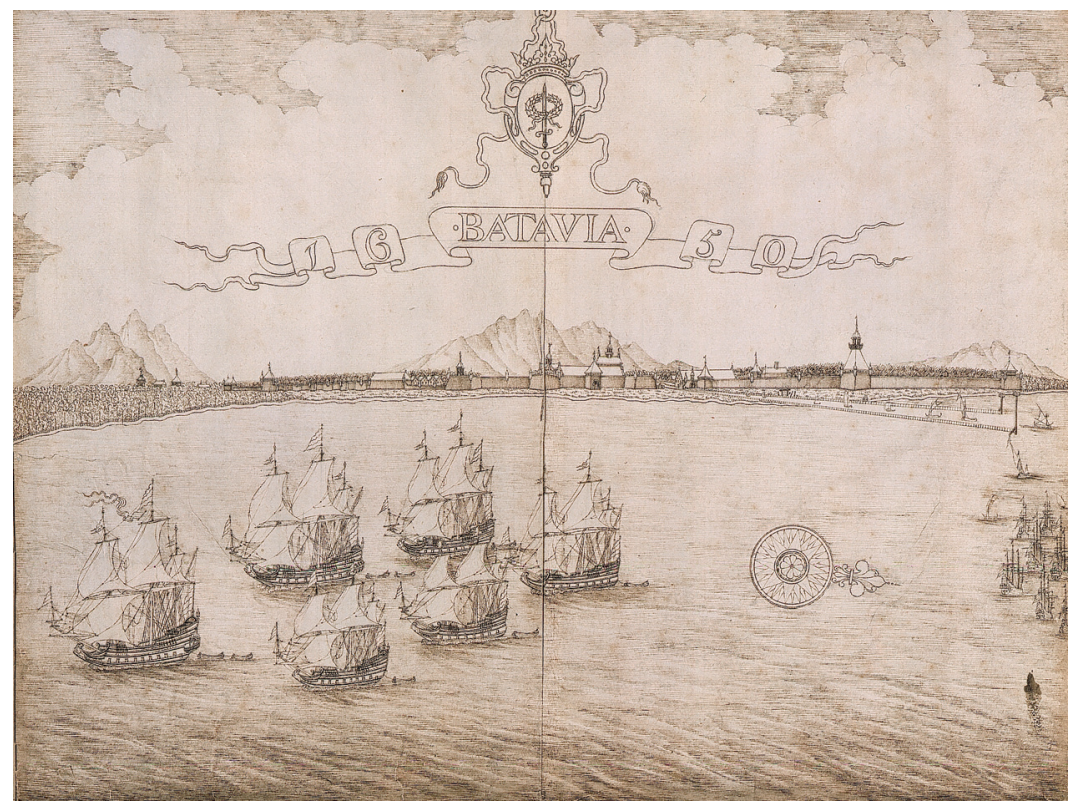

Een vloot van zes schepen vaart weg van de rede van Batavia. In Aziatische wateren zal geen vijand een aanval op hen wagen. Tot ver in de achttiende eeuw bleef de Compagnie op zee heer en meester. Nationaal Archief Den Haag. 


\section{De vloot van de Compagnie onder Van Diemen}

'Als maer de zee blijven domineren, heeft Ued. een vasten en gewenschten staet in India.' Antonio van Diemen aan de Heren Zeventien, december $1636^{\mathrm{I}}$

Wij zouden ons de VOC in ${ }^{6} 636$ makkelijk te groot kunnen voorstellen. Zij was echter (nog) geen enorme onderneming. Van Diemen kreeg de beschikking over een vloot van 85 schepen groot en klein, bemand met een paar duizend matrozen en ongeveer evenveel soldaten die de forten bezet hielden. Als alles op alles werd gezet kon Van Diemen een vloot van 20 schepen met een bemanning van 2000 koppen uitrusten. ${ }^{2}$

De VOC van Van Diemen kon zich in Azië in eigen forten alleen handhaven op de kusten van kleine rijken, of op eilanden waar direct toegang was voor haar schepen, want tot het einde van de negentiende eeuw maakten op zee de Europese kanonnen de dienst uit. In 1636 waren de Banda-eilanden met het monopolie van de foelie en de nootmuskaat het zekerste bezit van de Compagnie. Op Ambon en de Molukken was een tiental forten bij elkaar onvoldoende voor het afdwingen van het kruidnagelmonopolie. Met Batavia als spil waren de forten Gelria op de Coromandelkust van India en Zeelandia op Taiwan de twee eigen buitenposten. Daarnaast waren er handelskantoren in de belangrijkste havensteden waar de VOC toegang had van de Rode Zee tot in Japan, met in India en Perzië een tiental subalterne kantoren.

Voor de grote rijken die de enorme Aziatische landmassa beheersten waren in de zestiende eeuw de Portugezen, net zo min als de Engelsen en Nederlanders dat in de zeventiende eeuw zouden zijn, een machtsfactor van betekenis. Tegen het Turkse, Perzische, Groot-Mogolse, Chinese en Japanse leger en hun vorsten hadden de Europeanen in Azië niets in te brengen. Van enig militair overwicht van de Europeanen op het land was geen sprake. Als voorbeeld moge dienen dat de Turken nog in I683 Wenen met I3 8 duizend man belegerden en bijna innamen.

Deze ondergeschiktheid hield in dat de VOC in de grote Aziatische rijken alleen handel kon drijven op basis van de goedkeuring door de vorst. Naast natuurlijk de juiste handelswaar werd dit recht verkregen met geschenken en op basis van prestige. Toen Van Diemen aantrad, 
werd de Taj Mahal gebouwd in Agra en was de Blauwe Moskee in Istanbul net af. De Aziatische rijken waren rijk en machtig en tegelijkertijd wreed en tiranniek. In de beleving van de Europeanen was er geen sprake van een technische of economische superioriteit ten opzichte van de Aziaten. Ook nog aan het einde van de achttiende eeuw sprak Edmund Burke in zijn beroemde aanklacht tegen de East Indian Company (EIC ) met groot respect over de bevolking van India als 'a people for ages civilized and cultivated with their own governments, cities, economies and industries, agriculture and religion.'

De militaire en staatkundige ommekeer begon in 1757 toen het leger van de EIC bij Plassey dat van de nawab van Bengalen versloeg. Het werd het begin van de territoriale expansie van de Engelsen in India. In één klap kreeg de EIC greep op de belastinginning in Bengalen waarmee zij in een andere categorie terechtkwam, want veel van de legendarische Aziatische rijkdom kwam uit de opbrengst van de belasting die op lokaal niveau geheven werd. De eerste buit bedroeg meer dan 75 miljoen gulden. Nehru merkte later in zijn Discovery of India hierover bitter op dat 'loot' als een van de weinige Hindi-woorden tot de Engelse taal was doorgedrongen.

'The corruption, venality, nepotism, violence and greed of money of these early generations of British rule in India, is something which passes comprehension. Looking back at the Company's conquest of India, it is significant that one of the Hindustani words which has become part of the English language is loot.' ${ }^{4}$

Ten aanzien van de relatieve omvang van de Estado da India, de VOC en de EIC in de periode daaraan voorafgaand schreef Ashin das Gupta:

'With the exception of the monopoly established by the Dutch in the trade of Indonesian spices, there are no indications that European controls affected Indian trade adversely or that the Indian merchant was driven from the Indian Ocean in commercial competition. At the turn of the 18th century Indian shipping fully held its own against the English and Dutch vessels.' ${ }^{5}$

Hierop sluit Chaudhuri aan met zijn vele voorbeelden van netwerken van Indiase en vooral Armeense kooplieden die op grote schaal zaken deden door heel Azië.

Met name een vergelijking met de Armeense kooplieden en hun uitgebreide familie-clans is interessant en zou nader onderzocht kunnen worden. Gebaseerd op het monopolie van zijde-export uit Perzië dat hen door shah Abbas in 1602 was verleend, zouden zij vanuit Nieuw- 
Julfa bij Isphahan op grote schaal handel drijven van Amsterdam tot Manilla. ${ }^{67}$

Op het land konden de Europeanen weliswaar niets ondernemen tegen de grote Aziatische rijken, op zee waren de rollen omgekeerd. De Europese schepen waren op de open zee onverslaanbaar voor de Aziatische vloten. Elke confrontatie eindigde op een enkele uitzondering na in een Aziatische nederlaag. Voor de machthebbers in Azië was de zee een factor van ondergeschikt belang en in een vloot die het op zou kunnen nemen tegen de Europeanen, werd niet geïnvesteerd. ${ }^{8}$ Het was echter zeker geen gebrek aan technische kennis. De Chinese admiraal Zheng He voer immers tussen I405 tot 1433 zeven keer met enorme vloten uit tot aan de oostkust van Afrika. En in I6I3 bouwden de Japanners onder leiding van de Engelsman William Adams in negen maanden een schip naar Europees voorbeeld dat twee keer de reis naar Acapulco maakte. Voor de Portugezen en de Nederlanders lag dat anders. Hun 'navale macht' was essentieel voor het behoud van hun positie in Azië.

\section{Compagnies machtige vloot}

'Als maer de zee blijven domineren, heeft Ued. een vasten en gewenschten staet in India' schreef Van Diemen aan het einde van zijn eerste jaar als gouverneur-generaal aan de Heren Zeventien. ${ }^{9}$ Het was de vloot van de Compagnie die de basis vormde voor haar macht in Azië. Haar belang kan niet voldoende benadrukt worden.

De schepen van de Compagnie werden bijna zonder uitzondering in Nederland gebouwd. Al snel na de oprichting van de VOC namen de kamers hiervoor eigen scheepshellingen in gebruik waarop de schepen, jachten en fregatten onder nauwkeurige instructies werden gebouwd. Het waren bijzondere schepen omdat zij zowel strijd moesten leveren, als vracht vervoeren als bestand zijn tegen lange reizen en wisselende klimaten. Doordat in Nederland de scheepsbouw een bijzonder efficiënte bedrijfstak was, waren de kosten van de bouw en uitrusting van een schip relatief laag. In de zeventiende eeuw kostten de bouw en uitrusting van grootste schepen van de VOC I4O duizend gulden en de kleinste II duizend, terwijl de tonnages uiteen liepen van meer dan Ioo० tot ongeveer 200 ton. ${ }^{\mathrm{IO}}$ In I634 concludeerde Brouwer dat het bouwen van schepen in Batavia voor de Compagnie vanwege de kosten en de logistiek geen optie was. ${ }^{\text {II }}$ In twee eeuwen bouwde de Compagnie een kleine 1500 schepen. De eerste helft van de zeventiende eeuw had met 278 schepen hier een relatief gering aandeel in, niet alleen wat aantal, maar ook wat omvang betreft. Slechts io procent van de gebouwde schepen behoorde in deze periode tot de grootste twee van de vier cate- 
gorieën die werden onderscheiden. In de achttiende eeuw zouden juist meer grote dan kleine schepen worden gebouwd. Ten tijde van Van Diemen bouwde de Compagnie zo'n 6 tot 8 schepen per jaar. ${ }^{\mathrm{I2}}$ De levensduur van de schepen verschilde per soort. De grote sterke retourschepen, die de kern van de vloot vormden, gingen soms wel meer dan 20 jaar mee en maakten dan tot 9 keer de lange reis van Nederland naar Batavia en terug. Voor de overige kleinere schepen was dit zonder schipbreuk of ander geweld in uitzonderlijke gevallen I5 jaar, maar gemiddeld lag de levensduur daarvan rond de so jaar. Omdat vaak van meer dan de helft van de schepen die uitvoeren de bedoeling was dat zij niet in Nederland zouden terugkeren, kon zo in Azië een vloot worden opgebouwd. Hierbij maakten kleinere jachten vaak als bouwpakket aan boord van de grotere schepen de tocht naar Azië. Ook werden de incidenteel prijsgemaakte Portugese schepen aan de vloot toegevoegd.

Om een idee te krijgen van het aantal schepen en opvarenden is een tabel uit Dutch-Asiatic Shipping relevant: ${ }^{\text {I3 }}$

Uit de Republiek
\begin{tabular}{|r|r|r|r|r|r|}
\hline & Opvarenden & Schepen & Opvarenden & Schepen \\
\hline $1595-1602$ & $5,300 ?$ & 66 & & $?$ & 49 \\
\hline $1602-1610$ & 8,500 & 76 & 14.500 & 40 \\
\hline $1610-1620$ & 19,000 & 117 & & $(1602-1630)$ & 50 \\
\hline $1620-1630$ & 23,700 & 141 & & & 71 \\
\hline $1630-1640$ & $28.900 ?$ & 157 & & 10.000 & 75 \\
\hline $1640-1650$ & $33.100 ?$ & 165 & & 11.900 & 93 \\
\hline $1650-1660$ & $40.200 ?$ & 205 & & 13.000 & 103 \\
\hline $1660-1670$ & 40.900 & 238 & & 14.400 & 127 \\
\hline $1670-1680$ & 42.700 & 232 & & 15.900 & 133 \\
\hline $1680-1690$ & 37.800 & 204 & & $16.400 ?$ & 141 \\
\hline $1690-1700$ & 43.000 & 235 & & 18.300 & 156 \\
\hline & & & & & \\
\hline $1602-1700$ & 317.800 & 1.770 & & 114.400 & 989 \\
\hline $1700-1795$ & 655.200 & 2.951 & & 252.500 & 2.365 \\
\hline
\end{tabular}

In de eerste helft van de zeventiende eeuw was hierdoor de VOC als enige Europese of Aziatische organisatie in staat een vloot op te bouwen en te onderhouden in Aziatische wateren. De groei van de vloot verliep overigens niet gestaag. Zo kon Coen in I622 tijdelijk beschikken over maar liefst honderd 'zeylen' waarbij hij de schepen in Nederland en onderweg van en naar Azië meetelde. ${ }^{\text {I4 }}$ Het handhaven van een dergelijke omvang was onbetaalbaar en de vloot werd in de jaren daarna dan ook afgebouwd. 
Vanaf I6I9 werd jaarlijks in Batavia een overzicht van de 'navale macht' van de Compagnie in Azië opgesteld. Het gaf op een dubbel foliovel een opstelling waarin men duidelijk kon zien waar in Azië zich welk VOC-schip bevond. Over het algemeen werden ook de Engelse schepen in dit overzicht genoemd.

Door de jaren van I6I9 tot I646 achter elkaar te leggen krijgt men een goed beeld van de ontwikkeling van de vloot. ${ }^{\text {I5 }}$ Wat deze telling niet altijd vergelijkbaar maakt, is het gegeven dat niet elke keer de retourschepen werden meegenomen die op het punt stonden naar Nederland te vertrekken en soms ook de kleinere schepen, de 'fregatten en sloepen', niet werden meegeteld. Waar onder Coen de vloot gegroeid was van 47 schepen in I6I9 tot 77 in I623, kon in januari I625 gouverneurgeneraal Pieter de Carpentier over een relatief kleine vloot van 43 schepen beschikken, wat duidelijk onder het gebruikelijke gemiddelde lag. Het jaar daarop was dit aantal alweer toegenomen tot 63 .

Dit kwam onder meer door de aankomst van de schepen van de zogenaamde 'Nassause vloot' die door de Staten-Generaal was uitgezonden om een strooptocht rond de wereld te maken en de vloot van de VOC in Azië te versterken. Na de kusten van Zuid-Amerika onveilig gemaakt te hebben, deed deze vloot een vergeefse poging om de Spaanse zilvergaljoenen voor Manilla te veroveren.

In de jaren daarna bleef het aantal schepen tussen de 60 en 70. In de jaren I634 en I635 nam de vlootomvang verder toe, zodat op 4 januari I636 Van Diemen over 85 schepen, jachten en fregatten kon beschikken. Zonder al te grote uitslagen naar boven of beneden zou dit het gemiddelde blijven gedurende het gouverneurs-generaalschap van Van Diemen.

Belangrijk was dat in dezelfde jaren de Engelse vloot in Azië gestaag was ingekrompen. In I626 was deze met 22 schepen nog maar half zo groot als die van de Compagnie, in ${ }_{1} 636$ met 12 schepen nog maar een zesde daarvan, wat zo ook zou blijven.

Tussen I625 en I635 vond geen belangrijke uitbreiding van het gebied plaats waarin de schepen van de Compagnie actief waren. In januari $\mathrm{I}_{25} 5$ werden de schepen ingezet voor de vaart naar Banda, Ambon, de Molukken, Jamby en Atjeh op Sumatra, en de Coromandelkust. Maar liefst acht schepen voeren naar China en Japan, terwijl naar de Indische Oceaan bewesten Coromandel slechts twee schepen naar Suratte werden gezonden. Er zouden dat jaar nog twee volgen die via Suratte naar Nederland zouden terugvaren, maar in vergelijking met de Engelsen was de VOC nauwelijks actief in het westelijke deel van de Indische Oceaan.

Vanaf i626 zou dit veranderen. We kunnen zeggen dat de Compagnie de groei van haar vloot vooral gebruikte voor de ontwikkeling van de handel op Suratte en Perzië. Deze uitbreiding ging echter niet ten 


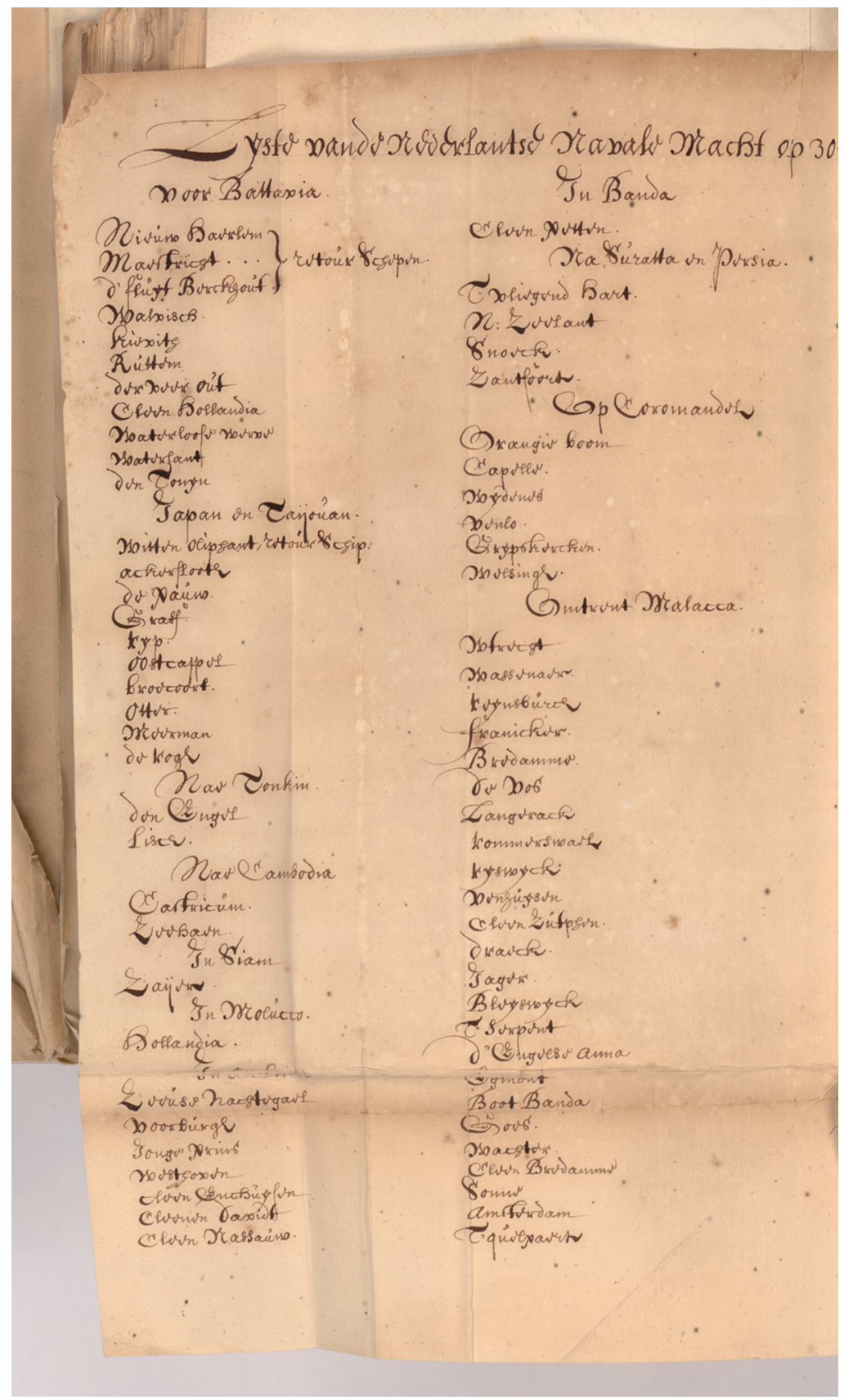

In september 1640 was de belegering van Malakka in volle gang. Maar liefst 23 schepen namen eraan deel. Nationaal Archief Den Haag. 


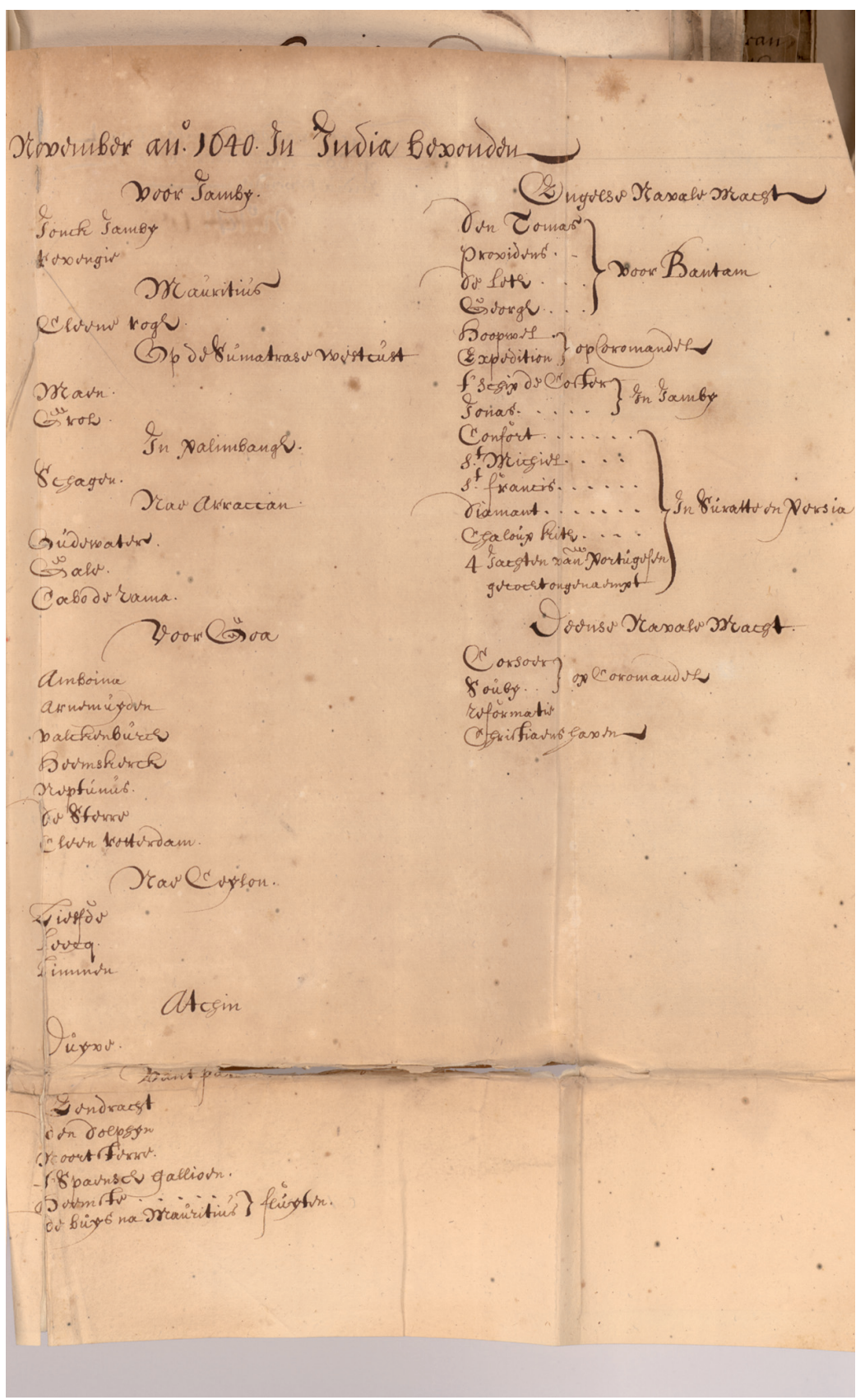


koste van de vlootinzet voor de kust van China en Japan. Deze bleef van I625 tot $\mathrm{I} 646$ constant op eenzelfde niveau van acht à tien schepen per jaar met een aantal uitschieters naar boven, bijvoorbeeld in $\mathrm{I}_{33}$ toen met vijftien schepen de aanval op de Chinese kust werd geopend of in I638 toen dertien rijkbeladen schepen naar Hirado voeren om de groei van de handel te kunnen bijhouden. ${ }^{\mathrm{I}}{ }^{\mathrm{In}} \mathrm{I}_{3} 6$ beschikte de Compagnie over genoeg schepen om zowel een grote vloot naar de Molukken te sturen, als de gebruikelijke zes tot acht schepen naar Taiwan en Japan te zenden, opnieuw de Straat van Malakka af te sluiten en voor de eerste keer Goa vanaf zee te blokkeren. Wat het overzicht vergrootte was de instructie in ${ }_{16} 66$ van de Heren Zeventien dat voortaan de schepen alleen nog in konvooi en alleen vanuit Batavia naar Nederland mochten vertrekken, dus niet meer alleen varend vanuit Suratte, zoals tot dan toe wel gebeurde. ${ }^{\text {I7 }}$

De gegroeide kracht van de VOC werd geaccentueerd door de gelijktijdige verzwakking van de Portugezen. Deze waanden zich nog veilig achter de muren van hun vestingen. ${ }^{18}$ Het waren er bij het aantreden van Van Diemen nog meer dan veertig, van Mozambique op de oostkust van Afrika tot aan Macao op de Chinese kust. Maar een vloot om die plaatsen voor een aanval vanaf zee te verdedigen was er niet meer. De laatste keer dat een grote Portugese vloot uit Goa wegvoer was in I629 naar Malakka, waarna deze een einde aan het beleg door de Atjeeërs maakte. Er waren in ${ }_{1} 6_{3} 6$ zelfs te weinig schepen om de jaarlijkse verbinding tussen Goa en Lissabon behoorlijk te onderhouden.

Tussen I63I en I640 bereikten 28 Portugese schepen Goa, minder dan de helft van de Io jaar daarvoor en slechts 15 schepen kwamen in die jaren uit Goa behouden aan in Lissabon. Twee decennia daarvoor ging het nog om drie keer zoveel schepen. ${ }^{\text {I9 }}$ Tussen I64I en I650 waren het er respectievelijk 42 voor de heen en 24 voor de terugreis naar Portugal. $^{20}$ De vergelijkbare aantallen voor de Compagnie spreken boekdelen: tussen I63I en I640 vertrokken I57 schepen vanuit Nederland en voeren 75 retour. In het decennium daarna ging het om I65 respectievelijk $93 .{ }^{21}$

Bij het aantreden van Van Diemen was het duidelijk dat de VOC de voornaamste 'zeemogendheid' in Azië was geworden. Overal waar zij naartoe voer, kon zij dat doen met een vloot die indruk maakte op haar vijanden of vrienden. Hierdoor kon de Compagnie haar positie vanuit kracht handhaven. Volgens Van Diemen was dat in de omgang met de tirannieke Aziatische vorsten noodzakelijk want 't Schijnt dat willen weten, hoe verre met ons gaen mogen'.22

'If no naval force no trade, if no fear no friendship' was ook honderd jaar later nog een geldige constatering. ${ }^{23}$ Van Diemen was daar uitgesproken in. Met de Compagnie werd niet gesold. 
Een tweetal fraaie voorbeelden om dit te ondersteunen. Het eerste speelde in Siam, het tegenwoordige Thailand, waar de VOC op zich een goede verstandhouding mee had. Het werd bekend als het 'picknick incident'. In september ${ }_{1} 6_{3} 6$ had de raad van Indië Justus Schouten een ambassade naar het hof van koning Prasat Thong geleid. Het was een grote gebeurtenis geweest. Twee schepen hadden de moeizame tocht stroomopwaarts naar de hoofdstad Ayutthaya gemaakt en, voorgegaan door een erewacht van honderd gewapende compagniessoldaten had Schouten met veel ceremonieel brieven en geschenken van stadhouder Frederik Hendrik aan de koning aangeboden. Daarnaast was een brief van Van Diemen overhandigd waarin deze zich beklaagde over de kleine hoeveelheid rijst die het jaar daarvoor vanuit Siam naar Batavia was gezonden. Vermoedelijk was door de zelfverzekerde toon van Van Diemen de trots van de koning gekrenkt, wat verklaart dat in december van datzelfde jaar veertien compagniedienaren hardhandig gevangen werden genomen nadat zij op de terugweg van een uitje dronken een tempel in de hoofdstad ontheiligd hadden, waarna zij direct voor hun vergrijp ter dood werden veroordeeld. Zij zouden vertrapt worden door olifanten. Om uitvoering van het vonnis te voorkomen bewoog Jeremias van Vliet, de opperkoopman ter plaatste, hemel en aarde. Hij nam de schuld voor het incident op zich en vernederde zich publiekelijk voor de koning. Hij had hiermee succes en de soldaten werden heelhuids overgedragen aan de Compagnie. Van Vliet was tevreden met de afloop en deed hierover in een lange brief verslag aan Van Diemen. ${ }^{24}$

Die reageerde daarentegen furieus. Wat had Van Vliet wel bezield om de eer en status van de Compagnie zo te grabbel te gooien. Van Diemen trok fel van leer tegen Van Vliet. 'Stroomde er wel 'Nederlands bloet' door zijn aderen,' zo vroeg hij zich in zijn brief aan Van Vliet af, 'dat hij zich als 'een buffel met een ring door zijn neus' had laten leiden? Had hij dan geen greintje eergevoel in zijn lijf?’ Volgens Van Diemen had hij onmiddellijk tegen de gevangenneming moeten protesteren en duidelijk moeten maken hoe makkelijk de Compagnie de kust van Siam kon blokkeren. Dan zou de koning het vonnis niet hebben durven uitvoeren. ${ }^{25}$

Deze tirade aan het begin van zijn gouverneur-generaalschap zal wel indruk hebben gemaakt op het personeel van de Compagnie. Het belemmerde Van Vliet niet nog een aantal jaren in Siam te blijven.

Het tweede geval speelde in I644. De handel met Perzië had zich onder Van Diemen voorspoedig ontwikkeld en jaarlijks werd hierop door de Compagnie rond 400 duizend gulden verdiend. Het kantoor in Gamron was dus een van de belangrijkste handelskantoren van de VOC. Vanaf i640 was echter de druk van de Perzische gezagsdragers op de VOC steeds verder toegenomen. Afspraken werden geschonden en voortdurend werd gepoogd de Compagnie en haar dienaren af te 
persen. In augustus I644 was de maat voor Van Diemen vol. Met geweld zouden de 'vexatiën en injuriën' een halt worden toegeroepen. Een vloot met zeven schepen en duizend man aan boord werd uitgezonden. Nadat eerst in alle stilte het kantoor in Gamron was gelicht, verscheen de vloot op de rede. Er werden twee scheepjes genomen en vervolgens werd het beleg geslagen voor het fort van Kismis (Qesh) op het gelijknamige eiland vlakbij Gamron met de bedoeling daar een tweede Hormuz van te maken. Het was een modern en sterk fort dat 25 jaar daarvoor door de Portugezen was gebouwd. Na zes weken was er echter nog geen bres geschoten. De meegenomen ladders waren te kort en de manschappen waren door de zomerhitte afgemat. Voortzetting van het beleg leek zinloos en het werd afgebroken.

Toch had de actie het gewenste resultaat. De Perzen wilden geen problemen met de Nederlanders die, als zij wilden, de handel over zee konden stilleggen. Hierop werd een Nederlandse delegatie met grote voorkomendheid aan het Perzische hof ontvangen. De Compagnie kreeg nieuwe voordelen en werd vrijgesteld van tol. ${ }^{26}$

De Heren Zeventien in Nederland waren er bijzonder ontstemd over dat zij over deze actie vooraf niet geraadpleegd waren. Zoveel haast was volgens hen niet nodig geweest en Van Diemen was veel te hard van stapel gelopen door een zo winstgevend kantoor op te breken en eigenmachtig het grote Perzische rijk de oorlog te verklaren. De goede uitkomst deed daar niets aan af. ${ }^{27}$

Het maakte niet veel indruk. De opvolger van Van Diemen, Cornelis van der Lijn, zou in I648-49 een vergelijkbare actie ondernemen voor de belangrijke Moghul-haven Suratte. Zoals voor Gamron een paar jaar eerder ging het ook hier om het tonen van de spierballen. ${ }^{28}$ Wat men er ook in Nederland van dacht, waar de regering in Batavia dat nodig vond, werd de zeemacht ingezet om de handelsbelangen veilig te stellen.

In de jaren tot 1650 nam de vloot van de VOC niet verder toe, maar dat was ook niet nodig, omdat haar suprematie onbedreigd bleef. Overigens relativeerde Van Diemen tegenover de Heren Zeventien steeds de omvang van de vloot. Dan weer gaf hij aan dat veel schepen in slechte staat waren, ${ }^{29}$ om het jaar daarop dringend om versterking van de scheepsmacht te vragen. ${ }^{30}$ In ${ }^{1} 638$ klaagde hij over een gebrek aan schepen en manschappen. ${ }^{3 \mathrm{I}}$ Toen in I640 op het hoogtepunt van de strijd tegen de Portugezen 25 schepen uit Nederland aankwamen, plaatste Van Diemen direct kanttekeningen. Zo waren de schepen een stuk kleiner dan die waarover Coen had kunnen beschikken in I6I9. Daarbij, zo stelde hij terecht, was de omvang van het bedrijf in een aantal jaren fors toegenomen. De retourvloot was gegroeid naar 9 à Io schepen met duizend man aan boord. ${ }^{32}$ 
Om over voldoende manschappen te kunnen blijven beschikken, eiste Van Diemen in december ${ }_{1} 636$ jaarlijks tenminste 3 duizend man waaronder duizend soldaten. India 'consumeerde' veel volk en bijvoorbeeld de Sumatraanse westkust, Borneo en Timor waren 'moortcuplen'. ${ }^{33}$

Ook dat getal groeide. In januari ${ }^{6} 643$ beklaagde hij zich erover dat maar 3600 man in Batavia waren aangekomen. ${ }^{34}$ Er waren 4500 toegezegd $^{35}$, terwijl het er minstens 5 duizend zouden moeten zijn. ${ }^{36}$ Op zich vonden de Heren Zeventien de vraag van Van Diemen naar meer manschappen begrijpelijk. Men deed wat men, kon zo werd aan Van Diemen geschreven, maar het 'aantal lieden' dat zich in Nederland aanmeldde om in dienst te treden van de Compagnie was 'schaars' door de andere vaarten en de visserij, maar vooral doordat de oorlogen in Europa aan velen het leven kostten. Voor het moment was de grens bereikt. $^{37}$

In de ons overgeleverde winst- en verliesrekeningen van de Compagnie in Azië werden de kosten van de vlootacties niet apart benoemd. Het is dus niet mogelijk om de vinger achter de kosten te krijgen, omdat ze onder de lopende kosten werden opgenomen. Zo kon in I637 de tocht van ruim 5 maanden met 2000 man en I7 schepen naar de Molukken in de boeken voor slechts 36 duizend gulden worden verantwoord. ${ }^{3}$ Ook de blokkades van Goa werden niet apart geadministreerd. Van Diemen schreef hierover dat de schepen immers ook steeds voor de handel werden gebruikt nadat ieder jaar in april de blokkade werd opgeheven. Voorts was het volgens Van Diemen zo dat door de hogere opbrengst van de peper dankzij de blokkade de kosten 'rijckelijck' werden goedgemaakt. ${ }^{39}$

Dat 'Sulcx die besettingh de Compagnie soo lastigh niet gevallen is, als wel uytterlijck geschenen heeft. ${ }^{40}$

Een uitzondering werd gemaakt voor de kosten van de campagnes op Ceylon. Deze werden overigens niet als last genomen, maar als een soort 'vooruitbetaalde kosten' in de boeken geactiveerd waarvan verwacht werd dat deze door de 'keizer' van Ceylon te zijner tijd zouden worden terugbetaald. ${ }^{4 \mathrm{I}}$

Van Dam becijferde dat Ceylon tussen I640 en I645 ongeveer een half miljoen gulden had gekost. Dat wil zeggen de lasten bedroegen ruim 600 duizend gulden, waartegenover opbrengsten stonden van meer dan een ton. ${ }^{42}$ Wat betreft de kosten van de zes of meer jachten die jaarlijks voor Malakka kruisten, werd gesteld dat dit een goede zaak was, omdat hierdoor de handel van Batavia was versterkt, ook al werden bijna geen Javaanse of Portugese schepen buitgemaakt. Handel en oorlog voeren steeds samen in hetzelfde schip.

Toen Van Diemen in zijn brieven naar de bewindhebbers in Nederland refereerde aan de vele brieven van participanten die bezwaar maakten tegen de hoge equipagekosten van het jaar I640, toonde hij zich 
hierover in het geheel niet onder de indruk en schreef dat er niet zoveel bezuinigd kon worden als sommigen wel dachten, omdat ook bij vrede de schepen en hun bemanning nodig zouden blijven om de handel te onderhouden. ${ }^{43}$

Hij zou hierin gelijk krijgen. Nadat in I644 met de Portugezen een wapenstilstand was gesloten zouden zijn opvolgers niet tot wezenlijke besparingen in staat blijken.

Het was ook niet zozeer dat Van Diemen een grote vloot ter beschikking kreeg, maar eerder het strategische gebruik dat hij ervan kon maken. Anders dan zijn voorgangers hoefde hij op zee voor niemand meer bang te zijn. Toen de strijd tegen de Portugezen naar zijn hoogtepunt ging, aarzelde hij niet om alle schepen daarvoor in te zetten. In december I638 bleven hierdoor op de rede van Batavia maar drie oude schepen achter. ${ }^{44}$

Van Diemens opmerking over het belang van dominantie op zee zou lang geldig blijven. Toen op het einde van de achttiende eeuw bij het uitbreken van de Vierde Engelse Oorlog de Engelse vloot voor het eerst in staat was de vaarroutes tussen Nederland en Azië af te sluiten, werd daarmee onmiddellijk het voortbestaan van de Compagnie bedreigd.

De rivaliteit tussen de VOC en de Engelse EIC zou in de eerste helft van de zeventiende eeuw een belangrijke rol spelen. Wij gaan hierna daarop eerst in voor aan het verhaal van de expansie van de Compagnie te komen.

\section{Noten}

I. Coolhaas, Generale Missiven, I, 580, Van Diemen 28 december I636.

2. MacLeod, De Oost-Indische compagnie als zeemogendheid II, 88.

3. Burke, E., The Writings and Speeches of Edmund Burke, Vol. V, India: Madras and Bengal 1774-1785 P. J. Marshall (ed.), (Oxford I98I) 389-90.

4. Nehru, J. The discovery of India (London I946).

5. Indian Merchants in the Age of Partnership, I500-I800, 28 in Ashin das Gupta, Merchants of Maritime India, 1500-1800 (Aldershot I984).

6. Chaudhuri, S. en K. Kévonian, Les Arméniens dans le commerce asiatique au début de l'ère moderne: Armenians in Asian trade in the early modern era (Paris 2008) 2.

7. Dijk, W. O., Seventheeth-century Burma and the Dutch East India Company, 1634-1680 (Kopenhagen 2006) I49. In I680 voeren de Armeense broers Jan en Joseph Markara met een relatief groot 
vrachtschip over de Indische Oceaan, waarmee zij olifanten en zijde vervoerden.

8. Andrade, T., 'The rise and fall of Dutch Taiwan, I624-I662: cooperative colonization and the statist model of European expansion', Journal of World History I7/4 (Honolulu 2006) 448: 'This antimarine bias is reflected in Mughal adages: for example, 'Mechants who travel by the sea are like silly worms clinging to logs'.

9. Coolhaas, Generale Missiven, I, 580, Van Diemen 28 december I636.

Io. Bruijn, Dutch-Asiatic Shipping, I, 28

II. Coolhaas, Generale Missiven, I, 460, 27 dec I634.

I2. Bruin, Dutch-Asiatic Shipping, I, 52

I3. Tabel 27 van Dutch-Asiatic Shipping, I, I44: Per decennium aantal opvarenden en schepen vertrokken uit de Republiek respectievelijk Azië.

I4. Bescheiden Coen IV, discours van 2I september I623

I5. NA VOC I082 Batavia 407 I6I9

NA VOC 1084 Batavia 20I-202 I625

NA VOC I087 Batavia I35-136 I625

NA VOC Io88 Batavia I I05-106 I626

NA VOC 109I Batavia 642-643 I627

NA VOC I093 Batavia 75 I627

NA VOC I095 Batavia 87-109 i628

NA VOC 1098 Batavia 219-220 I629

NA VOC I099 Batavia 2 92-93 I63I

NA VOC IIo3 Batavia I 64 I63I

NA VOC IIO4 Batavia 512-513 I632

NA VOC IIo8 Batavia 2619 I633

NA VOC IIo8 Batavia 2620 I633

NA VOC III5 Batavia 80I-802 I634

NA VOC III6 Batavia I94-I95 I636

NA VOC III9 Batavia 226-227 I636

NA VOC II22 Batavia 33I I637

NA VOC II26 Batavia 256 I638

NA VOC II29 Batavia 2 I2 I639

NA VOC II33 Batavia 80 I640

NA I.04.02 II34 Batavia 274 september I640

NA VOC II35 Batavia IIo I64I

NA VOC II38 Batavia I46-I47 I642

NA VOC II42 Batavia II2 I643

NA VOC II47 Batavia I25 I644

NA VOC II52 Batavia 207 I645

NA VOC II54 Batavia I46 I645

I6. Coolhaas, Generale Missiven, I, 736, 30 dec I638. 
I7. NA VOC 3I6 GM Patria, I23 24 september I636.

I8. Pissurlencar Assentos II Apendice IO, 516 brief van de bisschop van Meliapur aan de onderkoning in Goa over de zware verliezen van de Nederlanders tegen de Chinezen en de Spanjaarden.

I9. Newitt, M. D. D., A history of Portuguese overseas expansion, 14001668 (London 2005) 226.

20. Ibidem 239.

2I. Bruin, Dutch-Asiatic Shipping, I, I44.

22. MacLeod, De Oost-Indische compagnie als zeemogendheid, II, I62.

23. Chaudhuri, Trade and Civilisation, 3. Uitspraak uit I7I8 van de Charles Boone, Gouverneur van Madras.

24. Baker, C., D. Na Pombejra, A. van der Kraan en D. K.Wyatt, Van Vliet's Siam (Chiang Mai 2005) 37.

25. NA VOC 859, 742 en 774. 25 augustus en 4 september I637.

26. Baker, Van Vliet's Siam, 346.

27. Dam, van, II, derde deel, 295, Macleod II, I62-I67.

28. MacLeod, De Oost-Indische compagnie als zeemogendheid, II, 385.

29. Coolhaas, Generale Missiven, I, 579, 28 dec I636.

30. Heeres II, 332.

31. Coolhaas, Generale Missiven, I, 728, 28 dec I638.

32. Coolhaas, Generale Missiven, II, I20, 30 nov I640.

33. Coolhaas, Generale Missiven, I, 55628 dec. I636.

34. Coolhaas, Generale Missiven, II, I87, I3 jan I643.

35. NA VOC Gen Mis Patria 316, 39925 sept I642.

36. Coolhaas, Generale Missiven, II, I87, I3 jan I643.

37. NA VOC Gen Mis Patria 3I6, 342, 25 sept I642.

38. Zie tabel op p. I77.

39. Coolhaas, Generale Missiven, I 22 dec 1638.

40. Coolhaas, Generale Missiven, II, I70, I2-I2-I642.

4I. NA VOC I225 Batavia I72 ev.

42. Dam, van, Beschrijving VOC, Tweede deel, II, 434.

43. Coolhaas, Generale Missiven, II, I20, 30 november I640.

44. NA VOC ıı26, 256, Lijste van de Nederlantse navale macht in Indien op 22 December 1638. 


\title{
14 A tale of two companies: de concurrentie tussen de EIC en de VOC
}

\begin{abstract}
'But if any man allege the Dutch proverb, 'Live and let others live'; I answer that the Dutchmen notwithstanding their own proverb, do not only in these Kingdoms, encroach upon our livings, but also in other foreign parts of our trade (where they have power) hinder and destroy us in our lawfull course of living.' De Engelse koopman Thomas Mun in zijn verhandeling England's treasure by forraign trade, uit I63I. ${ }^{\text {I }}$
\end{abstract}

Johan Huizinga verhaalt in zijn 'Engelschen en Nederlanders in Shakespeare's tijd' dat lang voor de eerste Engelse Oorlog (I652-I654) 'Dutch' in de Engelse taal in overdrachtelijke zin ongeveer alles was gaan betekenen wat lelijk was. Dutch bride, Dutch gold, Dutch treat en al die andere vaak nog minder fraaie versieringen stammen uit de eerste decennia van de zeventiende eeuw. ${ }^{2}$ De Engelse politieke en militaire steun mocht dan van doorslaggevend belang geweest voor het succes van de strijd van de jonge Republiek tegen de Spanjaarden, door hun felle rivaliteit op het terrein van de handel hadden de twee natuurlijke politieke bondgenoten gedurende de eerste helft van de zeventiende eeuw een moeizame relatie. De emoties liepen hierbij hoog op vooral nadat 'the Massacre of Amboina' in mei I624 in Nederland en Engeland bekend werd. In vrijwel elke Engels-Nederlandse polemiek zouden decennia lang de cruel and barbarous tortures and excecutions van het personeel van de EIC op Ambon een rol spelen. ${ }^{3}$ Het Ambonse voorbeeld stond voor een harteloze handelspolitiek waarin de Nederlanders het eigenbelang boven alles stelden. Een vergelijking met Macchiavelli dringt zich op ook door het grafschrift dat op diens tombe staat: 'tanto nomini nullum per elogium', 'zoveel namen maar geen enkele lovend'. 4

De Nederlanders waren in Europa en daarbuiten niet geliefd. Dat was wat de Nederlanders in Azië wat de Engelsen betrof wederzijds. In de correspondentie van de VOC waren de Engelsen steevast de 'geveinsde vrienden' en nauwelijks te onderscheiden van de 'verklaarde vijanden'.

Zoals Chaudhuri beschreef, dolf de EIC in de eerste helft van de zeventiende eeuw het onderspit tegen de VOC., 6 De EIC was kleiner, minder agressief en leed met name gedurende het gouverneurs-gene- 
raalschap van Van Diemen chronisch aan geldgebrek. In december I636 schreef van Diemen dat er maar I2 Engelse schepen in Azië waren, waarvan een aantal er slecht aan toe was. Hij concludeerde tevreden 'sulcx dat wij die natie vooreerst ende totdat stercker equiperen, niet te duchten hebben."

Dat was de uitkomst van de concurrentieslag tussen de EIC en de VOC die minder voor de hand liggend is dan die op het eerste gezicht lijkt. De eerste dertig jaar van de zeventiende eeuw was de EIC namelijk aanzienlijk winstgevender dan de VOC en de investeerders stelden gedurende die periode in totaal bijna vijf maal zoveel kapitaal ter beschikking aan de EIC dan in $\mathrm{I} 602$ in de VOC was ingelegd. ${ }^{8}$ Waarin zat dan het verschil? Om dat te begrijpen moeten wij teruggaan naar de achtergrond van de oprichters van de EIC en de oprichtingsakte, het 'Charter'.

Toen de kooplieden van de Levant Company in juli 1599 uit Amsterdam het bericht kregen van het weergaloze succes van de scheepvaart van Van Neck, zagen zij onmiddellijk in dat hierdoor hun zeer winstgevende handel in specerijen vanuit Aleppo en Alexandrië zou verdwijnen. Het werd na een maand gevolgd door de mare dat de Nederlanders schepen in Engeland wilden kopen voor volgende tochten naar Java. Het was voor de Engelse kooplieden duidelijk dat als zij niet in actie kwamen en ook de route rond de Kaap zouden gaan volgen hun handel in peper en specerijen zou opdrogen. Onder leiding van de voornaamste kooplieden van de Levant Company werd besloten om aan Koningin Elizabeth toestemming te vragen hiervoor een nieuwe 'company' op te richten. In de herfst van 1599 liep het plan echter vertraging op doordat juist een Spaanse ambassade in Londen was aangekomen om bij de koningin de mogelijkheid te onderzoeken voor een Spaans-Engels vredesverdrag. Het tegelijkertijd openstellen door haar van de vaart naar Azië paste hier natuurlijk niet in. Na een jaar waren de onderhandelingen geheel vastgelopen en werd het initiatief opnieuw aan de 'Privy Council' van de koningin voorgelegd, dit maal met succes. ${ }^{9}$

Op 30 december $\mathrm{I} 600$ verleende koningin Elizabeth I aan 'our most dear and loving Cousin, George, Earl of Cumberland, and our well-beloved subjects, Sir John Hart, of London, and others' - hier volgden 2I4 namen het alleenrecht op de handel over zee op Azië voor een periode van vijftien jaar. Deze periode zou steeds stilzwijgend verlengd worden. De structuur waarin dat gebeurde is op zich helder: de kooplieden verenigen zich in one body corporate and politick. Zij kiezen jaarlijks uit hun midden een voorzitter (governor) en 24 directeuren (committees) voor het uitvoeren van de taken van de EIC. Daarnaast komen zij regelmatig in vergadering (court) bijeen waarin de voortgang wordt besproken en beslissingen worden genomen. De aandeelhouders kregen op de basis van one man one vote invloed op de gang van zaken bij de EIC. 
De kooplieden kregen het recht jaarlijks schepen en contanten uit te voeren en voor vier reizen vrijdom van belastingen. Anders dan bij de VOC werd niets geregeld over het kapitaal van deze Company. ${ }^{\text {IO }}$ De manier waarop de EIC werd gefinancierd was dus verschillend van de VOC. Door de EIC werd tot I6ı2 voor elke vaart op Azië apart een gezamenlijke rekening geopend. Op deze zogenaamde voyages konden de kooplieden die in het octrooi vermeld werden naar hun eigen believen inschrijven. Vergelijkbaar met de 'voyagies' van de Amsterdamse voorlopers van de VOC werd steeds per reis afgerekend. De winsten die door de EIC gemaakt werden waren ook op dit oude niveau en bedroegen vaak meer dan Io०\%. Om de administratieve chaos rond de heen en weer varende vloten te ondervangen werd in I6I3 overgestapt op een joint stock systeem waarin het geld voor een te voren bepaald aantal jaren ter beschikking werd gesteld aan de EIC. De eerste joint stock liep 8 jaar tot I62I en een tweede een stuk langer van I6I7 tot I632. Deze laatste was met een inleg van omgerekend ruim 16 miljoen gulden ruim tweemaal zo groot dan de 6,5 miljoen gulden kapitaal waar de VOC bij haar oprichting over kon beschikken. ${ }^{\text {II }}$ Er werd dus overgestapt op het systeem van afrekenen zoals dit ook voorzien was in het oorspronkelijke octrooi van de VOC. Het ging de EIC uitdrukkelijk om het handeldrijven met en in Azië en niet om zich permanent te vestigen. Steensgaard stelt op grond hiervan dat de EIC veel losser van de Engelse Staat opereerde dan de VOC in de Republiek. ${ }^{\mathrm{I} 2}$ Dat lijkt mij een verkeerde conclusie. De EIC had bij de oprichting een heel andere opvatting dan de VOC hoe de handel het best gevoerd kon worden.

Dit belangrijke verschil in uitgangspunten tussen de EIC en de VOC werd in I640 door niemand minder dan Hugo de Groot aan zijn zwager fraai geciseleerd als volgt omschreven:

'Ick ben van Ue opinie, dat op het beleid van de saecken van OostIndië de intentie van de Engelschen soo veel verschilt van de Hollandsche, dat tusschen deselve quaelijck eenige vereeniging van compaigniën sal connen vallen. De Engelschen soecken te gaen coopmansgewijs, de Hollanders oorlogswijse. De Engelschen soecken gereed proffijt te trecken, de Hollanders haere saecken voor altijd te stabiliëren." ${ }^{13}$

Doordat de EIC niet over permanent kapitaal beschikte concurreerde de EIC niet alleen met de VOC in Azië maar ook in Londen met de andere investeringsmogelijkheden die aan de kooplieden ter beschikking stonden. Dit laatste brak de EIC op bijna fatale wijze op toen de winsten van de enorme tweede joint stock ernstig tegenvielen. Het was hierdoor na I630 voor de EIC bijna ondoenlijk om nieuw kapitaal aan te trekken. Dit was zeker niet omdat de kooplieden armlastig waren, maar omdat zij het liever investeerden in andere markten. Zo waren veel kooplieden 
die bij de EIC betrokken waren ook actief in de Levant Company. Juist in de dertiger jaren van de zeventiende eeuw waarin gedacht werd aan het opheffen van de EIC maakte de Levant Company gouden tijden door. ${ }^{\mathrm{I}}{ }^{\mathrm{Bij}}$ de VOC daalde als het slecht ging de koers van het aandeel maar bleef het kapitaal intact. De EIC bouwde daardoor in de eerste helft van de zeventiende eeuw op veel kleinere schaal dan de VOC een permanente organisatie in Azië op. Van deze op zich bewuste keuze om de kosten zo laag mogelijk en de winst zo hoog mogelijk te maken, stapte de EIC in I634 af bij het begin van de derde joint stock. De directeuren raadden de aandeelhouders aan voortaan the wisdom of the Dutch tot richtsnoer te nemen en de winsten de eerste jaren opnieuw te investeren. ${ }^{\text {I5 }}$

Anders dan de VOC had de EIC dus terdege rekening te houden met haar aandeelhouders. Zoals wij hebben geleerd in de huidige economische crisis stimuleert dit alleen maar het korte termijn denken. Of en hoeveel schepen werden uitgezonden werd jaarlijks en in spannende tijden per kwartaal aan de aandeelhouders voorgelegd. Waar corporate governance bij de VOC vrijwel geheel ontbrak, was deze juist bij de EIC in al zijn glorie aanwezig, inclusief lastige en activistische aandeelhouders. Een fenomeen dat tegenwoordig elke aan de effectenbeurs genoteerde vennootschap kent en dat raden van bestuur en commissarissen tot wanhoop kan drijven. De governor en committees van de EIC werden tot hun grote ongenoegen de eerste ervaringsdeskundigen. De EIC kan zich er waarschijnlijk op beroemen dat zij de eerste daarvan in haar midden had. Thomas Smithwick heette hij en tot zijn dood in I642 was hij voortdurend in conflict met de directie van de EIC die hij bestookte met verzuurde en achterdochtige vragen afgewisseld met onwerkbare suggesties voor verbeteringen van de werkwijze van de EIC. Uiteindelijk werd hij voor insolent behaviour uit de vergadering verwijderd. ${ }^{\mathrm{I}}{ }^{\text {In }} \mathrm{I} 637$ bestond bij de directie van de EIC de vrees dat ontevreden aandeelhouders voor de ontbinding van de EIC zouden stemmen. De handel zou dan geheel in handen van de Nederlanders vallen, die om de Engelsen weg te concurreren bereid waren geweest met kleine winsten genoegen te nemen of zelfs met verlies te handelen. ${ }^{17}$ De belangrijkste argument dat hiertegen werd aangevoerd was dat 'the desertion of the trade will enrich the Hollanders and make them very proud neighbours ${ }^{\text {, } 8}$ maar ook dat 'by exporting East India commodities the Levant Company has prospered so much that it has almost driven the Hollanders out of the Mediterranean. ${ }^{\text {I9 }}$ Gezien de banden tussen de twee companieën zouden de kooplieden in eigen vlees snijden als de EIC ophield te bestaan. ${ }^{20}$

Daarnaast had de EIC te maken met wat wij nu een onbetrouwbare overheid zouden noemen. Koning Karel I verleende buiten het octrooi om vergunningen aan hem welgezinde kooplieden om aparte vaarten naar Azië te maken. De dreiging bestond volgens de directie 
van de EIC dat als de koning de EIC niet naar behoren zou beschermen de adventurers helemaal niet meer zouden inschrijven en 'the Dutch, taking advantage of the Company's weakness, will then become masters of the Indies ${ }^{21}$ en dat moest toch koste wat het kost voorkomen worden.

Het verschil tussen de EIC en de VOC zou na I649 verdwijnen met de puriteinse revolutie en het aantreden in Engeland van Cromwell. Cromwell zocht voor zijn 'commonwealth' politiek eerst een politieke eenheid met de Republiek en verregaande samenwerking in de handel. Toen de Nederlanders hier niets van wilden weten gingen de Engelse new-merchants waarop Cromwell steunde over op eenzelfde agressieve en militante manier van handeldrijven die tot dan toe de Nederlanders voorbehouden leek. Zoals Brenner schreef in zijn 'Merchants and Revolution', was dit het begin van 'a militant approach to foreign policy that was unprecedentedly favorable to the expansion of English trade and empire.... It initiated the use of political and military force to secure commercial and colonial parity with the Dutch, especially via the navigation act and the first Dutch war. ${ }^{22}$ Pas in deze fase dus na I649 ging de EIC over tot het bouwen van forten zoals het beroemde St George in Madras. Na de kapitaalsreconstructie van I657 beschikte de EIC ook over permanent vermogen en zou zij ontwikkelen tot een vennootschap die zich in eerste instantie kon meten met de VOC, maar die haar in de tweede helft van de $18^{\text {de }}$ eeuw zou overvleugelen.

Van Diemen kreeg bij zijn aantreden te maken met een nieuwe verwikkeling in de toch al complexe verhouding met de Engelsen in Azië. Om de Nederlanders te omzeilen hadden de Portugezen namelijk in I635 met de Engelsen een verdrag gesloten waarbij de Engelsen toegang kregen tot de Portugese havens. De Portugezen huurden hierop laadruimte in het Engelse schip de Londen dat in de zomer van ${ }_{16} 636$ van Goa via Malakka naar Macao voer. Nu vroeg Van Diemen aan de Heren Zeventien op een wel zeer bijzondere en arrogante manier hoe hij hiermee moest omgaan, als de schepen van de Compagnie die het vaarwater rond Malakka bezet hielden de London zouden aanhouden. Hij stuurde een brief mee met een Engels schip waarin hij schreef dat hij van plan was om Portugese goederen zonder meer uit Engelse schepen te lichten als die werden aangehouden. In de daarop volgende brief schreef hij daarentegen dat hij dit niet geïnstrueerd had, maar omdat de Engelsen de eerste brief voor aankomst zeker geopend en gelezen zouden hebben, zij zich hierover bij de bewindhebbers zouden hebben beklaagd. Daardoor zou Van Diemen vast snel te horen krijgen wat in dit geval hij wel en niet mocht doen. De werkelijke ontmoeting in de Straat van Malakka is door beide zijden uitvoerig beschreven. ${ }^{23}$ Uiteindelijk liep het met een sisser af omdat de Portugezen te trots waren meer dan één keer van de Engelse diensten gebruik te maken. De wer- 
kelijke vrees van Van Diemen dat Engelse schepen de verbinding tussen Goa en Lissabon zouden herstellen werd hierdoor niet bewaarheid.

Om de verhoudingen met de Engelsen niet onnodig op de spits te drijven verleende Van Diemen de Engelsen desgevraagd bijstand. Zo voorzag hij in I638 op verzoek van de president van de Engelse loge in Makassar een Engels schip ruimhartig van proviand en overige scheepsbenodigdheden voor de terugreis naar Londen. ${ }^{24}$

\section{Noten}

I. Mun, T., England's treasure by forraign trade. Reprint (Oxford I967) 6.

2. Huizinga, J., Verzameld Werk II, 350.

3. Chaudhuri, K.N., The English East India Company; the study of an early joint-stock company, 1600-1640 (London I965) 65.

4. Het graf van Macchiavelli met opschrift bevindt zich in Santa Croce te Florence.

5. Chaudhuri, The English East India Company, 56.

6. Zie ook W. Foster, England's quest of Eastern Trade, repr. 2000, 27I280, The Triumph of the Hollanders.

7. Coolhaas, Generale Missiven I, 579, 28 dec. 1636.

8. Idem, 209.

9. Foster, England's quest of Eastern Trade, repr. 2000, I44-I53.

Io. Mukherji, Panchanandas, ed., Indian Constitutional Documents (I600-I9I8). Vol. I. (Calcutta I9I8) I-20.

II. Ingeschreven kapitaal East India Company I600-I642. Bron: Chaudhuri, East india Company, 209. De tegenwaarde in guldens bedroeg ruim 32 miljoen gulden.

$\begin{array}{llll}\text { YEAR } & \text { VOYAGE } & \text { CAPITAL } & \text { PROFIT } \\ 1601 & \text { I st Voyage } & £^{68,373} & \\ 1603 & \text { 2nd Voyage } & £^{60,450} & \\ & & £ 128,823 & \text { 95\% combined } \\ 1606 & \text { 3rd Voyage } & £^{53,500} & \\ 1607 & \text { 4th Voyage } & £^{33,000} & \text { total loss } \\ 1608 & \text { 5th Voyage } & £^{13,700+} & \\ & & \left(£^{53,500)}\right. & \\ & & (3+5 \text { combined }) & \\ 1609 & \text { 6th Voyage } & £ 67,200 & 234 \% \\ 1610 & \text { 7th Voyage } & £ 80,163 & 121 \% \\ 1611 & \text { 8th Voyage } & £ 15,634 & 218 \% \\ 1611 & \text { 9th Voyage } & £ 55,947 & 211 \% \\ & & £ 19,614 & 160 \%\end{array}$




$\begin{array}{llll}1611 & \text { 10th Voyage } & £ 46,092 & 148 \% \\ 1611 & \text { 11th Voyage } & £ 10,669 & 230 \% \\ 1612 & \text { 12th Voyage } & £ 7,142 & 134 \% \\ 1613- & & & \\ 1621 & \text { 1st Joint-Stock } & >£ 418,691 & 87,5 \% \\ 1617- & & & \\ 1632 & \text { 2nd Joint-Stock } & £ 1,629,040 & 12,5 \% \\ 1628 & \text { I st Persian Voyage } & £ 125,000 & 60 \% \\ 1629 & \text { 2nd Persian Voyage } & £ 150,000 & 80 \% \\ 1630 & \text { 3rd Persian Voyage } & £ 100,000 & 40 \% \\ 1631- & & & \\ 1642 & \text { 3rd Joint-Stock } & £ 420,700 & 35 \% \\ 1 £=10 \text { gulden } & & \end{array}$

I2. Steensgaard, The Asian trade revolution of the seventeenth century, I974, I2O.

I3. Groot, H. de, Briefwisseling Hugo Grotius, XI no 4687. Aan N van Reigersberch 9 junir640.

I4. Sainsbury, E.B., A Calendar of court minutes EIC1635-1639, 245/292, Brenner, Merchants and Revolution, Io6.

I5. Chaudhuri, The English East India Company, 222.

I6. Sainsbury, A Calendar of Court minutes EIC I640-1643, I02, I26 en I57. Het uiteindelijke incident is voor de liefhebbers te mooi om niet nogmaals te boekstaven:

'Mr. Smithwick presses into the court in an uncivil and unmannerly fashion, and takes the seat of one of the Committees; and being rebuked by the Governor and others and desired to withdraw, as business of great importance is being discussed, he replies that he will not stir (unless he is thrust out) until he has received an answer to the order brought from the House of Commons. Hereupon he is informed that on conclusion of the present business he shall be called in; but not being satisfied he still keeps his seat. The Court being disturbed by his insolent and audacious behaviour (he having done the same many times before) and every one being ready to depart, Alderman Gayre advises him 'in a faire language' not to be thus refractory; wherupon he returned these words: that he would sit in the Court of Committees when Mr. Alderman should not. And notwithstanding all the intreaties and persuasions they could use, he refused to leave his chair or depart the court, untill by a general consent their beadle (ordebewaarder,pedel-w) was sent for and required to thrust him out; which, in obedience to their commands, and by reason of the obstinacy of the said Smithwick, he performed accordingly.' (I 3/4 pp.)(courtminutes. I640-I643 p. I57)') 
I7. Sainsbury, A Calendar of Court minutes EIC 1635-1639, 27I, memorandum gedateerd mei 1637 daar samengevat uit Public records Office East india.

I8. Idem, 272.

I9. Ibidem.

20. Sainsbury, A Calendar Court minutes EIC 1635-1639, 295, 303, 315, $334,335,336,34 \mathrm{I}$.

2I. Idem, 34I.

22. Brenner, Merchants and Revolution, 708.

23. Coolhaas, Generale Missiven I en Travels of Peter Mundy. Het is een grappig moment zoals de Nederlanders briefjes aan boord van de London gooien en de Engelsen aanbieden te delen in de buit.

24. Coolhaas, Generale Missiven I, 734, 30 dec I638. 


\section{De 'Memorie van Overgave'}

'Wij willen seggen dat uwen Generael in India niet min een ervaren coopman als cloecq soldaet verheijst te wesen' Antonio van Diemen aan de Heren Zeventien, december $1637^{1}$

Het komt voor dat een opvolger in een hoge positie van zijn voorganger een memorie van overgave krijgt waarin de voornaamste beleidspunten worden doorgenomen. Uit de beginperiode van de VOC heeft Coen zo voor Pieter de Carpentier in $\mathrm{I}_{2} 23$ een dergelijke advies bij zijn vertrek uit Batavia achtergelaten. ${ }^{2}$ Coen schreef voornamelijk over de zeer matige winstgevendheid van de VOC in de eerste twee decennia van haar bestaan en hoe die door bezuinigingen zou kunnen verbeteren. Twaalf jaar later heeft ook Brouwer aan Van Diemen een advies op de regeering en directie van Indië gericht. Het is niet in de officiële archieven van de VOC terechtgekomen, maar het werd later heimelijk in Batavia gekopieerd en is zo in een particulier archief bewaard gebleven. ${ }^{3}$ Het is een belangrijk stuk, want het geeft ons de mogelijkheid de agenda van Van Diemen in het perspectief van het beleid van zijn voorganger te zien. Hij schreef immers daags na zijn benoeming zelf naar de Heren Zeventien hoe tevreden hij met het bewind van Brouwer was geweest en hoeveel goeds dat had gedaan voor de VOC.

Van Diemen had expliciet aan Brouwer bij diens vertrek uit Batavia om het advies gevraagd. Hij hechtte dus waarde aan het oordeel van Brouwer.

Tijdens het eerste deel van zijn terugreis vertrouwde Brouwer zijn gedachten over de VOC in Azië aan het papier toe. Op 3I maart was hij hiermee klaar, terwijl de retourvloot voor anker lag in de baai van Robben-eiland bij de Kaap. De brief kwam daarna op een tot de verbeelding sprekende wijze bij de geadresseerde. Bij het vertrek van de vloot van de Kaap werden de brieven voor Batavia onder de zogenaamde Poststeen bij de Postboom achtergelaten in afwachting van de uitkomende vloot. Toen die in mei ${ }_{1}{ }_{3} 6$ de Kaap aandeed, werd de bundel brieven onder deze steen vandaan gehaald en meegenomen aan boord. Zo werd deze brief op 25 juli aan Van Diemen in Batavia overhandigd. ${ }^{4}$

Brouwer begon zijn advies met een in zijn soort interessante beschrijving van zijn vertrek en tocht. Hij was immers een echte zeeman. 
Daarna toonde hij zich retorisch verbaasd over het verzoek van Van Diemen, omdat zij elkaar toch zo goed kenden en in 'dagelijckse 29 maendige gehouden conversatie' het steeds eens waren geweest over hoe de positie van de Compagnie in Azië verbeterd kon worden en de handel vergroot om naar Nederland goede en winstgevende retouren te kunnen zenden. Maar daarna kwam hij 'ter materie'.

Veelbetekenend begon hij met een waarschuwing om de personen die in Batavia aankwamen vooral naar hun werkelijke kwaliteiten te behandelen 'voor wie, van wie en aan wie' hun aanbeveling voor benoeming in een hoge functie ook mocht zijn.'

Vervolgens ging hij kort in op de 'geringe oorlog' met Bantam waar de Heren Zeventien zijns inziens volledig misplaatst zo'n ophef over maakten. Als er een mogelijkheid kwam, zou Van Diemen maar vrede moeten sluiten met Bantam. Om Mataram in bedwang te houden zou een 'vlootje' van zes jachten steeds de kust van Java moeten afstropen. Als de bezetting van de Straat van Malakka werd volgehouden, zou de Javaanse handel verder bemoeilijkt worden waardoor 'het den Mattaram eerder dan ons sal coomen te verdrieten.'

Daarna volgde zijn eerste belangrijke advies. Het betrof de moeizame situatie op de Molukken rond het kruidnagelmonopolie. Brouwer zag de hernieuwde poging om dit te handhaven als veruit belangrijkste prioriteit voor Van Diemen:

'Maer alle de militaire macht die enigsints elders gemist sal connen werden dient op het spoedighst in de quartieren van amboina gebruijckt. Niet om eenige forten te beleggen nochte eenige verlatenen te repareren, maer op Ceram voor eerst alle de nagelboomen ende andere vruchtdragende te ruineren om alzoo te eerder des Compagnies wit te erlangen.'

\section{En even verder}

'gelieft doch dese vernielinge der nagelboomen wel te behartigen ende voor alle andere saecken, die eenigsints g'excuseert connen werden te preferen, alzoo vastelijcke is te verhopen dat het de Compagnie heel spoedigh groote voordelen in Nederlandt ende soulaes aen haere machten in Indien toebrengen zal.'

Belangrijk is ook wat Brouwer over de 'vigoreusche oorloghe' tegen de Portugezen schreef. Nadat in I634 en I635 een grote Nederlandse vloot langs Goa naar Suratte en Perzië was gevaren en het kruisen op Portugese schepen in het kanaal van Mozambique niets had opgeleverd, stelde hij aan Van Diemen een beperkte blokkade van Goa voor om aan de Portugezen zoveel mogelijk afbreuk te doen. ${ }^{6}$ Het zou een vloot van 
ten minste zes grote schepen moeten zijn om het tegen de Portugezen op te kunnen nemen: 'Alzoo de capitale schepen nergens beter als op de Indiasche Custen gebruijckt connen, aengesien men voor eerst noch niet en dient te resolveren voor Manilla te cruijsen om den Chinese handel niet te verachteren, dewijle daer geen ander buijt als die van de Chinese Joncken te halen is.'

Het doel was duidelijk: 'Conde men de Jaerlijkcx Caraacken inhouden die van Goa naer Portugael vertrecken, het soude de Comp andre proffijten toebrengen als de vracht van 't voeren der Moorse goederen uijt Indostan naer Gamron' (dat bracht alleen maar winst voor de particuliere handel van compagniesdienaren).Volgens hem zouden hiertoe het beste de schepen eerst in augustus van Batavia naar Perzië kunnen zeilen en nadat zij daar van lading waren voorzien op de terugweg de rede van Goa aandoen, die zij dan in de maanden februari en maart bezet zouden kunnen houden afhankelijk van de omvang van de Portugese vloot. ${ }^{7}$ Van de Japanse handel verwachtte Brouwer een blijvende groei. De cargasoenen zullen moeten blijven toenemen om de positie van de Portugezen te kunnen overnemen. En verder 'Hierom dient met alle industrie gepractiseert om de gemene Portugesen in Japan noch al hatiger bij de grooten te maecken dan sij zijn.'

Naast de grote verwachtingen van het te werkstellen van 'veele arme Chineesen' op Taiwan in de landbouw, wees hij Van Diemen op het mogelijke bestaan van goud- en zilvermijnen op Taiwan.

Ook gaf hij Van Diemen een aanval op Macao ter overweging, maar natuurlijk pas nadat de nagelbomen op Ceram verwoest zouden zijn.

Over de Engelsen en de meeste andere problemen raadde hij Van Diemen aan te wachten op het advies uit Nederland. Over personen liet hij zich niet uit, met uitzondering van Pieter Nuyts om wiens vrijlating uit Japanse gevangenschap was verzocht. 'Als Pieter Nuyts verlost en tot Batavia zal gecomen wesen, het zal noodigh zijn dat zijn proces andermael voor den raet van Jusititie werde gevideert.'

$\mathrm{Na}$ de uitspraak moest hij dan naar Nederland vertrekken 'Deweijle het in alle deelen blijckt, dat hij door zijn vremt naturel in Indien geen goede diensten sal connen doen. ${ }^{8}$ Dat zal voor Van Diemen wel een understatement zijn geweest.

Verder was Brouwer een groot voorstander van ontdekkingsreizen naar de goud- en zilvereilanden die ten oosten van Japan zouden liggen 'daer menighte laackenen ende andere Nederlandtse manifacturen als oock mede specerijen souden connen vertieren'. Hetzelfde gold voor de grote landen die bezuiden Banda zouden liggen.

Tot besluit benadrukte Brouwer dat het uiteindelijk om de retourlading ging want, 'geen meerder nog te grooter Eere can er in Indien bij den 
aldergequalificeerste dienaeren behaelt werden als met jaerleijckse groote retouren naer Nederlandt te senden in oncostelijcke en proffitgevende waren.'

Dat hing af van het succes van de Aziatische handel opdat vanuit Nederland met een 'oncostelijcke equipage' volstaan kon worden.

Alles met name naar het goede voorbeeld dat Brouwer zelf aan Van Diemen had gegeven 'soo als nu begonnen is daervan ickzelve de fondamenten over geleyt hebbende, als mede dat Ue daerop in conformite onzes voornemens voortbouwen zal om des werck volmaecktheijt te becomen, dat ick Ue van ganscher herten toewensche, aengesien mijn driejarigh verbandt te cort is geweest om gemelte werck naer wensch te voltrecken, Zoo nogthans mijn hope wel ware geweest om met die eere int Vaderlandt te mogen retourneeren.' ${ }^{9}$ Zijn afsluiting was warm en godvrezend:

'Hiermede concluderende en besluitende dit mijn advijs op de regeringe ende directie van Indien door mij ingestelt en aen Ue te senden op Ue versoeck, vrundelijcke ende ernstighe aenmaninge, soo bidde ick de almachtighe Godt ende Gever alle goede gaven dat hij Ue gelieve te verlenen tot den gewenschte uijtvoeringe van alles, dubbelen geest en krachten boven den mijnen ende dat hij door zijn grondeloose Barmhartitgheijt alle Ue doen ende verrichtinghe ten besten van de Compagnie zoo gelieve te begenadigen ende zeegenen dat er alles mach gedeijen tot zijnes heijligch naems loof prijse ende eere tot renome onzes vaderlandts, proffijt der participanten ende Ue bijsondere reputatie, Amen

Geschreven in't schip Nieuw Amsterdam, gelegen bij het Robben Eijlandt, den 31 maert anno $16_{3} 6$ Uw getrouwe dienstwillige vrunt,' Hendrick Brouwer

Brouwer was er overigens van overtuigd dat hij weer als bewindhebber bij zijn 'broeders' van de kamer van Amsterdam zou worden benoemd.

Het is duidelijk te zien hoe het advies van Brouwer aansloot bij de plannen van Van Diemen. Er is niet veel fantasie voor nodig om de gouverneur-generaal samen met zijn vertrouwde directeur-generaal aan het einde van de dag in samenspraak de plannen te zien maken.

Wij herkennen ook veel van de adviezen die Van Diemen zelf gegeven had in zijn generale missive van I63I. Wat dat betreft is er continuïteit in het beleid van Brouwer en Van Diemen. In zekere zin is het een rehabilitatie voor het bewind van Brouwer dat Van Diemen er veel van overnam. Niet voor niets had hij daags na zijn aantreden aan de Heren Zeventien geschreven dat hij zich volledig in het door Brouwer gevoerde beleid kon vinden en dat hij dit zou voortzetten. Het waren geen loze woorden geweest.

Er waren drie grote thema's die Brouwer veelvuldig met Van Diemen besproken had. Deze zouden ook de basis vormen voor het beleid van 
Van Diemen. De belangrijkste was de bevestiging van het kruidnagelmonopolie met alle mogelijke middelen. Ten tweede was daar de ontwikkeling op Taiwan en rond de Chinese en Japanse handel. De derde lijn was de strijd tegen de Portugezen in de Indische Oceaan. Door de inzet van de grootste schepen van de Compagnie voor een blokkade van Goa werd een confrontatie met de Portugezen geforceerd.

Deze drie punten vormden de kern van de agenda van Van Diemen.

In elk van de drie voornaamste geografische gebieden waar de Compagnie actief was, had deze expansie een geheel eigen karakter. Bij de uitvoering hiervan legde hij een rücksichtsloze ambitie aan de dag. Hoeveel mensen omkwamen, was van geen belang als het doel maar werd bereikt. Of het nu ging om de dorpen op Ambon onder het gezag van de Compagnie terug te brengen, wraak te nemen op inheemse stammen in Taiwan, of Portugese vestingen te veroveren. Waar Brouwer zich nog voornam 'groote concepten te sullen breydelen' zou bij Van Diemen alles op expansie van de macht van de Compagnie gericht zijn. ${ }^{\text {Io }}$

Van Diemen bracht de ontwikkeling van de VOC in een stroomversnelling en het resultaat zou zijn dat hij als empire builder niet onderdeed voor Coen, zeker ook niet wat betreft het geweld dat hij hierbij gebruikte. Een duidelijk verschil met Coen is dat Van Diemen zijn beleid grotendeels onafhankelijk van de Heren Zeventien formuleerde, én uitvoerde.

\section{Noten}

I. Coolhaas, Generale Missiven I I, 64I. 9 december 1637.

2. Colenbrander, Jan Pietersz. Coen, Bescheiden III, 288-307.

3. NA I.I0.78 Collectie Sweers no 3 f I-22.

4. Voor de data van de uitvarende vloot: Bruin, Dutch Asiatic Shipping 2,72 .

5. NA I.I0.78 Collectie Sweers, 3v.

6. MacLeod, De Oost-Indische compagnie als zeemogendheid in Azië II, $68 \mathrm{ev}$.

7. NA i.Io.78 Collectie Sweers f7.

8. Idem fiov.

9. Idem f2Iv.

Io. Coolhaas, Generale Missiven I, 470. 27 dec I634. 


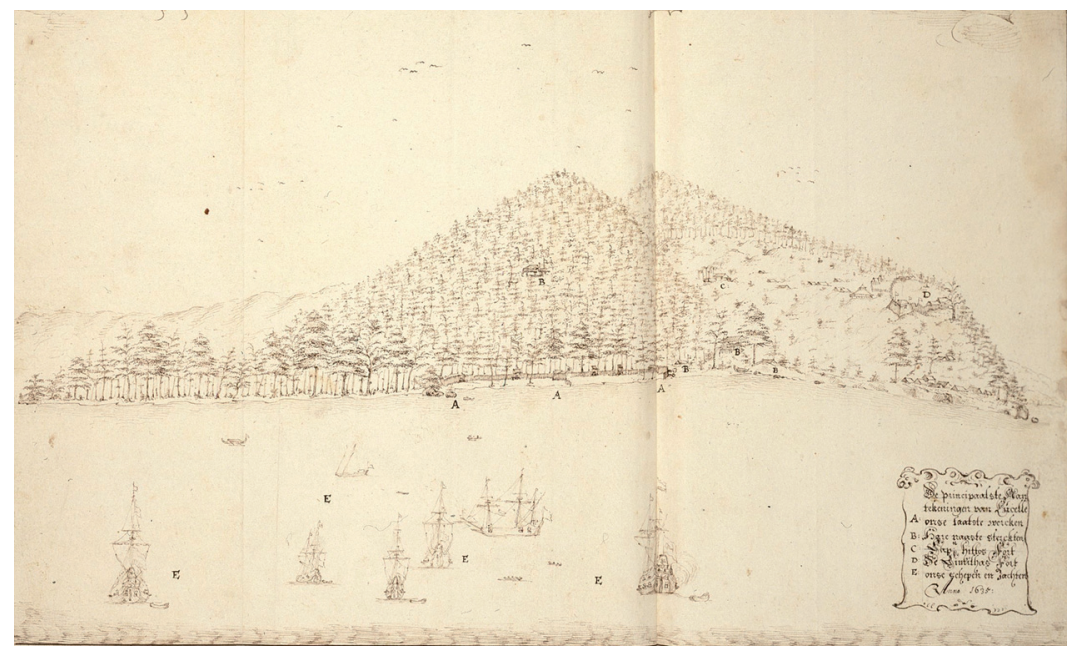

Artus Gijssels tekende in 1635 deze kaart tijdens zijn mislukte beleg van het sterke rebellen fort Lusiëla op Ceram, het knooppunt van de kruidnagelhandel buiten de VOC om. In januari 1637 gebruikte Van Diemen deze schets om zijn geslaagde bliksemaanval voor te bereiden. Badische Landesbibliothek, Karlsruhe. 


\section{De bevestiging van het kruidnagelmonopolie, Ambon en de Molukken}

De vloot die in de loop van ${ }_{1} 636$ uit Nederland in Batavia aankwam, was niet bedoeld voor een aanval op de Portugezen. In de brief van de Heren Zeventien die de vloot begeleidde, werd overduidelijk aangegeven dat de handhaving van het kruidnagelmonopolie het belangrijkste, zo niet het enige doel voor Van Diemen moest zijn, én blijven. ${ }^{\mathrm{I}}$

Hoe weinig effectief dat monopolie op dat moment was, bleek uit de grote aanvoer van nagelen door de Engelsen. In de herfst van ${ }_{1} \sigma_{3} 6$ waren twee Engelse retourschepen aangekomen die bij elkaar 300 duizend pond nagelen aan boord hadden. ${ }^{2}$ Om de markt voor hen te bederven werd prompt door de VOC dividend in de vorm van nagelen uitgekeerd. ${ }^{3}$ De Heren Zeventien ordonneerden:

'Achter volgende onze voorgaande ordre jaerlijkcks te continueren met het uitroeien van de nagelbomen in de verscheidene kwartieren zonder enige intermissie of verschoninge alle hoeken en gaten te doorsnuffelen. ${ }^{4}$

In hun brief van het jaar daarop schreven zij dat na lange 'patientie' nu de tijd was gekomen:

'Het momaanzicht af te leggen en Amboyna (alwaer doch soo veele nagelen en meer nagelen als de gehele werelt verteren can vallen) te verseeckeren en alle andere te vernietigen. Waermede wij dan den handel met exclusie van alle anderen geheel moogen versekert blijven 't welck dan oock met soodanigen competente macht onder het beleyt van swackere opperhoofden. ${ }^{5}$

Het was ook het belangrijkste advies van Brouwer aan Van Diemen geweest om

'Maer alle de militaire macht die enigsints elders gemist sal connen werden dient op het spoedighst in de quartieren van Amboina gebruijckt. Niet om eenige forten te beleggen nochte eenige verlatenen te repareren, maer op Ceram voor eerst alle de nagelboomen ende andere 
vruchtdragende te ruineren om alzoo te eerder des Compagnies wit te erlangen.'

En even verder

'Gelieft doch dese vernielinge der nagelboomen wel te behartigen ende voor alle andere saecken, die eenigsints g'excuseert connen werden te preferen, alzoo vastelijcke is te verhopen dat het de Compagnie heel spoedigh groote voordelen in Nederlandt ende soulaes aen haere machten in Indien toebrengen zal. ${ }^{, 6}$

Vanaf haar oprichting werden de monopolies in kruidnagelen, foelie en nootmuskaat de belangrijkste steunpilaren van de VOC. 'Met geweld of tractaat' moesten de eilanden waar deze specerijen groeiden aan de VOC worden verbonden.7 Op papier werden vóór I6ı de gewenste overeenkomsten verkregen in de Molukken en de Banda-eilanden.

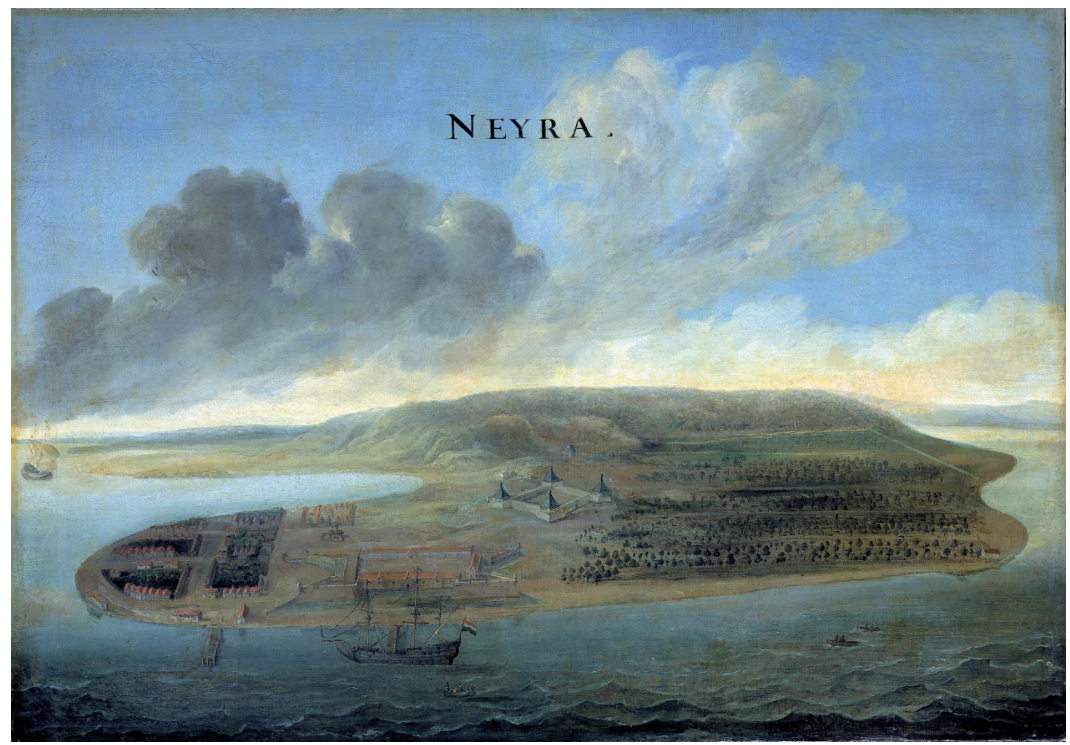

De minuscule Banda-eilanden zijn bij elkaar aanzienlijk kleiner dan Texel. Zij liggen dicht bij elkaar en rijzen op uit een kilometers diepe oceaan rond een actieve vulkaan. Op elk ervan liggen nog steeds de grote forten van de VOC. Op het hoofdeiland Banda Neira zelfs twee. Het bezit van deze archipel waarop als enige plek ter wereld de nootmuskaat groeide, was goud waard. Rijksmuseum Amsterdam. 
Toen ik deze tractaten voor het eerst las, kreeg ik een ongemakkelijk gevoel: de VOC was een wolf nauwelijks verhuld door schaapskleren. Namelijk, als dank voor de bevrijding uit de handen van de Portugezen werd plechtig een 'eeuwig verbondt' met de VOC gezworen en beloofden de inwoners de nagelen of nootmuskaat en foelie 'niemandt zullen verkoopen als aan de Hollanders' en wel tegen een vaste prijs die buiten het verdrag werd overeengekomen. Deze prijs zou natuurlijk steeds laag zijn. $^{8}$

Op deze contracten baseerde de VOC haar recht om dit monopolie met alle middelen te handhaven. Het besef dat het woordje 'eeuwig' het verlies van hun vrijheid en vaak hun leven zou betekenen, drong bij de Molukkers en Bandanezen in de jaren daarna pas door toen de VOC forten bouwde en de gewelddadigste middelen die zij tot haar beschikking had, zou inzetten om de monopolies ook werkelijk te verkrijgen.

Ten tijde van het aantreden van Van Diemen was het monopolie op foelie en nootmuskaat vijftien jaar eerder door Coen veroverd met de dood of deportatie van het merendeel van de oorspronkelijke bevolking van de Banda-eilanden. Toch bleef men er in Nederland niet gerust op. Nog in april I635 riepen de bewindhebbers op om vooral ook de laatste 'zuivere Bandanezen te vervangen door slaven.' 9

Op de Molukken lag dat anders. Daar was de VOC al meer dan dertig jaar gewikkeld in een hardvochtige campagne. Zoals Matelief had voorzien, zou het verkrijgen van het monopolie in de kruidnagelen moeizaam zijn. De strategie van de VOC was erop gericht de kruidnagelteelt te concentreren op Ambon en een paar kleine eilandjes daar vlakbij, waarover men het beste het gezag kon uitoefenen.

Daartoe werden op alle andere eilanden in de Molukken de kruidnagelbomen omgehakt.

Deze strategie, de dwingende verdragen en vooral de mogelijkheid om buiten de VOC een veel hogere prijs voor de kruidnagelen te krijgen, werkte ontduiking en opstand in de hand. De vaste inkoopprijs van de VOC bedroeg vijf stuivers het pond, terwijl buiten het gezag van de VOC de prijs tenminste het drievoudige daarvan bedroeg. ${ }^{\text {Io }}$ Rond I635 was er sprake van een openlijke opstand tegen de VOC. De rebellen hadden als voornaamste uitvalsbasis een groot fort, Lusiëla, op het eiland Ceram. Toen in maart I635 een poging van de gouverneur van Ambon om Lusiëla te veroveren in een nederlaag eindigde, was de crisis voor de Nederlanders compleet. ${ }^{\text {II }}$

De manier waarop Van Diemen hierop reageerde, was doortastend en met risico. Zoals hij in I63I al geschreven had, dacht hij dat een grote expeditie vanuit Batavia tezamen met diplomatie de Molukken zou kunnen beteugelen. In dit verband hechtte hij geen waarde aan kostenverslindende grote forten of garnizoenen. 
De meest ongebruikelijke stap was nu dat hij zichzelf aan het hoofd stelde van de vloot die 30 december ${ }_{16} 66$ uitvoer. Misschien was Van Diemen ook gewoon nieuwsgierig. Hij was in achttien jaar nooit verder gekomen dan Batavia en omgeving. Nu had hij een reden de specerij-eilanden met eigen ogen te zien. Op zijn voorstel had de Raad van Indië zijn tweede man, Philips Lucasz, tot zijn plaatsvervanger benoemd.

Het was een forse vloot van I7 schepen bemand door 8io matrozen, 905 soldaten, 60 Bandanezen, 70 Maredijkers en 200 lijfeigenen. Met Van Diemen ging zijn vrouw, Maria, mee en een persoonlijk gevolg van 25 'coppen'. I2 Bij elkaar 2070 'zielen'.

De tactiek die Van Diemen volgde, was gewaagd. De vloot voer zonder ergens aan land te gaan rechtstreeks naar de baai op Ceram waaraan het onoverwinbaar gedachte fort Lusiëla lag. In de vroege ochtend van de $20^{\text {ste }}$ januari gingen 1575 man van de vloot daar aan land.

Uit het verslag is te lezen hoe Van Diemen persoonlijk nauw bij de voorbereiding was betrokken. Maar 'aangezien de alles verslindende oorlog in het uitdelen van zijn blinde vruchten niemand ontziet' was door de scheepsraad besloten dat Van Diemen van zijn plan af moest zien om zelf met het leger te velde te gaan. ${ }^{\mathrm{I}}$ De leiding van de aanval kreeg Antonio Caen.

Nadat onder slechts sporadisch vuur vanaf de wal de landing geslaagd was, trokken de vendels door het oerwoud bergopwaarts naar het fort en werd de werkelijke aanval ingezet. $\mathrm{Nu}$ onder fel vuur begon de stormloop. Deze verliep eerst moeizaam omdat de meegebrachte ladders te lang waren en makkelijk van de borstwering teruggeduwd konden worden. Snel werd een gedeelte afgezaagd waarna de muur op verschillende plaatsen beklommen kon worden, waarop de verdedigers wegvluchtten. Zo was de 'voor onoverwinbare gerenommeerde sterkte' voor Io uur 's ochtends gevallen. ${ }^{\text {I4 }}$

Aan Nederlandse kant waren Io doden te betreuren en 38 gewonden van wie er later nog 8 bezweken. In het fort werden de lijken van slechts 2 verdedigers aangetroffen, de rest van de bezetting was gevlucht.

Na deze overwinning verpakte Van Diemen zijn ijzeren vuist in fluweel. Hij schreef de afvallige hoofden persoonlijk aan als 'waarde vrunden' en nodigde hen met klem uit op een landdag in het kasteel van Ambon. Hij toonde zich bereid het gepasseerde 'in het diepste des zees te begraven' om vervolgens eventuele klachten minnelijk tegemoet te komen. Maar, als zij niet op de genoemde dag naar het kasteel zouden komen, dan zouden zij voortaan als rebellen en vijanden van de Nederlandse staat beschouwd worden. ${ }^{\text {I5 }}$

In de maanden die volgden, neutraliseerde Van Diemen met geweld en onderhandelingen zoveel mogelijk dorpen. Het contract dat uiteinde- 
lijk op I juni I637 werd ondertekend, bevestigde het monopolie. Om tegemoet te komen aan de klachten beloofde de VOC de prijs van rijst en kleden die door de VOC werden aangevoerd 'wat civijler' te zullen vaststellen. ${ }^{\text {IG }}$

Op de terugtocht naar Batavia deed de vloot Makassar aan. Daar werd niet zozeer een vredesverdrag overeengekomen, als wel Makassar tot neutraal gebied verklaard, zowel voor de Nederlanders als de Portugese en Spaanse vijanden. De Nederlanders mochten echter wel met geweld optreden tegen schepen uit Makassar die in door Nederlanders bepaald 'onvrij vaarwater' omtrent Malakka, Ceram en de Molukken zouden komen, zonder dat daarmee het verdrag zou worden verbroken. ${ }^{17} \mathrm{Om}$ de grimmige militaire macht te onderstrepen achter deze diplomatie vuurde ter 'viering' van de ondertekening de vloot meerdere malen uit alle kanonnen. Een duidelijke boodschap. Tegen de verwachting in hield deze 'vrede' tot na I650 stand. ${ }^{\mathrm{I} 8}$

In I638 ondernam Van Diemen nogmaals de tocht naar Ambon en de Molukken, ditmaal om met de sultan van Ternate de afspraken over het kruidnagelmonopolie opnieuw te bevestigen. Sultan Hamsa van Ternate was de regerend vorst over de Molukken op een gedeelte van Ambon en wat kleine omliggende eilanden na. Het verdrag werd uiteindelijk na vele vertragingen in juni 1638 getekend.

Het beschrijft de tactiek van Van Diemen en begint in een zeer verontwaardigde toon over hoe trouweloze onderdanen van de sultan de verdragen 'om vuil gewin' hadden geschonden en dat door de Nederlanders wel moest worden opgetreden, zoals het jaar daarvoor was gebeurd. Onderdanen van de sultan die het monopolie trachten te ontduiken, zouden door de VOC met de dood gestraft mogen worden. Voorts werd de lage inkoopprijs voor de Compagnie bevestigd van 60 realen voor een baal van 550 Hollandse ponden. De verkoopprijs in Makassar bedroeg hetzelfde jaar bijna het drievoudige hiervan, namelijk I7o realen. Dat was de prijs die de Nederlanders er zelf voor hadden moeten betalen, omdat zij nagelen tekort kwamen voor handel in Azië. Die prijs van I70 realen werd gezien als de laagste prijs die ooit op de 'vrije' markt was betaald. ${ }^{\text {I9 }}$

Hiertegenover werd het territoriaal gezag van de sultan uitgebreid en tot slot werd de sultan omgekocht. Aan hem en zijn opvolgers zou jaarlijks een bedrag van vierduizend realen door de VOC uitgekeerd worden, als zij zich sterk zouden maken dat alle kruidnagelen in de Molukken en Ambon alleen aan de VOC zouden worden geleverd en hij tevens zijn medewerking zou geven aan de vernietiging van alle nagelbomen buiten het door de Compagnie aangewezen gebied. ${ }^{20}$ 


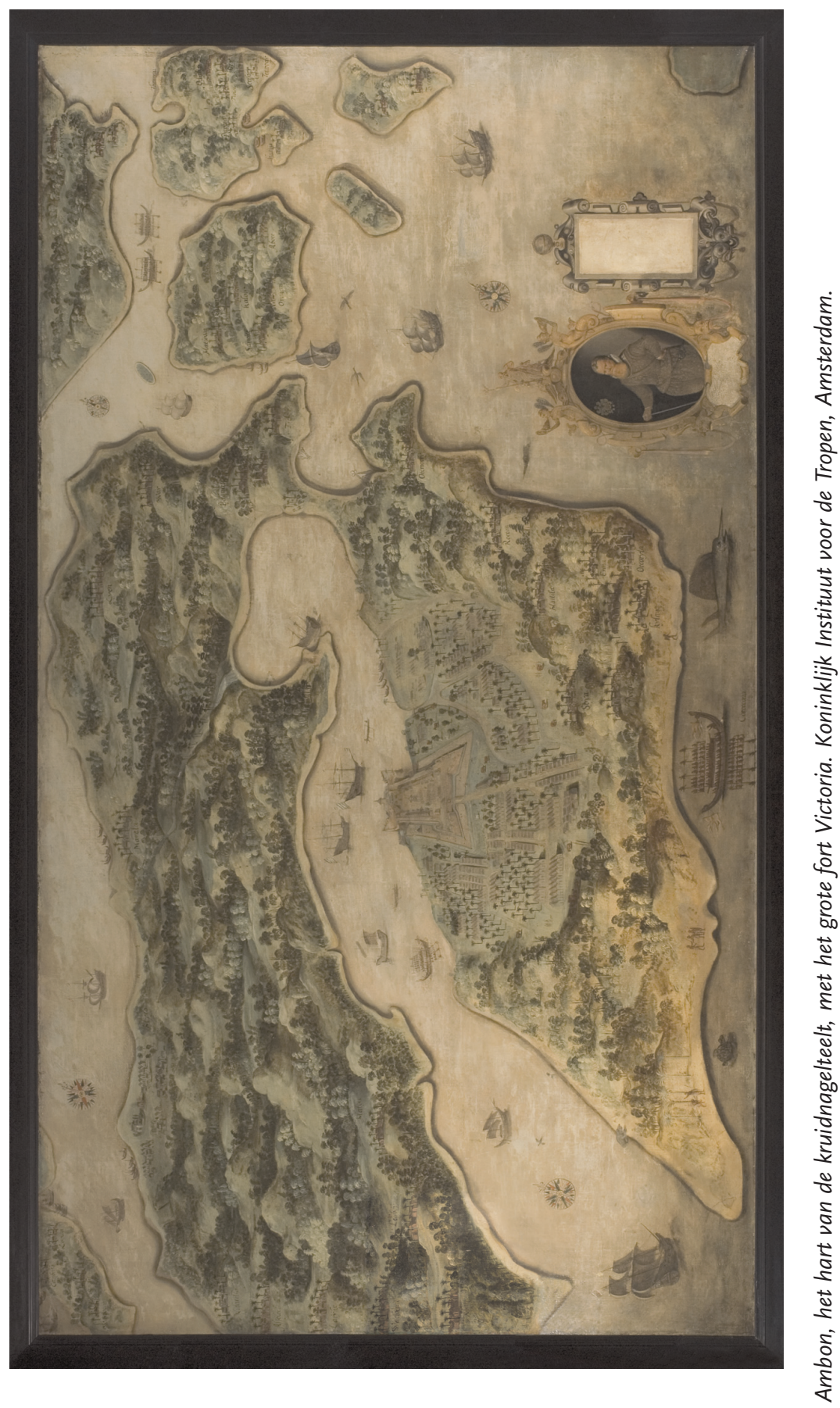


Bij zijn terugkeer in Batavia riep Van Diemen net als het jaar daarvoor een overwinning uit, maar deze bleek zeker niet volledig te zijn. Weliswaar was het Nederlandse gezag onmiskenbaar versterkt en de opstand goeddeels bedwongen, maar met hulp van Makassar werd het monopolie op Ambon en de Molukken nog steeds ontdoken. De winsten die met kruidnagelen behaald konden worden, waren te aantrekkelijk voor velen. Veel mensenlevens werden daaraan opgeofferd.

Deze expeditie zou de laatste vlootexpeditie zijn die onder het commando van een gouverneur-generaal werd gemaakt. Dat Van Diemen met de eerste tocht was meegegaan, werd al roekeloos gevonden vanwege 'het perikel te loopen van sijn hooft te stooten'.2 ${ }^{21}$ Hij leek echter de smaak te pakken te hebben gekregen en had het plan opgevat mee te gaan met de vloot die op het punt stond uit te varen om op Ceylon de grote Portugese vesting Colombo aan te vallen. Zijn omgeving greep echter in en op I5 augustus I639 werd in een resolutie door gouverneur en raden vastgesteld dat een gouverneur-generaal Batavia niet mocht verlaten, tenzij de taak niet door een raad van Indië kon worden uitgevoerd, wat natuurlijk nooit het geval was. ${ }^{22}$

Ondertussen klaagden de Heren Zeventien dat ondanks de twee tochten van Van Diemen de Engelsen in I640 toch weer kruidnagelen hadden overgevaren uit Azië. ${ }^{23}$ Het bleef hun natuurlijk een doorn in het oog dat de Compagnie in Makassar kruidnagelen opkocht die haar volgens de Heren Zeventien al rechtens toekwamen. Zij hadden dan ook weinig begrip voor de inzet van de vloot voor Ceylon, want nergens konden de 'wapenen van de Compagnie' beter worden ingezet dan om de nagelhandel te verzekeren. ${ }^{24}$

Op Ambon en de Molukken concentreerde in de jaren die volgden het verzet tegen de VOC zich op Hitu, het grote noordelijke schiereiland van Ambon. De tragische held was hier de voorman, 'kapitan Hitu', Kakiali. Hij wilde de onafhankelijkheid van Hitu behouden en kreeg hierin natuurlijk volop steun vanuit Makassar. Het zou voor velen letterlijk uitstel van executie betekenen. In $\mathrm{I}_{42} 2$ werd een grote vloot die uit Makassar naar Hitu was gevaren om kruidnagelen te halen, door de schepen van de Compagnie in de grond geboord. Kakiali verschanste zich met zijn volgelingen en de gestrande Makassaren in het gebergte. Een korte veldtocht onder leiding van Antonie Caen maakte aan dit verzet meedogenloos een einde. Kakiali zelf was vlak daarvoor door een overloper vermoord. ${ }^{25}$

Dat door deze actie al vanaf 1642 gesproken kan worden van een monopolie voor de Compagnie zoals Knaap stelt, gold wellicht voor Europa, omdat de EIC door de Engelse burgeroorlog geen middelen meer had om in Makassar in te kopen. ${ }^{26}$ Als gevolg hiervan zou in 1644 voor het laatst een dividend aan de aandeelhouders van de Compagnie ge- 
heel of gedeeltelijk in kruidnagelen worden uitgekeerd. Voortaan was het geheel in contanten. ${ }^{27}$ Maar in Azië lag dat anders. De verkoopprijs van kruidnagelen in Suratte steeg pas na $1653 .{ }^{28}$ Boxer beschreef hoe de Portugese handelaar Francisco Vieira de Figueiredo rond I650 nog op vrij grote schaal in kruidnagelen handelde. ${ }^{29}$ Juist in de periode I636 tot $6_{54}$ bleef de verkoopprijs van kruidnagelen in de belangrijke Indiase havenstad Suratte laag. ${ }^{30}$

Ook aan het bloedvergieten was nog geen einde gekomen. In I65I brak de Grote Ambonse of Hoamoalese oorlog uit die tot ${ }_{1} 6{ }_{5} 6$ zou duren. Met bijzonder hard optreden werd in die jaren het gezag van de Compagnie bevestigd. ${ }^{3 \mathrm{I}}$ De kruidnagelteelt werd volledig op Ambon en de omliggende kleine eilanden geconcentreerd. Makassar werd uiteindelijk in 1667 veroverd door de VOC zodat het kruidnagelmonopolie niet meer bedreigd kon worden. ${ }^{32}$

\section{Noten}

I. $\quad$ NA VOC 3 i6 $\mathrm{f} \mathrm{66,} \mathrm{2I} \mathrm{april} \mathrm{i635.}$

2. NA VOC 316 f I40. Kamer Amsterdam 25 januari i6 36 .

3. NA VOC $316 \mathrm{f} 67.2 \mathrm{I}$ april $\mathrm{I} 635$.

4. NA VOC $3 \mathrm{I} 6 \mathrm{f} 68$.

5. NA VOC 316 f 128.

6. NA I.I0.78 Collectie Sweers eerste deel I-22 brief Brouwer aan Van Diemen $\mathrm{I}_{3} 63 \mathrm{~V}$.

7. Heeres, J. E., Corpus Diplomaticum Neerlando-Indicum, verzameling van Politieke contracten en verdere Verdragen door de Nederlanders in het Oosten gesloten, van Privilegebrieven, aan hen verleend, enz. ('s-Gravenhage I907) 66.

8. Ibidem 32; 63 , Molukken, juli I609; 67 , Banda io augustus I6०9

9. NA VOC $3 \mathrm{I} 6 \mathrm{f} 68$.

IO. De Jonge, De opkomst van het Nederlandse Gezag in Oost-Indië, II, 352. Generale Missive 22 december 1638.

II. Knaap, G. J., 'Crisis and failure: war end revolt in the Ambonese Islands, I636-I637', Cakalele, Maluku Research Journal 3 (1992) p. I27.

I2. Het 'Journael' van de expeditie van I637 naar Ambon is bewaard gebleven in het Regionaal Archief van West-Friesland in Hoorn (Oud Archief Enkhuizen 399). Het Journaeal is getranscribeerd door Mevr J.Steendijk-Kuypers en mij welwillend ter hand gesteld door Dr. G.J. Knaap. Vandaar de verwijzing naar Enkhuizen 399.

I3. Enkhuizen 399, I8.

I4. Ibidem 24 .

I5. Ibidem 70. 
I6. Heeres, Corpus Diplomaticum Neerlando-Indicum, I, 302.

I7. Ibidem 304.

I8. MacLeod, De Oost-Indische compagnie als zeemogendheid in Azië, II, 255 en 295.

I9. Generale Missiven 22 december I638, afgedrukt Tieles Heeres II, 352.

20. Heeres, Corpus Diplomaticum Neerlando-Indicum, I, 316-324.

2I. NA VOC 3I6, f I56, 3 oktober 1637.

22. Chijs, J. A. van der, Realia: register op de generale resolutien van het kasteel Batavia, 1632-1805 3 delen (Leiden I882) 469, Resolutie GG en Raden dd I5 augustus 1639.

23. NA VOC 3І6, 297V iI september I640.

24. NA VOC 3i6, 3465 september i64I.

25. Knaap, Kruidnagelen en Christenen, 32.

26. Ibidem 28.

27. MacLeod, De Oost-Indische compagnie als zeemogendheid in Azië, II, 247-295, Knaap, 'Crisis and Failure', 21.

28. Santen, H. W. van, De Verenigde Oost-Indische Compagnie in Gujarat en Hindustan, bijlage 2, $2 \mathrm{I} 7$.

29. Boxer, C. R., 'Francisco Vieira de Figueiredo: a Portuguese Merchant-Adventurer in South East Asia, I624-I667', Verhandelingen van het Koninklijk Instituut voor Taal-, Land-en Volkenkunde Vol. 52. ('s-Gravenhage i967).

30. Santen, van, De VOC in Gujarat en Hindustan, 48.

31. Knaap, Kruidnagelen en Christenen, 34.

32. Gaastra, Geschiedenis van de VOC, 46. 


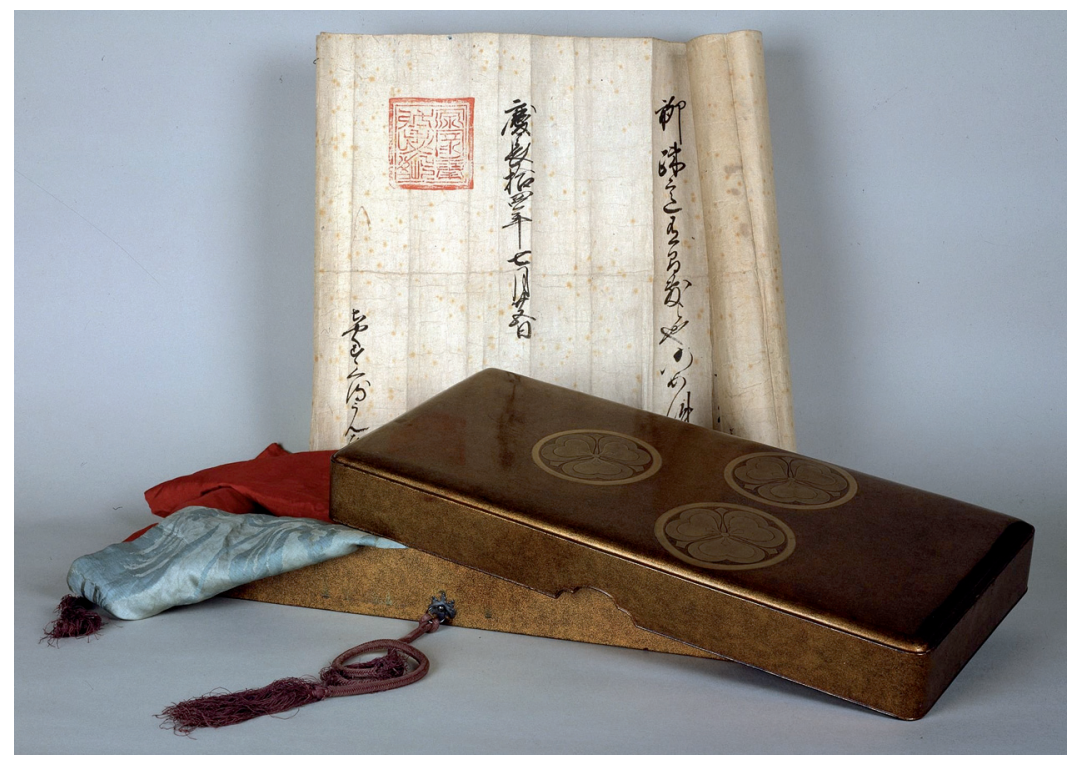

Akte van vrijgeleide voor de schepen van de Compagnie voor alle havens in Japan. Gedateerd 24 augustus 1609 en getekend door de Shogun leyasu. De praktijk zou aanzienlijk weerbarstiger blijken. Nationaal Archief Den Haag. 


\section{De VOC in de Chinese Zee en de kolonisatie van Taiwan}

Het is volgens mij een misvatting te denken dat succesvol ondernemen over het algemeen begint met het ontdekken van een gat in de markt. Tenzij het gaat om een nieuw product, is het veeleer zo dat nieuwkomers na-apen of net iets anders doen en bijna altijd met minder winst genoegen nemen dan de spelers die al in een markt actief zijn. Wijzigen de omstandigheden zich, dan zijn de oude partijen met gevestigde belangen vaak moeilijk in staat zich hieraan aan te passen en lopen zij het risico hun positie te verliezen ten gunste van de opportunistische indringer die nog een wereld te winnen denkt. De afloop is onvoorspelbaar. Een bijzonder voorbeeld hiervan geeft de VOC die in I6or op zoek naar fortuin de Chinese Zee binnenvoer. In de zestiende en de eerste helft van de zeventiende eeuw was namelijk een van de kortste en tegelijkertijd meest winstgevende zeehandelroutes in Azië die tussen China en Japan. De grondslag hiervoor was de grote vraag naar Chinese zijde door de Japanse elite. Het Japanse zilver waarmee werd betaald, was anderzijds bijzonder welkom in de enorme Chinese economie.

Een fascinerend aspect van de Europese expansie in Azië blijft het verhaal hoe het mogelijk was dat eerst de Portugezen en daarna de Nederlanders, afkomstig uit twee van de kleinste Europese landen, een deel van juist deze handel tussen machtige buurlanden konden beheersen.

Zoals Blussé stelt in zijn artikelen Divesting a Myth: Seventeenth Century Dutch-Portuguese Rivalry in the Far East ${ }^{\mathrm{I}}$ en The VOC as Sorcerer's Apprentice, Stereotypes and Social Engineering on the China Coast ${ }^{2}$, is het belangrijk in te zien dat de Portugezen en de Nederlanders een belangrijke, maar wel ondergeschikte rol speelden. De twee koks in deze Aziatische keuken waren de Chinezen en Japanners terwijl de Portugezen en de Nederlanders nooit meer dan de rol van kelner konden spelen. De Nederlanders begonnen moeizaam aan hun carrière in dit restaurant omdat zij de Chinese Zee binnenvoeren met het idee-fixe dat zij een koksmuts op hadden. Het zou echter meer dan dertig jaar duren voordat de Compagnie begreep dat voor haar niet meer dan een dienblad was weggelegd. Toen zij zich uiteindelijk hierin schikte, kreeg zij op een onverwacht toneel toch een hoofdrol toebedeeld: ten tijde van Van Diemen ontpopte de Compagnie zich tot kolonisator van Taiwan. 
De Portugezen waren toen al bijna een eeuw bij deze handel betrokken. Dat was mogelijk geworden nadat in I547 als reactie op de Japanse zeerovers die de kust van China onveilig makten, de Chinese keizer de handel op of met Japan aan zijn onderdanen verboden had. Naast ontduiking van dit verbod door smokkel, schakelden de Portugezen zich in als tussenpersoon voor de Chinese en Japanse kooplieden. De Portugezen voeren in die tijd al jaarlijks vanuit Goa en Malakka naar China, waar zij in de havenstad Kanton, het tegenwoordige Gwanzhou, met andere niet-Chinese kooplieden werden toegelaten. ${ }^{3,4}$

Voor de Portugezen begon de driehoekshandel op grote schaal in I556 toen Portugese handelaren van de Chinese autoriteiten informeel toestemming verkregen zich te vestigen in Macao. Hierdoor verkregen zij direct toegang tot de grote Kantonese zijdemarkt. De Portugezen werden 'gedoogd', zo mochten zij Macao niet ommuren en zou de stad buiten de jurisdictie van de onderkoning in Goa blijven vallen. Het bestuur van de stad benoemde zichzelf. Macao werd dus een kleine republiek, grotendeels onafhankelijk van Goa. De Portugezen exporteerden zijde vanuit Macao naar Malakka en Goa en importeerden peper en katoen. Maar vooral de zijdehandel op Japan nam een enorme vlucht. Daarnaast zorgden de Japanse zilvermijnen die in die jaren hun productie opvoerden, voor een stroom zilver naar China die in het begin van de zeventiende eeuw in omvang alleen de jaarlijkse zilvervloten van Mexico naar Spanje moest laten voorgaan.

In I570 stichtten de Portugezen in Japan Nagasaki, zodat zij over 'eigen' havens konden beschikken zowel in China als Japan.

Om ook van deze bonanza te kunnen profiteren bracht de onderkoning in Goa zijn primaat op de handel over zee in stelling. Hij verordonneerde dat maar één schip per jaar met een door hem benoemde kapitein mocht varen tussen Macao en Nagasakai. Deze 'concessie reis' leverde de kapitein in I580 naar schatting 35 duizend cruzados op, ongeveer 90 duizend gulden, waarvoor hijzelf of een consortium eerst 20 duizend cruzados voor op tafel had gelegd om het recht op de reis van de onderkoning te kopen. ${ }^{5,6}$ Het was de jaarlijkse vaart van het grote schip van Amazon van Goa via Malakka en Macao naar Nagasaki en weer terug.

In Macao kochten handelaren scheepsruimte voor hun zijde en beladen met zilver keerde het schip dan weer uit Nagasaki terug. Tenminste als het schip niet tijdens de lange tocht in moeilijkheden was gekomen.

In het kielzog van de Portugese schepen trok in China en Japan nog een ander soort onderneming binnen: de katholieke missie onder leiding van de Jezuïeten. In de laatste decennia van de zestiende eeuw was hun succes vooral in Japan groot. Voor een korte tijd (I580-I587) stond het snel groeiende Nagasaki zelfs onder Jezuïtisch gezag. In het zuiden van Japan bekeerden zich enkele honderdduizenden Japanners 
tot het katholieke geloof. De toenemende invloed van de katholieke missie zou echter steeds meer weerstand oproepen.

Toen de Japanse krijgsheer Toyotomi Hideoyshi in 1587 het gezag over Nagasaki naar zich toetrok, vaardigde hij een verbod uit op de activiteiten van de missionarissen. ${ }^{7}$ De katholieke kerk werd door hem gezien als potentiële ondermijning van het gezag waaronder hij heel Japan wilde verenigen. Een groeiend aantal van zijn onderdanen erkende immers de autoriteit van een paus in het verre Rome. Juist deze aanwezige en dreigende inmenging van buitenaf zou een buitengewoon aspect geven aan het proces van centralisatie van de macht in Japan. Deze zou gepaard gaan met een politiek van bijna complete afzondering van de wereldorde. Deze zelfopgelegde isolatie duurde meer dan twee eeuwen en is zonder weerga in de wereldgeschiedenis.

Toen de missionarissen het verbod op hun activiteiten negeerden en naast Jezuïtische ook Franciscaanse missionarissen vanuit het Spaanse Manilla actief werden in Japan, was dit de aanleiding voor de eerste christenvervolgingen. In februari 1597 werden 26 katholieken in Nagasaki gekruisigd.

Nadat in I60o bij de slag van Shekigahara de krijgsheer Ieyasu van de Tokugawa-clan zijn laatste rivalen had verslagen, werd hij de eerste militaire dictator over heel Japan, de shogun. Deze Tokugawa shoguns werden de feitelijke heersers die van 1603 tot I868 in naam van de keizer van Japan zouden regeren. In I6I4 verbood de tweede Tokugawa shogun, Hidetada, (I579-I632, Ri604-I623) het christelijke geloof in Japan. In de jaren daarna begon de hevigheid van de vervolgingen toe te nemen. Wie het katholieke geloof niet afzwoer, kwam vaak onder gruwelijke martelingen aan zijn einde.

De derde shogun, Iemitsu, (I604-I65I) wilde met de radicale macht van een alleenheerser alle buitenlandse invloeden uitschakelen en de invloed van het katholieke geloof definitief uitbannen. In I635 vaardigde hij daartoe een edict uit waarbij op straffe van onthoofding het aan Japanners verboden werd naar het buitenland te reizen en uit het buitenland weer naar Japan te komen. De buitenlandse handel met eigen schepen van de Japanse kooplieden kwam hierdoor in één klap stil te liggen.

In I637 en I638 brak de Shimabara-opstand uit op het gelijknamige schiereiland in de buurt van Nagasaki. Het was een boerenopstand, maar onder de rebellen waren veel katholieken en bij de verdediging van hun grote vesting Hara hingen kruizen op de omwalling. Toen het beleg van het fort niet vlotte, werd door de troepen van de shogun $\mathrm{Ne}$ derlandse hulp ingeroepen. Niet alleen werden toen door de Nederlanders kanonnen aan wal gebracht, maar werd ook vanaf het schip 'De Rijp' de vesting beschoten. Na felle strijd werd de rebellie neergeslagen. Het gruwelijk slot was het opsporen en ter dood brengen van bijna alle 
overgebleven katholieken. Geen land kent zoveel heilige katholieke martelaren als Japan.

Geïsoleerd van de rest van de katholieke kerk bleef een kleine groep het geloof trouw. Toen na I860 het katholieke geloof weer werd toegestaan, verrees in Nagasaki een kathedraal. Toen jaren later, op 9 augustus I945, Nagasaki getroffen werd door de tweede atoombom lag deze kathedraal in het epicentrum van de ontploffing. Een kathedraal onder een slecht gesternte. ${ }^{8}$

Het is een paradox dat juist in de jaren van de grootste christenvervolgingen de Portugees-Japanse handel zijn hoogtepunt bereikte. De hoeveelheid zilver die de Portugezen jaarlijks in hun schepen laadden, was gemiddeld $\mathrm{I} 8$ tot $\mathrm{I} 9$ ton in de periode $\mathrm{I} 580$ tot $\mathrm{I} 600$. In de jaren I6Io tot ${ }^{6} 635$ zou de omvang stijgen tot werkelijk fabelachtige hoogte: tussen de 87 en I50 ton per jaar! ${ }^{9}$ Ter vergelijking, de fameuze zilvervloot die Piet Hein in 1628 veroverde, had IIo ton zilver aan boord. Geen wonder dat Jacques Specx toen hij zich in I6og als eerste Compagniekoopman in Japan vestigde, met ongeloof naar Batavia schreef over deze handel en de koninklijke staat die Portugese kooplieden voerden bij hun jaarlijkse missie naar Nagasaki. Het ging om ongeveer tweehonderd kooplieden die voor een paar maanden in Nagasaki huizen huurden en geld als water uitgaven. ${ }^{10}$

\section{De VOC vaart de Chinese Zee binnen}

Dirck Gerritsz Pomp, beter bekend als Dirck China, was in Portugese dienst al een keer in China geweest toen hij in 1585 als eerste Nederlander in Japan voet aan wal zette. Met het geld dat hij op deze reis had verdiend, keerde hij samen met Jan Huygen van Linschoten naar Nederland terug, die daarna zijn beroemde Itinerario schreef. De enorme winsten van de Japans-Chinese handel waren de Nederlanders dus al goed bekend toen in I6oI Van Neck tijdens zijn tweede schipvaart met twee schepen de Chinese zee invoer. ${ }^{\text {II }}$ Zijn doel was simpel: het verkrijgen van toegang tot de handel in Kanton. Zijn aanpak is achteraf alleen begrijpelijk omdat wij weten dat hij op zijn reis in de Atlantische Oceaan wel vriendelijk was ontvangen door de Portugese gouverneur van het Annabon, een eilandje voor de kust van Equatoriaal Guinee. Op de rede van uitgerekend Macao ging Van Neck met zijn schepen voor anker en stuurde een sloep naar de stad om polshoogte te nemen. Toen deze niet terugkwam, werd een tweede naar de wal gestuurd. Machteloos moest hij vervolgens toezien hoe deze buiten het bereik van zijn kanonnen werd geënterd en veroverd. De in totaal twintig opvarenden werden onmiddellijk door de Portugezen gevangengenomen die, naar 
later bleek, achttien van hen zonder pardon ophingen en de twee overgeblevenen naar Goa zonden. Onverrichter zake voer Van Neck zelf hierna terug. ${ }^{\text {I2 }}$

Maar ook zonder tussenkomst van de Portugezen bleef China gesloten voor de 'roodharige barbaren', zoals de Nederlanders genoemd werden door de Chinezen. Van Warwijck in 1606 en Matelief één jaar lukte het ook niet hier een voet aan de grond te krijgen. Tot 1622 zou de Compagnie geen nieuwe poging wagen om toegang te verkrijgen tot het Chinese vaste land. ${ }^{\mathrm{I}}$

De Nederlandse handel met Japan had zich intussen op een hele andere wijze ontwikkeld. Deze begon toen op ig april I60o het schip 'De Liefde' voor de Japanse oostkust het anker liet vallen. Van de oorspronkelijke IIo bemanningsleden waren er nog 24 in leven van wie nog maar 6 op eigen benen konden staan. ${ }^{14}$ Het was het restant van de vloot van 5 schepen die in 1598 uit Rotterdam was vertrokken met 5 IO man aan boord. Een van de opvarenden was de eerder genoemde Dirck China. Na een moeizame tocht door de Straat Magelhaens waren nog 2 schepen over die de oversteek over de Stille Oceaan waagden. Dirck China was inmiddels op de Zuid-Amerikaanse westkust gevangen genomen door de Spanjaarden waar hij zich vrij gekocht en naar Nederland terugkeerde. ${ }^{15}$ Een drietal opvarenden van 'De Liefde' zou een rol spelen in de ontwikkeling van de relatie tussen Japan en Nederland. De belangrijkste was de Engelsman Will Adams (I564-I620) die als loods aan boord was geweest. Hij zou een belangrijke vertrouweling van de shogun worden en voor hem de eerste Westerse schepen ontwerpen, die later onder Adams' supervisie werden gebouwd. Adams zou ook een rol spelen bij het verkrijgen van de handelsrechten van de Engelsen en de Nederlanders. De tweede was Jan Joosten van Lodensteijn (c. I560I623) die een adviseur van de shogun werd. Van Lodensteijn en Adams werden beiden daarnaast handelaar en huurden vanuit Hirado verscheidene malen schepen waarmee zij naar onder meer Siam voeren. Lodensteijn verdronk in $\mathrm{I}_{224}$ in de buurt van Taiwan. De derde was Jacob Jansz. Quaeckernaeck, de kapitein van 'De Liefde'. Hij kreeg in I604 toestemming Japan te verlaten. Quaeckernaeck had een uitnodiging van de shogun bij zich om een handelskantoor in Japan te vestigen. Wat zal hij verbaasd zijn geweest toen hij in augustus 1606 voor de Portugese vesting Malakka aan boord stapte van de VOC-vloot onder het gezag van zijn neef Cornelis Matelief. Die benoemde hem tot eerste stuurman op zijn admiraalsschip. Op 21 september I606 kwam Quaeckernaeck om het leven in de zeeslag met de Portugese vloot. ${ }^{\mathrm{I} 6}$ Maar de eerste handelspas die hij van de shogun bij zich had, zou de Heren Zeventien wel bereiken. Op basis hiervan zou in juli I609 Jacques Specx, de latere gouverneur-generaal, met twee schepen in Japan aankomen om een factorij te stichten. Al een maand later werd een nieuwe handelspas voor- 
zien van het stempel van de teruggetreden shogun Ieyasu aan de Nederlanders overhandigd. Dit kostbaar document is bewaard gebleven en gaf aan de Compagnie het recht op vrije handel door heel Japan. Veel meer dan ooit aan de Portugezen was toegestaan.

De factorij werd gevestigd op het kleine eiland Hirado dat voor de noordwestkust van Kyushu ligt, het meest zuidelijk gelegen grote eiland van Japan. In de brieven van de Compagnie werd Hirado vaak ook Firando genoemd. Het was eerder de haven geweest waaruit de Portugezen handel dreven totdat zij in I570 de voorkeur gaven aan het nabij gelegen Nagasaki. De Engelsen zouden in I6I3 het Nederlandse voorbeeld volgen en zich ook in Hirado vestigen. Jacques Specx leidde de factorij tot I62I met een onderbreking van I6I4 tot IGIG toen Hendrick Brouwer deze positie bekleedde. Vanuit Hirado ondernam de Compagnie naast handel ook kaapvaart op de Portugese schepen en de Chinese jonken die van het Chinese vasteland naar Manilla voeren. De buitgemaakte goederen werden in Hirado verkocht. Toen in I62I de Engelsen en de Nederlanders gezamenlijk vanuit Hirado een vloot wilden uitsturen om Portugese schepen aan te vallen die van Macao op Nagasaki voeren, werd dit echter snel verboden door de Japanse shogun, die zelf belangen had in deze handel. ${ }^{\mathrm{I}}$ Het was voor de Engelsen in I623 de aanleiding om hun loge op Hirado te sluiten. De Compagnie bleef tot haar frustratie al die jaren uitgesloten van de Chinees-Japanse handel.

Om toch een deel van de Chinese handel in handen te krijgen volgde Coen in I622 het advies van opperkoopman Camps, die Specx in I620 was opgevolgd. Naar zijn aard koos Coen voor de aanval en zond een vloot van twaalf schepen met meer dan duizend man aan boord naar de Chinese Zee. Direct na bij de afloop van het Twaalfjarig Bestand was het doel niet minder dan de verovering van Macao op de Portugezen. ${ }^{\text {I8 }}$ De vloot ging op 22 juni op de rede van de nauwelijks versterkte stad voor anker. Aan Portugese kant waren om de stad te verdedigen bij elkaar ongeveer driehonderd soldaten en vrijwilligers. Op 24 juni gingen de Nederlanders aan land waar zij onmiddellijk de aanval in zetten. Een overwinning leek binnen handbereik. Toen de oprukkende troepen binnen het schootsveld kwamen van de paar kanonnen die op het half afgebouwde fort Sao Paolo del Monte stonden, trof de jezuïet Vader Giacomo Rho met ongeveer zijn eerste schot bij toeval de wagen waarop de voorraad buskruit van de aanvallers lag. De explosie had een desastreus effect en de soldaten raakten in paniek. Op dat moment werd door de Portugezen met de moed der wanhoop een tegenaanval ingezet en werden de Nederlanders teruggedreven naar de boten waarmee zij waren geland, waarna zij hals over kop vluchtten naar de veiligheid van de schepen. De Nederlanders verloren die dag meer dan tweehonderd man. De Portugezen dankten hun overwinning aan de interventie van 
Johannes de Doper, wiens naamdag het was. Johannes de Doper werd zo de beschermheilige van de stad. In de jaren daarna werd de stad zwaar versterkt.

Overigens vieren na bijna vier eeuwen de inwoners van Macao nog jaarlijks uitbundig de $24^{\text {ste }}$ juni.

De Nederlanders voeren door, want zou de verovering van Macao mislukken, dan had de commandant van de vloot Reyersen de order gekregen een fort te bouwen op de Pescadores-archipel in de Straat van Formosa. Dit gebeurde ook inderdaad, maar het fort lag voor de Chinese machthebbers te dicht bij de kust en binnen de Chinese invloedssfeer. Zij stuurden dan ook een grote vloot en een leger van io duizend man naar de archipel om het fort in aanbouw te belegeren. Toen in augustus I624 de nieuw benoemde gouverneur Martinus Sonck vanuit Batavia op de Pescadores aankwam, was de situatie voor de Nederlanders precair. Hij trof, 'de zaecken tusschen ons en de Chineesen in heel andere staedt, als wel gewenscht hadden'. ${ }^{19}$ Hem restte niets anders dan toe te geven aan de Chinese druk en op te breken met fort en al.

Met een vage toezegging van vrije handel vestigde hij zich in augustus I624 in de baai van Tayouan op de westkust van Taiwan. Daar verrees op een landtong het kasteel Zeelandia.

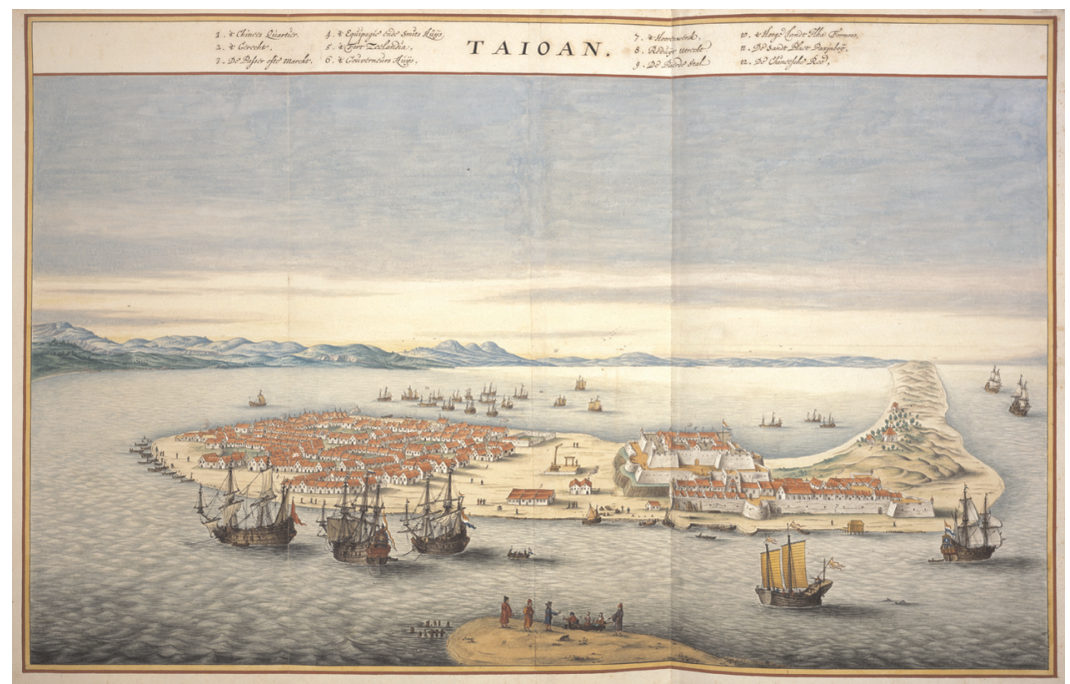

Van dit enorme VOC-fort op Taiwan werd een maquette gezonden naar Nederland. Het schip dat het vervoerde, verbrandde op zee, maar deze afbeelding uit de beroemde atlas Van der Helm van de hand van Vingboons geeft een indruk van de schaal waarop de VOC dacht. Österreichische Nationalbibliothek, Wenen. 
Voor de komst van de Nederlanders was de baai van Tayouan een ontmoetingsplaats voor Japanse en Chinese smokkelaars en zeerovers geweest.

De situatie werd voor de Compagnie de jaren daarna haast onmogelijk: na met zoveel moeite een eigen handelspost te hebben gevestigd van waaruit door de Compagnie gehandeld kon worden met de Chinezen, werd die door de Japanners gebruikt om rechtstreeks met de Chinezen zaken te doen, dus onder het oog en de bescherming van de Nederlanders in hun nieuwe fort. ${ }^{2 \circ}$ De Japanners erkenden het gezag van de Nederlanders niet en weigerden op Taiwan tol aan de Compagnie te betalen om de simpele reden dat de Nederlanders ook zonder heffing in Hirado mochten handelen. De situatie werd hachelijk toen in I627 de Spanjaarden vanuit Manilla een offensief openden tegen de Nederlanders op Taiwan. Aan de noordkust van Taiwan wierpen zij een tweetal forten op. De Nederlanders hadden geluk toen het jaar daarop een Spaanse vloot door een storm uiteen werd gedreven terwijl die op weg was om het nog zwak verdedigde fort te veroveren en de Compagnie van het eiland te verdrijven. Met man en macht werd daarna aan de versterking van Zeelandia gewerkt.

In I628 kreeg de handel op Japan een verdere klap door het tactloze optreden van Pieter Nuyts die van ${ }^{1} \sigma_{27}$ tot ${ }_{1} \sigma_{29}$ gouverneur van Taiwan was. In 1626 was deze 28 jarige Leidse academicus in de hoge rang van buitengewoon raad van Indië in Batavia aan gekomen en door Coen uitgezonden om na een hofreis naar de shogun in Edo naar Taiwan door te varen om daar als gouverneur aan te treden. Het begon ermee dat hem door zijn arrogante optreden in Japan de audiëntie door de shogun werd geweigerd. Op Taiwan wilde hij zijn gram halen tegenover Japanse handelaren, die zo door hem getergd werden dat zij hem gijzelden. Hij herkreeg zijn vrijheid onder vernederende voorwaarden. Zo namen de Japanners zijn zoontje van 7 jaar als gijzelaar mee naar Japan. Dit had als rechtstreeks gevolg dat de handel van de Compagnie met Japan volledig stil kwam te liggen. De schepen van de Compagnie werden door de Japanners aan de ketting gelegd, de voorraden in beslag genomen en de Nederlanders gevangen gezet. Toen dit in Batavia bekend werd, riep Coen hem terug uit Taiwan. Pas in I632 kwam de handel met Japan weer op gang nadat Specx de buitengewone stap had genomen ter genoegdoening aan de Japanners Nuyts als gevangene aan hen uit te leveren. ${ }^{2 \mathrm{I}}$ Tezelfder tijd maakten Chinese zeerovers de handel tussen China en Taiwan bijkans onmogelijk. De machtigste onder hen was Cheng Chih-lung (1604-I66I). Hij was in Macao gedoopt als Nicholas Gaspard. In de archieven van de Compagnie zou hij bekend blijven als Iquan. Zijn zoon was Zheng Chenggong (I624-I662) die als Koxinga de geschiedenis van de Compagnie in zou gaan. Het lot van de Compagnie op Taiwan zou nauw verbonden blijken te zijn met dat van deze 
bijzondere vader en zoon. Nadat Iquan in $\mathrm{I}_{2} 4$ korte tijd als tolk in dienst was geweest bij de Compagnie op de Pescadores, ontwikkelde hij zich in onwaarschijnlijk korte tijd tot een beruchte zeerover die het commando voerde over een grote vloot van jonken. Het verschil tussen handelaar en piraat was blijkbaar klein.

Ten aanzien van de zeerovers voerden de Chinese machthebbers een ook in Europa bekende pacificatiemethode uit de feodale middeleeuwen. Wie te machtig werd en in feite onbestrijdbaar, werd in het systeem opgenomen. Zo werd Iquan in ${ }^{6} 628$ admiraal in dienst van de keizer en aangesteld als beschermer van de kusten die hij tevoren onveilig had gemaakt. ${ }^{22}$

De Compagnie stond in deze jaren tot haar frustratie voortdurend op het verkeerde been. Wat moest zij nu doen om vrije toegang tot de Chinese markt te krijgen? Zich aansluiten bij de zeerovers, of ingaan op het verzoek van de Chinese autoriteiten om juist te helpen de piraten te verslaan?

Een ondercommandant van Iquan, de beruchte Quitsicq, nam de rol van zijn oude baas over. Hij verzamelde snel een grote vloot om zich heen en versloeg Iquan. Hierop dacht de Compagnie met haar vloot het pleit in haar voordeel te kunnen beslechten door Quitsicq te verslaan en daarmee de Chinese autoriteiten gunstig te stemmen. De eerste stap van het plan lukte: op 9 februari I630 werd de vloot van Quitsicq overtuigend verslagen. ${ }^{23}$ De overwinnaars kregen in de stad Xiamen op het Chinese vasteland een heldenontvangst, maar toen de vraag van de vrije handel ter sprake kwam, bleek niemand daarover aanspreekbaar te zijn. De Chinese handel naar Taiwan kwam maar niet werkelijk op gang. Sterker nog, Iquan, die na de overwinning op Quitsicq zijn functie van admiraal weer uitoefende, breidde zijn machtsbasis steeds verder uit. Hij had zich gevestigd in Anhai dicht in de buurt van Xiamen en zijn grote handelsvloot beheerste weldra de Chinese Zee van Japan tot voorbij Vietnam.

De Nederlanders waren bang opnieuw het nakijken te krijgen toen maar aan één handelaar toestemming werd gegeven om met de Nederlanders op Taiwan zaken te doen, terwijl Iquan in de havens plakkaten had laten ophangen die handel op Taiwan zonder officiële passen ten strengste verbood.

Op advies van gouverneur Putmans van Taiwan besloot de Compagnie zich nu ook als piraat op de Chinese kust te gaan gedragen net zolang tot de verlangde vrijhandel zou zijn verkregen. In de zomer van I633 ging een Nederlandse vloot van I2 schepen tot actie over en stroopte de kust af. Maar ondanks een eerste nederlaag tegen de Nederlanders wist Iquan het initiatief langzaam maar zeker naar zich toe te trekken. De tijd werkte in zijn voordeel door de nadering van het stormseizoen. Nadat een tyfoon de Nederlandse vloot uiteen geslagen had, 
zette hij zijn val. Hij daagde de acht overgebleven Nederlandse schepen uit en met een onverwacht sterke vloot dreef hij de Nederlanders in het nauw. De zeeslag werd door hem gewonnen en twee Nederlandse schepen werden vernietigd. De Nederlanders hadden geen andere optie dan zich naar Taiwan terug te trekken. ${ }^{24}$

Toch kreeg de tactiek zijn gewenste uitwerking. $\mathrm{Nu}$ de rollen waren omgekeerd, kwam de handel vanuit China op Taiwan goed op gang. De jaren daarop zeilden jaarlijks jonken met zijde en porselein naar Zeelandia. Hierdoor kwam ook de handel vanuit Taiwan op Japan tot bloei. Om deze relatieve rust niet te verstoren, werd door de Compagnie besloten geen Portugese schepen aan te vallen benoorden Macao, en zeker geen Chinese jonken. ${ }^{25}$

Bij het aantreden van Van Diemen had de VOC de hoop dat na vele misslagen de handel eindelijk het beloofde succes zou brengen. De handel tussen het vasteland van China en Taiwan was op gang gekomen en de fricties met de Japanners aldaar waren in één keer achter de horizon verdwenen, omdat het in ${ }^{1} 635$ de Japanners verboden werd zich buiten Japan te begeven. Hierdoor leek ook de Japanse handel met Siam, Cambodja en Vietnam voor het oprapen. ${ }^{26}$

De winsten van de factorij op Hirado namen spectaculair toe. Door het handelskantoor van de VOC op Hirado werd in ${ }^{6} 637$ een winst geboekt van maar liefst 2,5 miljoen gulden. De Heren Zeventien in patria juichten op afstand mee. Volgens hen was deze handel:

'Het principaelste ja eenigste middel om compagnies beswaerden standt te subleveren en de participanten de gewenschte Indische vruchten te doen toecomen. ${ }^{27}$

In I638 bedroeg de waarde van de naar Japan verzonden goederen maar liefst bijna 7 miljoen gulden. Gehoopt werd hierop een winst te maken van 70 procent.

De Portugezen waren in Japan door de christenvervolgingen in grote problemen gekomen, binnen de VOC werd daarop voortdurend gespeculeerd over de enorme jaarlijkse winsten die daardoor aan de VOC zouden gaan toevallen. Uit de generale missive van december $\mathrm{I}_{3} 8$ bleek hoezeer het een dubbeltje op zijn kant bleef voor de Nederlanders. Enerzijds vertrokken de Portugezen na een zeer goede handelsmissie met meer dan io miljoen gulden in zilver terug naar Macao, anderzijds inspecteerden de Japanners bij de Nederlandse loge in Firando de handelsgoederen om te onderzoeken of de Nederlanders in staat zouden zijn de plaats van de Portugezen over te nemen in Japan. Als dat zo was, zouden zij 'resolveren de Portugesen uyt te setten, gelijck gesyt wort. ${ }^{28}$ 
Hierop volgde inderdaad in I639 een tweede edict waarbij de Portugezen definitief de toegang tot Japan werd ontzegd op straffe van onthoofding, zoals de bemanning van het Portugese schip die in $\mathrm{I} 642$ toch voet aan wal zette in Nagasaki tot haar ongeluk ondervond. Toen januari I640 het bericht van de uitzetting van de Portugezen uit Japan Batavia bereikte, was deze bijzondere gunst van God aanleiding voor een 'danken bededag'.

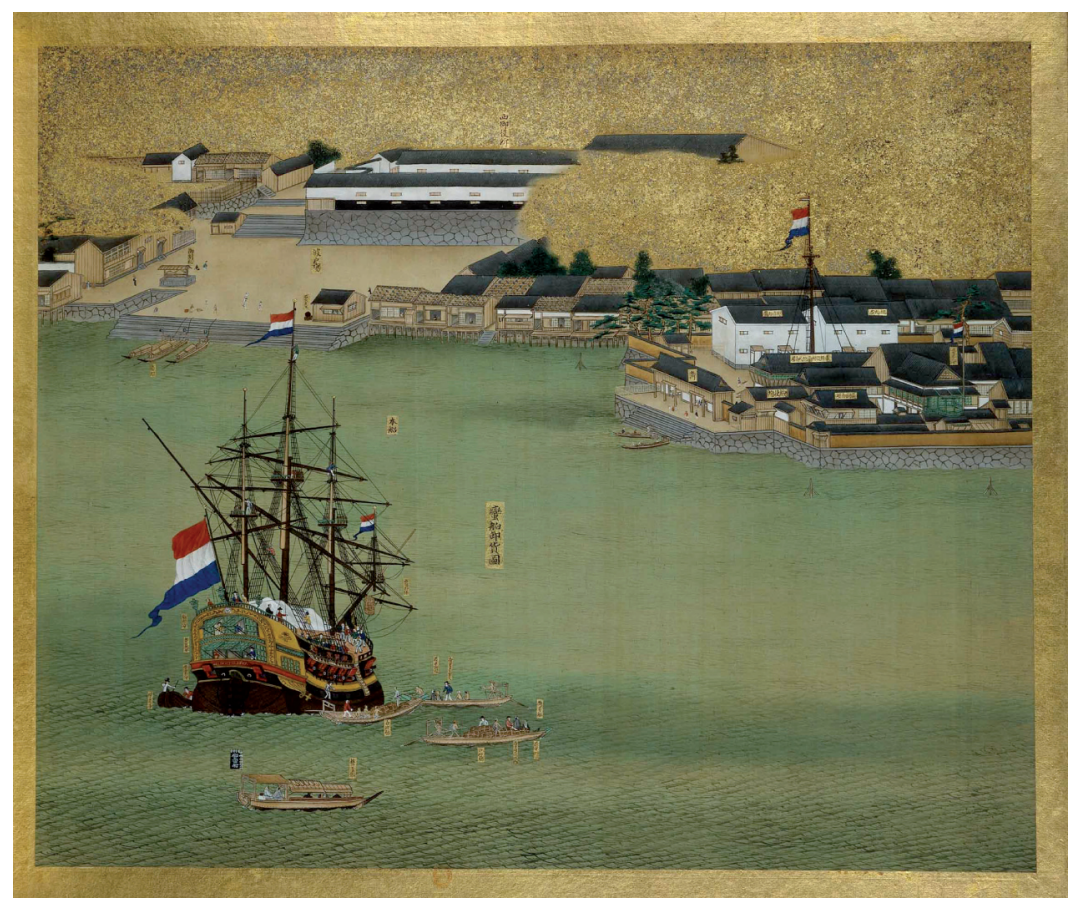

Zo machtig als de VOC op zee was, zo weinig bleef daarvan over eenmaal aangekomen voor het kunstmatige eilandje Decima bij Nagasaki. Daar werden op last van de Shogun de schepen van hun roer en kanonnen ontdaan, totdat zij verlof kregen voor vertrek. Bibliothèque National de France, Parijs.

Francois Caron, de toenmalige president van de loge op Hirado, was aanzienlijk minder enthousiast. Hij vermoedde direct al dat het maar de vraag was of de Nederlanders er werkelijk op vooruit zouden gaan. ${ }^{29}$ Hij zou gelijk krijgen. Het feit dat de Portugezen werden uitgezet, betekende niet dat de Nederlanders vriendelijker of met minder achterdocht werden behandeld. Het tegendeel was eerder het geval. De stenen loge die door de VOC was gebouwd op Hirado, moest tot de grond toe worden afgebroken omdat in de gevelsteen onder een kruis het bouwjaar 
I639 stond. Hiermee hadden de Nederlanders de verdenking op zich geladen niet zo los te staan van het katholieke geloof als zijzelf bij hoog en laag beweerden. Weliswaar werden de Nederlanders onder zeer strikte voorwaarden als enige Europese natie tot de handel in Japan toegelaten, maar dit betekende dat zij vanaf I64I tijdens hun jaarlijkse verblijf onder huisarrest gesteld werden op het kleine Decima, het beroemde kunstmatige eilandje in de baai van Nagasaki dat oorspronkelijk voor de Portugezen was bedoeld. De handel en winst van de Compagnie zouden voortaan maar een klein deel bedragen van de omvang die daarvoor onder de Portugezen werd bereikt. Dit kwam omdat naast de Nederlanders ook de Chinezen het recht behielden op Japan te varen.

De machtige Iquan zorgde er wel voor dat hij deze handel beheerste ten koste van de Compagnie. Dit werd duidelijk in I64I. Van Diemen had gehoopt in Japan een winst als nooit te voren te behalen. Het werd maar 400 duizend gulden en dat terwijl er maar liefst voor 3,3 miljoen gulden in goederen van de Chinezen was geleend. Van Diemen schreef hierover aan de Heren Zeventien berustend: l'homme propose, Dieu dispose. ${ }^{30}$

Ook de grote inspanningen die de Compagnie zich getroostte om de handel die tot ${ }^{6} 635$ vanuit Japan op Siam, Cambodja en Vietnam bedreven werd, over te nemen, hadden maar deels succes door de concurrentie van de Chinese schepen van dezelfde Iquan. Een tweetal recente studies geeft echter aan dat Van Diemen persoonlijk ook een rol hierin heeft gespeeld. Hij overschatte de kracht van de Compagnie tegenover de kleinere koninkrijken die grensden aan de Chinese Zee. Zowel in 'Murder and Mayhem in Seventeenth Century Cambodia, Anthony van Diemen vs. King Ramadhipaty I' als in 'Silk against Silver, Dutch-Vietnamese relations, 1637-1700,31,32 wordt beschreven hoe Van Diemen reageerde als een stier op een rode lap. wanneer naar zijn mening de eer of het aanzien van de Compagnie gekwetst was.

Het eerste beschrijft het geval dat speelde in Pnom Phen, de hoofdstad van Cambodia. De VOC had daar een kantoor dat bevoorraad werd door schepen die moeizaam de Mekong opvoeren tot aan de stad. In I642 werden in Cambodia twee compagniedienaren door Portugezen vermoord. Op hoge toon eiste Van Diemen hiervoor van de koning van Cambodia genoegdoening. Dit werkte averechts. Op bevel van de koning werd de Nederlandse loge afgebrand. Meer dan vijftig man kwamen hierbij om en eenzelfde aantal werd gevangen gezet. Tot overmaat van ramp werd een tweetal schepen op de Mekong buitgemaakt. Van Diemen zon op wraak. Op zijn bevel voer in I644 een vloot van vier zwaarbewapende schepen moeizaam tweehonderd kilometer de Mekong op naar de hoofdstad Punompingh (Phnom-Penh). Daar was op de komst van de vloot gerekend en was een zorgvuldig voorbereide hinderlaag uitgezet. Een zwaar versterkte scheepsbrug werd over de Me- 
kong achter de schepen gelegd om hun terugkeer te verhinderen. Een hevige strijd ontbrandde en met grote verliezen konden de Nederlanders zich een weg banen naar de open zee.

Van Diemen schreef hierover dat de eerste poging om wraak te nemen niet het gewenste resultaat had gehad, maar dat de volgende dat wel zou hebben: de zaak kon niet rusten vanwege het gezichtsverlies dat de Compagnie zou leiden.

Voor het zover was overleed Van Diemen. Zijn opvolger Van der Lijn kreeg zonder verder bloedvergieten gedaan dat de nog levende Nederlanders werden vrijgelaten en aan boord van een van de geroofde schepen naar Batavia konden varen.

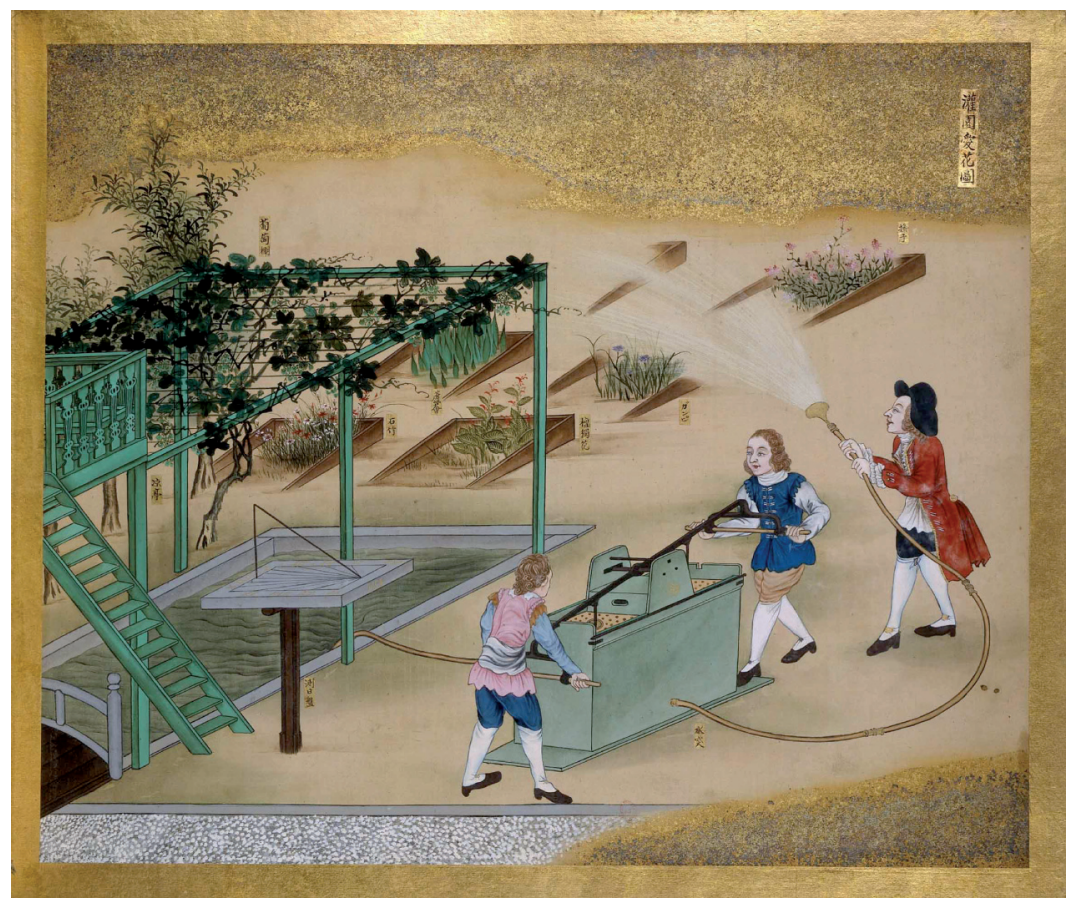

Op Decima leefden de Nederlanders als in een veredelde gevangenis. Verveling was vaak aan de orde zoals te zien is aan de brandspuit die gebruikt werd om de planten water te geven. Bibliothèque National de France, Parijs.

Het tweede gaat om de reactie van Van Diemen op de gevangenneming in I64I van de overlevenden van twee gestrande schepen van de Compagnie op de kust van Quinam in het zuiden van Vietnam. ${ }^{33}$ Toen het nieuws hierover Batavia bereikte, werd onmiddellijk door de Hoge Regering besloten om wraak te nemen en Quinam aan te vallen. Drie ach- 
tereenvolgende jaren werd een vloot uitgezonden om de kust van Quinam af te stropen. Maar net als in Cambodia bleken de schepen in nauw vaarwater, of vlak onder de kust kwetsbaar voor onverwachte aanvallen. Tot tweemaal toe werd een nederlaag geleden.

Of Van Diemen werkelijk gedacht heeft dat deze crises door geweld konden worden opgelost, is onduidelijk. Maar voor hem stond blijkbaar vast dat een andere diplomatieke reactie, zoals eerder Van Vliet in Siam had gegeven, het aanzien van de Compagnie structureel zou ondermijnen. Dat was onbespreekbaar. Misschien was het een compensatie voor de machteloze situatie waarin de Nederlanders inmiddels op Decima bivakeerden.

In Japan was er geen sprake van dat men de eigen kracht overschatte. Alle vernederende voorwaarden die gesteld werden aan de Nederlanders op Decima werden zonder weerwoord aanvaard. Hoe angstig men was om de unieke positie te verliezen, blijkt ook uit de grote moeite die werd genomen om de geschenken die op de jaarlijkse hofreis werden meegenomen, zo bijzonder mogelijk te maken. Een groot deel van de correspondentie over Japan tussen Batavia en Nederland werd hierdoor in beslag genomen. In december ${ }_{1} 636$ schreef Van Diemen dat een grote koperen kroon 'alleen oorsaecke is dat onse reputatie aldaer weder wat begint te respireren'. ${ }^{4}$ Zo werd in de jaren daarna heen en weer geschreven over de verscheping van Nederland naar Japan van een vierspan Friese volbloeden. De kostbare paarden waren al aangeschaft toen na rijp beraad werd afgezien van het oversturen, hoewel het ruim van een fluitschip al speciaal voor het transport was ingericht. ${ }^{35}$ Maar de manshoge koperen kandelaars en kroonluchters die ten geschenke werden gegeven, zijn nog steeds te bewonderen. In december I64I werd zelfs speciaal een kopergieter meegezonden om een grote 'cooperen lantaren' goed op te stellen. ${ }^{36}$ De winst was met gemiddeld 600 duizend gulden weliswaar aanzienlijk lager dan gehoopt, maar nog alleszins de moeite waard. Het zilver waarmee de Japanners betaalden, was van vitaal belang voor de intra-Aziatische handel.

$\mathrm{Na}$ al deze gebeurtenissen schreven in I645 de Heren Zeventien over Japan:

'Die natie gaet in al haer doen boven ons begrijp ende is haer gront niet te diepen. ${ }^{37}$

\section{De kolonisatie van Taiwan}

Terwijl de Nederlanders in China en Japan weinig invloed hadden op de loop der gebeurtenissen, lag dit op Taiwan geheel anders. Als hoofd van het kantoor op Hirado had Brouwer in I6I3 al geschreven over het 
strategisch belang van Formosa (Taiwan) voor de Compagnie, omdat het buiten de invloedssfeer van zowel China als Japan lag en niet gekoloniseerd was door de Portugezen of de Spanjaarden. Als gouverneurgeneraal gaf Brouwer twintig jaar later de aanzet voor de kolonisatie van het eiland. Op 4 januari I636 schreven Brouwer en Van Diemen over deze plannen aan de Heren Zeventien:

'...dat de Compagnie daer in seer corten tijt sal becomen soo heerlijcken colonie, als ooit de Portuguysen in Indien hebben gehad ende by Ceylon gansch niet te gelijcken, ten aensien van de getemperheyt des climaats, gesontheyt des luchts, vrugtbaerheyt des aertrijckx, buyten de jurisdictie van eenigh machtigh potentaet, bewoont met plomp en dom heydens volck, maer dight gelegen bij het maghtigh Chijnese rijck, van waer dees colonie sooveel arm, arbeydsaem volck toevloeyen sal, als men eenigshsints soude connen wensen. ${ }^{38}$

Om de Chinese kolonisten te beschermen tegen de inheemse bevolking waren 475 soldaten naar Taiwan gestuurd. ${ }^{39}$ Met het aantreden van Van Diemen begon zo een bijzonder hoofdstuk van de geschiedenis van de VOC: de Chinese kolonisatie van Taiwan onder Nederlands oppergezag.

Het eiland was toentertijd dunbevolkt door Austronesische stammen, die geen enkele genetische of culturele band hadden met China. Omdat elke jongen zijn mannelijkheid moest bewijzen door een kop te snellen, waren de naburige stammen voortdurend met elkaar in oorlog. De Nederlanders hadden de agressiviteit van de inheemse stammen tegen buitenstaanders de jaren daarvoor aan den lijve ondervonden. Op het eilandje Lamey voor de zuidwestpunt van Taiwan was de bemanning van twee gestrande schepen uitgemoord en waren bij hun terugtocht uit het dorp Matthau 60 soldaten ter dood gebracht toen die zich over een rivier lieten dragen.

In ${ }_{16} 63$ was de invloed van de Nederlanders beperkt tot de directe omgeving van het kasteel Zeelandia rond de baai van Tayouan. Aldaar werden de eerste gronden in pacht uitgegeven aan de Chinese kolonisten. Dit was het begin van een snelle expansie van de landbouw op Taiwan. De landbouwers moesten wel beschermd worden tegen de aanvallen door de inheemse bevolking. Dit betekende dat langzaam maar zeker het uitgestrekte westelijke laagland van Taiwan werd onderworpen. Eenmaal in gang gezet was hier geen weg terug. Jaar na jaar breidde het gebied dat onder het gezag van de Compagnie stond, zich uit. Wat deze pacificatie buitengewoon maakte, was dat het geen puur militaire operatie was. Zij ging namelijk hand in hand met een serieuze inspanning om de bevolking te bekeren tot het gereformeerde geloof. Wij wanen ons even in een andere wereld wanneer dominee Robert Junius zich 
meer dan eens te paard aan het hoofd stelde van de christelijke troepen die optrokken tegen de dorpen die het licht nog niet gezien hadden. ${ }^{4 \circ}$

De instructies van eerst Brouwer en daarna Van Diemen aan de gouverneurs van Taiwan hadden van Coen afkomstig kunnen zijn. Het lot van de bewoners van het eilandje Lamey voor de zuidwestkust van Taiwan spreekt voor zich. In I622 was het schip 'de Gouden Leeuw' bij het eiland op de rotsen gelopen en hadden de lokale bewoners de opvarenden ter dood gebracht. Hetzelfde gebeurde in I632 met de bemanning van de gestrande 'de Beverwijck'. De overlevenden, ongeveer 50, werden tot de laatste man vermoord. De wraak was vreselijk. Een eerste strafexpeditie mislukte. Maar het werd bekend dat een deel van de bevolking in tijden van gevaar een grote grot in vluchtte. In 1636 blokkeerde daarom een tweede strafexpeditie deze grot, terwijl de bevolking daar haar toevlucht in had genomen. De lucht in de grot werd acht dagen lang vergiftigd met zwavelrook en brandend pek. Toen het geschreeuw in de grot was verstomd, werden de lijken van 300 mannen, vrouwen en kinderen gevonden. Het eiland werd de jaren daarna geheel ontvolkt en wie nog restte van de oorspronkelijke I200 eilandbewoners werd als slaaf naar Batavia gedeporteerd. Maar weinigen overleefden daar het andere klimaat en het verdriet. Van Diemen prees uitvoerig de wraakoefening op de wrede moordenaars. ${ }^{4 \mathrm{I}}$

Toen een paar jaar later nog inwoners op het eiland bleken te zijn, schreef van Diemen naar Taiwan dat ook deze dood of levend van Lamey gedeporteerd moesten worden, ook al waren het er maar 40. In juni I64I schreef hij nog dat hij hoopte dat de Chinese kolonisten op Lamey de laatste 40 oorspronkelijke bewoners gevangen zouden nemen en naar Batavia sturen. Hier, zoals elders, is Van Diemen de hardvochtigheid zelve. ${ }^{42}$ Hij instrueerde dat

'de wvrevelmoedige ende die hun tegen onse ordonnantie opposeren, dienen door vreundelijcke aenmaninge, ende inductie tot haer devoir gebracht, ende dat alles niet helpende, moeten met de wapenen gestraft werden, ende totalijck uitgeroeyt werden, opdat anderen daeraen spiegelen.' 43

Steeds schoof hij de bezwaren van de mannen ter plekke tegen zijn onverzoenlijke aanpak ter zijde. Het ging om respect voor de autoriteit van de Compagnie en ter bescherming van de arme hardwerkende Chinezen.

Vanaf het moment dat hij was benoemd tot gouverneur-generaal werd Van Diemen geobsedeerd door de geruchten dat er goudmijnen waren in het moeilijk toegankelijke bergachtige noordoosten van Taiwan. De reden van zijn goudkoorts is goed voorstelbaar. Als de Compagnie een eigen goudmijn zou bezitten, zou het zwaartepunt van het 
bedrijf definitief niet meer in Amsterdam, maar in Batavia komen te liggen. Tegenover haar concurrenten zou haar positie onaantastbaar worden. En ongehinderd zou Van Diemen zijn plannen kunnen uitvoeren. Op zijn aanwijzing werden telkenmale zoektochten ondernomen, steeds verder het binnenland in.

Een doorbraak leek nabij toen in augustus I642 Quelang, de laatste vesting van de Spanjaarden op de noordkust, door de Compagnie werd veroverd en men daar de Castiliaan Domingo Aguilar aantrof. Deze woonde al I5 jaar op Taiwan en was daar ook getrouwd. Hij zei belangrijke informatie over de goudmijnen te hebben. Aguilar werd uitvoerig ondervraagd en gaf daarbij zulke nauwkeurige informatie dat in $\mathrm{I} 645$ een grote expeditie werd uitgerust naar de onherbergzame noordoosthoek van Taiwan. ${ }^{44}$ De teleurstelling was groot toen in het aangewezen kustdorp alleen kleine hoeveelheden goud die de inwoners uit de rivier zeefden, werden aangetroffen. Moeizaam werd de rivier stroomopwaarts gevolgd, maar na het trotseren van watervallen betekende een steile, dichtgegroeide klif een te grote hindernis. Er liep nog wel een ijzingwekkend smal pad naar boven, maar verhalen over mannen met apenhoofden die stenen naar beneden gooiden, deden zelfs de moedigsten omkeren. ${ }^{45}$ Veel later bleken de geruchten over het goud toch waar te zijn. Dieper in dit gebergte werden aan het einde van de negentiende eeuw rijke goudaders gevonden, die een heuse gold rush tot gevolg hadden. De goudmijnen zijn inmiddels gesloten, maar het museum ter plekke bewaakt als tastbare herinnering een van de grootste goudbaren ter wereld. ${ }^{46}$ Hoe dichtbij was men geweest?

Toen het bericht van de mislukte tocht in Batavia aankwam, was Van Diemen overleden en opgevolgd door Van der Lijn. Deze miste de gedrevenheid van zijn voorganger en nam het bericht voor kennisgeving aan. Het zoeken naar goud werd gestaakt.

Ondanks de vergeefse zoektocht naar het goud had Taiwan zich ontwikkeld tot een welvarende kolonie. Van Diemen zelf heeft dit commerciële succes niet meer meegemaakt. Gedurende zijn regering was Taiwan een lastenpost. Maar rond I650 was door de toename van de handel en de landbouw Formosa/Taiwan ontegenzeggelijk 'uitgegroeid tot een van de bloeiendste vestigingen van de VOC in Azië'. ${ }^{47}$

Het Nederlandse gezag over Taiwan zou van korte duur blijken te zijn. Dit kwam door de ontwikkelingen op het Chinese vasteland. In I644 was de Ming-dynastie verslagen door de Manchu's die de Ch'ingdynastie vestigden. Ming-loyalisten gaven zich in het zuiden van China echter niet gewonnen. Met name Coxinga, de zoon van Iquan, ontwikkelde zich tot de voornaamste steunpilaren van het verslagen regime. Hij ondernam in I66I een grote expeditie tegen Nanking die voor hem zo desastreus eindigde dat hij het vaste land moest ontvluchten. Coxinga zocht met zijn leger en vloot een veilig heenkomen op Taiwan, dat 
hij tot zijn nieuwe uitvalsbasis wilde maken. Tegen zo'n groot en geoefend leger was de Compagnie machteloos. Snel veroverde Coxinga heel Taiwan op het kasteel Zeelandia na. Het beleg daarvan duurde negen maanden, waarna de bezetting zich inscheepte naar Batavia. Zo kwam na 38 jaar een einde aan de Chinees-Nederlandse kolonie.

In I6 36 had Van Diemen hooggespannen verwachtingen over de toekomst van de Japanse handel en de kolonisatie van Taiwan. Kosten nog moeite werden gespaard om het succes af te dwingen. In de jaren daarna leek het ook te lukken. Maar op termijn kregen geheel verschillende ontwikkelingen buiten de Compagnie om, eerst de Japanse handel in hun greep en maakten daarna abrupt een einde aan de Nederlandse aanwezigheid op Taiwan.

Wat na I662 nog restte, was één jaarlijkse vaart op Decima bij Nagasaki. De omvang van deze handel was veel minder dan in Portugese hoogtijdagen een halve eeuw daarvoor. Van Diemens rol in dezen is bescheiden geweest. De ontwikkelingen waren door zijn voorgangers Specx en Brouwer in gang gezet. Zij beiden waren oudgedienden in het Japanse Hirado die door die ervaring de kansen van de Japanse handel, de mogelijkheden van de kolonisatie van Taiwan en het belang van het kasteel Zeelandia op waarde hadden ingeschat.

Van Diemen bouwde hierop voort. Wat opvalt is dat hij om de macht van de Compagnie te schragen vooral angst wilde inboezemen. De vele wraakacties die hij in gang zette, hadden geen ander doel dan respect af te dwingen. Je vraagt je af wat deze burgemeesterszoon uit Culemborg tot zo'n onmens maakte. Hij had zich de lijfspreuk van Caligula eigen gemaakt: 'oderint dum metuant' men mag mij haten als men mij maar vreest.

Angst regeerde volgens van Diemen het beste, misschien wel als enige. Elk teken van zwakte kon de Compagnie fataal zijn in de voortdurende confrontatie met de wrede Aziatische vorsten.

\section{Noten}

I. Blussé, L., 'Divesting a Myth: Seventeenth Century Dutch-Portuguese Rivalry in the Far East', Hoofdstuk 25 in Vasco da Gama and the linking of Europe and Asia, A.R. Disney and E. Booth, (New York 2000).

2. Blussé, L., 'The VOC as Sorcerer's Apprentice, Stereotypes and Social Engeneering on the China Coast', in Leyden Studies in Sinology, W.L. Idema, Editor (Leiden I98I) 87-I05.

3. Boxer, C.R., The great ship from Amacon; annals of Macao and the old Japan trade (Lisboar959). 
4. Boxer, C.R., Portuguese merchants and missionaries in feudal Japan, 1543-1640. reprint (London I986).

5. Er waren rond I580 34 van dergelijke 'concessiereizen', die in waarde varieerden van 3.000 cruzados tot 35.000 . Ook de positie van commandant van een van de vele Portugese forten in Azië werden als zeer lucratieve benoemingen gezien. Oorspronkelijk waren deze concessies en benoemingen beloningen die de koning aan de hoge hofadel of succesvolle militaire commandanten. Zo kreeg de Spaanse koningin Margarita een tweetal reizen van Goa naar Nagasaki net als eenmaal een Augustijner klooster.

6. Prakash, O., 'The Portuguese in the Far East, I540-I640', Hoofdstuk 8 in Vasco da Gama and the linking of Europe and Asia, A.R. Disney and E. Booth, Editors (New York 2000).

7. Blussé, L., 'Divesting a Myth: Seventeenth Century Dutch-Portuguese Rivalry in the Far East., 395.

8. In het gebouw van de Verenigde Naties in New York wordt en klein beschadigd Maria beeldje ten toongesteld. Naast een bijna weggeblazen muur een van de weinige voorwerpen die de verschrikkelijke kracht van de explosie hebben overleefd.

9. Newitt, M.D.D., A history of Portuguese overseas expansion, 1400-1668 (Londen 2005) 232.

I0. 250.000-300.000 tael Prakash, O., 'The Portuguese in the Far East, I540-I640', I37 en Boxer, C.R., The great ship from Amacon; annals of Macao and the old Japan trade, I6.

II. Voor het verslag van deze reis: Commelin, I., Begin en Voortgang der Nederlandsche Oostindische Compagnie I, de tweede reis van I van Neck, (Amsterdam I648).

I2. Commelin, I., Begin en Voortgang der Nederlandsche Oostindische Compagnie I, de tweede reis van I van Neck, 9.

I3. Andrade, T., 'The Company's Chinese Pirates: How the Dutch East India Company Tried to Lead a Coalition of Prates to War against China, I62I-I662' in Journal of World History, 2005. I5(4) 30.

I4. Wieder, F.C., De reis van Mahu en de Cordes door de Straat van Magalhaes naar Zuid-Amerika en Japan, 1598-1600. Deel III Het eerste Hollandse Schip in Japan, Werken uitgegeven door de LinschotenVereeniging, Vol. XXIV (Den Haag I925).

I5. IJzerman, J.W., Dirck Gerritsz Pomp, alias Dirck Gerritsz China (1544 -1604). werken uitgegeven door de Linschoten-Vereeniging. Vol. IX. ('s-Gravenhage I9I5).

I6. Idem 37.

I7. Blussé, L., 'Divesting a Myth: Seventeenth Century Dutch-Portuguese Rivalry in the Far East', 396.

I8. Idem 397. 
I9. Blussé, L., Dagregisters van het kasteel Zeelandia Taiwan 1629-1662, deel I, (Den Haag I985) Inleiding XII.

20. Andrade, 'The Company's Chinese Pirates: How the Dutch East India Company Tried to Lead a Coalition of Prates to War against China, I62I-I662' geeft een mooi verslag van de verwikkelingen die volgden.

2I. Blussé, L., 'Spitsvinnighe warvogels. Vier juristen en de totstandkoming van de eerste politiewetten in Nederlands-Indië' in Macht en Majesteit, Eds J.Thomas Lindblad en Willem van der Molen (Leiden 200I) I54.

22. Blussé, L., 'The VOC as Sorcerer's Apprentice, Stereotypes and Social Engeneering on the China Coast', 93.

23. Andrade, 'The Company's Chinese Pirates: How the Dutch East India Company Tried to Lead a Coalition of Prates to War against China, I62I-I662', 4I5 ev.

24. Blussé, L., 'The VOC as Sorcerer's Apprentice, Stereotypes and Social Engeneering on the China Coast,', IO2-IO4.

25. Coolhaas, Generale Missiven I, 490, 8 jan I635, idem 522, 4 jan I636.

26. Blussé, L., Divesting a Myth: Seventeenth Century Dutch-Portuguese Rivalry in the Far East, 400; Alfons van der Kraan, Murder and Mayhem; Hoang Ahn Tan, Silk for Silver; Baker,Van Vliet's Siam.

27. NA VOC $3 \mathrm{I} 6 \mathrm{f}$ I75.

28. Coolhaas, Generale Missiven I, 74I.

29. NA VOC OBP II33 Japan 236-257 Copie missijve door den Ed. president van Firando François Caron aende Ed. heer gouverneur generael Antonio van Diemen 26 October anno i639. Caron kreeg gelijk.

30. Coolhaas, Generale Missiven II, I34, 8 jan I64I, idemi35, 3I jan I64I, idem I72, I2 dec, I642.

3I. Kraan, A.v.d., Murder and Mayhem in Seventeenth-Century Cambodia, Anthony van Diemen vs. King Ramadhipati I (Chiang Mai 2009).

32. Hoang, T.A., Silk for Silver, Dutch-Vietnamese Relations, 1637-1700. (Leiden 2007).

33. Idem, 74.

34. Coolhaas, Generale Missiven I, 587, 28 dec I636.

35. NA VOC 316, 268v, i2 september I639; 284, 8 dec.I639 kamer van Amsterdam; 309, II september i640.

36. NA VOC 3I5, 3565 september I64I en 362 I2 dec i64I. Kamer van Amsterdam.

37. NA VOC 3I6 f305, iI september i640. 
38. Coolhaas, Generale Missiven I, 520; Blussé, 'Retribution and Remorse', I58.

39. Coolhaas, Generale Missiven I, 520, 4 jan ${ }^{6} 636$.

40. Blussé, L., 'Retribution and Remorse', I69.

4I. Blussé, L., and N. Everts. The Formosan Encounter: Notes on Formosa's Aboriginal Society: A Selection of Documents from Dutch Archival Sources, Volume II I636-I645 (Taipei 2000). 7I, Missive GG Van Diemen en Raad aan gouverneur van der Burgh dd 23 mei I637, I50 en Blussé, L., 'De Grot van de Zwarte Geesten, op zoek naar een verdwenen volk'. Tijdschrift voor Geschiedenis III (Meppel I998).

42. Blussé, L., The Formosan Encounter, iı6-ı27.

43. Idem, 233, 455.

44. Idem, 3I4.

45. Idem, I54.

46. http://www.gep-en.tpc.gov.tw/econtent/theme/themeo5.asp The Museum of Gold is housed in the former offices of the Taiwan Metal Mining Corp. The first floor exhibitions include gold discovery journey, Benshan tunnels (I-9), ore seam display and old mining equipment, mining transport systems and cultural artifact display. There is also an introduction to the Japanese WWII camp for Allied prisoners (I942-I945). DThe second floor has gold as the theme, including gold characteristics, gold art works and a world record $220 \mathrm{~kg} 999$ pure gold ingot which is unprecedented. You can touch it, too!

47. Blussé, L., Dagregisters Taiwan II, XII. 

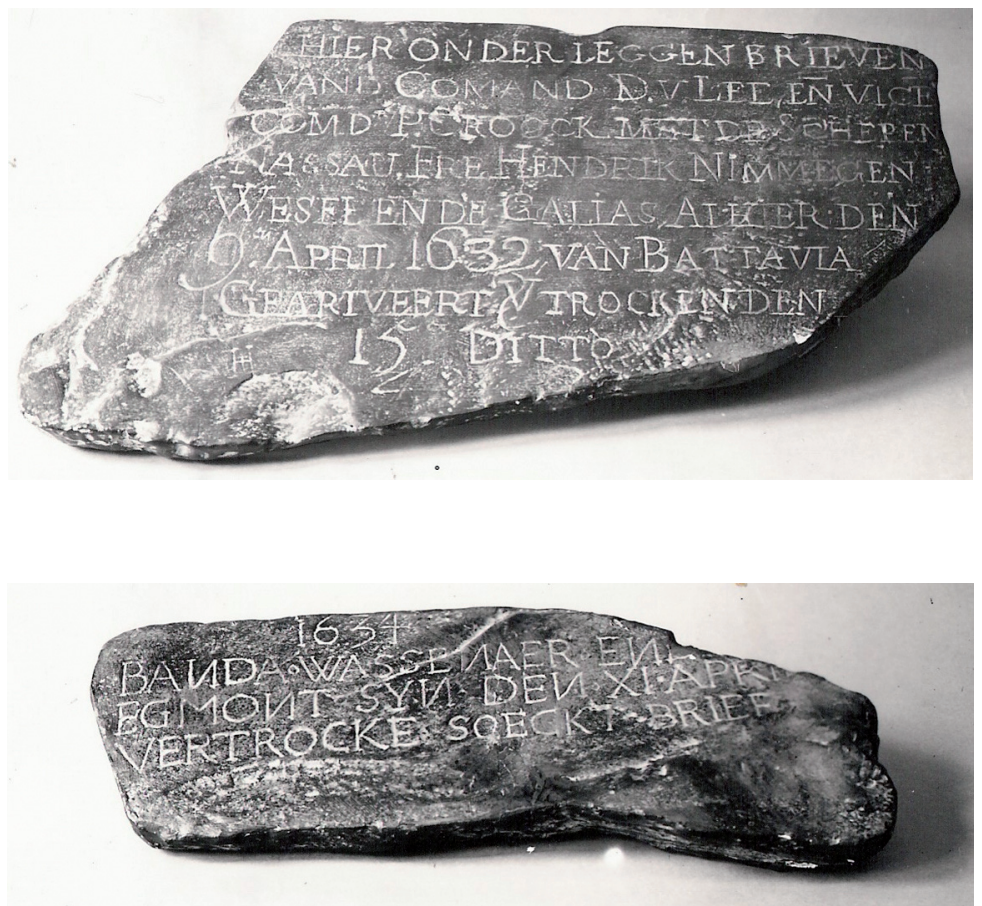

'SOECKT BRIEF'. De memorie van overdracht Brouwer bereikte Van Diemen via een unieke brievenbus. Voordat Jan van Riebeeck op Kaap de Goede Hoop een VOCvestiging stichtte begroeven de passerende schepen brieven op een vaste plaats die werd gemarkeerd met een steen. Uit de tijd van Van Diemen is het bovenstaande tweetal bewaard gebleven. Kunnen wij het ons nog voorstellen? 


\section{De situatie op Java}

Bij het aantreden van Van Diemen heerste het rijk van Mataram over Java, uitgezonderd Bantam en Batavia. Na de twee mislukte belegeringen van ${ }^{6} 628$ en ${ }^{6} 629$ ondernam het rijk van Mataram onder zijn vorst soesoehoenan Agung weliswaar geen expedities meer tegen Batavia, maar toch breidde het de macht in de Archipel uit van Java naar Sumatra en Borneo. ${ }^{\text {I }}$

Toen in I639 de VOC een Perzisch paard schonk aan de vorst van Palembang, de belangrijke peperhaven op Sumatra, werd dit kostbare rijdier op dringend Matarams verzoek in gezelschap van een klein olifantje aan de soesoehoenan vereerd. ${ }^{2}$ Ook Djambi op de oostkust van Sumatra en Bandjarmassin op Borneo dreigden vazalstaten van Mataram te worden. ${ }^{3}$

Op I6 april I638 werd in Batavia het bericht ontvangen dat vrijwel de gehele loge te Martapoera op Borneo was uitgemoord, evenals bijna de voltallige bemanning van een drietal kleinere schepen, bij elkaar zo'n tachtig man. De wrede reactie van de Hollanders hierop maakt over de eeuwen heen de onveiligheid nog voelbaar die door de omsingeling van Batavia was gegroeid. Uit wraak en om de eis tot vrijlating van de zeven overlevende Nederlanders kracht bij te zetten werd bij dertig gevangen Martapoerezen een been en een arm afgehakt, een oog uitgestoken, een gedeelte van de tong afgesneden en werden zij gecastreerd. Als de vrees maar groter was dan de haat.

Aan de vorsten op de Archipel liet men weten dat de Compagnie gezworen had wraak te nemen. ${ }^{4}$ In 1643 schreef Van Diemen hierover dat hij nog steeds vast van plan was zo wraak te nemen dat zelfs Mataram er een 'horreur' van zou krijgen en niets meer zou durven te ondernemen tegen de Nederlanders. ${ }^{5}$

Niet alleen de Heren Zeventien in Nederland, maar ook gouverneurgeneraal Brouwer vond dat Batavia aan de landzijde onvoldoende beschermd kon worden tegen de aanval van een groot Javaans leger. Hij had als gouverneur-generaal voorgesteld alsnog het eiland Banka boven Batavia te verkiezen. ${ }^{6}$ Van Diemen echter makte zich weinig zorgen over de oorlogen met Bantam en Mataram op Java. Hij schreef over Bantam: 'uit Batavia's opgang volgt Bantams rüne' gevolgd door een steek onderwater: 'Wien nu het meest aen den vreede gelegen is, geven des- 
ulcke te bedencken die in Ued. staet ervaren syn en van Bantams gelegenheyt kennisse hebben.'

Belangrijker was 'dat men Bantam niet te klein en den Soesoehoenan niet te groot mocht maken."

Ondertussen was de situatie voor de VOC op Java in de eerste jaren van het bewind van Van Diemen aanmerkelijk verbeterd. Van Diemen toonde zich een bekwaam diplomaat. Onderhandelingen voor een wapenstilstand kwamen in de eerste maanden van 1636 op gang via Chinese handelaren die op Bantam voeren. Met geschenken aan de hofgroten werd een goede stemming gekweekt en vooral door 'niet te verhaesten, maer vooreerst op sijn beloop te laeten' verdampten de forse vredeseisen van de Bantammers een voor een. ${ }^{8}$

In juli I636 koos de Bantamse koning eieren voor zijn geld en hij verbood zijn onderdanen om op lijfstraf 'die van Batavia' nog aan te vallen, waarop gouverneur en raden eenzelfde besluit namen. Hierdoor was informeel binnen een halfjaar een wapenstilstand tot stand gebracht. Van Diemen hield Bantam nog een tijd aan het lijntje, zodat pas in 1639 de wapenstilstand geformaliseerd werd. Een vredesverdrag werd echter pas in september I645 getekend. ${ }^{9}$

Tegelijkertijd kwam in ${ }_{16} 636$ de handel tussen Mataram en Batavia langzaam op gang. Voor beide was de handel aantrekkelijk, waarbij Van Diemen in het algemeen erop vertrouwde dat: 'den oorloghe soo van Mattaram als Bantam op 't hoogst sijn geweest en hun selver (sonder conditie) tot vreede voegen sullen.'

Dat bleek nog te optimistisch, maar wel was het zo dat bedreiging van Batavia door een van beide definitief tot het verleden ging behoren.

Door de opkomst van de VOC waren de banden tussen Mataram en de Portugezen hechter geworden. Zo bereikte een Portugees gezantschap uit Goa in februari I636 Mataram. De Portugezen brachten twee grote bronzen klokken als geschenk mee en opperden het plan samen Batavia te belegeren. Natuurlijk wilde Mataram dat ook, maar het had geen vertrouwen in de toezegging van de Portugezen dat zij een vloot zouden sturen die de Nederlandse de baas zou zijn. ${ }^{\text {II }}$ Het gedaalde prestige van de Portugezen bleek uit de magere geschenken die de Portugese ambassadeur kreeg: niet meer dan twee krissen nam hij retour. $^{.2}$

In 1638 kwam weer een Portugese gezant aan en in 1640 werden nog twee kanonnen uit Malakka overgevaren ${ }^{\mathrm{I} 3}$ met een brief van de onderkoning, Antonio Telles. Datzelfde jaar werd een Dominicaanse missie in Japara gevestigd die er tot 1676 zou blijven. De verovering van Malakka bracht een ommekeer teweeg in het ontzag dat Mataram buiten Java inboezemde. 
Het bericht van de val van Malakka kon men in Palembang eerst nauwelijks geloven. Doch enige maanden later, zo schreef Van Diemen: 'd'Overwinninghe van Malacca... de menschen aldaer gansch getransformeert; waeren tot verwonderens toe vrundelyek en de dienstbaer.' I4

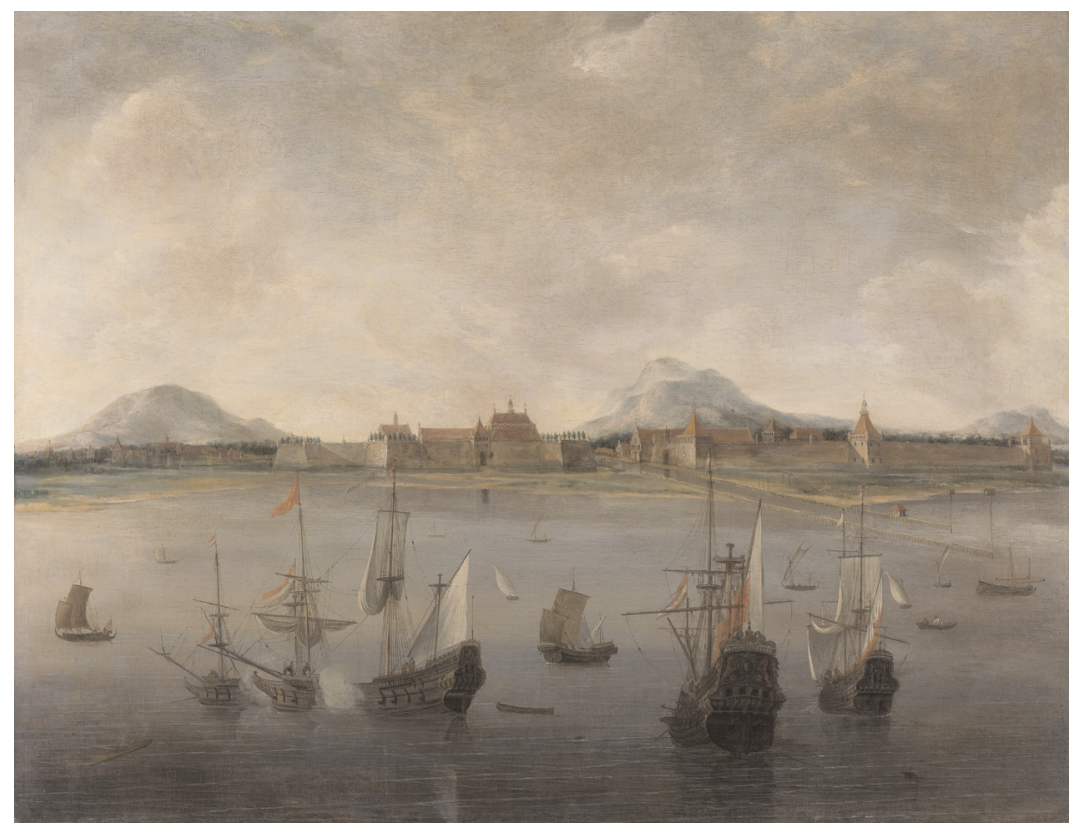

Handelsschepen uitgerust als oorlogsbodems op de rede voor het machtige kasteel van Batavia. Rijksmuseum Amsterdam.

Hierna kwam ook de handel tussen Mataram en Batavia werkelijk op gang. Van Diemen weigerde echter om toenadering tot Mataram te zoeken zolang de gevangen Nederlanders niet waren vrijgelaten. ${ }^{15}$ Het lot van de ongeveer veertig Nederlandse gevangenen in Mataramse handen was uitzichtloos. Enkelen zaten al meer dan tien jaar vast. Wel was regelmatig contact per post met hen. Zo kwam begin $\mathrm{I}_{42} 2$ het bericht in Batavia binnen dat een Javaans gezantschap zich gereed maakte voor de tocht naar Mekka. Het eerste deel van de reis zou gaan aan boord van het Engelse schip 'the Reformation'. Van Diemen besloot tot een machtsspel door het gezantschap gevangen te nemen. Op II juli I642 werd 'the Reformation' door een Nederlands eskader aangehaald en werden de Mekka-gangers met grof geweld van boord gehaald. Eén Engelsman en meer dan twintig Javanen kwamen hierbij om het leven. Het gezelschap werd in Batavia gevangen gehouden. Van het plan van Van Diemen om de gevangenen uit te wisselen, wilde Mataram echter nog 
steeds niets horen. Integendeel, als wraak voor het gebeurde werd de voorman van de Nederlandse gevangenen, Antonie Paulo, voor de krokodillen gegooid. ${ }^{\mathrm{I}}$

Uit de resolutie van de gouverneur-generaal en raden van 29 augustus I644 blijkt dat de Javanen nog een laatste poging ondernamen om van de Nederlanders af te komen. De Javanen die in Batavia woonden, zworen samen om Van Diemen te vermoorden en de stad in brand te steken. Hun leider was de gewezen voorman van de Javanen in Batavia, Jan Pekel, een familielid van de laatste regent van Jakarta. Met de steun van negentig Javanen zou Pekel het kasteel binnendringen en eerst Van Diemen en daarna de andere Nederlanders vermoorden om daarna de stadspoorten te openen. Ook de soesoehoenan van Mataram en de sultan van Bantam zouden in het complot betrokken zijn geweest. ${ }^{\text {I7 }}$ Of er werkelijk een complot geweest is, is uit de overgeleverde gegevens niet te halen.

Vanwege haar machtspositie werd de Compagnie steeds verder bij de politieke verwikkelingen op Java betrokken. Zonder dat daar een strategie aan ten grondslag lag, breidde haar macht zich in de zeventiende en achttiende eeuw langzaam uit over Java. Telkens als er een machtsvacuüm ontstond of onrust dreigde, koos de Compagnie partij. Zo kwamen Bantam, Mataram en uiteindelijk heel Java binnen haar invloedssfeer. In de achttiende eeuw was in de Archipel buiten Banda, de Molukken en Makassar van zo'n machtsuitbreiding nog geen sprake. De koloniale verhoudingen ontstonden pas in het begin van de negentiende eeuw.

\section{Noten}

I. De Graaf, H.J., 'De regering van Sultan Agung, vorst van Mataram, I6I3- I645', Verhandelingen van het Koninklijk Instituut voor taal-, land-en volkenkunde. Vol. XXIII ('s-Gravenhage I958).

2. Ibidem, 267 .

3. Ibidem, 277.

4. De Jonge, De Opkomst van het Nederlandsch gezag in Oost-Indie. Verzameling van onuitgegeven stukken uit het Oud-Koloniaal Archief III, ıा6; MacLeod, De Oost-Indische compagnie als zeemogendheid in Azië 2, 95; De Graaf, H.J., 'De regering van Sultan Agung, vorst van Mataram, I6I3-I645', 290

5. Coolhaas, Generale Missiven II, I97, 7 maart I643.

6. NA VOC 316 f75 I3 september I635.

7. De Jong De Opkomst van het Nederlandsch gezag in Oost-Indie, V, 225/226 Brief GG en Raden 27 december 1636.

8. Coolhaas, Generale Missiven II, 227. 
9. Heeres, Corpus Diplomaticum Neerlando-Indicum, I, 457.

Io. De Jonge, De Opkomst van het Nederlandsch gezag in Oost-Indie, V, 229.

II. De Graaf, H.J., 'De regering van Sultan Agung, vorst van Mataram, I6I3-I645', 223.

I2. Volgens De Graaf bevond zich in het museum van het Koninklijk Bataviaasch Genootschap een bronzen klok, genummerd: 20889 . Deze draagt twee Portugese opschriften: Este sino mandou fazer Conde de Linhares, en daar onder: Vizorei da India Pera el Rei do Matarao A. (I)633. Het was dus een klok, gegoten op bevel van de Graaf de Linhares

I3. De Graaf, H.J., 'De regering van Sultan Agung, vorst van Mataram, I6I3-I645', 229.

I4. Idem, 276.

I5. De Jonge, De Opkomst van het Nederlandsch gezag in Oost-Indie, V/ II, CXXI.

I6. MacLeod De Oost-Indische compagnie als zeemogendheid in Azië II 340; De Jonge, De Opkomst van het Nederlandsch gezag in Oost-Indie, V/ II, CXXIV; De Graaf, H.J., 'De regering van Sultan Agung, vorst van Mataram, I6I3-I645', 25.

I7. De Jonge, De Opkomst van het Nederlandsch gezag in Oost-Indie, V/ II, CXXIV. 


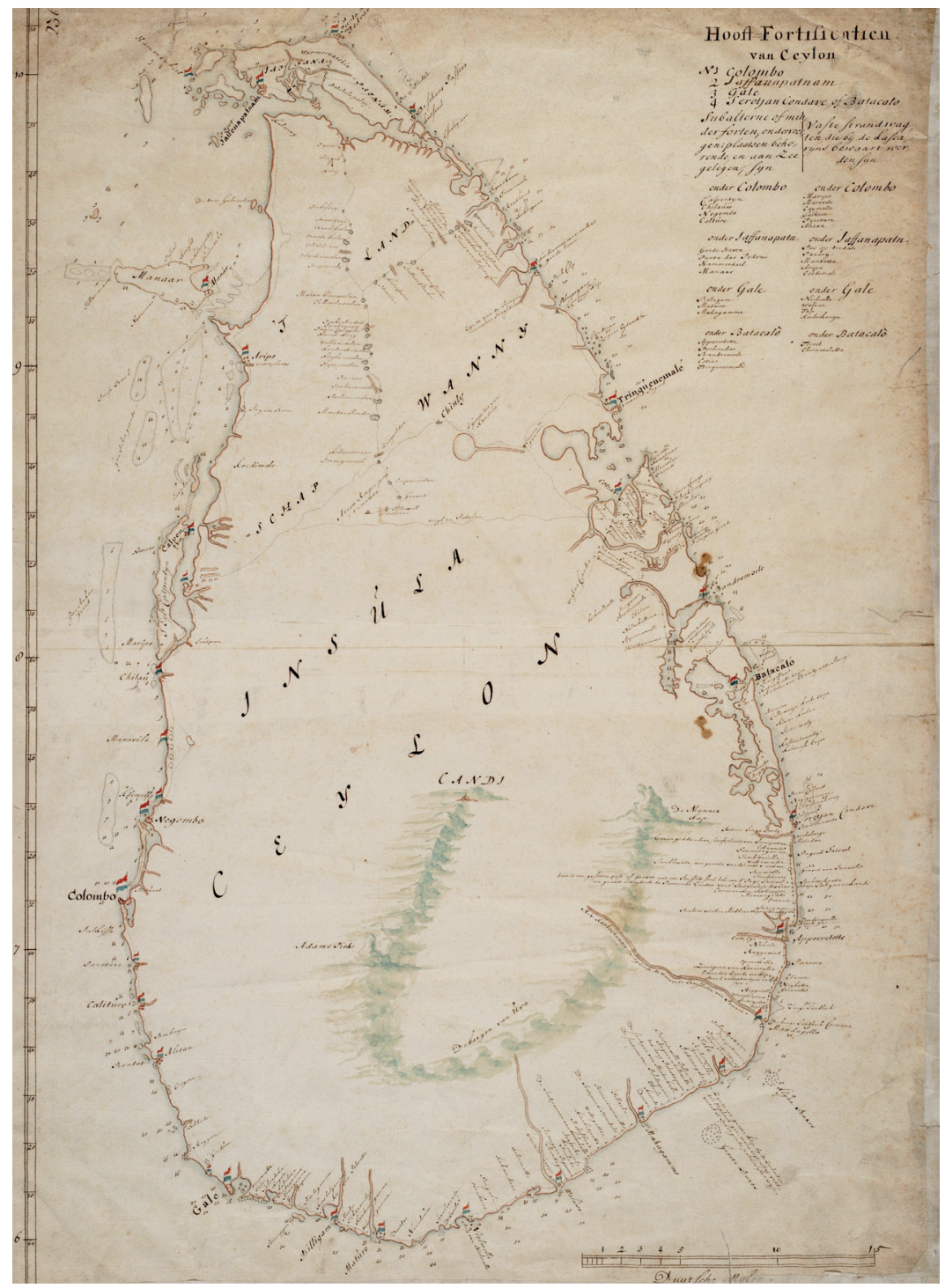

Op deze kaart van Ceylon, gemaakt in 1676 staan twintig rood-wit-blauwe vlaggetjes langs de kust. Evenveel forten waren nodig om het kaneelmonopolie te beschermen. Nationaal Archief Den Haag. 


\section{De strijd tegen de Portugezen in de Indische Oceaan}

Toen Philips II van Spanje in 1580 zoals hij zelf zei 'Portugal erfde, kocht en veroverde,' deed hij de concessie dat hij niets zou veranderen aan het bestuur in Portugal en aan diens bezittingen overzee. ${ }^{\mathrm{I}}$ Dit hield onder meer in dat de Portugese bezittingen in Azië strikt gescheiden zouden blijven van de Spaanse. Het betekende natuurlijk wel dat Portugal bij de Europese oorlogen van de Habsburgers werd betrokken.

Door de Spanjaarden werd een voortdurend beslag op de Portugese middelen gelegd. De geschiedenis van de Estado da India, zoals de Indiase bezittingen werden genoemd, leest hierna als één grote roofbouw.

Deze situatie zou zo blijven totdat in I640 Portugal zich in een paleisrevolutie weer losmaakte van de Spaanse kroon waarmee aan deze 'Babylonische gevangenschap' een einde kwam.

De Spaanse armada van 1588 bestond voor ongeveer de helft uit Portugese schepen, die bijna alle verloren gingen. De Portugezen konden hun jaarlijkse vloten naar Goa niet meer behoorlijk konden uitrusten met werkelijk desastreuze gevolgen: in het decennium na I590 ging bijna de helft van de retourschepen verloren. ${ }^{2}$ De verbinding tussen Goa en Lissabon werd steeds slechter door schipbreuk, en niet, tot het aantreden van Van Diemen, door aanvallen van de Nederlanders op zee.

Daarnaast werd voortdurend waar mogelijk geld afgetapt dat daarvóór als bloed door de handelsaderen stroomde. De Italiaanse edelman Pietro della Valle bezocht in $\mathrm{I}_{22}$ Goa, waar hij het prachtige beeld schetste van een verarmde edelman die naar buiten deed alsof er niets aan de hand was, maar wiens kleren tot op de draad versleten waren. ${ }^{3}$

Er werden wel pogingen ondernomen om de verbinding tussen Lissabon en Goa weer op peil te brengen. De bekendste daarvan is de oprichting in 1629 van een Portugese Oost-Indische Compagnie naar Nederlands voorbeeld door de Spaanse graaf hertog Olivares, de eerste minister van Philips IV. De nieuwe compagnie zou het staatsmonopolie van de peperhandel tusen Goa en Lissabon overnemen door jaarlijkse vloten. Het werd een mislukking. De kooplieden weigerden kapitaal te stoppen in een onderneming waarin de werkelijke macht lag bij de Spaans/Portugese overheid. Daarnaast werd dit initiatief tegengewerkt omdat het inbreuk zou maken op de gevestigde 
belangen van de adel en de kerk. Na vijf jaar werd de compagnie dan ook weer opgeheven. ${ }^{4,5}$

Oppervlakkig bekeken leek er in ${ }_{1} 636$ nog weinig aan de hand. Buiten het kleine fort op Ambon in I605 en het grote op Hormuz in I622 hadden de Portugezen geen vesting verloren. Daarnaast waren de Portugese handelaren privé in staat gebleven geld te verdienen en elke Portugees was koopman, of hij nu de onderkoning was of een handelaar in Makassar. Zo kon in ${ }^{6} 636$ de graaf van Linhares bij zijn terugkeer in Europa aan Philips IV diamanten schenken met een waarde van honderdduizend ducaten, wat naar men aannam slechts een klein deel was van het fortuin dat hijzelf in zes jaar als onderkoning vergaard had. ${ }^{6}$

Tevens waren onafhankelijke Portugese handelaren gevestigd in alle havensteden aan de Indische Oceaan en door de Straat van Malakka richting China en Japan. Buiten de Estado da India om waren door een krachtige diaspora Portugese steden gesticht als Macao en Sao Thome op de Coromandelkust. Anders dan de Nederlanders konden de Portugezen in Azië op eigen benen staan. Zo groot was hun invloed dat Portugees de lingua franca werd voor de zeehandel in Azië en zelfs in Batavia.

Onder Van Diemen kreeg de aanval op de Portugezen prioriteit. Waarom koos hij hiervoor? Deze vraag is in de literatuur tot nu toe op verschillende manieren beantwoord. Zo schreef Van Veen in 200I in zijn Decay or Defeat, An inquiry into the Portuguese decline in Asia 1580-1645 hierover alleen dat de aanval door Van Diemen zonder goedkeuring van of overleg met de Heren Zeventien werd ingezet, maar niet waarom hij daartoe overging. ${ }^{7}$

Blussé en Winius stelden in hun eerdere artikel 'The Origin and Rythm of Dutch Agression against the Estado da India, 1601 -1661' het voor als een plan dat allang bestond, maar dat pas tot uitvoer gebracht kon worden met het Japanse zilver dat rond I635 de kas van de VOC begon te spekken. Er zat volgens hen logica in de opeenvolgende acties van de Nederlanders. Eerst verdreven zij de Portugezen uit de specerij-eilanden, vervolgens nam de VOC de plaats in van de Portugezen in de handel op Japan, waarna er pas ruimte was voor de eigenlijke aanval op de Portugezen in de Indische Oceaan. Het was volgens hen een vooraf uitgestippelde strategie. $^{8}$

Gaastra zwakte dit weer af. Van een masterplan was wellicht geen sprake maar 'wel van een zekere systematiek en, ten aanzien van de bestrijding van de Portugese macht, van een duidelijke strategie.' 9

Maar waarom deze aanval als die niet nodig was voor het geld? Per slot was de VOC voor aandeelhouders niet direct een vetpot geweest en het zou daarom te verwachten zijn geweest dat de winsten nu naar $\mathrm{Ne}$ derland zouden stromen. En als het plan allang bestond, waarom was het dan niet bekend bij de bewindhebbers in Nederland? 
In hun brief die de vloot van ${ }_{1} 6_{3} 6$ begeleidde, werd namelijk met geen woord gerept over een aanval op de Portugezen. Sterker nog, zij schreven als steek naar Brouwer: 'Wij verclaren Ue dat ons al dat dat overhoop halen van oorlogen niet en gevalt, 't welck meer verachteringe als bevoordelingen van compagnies affairen brengen zal. ${ }^{\text {,० }}$

De Heren Zeventien zouden pas de acties tegen de Portugezen gaan ondersteunen nadat zij ervan op de hoogte waren gesteld. ${ }^{\text {II }}$

In reactie op het artikel van Blussé stelde Vink in zijn artikel 'South India and the China Seas: how the V.O.C. Shifted its Weight from China \& Japan to India around A.D. ${ }_{16} 6$ ' dat het juist andersom was:

'To researchers in Indo-Portuguese history, for whom V.O.C. operations form an important but often incomprehensible backdrop, the reasons why it behaved as it did seem all but totally capricious and mysterious. This they were not... It would seem that after its ambitions in China and Japan went unrealised, at least in part, it turned aggressively upon Ceylon and the Portuguese stations in Malabar.'

Om te besluiten met

'Though no deliberations have been found which explain the dramatic shift from the Far-East, there can be little doubt but that India only became interesting to the V.O.C. warlords when similar policies had failed to open markets in China and Japan to the levels of trading they desired. ${ }^{, 12}$

Deze laatste conclusie van Vink is onjuist. In commerciële zin leek bij het aantreden van Van Diemen de Japanse handel van de Compagnie zich op te maken voor een ongekende bloeiperiode en tot $\mathrm{I} 640$ was dit ook het geval. In de vier jaar na ${ }_{1} 636$ was de strijd tegen de Portugezen al in alle hevigheid losgebrand en was zijn ontknoping nabij.

Uit de brieven die Van Diemen in december I632 schreef, tekenen zich de contouren af van een ander ander beeld. Van Diemen voerde een plan uit dat in de loop der jaren bij hem was gerijpt. De grondslag hiervan was zijn stellige overtuiging dat een onafhankelijke Portugese handelaar het weinig efficiënte en bureaucratische handelsnetwerk van de Compagnie altijd te snel af zou zijn. Tegelijkertijd was hij van mening dat de positie van de VOC als handelaar met het zwaard in de hand was gewonnen.

Het was hem daarbij in ${ }^{6} 6_{32}$ tijdens zijn verblijf in Nederland duidelijk geworden dat de oorlog tegen de Spanjaarden en Portugezen eindig zou zijn. Als de Portugezen in Azië niet overtuigend verslagen zouden 
zijn, zou in een tijd van vrede de VOC zich door haar logheid niet kunnen handhaven tegenover de Portugese particuliere handelaren. Zij zou dan niet meer in staat zijn te profiteren van de intra-Aziatische handel en dat zou tot gevolg hebben dat de VOC de retourladingen zou moeten inkopen tegen een hogere kostprijs. De toch al lage winstgevendheid van de VOC zou hierdoor onder druk komen te staan waardoor het voortbestaan van de Compagnie regelrecht zou worden bedreigd.

Coen had als eerste dit gevaar al onderkend en voorgesteld om net zoals de Portugezen de intra-Aziatische handel vrij te geven aan particuliere handelaren. Deze route was in de jaren daarna door het beleid van de Compagnie afgesloten. Er bleef in de ogen van Van Diemen maar één andere weg over. Tegen elke prijs moest ervoor gezorgd worden dat de Portugezen geen concurrenten meer konden zijn.

De reden van de aanval is daarmee onverwacht en in tegenspraak met de vaak aangenomen superieure efficiëntie van de VOC en EIC tegenover de verouderde Estado da India. Van Diemen was ervan overtuigd dat de VOC niet bij machte zou zijn zich staande te houden in directe vreedzame concurrentie met de Portugezen. De omweg van alle mensen en goederen via Batavia was bijzonder kostbaar. ${ }^{13}$ En tegelijkertijd zorgden de hoge kosten die de handhaving van de monopolies in nootmuskaat, foelie en kruidnagel met zich mee brachten dat de interne transactiekosten hoog en weinig flexibel waren. Daartegenover stond dat juist de centralisatie van haar bedrijf in Azië de VOC de kracht gaf om toe te slaan en daar wilde Van Diemen gebruik van maken.

Natuurlijk klopten de verhalen over de corruptie, inefficiëntie en verwaarlozing door de Portugezen, maar daartegenover stond een enorme veerkracht. Van Diemen was van mening dat de Portugezen in Azië in I636 aangeslagen waren, maar bepaald niet uitgeteld en dat zij, als zij de kans zouden krijgen, hun leidende positie weer zouden innemen zodra er een vrede werd gesloten in Europa, die ook in Azië de wapens zou laten rusten. Van Diemen had zichzelf de opdracht gegeven vóór dat tijdstip de Portugezen uit te schakelen, koste wat het kost. Hij ging hiermee veel verder dan het advies dat hij van Brouwer had gekregen.

In Nederland had men duidelijk grote moeite deze agenda van Van Diemen te volgen. Zo werd Van Diemen in I640 op het hoogtepunt van de strijd tegen de Portugezen stevig gekapitteld. De vergadering van de Heren Zeventien was er bijzonder ontstemd over dat de vloot gebruikt werd voor Ceylon op 'onseeckere exploiten' en verklaarde 'grootelijcks verwondert sijnde dat het redres van de Moluckse en Amboinsche saecken bij uE niet meer in consideratie quamen. ${ }^{\text {I4 }}$

Wellicht speelde bij Van Diemen nog een persoonlijk motief mee in zijn strijd tegen de Portugezen. Hij was in Amsterdam immers failliet gegaan doordat de zeeverzekeringstransacties die hij met Portugese kooplieden had afgesloten, voor hem verkeerd waren afgelopen. Koes- 
terde hij wrok? Het zou de hardvochtigheid kunnen verklaren waarmee hij tot het uiterste ging om de Portugezen te verslaan.

De VOC had in ${ }_{1} 636$ lange tijd geen grote acties meer tegen de Portugezen ondernomen. Na de mislukte overval op Macao in I622 en de korte blokkade van Goa gezamenlijk met de Engelsen in datzelfde jaar ${ }^{15}$ werden in de jaren daarna vooral kleine Portugese schepen buitgemaakt langs de kusten van India. Wel kruiste als het kon een VOC-eskader in de Straat van Malakka niet alleen op jacht naar Portugese schepen, maar ook naar die van Indonesische vorstendommen waarmee de VOC in oorlog was en die handel dreven op Malakka.

In die jaren bleek ook dat de Portugezen nog van zich af konden bijten. In I629 versloeg een vloot uit Goa eerst overtuigend een vloot uit Atjeh die Malakka belegerde, en daarna werden voor de Sumatraanse peperhaven Djambi drie Nederlandse schepen en een Engels jacht veroverd of tot zinken gebracht. De Nederlanders boekten dus niet alleen maar overwinningen. ${ }^{\text {IG }}$

Aan Portugese kant spraken de onderkoning en zijn raad in Goa tot I636 zelden over de Nederlanders die, wanneer wel onderwerp van gesprek, steevast werden afgedaan als 'rebeldes'. Zij vormden in hun ogen een dreiging op afstand, maar geen acuut gevaar. De Nederlanders bemoeilijkten de verbinding met Malakka en Macao en brachten de handel schade toe, maar waren zeker niet onoverwinbaar. In 1634 hechtten de onderkoning en zijn raad graag geloof aan het gerucht dat de bisschop van Sao Thomé aan de oostkust van India had gehoord. Het verhaal ging dat de Nederlanders er slecht aan toe zouden zijn nadat zij veel schepen hadden verloren in hun strijd tegen de Chinezen. ${ }^{\mathrm{I}}$ In februari ${ }^{6} 635$ besprak de onderkoning met de Engelse directeur Methwold plannen om gezamenlijk de vestingen van de Nederlanders aan te vallen met het doel Batavia en Banda te veroveren. Daarvoor waren dan wel twaalf schepen nodig uit Lissabon, zoals hij aan de koning schreef. ${ }^{\mathrm{I}}{ }^{\mathrm{In}}$ het najaar van $\mathrm{I} 635$ werd krachtige steun beloofd aan Mataram als die Batavia weer zou gaan belegeren. ${ }^{\text {I9 }}$

Toen de VOC in ${ }_{1} 636$ haar aanval inzette, kwam de heftigheid daarvan voor de Portugezen volledig onverwacht. De kern was een jaarlijkse blokkade van Goa van oktober tot april. Deze trof de Portugezen in het hart. Negen jaren achtereen ging een Nederlandse vloot in de baai van Goa voor anker. Het directe effect van deze blokkade was dat de rechtstreekse verbinding van Goa over zee met Portugal praktisch werd verbroken. ${ }^{20}$ Maar minstens zo belangrijk was dat aan de Aziatische vorsten overduidelijk werd getoond dat de Nederlanders de suprematie op zee van de Portugezen hadden overgenomen.

Het gevolg hiervan was verlies van prestige en een drastische daling van de inkomsten van de Cartazes, de vrijgeleiden die de Portugezen aan schepen van Indiase koopvaarders verkochten. 


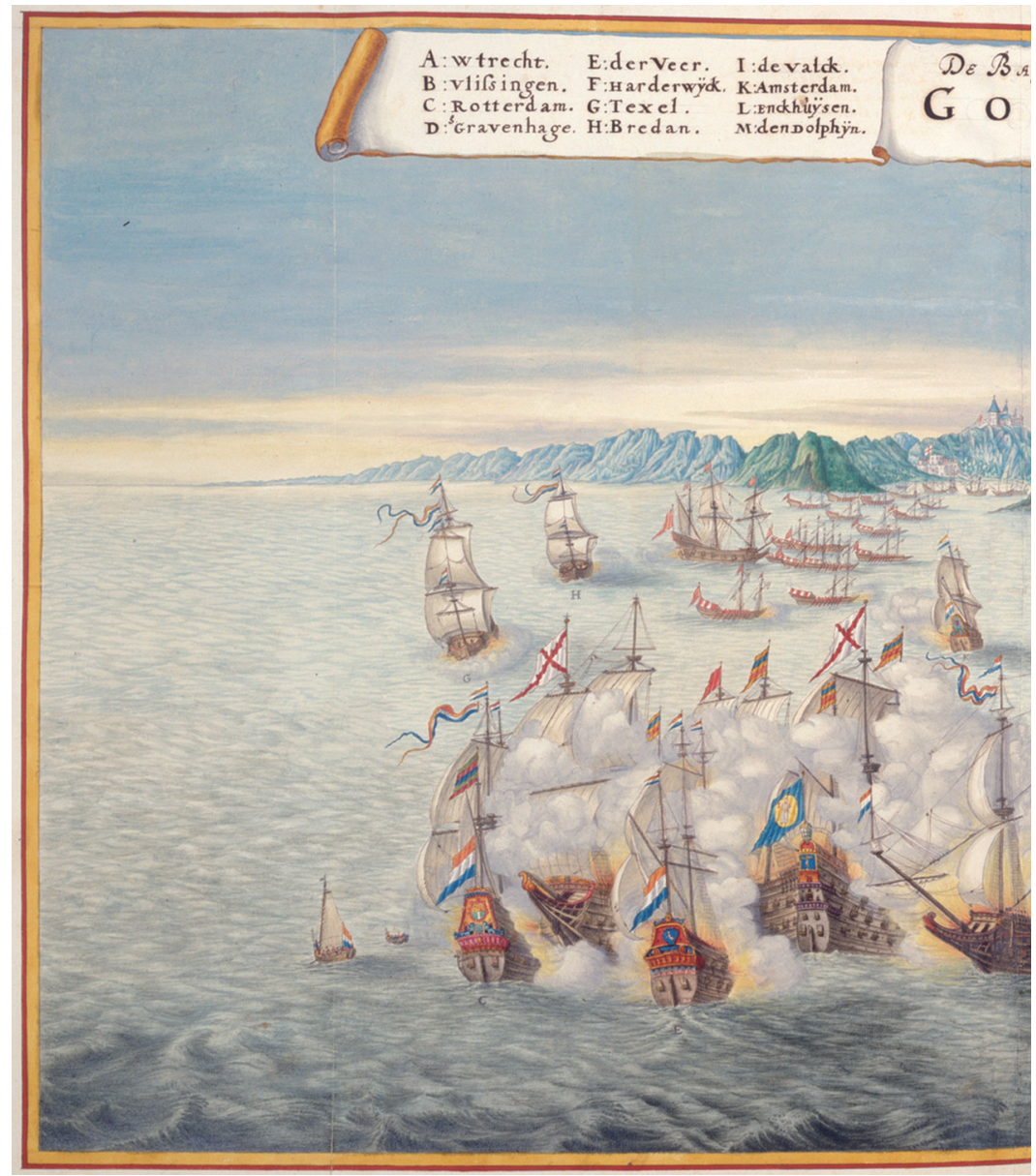

In deze belangrijkste zeeslag van de VOC werd op 24 januari 1638 de Portugese vloot met grote verliezen teruggedreven in de haven van Goa. De hegemonie op zee werd daarmee een feit. Atlas Van der Helm, Österreichische Nationalbibliothek, Wenen.

Overigens, met kleine snelle schepen konden de Portugezen de blokkade makkelijk omzeilen. De Portugese kustvaart werd gehinderd, maar niet verhinderd. Zo telde de Duitse reiziger Johan Albrecht van Mandelslo die in januari I639 in Goa aankwam, ondanks de Nederlandse blokkade op één dag wel driehonderd kleine schepen die Goa wisten te bereiken. $^{2 \mathrm{I}}$

De commandant van de eerste blokkadevloot was de ervaren Jacob Cooper. Hij had hiervoor drie jaren met zes jachten de Straat van Malakka afgesloten en daar gejaagd op Portugese en Mataramse schepen. In zijn instructie werd hij gewaarschuwd voor de nieuwe Portugese on- 


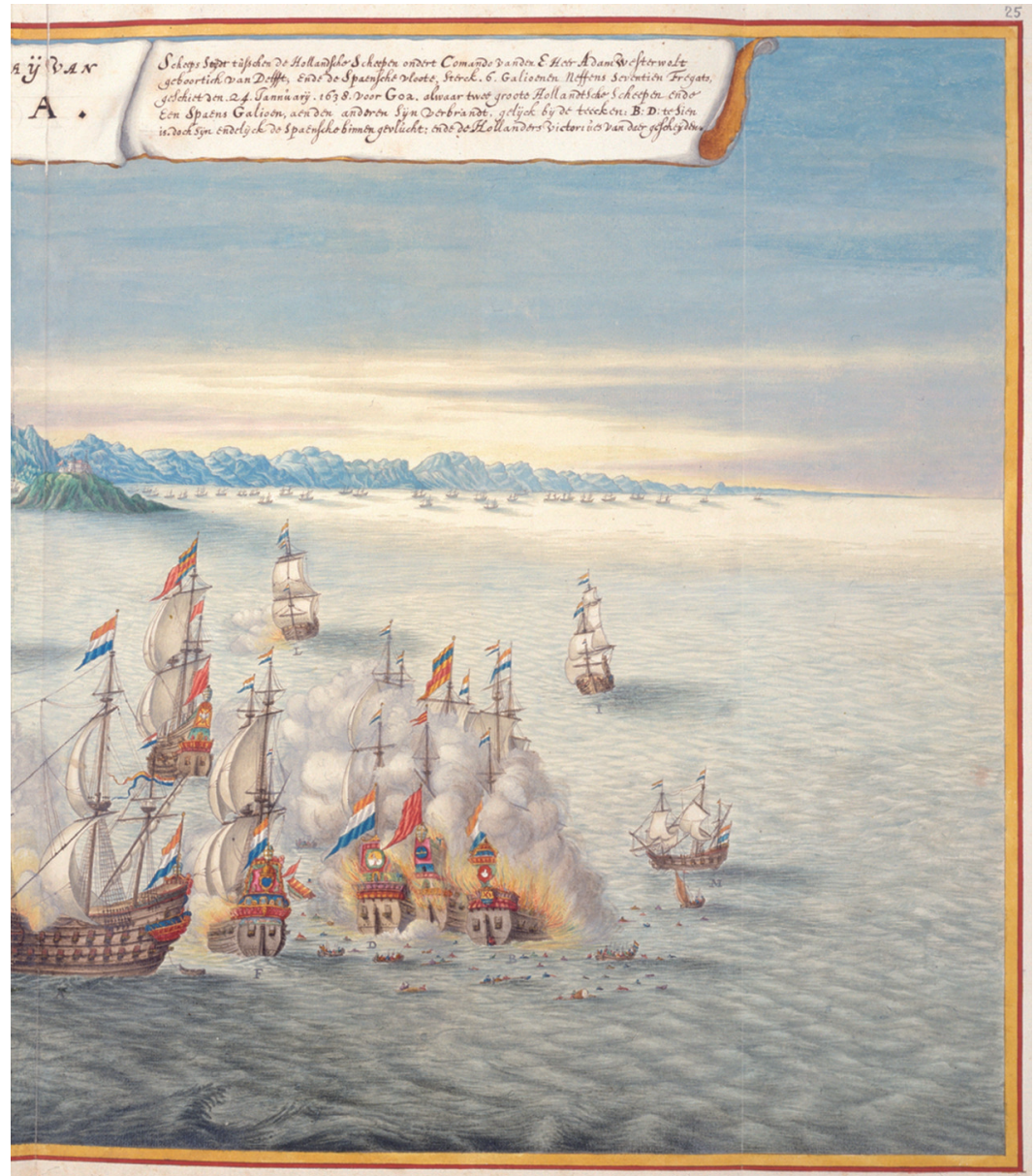

derkoning, die stond bekend als een moedig man en hij zou zeker met zijn vloot uitvaren om de blokkade te breken en de Nederlandse schepen van de rede van Goa 'weg te slaen'. Een voordeel voor de Nederlanders was dat de Portugese vloot pas buiten de haven slagvaardig gemaakt kon worden zodat Cooper altijd meer dan voldoende tijd zou krijgen om zich op de strijd voor te bereiden.

Uit de instructie blijkt dat Van Diemen ook veel verwachtte van de peperhandel op de kust van Malabar. Daar zou met schepen die niet strikt voor de blokkade nodig waren in december naartoe gevaren kunnen worden om zo direct na de oogst vrij goedkoop een grote hoeveel- 
heid peper in te kopen. Het was voornamelijk ruilhandel tegen lood, kwikzilver, vermiljoen, Japanse kamfer en sulfer. Cooper kreeg de opdracht zo maximaal 8 duizend quintalen van I25 pond, dus maximaal I miljoen pond peper in te kopen. ${ }^{22}$

Pogingen om de blokkade te breken waren er in $\mathrm{I}_{3} 7, \mathrm{I}_{3} 8$ en $\mathrm{I} 6_{39}$. De Portugese vloot voer onder de bescherming van de kustbatterijen uit en bracht de Nederlanders de nodige verliezen toe, maar leed telkens een nederlaag. ${ }^{23}$ In januari ${ }_{16} 63$ erkenden de onderkoning en zijn raad dat de Portugese schepen niet op konden tegen de superieure vuurkracht van de Hollandse ijzeren kanonnen. ${ }^{24}$ De Portugezen waren hiertegen machteloos.

Buiten deze gevechten leverde de jaarlijkse blokkade in negen jaar geen spannende verhalen op, maar wel een fraai schilderij.

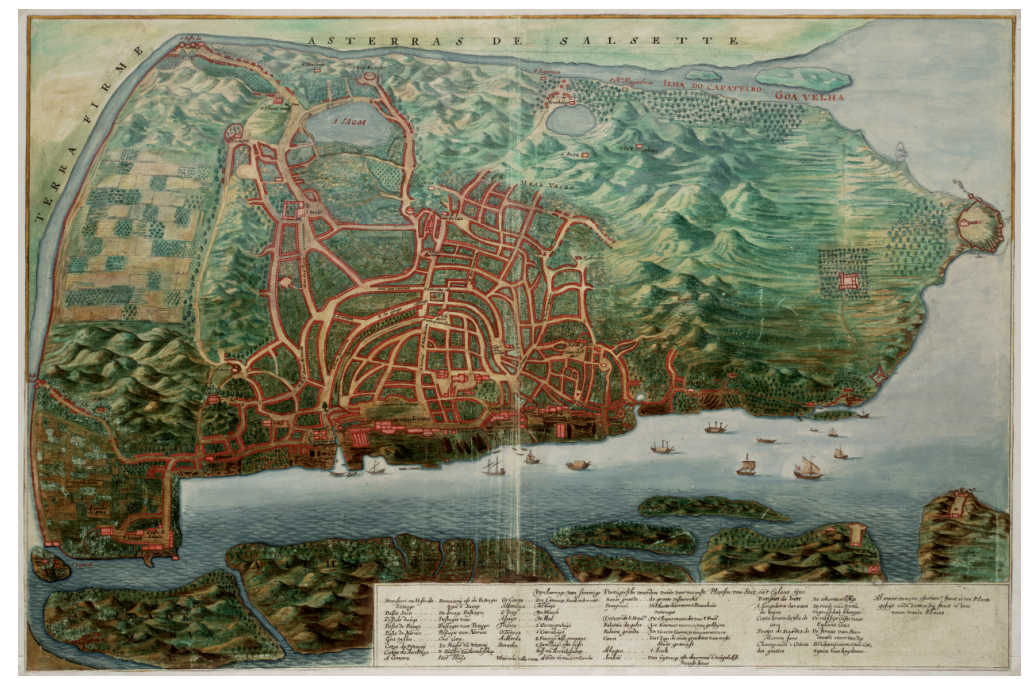

Het 'gouden' Goa bleef groter dan Batavia, maar raakte ontdaan van haar zeemacht steeds verder in verval. Atlas Van der Helm, Österreichische Nationalbibliothek, Wenen.

Naar buiten hielden de Portugezen in Goa de schijn van rijkdom op, zoals dezelfde Mandelslo in I639 beschreef. ${ }^{25}$ Toen in september I640 na een lange en moeizame tocht de nieuwe onderkoning met 2200 man aan boord in Goa aankwam, vlak voordat de Nederlandse blokkadevloot aanlandde, werd dit als een overwinning gevierd. ${ }^{26}$

In Nederland steunden de bewindhebbers de blokkade van Goa zodra zij ervan hoorden. In hun brief van oktober I6 37 prezen zij de activiteiten van de vloot voor Goa. Zij spraken zich uit voor voortzetting van de blokkade. ${ }^{27}$ In de jaren daarna werd hun enthousiasme alleen maar groter. In de brief van de kamer Amsterdam van april I638 werd geschre- 
ven dat de Portugezen die via de kamer Amsterdam aandelen hielden in de VOC, gezegd hadden dat zij bericht uit Portugal hadden gekregen dat de handel tussen Portugal en Goa tot stilstand was gekomen. Volgens hun zegslieden waren de Nederlanders in Azië nu heer en meester op zee en dreigde de toestand voor de Portugezen in India hopeloos te worden. Daarom was er in Portugal zelf ook geen 'lust of couragie' om een bijzondere vloot te equiperen. Er lagen slechts twee kleine schepen klaar om naar Goa uit te varen.

Van Diemen werd opgeroepen om, als dat kon, Goa het volgend jaar opnieuw met 'een goede macht van grote en kleine schepen te bekruisen. ${ }^{28}$ De eerste successen van Van Diemen vonden dus weerklank in Nederland. Zij prikkelden de fantasie. Daar was de sfeer ook naar in dat jaar. De West-Indische Compagnie (WIC) had in I637 niet alleen Noord-Brazilië veroverd, maar ook El Mina, het grote Portugese fort op de WestAfrikaanse kust, van waaruit jaarlijks duizenden slaven naar Amerika werden vervoerd. Frederik Hendrik had in datzelfde jaar weliswaar Venlo en Roermond verloren, maar Breda heroverd. Het paste het prestige van de VOC in Nederland om ook toonbaar schade toe te brengen aan de vijand aan de andere kant van de wereld, maar het was vooral goed voor de handel, zo werd aan Van Diemen geschreven.

Doordat de Nederlanders de vaart tussen Portugal en Goa blokkeerden, stegen in Amsterdam de prijzen voor peper, zodat in I637 'peper voor 32 1/2 groten het pond' niet te koop was. Goed nieuws, want het had 'met de peperhandel nu enige jaren niet wel voort gewilt." 9

Nadat in oktober I639 in de zeeslag bij Duins de laatste eskaders van de eens zo machtige Portugese vloot waren vernietigd, was verdere hulp uit hun vaderland niet meer te verwachten. Voor de Engelse kust werd het Portugese smaldeel van de tweede Spaanse armada onderschept door de Nederlandse vloot onder admiraal Johan Evertsen, die daarop een ware slachting onder zijn vijand aanrichtte.

\section{De strijd op Ceylon}

In het verlengde van de blokkade van Goa begonnen in I637 de pogingen om op Ceylon het kaneelmonopolie op de Portugezen te veroveren. Dat was een grote onderneming. Rond I635 was de Portugese macht op Ceylon stevig verankerd. De opbrengsten van de kaneel waren voor de regering in Goa van groot belang, omdat hiermee het verlies van de specerijhandel gedeeltelijk werd goedgemaakt. Vanuit de grote forten Negombo, Colombo en Galle op de westkust van het eiland werden de laaggelegen streken waar de kaneel werd verbouwd, beheerst. Aan de oostkant maakten de kleine forten Trincomale, Baticalao en Jafna de beheersing van de kust compleet. Weliswaar was de poging om het cen- 
traal gelegen koninkrijk Kandy te veroveren in r630 op een ramp uitgelopen, toch kon radja Singha van Kandy niets tegen de Portugese forten aan de kust uitrichten. In I634 werd de vrede tussen de Portugezen en Kandy opnieuw getekend.

Stel nu, zo schreef de Portugees Joao Ribeiro in I685, dat rond I625 de Portugezen net iets meer geld, manschappen en schepen tot hun beschikking hadden gekregen van de Spanjaarden, dan zou het wellicht mogelijk zijn geweest het hele eiland Ceylon te veroveren. De effectieve katholieke missie zou zijn werk hebben kunnen doen en het eiland zou de rijke, onoverwinlijke basis zijn geworden voor het Portugese rijk in India. ${ }^{30}$ Het liep echter anders.

Toen in 1636 de Nederlandse vloot de baai van Goa bezet hield, benaderde radja Singha de VOC-gouverneur aan de Coromandel-kust, Carel Reiniers, en vroeg door zijn tussenkomst hulp aan Van Diemen bij hervatting van de strijd tegen de Portugezen. Gevolg hiervan was dat Adam van Westerwolt, de commandeur van de blokkadevloot die in augustus I637 naar Goa vertrok, de opdracht mee kreeg om actie tegen de Portugezen op Ceylon te ondernemen. ${ }^{3 \mathrm{I}}$

Dat gebeurde op de terugtocht van deze vloot. Op Io mei I638 lieten drie schepen hun anker vallen voor Baticalao aan de oostkust. Het Portugese fort aldaar was niet bijzonder groot, maar het was wel modern en zo stevig gebouwd dat een groot leger van radja Singha een paar jaar eerder er niets tegen had kunnen uitrichten. Westerwolt bracht zwaar scheepsgeschut aan wal. Nadat dit in stelling was gebracht, werd het vuur geopend met een verwoestende uitwerking. Na een beschieting van slechts enkele uren gaf de bezetting zich over. De Portugezen kregen op Nederlandse schepen een vrijgeleide naar Negapatman op de Coromandelkust. Weer waren het de kanonnen die het verschil maakten.

Op 23 mei werd een verdrag door de VOC met radja Singha afgesloten om ook in de volgende jaren samen als bondgenoten op Ceylon tegen de gemeenschappelijke Portugese vijand te strijden. De prijs van de Nederlandse hulp zou het kaneelmonopolie zijn dat aan de VOC werd gegeven als het op de Portugezen werd veroverd. Verder mochten de Nederlanders garnizoenen leggen in de veroverde forten. Of dat alleen na toestemming van radja Singha kon gebeuren, zoals in de Portugese tekst stond, of zonder meer zoals in de Nederlandse, gaf later aanleiding tot verschil van mening. ${ }^{32}$

De Portugezen maakten het ondertussen niet beter voor zichzelf. Een Portugese strafexpeditie van vijfentwintighonderd man veroverde in I638 Kandy, de hoofdstad van radja Singha, maar op de terugtocht werd het met buit beladen leger overvallen en haast tot de laatste man uitgemoord. Troepen die de Portugezen niet konden missen.

In juni $6_{3} 9$ veroverden de Nederlanders en Singalezen het tweede kleine fort op de oostkust, Trincomale. Het jaar daarop werden Galle en 
Negombo veroverd, waarmee de VOC toegang kreeg tot de kaneellanden. Bij de inname van deze forten werden enorme risico's gelopen, maar voor de Nederlanders liep het telkenmale goed af. Colombo, het grootste fort van de Portugezen op Ceylon, bleef echter in Portugese handen.

In Nederland plaatsen de bewindhebbers vraagtekens bij de 'grote concepten' op Ceylon. Die waren hen te kostbaar en de kans leek hen reëel dat radja Singha zich van de Nederlanders zou ontdoen zodra zij hem geholpen hadden zich van de Portugezen te bevrijden. ${ }^{33}$ De verhouding met radja Singha verslechterde inderdaad. Naar zijn interpretatie van het verdrag zou de VOC uiteindelijk maar één fort in eigendom krijgen, terwijl de Nederlanders alle vestingen voor zichzelf wilden houden. Onder druk gaven zij de onbelangrijke forten Baticalao en Trincomale over aan de Singalezen, maar behielden Galle en Negombo. Dit kon niet verhinderen dat de Nederlandse gouverneur op Ceylon met een gedeelte van zijn gevolg na een bezoek aan radja Singha in Kandy op de terugweg werd vermoord.

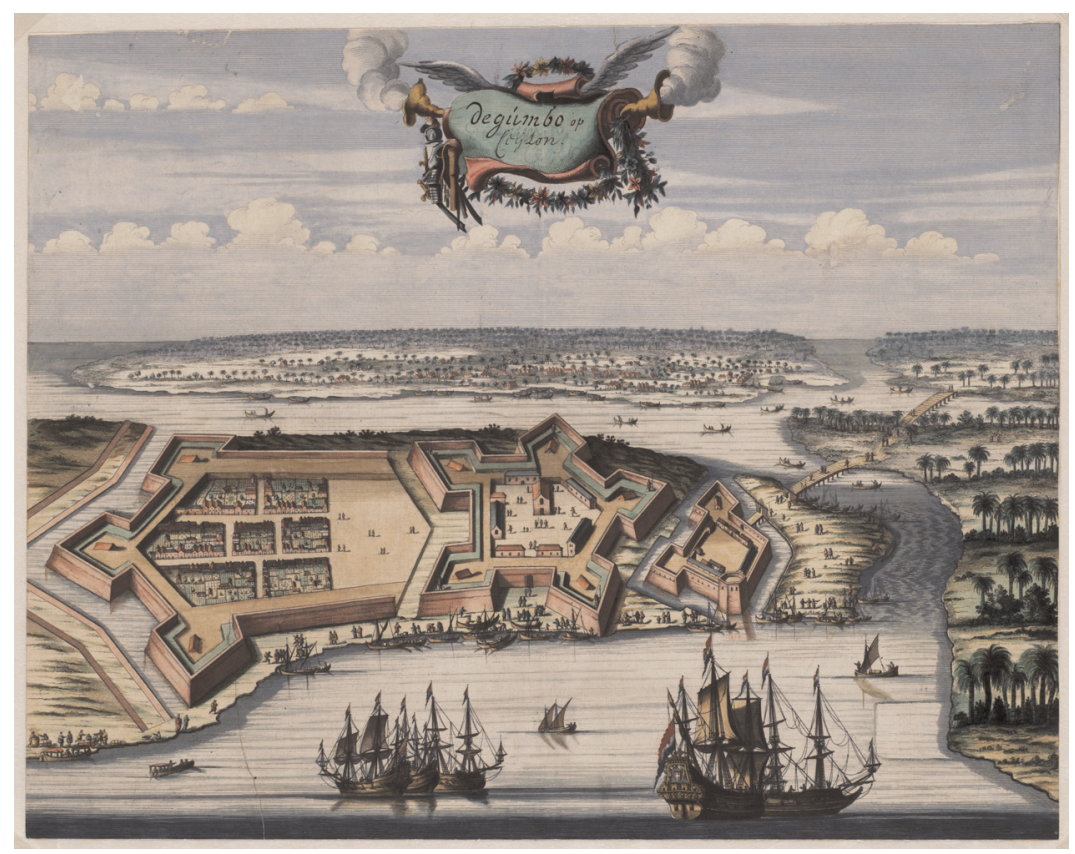

'Bezit van de zaak, einde van het vermaak', gold voor de VOC op Ceylon. dat in financiële zin een molensteen was. De enorme fortificaties getuigen ervan. Nationaal Archief, Den Haag. 
Daarbij kwam dat de Portugezen versterking kregen uit Goa en met deze troepen vanuit Colombo optrokken naar Negombo. De bezetting van de vesting liet zich verrassen en moest zich na een korte belegering op 8 november 1640 aan de Portugezen over geven. ${ }^{34}$

Met nog alleen Galle in handen en een slechte verhouding met hun bondgenoot waren de Nederlanders ultimo I640 nog ver verwijderd van een aandeel in de kaneeloogst, laat staan een monopolie. De heren bewindhebbers vroegen zich dan ook af of de grote vloot niet beter in de Molukken gebruikt zou kunnen worden. ${ }^{35}$ Ze spraken zelfs van de eerdere veroveringen op Ceylon als de 'ongeluckige successen van Comp's machtige vloot' en verzuchtten laet ons doch eenmael soo wijs werden dat niet meer compagnies macht soodanighe onseeckere explooiten uijtsetten. ${ }^{36}$

Met grote moeite zou in I643 Negombo weer door de Nederlanders veroverd worden.

Toch was voor Van Diemen de blokkade van Goa of de strijd op Ceylon niet het zwaartepunt van zijn aanval op de Portugezen. Dat zou zijn voorbehouden aan het machtige fort Malakka.

\section{De verovering van Malakka}

De verovering van Malakka in I64I is ongetwijfeld het belangrijkste wapenfeit van de VOC geweest tijdens het regime van Van Diemen. Aan het besluit om de vesting te belegeren waren jaren van voorbereiding voorafgegaan. Vanaf I626 kruisten schepen van de VOC in de Straat van Malakka. Niet alleen hinderden zij de handel, maar in vaak felle gevechten brachten zij de Portugezen grote verliezen toe en voorkwamen zij veelal dat voedsel en manschappen de vesting bereikten. Daarnaast werden de banden met de nabij gelegen vorstendommen Athjeh en Johor aangehaald, waardoor de Portugezen in Malakka meer en meer werden geïsoleerd. ${ }^{37}$ Steeds regelmatiger kwamen gezantschappen naar Batavia om een gezamenlijke aanval op Malakka te bespreken. ${ }^{38}$

In september I639 voer een vloot met tweeduizend man onder commando van directeur-generaal Philips Lucasz via Malakka naar Ceylon. Een aanslag werd overwogen, maar de Portugezen waren op de hoogte van de Nederlandse plannen en in opperste waakzaamheid bemanden zij de muren. Men beperkte zich daarop tot het verzamelen van zoveel mogelijk inlichtingen over de staat van het fort en zijn verdedigers. $\mathrm{Na}$ wat schermutselingen voer de vloot eind oktober door.

Het volgende jaar werd op 5 mei in Batavia het besluit genomen om dat jaar Malakka te belegeren en te veroveren. Door de blokkade van Goa en de gevechten op Ceylon waren de Portugese krachten versnip- 
perd en waren de Portugezen niet in staat om versterkingen naar Malakka te sturen. ${ }^{39}$

De Heren Zeventien hadden in de jaren daarvoor na aanvankelijke aarzelingen $^{40}$ herhaaldelijk aangedrongen op de verovering van Macao. ${ }^{4 \mathrm{I}}$ Toen in 1638 het bericht Nederland bereikte dat de Portugezen de handel op Japan waarschijnlijk ontzegd zou worden, verviel deze gedachte als noodzaak en ondersteunden zij het jaar daarna het plan om Malakka te veroveren samen met de Atjeh'ers: 'Dewijle het vermeesteren van Malacca de Coninck [van Atjeh] ernst schijnt te zijn verstaen wij oock dat onse macht daertoe employeren moeten.'

Om even verder de nadruk te vergroten door te schrijven dat zij 'het succes met verlanghen tegemoet sien. ${ }^{42}$

Deze steunbetuiging bereikte Batavia overigens pas toen de voorbereidingen voor het beleg al in volle gang waren.

Van Diemen had in december I638 geschreven: 'Den tijt is gebooren om den Portugees uyt India te helpen, soo maer wat extra ordinaris volck ende schepen gesecondeert wierden, ${ }^{43}$ om in dezelfde toon verderop te vervolgen dat 'den tijt nu gebooren is omme den vyandt aen te tasten ende ons meester van Malacca te maecken. 44

Hij kreeg uit Nederland een instemmende echo als antwoord: 'Wij kunnen de Portugees de handel geheel afsnijden en in haer plaetse te gaen sitten, waer door sich doorgaens de apparentie nooit zoodanich als tegenwoordich vertoont hebben en om daertoe te geraecken d'onse geen gelegenheijt moeten laten voorbijgaen.'45

Dus Van Diemen kreeg zijn vloot. Nooit eerder voeren zoveel Nederlandse schepen naar Azië als in I640. Maar liefst 25 schepen waren uitgerust. Maar het had moeite gekost deze bemand te krijgen doordat ook de WIC dat jaar vele zeelieden nodig had. ${ }^{46}$

Het beleg van Malakka was veruit het grootste en meest riskante avontuur dat de VOC onder Van Diemen zou ondernemen. En met goede redenen, zo schreef Van Diemen: 'Alsoo het welvaren van de Compagnie daeraen gedependeert en d'importantste conqueste sal wesen, die oyt in India becomen hebben; daeromme oock d'uytterste middelen aenwenden, om deselve saecke te seconderen, met volck, vivre, ammunititie van oorloge, etc. ${ }^{27}$

Malakka was dan ook niet zomaar een fort, maar één in zijn tijd grote moderne vestingstad met een omtrek van anderhalve kilometer en beschermd door muren van tien meter hoog en acht meter dik. Aan de oostkant lag buiten de vesting een moeras en aan de westkant een rivier waarover een belegeraar een brug moest leggen voordat hij een stormaanval kon beginnen. Niet voor niets had Malakka al meer dan een 
eeuw vele belegeringen doorstaan, voordat de Nederlanders ruim dertig jaar na Matelief opnieuw hun geluk probeerden.

'En alzoo wij van tijd tot tijd meer en meer ondervinden, hoe gansch dienstig en noodzakelijk voor de Generale Compagnie is, meester van Malakka worden en onze vijanden de Portugezen van daar te verdrijven, zoo blijven wij als nog bij onze voorgaande resolutie dato ultimo April en 20 augustus 1639, mitsgaders 27 maart dezes jaars, zonder verandering persisteren, om dat werk dezen jare bij der hand te nemen, en met Godes hulpe te effectueren. Waartoe vaststellen van hier derwaerts te schikken, zoo veel magt en middelen als uit maken kunnen en binnen kort van het patria of eenige kwartieren kunne verwachten. ${ }^{48}$

Ondanks de grote macht die op de been was gebracht, begon het beleg moeizaam. Pas een maand nadat de vloot voor Malakka ten anker was gegaan, konden troepen aan land gezet worden. De werkelijke belegering van Malakka begon in augustus ${ }^{6} 640$.

Met zwaar geschut werd voortdurend op de muren gebeukt om er een bres in te maken. Men rekende erop dat de Portugezen niet langer dan één, hooguit twee maanden stand zouden kunnen houden. ${ }^{49}$ Maar de kracht van de verdediging was ernstig onderschat. September werd oktober en ondanks voortdurende versterkingen verloren in de maanden daarop steeds meer mannen het leven, vooral door ziekte. Binnen de vesting begonnen honger en gebrek hun tol te eisen. Herhaalde uitbraakpogingen werden teruggeslagen. Slechts één keer konden twee schepen met een lading rijst de vesting bereiken. Naar schatting zevenduizend inwoners stierven tijdens het beleg. Ook aan Nederlandse zijde werden zware verliezen geleden. 'Malacca cost veel menschenvleesch' schreef Van Diemen op 30 november. ${ }^{\circ}$ Meer dan vijftienhonderd man, waaronder drie opeenvolgende commandeurs van de expeditiemacht, stierven voor Malakka.

De tijd begon te dringen. Door de naderende omslag van de moesson zouden spoedig geen schepen uit Batavia Malakka meer kunnen bereiken. Een nederlaag dreigde. Eindelijk, na vijf maanden was de vesting stormrijp. Ondanks de herhaalde versterkingen uit Batavia waren in januari I64I nog maar zeshonderd vijftig man gezond genoeg om aan de bestorming deel te nemen. Het was een gelukkige omstandigheid dat eind december een uitbraak door honderd vijftig Portugese soldaten gedeeltelijk was geslaagd. Zij werden pas rond de derde week van januari met hun voorraden terug verwacht. ${ }^{{ }^{\mathrm{I}}}$ Waren die ten tijde van de bestorming nog in de vesting geweest, dan zou de aanval wellicht anders zijn afgelopen. 
$\mathrm{Nu}$ ging de bestorming in de vroege ochtend van I4 januari van start, nadat de Johorse hulptroepen de avond daarvoor een brug over de rivier hadden gelegd. De drie Nederlandse vendels trokken op tegen het bolwerk Santa Domingo, waarin met meer dan duizend kanonskogels een bres was geschoten. Met een regen van handgranaten drongen de $\mathrm{Ne}$ derlanders het bolwerk binnen en in felle man-tegen-mangevechten werden de Portugezen eerst van het reeds aangevallen bastion verdreven, waarna nog twee bastions werden veroverd. Hierna stokte de aanval en moesten de Nederlanders in hernieuwde wanhopige gevechten het laatst veroverde bastion weer prijsgeven. Tijdens de luwte in de strijd die volgde, deed de Nederlandse commandant, Minne Willemsz. Caertekoe, een aanbod aan de Portugese gouverneur, Manuel de Sousa Coutinho, om zich onder zeer gunstige voorwaarden over te geven. ${ }^{52}$ Ziek en zwak als laatstgenoemde was, gaf hij de stad over. Hij overleed twee dagen later en werd met ere in de kerk van Malakka begraven. ${ }^{53}$

Door deze onverwachte overgave gingen in de achttiende en negentiende eeuw sommige Engelse en Franse schrijvers ervan uit dat de Portugese gouverneur was omgekocht en daarna vermoord. ${ }^{54}$ Een verhaal dat buiten Nederland zo bekend was dat Karl Marx het zonder meer in Das Kapital opnam. ${ }^{55}$

Hoe dan ook, de overwinning was verre van zeker geweest. De toon van Van Diemen werd minder zelfverzekerd toen het fort 'buiten expectatie' stand hield. ${ }^{5}$ De kans had bestaan dat de aanval werd afgeslagen en na de herovering van Negombo door de Portugezen in I640 zou dan de expansie van de VOC na vijf jaar strijd op een volslagen mislukking zijn uitgelopen. Toen het verlossende bericht van de verovering in Batavia aankwam, was de opluchting dan ook enorm.

Zoals Van Diemen besefte was het een dubbeltje op zijn kant geweest:

't Heeft sijn peryckel geloopen ende zijn al dickwijls bedruckt in dese belegering geweest, soo hadden moeten aftrekken, souden veel vijanden gecregen hebben, doch des Grooten Godt sij gedanckt, dit ons heeft laeten gelucken, 't respect ende d'eere is te grooter omdat dese onwinbare stadt in ieders ooggen, buyten d'adsistentie van de Atchinder sij gewonnen enden sonder hulp van Jhoorit met storm overloopen. ${ }^{57}$

Hij wist toen niet dat een Portugees eskader met troepen en voedsel aan boord door ongunstige wind de Golf van Bengalen niet had kunnen oversteken om Malakka te hulp te komen. ${ }^{58}$

Met de verovering van Malakka waren de machtsverhoudingen definitief in het voordeel van de Nederlanders veranderd. 'De handel zal ervan 
profiteren,' zo schreef Van Diemen en alle omliggende prinsen zullen ons 'adoreren' en zelfs 'Mataram moet nu onze vriend worden.'59

Later in het jaar voegde hij er nog aan toe: 'Vooral is dese conqueste te estimeren, by aldien met Portugaael in vrede comen, die ons, als Malacca vredigh possideerden, souden bevoorderen, daer nu weijnigh voor te duchten en de vrede met hun te geruster aen te gaen $s{ }^{, 60}$

Van Diemen had toen juist bericht uit Nederland ontvangen dat in december $\mathrm{I} 640$ Portugal zich in een revolte los had gemaakt van Spanje. ${ }^{\text {I }}$ Maar gelukkig was Van Diemen daar niet mee:

'Wij sijn van gevoelen dat, soo veel den staedt van India raeckt, te wenschen waere geweest, den Portugues nooit van Spangnien gesepareert hadde, ofte wij genootsaeckt wierden, den oorlogh, die tot noch met bijzonder voordeel jegens deselve gevoert hebben, te staecken. Hij is met de hulpe Godes sedert eenige jaeren soodanigh gematteert, dat in corte coorts geheel uijt India te crijgen soude sijn, hetwelck inestimabel veel voor de Comp waerdigh ware; want off wel (vermits hem allewege op de hielen sijn geweest) seer verarmt ende, ten ware dit interval, t'eijnde s'raedts gebraght sij, soo mogen echter wel staet maecken, dat noch Deen, noch Engelsman, noch eenige anderen Europasen handelaer ons sooseer in den wegh sal wesen als den Porugees, bijaldien met hem in vrede comen. ${ }^{62}$

De Republiek zou Portugal snel als nieuwe bondgenoot tegen de Spanjaarden in Europa steunen, maar in Azië zou de strijd nog een drietal jaren voortduren.

De val van Malakka was voor de Portugezen een catastrofe. Zo strategisch gelegen en zo belangrijk voor het Portugese handelsnetwerk was deze stad geweest dat met het verlies ervan ook de pretentie voor altijd verdween dat de Estado da India de handel over zee in Azië kon beheersen. ${ }^{6} 3$ 'India was verloren' zeiden de gevangengenomen Portugezen tegen Van Diemen. ${ }^{64}$

In Goa brak paniek uit en de onderkoning en zijn raad waren bang dat zij nu aan de beurt zouden zijn, zoals doorklonk in het verslag van hun vergadering:

'Hun motieven en geluk (van de Nederlanders-w) zetten hen op de weg naar wat ze zozeer wensen, namelijk de ondergang van deze stad, en als die ten onder is gegaan (Wat god verhoede) zullen ze de absolute heren en meesters zijn van heel India, omdat deze kleine staat als enige hun nog belemmert en waar tegen ze al jaren strijden. Hierdoor wordt onze handel al jaren belemmert zodat de inkomsten 
van de douane evenals alle andere inkomsten geheel zijn verdwenen. ${ }^{65}$

Van Diemen had hier inderdaad zijn zinnen opgezet. Hij vroeg om een nog grotere vloot met zesduizend man aan boord. Als de bewindhebbers in Nederland daartoe zouden besluiten, kon hij 'den Portugees in corte geheel India sullen doen ruymen. De Engelsen en Deenen moeten dan verdroogen ende sal U Ed. meester van van dese rijcke traffique blijven. ${ }^{66}$

In Nederland trok men zich van het grote plan terug nu door de Staten-Generaal de vrede met Portugal was getekend. Het werd ook steeds moeilijker voldoende zeevarend volk te werven voor de VOC. ${ }^{67}$

Toen op 8 september I64I het bericht van de revolte tegen Spanje Goa bereikte, schaarde de onderkoning zich na een korte aarzeling aan de zijde van de nieuwe koning Joao IV, zoals dat in alle overzeese vestigingen gebeurde, op Ceuta na. ${ }^{68}$ Ondertussen had de regering in Goa in juni I64I aan de vorst Wingurla, wiens rijk Goa aan de landzijde omsloot, een grote hoeveelheid kaneel en geld in het vooruitzicht gesteld indien hij de Nederlanders geen hulp meer bood en hun de toegang tot zijn land ontzegde.

In Europa was in april I64I een wapenstilstand tussen de nieuwe Portugese regering en de Republiek overeengekomen die ook voor West- en Oost-Indië zou moeten gelden. Het artikel over de vestigingsplaatsen was echter zo geformuleerd dat het volgens de Heren Zeventien 'zeer breed voor ons can en moet worden geïnterpreteerd. ${ }^{69}$ Om te vervolgen dat aangezien de Portugezen voorlopig alle middelen moesten inzetten in de strijd tegen Spanje, er weinig zou overschieten voor hulp naar Goa. Zolang het verdrag nog niet door de Staten-Generaal was geratificeerd, moest de staat van oorlog in Indië gehandhaafd blijven. ${ }^{70}$ Maar de Portugezen van hun kant voelden zich ook sterker. Zij weigerden herhaaldelijk aan de Nederlanders het recht op een gedeelte van de kaneeloogst op Ceylon bij een vredesverdrag.

De Hollanders hadden eind I640 alleen nog maar Punto de Galle in hun bezit en waren hun leven niet zeker zodra zij de poort van het fort verlieten. De Portugezen zagen niets in het voorstel waarmee in I643 de Nederlandse onderhandelaar Boreel naar Goa reisde om de kaneellanden rond het fort aan de Nederlanders af te staan. Dus bleef Goa geblokkeerd en kregen de Nederlanders de kans Negombo opnieuw aan te vallen en bij verrassing in te nemen. De uitkomst was een verdere nederlaag voor de Portugezen.

Uiteindelijk gingen zij met grote moeite en onder protest met een wapenstilstand akkoord waarbij de opbrengst van de kaneellanden rond Punto de Galle en Negombo aan de VOC toevielen. In deze moeizame laatste onderhandelingen beseften de Portugezen dat zij met de rug te- 
gen de muur stonden. Van Nederlandse kant werden de onderhandelingen door de latere gouverneur-generaal Maetsuycker verder gevoerd in Goa. Zoals de onderkoning en zijn raad in hun beraadslagingen in oktober en november I644 bespraken, was de situatie van Goa en heel Portugees Azië zeer moeilijk. Er was, zo stelden zij, gebrek aan mensen, geld, kanonnen, kruit en munitie.

In Goa lagen maar drie schepen met vijfhonderd soldaten aan boord, veel te weinig om verschil te maken in Ceylon. Het was een wonder dat de stad Goa na negen blokkades nog leefde. Op grond van deze situatie vonden de onderkoning en zijn raad een overeenkomst onvermijdelijk, waarbij zij zich moesten schikken in de eisen van de Hollanders. De onderkoning voegde hier dramatisch aan toe dat als er geen wapenstilstand kwam, hij de dood zou zoeken door persoonlijk het grootste schip in de haven van Goa als brander op een Hollands blokkadeschip af te sturen. ${ }^{\mathrm{I}}$ Dat zou niet nodig zijn. Op 9 november $\mathrm{i} 644$ werden alsnog de voorwaarden voor de wapenstilstand overeengekomen. De kaneeloogst van het gebied rond Galle en Negombo zou aan de VOC toekomen.

$\mathrm{Na}$ afloop van het bestand zou in I654 de strijd om Ceylon weer ontbranden. In moeizame campagnes veroverden de Nederlanders in 1656 Colombo. Met als argument dat de veroveringen op Ceylon veiliggesteld moesten worden voor Portugese tegenaanvallen werd daarna Negapatman op de Coromandelkust in I659 en Cochin op de Malabarkust in I663 op de Portugezen veroverd. Het zouden de laatste grote veroveringen van de VOC buiten de Indonesische archipel zijn.

Anders dan bij foelie, nootmuskaat en kruidnagel zouden de opbrengsten van het kaneelmonopolie niet tegen de kosten van het bezit opwegen. (Gaastra, VOC 52). Dit bezit is een molensteen om de nek van de VOC. Zoals Van Dam schreef: 'Hoe dat alles is uytgevallen, is de beurs van de Compagnie wel gewaar geworden. ${ }^{72}$

In de 55 jaar tussen 1640 en 1695 zou de Compagnie in Ceylon meer dan 17 miljoen gulden verliezen. ${ }^{73}$ Ceylon bleef voor de Compagnie een 'lastig pack'. ${ }^{74}$

Maar Van Diemen had toen al veel eerder zijn doel bereikt. Als concurrent van de Compagnie waren de Portugezen met name door het verlies van Malakka uitgeschakeld. Met de stichting van de Kaap Kolonie in I652 door Van Diemens neef Jan van Riebeeck kwam een verversingspunt op de lange reis van of naar Europa. Na een halve eeuw was dit het eerste bezit dat zonder strijd door de Compagnie verkregen was.

De Portugese koningen zagen zich gesteld voor de keuze tussen hulp aan de restanten van hun Aziatische rijk of aan hun kolonie in Brazilië. Het werd de laatste. Het pakte goed uit. Zolas Newitt schreef: 'so the empire in the South Atlantic was restored and in the next century and a half 
grew impressively in size and wealth totally eclipsing the old Estado da India'. ${ }^{75}$ Het eens zo machtige rijk in Azië bleef verweesd achter.

\section{Noten}

I. Newitt, A history of Portuguese overseas expansion, 1400-1668. (Londen 2005) I83.

2. Ibidem, I93.

3. Della Valle, P. en G. Bull, The pilgrim: the travels of Pietro Della Valle. (Londen i990) 247.

4. Newitt, A history of Portuguese overseas expansion, 1400-1668, 226.

5. Disney, A.R., Twilight of the Pepper Empire, Portuguese Trade in Southwest India in the Early Seventeenth Century (Cambridge, Massachusetts i978).

6. Newitt, A history of Portuguese overseas expansion, 1400-1668. I88.

7. Veen, E. van, Decay or defeat? An inquiry into the Portuguese decline in Asia, 1580-1645 (Leiden 2000) 200.

8. Blussé, L. en D.Winius, 'The Origin and Rythm of Dutch Agression against the Estado da India, I6or-I66I'. In D.R. De Souza, Indo-Portuguese history: old issues, new questions. (New Delhi ig85) 80.

9. Gaastra, De geschiedenis van de VOC, 56.

Io. NA VOC 3I5, ff 67 2I-4-I635.

II. NA VOC 3I5, fi46, 3-гог637.

I2. Vink, M., 'South India and the China Seas: how the V.O.C. Shifted its Weight from China \& Japan to India around A.D. I636', 4 in G. D.Winius Studies on Portuguese Asia, 1495-1689 (Burlington 200I) I25-I4O.

I3. Meilink-Roelofsz, M.A.P., 'Hoe rationeel was de organisatie van de VOC?’ in Economisch en sociaal-historisch jaarboek 44(I982) I83.

I4. NA VOC 3i6 f3OI. II-9-I640.

I5. MacLeod, De Oost-Indische compagnie als zeemogendheid in Azï̈ I (Rijswijk I927) 276.

I6. Ibidem 347.

I7. Pissurlencar, P.S.S., Assentos do Conselho do Estado II (Goa I953) 516.

I8. Ibidem 529. Brief I9, 9-2-1635.

I9. Ibidem 54I. Document 26, instructie voor de ambassade naar Mataram.

20. Newitt, A history of Portuguese overseas expansion, 1400-1668, 226.

2I. Mandelslo, J.A. van, De gedenkwaardige Zee en Landt Reyse deur Parsen en Indien gedaan van den E.H. Johan Albrecht van Mandelslo, (Amsterdam i658), 93.

22. NA VOC 858 I $6_{3} 6$ f 653 , Instructie Cooper dd 25-8-1636. 
23. MacLeod, De Oost-Indische compagnie als zeemogendheid in Azië II, $98 \mathrm{ev}$.

24. Pissurlencar, P.S.S., Assentos do Conselho do Estado II, 546, 2-I-I638 instructies aan generaal Antonio Telles.

25. Mandelslo, J.A. van, De gedekwaardige Zee en Landt Reyse deur Parsen en Indien gedaan van den E.H. Johan Albrecht van Mandelslo, 9II25.

26. Boxer, C.R., Portuguese India in the mid-seventeenth century (Delhi I980) I.

27. NA VOC $3 \mathrm{I} 6, \mathrm{f}_{4} 46$.

28. NA VOC $3 \mathrm{I} 6, \mathrm{f}$ i 88.

29. NA VOC 3i6, f I40 kamer van Amsterdam aan GG en raden 25-II637 en idem 4-Io-I638, f 228 en f 284, 8 december I639, kamer van Amsterdam.

30. Ribeiro, J.P. en P.E. Pieris., The Historic Tragedy of the Island of Ceilao. (Colombo I925).

3I. MacLeod, De Oost-Indische compagnie II, I08, III, II3.

32. Heeres, Corpus Diplomaticum Neerlando-Indicum, I, 308.

33. NA VOC 3І6 f255 I2-9-I639, f 296 II-9-I640 kamer van Amsterdam.

34. MacLeod, De Oost-Indische compagnie II, I30.

35. NA VOC 3I6, f 302, 307. I2-4-I640.

36. NA VOC 3І6, f 307 Heren XVII II-9-I640.

37. Leupe, P.A., 'Stukken betrekkelijk het beleg en de verovering van Malakka op de Portugezen in I640-I64I', in Berigten van het Historisch Genootschap te Utrecht (Utrecht I859).

38. MacLeod, De Oost-Indische compagnie II, 2 II.

39. Newitt, A history of Portuguese overseas expansion, 1400-1668. 235.

40. NA VOC 316 f I25 24-9-1636.

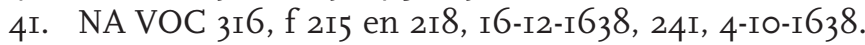

42. NA VOC 3i6, f256 г2-9-г639.

43. Generale Missive December I638 afgedrukt De Jonge, De Opkomst van het Nederlandsch gezag in Oost-Indie. II, 358.

44. Idem, 359

45. NA VOC 3I6, f 254 I2-9-I639.

46. Idem, f 255 .

47. GG en Raden aan heren Zeventien, 30-II-I640 afgedrukt in De Jonge, De Opkomst van het Nederlandsch gezag in Oost-Indie. V, 245.

48. Leupe, P.A., 'Stukken betrekkelijk het beleg en de verovering van Malakka op de Portugezen in I640-I64I', I52.

49. Ibidem, $\mathrm{I} 62$.

50. GG en raad aan heren Zeventien, 30-II-I640 afgedrukt in De Jonge, De Opkomst van het Nederlandsch gezag in Oost-Indie. III, I2. 
51. Leupe, P.A., 'Stukken betrekkelijk het beleg en de verovering van Malakka op de Portugezen in I640-I64I', 2II.

52. Valentijn, Oud en nieuw Oost-Indiën, V, 342.

53. MacLeod, De Oost-Indische compagnie II, 2IO.

54. Leupe, P.A., 'Stukken betrekkelijk het beleg en de verovering van Malakka op de Portugezen in I640-I64I', I28.

55. Karl Marx Het Kapitaal boek 24 par 6: www.marxists.org/nederlands/marx-engels/1867/kapitaal/24.htm

56. Gouverneur-generaal en raden aan Heren Zeventien, 30-II-I640 afgedrukt in De Jonge, De Opkomst van het Nederlandsch gezag in Oost-Indie. V, 245.

57. NA VOC OBP II34, f 5 GG en Raden aan HH I7 3I-I-I64I.

58. P.S.S. Pissurlencar, Assentos do Conselho do Estado. II (Goa I953) 305. Document I03, april I64I.

59. NA VOC OBP II34 f 5v. Gouverneur-generaal en raden aan Heren XVII, 3I-I-I64I.

6o. GG en Raden, I2-I2-I64I. Afgedrukt in De Jonge, De Opkomst van het Nederlandsch gezag in Oost-Indie. V, 252.

6r. NA VOC 3i6, f 330, I5-3-i64I.

62. GG en Raden, I2-I2-I64I afgedrukt in De Jonge, De Opkomst van het Nederlandsch gezag in Oost-Indie. II, xiii.

63. Newitt, A history of Portuguese overseas expansion, 1400-1668, 235.

64. NA VOC OBP II34 f5v, Gouverneur-generaal en Raden aan Heren XVII 3I januari I64I.

65. Pissurlencar, P.S.S., Assentos do Conselho do Estado II, 3I2, 20 augustus I64I.

66. NA VOC OBP II34 f5v, Gouverneur-generaal en raden aan Heren XVII, 3I januari I64I.

67. NA VOC 3I6 f3I5 Kamer Amsterdam, 22 december I640.

68. Newitt, A history of Portuguese overseas expansion, 1400-1668, 237.

69. NA VOC 3i6, f 336, 5 september i64I.

70. Ibidem, f 339 .

7I. Pissurlencar, P.S.S., Assentos do Conselho do Estado III, 63. Document 40, november I644.

72. Van Dam, Beschrijvinge van de Oostindische Compagnie, Tweede deel, II, 296.

73. Idem, Tweede deel, II, 434 .

74. Idem, Tweede deel, II, 393.

75. Newitt, A history of Portuguese overseas expansion, 1400-1668, 244. 


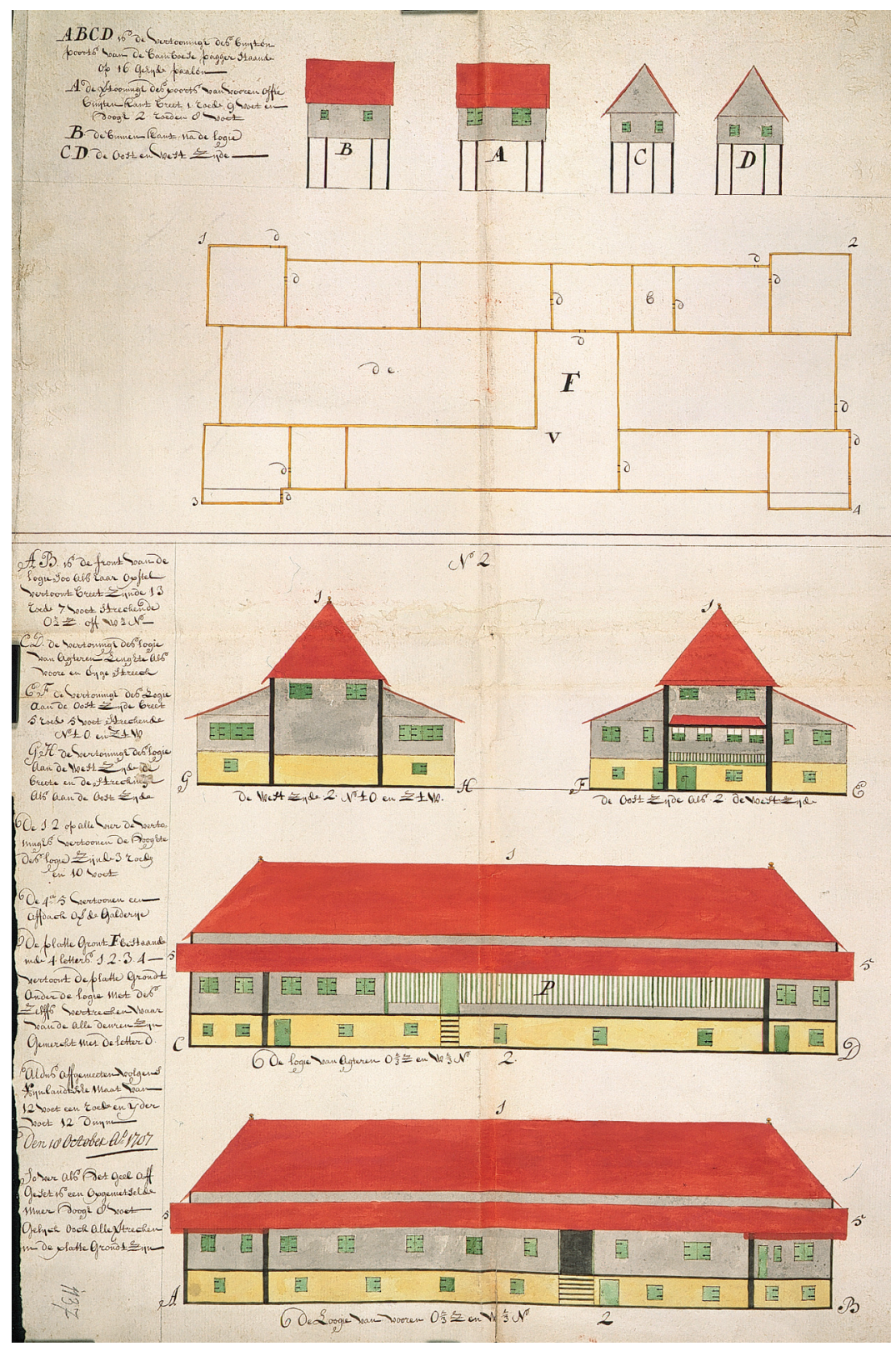

In de belangrijke peperhaven Jambi op Sumatra bouwde de Compagnie een groot pakhuis. Het werd een fors gebouw met een grondmaat van ruim 50 bij 20 meter. Nationaal Archief Den Haag. 


\section{De regering van Van Diemen}

\section{Het ontstaan van een nieuwe elite}

Nadat in I632 het experiment om de handel in Azië vrij te geven was teruggedraaid, werd het duidelijk dat alleen een hoge rang binnen de VOC de weg effende naar macht en rijkdom. ${ }^{\text {I }}$

De top van deze piramide - de gouverneur-generaal en de raden van Indië - woonde in de zeventiende eeuw aan het Paradeplein in het kasteel van Batavia, op nog geen vijftig meter van elkaar en afgeschermd van de stad. Deze mannen hadden geen gemeenschappelijke achtergrond anders dan een lang verblijf in Azië. Het waren bijna zonder uitzondering mannen die in een lage rang waren uitgevaren en die, net als Van Diemen, carrière gemaakt hadden binnen de VOC. Dat gold bijvoorbeeld ook voor de directeur-generaal Philips Lucasz, die in I6I8 Van Diemens scheepsmaat aan boord van 'de Mauritius' was geweest. Lucasz werd na zijn dood in I640 opgevolgd door Cornelis van der Lijn, die ook als assistent-koopman was uitgevaren, net zoals de raden van Indië Justus Schouten, Arent Gardenijs, Johan van der Burg, Gerard Demmer en de vechtjas Antoni Caen.

Bij Brouwer konden outsiders die zonder Indische ervaring direct zitting namen in de Raad van Indië zoals bij Coen gebeurde, nog wel rekenen op een ontvangst, zij het een kille. Zo werd ene Jan van Broekom, die in I634 aankwam in de hoge rang van raad van Indië, benoemd als gouverneur op de Molukken met de cynische motivering: 'Alsoo vertrouwende sijn dat sijn Ed. ten aensien van sijn indische ervarentheijt ende ommeganck met Indiaensche Natien hetselve gouvernement ende directie wel en behoorlijck sal connen waernemen.'2 Van Broekom stierf na een paar jaar en zijn weduwe kreeg een wissel voor zesduizend realen opgestuurd. ${ }^{3}$

Bij Van Diemen echter, was hier geen sprake van. Uitzonderingen vormden evenwel de jurist Johan Maetsuycker (I636) en de Zeeuwse jurist en regentenzoon Pieter Boreel (I642). De eerste zou gouverneur-generaal worden, de laatstgenoemde overleed al na één jaar op de Coromandelkust, waar zijn grafsteen van zijn korte carrière getuigt. ${ }^{4}$ 
Tegelijkertijd begonnen aan de top vrouwen een belangrijke rol te spelen, doordat een goed huwelijk vaak bepalend werd voor de positie van een compagniedienaar binnen de hiërarchie van de VOC. Zo dankte Pieter Vlack zijn hoge positie als directeur-generaal aan zijn huwelijk met de zuster van Coens vrouw. Hetzelfde gold voor de twee zwagers van gouverneur-generaal Specx, Lucasz en Gardenijs, die verbonden door de gezusters Buys aan de top van de VOC in Batavia stonden. Tijdens Van Diemen klom de jurist Simon van Alphen op tot extraordinair raad van Indië na zijn huwelijk met Annette Hendricksz, de weduwe van de broer van Maria van Diemen. En de invloedrijke secretaris van de Raad van Indië, Pieter Mestdagh, was eerst gehuwd geweest met een zuster van Antoni Caen en na haar overlijden getrouwd met een zuster van Justus Schouten.

De sfeer in het kasteel van Batavia veranderde met het vertrek van Brouwer. Het lijkt erop dat dit niet alleen door Van Diemen kwam, maar vooral ook door de rol die zijn vrouw Maria voor zich opeiste. Met haar kwam een vrouw in het centrum van de macht die in tegenstelling tot haar voorgangsters al vele jaren in Batavia woonde, eigen handel dreef en geld van zichzelf had. Maria was de eerste Grande Dame van Batavia en zij werd 'mevrouw Generaelse' en 'die regeerszuchtige vrouwe' genoemd. ${ }^{5}$ De pracht en praal van Batavia zette met Maria in.

Van Diemen werd gekapitteld over het feit dat Maria op kosten van de Compagnie snuisterijen uit Nederland liet overkomen en dat het de dames werd toegestaan met de compagniekoetsen uit rijden te gaan. ${ }^{6}$ Wat een wereld van verschil met de sobere Brouwer die de koets juist uit elkaar had laten halen en binnen het kasteel had laten opslaan en die tevreden naar de Heren Zeventien schreef dat onder zijn regime het uiterlijk vertoon sterk was teruggedrongen door zijn goede voorbeeld. Na zijn vertrek werd de koets weer van stal gehaald en het werd gewoonte dat mevrouw en de juffrouwen - alleen de vrouw van de gouverneur-generaal werd 'mevrouw' genoemd - twee keer in de week een plezierritje gingen maken.'

Hoe is een ingetogen burgerlijk familieportret uit Holland nog te vergelijken met de rijtocht in 1648 van gouverneur-generaal Van der Lijn met zijn gezelschap zoals deze werd beschreven door de Parijse juwelier-avonturier Jean Baptiste Tavernier: Voor de schitterende koets waren niet minder dan zes Perzische paarden gespannen. De compagnie ruiters die als lijfwacht het gezelschap begeleidden was gekleed in een livrei van gele zijde met kanten biezen, zilveren gespen en zilveren sporen.

De vaak beschreven exorbitante manier waarop de vrouwen ter kerke gingen, werd een onderdeel van het sociale leven, net als het voortdurend kauwen van betelbladen die de gebruiksters een bloedrode mond gaf. 


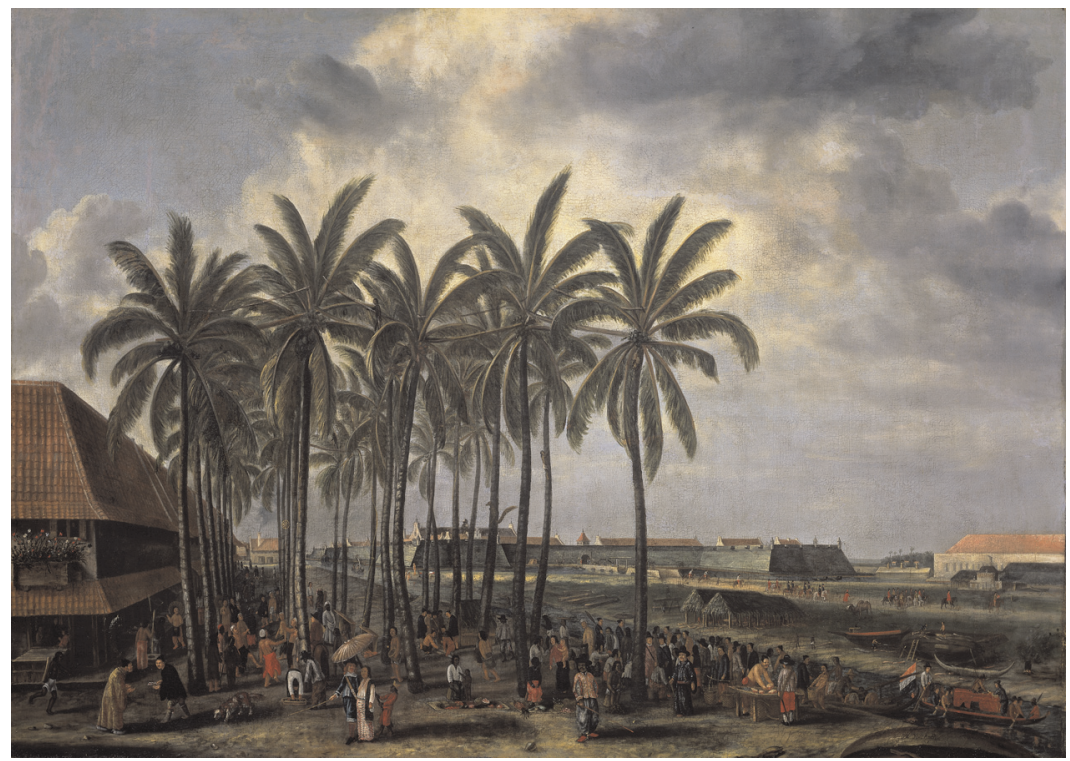

Onder de hoge kokospalmen van Batavia wordt markt gehouden. Mannen halen kokosnoten uit de boom. Op de voorgrond zijn Javanen, Chinezen, Bengalezen en Europeanen druk doende met hun handel. Op de achtergrond, maar duidelijk aanwezig, is het Kasteel van Batavia te zien: de zetel van het hoofdbestuur van de VOC overzee. In het midden stroomt de Tjiliwoeng, ook wel Kali Besar ('Grote Rivier') genoemd. Andries Beeckman schilderde dit tafereel rond 1657. Rijksmuseum Amsterdam.

Hoezeer het in Batavia om geld draaide, blijkt uit de brieven die Salomon Sweers naar zijn familie in Enkhuizen stuurde. Hij was een protégé van Van Diemen, voer met hem uit als secretaris van de vloot in I632 en zou later raad van Indië worden. Hij schreef naar huis over de goede huwelijken die zijn nagereisde broer en zuster in Batavia hadden gesloten. 'Frère Jacob' trouwde in $\mathrm{I}_{42} 2$ met de weduwe 'juffrouw Maria Aucx Brebis, oudt 40 jaren, wort op 40.000 gl geestimeert' terwijl 'ma seur Catharina haer den laetsten juli met Jeremias van Vliet heeft gehuwd, wiens tijdelijcke middelen worden op 30.000 guldens geestimeert.'

Van Vliet wilde extraordinair raad worden 'deshalve versoucken gans gedienstigh Ue hem te dien eijnde op 't favorabelst bij alle occasie ande $\mathrm{Hr} \mathrm{Be}$ windthebberen gelieft voor te dragen.'

Een ander verzoek aan zijn neven geeft een onverwachte menselijke blik in de kleine wereld van Batavia 'Ue gelieve mij per den eersten met wat vars Canarisaat voor mijn quinckelerende vogelkens te versien, voor 2,3, a 4 gulden opdat mijn voogelkens het leven behouden moogen. ${ }^{8}$ 
Ach, het leven was vluchtig in dienst van de VOC en Van Diemen moest dan ook vaak afscheid nemen. Toen zijn vriend Philips Lucasz in maart I640 op zijn terugreis uit Ceylon aan een 'kwellende ziekte' overleed, kreeg deze in Batavia een statige begrafenis die een edelman niet zou hebben misstaan, waarbij in de stoet zijn 'veltstock, helm, handschoenen, sporen en degen' door hoge compagniedienaren werden gedragen. ${ }^{9}$

Nadat Arent Gardenijs in I643 op de kust van Coromandel was overleden, keerden zijn weduwe en dochter terug naar Batavia. Antonio en Maria begeleidden hen naar het schip dat hen naar Nederland terug zou brengen. Met weemoed schreef Van Diemen hierover: 't Schijnt egheene in India te blijven inclineren, veel minder Batavia met hare dochters te peupleren, ${ }^{\text {Io }}$ om verderop te vervolgen: " $t$ Valt wel verdrietigh, dat ijdereen dus nae 't patria haeckt; 't is seecker, daer niet vinden sullen, tgene hier verlaten. ${ }^{\text {"I }}$

Deze laatste zin ondersteunt de mening van Maetsuycker die in de maanden na Van Diemens dood schreef dat Van Diemen nooit werkelijk van plan was geweest om naar Nederland terug te keren. Hij was daarvoor te vast verbonden met Batavia en de VOC.

Zoals wij hebben gezien aan de affaire waarin Van Diemen in I63I verzeild was geraakt, ontstonden binnen de muren van het kasteel rivaliserende partijen. Toen Van Diemens krachten af gingen nemen, kwam dit sluimerend conflict aan de top van Compagnie tot een heftige uitbarsting, die gedetailleerd beschreven in de archieven bewaard is gebleven.

Op zondagavond 25 januari I645 hadden Salomon Sweers en zijn vrouw een drietal hooggeplaatste VOC-functionarissen met hun vrouwen voor de maaltijd uitgenodigd samen met directeur-generaal Cornelis Van der Lijn en zijn echtgenote. Dat was op zich gewaagd, want Sweers had daags daarvoor nog met Van Diemen voor de tweede maal gesproken over zijn vermoeden van sluikhandel door Van der Lijn. De sfeer raakte gespannen toen het echtpaar Van der Lijn geruime tijd op zich liet wachten. Nadat herhaaldelijk door een slaaf geïnformeerd was of nog op hen gerekend kon worden, betrad het paar om negen uur 's avonds de woning, waar het direct kwam tot een felle woordenwisseling waarin Sweers ontkende dat hij Van der Lijn achter diens rug bij Van Diemen ten tweede male had beschuldigd.

Daarop verloor Van der Lijn zijn zelfbeheersing en schreeuwde: 'Jou hondsvot sulcx moste de derdemael niet gebeuren ofte ick zou jou op jou backhuijs trommelen.'

Dat liet Sweers zich niet zeggen en riep terug: 'Mijn heer moet niet dencken dat mijn handen met blauw garen aan mijn lijf genaijt sijn.' Buiten het gezicht van het gezelschap kwam het hierop tot een handgemeen waarbij Van der Lijn hoorbaar met een rotan 'drie of vier toetsen' aan 
Sweers toedeelde. Sweers pakte op zijn beurt een rotan, maar werd bij zijn armen vastgepakt door de juffrouwen Sweers en Van der Lijn zodat zijn slagen 'sonder effect' bleven. Ongehinderd gaf Van der Lijn daarop Sweers een zestal rottingslagen, terwijl Sweers uitriep: 'Jou blooden guijt ick hebbe wel andere onder de oogen gesien ende also langhe als ghij, 't is geen rechtschapen kerelswerck dat men een man slaat die van vrouwen vastgehouden wert ende niets in handen heeft.'

Wat daarna volgde uit de mond van Sweers schreef de secretaris van Justitie 'onder reverentie' neer: 'Als ick jou op een ander plaets hadde ende mochte begaen ick soude jou wat in den speelcont jagen! Ghij sult noch in jou ruine ofte verderf loopen. Ick hebbe de obligatie wel in mijn zack daermede ick bewijsen zal ende als ick gehoort werde sal ront uijt seggen, ick zou jou ruineren tot in de grond. ${ }^{\text {I2 }}$

Zo beschuldigde hij Van der Lijn in krachtige bewoordingen van handel voor eigen rekening. Het ging om een zestal voorvallen, die hij echter later geen van alle met feiten kon staven. Het incident leidde ertoe dat beiden zich wendden tot Van Diemen die het geval liet afdoen door een gelegenheidsrechtbank van hoge compagniedienaren, in dit geval de Raad van Justitie die versterkt werd met enige 'gequalificeerde dienaren'. De afloop was dat Sweers honderd en Van der Lijn tweehonderdvijftig realen aan de armen moesten geven en voorts moesten beiden verklaren 'wedersijds voortaen weder vrunden te zullen wesen, mitdgaders sulcx over ende weer met een dronck becrachticht.' ${ }^{\text {'3 }}$

Natuurlijk bleef het daar niet bij. De ontstane kampen zouden in de loop van het jaar verder met elkaar in de clinch raken.

Onder Van Diemen liep de jacht op handelaren voor eigen rekening onder het hogere compagniepersoneel toch teneinde. En, tenzij dit handelen de spuigaten uitliep, werd het oogluikend toegestaan juist aan de hoogsten in rang. Dat blijkt uit het rumoerige verloop van de carrière van Salomon Sweers zelf op dit terrein. Hij was namelijk tegen de lamp gelopen met handel voor eigen rekening. In februari I642 was uitgekomen dat hij een partij barnsteen die hij uit Europa had meegenomen, aan een Chinees had verkocht. Dit had tot gevolg dat hij enige maanden geschorst werd als raad van Indië en raad van Justitie. In juni I642 werd hij weer in zijn vorige kwaliteit hersteld. De Heren Zeventien werden hiervan op de hoogte gesteld en zij schreven dat Sweers niet meer in de Raad van Indië toegelaten mocht worden, omdat dat al te aanstootgevend zou zijn. Aan dit bevel werd in Batavia geen gevolg gegeven. Sweers bleef de vergaderingen gewoon bijwonen.

Dat werd anders na het overlijden van zijn beschermheer Van Diemen. Vanaf juli I645 werd Sweers wel buiten de vergaderingen gehouden en hij vertrok met de retourvloot naar Nederland, waar hij in I646 de Heren Zeventien voorzag van een bijzonder sappig verslag van de 
wantoestanden die op het kasteel heersten, met name die waar Van der Lijn de hand in had. ${ }^{\text {I4 }}$ De Heren Zeventien ondernamen echter geen actie.

De grote stijl waarin de kooplieden leefden en het vele geld dat zij voor eigen rekening konden verdienen, was de compensatie voor het harde bestaan. Het was het bindmiddel en voor velen de reden van hun komst. Van Diemen zelf en zeker Maria stonden hierbij niet boven verdenking. Het ging in haar geval vooral om handel in diamanten.

De diamanten werden gedolven in de legendarische mijn van Golconda in India, de oudste diamantmijn ter wereld in het tegenwoordige Uthar Pradesh, en werden verhandeld in Masulipatnam aan de oostkust van India. Masulipatnam was volgens Valentijn een 'fraaie grote stad' waar 'veel Mongolen, Turken, Perzen, Jentiven, enige Joden en een stroom van Armeniërs, Malabaaren, Peguanen, Bengalezen, Arabiërs, Siammers, Portugeezen en meer volkeren een zeer groote handel dreven met diamanten en schoone robijnen.' ${ }^{\text {I5 }}$

Bartolomeus de Gruyter, de neef van Van Diemen, werd in Masulipatnam geplaatst waar hij opklom tot opperhoofd van de vestiging van de VOC aldaar. ${ }^{16}$ Het was een grote loge geweest 'eer dat groot beest van besnoeiing, of vermindering van onkosten, anno 1678 in Indiën over zee kruypen kwam.' ${ }^{\text {'7 }}$ In Masulipatnam handelde hij op grote schaal in diamanten voor de VOC en vermoedelijk voor zichzelf, al dan niet in opdracht van Maria. ${ }^{\mathrm{I}}$ Dat zij voor eigen rekening handelde, staat vast. Zo werd voor haar één in een punt geslepen grote diamant aan de koning van Siam verkocht voor 2.880 gulden. Deze diamant was haar vanuit Nederland gestuurd door de vader van Bartholomeus, Pieter de Gruyter. ${ }^{\text {I9 }} \mathrm{Zij}$ had ook diamanten verkocht aan de Compagnie in Batavia.

$\mathrm{Na}$ de dood van Van Diemen werd over haar handel geschreven door Maetsuijcker en Van Alphen. Maar eigenlijk was volgens hen iedereen betrokken bij handel voor eigen rekening:

'Niet sonder reden doleren Uw Ed over den groten handel der particulieren, nadien deselve niet alleen tusschen dit ende 't vaderlant, maer oock op ende van alle plaetsen van India sodanich in swangh gaet, selfs onder de meesten, dat qualijck bedencken connen met wat middelen uyt te royen sal wesen. ${ }^{20}$

In I639 had Van Diemen geschreven aan de Heren Zeventien over de diamanthandel: 't $I$ s ons leet, $U$ Ed doleeren, soo merckelijcken quantiteyt diamanten van particuliere werden overgevoert. Wenschten, daer eenmael conden achter geraken. Wij practiseren bij alle middelen sooveel doenlijck dese fraude voor te coomen. ${ }^{2 \mathrm{I}}$ 
Ten tijde van Van Diemen drong de privéhandel door in de boekhouding van de VOC zelf. Het werd gebruik om aan compagniedienaren in Azië toe te staan hun Indische winsten te repatriëren door middel van wissels getrokken op de VOC in Nederland. Zij stortten hiervoor geld in de kas van de VOC in Batavia en konden dit in Nederland weer door de begunstigden laten opnemen. Natuurlijk rekende de VOC hier een forse provisie voor, maar haar voordeel was daarnaast dat zij minder contanten naar India hoefde te zenden. Ten tijde van Van Diemen ging het jaarlijks om bedragen tussen de twee en drie ton, met een eenmalige forse stijging tot meer dan een half miljoen in het jaar dat Maria naar Nederland voer. Deze bedragen groeiden tot boven het miljoen aan het einde van de zeventiende eeuw en namen na 1750 in een hoog tempo toe tot meerdere miljoenen per jaar. ${ }^{22}$

Op papier was het besluit van de VOC om de intra-Aziatische handel niet vrij te geven goed verdedigbaar geweest, maar in de praktijk kwam het erop neer dat iedere hoge compagniedienaar een succesvolle handelaar voor eigen rekening werd, waarbij, zoals Van Diemen schreef, het hen niet uitmaakte dat hun winst ten koste van de VOC ging. ${ }^{23}$ Zo kreeg de VOC te maken met de nadelen van het Portugese systeem, maar niet met de voordelen.

Omdat de aandeelhouders in de VOC, monddood als zij waren, genoegen namen met hun jaarlijkse lage dividend en de bewindhebbers bewust de andere kant opkeken, kon dit ruim anderhalve eeuw lang vrijwel ongestoord doorgaan tot het uiteindelijke faillissement van de VOC. Zo zwom de VOC in Nederland en Azië langzaam in de fuik waarin haast alle naamloze vennootschappen in de zeventiende en achttiende eeuw terechtkwamen.

De voorspelbare uitkomst hiervan sloot aan bij het vernietigende oordeel dat Adam Smith, Edmund Burke en Abbé Mortelet aan het einde van de achttiende eeuw velden. Zij zagen de naamloze vennootschappen als inefficiënte bedrijven en broedplaatsen voor corrupte bestuurders, die louter uit waren op eigen gewin. De lange reeks vennootschappelijke schandalen die het eerste decennium van de eenentwintigste eeuw ontsieren, laten zien dat deze criticasters verrassend actueel waren. Adam Smith schreef in zijn beroemde Inquiry on the wealth of nations waar het systeem van de naamloze vennootschap zijns inziens tekort schoot:

'The directors of such companies, however, being the managers rather of other people's money than of their own, it cannot well be expected that they should watch over it with the same anxious vigilance with which the partners in a private copartnery frequently watch over their own. Like the stewards of a rich man, they are apt to consider atten- 
tion to small matters as not for their master's honour, and very easily give themselves a dispensation from having it. Negligence and profusion, therefore, must always prevail, more or less, in the management of the affairs of such a company. It is upon this account that joint stock companies for foreign trade have seldom been able to maintain the competition against private adventurers. They have, accordingly, very seldom succeeded without an exclusive privilege, and frequently have not succeeded with one. Without an exclusive privilege they have commonly mismanaged the trade. With an exclusive privilege they have both mismanaged and confined it. ${ }^{24}$

Ook op de top van de VOC in Batavia en Amsterdam was deze beschrijving van toepassing. Dat wil niet zeggen dat men zich onverantwoord gedroeg of lui was, maar wel dat het eigenbelang belangrijker was dan de vennootschap en zeker dan de winst voor de aandeelhouders. Wat dat betreft is er niets nieuws onder de zon.

\section{De regering aan het werk}

De vergaderingen van de gouverneur-generaal Antonio van Diemen en de raden van Indië werden steevast door secretaris Pieter Mestdagh genotuleerd. Men kwam bijeen met vaste vergaderdagen op maandag, woensdag en zaterdag, maar indien nodig op elk andere dag, inclusief de zondag. Ook buiten de vergaderingen hield Van Diemen de teugels strak in handen. Dagelijks werd hij in alle vroegte, vaak al tussen zes en zeven uur 's ochtends, door de opperkooplieden van het kasteel, de shahbandar (havenmeester), de baljuw (hoofd van de politie) en andere functionarissen bijgepraat, zodat er haast niets in Batavia kon gebeuren of Van Diemen was ervan op de hoogte. Later in de ochtend volgde een lange reeks van mensen die hem wilden spreken of een verzoek wilden toelichten voordat dat in de Raad van Indië zou worden behandeld. Veel vrije tijd had hij niet, misschien twee middagen per week gunde hij zich, vakantie was een nog onbekend begrip. ${ }^{25}$

Waarschijnlijk als vastlegging van een in de loop der tijd gegroeide gewoonte werd in februari $\mathrm{I}_{42}$ besloten de raden van Indië elk verantwoordelijk te maken voor de correspondentie met een deel van het octrooigebied. Hiervan was de directeur-generaal die verantwoordelijk was voor de gehele handel, vrijgesteld. Ook hiermee structureerde Van Diemen de werkwijze van het bestuur van de VOC in Batavia en daarbuiten. $^{26}$

Het leek alsof Van Diemen 'al spelende het grote werck te dirigeren wist' schreef zijn opvolger Cornelis van der Lijn in juli I645 met een onder- 
toon van respect en jaloezie toen hijzelf na een paar maanden de last van de Indische regering op zijn schouders voelde drukken. ${ }^{27}$ Dit beeld wordt versterkt door het schilderij waarop Van Diemen staat als gouverneur-generaal.

Wij worden aangekeken door een intelligente, zelfbewuste, sluwe en afstandelijke man. Van Diemen kende de VOC door en door en was net als Coen ontegenzeggelijk de baas en bepaald geen eerste onder gelijken zoals Reael, De Carpentier, Specx en Brouwer dat geweest waren. Hij regeerde de VOC vanuit het grote kasteel van Batavia met de feodale instelling van een graaf en de vaardigheid van een telg uit een burgemeestersgeslacht.

Zeker de eerste jaren draaide alles om hem. Zo kwam in mei en juni I638 de besluitvorming in Batavia bijkans tot stilstand toen Van Diemen langer dan verwacht wegbleef op zijn tweede tocht naar de Molukken. Philips Lucasz en Cornelis van der Lijn, die hem officieel in Batavia vervingen, wilden of durfden niet zonder hem te beslissen over het uitzenden van de schepen naar Taiwan en Japan en tal van stadszaken. De hele maand juni lagen de schepen zeilklaar. Men besloot uiteindelijk op I juli 'also het bequaemste saisoen om met de minste incommoditeijten naer japan te navigeeren seer begint te verloopen' om het schip 'de Breedam' tot uiterlijk I5 juli op de rede van Batavia te laten wachten, 'op hope dat onderwijl de heer Generael van Amboina retourneren sal.' Op zaterdag Io juli kon men tevreden schrijven dat van Diemen en Caen terug waren in Batavia 'nae volcomen redres en afhandelinghe van saecken aldaer.'

In de dagen daarna werden vele besluiten genomen die lang op zich hadden laten wachten, onder andere over het uitzenden van de schepen in het octrooigebied, waaronder zo snel mogelijk 'de Breedam' en een grote variëteit aan stadszaken. Zo werden op vrijdag i6 juli vele beslissingen genomen, met name rond het uitzenden van de blokkadevloot naar Goa met de bezending naar Suratte. Onder het commando van de juist uit de Molukken mee teruggekomen Antonie Caen zou een vloot van I2 schepen met aan boord 980 matrozen en 335 soldaten met voorraden voor I2 maanden de Portugezen van oktober tot april 'benauwen'. $^{28}$

Onder Van Diemen was de haast groot en de effectiviteit hoog. Zodra een schip aankwam, kreeg het een nieuwe bestemming. Bijvoorbeeld 'de Zeelandia', een groot schip dat na een reis van zes maanden op 3 juli aankwam uit Nederland. Het werd gelost, gereedgemaakt en opnieuw geladen, zodat het de $16^{\text {de }}$ juli klaar was om naar Taiwan uit te varen. Met laatste missiven voor de gouverneur van Taiwan voorzien, vertrok het daadwerkelijk in de avond van de $2 \mathrm{I}^{\text {ste }} \cdot{ }^{29}$ 
Ook de verbetenheid waarmee de strijd tegen de Portugezen werd gevoerd, is in de beraadslagingen terug te vinden. In september $\mathrm{I}_{3} 8$ kwam een fel protest van de Deense Compagnie binnen. In de Straat van Malakka was namelijk een Deens schip door de Nederlanders aangehouden en met harde hand doorzocht. Een Italiaan werd daarbij zelfs gemarteld om te zeggen welke Portugese goederen het schip vervoerde. Vervolgens was een aantal Nederlanders aan boord in dienst van de Denen, gevangengenomen.

In antwoord daarop liet Van Diemen schrijven dat het schip zich in 'vijandsvaarwater' had bevonden en dat de commandant nota bene de Nederlandse overloper Barent Pessaert was die aan de Spaanse gouverneur in Manilla had geschreven over de staat van de Compagnie. Van excuses kon derhalve geen sprake zijn. ${ }^{30}$

Barent Pessaert was in $\mathrm{I}_{34}$ heimelijk uit Batavia naar Nederland vertrokken om daar dienst te nemen bij de Deense Compagnie. De Deense Compagnie werd over het algemeen met rust gelaten. ${ }^{3 \mathrm{I}}$ Maar toen Pessaert in I645 een tocht naar Japan ondernam, werden schip en bemanning aangehaald en naar Batavia opgebracht. Daar werd de lading overgenomen en, terwijl het onduidelijk is of Pessaert in dienst van de Compagnie trad, voer hij onder Deense vlag met een nieuwe lading naar Manilla. Pessaert werd op een eiland nabij Manilla terwijl hij aan het vissen was, door inwoners doodgeslagen. ${ }^{32}$ In Manilla werd het schip op beschuldiging van spionage in beslaggenomen en met de bemanning aan de ketting gelegd. De schipper en de stuurman werden eerst ter dood veroordeeld, maar later werden zij naar het gerechtshof van Madrid(!) gezonden ter behandeling van hun zaak. ${ }^{33}$

\section{Van Diemens wraak op Van den Heuvel}

In het eerste jaar als gouverneur-generaal maakte Van Diemen duidelijk wat zijn vijanden van hem konden verwachten. Instructief daarvoor is de omslachtige manier waarop hij wraak nam op Antonie van den Heuvel, de fiscaal die hem in I63I door beschuldiging van handel voor eigen rekening zo in het nauw had gebracht. Dat was niet zo eenvoudig, omdat Van den Heuvel zolang hij fiscaal was - wij zouden nu zeggen 'officier van justitie' - zelf niet kon worden aangeklaagd. Voor hem moest dus een valstrik worden gespannen, die goed gedocumenteerd in de archieven is te volgen.

Toen in juni ${ }_{1633}$ Van den Heuvel terugkwam van zijn inspectiereis naar Ambon, beschuldigde hij de zittende gouverneur van Ambon, Artus Gijsels, van veel oneerlijke praktijken. Dit zou de laatste daad van Van den Heuvel in Azië hebben kunnen zijn geweest als hij, zoals de 
bedoeling was geweest, in december van dat jaar als vice-commandeur van de retourvloot naar Nederland was vertrokken. ${ }^{34}$ Van den Heuvel werd echter overgehaald om voor drie jaar zelf gouverneur van Ambon te worden om daar de door hem geconstateerde misstanden recht te zetten. Hij ging op het verzoek in en vertrok in januari I634 naar Ambon. Daarmee verloor hij zijn juridische onschendbaarheid, want hij was niet langer 'fiscaal'.

Saillant detail is dat deze intrigant in Ambon een afschrift van de Dagregisters van Batavia toegezonden kreeg van Pieter Mestdagh tegen betaling van twee realen per maand..$^{35}$

Van den Heuvel zal verbaasd zijn geweest toen hij in hetzelfde jaar weer werd teruggeroepen naar Batavia onder het voorwendsel dat 'alsoo wij vertrouwen dat sijn geleertheyt ons hier beter sal te passen als int Gouvernement van Ambonya'36 en dat Artus Gijsels op dezelfde dag wederom naar Ambon werd gezonden, opnieuw in de rang van gouverneur. ${ }^{37}$

Bij zijn terugkomst in Batavia was voor Van den Heuvel en zijn vrouw geen plaats meer in het kasteel. Onder protest werd hij gedwongen een huis in de stad te huren. ${ }^{38}$ Op 5 juni ${ }^{6} 635$ werd de lus vervolgens aangetrokken. Van den Heuvel werd ten laste gelegd dat door zijn fout het schip 'De Gouden Leeuw' op de terugreis van Ambon verongelukt was. Van den Heuvel deed hierop beroep op zijn onschendbaarheid, maar dit werd afgewezen: hij was immers door zijn benoeming tot gouverneur de wetsbescherming die hij genoot als fiscaal kwijtgeraakt. ${ }^{39}$

Met de jaarlijkse brief uit Nederland werd Van den Heuvel nog wel bevorderd tot raad van Indië, maar hier werd in Batavia geen gevolg aan gegeven, omdat Van den Heuvel 'over diverse verzuimen onder het recht' was. ${ }^{40}$

De zaak was niet sterk en bleef een jaar lang slepen, totdat Van den Heuvel op 8 oktober ${ }_{1} 636$ over 'zijn eigen ongedediceerd proces' aan zijn juridische vakgenoot Maetsuycker vroeg of deze het niet ter hand kon nemen, omdat Van den Heuvel zijn rechters 'idioten en weetnieten' vond. De Raad van Justitie vond deze minachting aanleiding om vonnis te wijzen en veroordeelde hem tot een geseling waarna een zilveren priem door zijn tong zou worden gestoken. Dit ging Van Diemen blijkbaar te ver. Bij resolutie van I6 december I636 werd de geseling geschrapt, maar voor het overige bleef het vonnis 'in vollen rigeur'. ${ }^{\mathrm{I}}$ Hierna vertrok Van den Heuvel met de retourvloot naar Nederland.

In hun brief van september I636 schreven de Heren Zeventien dat tegen Antonio van den Heuvel 'met exempel geprocedeert' mocht worden, het kwam als mosterd na de maaltijd. ${ }^{42}$

Veel genoegen aan zijn wraak zou Van Diemen echter niet beleven. Terug in Nederland zou Van den Heuvel nog voor veel problemen zor- 
gen. In een vileine brief, die ook in Batavia bekend werd, stelde hij de rol van Van Diemen in de affaire van Sara Specx en Pieter Cortenhoeff in een ongunstig daglicht. En hiermee trof hij doel.

In I639 schreef Van Diemen een repliek aan de Heren Zeventien:

'Antonio van den Heuvels remonstrantie waren beter uijt India gehouden als derwaerts gesonden, van vele notoire leugenen ende schandelijcke blamen van denselven overtuijght worden, selffe bij de Comp als haer Ed gelieft hadden de moeijte aen te nemen doch t'werck sal sijn meester wel loonen.

T' blijckt bij resolutie, dat de sententie tegen Pieter Cortenhoeff gestreecken niet geapprobeert hebbe, daerover oock in d'ongunste van den generael Coen sal. geraeckte, des niettegenstaende seijt van den Heuvel in sijn eerste remonstrantie met dese woorden: Sij beijde (verstaet Cortenhoeff ende Sara Specx) waren bij de generael ende sijn aenwesende Raden Vlacq ende van Diemen gecondemneert, omme d'een onthalst ende d'ander verdroncken te worden.'

Notoire Leughen' schreef Van Diemen persoonlijk met vette letters. ${ }^{43}$

Door zijn diensten te verkopen aan de Engelse koning Karel I zou Van den Heuvel tot zijn dood in I64I voor nog grotere problemen zorgen. Hij voorzag de EIC in haar voortdurende geschil met de VOC van veel nieuwe ammunitie juist over het handelen van de VOC in Batavia. ${ }^{44,45}$

\section{Het stempel van Van Diemen op VOC}

Niet alleen door zijn gelukkig gevoerde oorlogen drukte Van Diemen zijn stempel op de VOC. Een viertal op zich verschillende onderwerpen verdient daarnaast onze aandacht. Onderwerpen die ook tijdens de regering van Van Diemen een rol speelden en van blijvende invloed op de VOC zouden zijn. Het betreft de wetgeving, de Statuten van Batavia, de ontdekkingsreizen van Abel Tasman, het belangrijke, en naar zou blijken definitieve standpunt over de kolonisatievraag en de moeizame verlenging van het Octrooi.

\section{De Statuten van Batavia}

Geldt tegenwoordig ook niet nog steeds dat de nalatenschap van een regering mede afhangt van de wetgeving die onder haar tot stand gekomen is? Het gaat in ieder geval op voor de regering van Van Diemen. Vanaf de oprichting van de VOC werd het recht zoals dat ten tijde gold 
in Holland, zoveel mogelijk van toepassing verklaard binnen haar octrooigebied. Wij zouden nu zeggen een mengeling van oud-vaderlands en Romeins recht.

Vanwege, in vergelijking tot Holland, de uitheemse situatie met Chinezen, slaven, Moren, compagniedienaren en vrije burgers werden binnen het octrooigebied van tijd tot tijd wijzigingen en aanvullingen op de regels vastgelegd in verordeningen en plakkaten. Vanwege het ad hoc karakter van deze codificatie en omdat er geen verzameling van was aangelegd, raakten de vindplaatsen makkelijk in vergetelheid en spraken nieuwe regels onbedoeld oude tegen. Er was zo in de korte tijd van het bestaan van Batavia een onoverzichtelijke situatie ontstaan.

Om, zoals van Diemen schreef, aan deze 'verwarring' een einde te maken, heeft hij op dit terrein doortastend actie ondernomen. ${ }^{46}$ Volgens Valentijn zou Van Diemen met deze ordening al zijn begonnen. ${ }^{47}$ Waar Valentijn zich op baseerde is niet te achterhalen. In ieder geval belastte Van Diemen in I64I de voorzitter van de Raad van Justitie, Johan Maetsuycker, met het karwei de bestaande regels te achterhalen, met elkaar in overeenstemming te brengen, aan te vullen of te bekorten en dat alles vooral in heldere, begrijpelijke taal. Dat laatste is ook tegenwoordig een niet onbekend vereiste. Met de Bataviase Statuten is men, ook vanuit een hedendaagse blik, daarin wonderwel geslaagd.

$\mathrm{Na}$ één jaar legde Maetsuycker een ontwerp voor, waar een uitgebreide commissie zich vervolgens over boog en uiteindelijk geen enkele wijziging voorstelde. Zo werden de Statuten van Batavia op I juli I642 vastgesteld door de Raad van Indië. Blijkbaar was al een exemplaar naar Nederland verstuurd, want in hun brief van 25 september van hetzelfde jaar hechtten ook de Heren Zeventien hun goedkeuring aan het concept. Het is een overzichtelijk werk geworden waarin de bestuurlijke en juridische structuur van het gebied waarin de VOC de macht uitoefende, werd vastgelegd.

In de Bataviase Statuten komt alles aan de orde. Niet alleen de schout en schepenen, maar ook de behandeling van slaven, de werkwijze van de notarissen, de taken van de weesmeesters, de ijkmeester en de vergoedingen voor de beul. Deze laatste met lugubere details, bijvoorbeeld dat hij voor het uitsteken van het tweede oog van een veroordeelde maar de helft kreeg van het eerste. Valentijn noemde de Statuten in I72I 'dat algemeen en heerlijk Recht-boek van Indien, waarna alle vonnissen alomme in het Oosten uitgewezen werden. ${ }^{48}$

Dat de Statuten ten tijde van de VOC niet zijn herzien, is een voorbeeld van de toegenomen gezapigheid en bureaucratie binnen de VOC die slagvaardig optreden vaak onmogelijk maakten. Over een periode van maar liefst vijftig jaar - van I7I5 tot I766 - is in Batavia door opeenvolgende commissies en gouverneurs-generaal gewerkt aan een nieuwe redactie van de Statuten. Toen de nieuwe Statuten in I766 door 
de toenmalige gouverneur-generaal Van der Parra 'na zeer veel moeite eindelijk tot perfectie gebracht' waren, werden deze om onduidelijke redenen door de Heren Zeventien niet bekrachtigd. ${ }^{49}$ Hierdoor zouden de Statuten van I642 tot na de compagnietijd van kracht blijven.

In de bijzondere collectie van de Koninklijke Bibliotheek ligt een prachtig in verschillende kleuren inkt handgeschreven exemplaar van de Statuten van Batavia. Dit exemplaar stamt uit het midden van de achttiende eeuw.

Het in de Koninklijke Bibliotheek bewaard gebleven exemplaar geeft aanleiding tot een andere observatie. Namelijk dat het ten tijde van de VOC met de boekdrukkunst in Batavia matig gesteld was. Het drukwerk van de VOC werd eigenlijk allemaal in Nederland uitbesteed. In Batavia werd weliswaar een eerste drukpers rond I670 geïnstalleerd, maar het gebruik bleef beperkt. Het had er volgens Landwehr waarschijnlijk mee te maken dat maar zo weinig inwoners konden lezen. ${ }^{50}$

Zo zijn pas lang na het verscheiden van de VOC in de tweede helft van de negentiende eeuw de Statuten van Batavia voor het eerst in druk verschenen. Tot onverwacht lang in de tijd hebben zij invloed gehad. Zo lang zelfs dat in de Tweede Kamer op 9 december I862 nog door een afgevaardigde werd gesteld: 'Het strafrecht (in Nederlands Indië-w) berust in de eerste plaats op de oude Statuten van Batavia van I642.' Waarna hij betoogde dat aan deze achterlijke situatie onmiddellijk een einde moest komen, hetgeen in de jaren daarna geschiedde. ${ }^{\text {I }}$

De Statuten zijn het belangrijkste voorbeeld van Van Diemens ordeningszin, maar zij zijn niet de enige. Mutatis mutandis kan hetzelfde verhaal gehouden worden voor de kerkordening zoals die in $\mathrm{I} 643$ door Van Diemen werd vastgesteld voor het octrooigebied. In hetzelfde jaar was de oprichting van een Latijnse school echter minder succesvol.

Van Diemen ordende en regelde. Hij was de gouverneur-generaal die de buiten- en binnengrenzen van de VOC probeerde vast te leggen.

\section{De ontdekkingsreizen}

Een van de eigenschappen van Van Diemen die nog niet belicht is, was zijn nieuwsgierigheid. Hij was geïnteresseerd naar de zeden en gewoonten van volken en het ontdekken van nog onbekende landen. Zijn ondergeschikten wisten dit en schreven een aantal bijzondere studies. Zoals Simon van Vliet over Siam en François Caron in zijn beroemde werk over Japan. Zelf beval Van Diemen de studie van Rogerus 'Bä̈ls priester over de zeden en gewoonten der Bramanen de heren Zeventien aan met de woorden: "t sal de leesgierigen leser buyten twijffel aengenaem 
sijn. ${ }^{52,53}$ De grote ontdekkingsreizen in de vroeg moderne tijd hadden altijd een commercieel of politiek doel voor ogen. De nieuwsgierigheid, het willen weten om te weten, was natuurlijk ook aanwezig, maar was niet de primaire drijfveer achter de ontdekkingsreizen. Dat gold ook voor die reizen die op instigatie van Van Diemen werden gedaan. In zijn afscheidsbrief had Brouwer Van Diemen aangespoord op zoek te gaan naar het goud- en zilvereiland dat beoosten Japan ergens in de onmetelijke oceaan moest liggen 'daer menighte laackenen ende andere Nederlandtse manifacturen als oock mede specerijen souden connen vertieren.' Het klinkt toch weinig prozaïsch. ${ }^{54}$

Het zou een zoektocht zijn op basis van een legende die in 1606 door de Portugees Pedro Fernández de Quirós nieuw leven was ingeblazen. Hij was met drie schepen uit Peru vertrokken op zoek naar het legendarische Zuidland en, waarschijnlijk om een mislukte tocht te verbloemen, schreef hij aan de Spaanse koning Philips III over een groot eiland in de Stille Oceaan waar goud, zilver en parels in overvloed waren en dat bewoond werd door een zachtaardig volk. De inhoud van deze brief was bekend geworden en in het Engels vertaald in druk verschenen.

Een zo groot geloof werd hieraan gehecht dat Van Diemen tweemaal - in I639 en I643 - een expeditie uitrustte van twee schepen om in brede banen de zee tussen Japan en Amerika te doorkruisen. Tijdens de eerste expeditie onder leiding van Abel Tasman werden de Bonin-eilanden ontdekt. De tweede tocht is met moderne blik boeiender, doordat de elementen de twee schepen al snel uit elkaar dreven en de koers van beide ver naar het noorden verlegden. Van deze expeditie waren de geografische resultaten belangrijk, maar nieuwe gebieden waarop handel kon worden gedreven werden niet gevonden..$^{55}$

Deze tochten raakten in de vergetelheid, maar met de ontdekkingsreizen naar het Zuidland, zoals Australië genoemd werd, zou dat niet gebeuren.

In 1606 betrad Willem Jansz als eerste Europeaan op de noordkust het vaste land van Australië. Hetzelfde jaar al zeilde de Spanjaard Torres weliswaar tussen Nieuw Guinea en Australië door, maar deze route raakte in de archieven van Manilla verloren. Pas bijna twee eeuwen later kon de Engelse ontdekkingreiziger Cook opnieuw aantonen dat Nieuw Guinea een eiland was, hij noemde de zee-engte naar de eerdere ontdekker 'Straat Torres'.

Door de tocht van Willem Jansz en de vele onbedoelde landingen van VOC-schepen op de west- en zuidkust, was van Australië, het 'Zuidland' waar Aristoteles als eerste over speculeerde, al het nodige bekend. Op I augustus I642 besloot Van Diemen tot de expeditie 'tot ontdeckinghe van d'apparent rijcke Suyder- en Oosterlanden.' Hoe groot was het en kon men eromheen zeilen? ${ }^{56}$ 


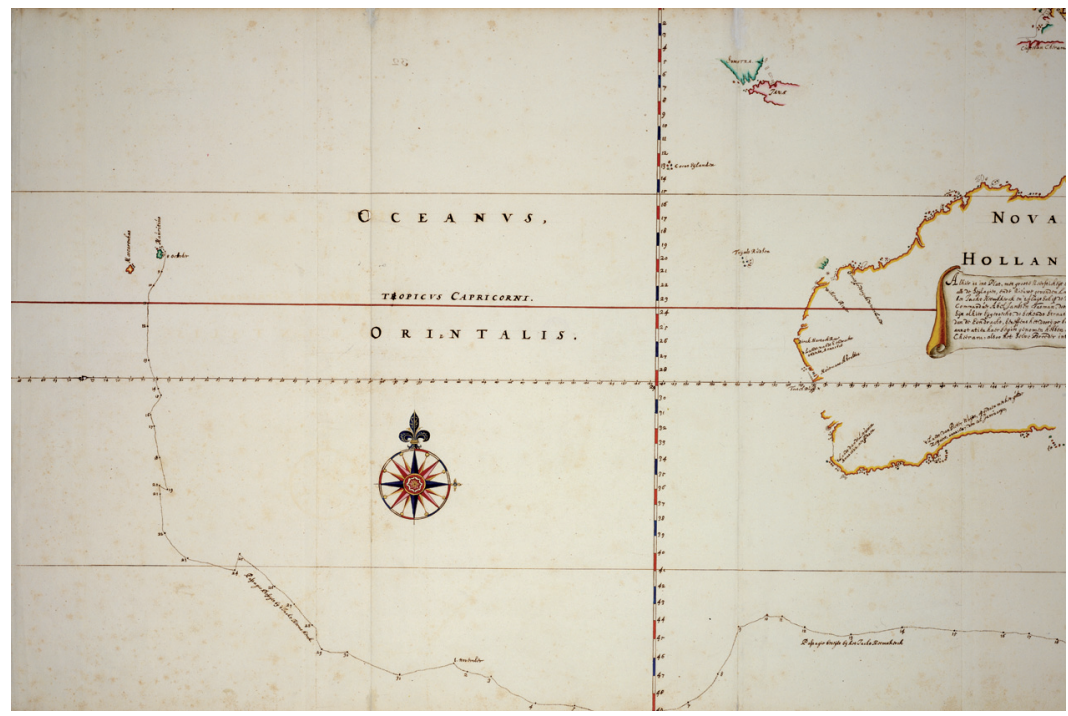

Kaart van de beroemde reis van Abel Tasman. Van Diemen was bijzonder ontevreden over het resultaat, omdat Tasman de binnenlanden van Australië niet had onderzocht. Österreichische Nationalbibliothek

Daarnaast was het de bedoeling om indien mogelijk een nieuwe route naar Zuid-Amerika open te leggen om rechtstreeks handel te kunnen gaan drijven op Chili, en de Spanjaarden in Peru aan te vallen. Het was niet alleen het plan van Van Diemen, ook de Heren Zeventien hadden herhaaldelijk hierop aangedrongen. ${ }^{57}$ De voorbereidingen verliepen vlot en nog in dezelfde maand voeren twee schepen weg van Batavia naar Mauritius.

Tasmans beroemde tocht begon pas echt op 8 oktober I642 toen de rede van Mauritius werd verlaten. Vandaar werd koers ver naar het zuiden uitgezet en op 50 graden zuiderbreedte werd de koers naar het oosten verlegd. Vanwege de voortdurende stormen op die hoogte werd de koers vervolgens noordelijk verlegd naar 42 graden. Op 24 november kregen de twee schepen eindelijk land in zicht. Het werd 'Anthonie van Diemensland' genoemd, men wist niet zeker of het een eiland of een schiereiland was

In I803 vestigden de Engelsen op Van Diemensland een kleine nederzetting die al snel een strafkolonie werd. In I856 werd de naam gewijzigd in 'Tasmanië', omdat in het Engels 'Van Diemensland' klonk als 'Vandemonianland'.

Toch werd de naam buiten Nederland niet helemaal vergeten Van Diemens Land is de titel van het tweede nummer van het geflopte album Rattle and Hum van de Ierse rock band U2 uit I988 ter herdenking van de vele gedeporteerde Ieren..$^{5}$ 


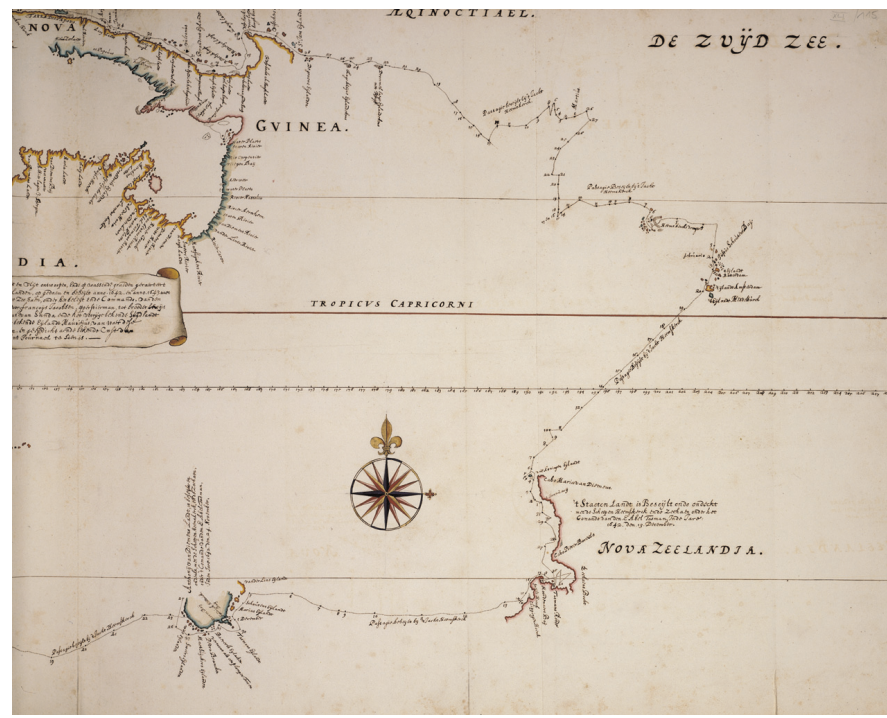

Zoals bekend is, voer Tasman daarna oostwaarts en was hij de eerste Europeaan die voet aan wal zette op het latere Nieuw-Zeeland. Het meest westelijke punt van Nieuw-Zeeland heeft wel de naam behouden die Tasman eraan gegeven had, 'Kaap Maria van Diemen'. Het belangrijkste resultaat van deze tocht was dat vastgesteld kon worden dat Australië niet aan de vermeende landmassa rond de Zuidpool vast zat, zoals tot dan de algemene gedachte was. Nieuwe handelsstreken waren echter niet ontdekt en ook van een kortere route naar Zuid-Amerika was niets gebleken.

Het jaar daarop werd daarom een tweede tocht ondernomen om Australië zelf te onderzoeken. Dit keer begon de tocht op Banda en voer Tasman vandaar naar het zuiden. Door het slechte weer kon hij dit keer niet meer doen dan het in kaart brengen van een groot deel van de noordkust van Australië.

Van Diemen was bijzonder teleurgesteld over de uitkomsten van deze tweede tocht en verweet dit Tasman persoonlijk. Hij nam het hem met name kwalijk dat hij niet had onderzocht of Nieuw Guinea dan wel Van Diemensland aan Australië vast zaten en dat hij niet het binnenland had onderzocht. Van Diemen schreef hierover aan de Heren Zeventien dat hij een nieuwe expeditie wilde uitzenden geleid door 'vigilanter en couragieuser personen, als tot nu gebruyckt sijn. Landen t'ondersoecken is yders werck niet.' Met dat oordeel van zijn meerdere kon Nederlands bekendste ontdekkingsreiziger het tijdens zijn leven doen, want het kon 
volgens Van Diemen niet anders dan dat een land dat zo groot was en dat zich over zoveel 'verscheyden climaten' uitstrekte, wel belangrijke goederen moest voortbrengen. ${ }^{59}$ Tot een nieuwe tocht is het echter niet meer gekomen.

Zijn opvolger Cornelis van der Lijn probeerde goede sier te maken bij de Heren Zeventien door onomwonden te stellen dat hij geen geld meer zou besteden aan dit soort dure en nutteloze escapades. Pas in de tweede helft van de achttiende eeuw werden er weer expedities uitgerust, nu vooral wetenschappelijke waarvan de bekendste die van James Cook zou worden. Voordien was het ontdekken van de natuur om een andere dan een commerciële of politiek strategische reden niet aan de orde. $^{60}$

\section{De kolonisatievraag tijdens de regering van Van Diemen}

Tijdens de regering van Van Diemen speelde opnieuw de vraag of de Compagnie toch niet zou moeten overgaan tot het koloniseren van de gebieden die zij onder haar gezag had verkregen. In I639 kaartten de Heren Zeventien 't stuck van de Nederlants Indische Colonie' wederom aan. De discussie die onder Coen was begonnen, - zo schreven zij was nooit naar behoren afgerond. Het gevoel was gebleven dat zonder Nederlandse kolonie naar het voorbeeld van de Portugezen en Spanjaarden in Goa, Malakka, Macau en Manilla, de Compagnie in Batavia en elders het 'perijckel' zou lopen 'van onse vijanden overrompelt te werden. ${ }^{6 \mathrm{I}}$

$\mathrm{Na}$ twee jaar werden de conclusies getrokken. In een opvallend genuanceerd gestelde brief aan Van Diemen en zijn raden werden de voor en tegens nogmaals op een rij gezet. Het zou het definitieve standpunt blijken te zijn.

Om te beginnen werd gesteld dat op basis van de historische en Portugese voorbeelden het ongetwijfeld zo was dat Nederlandse koloniën de Compagnie in Azië 'ten rechten' zouden 'verseeckeren'.

Maar, was dit mogelijk, zo vroeg men zich af. Ten eerste waren de Nederlanders geen Portugezen en de Nederlanders namen ongaarne ander land tot vaderland aan. Daar was ook geen reden voor vanwege de 'menichvuldige goede gelegentheden' om in Nederland te kunnen leven en werken. Dat was anders voor de Portugezen, want die woonden in een 'schraal' land, 'waerbij hen oock toevalt, dat sij uyt eigenen nature en aerdt beter der landen natien als Nederlanders connen gouverneren.'

Daarnaast was de VOC opgericht om zoveel mogelijk winst te maken, wat niet strookte met het vestigen van koloniën, want die zouden niet kunnen bestaan als alleen 'tweederangs' handel voor de burgers over- 
bleef. Tot slot was het moeilijker geworden jongelingen 'te moveren' in dienst te treden bij de VOC. Er was in Nederland zelf krapte aan zeevarenden en door de oorlogen in Europa waren de soldaten 'schaars'. Maar ook de verhalen dat 'insonderheyt d'Indische veel menschen smelt' maakten de Compagnie als werkgever minder aantrekkelijk. De conclusie was dan ook dat koloniën wellicht wenselijk waren, maar welbeschouwd geen optie van de VOC. ${ }^{62}$

Echte volksplantingen naar het idee van Coen werden hierna niet meer overwogen. Er werd een tussenweg gevonden. Zo werd aan het compagniepersoneel en de vrijburgers toegestaan onder goedkeuring door de Compagnie met Aziatische vrouwen te trouwen, mits deze zich bekeerden tot de hervormde kerk. Maar het werd hun in I639 verboden om met hun (Euro) Aziatische vrouwen en kinderen naar Nederland terug te keren. Hierdoor groeide met name in Batavia een unieke IndoPortugese-Nederlandse samenleving.

Ik denk dat een reden dat de Portugezen in bijvoorbeeld Goa en Macao meer een blijvende indruk hebben achtergelaten dan de Nederlanders in Batavia, is gelegen in het verschil in werkwijze tussen de katholieke missie en de protestantse zending. Hoe makkelijk het voor een Aziaat was om katholiek te worden, zo moeilijk was het om tot de protestantse kerk te worden toegelaten. De synode van Dordrecht, geheel overheerst door de contraremonstranten, schreef hierover in I6I9 aan de Bataviase dominee Hulsebos. Deze brief vormde het uitgangspunt van de zending en maakte de toetreding tot een ware hindernisrace. Een zware inburgeringcursus avant la lettre. ${ }^{6}$ Mede hierdoor bleef de Hervormde Kerk in vergelijking tot de Rooms Katholieke kerk een randverschijnsel in Azië.

\section{De moeizame octrooiverlenging van 1643}

Het octrooi van de VOC dat ultimo december I62I wederom voor 2I jaar was verlengd, verviel per 3I december I643. De Heren Zeventien hadden in I64I en I642 om verlenging verzocht en tot een halfjaar voor de datum van de hernieuwing dachten zij dat het octrooi zonder problemen door de Staten-Generaal zou worden verlengd. ${ }^{64}$ Dat bleek een forse misrekening. Wat volgde, is een studie over de besluitvorming binnen de Republiek waardig en het is verleidelijk om de buitengewone verwikkelingen die rond deze verlenging speelden, uitvoerig te beschrijven, maar in het kader van de voorliggende studie voldoet een korte samenvatting.

Het begon met de provincie Friesland die zich sinds het begin van de VOC buitengesloten voelde. Zij meende het recht te hebben een eigen 
Friese Oost-Indische Compagnie op te zetten en, om niet achter de feiten aan te lopen besloot zijzelf daartoe medio I643. Het kostte de Heren Zeventien moeite deze geest weer in de fles te krijgen.

De situatie werd werkelijk gecompliceerd toen daarnaast het voorstel kwam van de WIC aan de Staten-Generaal om de octrooiverlenging te gebruiken voor een fusie van de WIC met de VOC. Zo zou de WIC, die er slecht voorstond, gered kunnen worden.

De Heren Zeventien wezen beide voorstellen direct van de hand, maar de op gang gekomen lobby's waren daar niet direct van onder de indruk.

De besluitvorming binnen de Staten-Generaal die, in ieder geval op papier, op consensus tussen de provincies gebaseerd was, liep vervolgens helemaal vast toen in de Staten van Holland ook de steden Alkmaar, Haarlem en Leiden een grotere rol binnen de VOC opeisten. Toen het einde van het jaar naderde, was nog geen overeenstemming binnen bereik.

De vertegenwoordigers van de Staten van Holland stelden voor het octrooi met een halfjaar te verlengen om in die tijd de gerezen problemen op te kunnen lossen. Daar kregen zij de andere provincies niet in mee en zo werd het octrooi op het laatste nippertje eerst met zes weken verlengd. De kwestie werd slepend en het octrooi werd steeds slechts voor een korte tijd verlengd. In januari I645 zelfs een aantal malen met één week.

Steeds meer steden en personen probeerden een graantje mee te pikken uit de Oost-Indische ruif. Uiteindelijk werd na drie jaar op januari I647 het octrooi vrijwel ongewijzigd verlengd met 25 jaar na een aantal onbelangrijke wijzigingen in het octrooi zelf. Het is jammer dat de geheime notulen ontbreken met de lijst van 'vereringen' die hierbij aan de leden van de Staten-Generaal en andere belanghebbenden zijn gedaan. Wij moeten het doen met de uitspraak van Van Dam die stelde dat deze 'in vele gelegenheden tegemoetkomen' waren.

Ook zichtbaar moest de VOC fors over de brug komen. In een vijftal jaren moest in totaal I, 5 miljoen gulden worden betaald aan de StatenGeneraal, die deze bedragen op hun beurt ter ondersteuning zouden doorsluizen naar de zieltogende WIC.

Van belang in het kader van deze studie is mede dat deze situatie, die in ieder geval op papier het voortbestaan van de VOC bedreigde, geen merkbare invloed heeft gehad op de bedrijfsvoering in Nederland of Azië. Het verzoek van de Heren Zeventien aan Van Diemen om langer aan te blijven als gouverneur-generaal vanwege de onduidelijke situatie rond de octrooiverlenging bereikte Batavia pas na zijn overlijden. ${ }^{65,66}$ 


\section{De groei van Batavia}

Nadat De Carpentier op I9 september I6rg met een kleine ceremonie de eerste steen van het kasteel gelegd had $^{67}$, werd ook met de bouw van de stad begonnen. Opeenvolgende plattegronden tonen de groei van Batavia eerst op de rechteroever van de Tjiliwong en daarna op de overzijde. Vooral na het beleg van I629 kwam de bouw goed op gang. De geflatteerde plattegrond die gegraveerd stond op de gouden penning die Specx in I632 meekreeg als afscheid van de Chinese kolonie, toont het grote kasteel en de stad zoals die in wording was. De plattegrond van Clément uit ${ }^{6} 5_{52}$ geeft de stad weer zoals die onder Van Diemen was uitgebouwd.

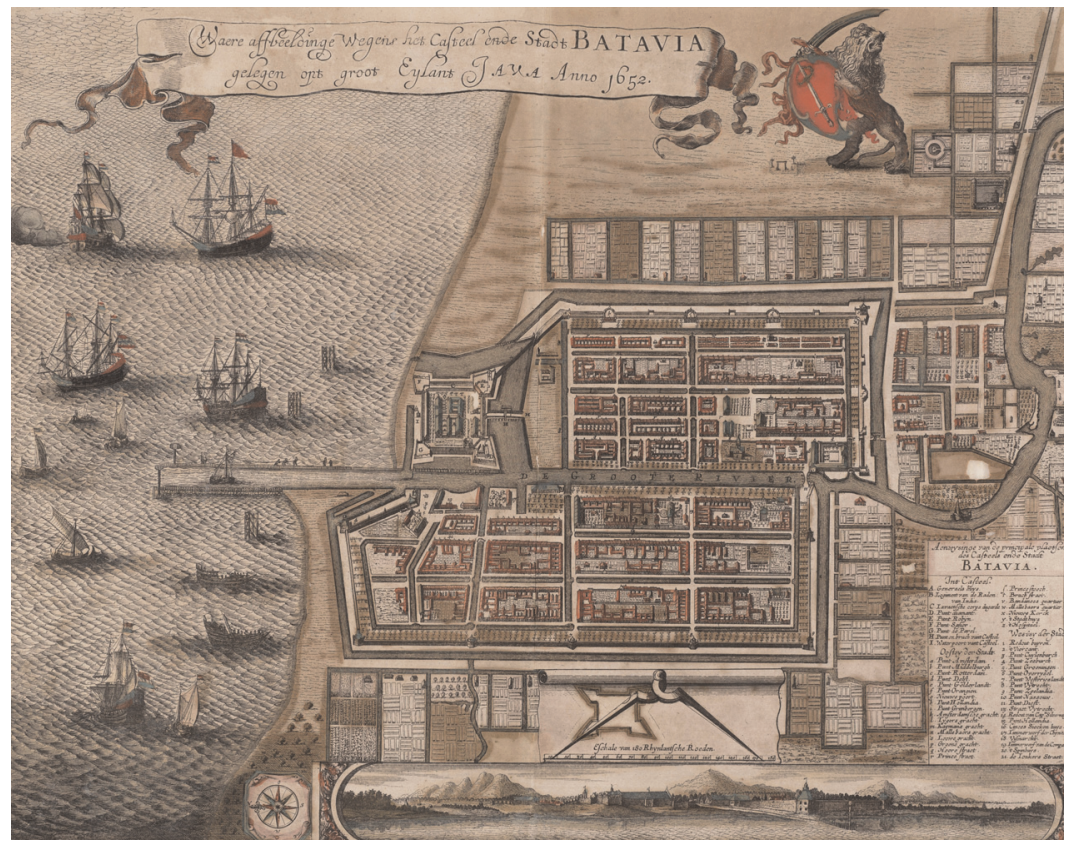

Nadat Batavia onder Van Diemen was uitgebouwd, werd door zijn opvolgers het land buiten de muren in cultuur gebracht. Nationaal Archief, Den Haag.

In de brieven van Van Diemen vinden wij regelmatig berichten over eerste steenleggingen en aanbestedingen aan de Chinese aannemers voor de uitbreiding van de stad. ${ }^{68}$ Met op de stadsmuren een tweetal schansen met de namen 'Culemborg' en 'Vianen' naar de woonplaatsen van Antonio en de moeder van Maria in Nederland werd een persoonlijk element van Van Diemen toegevoegd. 
Van de kerkbouw maakte hij een prioriteit. Vloeren en dakpannen hiervoor werden uit Nederland geïmporteerd en op I januari I645 legde hij vlak bij zijn woning binnen de muren van het kasteel, de eerste steen voor een kleine kerk waarvan hij de bouw zelf bekostigde. ${ }^{69}$ Wilde hij hier begraven worden?

Een schilderij van Beekman uit ${ }_{1} 656$ geeft het beste beeld dat wij hebben van de stad en haar bevolking uit deze periode. De indruk die deze stad maakte op de bemanningen van de schepen die na een reis van vele maanden aankwamen, moet overweldigend zijn geweest. Ontroerend ook wanneer men over het water voor het eerst de klokken hoorde luiden, terwijl de ochtendbries de nevel wegblies. Deze eerste indruk zou echter vaak misleidend blijken te zijn.

In I632 werd een volkstelling gehouden die een stadsbevolking telde van 8060 zielen. $^{70}$ Dat er weinig Nederlandse vrouwen en kinderen onder de inwoners waren, vinden wij niet zo bijzonder. Wel een aantal andere gegevens. Ten eerste dat de circa 2700 slaven bijna één derde van de bevolking vormden, dan, dat er meer Chinezen waren dan compagniedienaren, en natuurlijk ook het geheel ontbreken van Javanen in deze opsomming. Batavia was in $6_{32}$ een Chinees-Nederlandse enclave op een vijandig eiland.

In zijn grote studie over Oud-Batavia begon de cynicus De Haan in het dertiende hoofdstuk met de beschrijving van het vele wee en het weinige wel van de bevolking, die door de regering 'de dertiende groep' werd genoemd. ${ }^{7 \mathrm{I}}$ Ook Niemeijer in zijn recente studie over Batavia in de zeventiende eeuw beschrijft de moeizame, vaak korte levens en de permanente onveiligheid. Het was een 'frontier town', niet in het Wilde Westen maar in het Tropische Oosten.

In de zeventiende eeuw ging iemand naar Batavia om zo snel mogelijk rijk te worden en dan weer te vertrekken. Vaak eindigde dit met een vroege dood die in al zijn kilheid werd aanvaard. De Heren Zeventien schreven: D'Oostindische navigatie gelijck ons bekendt is, slijt veel volcxs. (316, 269. I2 september I639) Zo was de westkust van Sumatra een 'moordkuyl', terwijl Brouwer over de peperhavens aan de oostkust schreef:

'Het versterven voorleden jaer van veele onser coopluijden op gemelte custe die wij daer meeneen aen te queecken om ervaerenheijt te becomen sal Ued diene.... opnieuwe nieuwe bequame jongelingen derwaerts doen gebruijcken. ${ }^{72}$

Verbeeld hierbij de taferelen in de bordelen, gok- en drankhuizen na de aankomst van een vloot met aan boord vaak meer dan duizend man die 


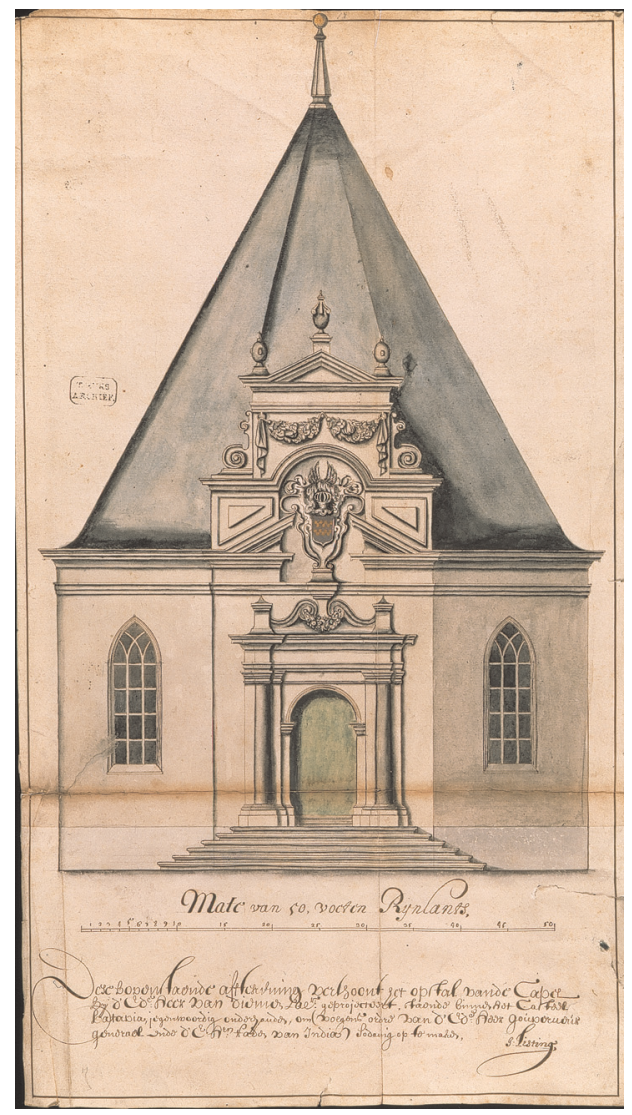

In het oorspronkelijk ontwerp van de kasteelkerk was een dak gedacht. Om de bouw te kunnen voltooien, stelde Maria in 1652 vanuit Nederland 15.000 gulden ter beschikking. Het werd in 1671 als volgt beschreven: 'In het kasteel pronckt ook een klein, dog net agtkantig kerkje.' Boven de deur 'pronkte' het wapen van Van Diemen. Nationaal Archief, Den Haag.

in geen maanden een vrouw gezien hadden, en het is duidelijk dat velen het hier slecht, en maar enkelen het goed hadden.

Voor velen was het leven in Batavia en daarbuiten in dienst van de VOC een morbide carrousel. De procesverslagen uit de tijd van Van Diemen geven huiveringwekkende voorbeelden van doodgeranselde slaven, mannen vergiftigd door hun seksslavinnen, muiterijen en verschrikkelijke straffen als voorbeeld die over de daders werden uitgesproken. ${ }^{73}$ Over het algemeen hield deze carrousel op bij de kasteelpoort.

Dat lag anders toen raad van Indië Justus Schouten in juni I644 beschuldigd werd van homofilie. Na een proces werd hij schuldig gevon- 
den en aan een paal gewurgd waarna zijn lichaam werd verbrand. Van Diemen schreef hierover: 'Van der Raad Joost Schouten waren wat groots verwachtende, maer sijn dapper bedrogen geweest. ${ }^{74}$ Anderen kregen eenzelfde lot toegemeten.

Batavia onder Van Diemen was geen verlichte maatschappij.

\section{Noten}

I. Gelman Taylor, J., The social world of Batavia, European and Eurasian in Dutch Asia (Madison I983).

2. NA I.04.23 'Klapper van Delden' Jan van Broekom, Res GG en raden 2 december I634.

3. NA VOC II33, f 70 Generale Missive 30 november i640.

4. NA I.04.23 'Klapper van Delden' Pieter Boreel: Tekst grafschrift 'Hier Leght begraven Mr. Pieter Boreel, doctor in beide de rechten en de Heer van Welthoven, int land gecomen met Achillo in den jare $\mathrm{I}_{642}$, in qualiteijt vam extraordinaris Raedt van India em naer beteghtinge van sijne commissie op Ceylon als in Goa ontslapen I july I643, out sijnde 45 jaer'.

5. De Jonge, De Opkomst van het Nederlandsch gezag in Oost-Indie.V, 270. Van der Lijn aan Heren XVII, I2 juli i645.

6. MacLeod, De Oost-Indische compagnie als zeemogendheid in Azië II, 43I en J Gelman Taylor, J., The social world of Batavia, European and Eurasian in Dutch Asia, 36. Coolhaas, Generale Missiven I, 640, 9 dec I637 'opdat eenige recreatie ende verlustingh mogen nemen en de zon vermijden bij het ter kercke gaan'. Het zou ook helpen het 'melancholijcke climate' te dragen.

7. Niemeijer, H.E., Batavia. Een koloniale samenleving in de 17de eeuw. (Amsterdam 2005) I56.

8. NA Collectie Sweers I.0.78 29-30.

9. NA VOC OBP II43 $\mathrm{f}$ 2II.

Io. NA VOC OBP II52 folio I26 Gen Mis 22 december I643.

II. Coolhaas, Generale Missiven II, 219.

I2. NA VOC OBP II52 $\mathrm{f} 55 \mathrm{ev}$.

I3. NA VOC OBP II52 ff 55 ev Coolhaas, Gegevens, 542.

I4. Leupe, P.A., 'Salomon Sweers, Raad van Indië I644', in Bijdragen tot de Taal- Land - en Volkenkunde van Nederlandsch-Indië. I873, Martinus Nijhoff: Den Haag. p. 36-67.

I5. Valentijn, Oud en nieuw Oost-Indiën. V, 24.

I6. NA 1.04.23 'Klapper Van Delden'

I7. Valentijn, Oud en nieuw Oost-Indiën.V, 24.

I8. Coolhaas, Generale Missiven II, I68, I2 december I642 spreekt over 5427 stuks, 4845 caraet voor f 86 I43; verder dagregister Batavia 
I643 fol 275, sept-okt, brief B van de gruyter van I9 juli I643 spreekt hij over $\mathrm{f} 50.000$ aan ruwe diamanten.

I9. NA VOC OBP I023 fol 97/ 8 january I635. Het gaat om een wissel van $f 2880$ aan Pieter de Gruyter en Johannes van Ravenswaij. 'Spruijtende deselve somme uit de provisie van een diamant punt sijne huisvrouw toegecomen hebbende'uit het vaderland. Deze diamant is aan de koning van Siam verkocht voor f2880. De compagnie krijgt het verschil in licht en zwaar zilver zijnde I6 ten hondert'.

20. Coolhaas, 'Gegevens over Antonio van Diemen', 546. Brief I2 juli I645.

2I. Coolhaas, Generale Missiven II. I8 december I639.

22. Gaastra, F.S., Particuliere geldstromen binnen het VOC-bedrijf 16401795. Van Gelder lezing. (Leiden 2002).

23. NA VOC II47 f I03 - IO9 Originele particuliere missive van Antonio van Diemen aen de heeren seventhiene [tot Amsterdam] in dato 20 Januarij 1645 (gehele brief in bijlage).

24. Adam Smith, Inquiry on the wealth of nations, Book 5, part 3, article I

25. De Haan, F., Oud Batavia I (Bandoeng I935) I32.

26. Colebrander, H.T., Dagregister gehouden int Casteel Batavia vant passerende daer ter plaetse als over geheel Nederlandts-India Anno 16411642, (Den Haagigoo) Voorwoord I.

27. De Jonge, De Opkomst van het Nederlandsch gezag in Oost-Indie II, 268. Van Lijn en raden van Indië 9 juli 1645 .

28. NA VOC 66I Resoluties hooge regering juli I638.

29. Ibidem en Bruin, Dutch Asiatic Shipping II, 76.

30. NA VOC 66I, Resoluties hooge regering september 1638 .

3I. De Jonge, De Opkomst van het Nederlandsch gezag in Oost-Indie III, I94-I95.

32. Coolhaas, Generale Missiven II 285 .

33. Coolhaas, Generale Missiven II,64,66,240,268,27I,278,285.

34. Coolhaas, Generale Missiven I, 235.

35. NA I.04.23 'Klapper Van Delden' 'Anthonie van der Heuvel' Resolutie GG en raden 2 juni 1635 .

36. Idem, Resolutie GG en raden 26 october ${ }^{6} 634$.

37. Idem, Resolutie GG en raden 26 oct ${ }^{6} 634$.

38. Idem, Resolutie GG en raden, I8 mei I635.

39. Idem, Resolutie GG en raden 5 juni 1635 .

40. Idem, Resolutie GG en raden 6 oktober 1635 .

4I. Idem, Resolutie GG I6 dec I636. Het proces in: F.W.Stapel 'Bijdragen tot de geschiedenis der rechtspraak bij de Vereenigde Oostindische Compagnie', in Verhandelingen van het Koninklijk Instituut voor Taal-, Land-en Volkenkunde 9o, (Dordrecht I933) 90. 
42. NA VOC 3i6, f 129.

43. NA VOC Iı28 fol. 325-333 Brief Van Diemen ıo januari i639 aan bewindhebbers.

44. Sainsbury, E.B., and W. Foster, A calendar of the court minutes etc. of the East India company, 1640-1643., (Oxford I909). Vele voorbeelden van de betrokkenheid van Van der Heuvel bij de EIC.

45. Sainsbury, E.B. and W. Foster, A calendar of the court minutes etc. of the East India company, 1635-1639. (Oxford I907). Vele voorbeelden van de betrokkenheid van Van der Heuvel bij de EIC.

46. Bataviase Statuten inleiding. afgedrukt in J.A.v.d. Chijs, Nederlandsch-Indisch Plakkaatboek 1602-1811, I 473.

47. Valentijn, Oud en nieuw Oost-Indiën, IV, 294.

48. Ibidem.

49. Mijer, P., 'Bijdrage tot de codificatie van Nederlandsch-Indië'. Tijdschrift van Nederlandsch-Indië, Tweede jaargang deel I (Batavia I839).

50. Landwehr, J., VOC: a bibliography of publications relating to the Dutch East India Company, 1602-1800. (Utrecht I99I) XXI.

51. Handelingen Tweede kamer, zitting 9 december I862 deel 38, 420.

52. Coolhaas, Generale Missiven II, 220, I2 dec I643.

53. Ibidem.

54. NA i.Io.78 Collectie Sweers no 3 f iI.

55. Verseput, J., De reis van Mathijs Hendriksz. Quast en Abel Jansz. Tasman ter ontdekking van de Goud-en Zilvereilanden, uitgaven van de Linschoten vereeniging ('s-Gravenhage I939) I30.

56. Stapel, Geschiedenis van Nederlandsch-Indië III, 273.

57. MacLeod, De Oost-Indische compagnie als zeemogendheid in Azië II, 334 .

58. http://en.wikipedia.org/wiki/Van_Diemen\%27s_Land_\%28song\% 29

59. Stapel, Geschiedenis van Nederlandsch-Indië III, 276.

6o. Posthumus Meyjes, R., De Reizen van Abel Janszoon Tasman en Franchoys Joacobszoon Visscher, ter nadere ontdekking van het Zuidland (Australie) in 1642 - 1644. Werken van de Linschoten I7 ('sGravenhage I9I9).

6r. NA VOC 316, f 265 i2 september i639.

62. NA VOC 316 f 347, 2Imaart I64I.

63. Spijker, W.v.t., De Synode van Dordrecht in 1618 en 1619 (Houten I987).

64. Van Dam, Beschrijvinge I, eerste deel, 46.

65. NA VOC 3I7, f I7, brief Heren XVII 2I sept I644.

66. Van Dam, Beschrijvinge I, eerste deel, 60. 
67. NA VOC io7o, Brief De Carpentier aan de kamer Amsterdam dd 7 oktober i6ig.

68. Blussé, L., 'Strange company: Chinese settlers, Mestizo women, and the Dutch in VOC Batavia'. In Verhandelingen van het Koninklijk Instituut voor Taal-, Land- en Volkenkunde I22. (Dordrecht I986).

69. Coolhaas, Generale Missiven II, 252.

70. Niemeijer, H.E., Batavia. Een koloniale samenleving in de 17de eeuw. (Amsterdam 2005) 400.

Mannen Vrouwen Kinderen Particuliere Totaal

$\begin{array}{llllll}\begin{array}{l}\text { Compagnies } \\ \text { dienaren }\end{array} & 1.560 & 106 & 64 & 182 & 1.912 \\ \text { Vrijburgers } & 229 & 260 & 149 & 735 & 1.373 \\ \text { Japanners } & 48 & 24 & 11 & 25 & 108 \\ \text { Mardijkers } & 249 & 140 & 106 & 154 & >649 \\ \text { Chinezen } & 1.702 & 554 & 134 & 34 & 2.424 \\ \begin{array}{l}\text { Compagniesslaven } \\ \text { Kettingslaven }\end{array} & 631 & 460 & 163 & & 1.254 \\ \text { Totaal } & 4.419 & 1.544 & 627 & 1.130 & 8.060\end{array}$

7I. De Haan, Oud Batavia I, 426.

72. NA I.I0.78 Collectie Sweers 3 f I-22.

73. Niemeijer, H.E., Batavia. Een koloniale samenleving in de 17de eeuw. 28.

74. NA VOC II52, fi30-I39, brief 20 jan I645 Van Diemen aan Heren I7. (in bijlage). 


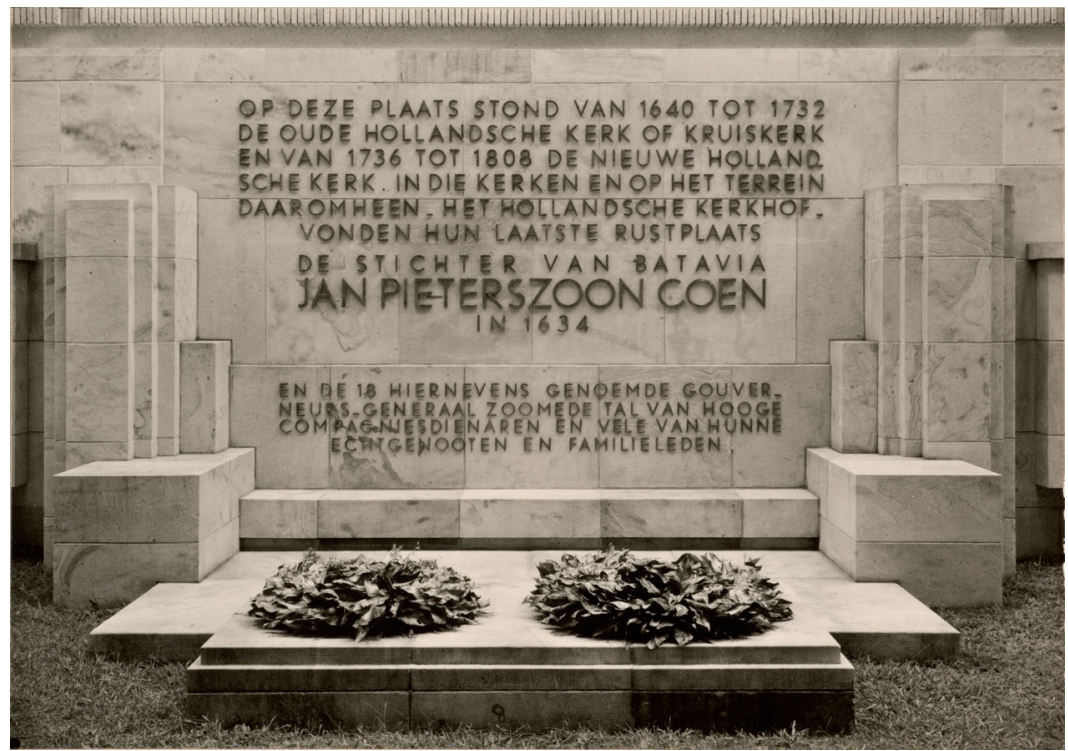

Gedenkteken Kruiskerk. In Jakarta zal men vergeefs zoeken naar de graven van Coen en Van Diemen. De omgang met het overzeese culturele erfgoed is Nederland zelden goed afgegaan. Er is bitter weinig over en wat rest kan bij hoge uitzondering rekenen op steun vanuit Nederland. Koninklijk Instituut voor de Tropen, Amsterdam. 


\section{Overlijden, opvolging en erfenis}

In december I644 werd Van Diemen ziek, maar in de maanden daarna besefte hij nog niet dat zijn einde naderde. Op 20 januari 1645 schreef hij omstandig aan de Heren Zeventien, dat hij 'geheel voornemens ende seecker geresolveert' was om in december I645 naar Nederland terug te varen. In deze brief gaf hij een waardering van wat hij had bereikt. Zijn opvolger zou het werk 'faciler en met minder becommeringe' kunnen doen nu de oorlog met de Portugezen op zijn einde liep. Voortaan zouden ervaren kooplieden in plaats van krijgslieden nodig zijn. Hier was een tevreden man aan het woord. 'Den Indische stant is god loff sulcx, dat die een cleenen misslach weijnigh can deeren ende alles can op nader bevindinge geredresseert werden.' Het was hem gelukt. Volgens Van Diemen kon de directeur-generaal Van der Lijn hem het beste opvolgen terwijl hij ook Salomon Sweers aanprees als een 'jongh cloeck man vigilant genoegh int executeren van dat hem gelast wert'. De mening van de Heren Zeventien dat hij ongeschikt was om extraordinaris raad van Indië te zijn, legde hij naast zich neer. Net als hun wens om meer raden van Indië in Batavia te benoemen. Er was in Indië eigenlijk geen plaats voor meer mannen aan de top. De wisselbrieven waren 'levende getuigen' hoe toch al velen naar Indië kwamen alleen om zich zo snel mogelijk te verrijken. Hij haalde hierbij een treffend voorbeeld aan waarbij compagniedienaren niet teruggeschrokken waren om de Compagnie in haar eigen magazijn in Batavia op grove wijze te benadelen. Van Diemen stelde nog een laatste keer het systeem van de Compagnie ter discussie. Nu de oorlog met de Portugezen was afgelopen moest volgens hem de intra-Aziatische handel worden opengesteld. Hij bleef zich zorgen maken over de continuïteit van de VOC: 'Buijten een welgestelde gepoliceerde Colonie can de Comp. dit groote werck niet gaende houden.' De handel van de Compagnie zou zich zo kunnen concentreren rond Batavia en Malakka, waardoor de kosten konden worden teruggedrongen en de winsten zouden stijgen. Dit pleidooi heeft overigens geen effect gesorteerd.

Aan het einde van de brief zullen de lezers in Nederland wel getwijfeld hebben aan zijn voornemen om terug te keren. Van Diemen schreef namelijk dat hij als 'memorie' op I januari van dat jaar de eerste steen had gelegd voor een kapel in het kasteel naast zijn woning. Hij 
had zijn zwager Pieter de Gruyter gevraagd hiervoor vloerstenen en een koperen kroon met de schepen van de Compagnie over te zenden.

$\mathrm{Na}$ de heftige ruzie tussen Van der Lijn en Sweers op 25 januari veranderde Van Diemen van mening over zijn opvolging. In een aanvulling op zijn brief schreef hij dat hij Van der Lijn vanwege het voorgevallene toch minder schikt achtte voor de hoogste functie. Er was dus geen geschikte kandidaat gouverneur-generaal in Indië en hij vroeg de Heren Zeventien 'een graeff ende conscientieus' man als zijn vervanger uit Nederland te zenden. ${ }^{\mathrm{I}}$ (Hele brief van 20 januari/ 6 februari in bijlage 6. )

In de maanden die volgden, ondervond Van Diemen steeds meer hinder van zijn ziekte. De zaken gingen nog wel hun gewone gang. Er werd misschien wat minder vergaderd, maar hij zat alle vergaderingen gewoontegetrouw voor. Totdat op dinsdag II april I645 Johan Maetsuycker terugkeerde uit Goa met de mededeling dat het bestand eindelijk was getekend 'hebbende de limitscheijdinghe op Ceylon tot wedersijdts contentement gedaen,' want dat was na de herovering van Negombo door de Nederlanders het enige nog uitstaande punt. $^{2}$

Het lijkt of Antonio op dat bericht had gewacht.

Woensdag I2 april, de dag erop, vond een dramatische vergadering plaats in de slaapkamer van de zieke Van Diemen, die voelde dat zijn einde nabij was. Wie moest hem opvolgen en onder welke voorwaarden, was natuurlijk de vraag. De verhoudingen in de Raad waren immers slecht. Het verslag is bewaard gebleven in de resoluties:

'Ed heer Gouverneur Generael Anthonio van Diemen eenige maenden herwaerts van Godt almachtigh met natuijrlijcke ziekte besocht ende daer door van tijt tot tijt sodanighe swackt en gedebiliteert sijnde, dat Godt betert genootsaekt sij geweest sedeert eenige dagen continuilick het bedde te houden. Heden den raet voor het selve in sijn slaepcamer bij een geroepen.'

Van Diemen sprak de aanwezigen eerst toe en zei dat hij niet meer bij machte was zijn functie waar te nemen. Hij vroeg hun voor het algemeen belang bij zijn naderende overlijden in overdrachtelijke zin 'malcander bij de handt te nemen' en te beraadslagen over de regering na zijn overlijden. Dat ging niet eenvoudig en na lange 'discoursen' zo wel aan het bed van Van Diemen 'als in een aparte camer tusschen de raden van India gehouden' werd besloten dat Cornelis van der Lijn als oudste raad en directeur-generaal het ambt 'onder titul van president in Rade van India om nevens de andere presente raden compagnies staet, omslagh ende negotie ten besten te besturen totdat de heeren meesters daer naeder ordre op sullen gelieven te geven.' 
Waar het om ging, was dat de extraordinaris raden Sweers en Van Alphen 'alle saecken mede geroepen ende continueel en consenderende stemme sullen hebben, insgelijcxs tot nader orde van de heren 17.'

Verder werd Pieter Mestdagh bevorderd tot extraordinaris raad voor drie jaar tegen 200 gulden per maand. Aldus 'gearresteert in het Casteel Batavia in de slaepcamer van gemelte ondertekend door Anthonio Van Diemen, Cornelis van der Lijn, Johan Maetsuycker, Salomon Sweers, Simon van Alphen en Pieter Mestdagh.'3

Het was een compromis dat geen stand zou houden. Er bestonden twee kampen in de regering van Batavia die elkaar voortdurend dwars zouden zitten.

Twee dagen na deze resolutie kwam de raad weer bijeen, ditmaal vanwege een verzoek van Van Diemen voor Maria: 'Namentlijck dat sij in het volle bezit van haer huijs mitsgaders alle andere prerogatieven, totdat sij naer Europa sal gelieven te vertrecken. ${ }^{4}$

Dit werd met algemene stemmen goed gevonden.

Op de $18^{\text {de }}$ werd nog een resolutie mede uit zijn naam getekend, maar op woensdag I9 april schreef de trouwe secretaris Pieter Mestdagh:

'Heden omtrent den avondt tot onse aller groote Droefheijt ende harte leet deser werelt aen natuijrlijcke sieckte in den heere onslapen wesende de heer Gouverneur generael Anthonio van Diemen waer bij de compagnie een oude ervaren loffelijcke dienaer en wij niet min een voortreffelijcke heer ende vader comen te missen. ${ }^{5}$

Met instemming van Maria werd besloten zijn lichaam zaterdag de $22^{\text {ste }}$ 's middags waardig in de Bataviase kerk ter aarde te bestellen. Het werd een grootse en plechtige begrafenis. De kosten van meer dan vijfduizend gulden werden door de VOC gedragen, waartegen in een volgende brief van de Heren Zeventien bezwaar werd gemaakt gezien het hoge bedrag. ${ }^{6}$ Als zoveel uit de tijd van de VOC is ook het graf van Van Diemen ten prooi gevallen aan de patriottische vernieuwingsdrift van Daendels aan het begin van de negentiende eeuw.

Uit de resoluties van de Raad van Indië in de dagen en weken na de begrafenis kunnen wij volgen hoe het werk snel zijn gewone gang hernam. De onderlinge verhouding tussen Van der Lijn en de andere raden van Indië bleef daarentegen buitengewoon slecht. Dat blijkt uit de brieven die meegingen met het fluitschip 'Postpaert' dat in juli speciaal naar Nederland werd gezonden om de dood en opvolging van Van Diemen te melden.

Naast de generale missive die de raden gezamenlijk hadden ondertekend, ging in het geheim een tweetal brieven mee. Eén van Van der Lijn en één gezamenlijke van zijn vijanden Maetsuycker en Van Al- 
phen. In de generale missive werd Van Diemen nog veel lof toegezwaaid als 'grooten voorganger' en gesteld dat Van der Lijn en de raden van Indië nu 'met naerstigheyt, vigilantie, trouwe ende goede enigheijt' de regering vormden en de zaken zonder mankeren een goede loop hadden. ${ }^{7}$ Uit de andere brieven blijkt échter een heel andere situatie. Van der Lijn schreef in de brief van I2 juli dat hij vond dat hij door van Diemen tot gouverneur-generaal benoemd had moeten worden. Hij had, zo schreef hij, zijn benoeming tot president niet aanvaard omdat de anderen hadden besloten dat Maetsuycker dan directeur-generaal zou worden. Aangezien die 'int stuck van de coophandel nochte boeckhouden' ervaring had, zou Van der Lijn dat werk erbij moeten doen 'ofte ander met syn edele dickwijls overhoop leggen. ${ }^{8}$

Maetsuycker en Van Alphen sloegen in hun brief van eveneens I2 juli een geheel andere toon aan. Zij openden de aanval op Van der Lijn. Van Diemen had immers over hem 'menichmael ronduyt verclaert daer geen capaciteyt toe te hebben' om gouverneur-generaal te worden. Dat Van der Lijn toch lang door Van Diemen als zijn opvolger aan de Heren Zeventien was voorgesteld, had volgens hen een andere achtergrond. Van Diemen was nooit werkelijk van plan geweest naar Nederland terug te keren en met Van der Lijn achter de hand zou niet zo snel iemand als plaatsvervanger van hem uit Nederland naar Batavia zijn gestuurd. Door zijn ziekte moest hij wel een keuze maken. Hij had hiertoe nog apart met Maetsuycker en Van Alphen op zijn slaapkamer gezeten om hun vooral op het hart te drukken Van der Lijn niet te veel macht te geven. Natuurlijk schreven zij dit alles met de beste bedoelingen en met het belang van de Compagnie voor ogen. ${ }^{9}$

Toen zij erachter kwamen dat Van der Lijn een eigen brief gestuurd had, volgde in december 1645 nog een brief waarin buitengewoon fel tegen Van der Lijn werd geageerd. Van der Lijn 'had zich niet geschaemt onwaerhyt te schrijven.' Waar het ze natuurlijk werkelijk omging, stond aan het einde.

Als Van der Lijn inderdaad gouverneur-generaal zou worden 'sullen de raden van India niet meer bij hem geacht wesen als jongens, die het werk mede tot haer verantwoordinge hebben lopende. ${ }^{\text {Io }}$

Verder schreven zij over de vermeende vermaningen die Van der Lijn tegen Van Diemen gemaakt zou hebben over 'sijn leven ende fauten' dat hij 'noyt de couragie heeft gehad sulcx te denken, laten staen te doen.' ${ }^{\text {II }}$

Overigens werd Van der Lijn door de Heren Zeventien toch benoemd tot gouverneur-generaal. Hij had niet de grote plannen van Van Diemen. Zoals hij schreef aan de bewindhebbers zou hij in de eerste plaats koopman zijn en 'met het excuseren van nieuwe ontdeckingen ende andere noodeloose uijtsettingen in toecomende met vrij cleender equipage grooter ommeslagh in India verhoopte waer te nemen' door lagere kosten en winstgevender handel in vrede ervoor zorgen dat de zware lasten zouden dalen 
en uit de Indische winsten de retouren zouden worden betaald. Ook zou hij de particuliere handel krachtig bestrijden. ${ }^{\text {I2 }}$

De gehoopte omzetgroei kwam er niet, evenmin als een daling van de kosten. Behalve dat eindelijk de vrede met Mataram werd getekend, was weinig aan de situatie van de VOC veranderd toen Van der Lijn in I650 werd vervangen door een van zijn vijanden, Carel Reiniersz.

In deze jaren waren de grote en kleine onaangenaamheden waarmee men elkaar aan de top van de VOC het leven zuur kon maken, gewoon doorgegaan. Nadat Reiniersz na twee jaar gek werd, werd hij door de Raad van Indië uit zijn ambt ontzet. Toen hij daags daarna overleed, begon in ${ }^{6} 653$ de eindeloze periode van het gouverneur-generaalschap van Johan Maetsuycker. Deze zou tot I678 lopen, een kwart eeuw lang.

De macht van de Compagnie zou zich verder uitbreiden, vooral in de Indonesische-Archipel, Ceylon en de westkust van India, terwijl Taiwan verloren ging. De organisatie groeide, de retouren namen toe en parallel daaraan de kosten. De dividenden voor de participanten stabiliseerden zich op een lager niveau. De persoonlijke verrijking, zoals die begonnen was onder Van Diemen, zette zich voort. Toen gouverneur-generaal Speelman in januari I684 overleed, had hij op grove wijze een vermogen vergaard van meer dan I miljoen gulden. ${ }^{\mathrm{I}}$

De slechte onderlinge verhoudingen in Batavia hadden maar beperkt invloed op de bedrijfsvoering van de VOC. Die leed er niet onder en diende in zekere zin een doel, als de particuliere handel als een gegeven wordt aanvaard. Het is in bedrijven tegenwoordig over het algemeen niet anders.

Cynisch bekeken is te zeggen dat de rivaliteit ervoor zorgde dat iedereen scherp bleef. Hetzelfde gold in Nederland. Juist door het bestaan van verschillende kampen konden de Heren Zeventien iets van het gezag herwinnen dat zij bij Van Diemen bijna geheel verloren hadden. Dat de winst mager was, was van ondergeschikt belang geworden. Geschraagd door de ijzersterke structuur van een naamloze vennootschap en een monopoliepositie was dit handelsimperium door het verslaan van de enige serieuze concurrent bijkans onverwoestbaar geworden.

\section{Erfenis en erfgenamen}

Van Diemen had in zijn brieven regelmatig de Heren Zeventien opgedragen zijn verdiende tractement in Nederland uit te keren aan zijn zwager Pieter de Gruyter, die optrad als zijn zaakwaarnemer. Het waren forse bedragen. Zo verzocht hij nog in zijn brief van 20 januari 1645 om 40 duizend gulden op naam van zijn zwager te zetten vanwege zijn in 1644 verlopen driejarige verband. Hij vroeg hierbij om 4 duizend 
gulden apart te houden voor de inkoop van een koperen kroonluchter en stenen en tegels voor de bouw van de kasteelkerk.

Drie maanden later, op I6 april, liet hij zijn testament optekenen, vlak voor zijn overlijden. Het was een grote nalatenschap. Bij elkaar ging het om meer dan I20 duizend gulden, waarvan het leeuwendeel, Ioo duizend gulden werd toebedeeld aan zijn zusters en hun vijf kinderen. Daarnaast werden de armen en enkele anderen bedacht met kleinere bedragen. Wij krijgen een onverwachte blik in het huishouden als ook de negen huisslaven in dienst van het echtpaar niet vergeten worden. Maria werd voor het overige zijn 'enige en universele erfgenaam'. In het testament werd al geschreven dat Maria na het overlijden van Van Diemen van plan was met de eerste vloot naar Nederland terug te varen. Als zij daar zou zijn aangekomen, was zij gelast de legaten zo snel mogelijk uit te keren.

De terugkeer van Maria had nogal wat voeten in de aarde gehad. Zoals plechtig door de raden van Indië was beloofd, mocht zij tot haar vertrek in volle staatsie in de gouverneurswoning blijven. Het had veel commotie gegeven toen zij praktisch de hele inboedel liet inschepen en daarmee in Nederland aankwam, vergezeld door zeven slaven en slavinnen. Met haar reisden ook mee Bartolomeus de Gruyter en Salomon Sweers. De vrouw van haar overleden broer zou met haar tweede man, de raad van Indië Simon van Alphen, een jaar later volgen. De vloot onder commando van Isaac Lemaire maakte een redelijk voorspoedige terugreis. Maria bleef haar status voeren. Toen de vloot was aangekomen in de baai van St. Helena nodigde zij alle commandeurs en officieren uit voor een lunch bij haar aan boord om daarna gezamenlijk een excursie op het eiland te maken. ${ }^{\mathrm{I}}$

Ruim een halve eeuw later vond Van Dam het nog de moeite waard de afrekening tussen haar en de Compagnie op te schrijven. Bij de resolutie van oktober $\mathrm{r} 647$ werd bepaald dat zij nog 3і duizend gulden kreeg uitgekeerd aan achterstallige vergoedingen voor Van Diemen en tevens 'alle hare overgebrachte goederen en meubilen, in een excessieve quantiteit bestaande' mocht houden net als de koninklijke geschenken die Van Diemen op zijn doodsbed aan de Compagnie had willen laten. ${ }^{\text {I5 }}$

Ook de boedel van haar overleden broer werd dat jaar in Batavia afgewikkeld. Voor diens drie zonen, die inmiddels in Nederland studeerden, ondertekende gouverneur-generaal Van der Lijn in I647 een wissel voor het enorme bedrag van 50.939 gulden. ${ }^{\text {I6 }}$

In Nederland leek afwikkeling van de boedel van Van Diemen in eerste instantie vlot te gaan. Zo kreeg Diederick van Ravenswaaij, de zoon van de overleden jongste zuster van Van Diemen al op 7 januari I647 zijn 36 duizend gulden overgedragen, ter finale kwijting $^{\text {I7 }}$ en zo ook de anderen. Maar omdat Maria het meerdere dat zij van de Compagnie kreeg niet met de andere erfgenamen wilde delen en aan Pieter 
de Gruyter geen vergoeding wilde geven voor de jaren dat hij zaakwaarnemer was geweest, kwam het in 1648 tussen de twee partijen tot een rechtszaak voor het Hof van Utrecht waarvan de uitspraak niet meer te achterhalen is. ${ }^{\mathrm{I} 8}$

Maria hertrouwde op 9 oktober I646 in Amsterdam met de oud-directeur van het VOC-kantoor in Perzië, Carel Constant, die op dezelfde vloot was teruggekomen. ${ }^{\text {I9 }}$ Er volgde een kort verblijf in Culemborg waar het echtpaar aan de Barbarakerk, misschien wel ter nagedachtenis aan Van Diemen, een grote koperen kroonluchter schonk, die nog steeds in het middenschip van die kerk is te bewonderen. In I647 woonden zij in Utrecht waar hun dochtertje Anna Maria geboren werd, dat helaas na een paar dagen overleed. ${ }^{20}$ Het echtpaar kocht in I647 huizen in Utrecht en op 8 oktober van dat jaar verkocht Maria haar slavinnen. ${ }^{2 \mathrm{I}}$ Over het huwelijk is verder weinig bekend. Carel Constant overleed in maart i660. ${ }^{22}$

Op Io oktober i66I trouwde Maria voor de vijfde keer. Ditmaal met mr. Gijsbert van der Hoolck, oud-burgemeester van Utrecht en voor die provincie gecommitteerde in de vergadering van de Staten-Generaal. Een regent met aanzien die met Descartes correspondeerde.

Maria overleed in Den Haag in juni ${ }^{6} 674$ en werd op 22 juni in Utrecht bijgezet in het graf van de familie Van Hoolck in de Claeskerk in Utrecht. ${ }^{23}$ Haar testament is geheim gebleven, maar duidelijk is dat zij aan haar twee nog levende neven een enorm vermogen naliet. Dat wekte de jalousie en hebzucht van haar verdere familie op. In verschillende kongsies heeft deze meer dan zestig jaar lang een deel van de erfenis opgeëist en op werkelijk alle mogelijke manieren getracht inzage te krijgen in het testament van Maria. In de oude actes leest het als een tafereel uit Dickens. De twee fraaiste voorbeelden zijn de op I4 september I734 opgetekende rumoerige huisbezoeken op i9 juli I734 en de getuigenis van de 97-jarige Martinus Couros die verklaarde dat Maria nog een broer had gehad wiens erfgenamen ten onrechte geen deel van haar erfenis hadden gekregen. ${ }^{24}$

Toen in I737 vlak na elkaar de ongetrouwde dochters van de beide neven overleden, lieten zij gezamenlijk bijna een miljoen gulden achter dat geheel is terug te voeren op het vermogen waarmee Maria uit Batavia terugkeerde. ${ }^{25}$ Van deze enorme erfenis en inboedel is alleen een prachtige Japanse lakkist met zekerheid teruggevonden. Het is de zogenaamde 'Van Diemen Box' die nu in bezit is van het Victoria and Albert Museum in Londen. Via Madame de Pompadour en een Engelse lord die, 'heel toepasselijk' failliet ging, is deze daar terechtgekomen. Twijfel is er in dit geval niet, aan de binnenkant van de deksel is met een schrijfletter de naam Maria van Diemen ingelegd. 

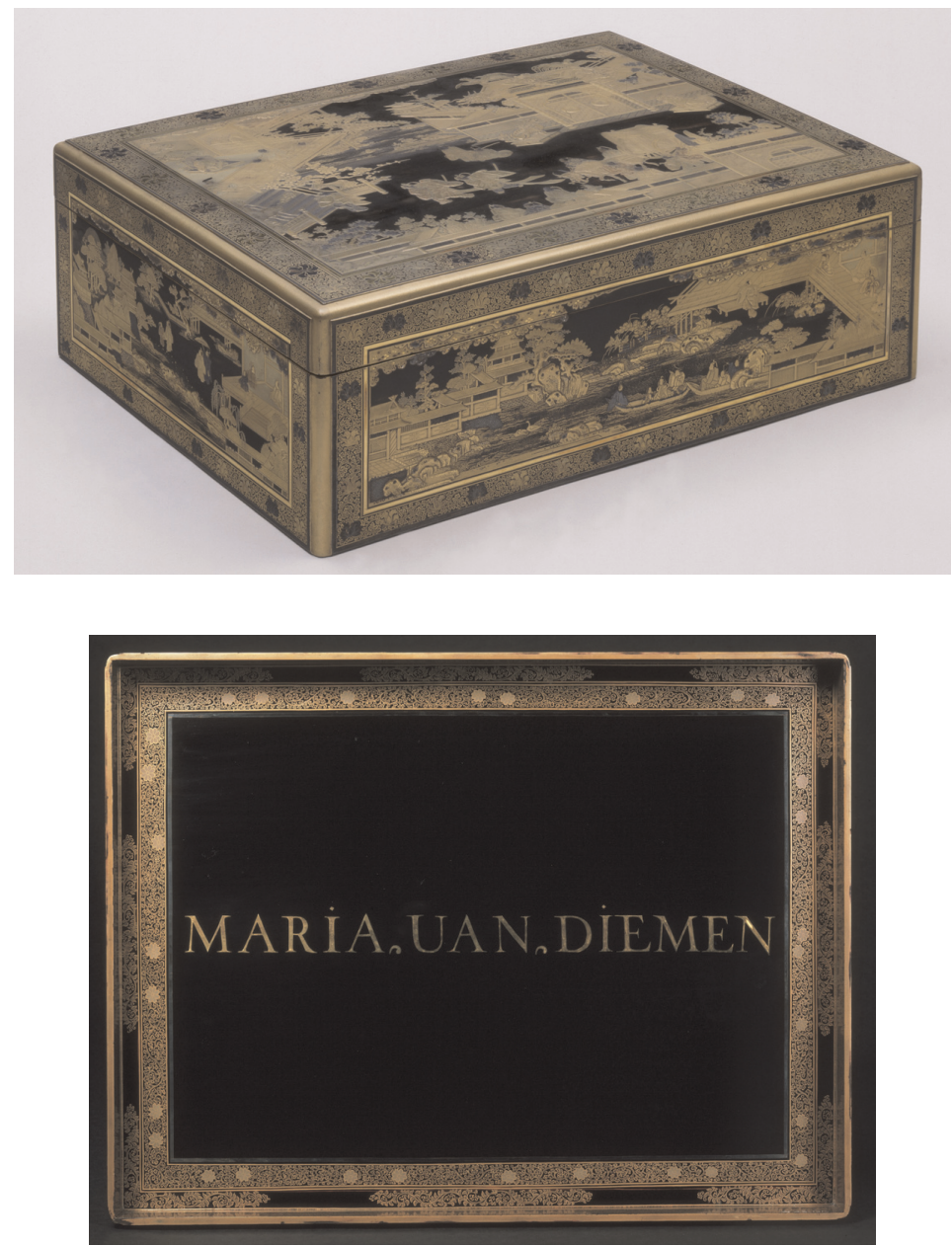

De prachtige Japanse lakdoos van Maria van Diemen kwam in de achttiende eeuw in bezit van Madame de Pompadour, de roemruchte maîtresse van Lodewijk XV. Via een Engelse graaf, die toepasselijk failliet ging, is het nu een pronkstuk van het Victoria and Albert Museum. Over wie de eerste eigenaresse was, bestaat bij uitzondering geen enkele twijfel. Victoria and Albert Museum, Londen.

Het gerucht ging in Batavia dat Bartolomeus de Gruyter bij zijn vertrek een enorme diamant had mee gesmokkeld. ${ }^{26}$ Terug in Nederland kon hij in ieder geval in grote stijl rentenieren. Hij ging wonen in Utrecht waar hij eerst schepen en later burgemeester werd. Hij kocht twee buitens, zodat hij zich 'Heer van Groenewoude' kon noemen en trouwde opvallend genoeg Maria Specx, de jongste dochter van de oude gouver- 
neur-generaal. Niemand minder dan Salomon Sweers was getuige bij juist dit huwelijk. ${ }^{27}$ Bien étonnés de se trouver ensemble?

\section{Noten}

I. Gedeeltelijk afgedrukt bij De Jonge, Opkomst III, 226, Hele brief NA VOC OBP II47, I03-I09.

2. NA VOC 667/668 generale resoluties, op datum (microfilm 3565).

3. NA VOC 667/668 generale resoluties, op datum (microfilm 3565).

4. Ibidem.

5. Ibidem.

6. Coolhaas, Gegevens over Antonio van Diemen, 546: 5275 gulden 9 stuivers en 4 penningen.

7. De Jonge, Opkomst V, tweede deel, 268.

8. Ibidem 27 .

9. Ibidem 272-274.

Io. Ibidem 277 .

II. Ibidem 276 .

I2. De Jonge, Opkomst III, LXXXII.

I3. Stapel, Geschiedenis van Nederlandsch Indie, III, 426.

I4. L'honoré Naber, S. P., Reisebeschreibungen von Deutschen Beambten und Kriegsleuten im Dienst der Niederländischen West- und Ost-Indischen Kompagnien, XIII vols. ('s-Gravenhage, I930-I932).. Deel IX 'Johan Sigmund Wurffbain, Reise nach den Mulukken und VorderIndien I632-I646, II, I39,I4I.

I5. Dam, van, Beschrijuinge, III, I4.

I6. GA Leiden, Weeskamer, 7e Penningboek, f ı8o.

I7. HUA, Not archief Utrecht, Inv nr. U O2I a oI4, f.3 nots. Gerrit Vastert.

I8. UA, Hof van Utrecht, inv nr. 239-I cap. LXXX, f.309-33I.

I9. GA Amsterdam, Ondertrouwen 464, p. 24, 6 sept. I646.

Carell Constant, van Middelburgh, out 33 jaer, geen ouders hebbende woon. op de Heeregracht, en Maria Aelst, van Steenbergen, wed. van heer Anthonis van Diemen, generael in Indien, won. als vooren geass. met Aeltien Aerts van Zijle, haer moeder.

Hij tekent Carel Constant en zij Maria Aelst.

20. Doop-, trouw en begraafgegevens en lidmatenregisters stad Utrecht.

HUA, Nederlands Hervormde gemeente Utrecht, inv.nr. 408, f. I33v, I juli I647.

Sr. Carel Constant, ende joffr Marija Constant, s.h. [zijn huisvrouw], naest de here van (Siabenesse?) met attestatie van Amsterdam van den 25 april 1647. 
Doopboek Utrecht

Anna Maria Constant, gedoopt Utrecht 29 aug. I647 (Geerte of Catharijnekerk), vader Carel Constant, moeder Maria.

Begraven Utrecht

kind van de Heer Caerl Constant, begraven aangifte 30 aug. I647 ( $f$ i2,-, Dom groot, twee knechten).

(in de index op het overluiden van de Dom geeft 27 aug. I647 ('dochtertje van Caerl Constant'), dit lijkt gezien de doopdatum niet correct).

2I. CBG, Collectie Bloys van Treslong Prins - Maria Aelst, weduwe van Anthonio van Diemen, tr. I647 Carel Constant, verkoopt slavinnen 8 okt. I647 (Reg. Schep. I57 I, blz. 5).

22. Begraven Utrecht.

De Heere Carel Constant, won. aen 't Preekheere kerckhof.

Begr. Dom aangifte 5 maart 1660.

Laat na: 'sijn huijsvrouw en de collaterale successie en onmund. erfgenamen', vast goed.

I6 dragers, te laat in de kerk 'een swarte baer en een wapen opgehangen'.

23. Huwelijk Utrecht.

Ghijsbert van der Hoolck, oud borgemeester der stadt Utrecht en wegens de selve provincie gedeputeert ter vergaderingen van de Ho. Mo. Heeren Staten Generaal, weduwnaar, huwde Utrecht ro okt. I66I (Jacobi) Maria van Aelst, weduwe van wijlen de Hr. Carel Constant.

NB Proclamaties in 's-Gravenhage, waarvan de akte is overlegd.

Begraven aangifte Utrecht 22 juni I674 (Claeskerk).

De vrouw van der Hoolack (!), 'uit den Haegh hier gebracht, heeft daer een publieke uitvaert gehadt, en hier met consent gezonken gratis'.

24. C. HUA, Notarieel Archief Utrecht, inv.nr. U I50 a Io, akte I2, I9 juli I734.

Jan Mulder, oud omtrent 39 jaar, en Bernardus Brinckman, oud omtrent 34 jaar, verklaart ten verzoeke van Henrij Louis Labbertsom, als gevolmachtigde van Wouter van Jaarsvelt, cum suis, dat het waar was dat zij lieden comparanten met en benevens Claas van 't Hoff ter Jongh in het bijzijn van de requirant [= Labbertsom] op 7 mei laatstleden van dit jaar om tien uur in Amsterdam zijn geweest ten huize van Maria van Aelst op de Herengracht tussen de Utrechtse straat en de Amstel en daar hebben gesproken een zekere heer N. de Bruijn, die zich op dat moment ten huize van juffr. van Aelst bevond en aan hem namens de erfgenamen van wijlen vrouwe Maria van Aelst, laatst huisvrouw van de heer en mr Gijsbert van der Holick, en hebben hem in der minne verzocht om 
een kopie authentiek van de testamentaire dispositie van de gemelde vrouwe van haar zelf van Aelst genaamd. Daarop antwoordde de Bruijn dat een kopie authentiek aan één van de erfgenamen was gegeven, waarop Mulder vroeg aan wie. De Bruijn antwoordde dat zij aan de eis hadden voldaan, hetgeen door Mulder werd ontkend en zij lieden bleven bij hun eis en vroegen aan mevrouw van Aelst om de vraag zelf te beantwoorden, waarop een juffrouw, zijnde de zuster van de voornoemde De Bruijn, naar binnen is gegaan en weer naar buiten is gekomen en deelde hen mede namens mevrouw van Aelst dat zij konden doen wat zij wilden, waarop de comparanten zijn weggegaan.

Hierop zij verklaarden om een uur of vijf of zes uur zijn gekomen tot Haarlem ten huize van Ed. Aghtb. Heer Johan de Bruijn, schepen van dezelfde stad, en dat Brinckman aan hem heeft gevraagd of hij een kopie van het testament van mevrouw van der Holick, van haarzelf van Aelst genaamd bezat, dat zijn Ed. antwoordde van ja, maar dat hij hen geen kopie of inzage hiervan wilde geven en voorts met veel heftigheid vervolgde dat dit 'caraljé' (daarmee de voorschreven erfgenamen bedoelende) dat zij hem sinds enige tijd aan huis lastig vallen en hij dit in de toekomst zou gaan beletten. Hij maakte hen duidelijk dat hij en niemand anders erfgenaam van de meergemelde mevrouw van der Holick was en dat zij, Mulder en Brinckman, maar opgeraapte erfgenamen waren, waarop Brinckman hem antwoordde dat hij uit de bewijzen die zij bij zich hadden wel in staat waren aan te tonen dat zij lieden de rechte erfgenamen 'uijt den bloede' waren van Maria van Aelst, genaamd van der Holick en omdat Zijn Ed. onwillig was de verzochte inzage en een kopie te geven van het testament. Mulder en Brinckman laten hem weten dat zij naar middelen zouden zoeken om de inhoud van het bewuste testament alsnog in handen te krijgen, waarna zij het huis in Haarlem hebben verlaten.

Beide comparanten zetten hun handtekening.

D. HUA, Notarieel Archief Utrecht, inv.nr. U I78 a 4, akte 85, I4 september I734.

Martinus Courus, burger en zakkendrager binnen deze stad [= Utrecht], oud 97 jaar, verklaart ten verzoeke van Andries van der Vlarck [=Vlerck] dat hij Frans Aartse Steenlandt, jongeman, geboren in Linschoten zeer wel gekend heeft en dat dezelve Frans Aartse Steenlandt in I7I2 de enige zoon was van Aardt Cornelisse Steenlandt en Anna Franse echtelieden, in haar leven gewoond hebbende te Linschoten dat Frans Aartse Steenlandt een mede erfgenaam ab intestato van vrouwe Maria Ariens Steenlandt in haar leven huisvrouw van de heer burgemeester Gijsbert van der Holick, en verklaart voor waar te wezen dat Frans Aartse Steenlandt 
trouwbeloften heeft gedaan aan Hendrina van Santen, toen een jonge dochter woonachtig binnen deze stad, en aan haar had overgegeven al zijn rechten en pretensien als mede erfgenaam ab intestato van de nagelaten boedel en goederen van de gemelde vrouwe Holick.

25. Elias, De Vroedschap van Amsterdam, I, 292.

GAA Collaterale Successie (5046), inv.nr. 25, f. 205-212.

Nalatenschap van Jonkvr. Anna van Aelst, obiit 8 juni I738 Haar testament is ook in Amsterdam t vinden: GAA 5075 Notarieel archief no 8I39 f34I ev Het dateert van 3 april I738 en verwijst herhaaldelijk naar de juwelen en goederen die zij had georven van Maria.

26. Leupe, 'Salomon Sweers', Bijdragen tot de Taal-, Land- en Volkenkunde van Nederlandsch-Indië, derde volgreeks, achtste deel ('s-Gravenhage I873) 36-67.

27. HUA Attestatie van Utrecht op I3 mei I655. 


\section{Nabeschouwing}

Toen Stapel in I939 zijn verbazing erover uitsprak dat er nog geen biografie van Antonio van Diemen was verschenen, had hij wel een punt. Want het optreden van Van Diemen als gouverneur-generaal is bepalend geweest voor de VOC. Het sloot de fase af waarin de Compagnie haar primaat vestigde over de zeehandel in haar enorme octrooigebied. Een periode die een halve eeuw daarvoor, in 1595 was begonnen met de eerste Amsterdamse scheepvaarten naar Java en de specerijeilanden en die in 1602 aanleiding hadden gegeven voor de oprichting van de Verenigde Oostindische Compagnie.

In 2002 is deze mijlpaal uit de Vaderlandse geschiedenis onder auspiciën van de stichting 'Viering 400 jaar VOC' uitgebreid herdacht. Een jaar lang werd op velerlei wijze met een voor Nederland unieke aanpak deze gebeurtenis uit een ver verleden naar voren gehaald. Het tij zat mee bij de voorbereiding. In het huidige sombere economische klimaat zou het, denk ik, niet meer mogelijk zijn geweest zoveel geld voor een herdenking los te krijgen. Een bijzondere episode uit de geschiedenis van Nederland kon daardoor voor een breed publiek op een aantrekkelijke wijze toegankelijk worden gemaakt.

In het kielzog van de VOC werd de Nederlandse expansie in Azië gepresenteerd als een ongemeen boeiend en prachtig prentenboek. Maar de inhoud bleef vaak aan de oppervlakte steken. 'Herdenking ontloopt iedere controverse' schreef Remco Raben hierover in Hervormd Nederland in december 2002. Wat hij daarmee tevens aangaf, is dat geschiedschrijving nooit af is. Om zichzelf te definiëren heeft elke generatie immers de opdracht haar verleden opnieuw te verklaren. Met de voortgang van de tijd veranderde inzichten vinden zo hun weg in de interpretatie van de geschiedenis.

Johan Huizinga, de conservatieve liberaal, schreef hierover: 'Geschiedenis is de geestelijke vorm, waarin een cultuur zich rekenschap geeft van haar verleden. ${ }^{\text {I }}$ En dan is de aanvulling hierop van Jan Romein, zijn marxistische leerling, interessant: 'Geschiedsbeoefening is de geestelijke vorm, waarin een cultuur haar heden tracht te verstaan, door zich rekenschap te geven van het haar toegankelijk verleden.' ${ }^{2}$ 
De kern van Huizinga's omschrijving ligt besloten in de zinsnede 'zich rekenschap geven van' en de belangrijke aanvulling van Romein hierop betreft 'het heden trachten te verstaan.'

In de afgelopen honderdvijftig jaar is het ontbreken van controverse bij de interpretatie van de Compagnie onder historici overigens geen regel geweest. De uitkomst is bijzonder verschillend geweest, variërend van een harde veroordeling vanwege de gewelddadige kapitalistische grondslag tot een ongeclausuleerd eerbetoon aan een schoolvoorbeeld van ondernemingszin, dat naar de ruwe gewoonten van zijn eigen tijd moest worden gemeten.

Het is vaak een moreel oordeel geweest, waarbij desgewenst Coen als zondebok of held naar voren werd geschoven. De Compagnie heeft wat dat betreft vele gezichten. Mijn beeltenis van de eerste fase van de expansie heeft als dragende elementen de vennootschappelijke structuur gekoppeld aan de contraremonstrantse dadendrang van mannen als Pauw, Coen en Van Diemen. Zij hadden een Wille zur Macht waar Nietzsche van zou hebben gewatertand en die in onverzettelijkheid en onverdraagzaamheid was gevormd van en in de bangste dagen van de Opstand. De calvinisten waren ervan overtuigd dat Gods Zegen op hun arbeid rustte waardoor elke twijfel aan het eigen gelijk letterlijk uit den Boze was, terwijl tegenstanders op oudtestamentische wraakzucht konden rekenen.

Het oordeel over de VOC is vaak langs geloofslijnen blijven lopen en verklaart mede het zwart-wit karakter van de waardering. Het is waarlijk geen toeval dat in I937 Colijn het voortouw nam bij de herdenking van de $350^{\text {ste }}$ geboorte dag van Coen en in 2006 minister- president Balkende de term 'VOC-mentaliteit' introduceerde (Algemene Beschouwingen, september 2006) en zichzelf een overtuigd calvinist noemt. (Reformatorisch Dagblad, 2 juni 2009).

Het zaad was hiervoor bij de oprichting van de Compagnie geplant in de vorm van de alles overheersende doelstelling om de specerijhandel te beheersen in Azië en Europa. Deze kon niet anders dan met geweld worden gerealiseerd en de oprichters waren zich daarvan terdege bewust. Dit werd versterkt doordat deze ambitie werd ondergebracht in een naamloze vennootschap. Ook tegenwoordig verschaft een vennootschap door haar eigen rechtspersoonlijkheid en beperking van de aansprakelijkheid een bijzonder krachtig platform aan een directie. Een vennootschap verwordt ook heden ten dage makkelijker dan men denkt tot een podium voor handelingen die een privépersoon nimmer voor zijn rekening zou willen nemen en die over het algemeen worden uitgevoerd met de rechtvaardiging dat het belang van de onderneming niets anders toeliet. Een potente variant van de vaak misbruikte raison d'état.' Coen en Van Diemen waren hier beiden duidelijke exponenten van. Wat dat betreft verschilden zij, en met hen de VOC in de beginpe- 
riode duidelijk van de Engelse EIC. Die nam pas in I657 na de Puriteinse Revolutie een vergelijkbare gedaante aan.

\section{Het poldermodel en de oprichting van de VOC}

De eerste scheepvaarten op Azië en de oprichting van de VOC waren het initiatief van Amsterdamse kooplieden onder aanvoering van Reinier Pauw. In het laatste decennium van de zestiende eeuw ontwikkelden deze Amsterdamse 'aartsvaders' een unieke en bijzonder ambitieuze strategie die hen onderscheidde van hun Europese 'verklaarde vijanden en geveinsde vrienden', met name de Portugezen en de Engelsen. De Amsterdamse kooplieden lieten hun schepen rechtstreeks naar Java varen met als doel een monopolie te verkrijgen in de kostbare specerijen nootmuskaat, foelie en kruidnagelen.

Het snelle succes dat zij hiermee bereikten, riep onverwachte problemen op. Dat was niet zozeer de binnenlandse concurrentie, zoals die in de bestaande literatuur een belangrijke rol krijgt toegedicht, als wel het grote kapitaal dat binnen een paar jaar in de heen en weer varende vloten vast ging zitten en het ontstane besef dat het nagestreefde monopolie niet zonder strijd zou kunnen worden verkregen.

De oplossing die de Amsterdammers hiervoor vonden, was even uniek als hun eerdere strategie was geweest: de oprichting in 1602 van de Verenigde Oostindische Compagnie (VOC), de eerste vennootschap met permanent kapitaal, verhandelbare aandelen en beperkte aansprakelijkheid van de bezitter daarvan.

De grote inpoldering van de Zijpe in Noord-Holland, die vergelijkbare kenmerken bezat en waarmee de Amsterdamse kooplieden en de Haagse magistraten goed bekend waren, had voor deze organisatie model gestaan.

De kooplieden behielden zo greep op de handel, maar het financiële risico werd gespreid over velen. Deze koppeling van lange termijn vermogen aan lange termijn ambitie was anders dan Van der Heijden, Glamann of Frentrop stellen, geen min of meer toevallig of geleidelijk proces, maar een onmiddellijke institutionele innovatie.

Het is hierbij opmerkelijk dat tot op heden in de historiografie het door Van der Chijs in I857 voor het eerst geschetste beeld standhoudt dat Van Oldenbarnevelt met hulp van Maurits de concurrerende kooplieden tot samenwerking dwong en daarmee aan de wieg stond van de VOC. Alsof de Amsterdamse regenten het zich zouden laten gebeuren dat derden zich zo verregaand in hun zakelijke belangen mengden. Van Oldenbarnevelt diende in dit proces het belang van de machtige Amsterdamse kooplieden wier steun voor hem onontbeerlijk was voor zijn positie als politiek leider van de Republiek. 
In I6I2 vond een wezenlijke verandering plaats in de verhouding tussen de aandeelhouders in de VOC en de onderneming. Een van de voorwaarden in het octrooi dat door de Staten-Generaal aan de VOC bij haar oprichting was verleend, vereiste dat na tien jaar, dus in I6I2, tussentijds afgerekend zou worden met de aandeelhouders. Deze hadden dan de keuze te blijven investeren in de VOC, of hun inleg met eventuele winst terug te krijgen. Bij de oprichting van de VOC waren al twijfels over de mogelijkheid hiervan verwoord, en gezien de verhandelbaarheid van de aandelen is de keuze om niet tot een afrekening over te gaan ook zonder meer verklaarbaar. Omdat hiervoor geen andere verantwoordingsverplichting jegens de aandeelhouders in de plaats werd gesteld, verdween in één klap elke noodzaak voor de bewindhebbers om verslag of verantwoording af te leggen.

Aandeelhouders van de VOC hebben nimmer inzage gekregen in het bedrijf waarin zij belegden. Hun restte niets dan een vaag omschreven winstrecht. Dit had bijzonder verstrekkende gevolgen die in hun volle omvang tijdens het gouverneur-generaalschap van Van Diemen naar voren zouden komen.

\section{De crisisjaren tot 1619}

Onmiddellijk na haar oprichting zette de VOC over een breed front de aanval in op de Portugese en Spaanse vestingen in het octrooigebied. De VOC verschoot haar kruit in een krachteloos beleg voor Malakka en in even zinloze vlootacties van Mozambique tot Manilla, terwijl het specerijmonopolie niet dichterbij kwam. De overmoedige en incoherente strategie van de VOC leidde tot een ernstige crisis die de Compagnie dankzij haar vennootschappelijke structuur overleefde. Door haar permanent vermogen kon zij de verliezen opvangen en blijven operen.

Terug in Nederland stelde Cornelis Matelief, de admiraal van de tweede VOC-vloot, nadat hij in I608 voor Malakka een 'blauw oogh' had opgelopen, als eerste vast dat de bakens verzet moesten worden.

De VOC moest een vaste hoofdplaats op Java krijgen onder leiding van een gouverneur-generaal zoals de onderkoning van de Portugezen in Goa en de Spaanse gouverneur-generaal in Manilla. Anders zou de VOC in Azië geen voortgang kunnen boeken en zouden de nagestreefde monopolies eerder verder weg raken dan dichterbij komen. Daarnaast zou om de kosten van de retourladingen zo laag mogelijk te houden, de VOC actief moeten gaan deelnemen aan de intra-Aziatische zeehandel.

Dit beleid werd overgenomen door de Heren Zeventien en in 1609 werd de eerste gouverneur-generaal benoemd. 
Dankzij haar vennootschappelijke structuur en op de been gehouden door financiële en politieke steun van de Staten-Generaal overleefde de VOC de kritieke jaren die eindigden in I6r9.

Deze eerste fase eindigde met twee grote gebeurtenissen waaraan de naam van Jan Pieterszoon Coen voor altijd verbonden zal blijven.

In I6I9 stichtte hij Batavia waardoor de VOC zich kon verankeren in de Indonesische-Archipel. Coen was de gepassioneerde en controversiële eerste grote man van de VOC en voerde een beleid uit dat op volledige steun vanuit Nederland kon rekenen zolang zijn contraremonstrantse meesters het in Amsterdam tijdens de bestandstwisten voor het zeggen hadden. De rücksichtslose campagne op de Banda-Archipel waarmee Coen in I62I het monopolie veroverde in nootmuskaat en foelie, voerde hij uit op last van de Heren Zeventien. Zij hadden juist Coen benoemd tot gouverneur-generaal omdat zij op hem konden rekenen voor een loyale uitvoering van hun beleid. Dat Coen in de vele publicaties eigenmachtig optreden wordt toegedacht waarmee de Heren Zeventien niet geassocieerd wilden worden, is in dat verband een onjuiste voorstelling.

Het was ook Coen die als eerste onderkende dat het centraal geleide apparaat van de VOC op zichzelf te log en te kostbaar was om concurrerend te zijn in de intra-Aziatische handel. Hij was van mening dat naar het succesvolle voorbeeld van de Portugezen deze handel zoveel mogelijk aan vrije handelaren moest worden overgelaten. Om dit plan goedgekeurd te krijgen legde hij in I623 zijn functie neer en voer hij terug naar Nederland.

De vorstelijke staatsieportretten die hij tijdens zijn verblijf in Nederland van zijn vrouw en zichzelf liet vervaardigen, wijzen op nog een andere ambitie. Hij wilde niet meer naar Batavia terugkeren als koopman, maar als graaf op het door hem gebouwde kasteel.

Pas nadat Coen weer als gouverneur-generaal naar Batavia was vertrokken, kwamen de Heren Zeventien, na aanvankelijke ondersteuning hierop terug en verboden de vrije handel in het octrooigebied. Deze beslissing had tot gevolg dat het experiment van een Nederlandse kolonie op Java nooit verder is gekomen dan de aanzet die Coen daaraan had gegeven.

\section{De carrière van Van Diemen}

Waarom Antonio van Diemen op zestienjarige leeftijd zijn geboortestad Culemborg verliet om zich als koopman in Amsterdam te vestigen, zullen wij hoogstwaarschijnlijk nooit zeker weten. Was het om het geloof, 
of gaf hij toe aan een drang naar avontuur dat deze burgemeesterszoon in zijn geboortestad niet zou kunnen vinden?

Een beter begrip van de carrière van Antonio van Diemen binnen de Compagnie is in ieder geval wel mogelijk geworden nu wij weten dat hij voor zijn faillissement in I6I6 niet één maar zeven jaar koopman was geweest in Amsterdam. Ook weten wij dat hij onder een valse naam dienst nam bij de VOC en zo uit Nederland wegvluchtte. Zijn vorige leven als koopman is mede een verklaring achter zijn snelle carrièrestappen in Batavia, die hij zonder die ervaring waarschijnlijk niet zou hebben gezet. In Batavia verkeerde hij dicht in de buurt van Coen en zijn band met hem werd versterkt door de contraremonstrantse kringen waarin hij in Amsterdam had verkeerd. Uit zijn enkele overgebleven brieven blijkt dat zijn faillissement hem bijzonder gedreven had gemaakt. Hij had voor zichzelf en in de ogen van de wereld wat goed te maken.

Toen hij op Java na een paar maanden werd ontmaskerd, had dit geen enkele invloed op zijn carrière. Onder protectie van Coen klom hij snel op en werd hij in I62I verantwoordelijk voor de boekhouding van de VOC in Azië. In I624 was Van Diemen opgeklommen tot raad van Indië, de hoogste rang onder de gouverneur-generaal.

In juni I629, tussen de twee belegeringen van Batavia door de Javaanse vorst van Mataram, raakte Van Diemen in een ernstig conflict gewikkeld met Coen. In de beruchte zedenzaak van Sara Specx en Pieter Cortenhoeff koos hij partij tegen Coen toen die Pieter ter dood veroordeelde. Hierbij speelde mee dat Van Diemen executeur-testamentair was van de vader van Pieter. Hierdoor leek aan de carrière van Van Diemen abrupt een einde te komen, maar het liep onverwacht anders.

Coen overleed een paar maanden later plotseling en zijn opvolger werd niemand minder dan Jacques Specx, de vader van Sara. Hierdoor behield Van Diemen niet alleen zijn positie, maar versterkte hij deze zelfs.

De onduidelijkheid over de rol van de intra-Aziatische handel en de interne conflicten die na het overlijden van Coen losbraken, werkten ontwrichtend binnen de VOC in Batavia. Van Diemen werd verdacht gemaakt van handel voor eigen rekening, maar kon deze verdachtmaking opvallend makkelijk pareren. Nadat hij de laatste schulden uit zijn Amsterdamse faillissement had afgelost, trouwde hij in I630 met de jonge en rijke weduwe Maria van Aelst.

Op instigatie van Van Diemen die in I63 naar Nederland was teruggevaren, grepen de Heren Zeventien in. De zwakke Specx werd teruggeroepen en de nieuw benoemde gouverneur-generaal, de oudgediende Hendrick Brouwer, kreeg de ondankbare opdracht van de Heren Zeventien om schoon schip te maken onder het hogere compagniepersoneel 
in Azië en een definitief halt toe te roepen aan de vrije handel in het octrooigebied. Het gevolg was dat hij weliswaar de winstgevendheid van de Compagnie aanmerkelijk verbeterde, maar dat hij zowel in Batavia als in Amsterdam uit de gratie was. Het is ten onrechte dat Brouwer bijkans uit de geschiedenis van de VOC is geschreven. Hij legde immers de basis voor het samen met Van Diemen geformuleerde beleid, waarvoor alleen de laatstgenoemde later alle eer heeft gekregen.

\section{Gouverneur-generaal}

Van Diemen bleef niet lang in Nederland. Na iets meer dan een jaar ging hij als directeur-generaal opnieuw scheep naar Batavia. Vlak voor zijn vertrek werd hij beïnvloed door een gebeurtenis op het slagveld van de Tachtigjarige Oorlog: de spectaculaire verovering van Maastricht in augustus $\mathrm{I}_{32}$ door Frederik Hendrik. Onmiddellijk begonnen bestandsonderhandelingen met de Zuidelijke Nederlanden. Van Diemen besefte plotsklaps dat ook de oorlog in Azië, in wiens schaduw de handel van de VOC gegroeid was, eindig was. Hij reageerde geschokt en riep de Heren Zeventien op toch vooral zolang mogelijk in oorlog te blijven: 'Houdt mijne heren het zwaard in de hand, het zal u niet rouwen,' schreef hij met gevoel voor dramatiek. Van Diemen was ervan overtuigd dat de Compagnie zich in vreedzame concurrentie niet staande zou kunnen houden tegenover de vrije Portugese handelaren. Het zou een van de leidende thema's worden tijdens zijn gouverneur-generaalschap.

De Compagnie was in ${ }^{1} \sigma_{3} 6$ bij het aantreden van Van Diemen nog geen grote organisatie en terecht maakte hij zich zorgen over de robuustheid van de winst zowel op de intra-Aziatische handel als de verkopen in Nederland. Hij had bij de start op twee belangrijke terreinen het tij mee. Ten eerste was de vloot van de Compagnie in Azië oppermachtig geworden. Dit kwam niet zozeer door grote versterkingen uit Nederland, als wel door het wegvallen van de Portugezen als zeemacht. Ten tweede begon de handel op Japan vrucht te dragen. Na het voorbereidende werk van Coen, Specx en Brouwer kon Van Diemen oogsten. Het Japanse zilver zou een essentiële rol spelen voor de winst van de intra-Aziatische handel en daarmee ook voor de winst van VOC in Nederland. Dat de Compagnie nauwelijks invloed had op deze winst, is van ondergeschikt belang.

In de deelstudies die over de Compagnie ten tijde van Van Diemen zijn geschreven, komt niet direct naar voren dat de Compagnie in de verschillende gebieden steeds een andere rol speelde. Het is fascinerend hoe zij zich in Japan onderdanig gedroeg, terwijl op het nabij gelegen Taiwan de oorspronkelijke bewoners werden geknecht en geker- 
stend om een succesvolle Chinese kolonie onder Nederlands oppergezag te vestigen.

Weer anders ging het op de specerijeilanden. Twee jaar achter elkaar leidde Van Diemen een grote vlootexpeditie om de rebellie op Ambon en de omliggende eilanden de kop in te drukken. Hij slaagde er maar gedeeltelijk in om na het monopolie in nootmuskaat en foelie ook dat in kruidnagelen te verzekeren. Door het wegvallen van de Engelse concurrentie en de moeizame verbinding tussen Goa en Lissabon lukte dit wel in Europa, maar niet in Azië. Daar was nog een oorlog voor nodig.

De strijd van de Compagnie tegen de Portugezen voerde Van Diemen tot ongekende hoogte op zonder de Heren Zeventien te raadplegen. Vóór het aantreden van Van Diemen was de Compagnie een werkelijke confrontatie met de Portugezen uit de weg gegaan. Terwijl Japan en Taiwan zich vanuit het gezichtspunt van de Compagnie gunstig ontwikkelden en de handel van de VOC in de Indische Oceaan snel groeide, zou men denken dat Van Diemen zijn handen vol zou hebben aan de grote campagnes in de Molukken. Echter, zoals hij zich in $\mathrm{I}_{32}$ op het einde zijn verblijf in Nederland had gerealiseerd, zou zijns inziens de positie van de VOC pas zijn veiliggesteld als de Portugezen in Azië definitief verslagen zouden zijn. Dat was dan ook de reden achter de militaire expansie van de VOC in de Indische Oceaan.

Winius, Blussé en Vink hebben de reden van deze strijd gezocht in de uitkomst van de gebeurtenissen in de Chinese Zee waar de Compagnie zich bij het aantreden van Van Diemen na veel moeite een positie had verworven in de zeer winstgevende Japans-Chinese handel. De aanval op de Portugezen zou een oud plan geweest zijn, waarvoor Van Diemen als eerste de middelen ter beschikking had.

Ik heb getracht aan te tonen dat de aanval op de Portugezen op zichzelf stond zowel wat redenen betreft als middelen. Van Diemen voerde met geluk aan zijn zijde riskante militaire campagnes. Door de jaarlijkse blokkade van Goa trof hij de Portugezen in het hart. De verbinding tussen Goa en Lissabon werd zo goed als verbroken. Doordat hierdoor in Europa de peperprijs snel steeg naar hoge niveaus, kreeg Van Diemen in eerste instantie steun voor zijn offensief. De Portugees-Aziatische handel werd door de blokkade maar gedeeltelijk verhinderd.

Veruit het belangrijkste militaire wapenfeit was de verovering van het grote Portugese fort Malakka in januari I64I. Daarnaast werd een gedeelte van Ceylon van de Portugezen afgenomen.

Maar de werkelijke reden voor de aanval op de Portugezen was de angst voor vrede bij Van Diemen. De oorlog werd niet gevoerd om verandering in de status quo te brengen, maar om een onverwoestbare positie te verkrijgen als de vrede zou zijn gesloten. Het is wat dat betreft tekenend dat de oorlog tegen de Portugezen in Azië drie jaar langer heeft geduurd dan in Europa. 
Ook in het Verre Oosten verloren de Portugezen veel van hun invloed. In I639 werd hun definitief de toegang tot Japan ontzegd, waarmee een einde kwam aan de buitengewoon winstgevende handel die zij vanuit Macao op Nagasaki hadden gevoerd. De Nederlanders namen hun plaats in en zouden meer dan twee eeuwen de enige Europese natie zijn aan wie de handel op Japan werd toegestaan. De door de Compagnie behaalde winsten in Japan zouden voortaan in vergelijking met de eerdere Portugese winsten kleiner zijn, maar doordat werd afgerekend in Japans zilver was deze handel van essentieel belang voor haar intra-Aziatische handel.

Nadat Portugal zich in I640 had losgemaakt van de Spaanse troon, werd in $\mathrm{I}_{44}$ een bestand in Azië overeengekomen. De Portugese macht in Azië was gebroken en de hegemonie op zee was definitief overgenomen door de VOC.

In I654 werd de strijd hervat. De laatste vestingen van de Portugezen op Ceylon werden door de Nederlanders veroverd, evenals de nabijgelegen forten op de Coromandel- en de Malabarkust. Mede bepalend voor de uitkomst was de Portugese keuze om alle beschikbare middelen in te zetten voor de herovering en groei van Brazilië. De eens zo machtige Estado da India bleef onmachtig en verweesd achter.

Van Diemen werd tot gouverneur-generaal benoemd in een tijd dat de belangstelling voor de VOC bij de bewindhebbers in Nederland tanende was. Zij waren niet meer de ondernemers van het eerste uur, maar hun nazaten die als regenten leefden en vele andere bezigheden hadden. Zo hadden zij ook geen band met de selfmade men die aan het hoofd kwamen te staan van de Compagnie in Azië. Na I640 zou lange tijd geen enkele bewindhebber Batavia met eigen ogen zien.

Door zijn carrière in Azië was Van Diemen lotsverbonden met de VOC aldaar. Anders dan zijn voorgangers, en dan met name Coen, voerde hij zijn agenda uit zonder instructie vanuit Nederland. De goedkeuringen of aarzelingen van de Heren Zeventien over het door hem gevoerde beleid kwamen vaak aan in Batavia nadat de gang van zaken zelf al onomkeerbaar was geworden. In deze periode legde het bestuur van de VOC in Nederland zich erbij neer dat de invloed op de gebeurtenissen in Batavia beperkt was. Men concentreerde zich meer en meer op de aankomst van de retourvloot en de verkoop van de goederen.

In de negen jaren dat Van Diemen gouverneur-generaal was, werd de grondslag gelegd voor een eigen sociale cultuur aan de top van de VOC in Batavia die hemelsbreed verschilde met de Nederlandse sobere moraal in de zeventiende eeuw. Een belangrijke rol was hierin weggelegd voor Maria, mevrouw Van Diemen. Zij was de eerste grande dame van Batavia.

Door het verbod op de vrije handel was het duidelijk geworden dat alleen hoge posities binnen de VOC toegang gaven tot macht en geld. Te- 
gelijkertijd namen de in Azië verdiende vermogens in omvang sterk toe door het praktisch verdwijnen van toezicht op de handel voor eigen rekening. Dit was goedbekend bij de Heren Zeventien in Nederland en de repatriëring van deze kapitalen werd vanaf omstreeks i640 door de Compagnie openlijk gefaciliteerd.

Als burgemeesterszoon had Van Diemen een vaardige administratieve hand. Het door hem vastgestelde wetboek, de Statuten van Batavia, zou bijna twee eeuwen dienst doen. Ook hierdoor verankerde zich door Van Diemen het systeem van de Compagnie zoals dat zonder grote wijzigingen tot het einde van de achttiende eeuw stand zou houden.

Van Diemen was een nieuwsgierig man, hoewel hijzelf weinig in Azië reisde. Uit zijn tijd stammen de eerste tractaten over de verschillende naties waarmee de Compagnie handelde en ook gaf hij de aanzet tot de ontdekkingsreizen van Abel Tasman die geen vervolg zouden krijgen. Op alle terreinen drukte Van Diemen zijn stempel en vormde hij het systeem van de Compagnie. Om bij zijn eigen woorden te blijven had het zijn 'perickel' gelopen, maar was het systeem onder zijn leiding zo sterk geworden dat een 'misslagh' het niet meer kon deren. De tijd zou hem gelijk geven.

In 1645 ten tijde van het overlijden van Van Diemen hadden onder het vennootschappelijke dak van de Compagnie aandeelhouders, bewindhebbers en de organisatie in Batavia ieder hun vaste positie ingenomen.

Het gewaagde huwelijk van kapitaal en ondernemerschap was veranderd in een stabiel ménage à trois, de resultante van de verschillende ambities van drie verschillende mannen: Pauw, Coen en Van Diemen.

\section{Noten}

I. Huizinga, J., Over een definitie van het begrip geschiedenis, in Verzameld werk VII, IO2.

2. Romein, J., kanttekeningen bij Huizinga's Cultuurhistorische Verkenningen, Het onvoltooid verleden, (Amsterdam I948) 82-85. 


\section{Summary}

\section{Antonio van Diemen, the rise of the VOC in Asia}

The tenure of Antonio van Diemen (I593-I645) as governor-general was decisive for the Dutch East India Company, the VOC (Verenigde Oostindische Compagnie). It concluded the phase during which the Company established primacy over the sea trade in Asian waters.

\section{The formation of the VOC}

The first shipping expeditions to Asia and the formation of the VOC were the initiative of Amsterdam merchants headed by Reinier Pauw. During the last decade of the I6th century, these Amsterdam 'founding fathers' developed a unique and extremely ambitious strategy which distinguished them from their European 'proclaimed enemies and feigned friends', particularly from the Portuguese and the English. They let their ships sail directly to Java with the aim of securing a monopoly in expensive spices such as nutmeg, mace and cloves.

The rapid success they achieved invited unexpected problems. These consisted more of the large amounts of capital tied down in the fleets sailing back and forth rather than the native trade competition, and of the correct assumption that the intended monopoly would not be gained and maintained without armed struggle.

The solution that the Amsterdam merchants came up with was as unique as their earlier strategy had been: the formation in 1602 of the Dutch East India Company, the first company with permanent capital, tradable shares and limited liability. This linkage of long-term capital to long-term ambition was an important institutional innovation.

The large reclamation project (inpoldering) of the Zijpe sea inlet in North Holland, which had similar characteristics and which was well known to the merchants of Amsterdam and the magistrates in The Hague, served as a model for this organization.

The merchants maintained their grip on the trade, while the financial risk was shared by many. 
In this process the Grand Pensionary of the States General, Johan Van Oldenbarnevelt, served the interests of the powerful merchants of Amsterdam whose support was indispensable for his position as political leader of the Republic.

In I6I2 a substantial change took place in the relationship between the shareholders and the Company. One of the conditions of the charter granted by the States-General of the Netherlands at its formation demanded an intermediate settlement with the shareholders after Io years. They were then offered the choice either to continue their investment in the VOC or to be repaid their deposit together with any profit. At the formation of the VOC, doubts concerning this possibility had been expressed, and given the tradability of the shares, the choice not to opt for repayment can easily be explained. Because this was not replaced by any other obligation, all necessities for governors to report or account towards the shareholders disappeared in the blink of an eye.

Throughout the two hundred years the Company existed, shareholders of the VOC never gained any insight into the Company in which they had invested. All that they were left with was an obscurely described right to dividends.

\section{The years of crisis until 1619}

Immediately after its formation, the VOC started large-scale attacks on the Portuguese and Spanish settlements in Asia. An ineffectual siege of the Portuguese stronghold of Malacca and pointless fleet actions from Mozambique in the west to Spanish Manila in the east did not bring the spice monopoly any nearer. This incoherent strategy led to a serious crisis which the VOC survived thanks to its unique company structure. With its permanent capital, it could bear the initial losses and continue its operations.

In I608, Cornelis Matelief, admiral of the second VOC fleet, was the first to state that a new course would have to be tried. The VOC was to have a permanent headquarters in Java led by a governor-general and council, like the viceroy of the Portuguese in Goa and the Spanish governor-general in Manila. Otherwise the VOC would not be able to make progress, and the hoped-for monopolies would dissolve sooner than they could be effectuated. Furthermore, the VOC would have to participate actively in the intra-Asian sea trade in order to keep the costs of return cargo as low as possible.

This policy was accepted by the Gentlemen Seventeen, and in I609 the first governor-general was appointed. 
In I6r9 Jan Pieterszoon Coen founded the 'general rendez-vous' Batavia as a result of which the VOC was able to anchor itself in the Indonesian Archipelago. Coen was the passionate and controversial first 'man of prowess' of the VOC and pursued a policy that could count on the full support from the Gentlemen Seventeen. The merciless campaign in the Banda Archipelago, with which Coen seized the monopoly of nutmeg and mace in I62I, was carried out under orders from above. Coen felt that the apparatus of the VOC, which was centrally led, was in itself too unwieldy and capital-consuming to be competitive in the intraAsian trade. In his view this trade had to be left to the free traders as much as possible, as in the successful example of the Portuguese Estado da India. In order to get approval for this plan, he resigned his post in I623 and sailed back to The Netherlands.

Shortly after Coen had left again for Batavia as governor-general, the Gentlemen Seventeen retracted their initial support and prohibited free trade in the region. As a result of this decision, the experiment of a Dutch colony on Java was never taken any further than the initial impetus given by Coen.

\section{The career of Van Diemen}

We will probably never know why Antonio van Diemen left his hometown Culemborg at the age of sixteen in order to settle as a merchant in Amsterdam. Did it have to do with the religious strife between the Gomarists and the Arminians, or was it in search of business opportunities which this son of a mayor was not able to find in his hometown?

Since we know that prior to his bankruptcy in I6I6 he had been a merchant in Amsterdam for seven years, a more profound understanding of the career of Antonio van Diemen within the Company has become possible. It is well known that he joined the VOC as a midshipman under a false name to escape his creditors in the Netherlands.

When he was exposed after a couple of months in Batavia, his career did not suffer. Under the protection of Coen, he quickly moved up the ranks and joined the bookkeeping office at the VOC headquarters in Asia in I62I. In I624 Van Diemen was promoted to Councilor of the Indies.

In June I629, in the interval between two sieges of Batavia by the Susuhunan of Mataram, Van Diemen got involved in a serious conflict with Coen. In the notorious case of Sara Specx and Pieter Cortenhoeff, he sided against Coen as the latter had the adolescent boy condemned to death and the girl flogged in public. Coen suddenly died a few 
months later, and his successor was none other than Jacques Specx, the father of Sara. As a result, Van Diemen not only kept his position, but was even able to improve it.

The ambiguity of the VOC's role in the intra-Asian trade and the internal conflicts which set in after the death of Coen had a disrupting influence on the management in Batavia. Van Diemen was accused of trading for his personal account, but he countered this accusation remarkably easily. After he had paid the final debts of his Amsterdam bankruptcy, he married the young and rich widow Maria van Aelst in I630. In I63I he returned to Holland for a short stay.

Back in The Netherlands, he reported negatively on the situation in Batavia. At the instigation of Van Diemen, the Gentlemen Seventeen intervened in the management. The weak Specx was recalled, and the newly appointed governor-general, the stern Hendrick Brouwer, received the unpopular order to make a clean sweep among the higher Company personnel in Asia and to stop the free trade by Company personnel once and for all. Although Brouwer's efforts increased the profitability of the Company, he fell into disfavour with Batavia as well as Amsterdam. With Van Diemen's help, Brouwer nonetheless laid the foundation of the policy for which his successor has received all the credit.

\section{Governor-general}

Van Diemen did not stay in The Netherlands for long. After a year he embarked again to Batavia as director-general. Just before his departure, the spectacular seizure of Maastricht by Prince Frederik Hendrik in August $\mathrm{I}_{32}$ alerted him to a risk to the VOC's freedom of action in Asia. Truce negotiations with the Southern Netherlands had been started immediately. Van Diemen suddenly realized that the war in Asia, in the shadow of which the trade of the VOC had grown, might soon come to an end. He incited the Gentlemen Seventeen to remain at war as long as possible: 'Keep the sword in the hand Gentlemen, you will not regret it,' he wrote with a sense of drama. Van Diemen was convinced that the Company would not be able to survive a peaceful competition against the free Portuguese merchants under the current circumstances. This issue would become one of the most prominent themes during his time as governor-general.

In 1636 , when Van Diemen was appointed governor-general, the Company was not yet a very large organization, and he was right to worry about the robustness of the profit from the intra-Asian trade as well as from the sales in the Netherlands. At the start of his tenure, he enjoyed 
benefits in two important areas. Firstly, the Company reigned as a seaborne power in Asia. This was as much the result of reinforcements from the Netherlands as of the Portuguese declining as a sea power. Secondly, the trade with Japan started to bear fruit. After the preparatory work by Coen, Specx and Brouwer, Van Diemen was now able to reap the reward.

In the existing case studies about the Company in Van Diemen's time, it is not evident how the Company successfully played various roles in different areas. It is fascinating how the VOC behaved submissively in Japan while it colonized Taiwan as an overlord with the help of Chinese settlers.

In the Spice Islands it was a completely different story again. Over two consecutive years Van Diemen led large fleets to put down a chronic rebellion in Ambon and the surrounding islands. However, he only partially succeeded in seizing the monopoly of cloves.

Before Van Diemen was appointed governor-general, the Company had been avoiding a direct confrontation with the Portuguese. He was convinced that the VOC's position would only be ensured if the Portuguese were dealt a definitive defeat. This was also the prime motive behind the military expansion of the VOC in the Indian Ocean which he undertook without consulting the Gentlemen Seventeen.

Van Diemen fought his hazardous military campaigns with luck on his side. He attacked the heart of the Estado da India with a year-long blockade of Goa. The connection between Goa and Lisbon was practically broken. As the price for pepper quickly rose in Europe, Van Diemen received support from the Gentlemen Seventeen for his offensive. Foremost in importance was the seizure of the Portuguese fortress city of Malacca in January I64I, and in the years that followed, a part of Ceylon was also taken from the Portuguese.

It is significant, therefore, that the war against the Portuguese in Asia continued for three more years after Portugal had seceded from the Spanish throne in I640. In Europe Portugal had become an ally of the Dutch.

In the Far East the Portuguese lost much of their influence. In I639 they were denied access to Japan. The Dutch replaced them, and for two centuries they would be the only European nation allowed to trade with Japan. The profits reaped in Japan by the VOC were smaller than the former Portuguese profits, but because payments were made in locally produced silver, the Nagasaki trade was of essential importance for the Company's intra-Asian trade. 
In $6_{54}$ the battle with the Portuguese in Asia was rekindled. The last settlements of the Portuguese on Ceylon were conquered by the Dutch, and the nearby forts on the coasts of Coromandel and Malabar were taken. The once powerful Estado da India was left weak and orphaned.

Van Diemen's career was that of the man on the spot. Unlike his predecessors, in particular Jan Pietersz Coen, he managed his agenda with little interference from The Netherlands. The approvals or doubts of the Gentlemen Seventeen concerning the policies he carried out reached Batavia after affairs had become irreversible. As a result, the Gentlemen Seventeen resigned themselves to the fact that their influence on the High Government in Batavia was limited.

Owing to the strict prohibition of free trade, it became obvious that only high positions within the VOC administration gave access to power and money. The private wealth acquired by high officials in Asia increased as a result of the almost complete disappearance of supervision of their private dealings. The Gentlemen Seventeen in the Netherlands were well aware of this, and the repatriation of capital was publicly facilitated by the Company from approximately $\mathrm{I} 640$ onwards.

As son of the mayor of Culemborg, Van Diemen had a knack for administration. The Statutes of Batavia, which he had helped draw up, firmly fixed the judicial system of the Company. It would serve as a law book for more than two centuries without revisions.

Van Diemen also possessed a healthy curiosity regarding the neighbouring countries in Asia, perhaps because he did not have the opportunity to travel much himself. From his tenure in office date the first tracts on the various nations that the Company traded with, and he also gave the initiative for the various voyages of discovery by Abel Tasman and others to the Australian continent and the mythical Gold and Silver Islands east of Japan.

In January I645, in his last letter to the Gentlemen Seventeen before his death in April, Van Diemen described how his administration had left its mark on the VOC in Asia. Proudly he stated that the Company was now so powerful that it could face occasional setbacks without any peril to its performance. Time would prove him right. This state of affairs would continue until far into the eighteenth century. 


\section{Bijlagen}

I. Brief van Antonio van Diemen aan de Heren Zeventien dd I augustus I6I9. Hierin gaf hij aan waarom hij onder een valse naam naar Azië was gevaren.

NA VOC ro6g f447

2. Brief van Antonio van Diemen aan de kamer Amsterdam dd 20 november I629, plus bijlage

In deze brief worden de schulden uit zij failissement en hun aflossing behandeld. Tevens een afrekening waaruit blijkt dat hij in Io jaar tijd maar I.497 gulden uit de kas van de Compagnie had opgenomen.

NA VOC OBP Iog8

Batavia 544, 545-546.

3. Twee brieven van 2 en 9 decemberi632 van Antonio van Diemen aan de kamer Amsterdam. Hierin riep hij op de strijd tegen de Portugezen zo lang mogelijk vol te houden.

NA VOC 7547, resoluties XVII, achter de resoluties van de najaarsvergadering van $\mathrm{I}_{32}$

4. Eerste brief als van Antonio van Diemen als gouverneur-generaal dd 3 januari I636 aan de Heren Zeventien. Hierin verdedigde hij Brouwer en creëerde voor zichzelf speelruimte om zijn beleid uit te kunnen voeren

NA VOC OBP III6

f207-209

5. Brief van Antonio van Diemen aan de Heren Zeventien dd 20 januari I645 plus aanvulling dd 6 februari 1645 .

Dit is de laatste brief van Van Diemen. Hij ging hierin in op het einde van de strijd tegen de Portugezen en zijn opvolging NA VOC OBPII47 IO3-IOg

6. Beschrijving hele retour I64I met opbrengsten. 
7. Testament Antonio van Diemen en Maria van Aelst I632

8. Testament van Antonio van Diemen dd I6 april I645

9. Genealogie van Antonio van Diemen 


\section{Bijlage 1 \\ Brief van Diemen aan de Heren Zeventien dd 1 augustus 1619}

Bron: NA VOC OBP Io69, f. 447.

'Ed. Eerentfeste, wyse, voorsienige ende zeer discrete Heeren,

Omtrent I3 maenden, nadat ik mij van Amsterdam (par faute van vermogen) absendt gehouden hadde, ben met UEd. schip Mauritius op 4 January I6I8 na Indiën gevaeren, ende den 22en Augusti (Godt loff) voor Bantam wel aengecomen, in goede en vaste hoope, door wel doen van mijn geringhe en slechte conditie (daer inne wt gecomen ben) tot meerder metter tijt te geraecken. D'apparentiën hebben mij tot noch toe met seer goede hoope gevoedet, alsoo weynich dagen naer ons arrivement, tot Jacatrà, geordonneert ben om in voorvallen, daar toe bequaem mochte wesen, gebruyckt te werden.

Dit en is niet door gratie, faveur noch briefven van recommandatie door mij te weghe gebracht (alsoo geene gehadt hebbe), veel min kennisse aan d'Overhoofden, soo van 'tschip, als hier aan landt; maar Godt, die alleen mijn goet voornemen in dese bekendt is, den welcken bidde t'selvighe voirder te laeten succedeeren, tot profijt van de generaele Compagnie, contentement van mijn crediteuren, t'mijnder eere, ende tot verdriet van mijn benijders. Doch tot mijn groot leetwesen en discourage van mijn goede intentie, is mij voor weijnich dagen bij gevalle ter notitie gecomen de recommandatie, die UEd over mijn persoon (int artickel van de gedebautscheerde quanten) aen de Ed. H. Generael ende zijnen Raet, per den brief van dato ıo April ı6ı8, met t'schip Haerlem gesonden, sijn doende, genoechsaem om mij van alle hoope t'ontblooten. UEd. hebben meer dan gelijck op haere dienaren hier ter lande te doen letten. Jaa, is haar niet weynich alhier in Indiën aen goet en getrouw volck gelegen. Ondertusschen hadden wel gewenst UE. met meerder consideratie ende minder partyschap over mijn persoon end de fayten geaviseert hadden ende soo my gesint waeren geweest de zelvighe t'excuseeren, niet en behoorden met calomnien te beswaren. UEd. zeggen, (naer veele circumstantien over de gedebausscheerde en de ongeregelde quanten) aldus: "Van dese soorten is eenen Antony van Diemen onlangs binnen Amsterdam gefaillieert" (welck onlangs II/2 jaer is), mij met een onlangs beswarende, als off ick datelyck, naar t' overcomen ongeluck, te landt wt geloopen was, sonder yemandt te wille 
te wesen, daer ick my ter contrarie een geheel jaar onthouden hebbe in myns vaders huys, met weeten ende toeganck van een yegelyck. Grooten moyte endte groote instantien gedaan alles gepresenteert wat doenlijck was, om tot accoordt te geraecken, jaa, naar lndiën te gaen, opdat door myn verdiennende maendt gelden tot haer guarandt mochten comen maar heb niet connen voirderen. Dat ick onder den naem van Thonis Meeusen ben scheep gecomen, is wt oorsaecke, dat vrese hadde den naem van Antonio van Diemen meer in Indiën bekent was als den parsoon selfts, ende niet om UEd. $t^{\prime}$ abuseeren oft voor onbekend t' scheepe door te gaen.

De waerheyt hier van blijckt, want scheep comende en was van niemant gekendt; hebbe my selffs aende H. Hendrick Brouwer (nadat ettelycke dagen door hem geimploieert was geweest) geopenbaert ende bekendt gemaeckt, als wel wenschten, dat UEd. van myn vertreck verwichticht waeren, op hoope van haer faveur te genieten, by UEd. geconsidereert synde de genegentheyt ende rechtvaerdighe occasie, die ick voor hadde. Soo UEd. gelieven informatie te nemen op myn vorighe leven ende wandel, sullen nimmermeer bevinden, dat oyt gedebausscheert ben geweest, noch my in ongeregeltheyt van leven hebbe verloopen, Jan Engels is d'eenigh oorsaecke van myn ruinne ende verderff, die sy Godt myn getuyche, die ick bidde UEd. t'inspireeren tot moderatie vande gegeve ordre, laetende desulcke daarvan alhier disponneeren, die mettertyt van myn weldragentheyt volcomen contentement sullen hebben, op dat recompentie na myn daden mach genieten. De Comp.is machtich, doch heeft somwijlen t'faveur van sulcke noode, die t'welvaeren van Antonio van Diemen lief is.

De H. Generael is niet licht vaerdich int' verkiesen, noch en gelt by syn Ed. geen faveur, soo de persoonen sulcx niet en meriteeren. Dan $t^{\prime}$ schijnt het op my gemundt is geweest, en heel disgratie ben verhoope met Godt, dat de weldragentheyt ende goede diensten my (desniettegenstaende) sullen doen avanceeren ende voirderen. Bidde alleenlyck UEd. om soo veel credits te geven, als de daden sullen meriteeren. Hiermede,

Ed. Eerentfeste wyse, voorsinighe ende seer discrete Heeren, sal. UEd. naer hertelycke ende onderdanighe groetenisse, inde genadighe bescherminge des Alderhoochsten beveelen, die UEd. verleene, dat salich is.

UEd. dienstwillige Dr. Antonio van Diemen.

Int fordt Jacatra op Java ady pme Augusto i6rg. 
Superscriptie.

Ed. Eerentfeste, wijse, voorsienighe ende seer discrete Heeren, mijn Heeren de Bewindhebberen der Generale Vereenichde Oost-Indische Compa. residerende tot Amsterdam: per schip den Eenhoren, dat Godt bewaere.' 


\section{Bijlage 2 \\ Brief van Antonio van Diemen aan de kamer Amsterdam dd 20 november 1629, plus bijlage}

In deze brief worden de schulden uit zijn faillissement en hun aflossing behandeld. Tevens een afrekening waaruit blijkt dat hij in to jaar tijd maar I.48I gulden uit de kas van de Compagnie had opgenomen.

NA VOC OBP 1098

Batavia 544, 545-546.

Ed. Erntfeste wijse voorsienighe heeren.

Mijn Heeren, door d' Hr Generael Carpentier, (aen wien mijne particuliere affaire in NederIant hadde gerecommandeert) wort mij met brieven van 20 Decembr. I628 geadviseert, dat Ued. aen hem op mijn reeckh. van mijn lopende gagien in twee distincte reijsen hadden doen betalen de somme van acht duijsent gulden, twelck mij op t' hoogst aengenaem is geweest te verneemen, sal niet alleen daer voor danckbaer sijn maer tselve met goede ende trouwe diensten (gelijck tot noch toe gedaen hebbe) aende generale Compe. ende Ued. int particulier soecken te verschuldigen.

$\mathrm{T}^{\prime}$ gene aende genle. compe, tot Amsterdam mitsgaders aen d' Hr Voet schuldich ben, tsamen bedragende f 2683/15- sien UEd. gerescontreert hebben ende daer tegen ingehouden mijne verdiende gagien tot 18 november I 624 monterende f $2846 / 3 / 3 \mathrm{t}$ ' welck voor wel gedaen houde.

Tot vereffeninghe van mijn ongelegenheijt in Amsterdam sout ongeveer noch van noode wesen acht. negen a t' hienduijselnt guldens, Ende alsoo niet liever sage (gelijck billick ende reden is) dat mijne crediteuren ten vollen mochten worden gecontenteert ende hun rest betaelt, sal UEd. per desen andermael gansch vrintel. versoecken dat UEd. gelieven aen gemeltell Hr. Generael Carpentier ende in des selffs absentie, die mijn procuratie sullen verthoonen, de voorsz. somme van acht a thienduijsent guldens, off so veel min, als tot voldoeninge van vrundschap sal geschieden.

Pr. nevengaende extract van mijn reeckh. uijt de soldijeboecken deses casteels getrocken ende bij den oppercoopm. Danjel du Bucquoij geteekent gelieven UEd. te sien. hoe ick alhier tot mijn onderhout $t^{\prime}$ sedert I8 november I624. dat mijn vorigste reecke. is gesloten tot dato deser hebben genoten $\mathrm{f}$ I48I/I7/6 daertegen mij op I8 deser maent Novembr. I629 vervallen sijn ende vande generaele Compe. competeren sestich 
maenden gage, hebben de $t^{\prime}$ sedert de generale directie van Comp negotie in India waer genomen ende volgem missive vande Hrn. seventhienen dato I5 April I625 in t'raetschap van India geconfirmeert ende geordonneert nevens de Hrn van der Leck, Schram ende yan Duijnen als parmenent Raet in Batavia te continueren. de gemelte Heren hadden van de Compe bedongen, tractementen van 600, 500 ende 3I5 gulden ter maent. Wij vertrouwen dat nevens voorn.de Heeren Raden yan UEd. in gage sullen worden getracteert ende dat UEd. dien volgende geen schrupule sullen maken op reeckening van voorsz. sestich maenden alrede verdiende gage mijn versoeck te voldoen, ende aen d'Hr. Genl. Carpentier te doen aentellen tot de somma van 8, 9 off thien duijsent guldens daertoe mij sal yerlaten. Vastelijcken sijn geresolveert geweest enne hadden ons affscheijt yan d'Hr. Genl. Coen zalr. al rede becomen, omme met dese treffel. vlote, die Godt in salvo geleijde, ons na $t^{\prime}$ patria vervoegen twelck doorde veranderinge enne $t^{\prime}$ subit overlijden van d' Hr. Coen geen effect heeft connen sorteren. alsoo den Raet nader hant niet heeft connen goet vinden, ons in dese gelegentheijt te demiteeren, ende siende den dienst vande Compe. onse presentie noch wel wat vereyschend was, hebbe mij laten bewegen op de discretie van U.Ed. tot het naeste jaer te contineeren, als wanneer vastel. geresolveert ben over te comen, ende sullen alsdan mijn twee jaren overgedient hebben. daer voor de recompentie op U.Ed. gewoonlijcke benevolentie sal laten rusten, met een vast vertrouwen in onse hope (om in desen na merite van U.Ed. te sullen worden gerecompenseert) niet bedrogen sullen vallen. Hiertoe ons andermael verlatende sullen desen eijndigen ende UEd. erntfeste wijse voorsienige Heeren inde bewaringe des Alderhoogsten bevelen ende blijfft van herte gegroet.

Int casteel Batavia desen $20 e n$ Novembr. I629

UEd. gans dienstwilligen Antonio van Diemen 


\section{Bijlage 3 \\ Twee brieven van Van Diemen uit december 1632}

NA VOC 7547 resoluties XVII, achter de resoluties van de najaarsvergadering van 1632

\section{A. Vanuit het schip Amsterdam op de rede van Texel 2 december 1632}

(waarschijnlijk door Van Diemen zelf geschreven)

Achtbare wijse voorsiene Heeren

Mijn Heeren. Den $20^{\text {ste }}$ november ben met mijn huijsvrouwe in texel aangecomen, dewaere seijlreet vonden 't schip Amsterdam, de jachten Oudewater en Iselsteijn, gelijkck oock 't jacht Veenhuijsen geequipeert bij de Camer tot Enchuijsen,'t samen met cloeck volk bemant ende van alle nootleijckheden tot de voyagie dienstigh geprovideert, in vougen omme onde voor genoemen reiijse re vorderen, alleen op den goeden windt met debvotie blijven wachten. Den almogende wil ons met de schepen van Seelant ende het jacht uijt de maase (die achte rond dato uijtgelopen sijn) spoedigh in salvo ter gedestineerde plaetse brengen omme de Generaele Compagnie aldaer soodanige diensten te doen als deselve van mijn parsoon is verwachtende. Tot een afscheijt can niet naelaeten ten dienste van de selve compagnie UE opthoogste te recommanderen, dat jaarlijcxs nae India werden gesonden de behoorlijcke provisien ende alle andere noodtwendigheden opdat wij door gebreck vandien niet worden genootsaect gelijck voordien wel gebeurt is parthijen vande gerede penningen (tot retour voor Europa gedestineert) uit te geven en te consumeren om den mont op te houden. 't sedert twee jaaren herwaerts is na India solcx capitaal gesonden, ten aansien der retouren van daer becommen ende immer soo becrompen is. In gem: tijt den eijsch van provisie en principaalijck van vleesch ende speck voldaan dat wel groote inconvenienten conden baare, versoucke oversulcxs UE gelieve de goede handt daer aan te houden dat het gebruijck van desen end'andere in toecommende mach werden gesuppleert reeckeninghe maeckende dat jaaerlijcxs met min als I200 vaeten vleesch ende speck 
naer India behooren noch mogen gesonden werden gelijck ter jongste vergaderingh in seelant geremonstreert hebben

Seer gaerne hebben gesien d'ordre ende 't reglement beraemt op den gepremitteerden handel der vrijeluijden in India, Namentlijck dat met hun eigen vaartuijgen sullen vermoogen haar profeijt te soecken in de quartieren van Bangale Aracan, Pegu, Patana, Siam, Cambodja tot in Cotchinchina, macassar, solor en andere plaetsen meer. Goede voordelen sijn daer te haalen ende den staet van de compagnie sal daerbij worden verbetert en de verseeckert mitsgaders onse vianden ende geveijnzte vrinden in haaren handel verachtert edoch gelijck Ue seer wel doen uwe ingesetenen van Batavia, Amboijna en Banda den handel in voorschreven quartieren open te stellen soo dienen Ue oock te versorgen (gelijck bij mijne generale missive geseijt hebbe) den borgerije bij provisie met eenige fluijten worden geaccommodeert tot dat de rimmeringe in India wat oncostelijck sal connen werden gedaan. Versoucke dat aen Ue gelijck aen de heeren tot Amsterdam mede ernstelijck ben versouckende dat opt voorjaer ende volgend jaer 2 a 3 goede fluijten van I6o a 200 lasten na India mogen worden gesonden omme de borgerije daer mede te dienen. Dienst sal de Compagnie daer aan geschieden ende met groote avance connen de selve overgelaaten en vercocht worden.

De Compagnie sal haer van de nieuw gecomen fluijten conne dienen, de halfsleeten in India sijnde daer tegen aende borgeerije voor contante vercoopen ten prijse als meer als in dese landen nieuwe gecost hebben. Ende soo men niet conde goetvinden d'Equipage met dese te senden fluijten te belasten, tenaensien bij de Seventiene daer op niet is geresolveert, connen de selve als effecten na India in facturen worden gestelt. 't Sal de Compagnie in India als gelt verstercken. Anno r63I hebben de Engelsen een oudt en verrot jacht, de Valcq aan de Burgerije in Batavia tot goede prijse vercocht.

De Compagnie als 't haer belieft can dit voordeel selve genieten ende Engelsen met haer afgevaren schepen sonder voordeel daer vaan te trecken laeten consumeren

\section{Hiermede}

Achtbate wijse voorsienighe heeren sal eijndigen dewijle de wint sich begint goet te verthoonene ende Ue in de genadige bewaringe der alderhoochsten bevelen, dien wij bidden Ue foen te geven ende ons te verlenen een spoedige overcomst. Blijft gegroet vaan

Ae geaffectioneerde Dienaar

Antonio van Diemen

Int schip Amsterdam dese 2 december 1632 


\section{B. 9 december 1632, vanaf het schip Amsterdam op de rede van Texel}

(Klerken kopie)

Achtbare, voorsiene heeren,

Ten antwoorde van UE aengenaeme dato 7 deser zal deses dienen niet soo al wenschte, maer naer mijn tegenwoordige dispositie toelatende D'experientie heeft ons van tijdt tot tijdt geleert zoo profitabel de oorloge in Indien tegen de Portugesen en Spangiaarden $\mathrm{uE}$ staet aldaer is geweest. Zulcxs oock voor zoo veel ick begrijpe dat het zo tot noch toe door Godes genade 't welvaren van de participanten is genouchsaem? totale ruine van $\mathrm{uE}$ vijanden voorschreven en hare consorten. Want het is zeker bij aldien zij Ao I609 wegens de treves in Indien hadden aengenomen met negotieren zouden ons overlange daer uijt gesien hebben. Sij sijn bastant als van ons niet getroubleerrt worden de Compagnie hare gantse handel in India infructueus te maken. Van rijcke en goede borgerije die alles weten op te soucken en te door snuffelen zijn zij beter als wij voorsien. Hoe de Portugees en Spangiaart gedurende dese oorloge zijn verarmt jae gantsch uijtgeput is staet in haere geintercipieerde clacht brieven. De gemene man is in duystereste armoede gekomen. Soo ue nu goet vinden met hun in vrede te treden, de handel overal open te stellen, zullen haest tot haere voorige opulentie comen ende wat daeruyt ontstaet zal zo licht te raden.

Hier tegen zullen wellicht eenige gelijc waar is zeggen de Comp. zal soo sware lasten en groot gevolch bij tijden van treves als oorloge niet hebben te dragen, maer dese lasten comen niet eens in consideratie tegen de verachteringe die de Comp in contrari zal lijden, want de Portugees zal ons altijt bij vredige handel vercloecken dat wil ick geerne bekennen.

In Suratte en Parsia zullen niet alleen bij tresves onse reputatie maer de gehele handel verliesen; den Portugees sal Ormus incorporeren oft immers den Parsian jaerlijcs soo incommoderen dat sijn waterloos fort Ormus sal onvoorsien blijven

Hoe de coninck van Persia ene nemen zal geve $u E$ wijse raadt te bedencken.

Suratte heeft sijne van d'onlijdelijckheden der Portugesen ontrocken zij sullen haer weder moeten sumitteren als gene hostiliteijt met haat plegen.

Soo dat wij daer mede perijckel sullen lopen. Daerbij kompt der Portugesen finessen en weten ons bij alle grote heeren en potentaten odieus 
te maken. Soo zegt de Vice Roy van Goa aen de Gouverneur van Suratte, soo uwe coninghe namentlijck den Mogul verbetert is bij den Nederlanders en Engelschen natie hondertduijsent rupias, wij Portugesen sullen betalen jaarlijcks driehondertduijsent rupioas ende zij cunnen dat beter daer als wij. De moor is begeerlijck: die hem meest geeft is zijn grootste vrundt.

Als nu de Portugees onbecommert mach varen inne de quartieren van Sta Tomé, Negapatnan, Cormandel etc, en in Malacca sal brenghen zulcke sortementen van doecken en andere Coopmanschappen als de suijder quartieren van doen hebben, soo sal de cleet ende binnenlandsche handel van de vereenigde compagnie onvruchtbaar voor de Comp. werden. De redenen zijn, dat se met beter opmerckinge en meerder voordeel als de comp. cunnen doen. Pattany, Sigoe Siam, Combodia en andere quartieren die se sullen met haer goede sortementen van cleden tot haar trecken.

Als den Portugees en Spangiaart onverhindert vaeret van Goa na Malacca van daer na Maccau ende retour item hem dan niet verhinderen de reijse op Jappan gelijck sulcxs uijt treves moet volgen, zoo houde ick India halft verloren, is de comp. dan in India geen voordeel altoos bij stilstant van wapenen doen. Admitteert men ons in Maccau dat niet aen is n..., want zullen dan wel den mandorijn van Canton wel voorcommen.

In Manilla is voor ons niets te doen, wij moeten den Chinees vandaer houden den Spangiaert betaalt de sijde aldaer 20 percento meer als wij in Taijwan doen. In Goa is voor ons geen negotie, in de omliggende quartieren sijn wij zoo vrij als de Portugees.

Niet een punct van voordeel can ick in 't stuck van treves met den Portugees voor de Comp bedencken.

Oft meijne oock niet dat ymant meyne sal, als den coningh van Spangien sich ontslagen vindt van deser landen oorloch, de oorloch in Indien zoo vigoreus sal bij den handt nemen, dat wij die uyt India zoude mogen slaan, het heeft inde voorige treves niet gebleecken. Ende door Godes genade is met goet beleyt ende voorsichtigheyt hun attentaten tijdich zullen cunnen voorgecomen werden. Houdt mijn heeren 't sweert inde handt, het sal $u$ niet rouwen.

' $t$ is seker datter niet een Portugees in Indien is, ofte wenscht met ons in vrede te zijn, twijffele oock niet $\mathrm{uE}$ zullen daertoe wel werden vergast. 
T'is seker dat de gemeijne negotianten in India wel geerne een grote somme jaerelijcks aen de Comp souden willen betalen zoo men haer ongemolesteert liet. Men hoort er oock op te staen, als men immers tot vreden zouden moeten verstaen. Dese andere fondamentele reedenen soude tot dese materijen connen bijbrenghen, maer mijn tegenwoordige gelegenheyt doet mij aftbreken ende salt voor dees tijdt hier bij laten, verhopende de Almogende mij eerlange meerder cracht zal geven om $\mathrm{uE}$ te dienen,

Hier mede

Achtbare, wijse voorsienige heeren blijven uwe E geaffectioneerde Sr Anthonio van Diemen

Bij 9 december Ao $\mathrm{I}_{32}$

Op derselver 


\section{Bijlage 4}

\section{Eerste brief als van Antonio van Diemen als gouverneur-generaal dd 3 januari 1636 aan de Heren Zeventien}

Hierin verdedigde hij Brouwer en creëerde voor zichzelf speelruimte om zijn beleid uit te kunnen voeren

NA VOC OBP IIIG

$\mathrm{f} 207-209$

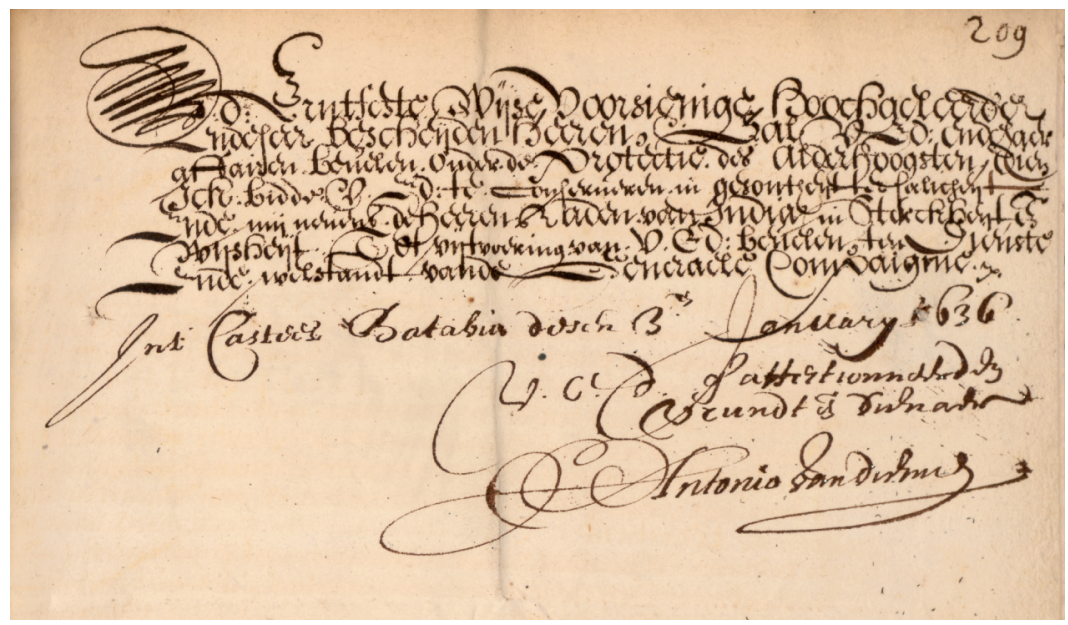

Manuscript met handtekening van Antonio van Diemen. Nationaal Archief Den Haag.

Weledele Ernstfeste, Wijse voorsieninge Hoochgeleerde ende seer Bescheijdene heeren:

Mijn heeren, d' ervaring heeft ons geleert hoevele den Staet der vereenichde Nederlanden aen D'Oost Indische Compaignie is gelegen. Ende gemelte Comp. aen de Regeringe ende goede directie derselve affaire in India. Mitsgaders dat de hoogste ampten of bedieningen ende voornaemtlijck 't generale Gouvernement alhier werden becleet door sufficante ijverige g'experimenteerde ende trouwe mannen. Derwegen soo ist, dat Ambt en de plichte sal men, al in den jaere I634 als wanneer ick vermercte, dat den heere Gouverneur Generael Henricq Brouwer, gans genegen was op d'expiratie van sijn Edele drij jarigen verbandt weder na Nederlant te keeren, denselver heere tot continuatie gansch ernstelijck hebbe versocht, Alsoo t' sedert mijne aencompst alhier tot den hedi- 
gen dach volcomen genoegen aen sijn Edele regieringe hebbe gehadt. Ten aensien alles met goedt respect, gestaadige communicatie, vrede, ruste ende veerdichijt is gedirigeert geworden. Ende door sufficante bondige ten dienste van de Comp. strekkende redenen sijn Edele soo verre beweegt, dat aennam met de retourschepen van dat jaer '34 Ued aen te schrijven (gelijck oock geschiet is) niet te sullen weijgeren een jaer over sijn verbant in India te verblijven bij al dien door $\mathrm{U}$ ed daertoe versocht wirdt ende sijne dienst $U$ ed aengenaem mochte wesen. Hiertoe mij dan verlaten hebbende ende blijvende met vast vertrouwen, dat $\mathrm{U}$ ed gemelte heer generael Brouwer tot eenige continuatie soude hebben aengemaendt, niet eens denckende dat $U$ ed soo precisen ordre op des voors. Heere generaels verlossinge soudet hebben gelieven te geven. Alsoo mijn oordeel (onder correctie) U ed. deese Eere tenminste den geseijden heere gouverneur generael Brouwer ginstch hadden behooren te laten toecomen. Ende dat ten regarde van sijne gedane groote diensten gelijck de wercken en effecten de levendige getuijgen daervan sijn.

$\mathrm{Nu}$ de saecke aldus notgevallen wesende, d'heere Gouverneur generael Brouwer ongenegen sijnde om te continueren, soo sijn $\mathrm{U}$ ed bevelen nootsaecklijck, als dat behoort, gehoorsaemt ende naegecomen moeten werden. Ende gelijck $\mathrm{U}$ ed hebben gelieven, achtervolgens uwe brieven van commissie ende surogantie mijn persoon als Gouverneur generael over des comp's standt in d'Oostindien t'eligeren en te promoveren, soo zijn ingevolge van dien op den eerste desers, nadat den heere gouverneur Generael Brouwer al voorens alle persoonen onder U ed gehoorsaemheijt resorterende ende tot Batavia sijnde, van den eet der getrouwicheijt, aen sijne E gedaen, hadde onstagen ende desselfs Ampt aen mij geresigneert, publickelijck ende in den beste forme door sijne geseijde E ende de heeren Raden van India int Generale Gouverne g'investigeert, als Gouverneur Generael voor de Gemeente g'authoriseert, daervoor erkent ende aengenomen. Den Alwijsen, altegenwoordigen, Almachtigen ende Goedertiteren Godt, gelieve ons bij te woon en cmet sijne Geest: des breets, omme onsen doen, actien en directien alomme soodanich te bestieren ende te begeven dat alles mach strecken tot grootmaeckinghe sijnes $\mathrm{H}$ naem , welvaert ende reputatie onse lieven vaderlandts, afbreuck onser vijanden, welstandt van de Generaele Comp, proffijt ende contentement van de participanten en tot mijne Eere int bijsondere, Waertoe sonderling grote hope hebbe ten aensien van de goede redresse ende reformatien in voorgaende drij jaren in India ingevoert ende de treffelijcke ordre in de Comm (unica) tie gestelt.

Den genadigen Godt gelieve den Persoon vand' heer Gouverneur Generael Brouwer ende sijn familie met sijne $\mathrm{H}$ engel op de reijse te geleijden ende bij te woonen. Hem is de d' oovergaende retourschepen met 
hare rijcke ingeladen goederen ende de voorder opgaende persoonen behouden bij $\mathrm{U}$ ed oover te brengen.

U Ed wijders gans vrundtlijcken bedanckende voor d'eere die mij hebt gelieven toe te voegen. Andermael den albestierende biddende mij met wijsheijt cloeckmoedigheijt te stercken opdat de hooge charge tot vernoeginge van die daeraen gelegen sijn wel ende prospere mach wtvoeren.

Belangende $\mathrm{U}$ ed Indische standt soo de regeringe, den Oorloge, commercie als andersints concernerende, mitsgaders 't passerednde in U ed affaire tsedert onse jongste advuijsen aen $U$ ed afgesonden, insgelijcx $t^{\prime}$ gene voornemens sijn in toecomende met de hulpeGodes tot verseeckering, vergrooting ende verbeteringe desselfs aen te leggen wert U ed bij onsen Generale Missive distinctlijcken geschreven ende grondich vertoont. Sulx dat mij geheelijcke aen den ingesonde derselver missive gedrage, gelijck oock ben doende ende mij referere tot de rapporten die den heere Generael Brouwer met lieft bij $U$ ed gecomen wesende tot welstandt van de Generale Comp sal doen.Hebbende gemelte heere soo grondige kennisse van d'Indische saecken int generael dat met recht den Indische Phoenix genoemd mach werden. $U$ ed voijders gans vrundtlijck versoeckende in andtwoorde deser onser advuijsen ons met uwen goeden raet, last ende ordre sulx te seconderen dat alles ten beste van de Comp aengeleijt ende na $U$ ed goede intentie alhier int werck gestelt ende wtgevoert mach werden.

Eenenlijcken ende ten oovervloecte sal $\mathrm{U}$ ed recommanderen ende gans ernstelijck versoecken dat op naevolgende saecken mach nood en geleth, namentlijck:

Dat ons worde beschickt de navale machten ende volck die sijn eijschende opdat door gebreck van dien comp(agnies) welstandt geen interest coome te lijden extraordiarij machten (als wel voor desen) worden niet versocht noch de comp(agnie) ijts boven vermogen geverght.

Tot bevoordering van den oovertreffelijcken nieuwen Choromandelsen handel op Pegu ende in Bengale vereijscht noodtsakelijcken twee a drij jachten ende fluijten meer als op Choromandels custe voor desen wtcomen geemploijeert worden.

Tawaij ende Tanaweij die nieuwde bevarens goede voordeelen sijn daer te behaelen soo sullen dan oock voorcomen om den Siamsen cleethandel die de mooren over Gasiassecij (?) drijven niet injfructueus werden gemaeckt 
Qumang ende Toncquin dienen met schepen ende capitael besorcht ende staet wt den handel aldaer de Comp groote proffijten te comen. 'dewijle door mandaet van de Japansche keijser egeene 'japanderen meer derwaerts vaaren mogen Meer als duijsent picol sijde hebben de Japanders jaerlijcx wt die quartieren getrocken ende in Japan met groot voordeel gedebiteert. Welcke sijde oock buijten pancado int rijck van Japan verkocht wort.

Tot overvoer van de hertevellen ende 't Sapan wt Siam ende Cambodia na Japan sal weeder meer scheepsruijmpte vereijschen. Als wel wanneer den Japanderen derwaerts haere negotie exerceren mochten.

Deese ende noch andere nooijt gedaene besendinghe sijn dan d'oorsaecke dat van U ed schepen ende jachten sijn eijsende. Doch soodanich gereguleert dat qualijck vergrooting mach genoempt worden.

Dat bij de overcomende lijste van Comp navale macht in India wel schijnt een groot getal schepen ende jachten te wesen, maer dat $U$ ed moeten gelooven dat veele derselve af sijn Ende niet lang meer varen connen, als daer sijn $\mathrm{T}$ Wapen van Hoorn, Beets, Arendt, Buren Sardam, Assendelft, $T$ Wapen van Delft 'T Zeepaert, Tholen de Brack, de Salm ende meer andere cleene Jachten.

Dat wij blijven verlangen omme te vernemen hoe $U$ ed den provisioneren Treves oft Vreede tusschen den portugues ende de engelsen in India g'accordeert sal gevallen, mitsgaders wat ordre $\mathrm{U}$ ed goetvinden sullen daerop herwaerts te geven. Soo gemelte vreede bestendich blijft (dat niet verhopen) ende d'engelse de portuguese goederen, op vracht, blijven oovervoeren, gelijck haer schip de Londen, sijnde van Goa over Malacca na Maccauo geseijlt gedaen heeft. Sal t'selve geen cleene obstaeckele ende verachtering soo sulcx gedoogen moeten in $\mathrm{U}$ ed commersie veroorsaecken. Alles feijtelijcken te beletten soude niet alleen tot verwijderinge strecken, maer tot een openbaere oorloge wtvallen. Dat nader wellicht grooter verachtering ende rusie soo hier als in Europa mocht causeren. Ende beijde de Portugues en de engelsman als vijanden te moeten afweeren soude de tegenwoordige constitutie alhier niet wel passen. Zover sulcx sullen volgen onse resolutie t doen der Engelsen, als ongemerckt laten passeren tot $U$ ed naerder ordre.

Maer bij aldien d 'Engelsen onderstaen tot protectie der portuguese scheepkens, eenich volck daerop te stellen sullen daeraen geen respect draegen ende bij recontre d'alsulcke portuguese vaertuigen voor goeden buijt aenslaen.

Dat Banda een quaede buerman sal hebben bij aldien d"engelsen op Poele Ron moeten worden gedooght te meer nu vrede met den portu- 
gues hebben $U$ ed ordre op dese gelegentheijt sien tegen April oft Maij tegemoet.

Dat U ed onse petitie wt Vaderlant voor India gelieve te voldoen, de goederen tot commertie daerbij geeijscht calculeren incoops sullen connen te bedragen omtrent drijhondertvijftichduijsent guldens in gelt, soo sullen $U$ ed daerover hebben te verwachten (ongeluck ende onverwachte obstaeckels in handel uijtgesondert) eene retour van vijfentwintich tonnen gouts.

Batavia verbetert dagelijcx. De plantage binnen de stadt neemt merckelijcker toe. De negotie gaet redelijck sulcx dat den naaem van costelijck Batavia eer lange in proffitabel Batavia staet te veranderen. Anno I634 ende 35 hebben de proffijten van den handel in Batavia met 'slants incompste meer opgebracht àls d'ongelden in voors. twee jaren gevallen 24.4I79.I9.3 niettegenstaende alle scheepsequipagen ende uijtsettinghe tot vervolgh van de commertie ende afbreuck van vijanden, alhier worden bekosticht. Twelck in gemelte twee jaren alleen ccompt te bedragen de verstreckte maendtgelden aent varent volck (daer voor op haere scheeps reeck. worden belast) daerin begrepen 2504742.I4.I2. Meer soelaes verhopen wij de Comp eer lang van batavia sal trecken. desen jaere verwachtenen ca 6 joncken uijt china.

met de vreemdeling wel te tractreren ende dat haer aente brengen coopmansgoederen met redelijcke proffijten worden afgenomen, gelijck gedaen is ende noch int voornemen blijven te continueren, mitsgaders dat volgens $U$ ed ordre alle oorloghe immer soo vele mogelijck buijten nadeel en respect quetsing van de comp. can geschieden eviteren ende excuseren. vertrouwen van de negotie ende den toeloop van volckeren alhier meer en meer sal doen accreseren. Soo moet oock de goede handt aen de menage (7) gehouden worden, gelijck nu alhier 2I/2 jaren welgedaen is als accomodatie tot nadeel van de Comp g'excuseert ende de besetting voor ende omtrent Malacca continueert, mitsgaders dat op Java, Sumatra, Borneo, Patany en elders geen Chinese joncken gedoogen. Dit sijn wel de principaele middelen om Batavia groot ende proffijtelijck voor de Comp. te maecken.

Tot besluijt wil $U$ ed gebeden ende versocht hebben om particuleijcke in andtwoorde t'adviseren de bevinding van de oovergaende retouren. Omme ons natoecomende daernaer te reguleren Verscheijdene coopmanschappen gaen tot een premie over als daer sijn de hertevellen, de swarte suijcker van Siam in potten, den indigo van Palliacatte, de blauwe oft cangans wt China rol ende sullen tot nader ordre int senden van gemelte coopmanschappen continueeren. 
Aen mijn swager Pieter de Gruyter hebbe gel ast dat op d'aencompste deser retourschepen voor mijn reeckeninghe prijs courant sal incoopen drijduusent gulden capitael... aldaer daertoe geldt vandaer heeft ende sulcx aen $\mathrm{U}$ ed versoect, gelieft en mijn obligatie tot last $\mathrm{U}$ ed caemer oft elders oft sooveele minder als soude mogen .... Daeraan mij.. ende vrundtschap sal geschieden ende de Compaignie voor betalinge valideren.

U ed Erntfeste wijse, voorsienige hoochgeleerde ende seer bescheijden heeren, sal $\mathrm{U}$ ed ende haer affairen bevelen onder de protectie der alderhoogsten dien ick bidden $\mathrm{U}$ ed te conservren in gesontheijt ter salicheijt ende mij nevens $d$ heeren Raden van India in sterckheijt en wijsheijt tot uijtvoering van $\mathrm{U}$ ed bevelen ten dienste ende welstandt van de Generaele Compaignie

Int Casteel Batavia deser 3de Januarij ${ }^{6} \sigma_{3} 6 \mathrm{U}$ ed geaffectionneerden vrundt en dienaer Antonio van Diemen 


\section{Bijlage 5 \\ Brief van Antonio van Diemen aan de Heren Zeventien dd 20 januari 1645 plus aanvulling dd 6 februari 1645}

Dit is de laatste brief van Van Diemen. Hij ging hierin in op het einde van de strijd tegen de Portugezen en zijn opvolging NA VOC OBPiI47 IO3 - IO9

Edele Erntfeste wijse voorsienige ende seer discrete Heeren

'tzedert mijnen jonghsten gedateert 9 Januarij anno passato per t' schip Leeuwarden hebben ontfangen u.Ed: schrijven van ultimo augustus I643 met de schepen Tijger ende Mauritius Eijlandt particulier aen mij geconsigneert. Den inhoude en U.Ed: motiven bij mij in overdencken gecomen sijnde, moet daeruijt besluijten tot dato in mijn geringe diensten contentement genomen hebt, dewijle mijn continuatie u.Ed: schijnen aengenaem, midts mij voordragende na anno 44 ten minsten noch een jaer in India te willen verblijven neven een ander voorstel emmers niet van hier te vertrecken alvoren daer van mooght verwitticht werden, opdat (gelieve u.Ed: te schrijven) als dan behoorlijcke ordre opt gouvernement generael gestelt mach werden. Op deze rescriptie hadde ten aensien mijn lange successive ernstige versochte verlossing egeen staet gemaeckt, maer wel in plaets van dien mijnen vervanger tegemoet oft ordre omme de generale directie alhier bij provisie te mogen resigneren ende alsoo met fatsoen desen jare tot $u$.Ed: gecomen te zijn, t'welck door u.Ed: contrarie ordre nu tot december aenstaende gestaeckt blijft. Alsoo staet maecke u.Ed: op den ontfangen van aengetogen schrijven per Leeuwarden op mijn iteratieff versoeck bij t' zelve soo inden aenvange als eijnde des brieffe gedaen sult hebben gelieven te letten. Ingevolge mijnen verlosser versocht ofte eenige ordre daer op gegeven daer mijn dienst ende erkennelijcke vrintschap ware geschiet. U. ed: weten anno passato july 2I mijnen tijt al weder is g'expireert geweest ende dat t'versochte jaer 45 god toelatende ende leven gunnende gesuppleert wert. Zulcx datter nu niet meer te seggen valt. Wel u.Ed: staet gelieven te maeckende voor g'adviseert ende gepreadverteert te sijn, t' zij mijnen vervanger oft ordre verschijnt oft niet geheel voornemens ende seecker geresolveert blijve anno i646 (des god toela- 
tende) persoonlijck vanden Indische stant ende gelegentheijt mondelinge raport te doen, daerop dan als geseijt staet gelieft te maecken.

T' zal hier tot becledingen van de generale directie aen bequame suffisante verstandige luijden niet manqueren, emmers omme de generale saecke tot u.Ed: nader dispositie te mainteneren. T'sal oock faciler ende met minder becommeringe voortaen te doen sijn, dewijle den oorloge met den Portugees nu in India come te cesseren ende dat beter cloecke ervaren Coopluijden als Crijgslieden sullen van node sijn omme van onse Competiteurs niet vercloeckt werden, daer op u.Ed: succesive int senden van coopluijden gelieven te letten.

Volgens u.ed ordre wenschte doorgaens met vier ordinaire Raden van India g'assisteert mocht werden, maer t'wil al gemeenlijck aen t'een ende t'ander haperen, sulx dat getal met convenabele personen beswaerlijck compleet cunnen houden. Ordinarij Raden omtrent den gouverneur generael sijn twee als den hr. Johan Maetsuijcker uijt desselfs commissie sal sijn geretourneert, dat wesen sal in Meert aenstende. namentlijck d'heer Cornelis van der Lijn present eerste Raet ende directeur generael buijten verbintenisse met 250 gul. ter maent op wat insichten sijn hr. nu een ruijme tijt met die gagie (niet condigne sijn ampt) buijten verbant oft nieuwe conditie te maecken continueert blijft mij onbekent, ende Johan Maetsuycker die op sijn legatie nae Goa dien titel op u.ed. approbatie gedefereert is.

De qualiteit van pensionaris comt daermede in sijn persoon op te houden ent is gelijck u.Ed: wel seggende pensionarissen inde steden ende collegien eenlijck hebben een deliberative stemme ende achter de Raden sitten, maer soodanige permanente pensionaris oordeelen in de Raet van India onnodigh. Als den hr. Maetsuycker voornamen in onsen Raet te gebruijcken conde niet wel resolveren omme reden u.Ed: bekent, dat nu cesseert. Sijn hr. tot extraordinaris Raet t'assumeren en evenwel dacht ons onfatsoenlijck jonger personen in India ende van minder experientie boven hem sessie souden hebben, werd derwegen als Raet pensionaris inden Raet van India gequalificeert ende voorsit gegeven te meer met sijn advijsen wel gedient waren.

Den hr. Salomon Sweers continueert als Raet extraorinaris compareert in Rade als geroepen wert ende ordinarij geschiet, dat echter u.Ed: ordre contrarieert maer dewijle gelijck geschreven is zijn hr. met gemeen advijs herstelt hadde ende bevoren u.ed; ordre bequamen, selve genomen hadde. hebben die saeck soo op sijn beloop gelaten, ende noch laten sal tot $u$.Ed: nader advijs. T'is een jongh cloeck man vigilant genoegh int executeren van dat hem gelast wert.

Van den Raet Joost Schouten waren wat groots verwachtende maer sijn dapper bedrogen geweest. D'almogende vergeve hem sijn sonden ende 
bewaere ons voor soodanige Raden. In sijn plaets is g'assumeeert ende tot Raet Extraordinarij gecreert den advocaet fiscael mr Symon van Alphen, nu president van het collegie van Jusititie. Sulx als Maetsuijcker zij gecomen den Raet van India in Batavia sal bestaen uijt den Gouverneur Generael, twee ordinarij ende twee extraordinarij Raden sijnde 5 personen met den secretaris Mestdagh, die nu dat ampt seven jaren bedient, waeerdoor groote ervaringe becomen heeft en dienvolgende t' collegie des Raets van India goeden dienst presteert. T'is niet apparent voor eerst iemant tot ordinari raden beroepen sal oock geen extraordinary maer blijven voornemens te wachten op u.Ed: nader advyijsen die tegen meert oft april tegemoet sien, te meer al eenige veranderinge presumeren met de vernieuwingh des Octroijs als andersints. Bij aldient $u$. Ed: goetvinden wenschten wel $u$.Ed: advijs opt advancement van den secretaris Pieter Mestdagh.

Aernolt de Vlamming van Oudshoorn uijt sijn Commissie van Atchin gekeert, becleedt het presidents ampt van Schepenen Collegie daer den hr. Paulus Croocq uijt getreden is.

Aernolt Heussen hebben gepromoveert tot vice gouverneur ende directeur des ommeslachs der Custe Coromandel tot tweehondert gulden ter maent voor drie jaren, ingaende I6 augustus I643.

Den oppercoopman Bartolomeus de Gruyter soliciteert sijn verlossinge, dat hem geaccordeert is

Nopende de voordere aensienelijcke administreurs in u.Ed: directie op diverse quartieren daer wert in de generale missive van getracteeert, daer mij toe referere.

T'zal dienstich sijn u.Ed: eenige weijnige maer grave conscientieuse eerlijcke mannen tot d'Indische regering ende versterckinghe als stijvinge der aenwesende personen herwaerts te comen beweeght, segge conscientieuse vigilante ende modeste personen van nederich humeur, echter reputatieus ende luijden van soodanige conditien niet connende aentreffen sal 't beter sijn geene gesonden. Verstaet Raden en extraordinarij Raden van India sijnde hier noch soo geheel destituijt niet, dat verlegen souden vallen, maer $u$.Ed: cunnen mede wel considereren goede verstanden de regeringh van India ten hooghsten nodig sijn. Alsnog can niet wijser worden dan dat ongetrouwde personen in uwen dienst hier te lande nutter als getrouwde sijn. Emmerss soo lange niet resolveren dan voor corten tijt oft tot meenen middelen bastant bij een geschraot te hebben om in Nederlant daer van te connen leven, dat tot grooten ondienst van de Comp. comt te gedijen. Sijnde veele soo neerstich omme conquesten te maecken dat t'particulier voor't generael oft Comp's dienst prefereren. Leth maer eens met aendacht, hoedanige middelen per dese vloote overgaende Comp's dienaren boven haer ver- 
diende gagien thuijs brengen. De wisselbrieven sijn daervan levende getuijgen. Met wat titul daeraen geraecken heeft sijn bedencken. Dit is seecker bijaldien Comp's Capitalen soodanige pro rato g'augementeert werden, de participanten souden geheel andere repartitien erlangen. Daer dient wel een anderen regel op geraemt ende comp's dienaren alle gelegentheijt van particuliern handel ontsetten, oft t'is geschapen in desen Staet nimmer gequalificeerde burgeren te verwachten sijn, dat nochtans een nodige saecke is. Ende buijten een welgestelde gepoliceerde Colonie can de Comp. dit groote werck niet gaende houden. Daeromme moeten $u$.Ed: mede helpen dit pregnant werck bevoorderen midts veel volck naer India sendende arme en rijcke, onder soodanige reglement als hier goetvinden. Sullen admitteeren geene getrouwde, als voor veele jaren, met restrictie nae Europa niet te mogen keeren ten zij eenige hunner descendenten in plaets laten. Ende soo doendesal het radt gestadich draijen sonder stil staen. Schippers, Stuerluijden, Timmerluijden tot gemeen volck incluijs Ofticieren, Soldaten ende Bootsgesellen connen u.Ed: onbeschroomt met haer vrouwen ende kinderen herwaerts licentieren midts dat resolveren tot veel jaren verblijf ende die daer toe niet can verstaen mogen alleen comen. Dese luijden cunnen haer families in Batavia en elders hier te lande beter coop onderhouden als in Nederlant. T'is wel soo de geringe in dienst wesende personen behoeftich sijn ende maentelijck hun betalinge genieten, maer dat moet weder in Comp's casse comen voorde nootwendigheden die van de Comp comen te trecken. Verscheijde personen hebben voorschrijven aen u.Ed: versocht op dat haer vrouwen gelegentheijt mocht gegunt werden met u.Ed: schepen over te comen, 't welck versoecke effect sorteren magh.

In alle manieren sal dienen stricte ordre gegeven, soo u.Ed: resolveren den handel volgens ons schrijven voor de vrije coopluijden open te stellen. Datter geen aenschrijven op Comp's dienaren toegelaten werde, maer sulcx door personen buijten Comp's dienst geschiede. Selffs behooren de getrouwde Comp's dienaren soo lange Comp's gagie trecken ende in dienst sijn haer eijgen middelen (zoo enige mogen hebben) niet te benificeren, maeer deselve onder factoors te stellen om geen preferentie op den burger $t^{\prime}$ usurperen, dat nu wat veel in swangh gaet. Goet reglement sal bij dese gelentheijt op den vrijen handel dienen geraaemt, t'selve sonder de minste conniventie gemaintineert. Ende sal den Wingierigen Mensch niet in termen te houden sijn, als door harde straffen volgens de placcaten daerop te raemen, want het scheelt veele weijnigh oft het vande Comp. oft den vijandt halen, gelijck t'volgende verhael in desen de waerheijt claer affirmeert:

Anthonio Varelle ende Comp.e Portugese coopluijden op den $22^{\text {ste }}$ passato alhier per sijn Cloe of Joncke van Maccause gearriveert, met sijde 
stuckwercken, geconfijte gember ende wortel China, met intentie alles aende Comp. te debiteren. Gelijck dienvolgende sulcx emmers t'gene voor de Comp. dienstich oordelen in onse magasijnen deden discargeren omme opt gesicht daerover met de Coopluijden prijs te maecken. Interim hebben eenige baetsoeckende erglistige personen den voors. Maccausse Coopman Anthonio Varelle gepersuadeert bedecktelijck in Comp's magasijn onder sijne maccausse sijde stuckwercken te schuijven partije slechte chinese sijde stuckwercken, voor jaer en dagh van de Chinesen gekocht, omme alsoo voor goede maccause stoften op den portugesen g'exhibeerde monsters de Comp. te doen betalen.

Onaengesien den gouverneur generael ende den directeur persoonlijck opt magasijn gecomen waren omme de Maccause sijde stuckwercken te besichtigen ende van de portugesen te contracteren, waere door oock dese fraude ontdeckt is geworden, sijnde in alles ses canasters met 150 stux damasten, brocades, grofgreijenen ende sattijnen, alles slechte vodden. Dat wel een groote stoute impudentie is de Comp. te willen bedriegen in hun eijgen huijs, midts daer steelswijse goederen brengende, die niet gelast sijn te herbergen ende dat noch van luijden die bij u.Ed: aen de Comp. fidiliteijt verobligeert sijn, schoon het een burger mochte wesen. Alsoo wij niemant exempt houden van de Comp. trouwschuldigh te sijn, t'zij vrije oft dienstbare. Maer dese sinistere practijcque bij ons ontdeckt sijnde, hebben de canasters op stont door den fiscael doen lichten bij gecommitteerden laten insisteeren ende versegelen en naderhant bij resolutie des Raedts van India (omme soo snode saecken parate te corrigeren ende aen te sijsen dat niet begeren met de regeringhe gespot, veel minder deselve gefraudeert) gemelte stoften bij provisie verbeurt verclaert, namentlijck een derde ten behouve van den armen deser stede, een derde voor de Batavise kerck ende t'resterende derde part voor den advocaet fiscael. Wanneer den eijgenaer sich openbaert sullen den zelven voor den Raet van Jusitie doen betrecken en soodanigen noch corrigeren als het voorgenomen bedroch verstaen wort te meriteren. Vertrouwen soodanige slagen wel sullen leeren anderen in toecomende omsichtiger te wesen ende de Comp. ( die niemant tracht te verongelijcken) wel ongeroert sullen laten.

Veele andere dingen daer metterteijt redres in vereijschen soude wel conne voordragen, maer dewijle uijstel mogen lijden, sullen supercederen tot personele verschijninghe alsoo de selve met beter fondament mondelinge als schriftelijck te remonstreren vallen ende ondertusschen niet nalaten meesten dienst van de Comp. int werck te stellen ende proftiteleijcke saecken niet langer verbij gaen, als den welstandt van Comp's affairen herwaerts over vereijscht, daer op u.Ed: hun wel verlaten mogen.U.Ed: laten ons voorsteaen den tijt geboren is dat sonder nabedencken en verachteringen van negotie verscheijde Comptoiren sul- 
len mogen intrecken ende den handel in Batavia als Malacca vergrooten. Den peper sal ons van Palimbangh ende Jambij (onaengesien daer geen volck houden) niet minder ontstaen als die van Benjarmassin, Andrigirij ende andere plaetsen. Sulx dat voor eerst een preuve van Palimbangh meenen te nemen ende sijn geresolveert desen jare derwaerts egeene besendingh te doen als eenlijck den Pangeram te begroeten ende vruntschap te houden. Den peper sal ons wel t'huijs gebracht werden, gelijck rede geschiet. Dienende Comp's middelen onder dit quaet en crom geslacht niet anders als tot onderpanden. Jamby (dar een costelijcke logie hebben ende d'Engelse hun principale cracht baren) sal men noch voor eerst moeten continueren, maer van tijt tot tijt besnijden. Ondertusschen de particuliere ende vreemdelingen daermede invoeren omme door die de peper herwaerts te brengen. T'is nu als geseijt den rechten tijt, dewijle d'Engelse door hun Inlantsche oorlogen hier te lande bij nae buijten posture raecken, ende apparent bij aldien de troublenen in corte niet cesseren t'eijnde adem sullen wesen. Van den Deen wort mede niets vernomen. Sulcx nu ten principale met den Portugees staen te woelen ende die gelijck wij oock sijn ter wederzijde gelimiteert ende als ijder in sijn limiten blijft, can niet bedencken ons seer schadelijck sullen wesen. Invoegen geschapen staet de oncosten veel sullen connen werden besneden, ende groote equipagien te minderen, Batavia ende Malacca in negotie t' accresseeren ende d'Incomste te wassen, twelck ons ooghmerck ende wit van deze costelijcke rendevousen zij. Op Ceylon sal voor eerst noch groot garnisoen soo voor d'ondercruijpinge ende list der Portugesen als den troubelen aen beijde sijde manck gaende Raja singa gehouden moeten werden, dat verhope de vruchten des lants goet maecken sullen. Als van Comp's gerechtigheijt op dat landt door u.Ed: niet gecedeert dient, daer vertrouwe den portugees omtrent de regeringh in Europa hert om aenhouden sal, alsoo schijne van de eijgendom des landts niet te willen affstaen. Maer t'gene op Raija Singas naem van haer met den swaerde geconquesteert hebben als gedepositeerde landen in ons gewelt laten, tot nader decisie van onse ende hare respectieve souverainen. daerop wel verdacht moet wesen in Comp's prejuditie costij niet iets gederneeert werde, maer vertrouwe gelijck billick ende recht is, de landen van Gale ende Negombo sullen verstaen worden wel geconquesteert te wesen ende dienvolgende onder den staet van onse landen te blijven sorteren tot dienst van de generale Oostindische Comp., dat ons aengenaem tsijner tijt te vernemen wert.

Meij wijders gedragende de gemeene saecke belangende aen onse generale missive daerbij u.Ed: nae uijtterste vermogen den presente consitutie getracht hebben t'informeren van alles dat weten te bedencken Comp's welstandt concernerende. Willen vertrouwen u.Ed: gelijck altijt gedaen hebt ons schrijven Credit sult geven, mitsgaders nae eijsch ende 
vermogen secondeeren soo in advijsen, ordre als effective waermede afflatende. Come weder tot mijn particuliere ende blijven u.Ed: versocht op reeckeninge van mijn jongste drie jarige verbant anno passato in July verschenen tedoen stellen aen mijn swager Pieter de Gruijiter een somme van veertich duijsent gulden tot $40 \mathrm{~d}$. den gulden. T'sal de Comp. voor betalinge strecken ende mij dienst ende vruntschap geschieden, noch meer bij aldien u.Ed: conden resolveren de helft sijnde 20.000 te houden tegen soodanigen interest als de Comp op dato is gevende. De rest oft $16.000 \mathrm{gl}$. versoucke dat in harde spetie aen voors. mijn swager de Gruiijter mogesn werden gestelt ende den den selven econsenteert gelijck bij de generale brieven versocht wert voor mijn reeckeninge en als vier duijsent Cruijsdaelders op e.ed: eerst vertreckende schepen herwaerts aen mijn gesonden mogen werden, tot belatinge van seecker kerxken oft Cappelle twelck op eijgen costen tot eene meorie hier binnen het casteel sal funderen. Daeraen oock Jaersdach I645 den eerste steen geleijt is. Dese vierduijsent Cruijsdaelders sijn hier in Batavia ruijm I2.000 gl. waaerdich, sooveel oock staet maecke de geprojecteerde kercke alhier ruijm sal comen te costen. D'afteeckeninge wort $\mathrm{u}$.Ed: tot speculatie gesonden. Evenwel soo meent dit senden van gelt de minste consequentie subject zij, can na blijven ende sullen dan echter tot de betalinge ( doch soo profitabel niet) gelt vinden. Wijders zij u.Ed: versocht ende gebeden voors. mijnen swager t'autoriseren oft macht te geven met Comp's schepen herwaerts te senden tot vloeringe van geseijde Cappelle achthondert soodanige viercante steenen als hem geordonneert hebbe ten fine voors. te coopen mitsgaders een Copere Croone. Dit alles consenteren sal mij aengenaemen dienst ende vruntschap geschieden. ende alhoewel dese contanten, steen nochte Croone niet sal inwachten, soo gelieft daeer op het consent niet uijt te stellen. Sal op den ontvange bij absentie behoorlijcke ordre laten. Soo sent mijne huijsvrouwe op reeckeninge van ons g'expireert verbant eenige rariteijten in een kist, een casse met een balie porcelijn voor de vrunden ende ons eijgen familie, die versoucke aen mijn swager mogen werden ter hant gestelt. In een derselver gaen drie drie loode dooskens met muscus, mij t'zedert twee jaeren van drie differente maccause portugese Coopluijden vereert. Bij aldien $\mathrm{u}$.Ed: t' zelve advoueert is t'procedido gedestineert tot betalinge van de 800 vloer steenen tot de vloeringe van onse Cappelle nodigh. Oft $u$.Ed: voor 't expireren vant Octroij ende veranderinge van meesters sullen gedacht hebben op t'gene mij competeert voor gedane prinsen ende andere extraordinary diensten sal t'sijnet aengenaem vernemen, gelijck noch doe. Hiermede dan aftbreeckende wel den grooten god bidden des Comp's affairen meer en meer te zegenen ende te geven salich sijnde u.Ed: in July I646 mondelinge in gesontheijt mach begroeten, denselven goeden god gelieve uwe no- 
bele persone ondertusschen met alle prosperiteijt te begenadigen ende voor alle schade bewaren, neven cordiale gebiedenisse van

U.Ed: gedienstigen dienaer ende g'affectioneerde vrint Antonio van Diemen

Batavia desen 20 Januarij Anno i645.I

\section{Aanvulling van 6 februari I645, nagezonden per Engels schip}

T'voorstaende is de Copie van mijnen particuliere brieff per de schepen Haerlem en Banda aen de respective Cameren der Oostindische Comp. gesonden, die bij dese confirmere. Ende goet gedacht per de gelegenheijt des Engelsen Willem van Bantam na London vertreckende u.Ed: den selven nevens onse nader advysen toe te laeten comen, opdat u.Ed: tijtelijcken van mijn ernstige meeninge gepreadverteert mocht wesen. T'sederet des Comp. gelegetheijt de directie rakende, wat nader bij mij overweegt sijnde, te meer mij d'een en d'ander voorgecomen is, dat niet behoort gevonden te worden in personen de hooghste qualiteijten in India bedienende op dat het respect van soo achtbaren regeringh geen crack crijge. Wat van de saecke zij sal niet specificeren, maer mij tot d'inliggende attestatie en requeste gedragen, die u.Ed: soo wel als ick ponderen connen, en met mij oordeelen de nootsaeckelijckheijt van een aensienlijck, graeff ende consientieus persoon uijt Nederlant tot mijnen vervanger gesonden worden. Gelijck verhope reede gebeurt is, want verclare u.Ed: bij aldien geresolveert mocht werden, ingevolge mij ende den Raet geauthoriseert haddet op den bequamste hier in loco tot mijnen verlosser te setten ende den selven bij provisie tot het generale gouverno t'eligeren, dat ons al wat verstelt sullen vinden. Ten aensien als daer toe souden promoveren den directeur de hr. Cornelis van der Lijn, die oock de ervarenste in Comp's saecken hier te lande is en de oock wel de capabelste. Dat dan comt te manqueren een bequaem directeur, nodich tot des generaels assistentie. Daertoe egeen bequame can voorstellen als d'heer Francois Caron. Als wanneer t'gouverno van Formosa comen te vaceren, waertoe Maximiliaen le Maire soo vertrouwe sich wel soude laten gebruijcken. Maer uijt verscheide inditien ende dat selver bevinden, in den cleenen tijt sijns aenwesens seer groote middelen bijeen geschraept heeft, blijve in den persoon geheel ongerust ende sal mij nader op sijn actien informeren. T'is sulcx dat aen de moeder van sijn hujsvrouw, die na dat met deselve een cleenen tijt getrouwt is geweest afgestorven is, herwaerts aen de moeder wegen haer dochters erve daer hij niet een penninge van genoten heeft, remitteert drie duijsent realen van $8 \mathrm{en}$ in spetie ende wordt geseijt noch veel inTayouan 
uijtstaende heeft. Daerenboven reede nae Nederlant per wissel geremitteert 2000 reaelen van 8en. T'scheijnt dat gemelte Le Maire alleen niet is, maer bij meer anderen veel particulariteijeten in swangh gaen. Ende als sulx bij den principalen gehanthaeft wert, soo is de Comp. ellendiger. U.Ed: hebben ondertussen te vertrouwen, dat in dese saecke discretelijck sal gaen ende trachten alle vuijligheden te weeren nae uijtterste vermogen, doch goede assistentie is mij daer toe nodigh.

Omme ront $\mathrm{t}$ gaen met d'aenwesende Raden comuniceerde de heeren mijnen particulieren brieff ende affirmeerde haer mijn uijtterste meeninge $u$.Ed: bekent maeckte, d'heer van der Lijn verclaerde daer op sich selver niet capabel tot het generale gouverno kende, dat voor complementen oft excusen sonder intentie oordeele. T'is soo het wil mijn advijs ten dienste van de Comp. is, dat een gerequireert persoon tot het hooghste ampt uijt nederlant behoort gesonden te werden ende dat d'heer van der Lijn onder desselfs regeringe het directeurs ampt waerneme, maer u.Ed: moeeten letten op soodanigen persoon die concienteus is, alle particulariteijten onder groot ende cleene in swangh gaende were, respect ende ontsach onder sijn Raden heeft. Dit hebbe tot mijner ontlastinghe niet conne verbij gaen, maer t'selve per dese gelegentheijt te cundigen, op dat u.Ed: goede resoltie neme, soo u.Ed: wijsheijt weet te behooren. Den Indische stant is god loff sulcx, dat die een cleenen misslach weijnigh can deeren ende alles can op nader bevindinge geredresseert werden. So als geseijt, t'zij mijnen verlosser comt oft niet, blijve geresolveert in december d'Indias te verlaten, mijnen dienst aft te leggen en u.Ed: tegen Julij I646 mondelinge raport te doen, daertoe den Almogenden sijnen zegen geven, in wiens heijlige bewaringe $u$.Ed: en Comp's affairen bevolen wil laten en blijft gegroet,

U.Ed geaffectioneerden ende trouwschuldigen dienaer

Antonio van Diemen

Int casteel Batavia

6 februarij 1645 


\section{Bijlage 6}

Beschrijving retourlading 1641 met opbrengsten en winsten

\begin{tabular}{|c|c|c|c|}
\hline 음 & 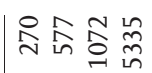 & 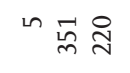 & 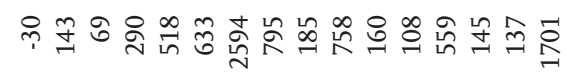 \\
\hline 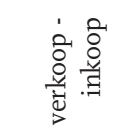 & 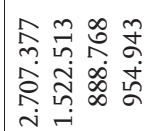 & 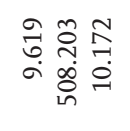 & 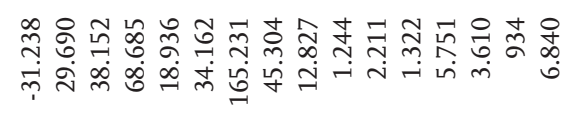 \\
\hline 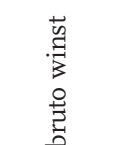 & 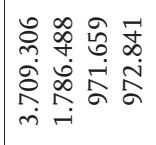 & 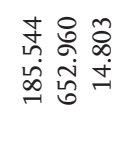 & 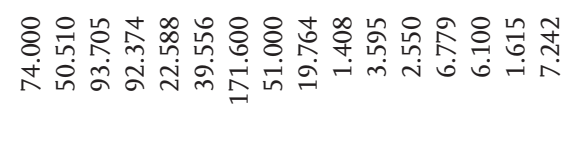 \\
\hline 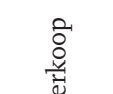 & 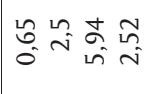 & 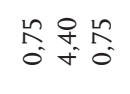 & 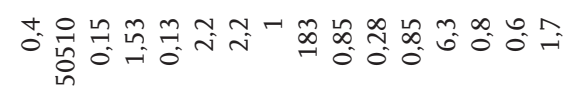 \\
\hline оి & 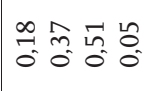 & 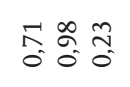 & 会 \\
\hline 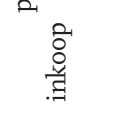 & 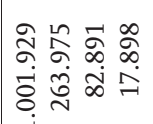 & 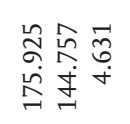 & 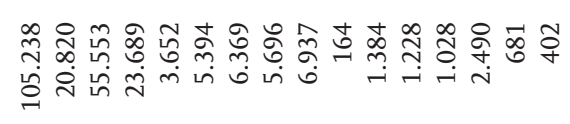 \\
\hline 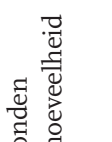 & 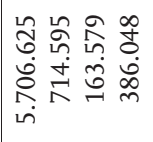 & 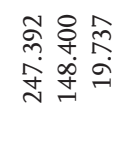 & 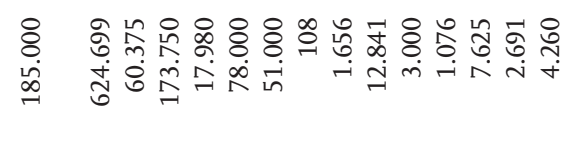 \\
\hline 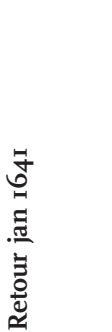 & 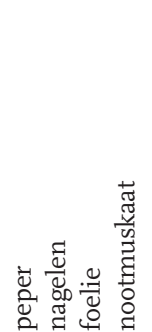 & 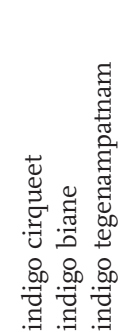 & 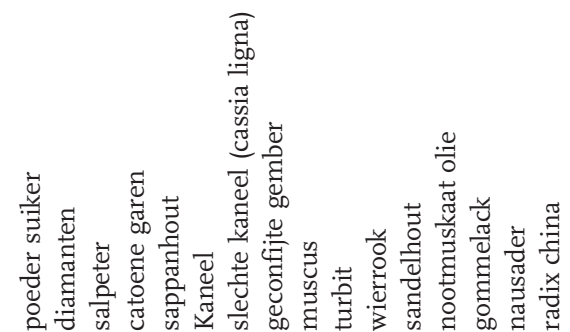 \\
\hline
\end{tabular}


苛 $\vec{m}$

: : :

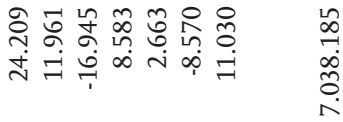

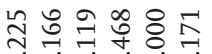

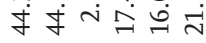

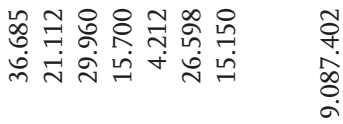

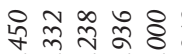
$\infty \infty \dot{\infty} \infty \dot{m} \tilde{m}$

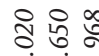

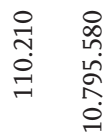

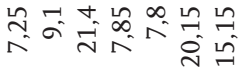

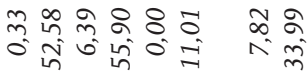

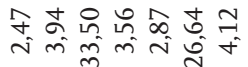

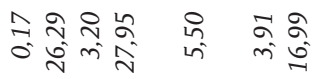

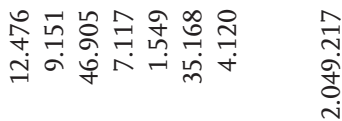

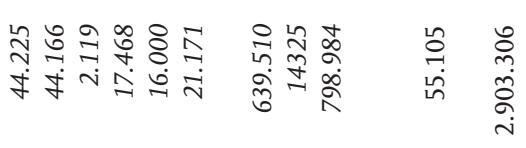

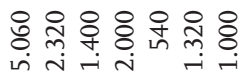

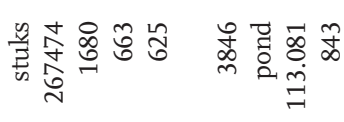

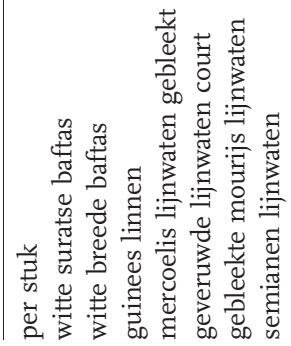

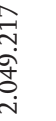

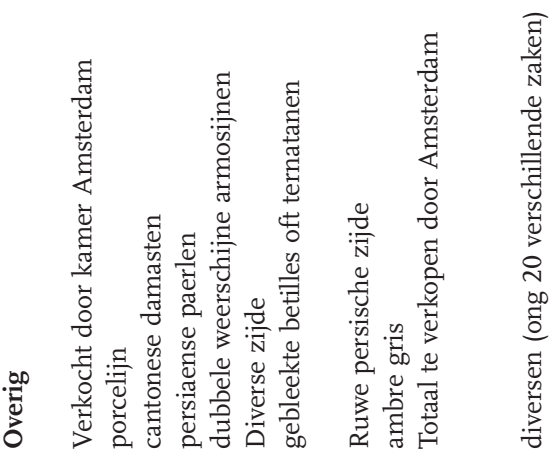


○ \&ें

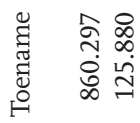

ல்

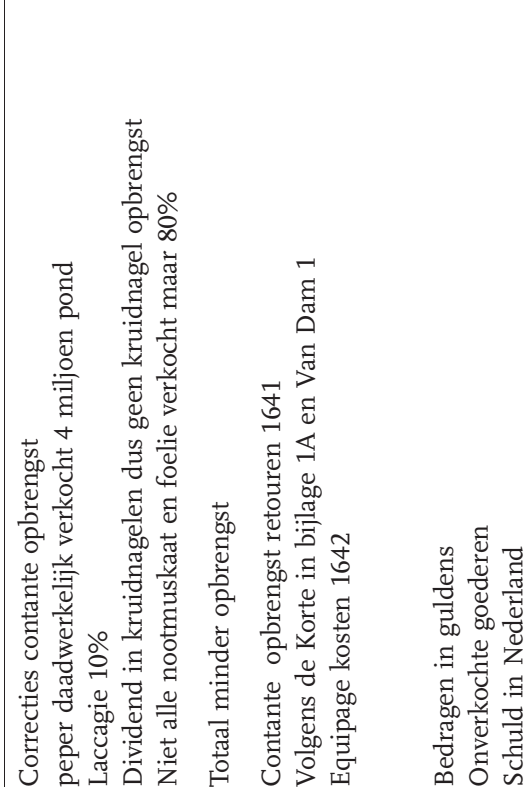

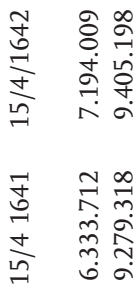




\section{Bijlage $7^{1}$ \\ Testament Antonio van Diemen en Maria van Aelst opgemaakt 4 oktober 1632}

'In de names des Heeres Amen, wij Antoni van Diemen ende Maria Aelst echteluijden, maecken condt ende kennelijcken eenen ieder, dat wij aenmerckende de brosheijt der menselijcke natuere die niet seckerder onderworpen is dan de doot, ende niets onseckerder dan de uure derselver, willende daeromme van onse tijtelijcke goederen ons bij Godt almachtich verleent, ende noch te verleenen,

disponeeren alleer wij door de doot daer van geprevenieert werden, hebben ingestelt gemaeckt ende gewilt desen onsen testamente ende vuytterste wille verclaeren, gelijck wij voor onsen testamente ende vuytterste verclaren 'tgeene hiernae volcht.

Erstelijcken soo revoceren wij, reciprocquelijck soodanige houwelijckse voorwaerden ende testamentaire dispositien als wij 't samenlijck off ijder bijsonder voor dato deeser gemaeckt ende opgericht hebben, deselve verclaerende voor null crachteloos ende onwaerde.

Ende naeder opnieuwe disponerende bevelen wij onse Zielen, soo wanneere die vuyten lichaeme gescheijden sullen wesen, die grondeloose barmhartichheijt Godes ende de lichaemen de christelijcke begraeffenisse.

Legateren voorts de armen driehondert gulden tot 2I stuyvers hollants 't stuck, 't selve de armen uytte rijcken bij den lancxtlevende van ons beijden, ses weecken nae den eersten overleden is, ende dat aen alsulcke armen als de langstlevende goet duncken sal.

Legateert noch bij testateur [dat is Antonio] aan Anna van Diemen, sijn outste Suster, huijsvrouw van Peter de Gruyter de somma van dry duijsent guldens,

aen Elisabeth van Diemen dry duijsent guldens, ende aen Hendericxjje van Diemen, huijsfrouw van de edele Johannes van Ravensway dry duijsent guldens ende bij het afsterven van alle deselve sijns susters opt de selver erven.

Noch maeckt hij Christina de Gruyter, sijn suster dochter vijffhondert guldens ende

Christina van Ravensway oock sijn susters dochter vijffhondert guldens, all welcke legaten de voorschroeven sijns susters ende derselver erven sullen uitgereijckt worden een jaer en zes weecken na sijnen overlijden. 
Ende ick Maria Aelst maecke eerste mijne Vader Aelt Jans ende mijne moeder Aeltjen Aerts in plaetse van de legitime partie soo henluyden in rechten in mijne na te laten goederen soude competeren de somma van tienduijsent guldens, 't selve haer uitgereijct te worden een jaere ende ses weecken nae mijnen overlijden. Maecke noch den voornoemde vader ende moeder (bij affsterven van hunluijden derselver erven) de somma van thienduijsent guldens, eerst uitte reijcken nae mijn ende mijnen mans overlijden.

Item legateren ende geve Aert Aelst, mijner broeder de somma van drijduijsend vijffhondert guldens, mede uijt te reijcken een jaer en ses weecken na mijn overlijden. Ende Anna Aelst mijn suster, oft bij affsterven van hun luijden derselver erven drijduijsend vijffhondert guldens, mede uijt te reijcken een jaer en ses weecken na mijn overlijden. Noch soo legetere ick mijnen mijnen broeder vijfduijsent guldens ende mijn suster vijffduijsent guldens, uijtgerijckt te worden nae mijn ende mijn mans overlijden. Item geve ick Geertjes Barent hondert guldens, aen Jacomijne Marchijs tot Rotterdam seshondert guldens, soos ij mijnen doot overleeft, anders te comen op mijn eijgen broeder ende suster, ende selver erven. Maecke ende legateren mede Emerentia Schatters, bij aftlijvicheijt van haer, hare kinderen drijhondert guldens, mits dat bij overlijden van de voorschreven Emerentia's kinderen 't selve legaat weder sal comen mijn testatrices hele broeder ende suste rende haren erven.Desedie legaten mede uijtte reijcken een jaer ende ses weecken nae mijnen overlijden. Dit alles soo wij comen te sterven sonder kinderen (bij den anderen geprocreert) nae te laten. Hebben wij testateur en testatrice voorts tot onse eenige ende universele erffgenaeme over ende weder over reciproce soo wij deser werelt comen t' overlijden sonder kinderen bij den anderen geprocreert nae te laten alsvooren genomineert ende geinsitueert, gel;ijck wij nomineren ende institueren mits desen in alle onse na te laten goederen egeene uitgesondert, de langst levende van ons beijden, omme alle de selve goederen, behalve de voorschreven legaten, als eigen goet te hebben en te behouden, als sijn of haer vrij eijgen goet. Nochtans op dese navolgende conditien te weten soo wij beijde op de reijse die wij voornemens sijn te doen nae Indie, off int wederkeeren quamen te verongelucken, dat alsdan onse goederen boven de voorschreven legaten, stervende sonder kinderen alsvooren, comen aen beijdersijts rechter erffgenamen. Mede oock soo een van beijde op de reijse int lant ofte wederkeeren quame te overlijden, ende de langstlevende schade van scheepsbreucke off andere notabele quade fortuijne in hare goederen quame te lijden, dat alsdan de legaten wedersijts gemaeckt bij de langstlevende sal mogen vermindert worden een quart part, ieder nae advenant hem gemaeckt is. 
Voorders willen wij, Testateur en Testatrice dat alle 'tgeene den testateur soo hij quame te overlijden op den reijse naer Indie, of wederkeeren, tot sijn sterffdach toe mocht aencomen van sijn gagevan de Oostindische Compagnie, d'een helft daer van comens al ende erven op sijn huijsvrouw ende de ander helft op des testateurs susters ende rechte erfgenamen, inschelijck oock bij bij afsterven van de testatrice de voorschreven gage tot haren overlijden toe, te comen d'een helft opten testateurs heuren man, ende d'andere helft op den testatrices erffgenamen, den testateur ende testatrice heur ende heuren erven inde voorschreven gagieingevalle alsvoorschreven onvermindert de voorafgaende hare gedane institutie, instituerende. Noch wil ick, testatrice, dat soo mijn voornoemde vader voor mij comt te sterven, dat als dan ende anders niet, mijn halve suster Trenske Aelst mede een jaer en ses weccken nae mijn overlijden een legaat sal uijtgerijckt worden van duijsent ende vijffhondert guldens, daervan sij alleen maer sal genieten den jaerlijcksen interest, blijvende heet capitael verbonden op haere kinderen, item maeckt ende legateert int gelijcke conditien soo haer vader voor haer overlijt, Hendrick Aelst de somme van vijhondert guldens, doch sonder verbants subject te sijn. Waermede ick wil dat de voorschreven Menckes ende Henrick van haer na te laeten goederen sullen affstaen sonder iets meer te mogen pretenderen in eenige manieren. Ende soo het voorschreven legaat niet quame te vallen, dat is dat haer vader heurer testatrices doot beleefde, soos al hetselve coomen op harer helen broeder ende suster, ende derselver erven. Lestelijck so is noch mijn testatrices wille ende begeren, dat bij aldus mijn broeder mijn doot niet en beleeft, $\mathrm{t}$ geene ick haer hierboven gemaeckt hebbe, alles sal comen op mijnen helen broeder ende suster ende derselver erven.

Alles welcke wij testateur en testatrice verclaren te wesen onse testamentee ende uijtterste wille, willende ende begerende dat den inhouden van dien na onses overlijden volcomentlijck achtervolcht sal worden, ende sijn effect sorteren als tastament, codicille, gifte ter facto end edoots ofte ondeer den levenden oft eeniges anderen uijttersten wille, al waert het soos at alle de selven intelijcke naer rechten off coustumes van den landen hierinne niet mochtenwesen geobserveert, jae eenige van dien geommitteert, voorbehoudende aen ons nochtans se macht van dese maecken ten alle tijden te mogen veranderen, verminderen, vermeerderen, soo ons sulcxs goet duncken sal. Alles sonder arch, toirconde deses met mijn testateurs eijgenhant geschreven ende met ons beijder schriftelijcke name beteijckent, ende met mijn testateurs signet hier onder gedruct, gedaen binnen Culenborch inden jare onzes heeren duysent zeshondert twee ende dertich des vierden october,

Ende was onderteijkent, Antonio van Diemen ende Maria Aelst, ende met sijn Diemens signet in roode lacque opt spatinne gedruct, In dozt 
so vant pampier daerinne dese uijtterste wille beslooten ende besegelt was, tout geschreven.

'Gijsbert jans schepen der Stadt Culemborch verconden dat wij op huijden ten versucke wegen Mevrouw Maria Aelst weduwe sijnde van de heer Antonio van Diemen in sijn leven Gouverneur Generael in Oostindie hebben ten huijse nog 4 regels toevoegen

in dorso met vijf zegels gesloten' De zegels worden onbeschadigd bevonden.

De handteekeningen onder de zegels zijn bekend; de stads secretaris Huibert van Diemen en de schout ende schepenen, Maria Aelst en Antonio van Diemen.

Het testament werd geopend op 25 augustus 1646 .

Op I34 recto staat:

Dit testament is gemaakt tijdens het verblijf van Antoni en Maria in Holland en wel 4 oktober $\mathrm{I}_{32} 2$ in Culemborg. Ondertekent Antonio van Diemen en Maria Aelst ende met sijn Diemens signet inde roode laque opt spatinne gedructin dorsoo vant pampier

Wij schout ende schepenen der stadt Culemborch onderschreven ende getuijgen dat voor ons in eijgenen persoonen .... ende bij goeden verstande gesondheijt sprake ende memorie bevonden sijn d' Antoni van Diemen ende Maria Aelst ..... de selve Maria ..uintatoxe ende verclaerden int pampier daer dit buijtenste omsloten is, geschreven te hebben ende te sijn uitte eijgen hant van Antoni van Diemen coorict ende int heurbeijder wijder Eijgener handen gesigneert.

\section{Noot}

I. Zie bijlage 8. In zijn laatste wil liet Van Diemen aan zijn neef die hij ten doop gehouden had 500 gulden na. 


\section{Bijlage 8 \\ Testament van Antonio van Diemen dd 16 april 1645}

Testament van den Edelen Hr Antonio van Diemen, gouverneur generael van Indien

In den name godes amen. Bij dese openbare instrument, sij ijdereen condt, ende kennelijck, hoe dat in de Jare onzes heeren ende salichnaker Jesu Christij duijsent seshondert vijfenveertich op den IGde dach des maent april ick, ondergetekende Johan van Zijll, secretaris van de Raet van Justitie des Casteels Batavia, nevens de mede genoemde getuijgen, geroupen waren ende gecompareert sijn voor den Edele hr Antonio van Diemen, gouverneur generael van Indien, sieck te bedde leggende, nochthans sijn verstant ende sinnen volcomen machtich ende gebruijckende, gelijck ons uijtterlijck bleeck.

Ende heeft sijn Edele met verstandighe clare woorden te kennen gegeven ende verclaert, hoe dat ten aenschouw vande broosheijt des menselijckes levens, dat niet seeckerder zij dan de doot ende niets onsekerder dan de tijt ende uijre van dien, ende niet wetende wat Godt almachtich met sijn sieckte mocht hebben voorsien, om niet uit dese weerelt te scheijden sonder alvoorens van zijne tijdelijcke middelen te hebben gedisponeert, opdat om de selve nae sijn overlijden, tuschen de erffgenamen geen different quame te vallen, willens ende voornemens was geworden sijn testament ende uijtterste wille te maecken ende heeft het selve gemaeckt in de forme ende maniere als volgt.

Eerstelijck so beval sijn Edele testateur sijn siele soo wanneer die uijt deser werelt sal scheijden in de genadige handen van Godt almachtich, ende sijn lichaem de christelijcke begraefenisse tot een salige opstandinge.

Voorts soo heeft hij edele testateur gerevoceert, gedoot ende vernieticht, gelijck hij revoceert, doot en vernieticht mits desen, alle voorgaende testamenten, codicilen ofte andere testamentaire dispositien, die bevonden worden voor desen gemaeckt ofte gepasseert te hebben, waer en voor wie deselve oock souden gemaeckt ofte gepasseert mogen sijn, geene uitgesondert, verklarende d'selve van nu voor altoos voor nul ende geene waerde. 
Waer mede dan comende tot dispositei sijner tijdelijcke mideelen, hem godt almachtich verleent, soo heeft sijn edele testateur daervan gewilt ende bevolen als volght.

Eerst soo maeckt ende legateert sijn edele testateur aende christelijcke armen de somme van duijsent guldens eenen van xx stuyvers het stuck: te weten aen de armen van Cuijlenbruch, sijn testateurs geboorteplaets de somme van vierhondert guldens, ende die van de stadt Utrecht ende dese stadt Batavia elck driehondert gulden.

Voorts aen sijn familie ofte huijsdienaren het volgende:

aen de jongens Antonij, Jan, Hendrick, Diogo elck veertic, ende cleijne Diogo twintich gelijcke guldens. Aen Monica van Bengale hondert, aen Annica van Borneo ende Elisabet van Java elck tweehondert ende aen Catarina en Esperance eld vijftich guldens. Aen den hooftmeester Matthijs Jansz hondert, aen de opperchirurgijn ue Pieter Andriesz ende ue Andries de Reus ijder driehondert gulden.

Voorts soo legateert, maeckt ende bespreeckt sijn edel testateur aende nagelaeten kinderen van sijn edele huijsvrouwen broeder Aert Aelst zal, Willen, Jan ende Hendrick Aelst, ijder dijsent guldens. Aen Anthonij Houvenaer, soone van Frederick Houvenaer, burgemeester tot Cuijlenburch ende aen Antonij van Diemen, soons soone van Joost van Diemen, mede tot Cuijlemburch, die sijn edele testateur ten doop gehouden heeft, ijder vijffhondert guldens eender.

Wijders soo legateert sijn edele testateur aen sijn suster Anna van Diemen, huijsvrouwe van Pieter de Gruyter tot Utrecht, de somme van twintich duysent guldens ende aen der selver kinderen, Lambert, Willem, Bartolomeus ende Elisabeth de Gruyter ijder vijftien duijsent guldens eenen.

Aen Dirck van Ravenswaij, sone van sijn Edle jongsgte suster Hendrickje van Diemen zaliger, verwect bij den eerwaerdige Johannes van Ravenswaij in sijn leven dienaer des goddelijcke woort tot Cuijlenburch de somme van zesendertichduijsent guldens, doch met de expresse conditie, dat voorschreven Capitael sal werden vastgeseth, sonder dat het selve sal vermogen te vervreemden, beswaren, ofte belasten in enighen wijse, noch bij uitterste wille daer van bevelen maer sal de voorschreven somme van hem erven op sijne echte kinderen, ende van de selve op de verdere descendanten, ende die comende te deficieren op des Testateurs naesten bloet. 
Alle welcke legaten geexogeert ende uitgekeert sullen werden bij sijn Edele huijsvrouwe, ue vrouwe Maria Aelst, soo haest in vaderlandt werwaerts gaat in cas van sijn testateurs overlijden met de eerste retour schepen vertreckt, sal wesen gearriveert, sonder dat de legatarisen van den tijt die tusschen beijde loopende enighes Interest sullen hebben te pretenderen.

Voorts soo institueert sijn edele testateur tot sijn eenige ende universele erffgename sijn gedachte edeke huijsvrouwe ue vrouwe Maria Aelst in alle sijne verdere goederen ende middelen geene ter weerelt uitgesondert, met vole recht van institutie om met deselve te doenals haer geliefte ende wegevallen, sonder iemants tegen seggen, mits dat haer de voorgenoemde legaten oock gehouden sal wesen uit te keeren, aen soodanige persoonen als haer edeke genoemt ende op schrift gegeven heeft de somme van twintich duijsent guldens ofte daer omtrent. Ende bij aldien deselve binnen de tijt van twee jaren niet te voorschijn quamen, nochte gevonden wierden, soo is sijn testateurs begeren, dat de sekve somme of te sodaniges deel als bij haren Edele blijven sal, gegeven sal worden aen den huijssittende armen der stadt Amsterdam.

Ende alsoo sijn Edele testateur boven sijn verdiende gagie enige deugdelijcke pretenties op de generale compagnie is hebbende, van welcken echter geen vaste staet maecken can, soo heeft gewildt dat het gheene van deselve sal comen tusschen sijn voorschr. nae te late weduwe ter eene ende de vijf kinderen van sijn genoemde susters met gelijcke portie hooft voor hooft gedeelt sal worden: mits dat de portie van Dirck van Ravenswaij voornoemt mede als boven vastgeseth ende niet vervreemt sal worden.

Dit verclaerde sijn edele testateur alsoo te wesen sijn testament, uijterste ende laetste wille, willende ende begerende hetselve voor ssulcx staet grijpen ende effect sorteren sal, ofte als codicil, gifte ter saecke des doots ofte eenige ander wijse, alwaert saecke eenige nodighe somenniteijten in desene vergeten mocht sijn, versoucken de heeren bewinthebbers ter camer Amsterdam, haer soo veel de verdiende gagie belangt, gelieven te drtagen akls executeurs gedaen ende gepasseert ten dage, maent ende jaer als boven. Onderstondt Antonio van Diemen ende oock lagen aen present Johannes van Zijll, secretaris als mede in margine present Joan Maetsuijker en Simon van Alphen.

Naer gedaene Collatie is dese met d'originele van woort tot woort d'accorde bevonden

Actum Batavia a d. 28 julij ao I645 


\section{Bijlage 9}

\section{Genealogie van de naaste familieleden van Antonio van Diemen (Culemborg)}

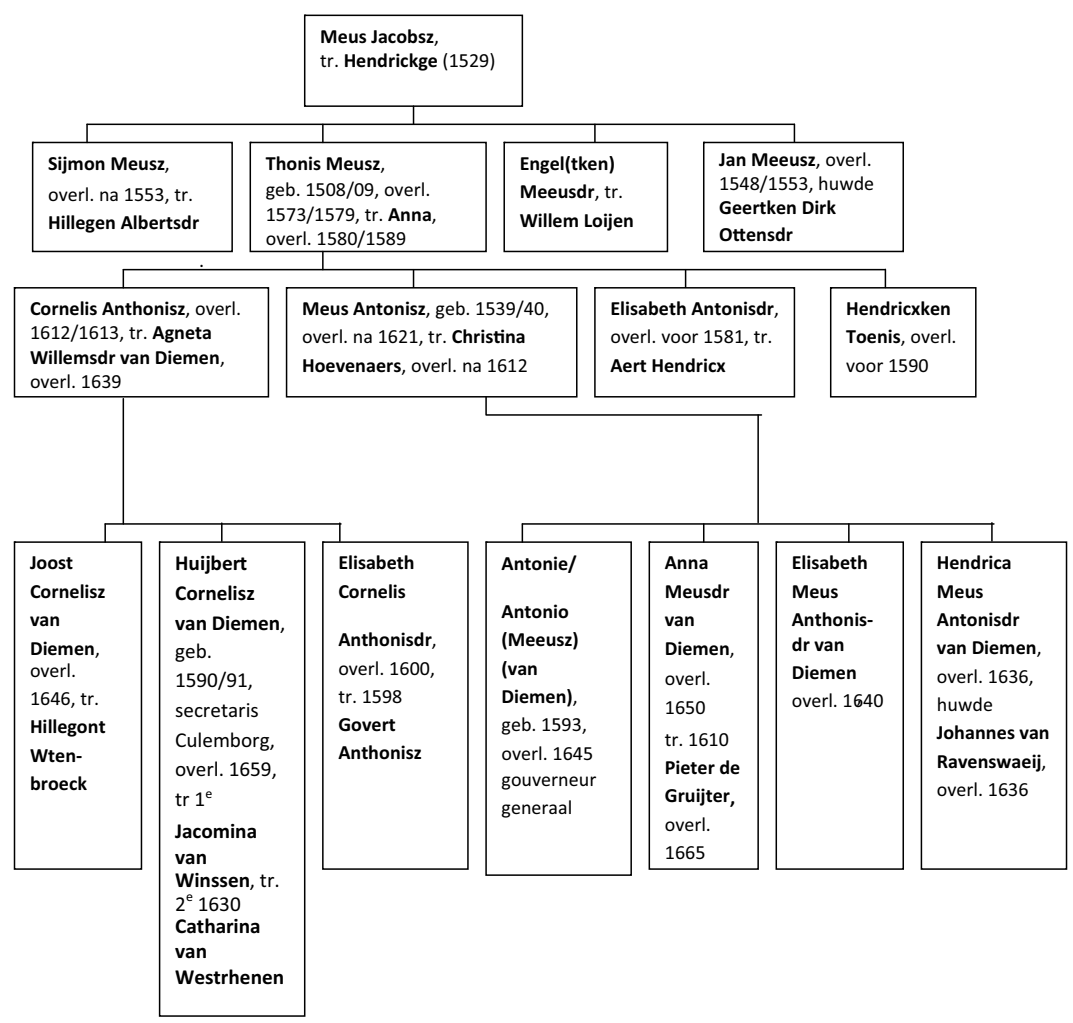

I. Meus (Meeus) Jacobsz, won. Culemborg, kreeg vrijgeleide voor de stad Utrecht I509, I5IO, I5I2, ', overl. voor 3 juli I539, huwde Hendrickge, sloot op 8 nov. I529 een rentebrief af samen met haar zoon Sijmon Meusz, ${ }^{2}$ overl. voor 3 juli I539.

Uit dit huwelijk (willekeurige volgorde):

I. Sijmon Meusz, wrs. houthandelaar, ${ }^{3}$ won. Achterstraat te Culemborg (I552-I553), huwde (voor I5 juni I544) Hillegen Aelbertsdr, weduwe van Jan Claesz. ${ }^{4}$

2. Thonis, volgt IIa. 
3. Engel(ken) Meeusdr, overl. voor 24 febr. $1587,,^{5}$ huwde Willem Loijen, borg voor zijn zwager Sijmon Meusz (I543), ${ }^{6}$ pachter tienden van de graaf van Culemborg (I542), waarvoor zijn zwager Thonis Meusz zich borg stelt. ${ }^{7}$

Uit dit huwelijk:

a. Meus Willemsz, scheepstimmerman te Culemborg, overl. na 6 mei $1626^{8}$

b. Anna Willems, huwde Thoenis Thoenisz, overl. voor 24 febr. I587.

c. Willemken Willemsdr.

d. Henricken Willemsdr, overl. voor 24 febr. 1587 , liet kinderen na.

e. Eloij (Loij) Willemsz, scheepstimmerman te Culemborg. overl. tussen 24 mei I6I4 ${ }^{9}$ en 25 okt. I6I9, huwde Elizabeth Willemsdr. ${ }^{\text {IO }}$

4. Jan

IIa. Thonis (Anthonis, Thoenis) Meusz (Meeuse, Meeusz), geboren Culemborg I508/I509, schipper (I543, I565, I573) en handelaar (I565), ${ }^{\mathrm{II}}$ vervoerde o.a. haring, bezat huis in de Kattenstraat te Culemborg (I546I554), ondertekenaar van een rekest als aanhanger van de nieuwe religie (I566), ${ }^{\mathrm{I} 2}$ overl. tussen 9 juli I573 ${ }^{\mathrm{I} 3}$ en 6 mei I579, ${ }^{\mathrm{I} 4}$ huwde (voor 9 juni I540) Anna, testeerde 3 maart I580, ${ }^{15}$ overl. voor 4 april I589. ${ }^{\text {I6 }}$ [zie bijlagen $I I]$

Uit dit huwelijk:

I. Cornelis,

2. Meus, volgt IIIb.

3. Elisabeth Antonisdr, overl. voor 3 maart I580, huwde Aert Hendricx ${ }^{\mathrm{I}}{ }^{7}$ wrs identiek met de schipper met die naam, die op 20 februari 1589 een nieuw koggenschip kocht van de broers Eloij en Meus Willemsz, neven van zijn echtgenote. ${ }^{\mathrm{I} 8}$

Uit dit huwelijk:

a. Aert Aert Hendricx, schipper, voor I/3 erfgenaam van zijn grootmoeder Anna en zijn tante Hendricxken Toenis (I589).

4. Hendricxken Toenis, overl. voor 4 april I589.

IIIa. Cornelis Anthonisz (Thonisz), lid St. Nicolaas- of koopmansgilde te

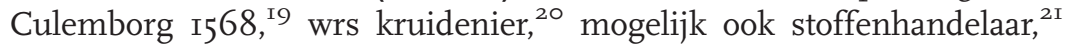
rentmeester van de kapel van Culemborg (I570/I57I, ${ }^{22}$ I576), ${ }^{23}$ potmeester $1579-1580,{ }^{24}$ rentmeester geestelijke goederen Culemborg, instructie I2 nov. I580-(I582), ${ }^{25}$ rentmeester van de goederen van het voormalige klooster Mariencroon I580-I582, ${ }^{26}$ I587-I6I2/I3, ${ }^{27}$ raad van de graaf van Culemborg I589-16ı2, verving Dirck van Baden als secretaris van Culemborg I9 sept. I573, aangesteld als 'garde des chartres ende apostillateur' I4 jan $1597,{ }^{28}$ raad en secretaris van de raadkamer van Culemborg, griffier van het leenhof van de graaf van Culemborg (I607), ${ }^{29}$ executeur van 
het testament van heer Ghijsbert Sijmonsz, priester ${ }^{30}$ in de jaren I575I579, ${ }^{3 \mathrm{I}}$ overl. tussen 29 maart I6 I2 en I6 april I6 I3, ${ }^{32}$ huwde (voor I7 april I570) ${ }^{33}$ Agneta Willems van Diemen/Agnietken Willem Joostendr, onmondig 20 sept. I567, begraven Culemborg 29 mei I639, ${ }^{34}$ dochter van Willem Joosten (van Diemen) en Elijzabeth Engbert Engbertsdr.

IIIb. Meus (Meeus, Bartholomeus) Antonisz (Toenisz), geboren I539/ I540, burger Culemborg (I579), schipper, voer o.m. langs de tol te Emmerik (voor of in I579), ${ }^{35}$ leverde na de reformatie aan de kerk van Culemborg de avondsmaalswijn, ${ }^{36}$ potmeester I590-I592, stadsburgemeester I594-I595, I602-1606, I609-I6I3, lid St. Nicolaas of koopliedengilde I598,, 37 overl. na 26 april I622, ${ }^{38}$ huwde Christina Hoevenaers, overl. na 22 juni $\mathrm{I}_{\mathrm{G}} 3$, dochter van Lambert Hoevenaers en Elizabeth Peter Gerritsdr (van Eijndhoven). ${ }^{39}$

Uit dit huwelijk: ${ }^{\circ}$

I. Antonie/Anthonio (Meeusz) van Diemen, geboren I593, legateerde onder meer aan Anthonij van Diemen, zoons zonen van Joost van Diemen te Culemborg 500 gld. (I645) en 400 gulden aan de armen van Culemborg, ${ }^{4 \mathrm{I}}$ overleden I9 april $\mathrm{I} 645,{ }^{42}$ begraven Batavia 22 april I645, overluid Utrecht 26 januari I646 (Dom), ${ }^{43}$ huwde (otr. Batavia I7 jan. I630) Maria van Aelst. ${ }^{44}$

Anna Meusdr van Diemen, volgt IVc.

Elisabeth (Lijsbeth) Meus Antonisdr van Diemen, testeerde te $\mathrm{Cu}$ lemborg 7 sept. I636 en I9 april I638,45 lidmaat Utrecht 25 september 1638 met attestatie van Culemborg, won. Lijnmarkt bij haar zuster en zwager te Utrecht (1638-I640), ${ }^{46}$ overl. aangeven Utrecht I2 oktober 1640,47 begraven St. Jacobskerk te Utrecht.

4. Hendrica van Diemen, volgt IVd.

IVc. Anna Meusdr van Diemen, overl. aangegeven Utrecht 4 maart I650, begraven Utrecht (St. Jacobskerk, te laat in de kerk, $f$ I2,-), huwde (otr. Utrecht, attestatie van Utrecht op Culemborg om te trouwen ig sept. I6ıо) Pieter de Gruijter, afk. van Arnhem, broer van Johan de Gruijter, lidmaat Utrecht 2I september I620 op belijdenis (getuigen Cornelis Dircksz, Roelant Gerobulus), ${ }^{48}$ won. Lijnmarkt (1626, I6 60 , I665), overl. aang. Utrecht 8 mei I665, begraven Utrecht (St. Jacobskerk, I zwarte baar, I knecht, te laat in de kerk, $f$ I5,-).

Uit dit huwelijk:

I. Lambert de Gruijter, volgt Va.

2. Willem de Gruijter, raad en schepen der stad Utrecht (I655).

3. Bartholomeus de Gruijter, volgt $\mathrm{Vb}$.

4. Elisabeth de Gruijter, vermeld I dec. I647. 
5. kind, gedoopt Utrecht 4 juni I626 (Dom), begraven Utrecht 3 september I627 (St. Jacob).

6. Anna de Gruijter, gedoopt Utrecht 2 december I630 (Dom), overl. aang. Utrecht 2 maart I640 (St. Jacobskerk, te laat in de kerk). ${ }^{49}$

7. wrs. Jan de Gruijter, overl. aang. Utrecht 25 aug. I634 (St. Jacobskerk). ${ }^{50}$

Va. Lambert de Gruijter, wrs als lidmaat Utrecht $1629,{ }^{5 \mathrm{I}}$ wijnkoopman, lidmaat Utrecht Io juli 1644 met attestatie van Nantes van 7 april I644, ${ }^{52}$ voogd over Christina de Souter (I662), ${ }^{53}$ won. Lijnmarkt (I640), in de Watersteeg (1640), aan de Jacobikerk (I647), omtrent de Geertebrug (I654, I66I, I663), overl. aang. Utrecht 2 maart i663.

Vb. Bartholomeus de Gruijter, geb. Utrecht $1619 / 1620,54$ heer van Groenewoude, raadsheer Hof van Utrecht, burgemeester en ouderling Utrecht I646, won. aan het Janskerkhof (I657, I660, I669), octrooi te testeren van de Staten van Utrecht 6 nov. I646, overleden Utrecht 7 december I685, overl. aang. Utrecht 2I december I685, begraven Utrecht (Janskerk, de wapens gezonken), ${ }^{55}$ huwde (otr. Amsterdam en Utrecht 7 mei I655, attestatie van Utrecht op Amsterdam I3 mei I655) ${ }^{56}$ Maria Spekx (Specks, Spex, Specx), gedoopt Amsterdam (Nieuwe kerk) 8 juni I636, overl. aang. Utrecht 7 jan. I704, dochter van Jacques Specx, gouverneur-generaal Nederlandsch-Indië, en Maria Odilia Buys. ${ }^{57}$

Uit dit huwelijk:

I. Anna de Gruijter, gedoopt Utrecht 23 april I656 (Dom, getuigen: Peter de Gruijter, Geertruijt van Someren, Elisabeth de Gruijter), overleden 30 januari I699, begraven St. Jan (Utrecht).

2. Maria de Gruijter, gedoopt Utrecht II augustus I657 (Catharinakerk), wrs begraven Utrecht 5 okt. I657 (St. Jacobskerk, twee knechten, Dom groot geluid I uur).

3. Jaques de Gruijter, gedoopt Utrecht 8 februari I659 (Catharinakerk, getuige: Petertje), heer van Groenewoude (I693), overleden 30 mei I693, begraven St. Jan (Utrecht). ${ }^{58}$

4. Bartholomeus de Gruijter, gedoopt Utrecht 3I juni I66o (Dom, getuigen: Lambert de Gruijter, wijnhandelaar, en Petronella Buijs).

5. Maria Odilia de Gruijter, gedoopt Utrecht 27 augustus I66I (Catharinakerk, getuigen: Willem de Gruijter, raadsheer, Maria van Aelst, weduwe van Antoni van Diemen).

6. Petrus de Gruijter, gedoopt Utrecht 22 juli I663 (Dom, getuigen: Johan Cardam, vrouwe Maria Lennip).

7. Paulus de Gruijter, gedoopt Utrecht 4 september I664 (Janskerk, getuigen: Paulus Buijs, kapitein van een compagnie garde, en Petertje de Vries). 
8. Elisabeth de Gruijter, gedoopt Utrecht Io september I665 (Janskerk, getuigen: Everard Schot en Elisabeth de Gruijter).

9. Margaretha de Gruijter, gedoopt Utrecht I4 april I667 (Janskerk, getuigen: Heer Salomon Sweers, Joff. Anna Andriessen).

Io. Geertruide de Gruijter, gedoopt Utrecht 23 maart I668 (Janskerk, getuigen: de heer Johan Coenen en joffr. Elisabeth de Gruijter).

II. Paulus Buijs de Gruijter, gedoopt Utrecht 22 augustus I669 (Janskerk, getuigen: Paulus Buijs, Maria van de Guarde, en Anna Andriesz).

I2. Johannes de Gruijter, gedoopt Utrecht 7 december I670 (Dom, getuigen: de heer raadsheer Willem de Gruijter, joffr. Elisabeth de Gruijter, huisvrouw van de Hr. Simon de Blanckendael).

Van de bovenstaande kinderen is het overlijden aangegeven:

a. Utrecht Io aug. I668, begraven Utrecht (Janskerk, 50 gulden aan de armen).

b. Utrecht I2 juli I669, begraven Utrecht (Janskerk, 50 gulden aan de armen).

c. Utrecht I6 aug. I669, begraven Utrecht (Janskerk, 50 gulden aan de armen).

IVd. Hendrica (Hendrickje, Hendericxken) Meus Antonisdr van Diemen, testeerde te Culemborg I4 aug. I636,59 begr. Culemborg 28 aug. ${ }_{1} 636,{ }^{60}$ huwde Johannes van Ravenswaeij, geb. Culemborg ca. $1594,{ }^{61}$ predikant Jutphaas $\mathrm{I}_{6} \mathrm{I} 3$, vruchteloos beroepen te Breukelen I6 I9, beroepen te Culemborg ${ }_{1620},{ }^{62}$ testeerde te Culemborg 3 nov. I635, overl. aan de pest, begr. Culemborg 7 aug. $1636,{ }^{6} 3$ zoon van Anthonis Jansz van Ravenswaeij, schoolmeester/rector Latijnse school te Culemborg I585-16 $22,{ }^{64}$ en Haesken Dircx. ${ }^{65}$

Uit dit huwelijk: ${ }^{66}$

[zie bijlagen akten $\mathrm{XV}$ ]

I. Dirck van Ravenswaeij, onmondig 2I aug. $1646,{ }^{67}$ mondig 9 jan. $1647 .^{68}$

2. Bartholomeus Ravenswaeij, gedoopt Culemborg 9 nov. 1634 , jong overleden, mogelijk begraven Culemborg I7 aug. ${ }^{6}{ }_{3} 6$ (of één van de twee kinderen hierna).

3/4. twee kinderen, begraven Culemborg I9 aug. I636.

Bronnen en afkortingen:

$\mathrm{CBG}=$ Centraal Bureau voor Genealogie

GAR $=$ Gemeentearchief Rotterdam

HUA $=$ Het Utrechts Archief 
Kort, Culemborg = J.C. Kort, Repertorium op de lenen van de hofstede Culemborg I25I-I648 (I649).

$\mathrm{NA}=$ Nationaal Archief

OA Culemborg = Oud Archief Culemborg (Archief Rivierenland (Tiel)). ONA $=$ Oud Notarieel Archief

ORA Culemborg = Oud Rechterlijk Archief Culemborg (Gelders Archief).

Het archief van Heren en Graven van Culemborg bevindt zich op het Gelders Archief.

\section{Noten}

I HUA, SA I, inv.nr. I6 (buurspraakboek), f. II2, f. Iıзv, f. ıз6 en f. I39V.

2 ORA Culemborg, inv.nr. 235, f. I49, 7 juni I543 en f. I7I, 2 I jan. I544.

3 OA Culemborg, inv.nr. 275 (stadsrekening I546), f. 9v. Gekocht van Sijmon Meusz twee grote stukken hout van I2,5 Philipsgulden ten behoeve van de stad juli I546 om te repareren hetgeen dat nodig was, $f$ I5-I2-6.

4 Uit dit huwelijk:

a. Floris Jansz die een doodslag pleegde op Adriaen Dirck Damensz pleegde waarvoor zijn stiefvader Sijmon Meusz de betalingen deed (ORA Culemborg, inv.nr. 224, f. I66, 24 febr. I545).

b. Elisabeth Jansdr, begraven Enspijk, die gehuwd was Rochus Aertsz.

5 ORA Culemborg, inv.nr. I55, f. 58.

6 ORA Culemborg, inv.nr. 235, f. I24v.

7 ORA Culemborg, inv.nr. 224, f. 77, I juli I542.

8 ORA Culemborg, inv.nr. 227, f. II2.

9 ORA Culemborg, inv.nr. I36, f. 2ov.

Io ORA Culemborg, inv.nr. I36, f. I30v.

II T. Marseille, Varen op de grote rivieren rond I580. De tolboeken van I565, I582 en I603 over kooplieden, schippers, goederen en schepen. Culemborgse akten over scheepsbouw. Een verkennende documentatie, Leeuwarden 2002, p. 50.

I2 Voet van Oudheusden, Historische beschryvinge van Culemborg, p. 22. Thonis Meeuse op 6 mei I566 ondertekenaar van een rekest (aanhanger nieuwe religie).

I3 ORA Culemborg, inv.nr. 238, f. 88. Hij machtigt dan zijn zoon Cornelis Toenisz en Johan Bartensz om te procederen tegen de kinderen van Peter Ceelen alias Roijbeen. 
I4 ORA Culemborg, inv.nr. 238, f. I80.

I5 ORA Culemborg, inv.nr. 23I, f. 23V.

I6 Haar herkomst is niet gebleken, mogelijk komt zij uit Tiel of omgeving. Op 27 september 1598 constitueerden voor het buitengerecht van Tiel Meeus Thonisz en Cornelis Thonisz, gebroeders tot Culemborg, Jacob van Bilandt in al hun zaken.

I7 Hij zou hertrouwd kunnen met zijn Marij Ghijsbert Neijendr. Hij geeft haar voor schout en gerecht van Lienden op I4 oktober I590 een procuratie (ORA Culemborg, inv.nr. I55, f. I5Ov). Er zijn tenminste gelijktijdig twee Aert Hendricx'en te Culemborg.

I8 ORA Culemborg, inv.nr. I55, f. IO3v, 20 febr. I589.

I9 OA Culemborg, inv.nr. I806, f. 3v: Cornelis Thonis Meusz.

20 OA Culemborg, inv.nr. 287 (stadsrekening), f. 36: Ten huize van Cornelis Thonisz Meeusz aan suiker, kaneel, 'capittelstocken, verisaet, olijven', gehaald $f$ 2-I7-Io.

2I OA Culemborg, inv.nr. 283 (stadsrekening), f. I4, I572/I573: betaald Cornelis Tonisz van zekere stoffen tot stads behoef vermogens zijn biljet 9-4.

22 OA Culemborg, inv.nr. 28I, f. 9: betaald aan Cornelis Tonisz als rentmeester van het kapittel van Culemborg $f$ 5-2-9.

23 ORA Culemborg, inv.nr. 238, p. I28v, I5 maart I576: Cornelis Toenisz als rentmeester van de kapel binnen Culemborg.

24 ORA Culemborg, inv.nr. I54, f. I45, 24 maart I579 en f. I62v, I6 jan. 1580 .

25 Jong, O. J. de., De Reformatie in Culemborg (Assen I957) p. 235; ORA Culemborg, inv.nr. I55, f. 27v, A.P. van Schilfgaarde, Het archief der Heeren en Graven van Culemborg, 's-Gravenhage i949.

26 Heren en Graven van Culemborg, inv.nr. 3992-3993; ORA Culemborg, inv.nr. I54, f. 22I, 23 nov. I582: Cornelis Toenisz, als tegenwoordige rentmeester van het convent van Mariencroon binnen Culemborg.

27 Heren en Graven van Culemborg, inv.nr. 4356 (rekeningen Marienkroon), rekening I6I2, ondertekend door C. Antonis als rentmeester, afgehoord 29 maart I6 2.

28 Van Schilfgaarde, Heeren en Graven Culemborg, Inleiding, p. XXXII.

29 Heren en Graven van Culemborg, inv.nr. 3592, f. 33v.

30 ORA Culemborg, inv.nr. I50, f. 37, 4 juli I542: Heer Gisbert Sijmonsz priester cum tutore draagt over aan Jan Aertsz de helft van 8 morgen land in Tienhoven, tussen Cornelis Jacopsz erven boven en Henrick Roes beneden.

3I ORA Culemborg, inv.nr. I54, f. 6Iv, 62, I27v, f. I44v en f. I56v. 
32 Heren en Graven van Culemborg, inv.nr. 4356 (rekeningen rentmeester Mariëncroon); Op 2I november I6I3 werd een nieuwe secretaris van Culemborg aangesteld.

33 Kort, Culemborg, p. 306. De Jong, p. I74: 'Ook is hij niet al te precies met de drie afkondigingen voor het huwelijk: dat van Cornelis Thoenisz werd zelfs 's morgens om vier uur gesloten zonder enige afkondiging'.

34 OA Culemborg, inv.nr. 564: 'Agnieta Cornelis Anthoenis wed.'.

35 Oud Rechterlijk Archief Culemborg, inv.nr. 238, p. I85.

36 De Jong, p. 246.

37 OA Culemborg, inv.nr. I806, f. I7.

38 ORA Culemborg, inv.nr. 227, f. $37 \mathrm{v}$.

39 H.Th. M. de Raad, Genealogie Hoevenaer, (Vianen I5de-I6 eeuw Culemborg i6de-I7e eeuw), in: De Nederlandsche Leeuw I996, k. 290.

40 Prof. dr W. Ph Coolhaes, Aanvullingen en verbeteringen op Van Rhede van der Kloot's De Gouveneurs-Generaal en Commissarissen-Generaal van Nederlandsch-Indië (ı6ı-I888), in: De Nederlandsche Leeuw, jrg. I956, p. 342-343.

4I OA Culemborg, inv.nr. I498, f. I5 (rekening potmeesters I647): De stad Culemborg uit alle de stadsgoederen een rente van 400 gulden kapitaal door de heer Anthonij van Diemen aan de armen vermaakt, verschijnende de eerste rente 8 aug. I647, 25 gulden.

42 NA, VOC, inv.nr. 667/668 (generale resoluties).

43 'Den Manhaften Gestrengen Heere Anthonis van Diemen, Governeur en Cap. Generael van wegens de Oostindische Geoctroijeerde Comp. der Vereenichde Nederlanden gestorven opt Casteel Batavia in Oostindien'.

44 Voor nadere gegevens over haar zie overzicht van het geslacht Van Aelst.

45 ORA Culemborg, inv.nr. 223, f. 57-58 en f. 85-85v.

46 HUA, Nederlands Hervormde Gemeente, inv.nr. 407, f. 69v: 'Lijsbet Meeusen van Diemen met attestatie van Cuilenberch geteekent bij de la Carr (?), woont in de Lijnmerckt bij de Gruiter'.

47 Te laat in de kerk, zij liet collaterale mondige en onmondige erfgenamen na, waarvan Peter de Gruijter, nomine uxoris, er één is en liet vast goed (dwz onroerend goed) na.

48 HUA, NHG, inv.nr. 405, f. Iov.

49 Als Annichgen, dochter van Peter de Gruijter.

50 Zoon van Peter de Gruijter. Er is gelijktijdig in Utrecht ook een Peter Jansz de Guijter (overl. aang. Utrecht 7 okt. I644 - St. Jacobskerk). Daarom is het niet helemaal zeker of het om een kind van Peter de Gruijter en Anna van Diemen gaat. 
5I HUA, NHG, inv.nr. 406, f. 4I: 'Met attestatie van Segwaert den 25 maart I629 getekent bij Casperus Rijckeman. Lambert Gruters, j.g. woon. in de Lijsbethstraet naest Casteel van Antwerpen bij de snijder'.

52 HUA, NHG, inv.nr. 408, f. I05v.

53 De Nederlandsche Leeuw I973, k. I8.

54 Bij ondertouwen in Amsterdam is hij 35 jaar.

55 Hij laat na zijn vrouw, drie mondige en 6 onmondige kinderen.

56 Stadsarchief Amsterdam, Notarieel Archief Amsterdam, inv.nr. III3, f. 85 (nots. J. v.d. Ven), 22 april I655.

57 Prof. dr W. Ph. Coolhaes, Aanvullingen en verbeteringen op Van Rhede van der Kloot's De Gouveneurs-Generaal en Commissarissen-Generaal van Nederlandsch-Indië (ı6ro-I888), in: De Nederlandsche Leeuw, jrg. I956, p. 342-343; Stadsarchief Amsterdam, Notarieel Archief Amsterdam, inv.nr. III4, f. 269-275 (Nots. J. v.d. Ven), 3I aug. I655.

58 HUA, Bibliotheek IX G 7 (handschrift afkomstig van Jhr. Mr. A.M. C. van Asch van Wijck, is geschreven door prof. A. Drakenborch), p. I25, no. 696.

59 ORA Culemborg, inv.nr. 223, f. 56.

60 OA Culemborg, inv.nr. 564 (rekeningen kerkmeesters).

6I F.A. van Lieburg, Repertorium van Nederlandse hervormde predikanten tot I8I6, deel I: predikanten, Dordrecht I996, p. 20I; geeft Culemborg geboren ca. I594, W.M.C. Regt, Naamlijsten predikanten geeft als geboorteplaats Utrecht (CBG).

62 De Jong, p. 222-229.

63 OA Culemborg, inv.nr. 564 (rekeningen kerkmeesters).

64 Brigiet Hackeng en Mariëtte Nelemans, De Latijnse school te $\mathrm{Cu}$ lemborg I578-I8I5, in: R. Bastiaanse, H. Bots en M. Evers, 'Tot meesten nut ende dienst van de jeught' Een onderzoek naar zeventien Gelderse Latijnse scholen ca. I580-I8I5, Zutphen I985, p. I26.

65 Gelders Archief, ORA Culemborg, inv.nr. I59, f. 37.

66 Doopboek Culemborg begint in 1634 .

67 HUA, Notarieel Archief Utrecht, inv.nr. U O2I a o13, akte 74.

68 HUA, Notarieel Archief Utrecht, inv.nr. U O2I a oI4, p. 3. 


\section{Geraadpleegde archieven}

Gemeentearchief Amsterdam (GAA)

Notariële archieven

Verzekeringsarchieven

Nationaal Archief Den Haag (NA)

Archief van de Verenigde Oostindische Compagnie

Archief van de Compagnieën op Oost-Indië ("voorcompagniën")

Archief Johan van Oldenbarnevelt

Collectie Sweers

Collectie Gijsels (film nr. zelfbediening 37I4)

Archip Nasional Republik Indonesia

Notariële archieven van Batavia en Ommelanden

Burgerlijke stand

Regionaal Archief Rivierenland

Oud Archief Culemborg

Regionaal Archief Gelderland

Oud Rechterlijk Archief Culemborg

Archief Heren en Graven van Culemborg

Gemeente Archief Leiden

Archief Weeskamer

Het Utrechts Archief

Notarieel Archief

Doop- Trouw en begraafgegevens lidmatenregisters stad Utrecht

Nederlands Hervormde gemeente Utrecht

Hof van Utrecht

Noord-Hollands Archief

Oud Notarieel Archief

Collectie Meerens 


\section{Literatuur}

Akveld, J. en E.M. Jacobs, De kleurrijke wereld van de VOC, Nationaal Jubileumboek VOC 1602-2002 (Bussum 2002).

Ames, G. J., Renascent empire? The house of Braganza and the quest for stability in Portuguese Monsoon Asia, c. I640-I683 (Amsterdam 2000).

Andrade, T., 'The Company's Chinese Pirates: How the Dutch East India Company Tried to Lead a Coalition of Pirates to War against China, I62I-I662', Journal of World History I5/4 (Honolulu 2005).

—, 'The rise and fall of Dutch Taiwan, I624-I662: cooperative colonization and the statist model of European expansion', Journal of World History I7/4 (Honolulu 2006).

Baker, C., D. Na Pombejra, A. van der Kraan en D. K.Wyatt, Van Vliet's Siam (Chiang Mai 2005).

Belonje, J., De Zijpe en Hazepolder, De ontwikkeling van een waterschap in Holland's Noorderkwartier (Leiden I933).

Beltjes, P. J. W., Jan van Riebeeck zijn voor- en nageslacht ('s-Gravenhage I952).

Berg, J. van der, Het verloren volk: een geschiedenis van de Banda-eilanden. ('s-Gravenhage 1995).

Blaeu, J. Toonneel Der Steden Van Holland Westuriesland En Utrecht by Joan Blaeu. (Amsterdam, I652).

Blok, P.J., Relazioni Veneziane. Venetiaansche berichten over de Vereenigde Nederlanden van 1600-1795 Rijks Geschiedkundige Publicatiën 7 ('s-Gravenhage I909).

Blucher, F. Richelieu (Paris 2003).

Blussé, L., 'The VOC as sorcerer's apprentice, stereotypes and social engineering on the China coast', in: W.L. Idema (ed.) Leyden Studies in Sinology (Leiden I98I).

_- 'Strange company. Chinese settlers, Mestizo women, and the Dutch in VOC Batavia', Verhandelingen van het Koninklijk Instituut voor Taal-, Land- en Volkenkunde I22 (Leiden I986).

_ , 'Retribution and remorse: the interaction between the administration and the protestant mission in early colonial Formosa', 
in: G. Prakashs (ed.), After colonialism: imperial histories and postcolonial displacements, (Princeton I995).

— volk,' Tijdschrift voor Geschiedenis III (Assen i998).

_ - 'Divesting a myth: seventeenth century Dutch-Portuguese rivalry in the Far East," in Vasco Da Gama and the linking of Europe and Asia', in A. R. Disney en E. Booths (ed.), Vasco da Gama and the linking of Europe and Asia, (New York 2000).

van de eerste politiewetten in Nederlands-Indië', in: J.Th Lindblad en W.van der Molen (ed), Macht en Majesteit. (Leiden 2OOI).

-, 'Four hundred years on, the public commemoration of the founding of the VOC in 2002', Itinerario 27-I (Leiden 2003).

Blussé, L. en N. Everts, The Formosan encounter: notes on Formosa's aboriginal society: a selection of documents from Dutch archival sources Volume II I636-1645 (Taipei 2000).

Blussé, L. en J. D. Moor, Nederlanders overzee: de eerste vijftig jaar, ı6ooI650 (Franeker I983).

Blussé, L., M.E. van Opstall, W.E. Milde en Ts'ao Yung-Ho, De dagregisters van het kasteel Zeelandia, Taiwan, 1629-1662 Vier delen. Rijks Geschiedkundige Publicatiën. Grote serie I95-229 . (sGravenhage i986-).

Blussé, L., F.P. van der Putten en H. Vogel, Pilgrims to the past: private conversations with historians of European expansion (Leiden I996).

Booth, A. en A. Merens, Een dienaer der Oost-indische compagnie te London in 1629 ('s-Gravenhage I942).

Borschberg, P., The Singapore and Melaka Straits, Violence, Security amd Diplomacy in the 17th Century (Leiden 2010).

Boxer, C. R., The Dutch in Brazil, I624-I654 (Oxford I957).

- The great ship from Amacon; annals of Macao and the old Japan trade (Lisbon I959).

'Francisco Vieira de Figueiredo: a Portuguese Merchant-Adventurer in South East Asia, I624-1667', Verhandelingen van het Koninklijk Instituut voor Taal-, Land-en Volkenkunde Vol. 52. ('sGravenhage i967).

- The Dutch seaborne empire 1600-1800 (London I977).

- Portuguese India in the mid-seventeenth century (Delhi I980).

- Portuguese conquest and commerce in southern Asia, 1500-1750 (London i985).

- Portuguese merchants and missionaries in feudal Japan, 1543-1640 (London I986).

—, The Portuguese seaborne empire 1415-1825 (Manchester I99I). 
Boyajian, J. C., Portuguese trade in Asia under the Habsburgs, 1580-1640 (Baltimore 1993).

Brakel, S. van, De Hollandsche handelscompagnieën der zeventiende eeuw, hun onstaan-hunne inrichting ('s-Gravenhage I908).

Braudel, F., Capitalism and material life, I400-I800. (London I974).

- The Mediterranean and the meditarraneum world in the age of Phillip II. 2e edition, 2 vols. (New York I976).

Bremer, J. T., De Zijpe, bedijking en bewoning tot omstreeks 1800 (Schoorl I985).

Brenner, R., Merchants and revolution: commercial change, political conflict, and London's overseas traders, I550-1653 (Princeton I993).

Bruck, C., The Predators' Ball: the inside story of Drexel Burnham and the rise of the junk bond raiders (New York I989).

Brugmans, P. D. H., Opkomst en bloei van Amsterdam (Amsterdam I9II).

Bruijn, J. R., F. S. Gaastra en I. Schöffer. Dutch-Asiatic shipping in the 17th and 18th centuries 3 vols., Rijks Geschiedkundige Publicatiën. Grote serie I65-I67 ('s-Gravenhage I979 - I987).

Burke, E., The Writings and Speeches of Edmund Burke, Vol. V, India: Madras and Bengal 1774-1785 P. J. Marshall (ed.), (Oxford ig8I).

The writings and speeches of Edmund Burke, Vol. VI, The Launching of the Hastings Impeachement 1786-1788. P. J. Marshall (ed.), (Oxford I99I).

Burrough, B. en J. Helyar. Barbarians at the gate: the fall of RJR Nabisco (New York I990).

Busken Huet, C., Litterarische fantasiën en kritieken Deel 5 (Haarlem I878).

Chaudhuri, K. N., The English East India Company; the study of an early joint-stock company, I600-1640 (London I965).

- Trade and civilisation in the Indian Ocean: an economic history from the rise of Islam to 1750 (Cambridge I985).

Chaudhuri, S. en K. Kévonian., Les Arméniens dans le commerce asiatique au début de l'ère moderne: Armenians in Asian trade in the early modern era (Paris 2008).

Chijs, J. A. van der, Geschiedenis der stichting van de Vereenigde O.I. compagnie en der maatregelen van de Nederlandsche regering betreffende de vaart op Oost-Indie, welke aan deze stichting voorafgingen (Leiden I857).

- Realia: register op de generale resolutien van het kasteel Batavia, 1632-1805 3 delen (Leiden I882).

- Nederlandsch-Indisch Plakkaatboek 1602-1811 I7 delen ('s-Gravenhage, I885-I900).

- De vestiging van het Nederlandsche gezag over de Banda-eilanden (1599-1621) ('s-Gravenhage I886). 
Colenbrander, H. T., Dagh-register gehouden int Casteel Batavia vant passerende daer ter plaetse als over geheel Nederlandts-India anno 1631-1634 ('s-Gravenhage I898).

Dagh-register gehouden int Casteel Batavia vant passerende daer ter plaetse als over geheel Nederlandts-India anno 1636 ('s-Gravenhage 1899$)$.

—, Jan Pietersz. Coen, levensbeschrijving ('s-Gravenhage I934).

- Jan Pieterz.Coen, bescheiden omtrent zijn bedrijf in Indië 7 delen ('s-Gravenhage I9I9-I923).

Colijn, D. H., Dispereert niet.....,Rede ter herdenking van den 35osten geboortedag van Jan Pietrsz. Coen uitgesproken te Hoorn den 1sten Februari 1937 (Amsterdam I937).

Commelin, I. Begin Ende Voortgangh, Van De Vereenighde Nederlantsche Geoctroyeerde Oost-Indische Compagnie: Vervatende De Voornaemste Reysen, by De Inwoonderen Derselver Provincien Derwaerts Gedaen, 2 vols. (Amsterdam, I646).

Coolhaas, W. P., 'Gegevens over Antonio Van Diemen', Bijdragen tot de Taal- Land- en Volkenkunde van Nederlandsch-Indië 77 ('s-Gravenhage i946).

_-, 'Een Indisch verslag uit I631, van de hand van Antonio van Diemen', Bijdragen en mededelingen betreffende de geschiedenis der Nederlanden 65 ('s-Gravenhage I946).

- Generale missiven van gouverneurs-generaal en raden aan de Heren XVII der Verenigde Oostindische Compagnie Deel I en 2. ('s-Gravenhage I960-I964).

—. Het huis 'De Dubbele Arend' Het huis Keizersgracht 141 thans 'Van Riebeeckhuis' genaamd, nu daar een halve eeuw gearbeid is voor de culturele en economische betrekkingen met Zuid-Afrika (Amsterdam I973).

Cools, R. H. A., Strijd om den grond in het lage Nederland; het proces van bedijking, inpoldering en droogmaking sinds de vroegste tijden (Rotterdam I948).

Dam, P. van en F. W. Stapel, Beschryvinge van de Oostindische Compagnie, 5 delen Rijks Geschiedkundige Publicatieën. Groote serie 63, 68,74, 76, 83, 87 en 96 ('s-Gravenhage i927-I954).

Das Gupta, A., Merchants of maritime India, I500-I800 (Aldershot I994).

Das Gupta, A. en M. N. Pearson, India and the Indian Ocean, 1500-1800 (New York i987).

De Souza, D. R., Indo-Portuguese history: old issues, new questions (New Delhi ig85).

Della Valle, P. en G. Bull. The pilgrim: the travels of Pietro Della Valle (London I990). 
Dooren de Jong, E. L. G. den, 'De practijk der Amsterdamsche zeeverzekering in de I7de eeuw', Het Verzekerings-Archief ('s-Gravenhage i927).

Heijer, H. J., den De geoctrooieerde compagnie. De VOC en de WIC als voorlopers van de naamloze vennootschap, Ars Notariatus I28 (Deventer 2005).

Deursen, A. T. van, Maurits van Nassau 1567-1625: de winnaar die faalde (Amsterdam 2000).

Deventer, M. L. van, Gedenkstukken van Johan van Oldenbarnevelt en zijn tijd, verzameld en met inleiding en aanteekeningen ('s Gravenhage I860).

Dijk, W. O., Seventheeth-century Burma and the Dutch East India Compa$n y, 1634-1680$ (Kopenhagen 2006).

Dillen, J. G. van, 'Isaac Le Maire en de handel in actiën der Oost-Indische Compagnie', Economisch-Historisch Jaarboek I6 ('s-Gravenhage, I930).

- Het oudste aandeelhoudersregister van de Kamer Amsterdam der Oost-Indische Compagnie ('s-Gravenhage I958).

- Van rijkdom en regenten; handboek tot de economische en sociale geschiedenis van Nederland tijdens de Republiek ('s-Gravenhage I970).

Disney, A. R., Twilight of the Pepper Empire, Portuguese Trade in Southwest India in the Early Seventeenth Century (London I978).

Efthymiou, N. S., De organisatie van regelgeving voor Nederlands Oost-Indië: stelsels en opvattingen (1602-1942) (Amsterdam 2005).

Elias, J. E., De vroedschap van Amsterdam, 1578-1795 (Haarlem I903).

Elink Schuurman, W. H. A., 'Korte aantekeningen betreffende verzekering in de dagen der Republiek' Economisch Historisch Jaarboek 3 (I9I7).

Elliott, J. H., Richelieu and Olivares, Cambridge studies in early modern history (Cambridge I984).

- The Count-Duke of Olivares: the statesman in an age of decline (New Haven I986).

Fisch, J., Hollands Ruhm in Asien: François Valentyns Vision des niederländischen Imperiums im 18. Jahrhundert (Stuttgart 1986).

Fletcher, W. M., Cyclopedia of the law of private corporations (Chicago I9I7).

P. J. W. Beltjes en H. W. E Beltjes-Fortgens., 'De Latijnse school te Culemborg', Bijdragen en Mededelingen der Vereniging "Gelre" 53 (Arnhem I953).

Foster, W., The travels of John Sanderson in the Levant, 1584-1602, with his autobiography and selections from his correspondence. (London, I93I). 
- The voyages of Sir James Lancaster to Brazil and the East Indies, 1591-1603 (London I940).

England's quest of eastern trade (New York I967).

Frederiks, J. G., 'Cornelis Cornelisz Matelieff de Jonge en zijn geslacht', Rotterdamsche Historie Bladen (Rotterdam I871).

Frentrop, P. Ondernemingen en hun aandeelhouders, corporate governance 1602-2002 (Amsterdam 2002).

Fruin, R., Tien jaren uit den Tachtigjarigen Oorlog, 1588-1598 ('s-Gravenhage I889).

Fruin, R. en P. J. Blok, Robert Fruin's verspreide geschriften, met aanteekeningen, toevoegsels en verbeteringen uit des schrijvers nalatenschap II delen ('s-Gravenhage I900-I905).

Fuchs, M. J. M., Jan Pieterszoon Coen in uitspraken van hemzelf en anderen (Baarn I938).

Furber, H., Rival empires of trade in the Orient, 1600-1800 (Minneapolis I976).

Gaastra, F. S., Bewind en beleid bij de VOC. De financiële en commerciële politiek van de bewindhebbers, 1672-1702 (Zutphen I989).

- De geschiedenis van de VOC (Zutphen, I99I).

- Particuliere geldstromen binnen het VOC-bedrijf 1640-1795 (Leiden, 2002).

Gabriëls, H., Koninklijke Olie: de eerste honderd jaar 1890 - 1990 ('s-Gravenhage I990).

Gascoigne, B., A brief history of the great Moghuls (London 2002).

Gaube, H. en E. Wirth, Aleppo: historische und geographische Beitrage zur baulichen Gestaltung, zur sozialen Organisation und zur wirtschaftlichen Dynamik einer vorderasiatischen Fernhandelsmetropole (Wiesbaden I984).

Gelderblom, O., Zuid-Nederlandse kooplieden en de opkomst van de Amsterdamse stapelmarkt (1578-1630) (Hilversum 2000).

Gelman Taylor, J., The social world of Batavia, European and Eurasian in Dutch Asia (Madison I983).

Gerretson, F. C., Coens eerherstel (Amsterdam i944).

Gijswijt-Hofstra, M., Wijkplaats voor vervolgden. Asielverlening in Culemborg, Vianen, Buren, Leerdam, IJsselstein van de 16de tot eind 18de eeuw (Dieren I984).

Glamann, K., Dutch-Asiatic Trade, 1620-1740 (Kopenhagen I958).

Goeters, J. F. G., Die Akten der Synode der Niederländischen Kirchen zu Emden vom 4.-13. Oktober 1571 (Neukirchen I97I).

Goldstein, T., 'Geography in Fifteenth Century Florence', in: J. Parkers (ed) Merchants and Scholars (Minneapolis I965).

Goody, J., Capitalism and modernity: the great debate (Cambridge, MA 2004). 
Goossens, E. J. H. P., 'Schat van beitel en penseel', Het Amsterdamse stadhuis uit de Gouden Eeuw (Zwolle I996).

Graaf, H. J. de, 'De regering van Sultan Agung, vorst van Mataram, I6I3- I645', Verhandelingen van het Koninklijk Instituut voor Taal-, Land-en Volkenkunde 33. ('s-Gravenhage I958).

Grayson, J. C., From protectorate to partnership: Anglo-Dutch relations 1598-162. (London I978).

Groot, H. de, Briefwisseling van Hugo Grotius I7 delen ('s-Gravenhage, I928-200I).

Haan, F. de, Oud Batavia 2 delen (Bandoeng I935).

Haan, H. den, Moedernegotie en grote vaart: een studie over de expansie van het Hollandse handelskapitaal in de 16e en 17e eeuw (Amsterdam, I977).

Hartgens, J., Journael, ende historische verhael van de treffelijcke Reyse gedaen naer Oost-Indien, ende China, met elf Schepen. Door den Manhaften Admirael Cornelis Matelief de Jonge. Uyt-gevaren in de Jare 1605. En wat haer in de volgende Jaren 1606. 1607. ende 1608 weder-varen is. Een seer Vreemde en Wonderlijcke Reyse (Amsterdam i648).

Have, O. ten, De leer van het boekhouden in de Nederlanden tijdens de zevetiende en achttiende eeuw (Delft I933).

Heer, C. de, Bijdrage tot de Financiëele geschiedenis der Oost-Indische Compagnie ('s-Gravenhage i929).

Heeres, J. E., Corpus Diplomaticum Neerlando-Indicum, verzameling van Politieke contracten en verdere Verdragen door de Nederlanders in het Oosten gesloten, van Privilegebrieven, aan hen verleend, enz. Eerste deel ('s-Gravenhage I907).

Heeres, J. E., Dagh-register gehouden int Casteel Batavia vant passerende daer ter plaetse als over geheel Nederlandts-India anno 1624-1629 ('s-Gravenhage 1896 ).

Heeringa, K., Bronnen tot de geschiedenis van den Levantschen handel Rijks Geschiedkundige Publicatiën. Grote serie 9 ('s-Gravenhage I9I0).

Heers, J., 'Le role des capitaux internationaux dans les voyages de découvertes aux xv et xvi siècles', in: F. Fernandez-Armestos (ed), The European opportunity (Aldershot I995).

Heijden, E. J. J. van der, De ontwikkeling van de naamlooze vennootschap in Nederland vòò de codificatie (Amsterdam I908).

Hoang, T. A., Silk for Silver, Dutch-Vietnamese Relations, 1637-1700 (Leiden 2007).

Huijbers, H. F. M., Jan Pieterszoon Coen (Utrecht I923).

Huizinga, J., Nederland's beschaving in de zeventiende eeuw, een schets (Haarlem i94I).

- Geschonden wereld (Haarlem i945). 
—, Verzamelde Werken, I - IX vols. (Haarlem, I948-I950).

Hunter, W. W. en P. E. Roberts, A history of British India (New York I966).

IJzerman, J. W., Dirck Gerritsz Pomp, alias Dirck Gerritsz China (1544 1604) Werken uitgegeven door de Linschoten-Vereeniging. Deel 9. ('s-Gravenhage, I915).

Israel, J. I., The Dutch Republic and the Hispanic world, 1606-1661 (Oxford New York, I982).

-, Dutch primacy in world trade, 1585-1740 (Oxford, New York I989).

- The Dutch Republic : its rise, greatness and fall, 1477-1806 (Oxford I995).

Ittersum, M. J. van, Profit and principle: Hugo Grotius, natural rights theories and the rise of Dutch power in the East Indies (Leiden 2006).

Jacobs, E. M., Koopman in Azië (Zutphen 2000).

Japikse, N., Resolutiën der Staten-Generaal van 1576 tot 1609 ('s-Gravenhage I9I5).

Jong, O. J. de., De Reformatie in Culemborg (Assen I957).

Jonge, J. K. J. de, M. L. van Deventer, L. W. G. de Roo, P. A. Tiele, J. E. Heeres, J. Meinsma en J. W. G. Van Haarst, De Opkomst van het Nederlandsch gezag in Oost-Indie. Verzameling van onuitgegeven stukken uit het Oud-Koloniaal Archief, ig delen. ('s Gravenhage I862-I895).

Keay, J., The spice route: a history (London 2005).

Kellenbenz, H., Fremde Kaufleute auf der Iberischen Halbinsel (Keulen I970).

Kernkamp, J. H., De handel op den vijand 1572-1609 (Utrecht I93I).

, Johan van der Veken en zijn tijd (s'-Gravenhage I952).

Ketting Jr, H., Leven, werk en rebellie aan boord van Oost-Indiëvaarders (1595-士1650) (Amsterdam 2002).

Keuning, J., De tweede schipvaart der Nederlanders naar Oost-Indië onder Jacob Cornelisz. van Neck en Wybrant Warwijck, 1598-16oo. Journalen, documenten en andere bescheiden ('s-Gravenhage i938).

Kindleberger, C. P. en R. Z. Aliber, Manias, panics, and crashes: a history of financial crises (Hoboken, N.J., 2005).

Klein, P. W., Van stapelmarkt tot welvaartsstaat (Rotterdam I970).

Knaap, G. J., Memories van overgave van gouverneurs van Ambon in de zeventiende en achttiende eeuw, Rijks Geschiedkundige Publicatiën. Kleine serie 62 ('s-Gravenhage I987).

- ' 'Crisis and failure: war end revolt in the Ambonese Islands, I636-i637', Cakalele, Maluku Research Journal 3 (I992).

- ' 'Kruidnagelen en Christenen: de Verenigde Oost-Indische Compagnie en de bevolking van Ambon i656-1696', Verhande- 
lingen van het Koninklijk Instituut voor Taal-, Land- en Volkenkunde 212. (Leiden, 2004).

'The Governor-General and the Sultan: An Attempt to Restructure a Divided Amboina in I638', Itinerario 29-1 (Leiden, 2005).

Korte, J. P. de, De jaarlijkse financiële verantwoording in de VOC (Leiden I984).

Kraakman, E. A., The Anatomy of Corporate Law: a comparative and functional approach (Oxford 2009).

Kraan, A. van der, 'Anthony van Diemen: from Bankrupt to GovernorGeneral, I593-I645 (Part I)', The Great Circle, Journal of the Australian Association for Maritime History 26/2 (Perth 2004).

- ' 'Anthony van Diemen: from Bankrupt to Governor-General, I593-I645, Patron of Discovery and Exploration (Part II)', The Great Circle, Journal of the Australian Association for Maritime History (Perth 2005).

- Murder and Mayhem in Seventeenth-Century Cambodia, Anthony van Diemen vs. King Ramadhipati I. (Chiang Mai, 2009).

Krondl, M., De smaak van de verovering: Venetië, Lissabon, Amsterdam en de strijd om de specerijen (Amsterdam 2008).

L'honoré Naber, S. P., Reisebeschreibungen von Deutschen Beambten und Kriegsleuten im Dienst der Niederländischen West- und Ost-Indischen Kompagnien, XIII vols. ('s-Gravenhage, I930-I932).

Landwehr, J. en P. C. J. van der Krogt, VOC: a bibliography of publications relating to the Dutch East India Company, 1602-1800 (Utrecht I99I).

Le Moine De L'espine, J., De koophandel van Amsterdam, naar alle gewesten des werelds 2 delen (Rotterdam I763).

Leemhorst, H. C., Plechtige herdenking van Jan Pieterszoon Coen (Hoorn I937).

Lesger, C., Handel in Amsterdam ten tijde van de Opstand: kooplieden, commercièele expansie en verandering in de ruimtelijke economie van de Nederlanden, ca. 1550-ca. 1630 (Hilversum 200I).

Leupe, P. A., Stukken Betrekkelijk Het beleg en de verovering van Malakka op de Portugezen in I640-I64I," Berigten van het Historisch Genootschap te Utrecht (Utrecht I859).

- 'Salomon Sweers, Raad Van Indië I644', Bijdragen tot de TaalLand - en Volkenkunde van Nederlandsch-Indië ('s-Gravenhage I873).

Lowenstein, L., What's wrong with Wall Street: short-term gain and the absentee shareholder (Reading I988).

Lutz, E., Die rechtliche Struktur süddeutscher Handelsgesellschaften in der Zeit der Fugger (Tübingen I976). 
Macleod, N., De Oost-Indische compagnie als zeemogendheid in Azië, Deel I: Van I602 tot I632.-Deel 2: Van I632 tot I650. (Rijswijk, I927).

Magnusson, L., Mercantilist economics. (Boston, I993).

Mansvelt, W. M. F., Rechtsvorm en geldelijk beheer bij de Oost-Indische Compagnie. (Amsterdam, I922).

Martin, C. en G. Parker, The Spanish Armada (New York, I999).

Marx, K., Het Kapitaal http://www.marxists.org/nederlands/marx-engels/I867/kapitaal/index.htm (Marxists Internet Archive 2007)

Meilink-Roelofsz, M. A. P., Van geheim tot openbaar, een historiografische verkenning (Leiden I970).

—- De vestiging der Nederlanders ter kuste van Malabar, Vol. deel 4, Verhandelingen van het Koninklijk instituut voor Taal-,land -, en Volkenkunde van Nederlandsch-Indië (Den Haag, I943).

- Asian trade and European influence in the Indonesian archipelago between 1500 and about 1630. ('s-Gravenhage,, I962).

_- 'Hoe rationeel was de organisatie van de Nederlandse Oost-Indische Compagnie?', Economisch en sociaal-historisch jaarboek 44 (1982).

Meilink-Roelofsz, M. A. P., R. Raben en H.Spijkerman, De archieven van de Verenigde Oostindische Compagnie (1602-1795) (Den Haag I992).

Meteren, E. van, Historien der Nederlanden en haar naburen oorlogen tot het jaar 1612 (Amsterdam I647).

Micklethwait, J. en A. Wooldridge. The company: a short history of a revolutionary idea (New York 2003).

Mijer, P., 'Bijdrage tot de codificatie van Nederlandsch-Indië', Tijdschrift van Nederlandsch-Indië Tweede jaargang deel I ('s-Gravenhage I839).

- Verzameling van instructiën, ordonnanciën en reglementen voor de regering van Nederlandsch Indië, vastgesteld in de jaren 1609, 1617, $1632,1650,1807,1815,1818,1827,1830$ en 1836 , met de ontwerpen der Staats-commissie van 1803 en historische aanteekeningen (Batavia 1848$)$.

Moir, M., A general guide to the India Office Records (London I988).

Moll, G., De Desolate Boedelskamer te Amsterdam (Amsterdam I879).

Mollema, J. C., De eerste schipvaart der Hollanders naar Oost-Indië, 15951597, naar de oude journalen, uitgegeven door de Linschoten-vereeniging, opnieuw beschreven en voorzien van een inleiding, waarin behandeld de voorgeschiedenis, het doel, de uitreeding en de lotgevallen der deelnemers, ook na hun thuiskomst ('s-Gravenhage I935).

Monks, R. A. G. en N. Minow, Corporate governance (Cambridge, Mass. I995). 
Mukherji, P., Indian constitutional documents. 2d edition. (Calcutta, I9I8).

Mun, T., A discourse of trade. Herdruk I969 (London/Amsterdam, I62II969).

—, England's treasure by forraign trade, Herdruk (London/Oxford i63I-I967).

Nauta, D., J.P van Dooren en O.J. de Jong, De Synode van Emden oktober 1571, een bundel opstellen ter gelegenheid van de vierhonderdjarige herdenking (Kampen I97I).

Nehru, J. The discovery of India (London I946).

Newitt, M. D. D., A history of Portuguese overseas expansion, 1400-1668 (London 2005).

Niemeijer, H. E., Calvinisme en koloniale stadscultuur: Batavia 1619-1725 (Almelo i996).

—, Batavia. Een koloniale samenleving in de 17de eeuw (Amsterdam 2005).

Noorderkerk, H., Handvesten der stad Amstelredam 4 delen. (Amsterdam I748).

Ormond, D., The rise of commercial empires. England and the Netherlands in the age of mercantilism, 1650-1770 (Cambridge 2003).

Parker, G., Guide to the Archives of the Spanish institutions in or concerned with the Netherlands, 1556-1706 (Brussels I971).

-, The Army of Flanders and the Spanish road, 1567-1659; the logistics of Spanish victory and defeat in the Low Countries' Wars (Cambridge I972).

- The Dutch revolt (London I977).

- Spain and the Netherlands, 1559-1659: ten studies (London, I990).

- Empire, war and faith in early modern Europe (London 2002).

Parr, C. M., Jan van Linschooten : the Dutch Marco Polo (New York I964).

Parthesius, R., Dutch ships in tropical waters, the development of the Dutch East India Company (Voc) shipping network in Asia 1595-1660 (Amsterdam 2007).

Pater, J. C. H. de, 'Jan Pieterszoon Coen en het Calvinisme van zijn tijd', Antirevolutionaire Staatkunde, driemaandelijksch orgaan van de Dr Abraham Kuyperstichting Io (1936).

- Jan Pieterszoon Coen en Indië in zijn tijd ('s-Gravenhage I948).

Pettegree, A., Emden and the Dutch revolt: exile and the development of reformed Protestantism (Oxford I992).

Pissurlencar, P. S. S., Assentos do Conselho do Estado 3 vols. (Goa I953I955).

Pistor, R. Die Fossa Eugeniana: Eine Unvollendete Kanalverbindung Zwischen Rhein Und Maas, 1626 (Keulen, I979). 
Pol, A., Schepen met geld : de handelsmunten van de Verenigde Oostindische Compagnie, 1602-1799 ('s-Gravenhage i989).

Posthumus Meyjes, R., De Reizen van Abel Janszoon Tasman en Franchoys Joacobszoon Visscher, ter nadere ontdekking van het Zuidland (Australie) in 1642 - 1644 Werken van de Linschoten Vereeniging Vol. I7 ('s-Gravenhage I9I9).

Potter Adams, J. One's company, three's a crowd : metropolitan state-building and east indies merchant companies in the early modern Netherlands, France and England, 1600-1800 (Wisconsin I990).

Prakash, O., The Dutch East Asia Company and the Economy of Bengal 1630- 1720 (New Jersey I985).

- Precious metals and commerce: the Dutch East India Company in the Indian Ocean trade (Aldershot 1994).

- European commercial expansion in early modern Asia (Aldershot I997).

-, 'The Portuguese in the Far East, I540-I640', in: A. R. Disney en E. Booths (ed) Vasco da Gama and the linking of Europe and Asia (New Delhi 2000).

- Bullion for goods: European and Indian merchants in the Indian Ocean trade, 1500-1800 (New Delhi 2004).

Ptak, R., Portuguese Asia: aspects in history and economic history (sixteenth and seventeenth centuries) (Stuttgart I989).

Ribeiro, J. P., The Historic Tragedy of the Island of Ceilao; translated from the Portuguese by P.E. Pieris (Colombo i925).

Ricklefs, M. C., A history of modern Indonesia since c. 1300 2nd edition. (Stanford I993).

Rietbergen, P. J. A. N., De Eerste Landvoogd Pieter Both (1586 -1615) Gouverneur-generaal van Nederlands-Indië (1609-1614) 2 delen, Werken uitgegeven door de Linschoten-Vereniging deel 86 en 87 (Zutphen i987).

Roeper, V. de en R. van Gelder, In dienst van de Compagnie: leven bij de VOC in honderd getuigenissen (1602-1799) (Amsterdam 2002).

Roeper, V. de en D. Wildeman, Om de Zuid: de eerste schipvaart naar Oost-Indie onder Cornelis de Houtman, 1595-1597 (Nijmegen I997).

Sainsbury, E. B. en W. Foster, A calendar of the court minutes etc. of the East India company, 1635 - 1639 (Oxford I907).

A calendar of the court minutes etc. of the East India company, 1640-1643 (Oxford 1909).

- A calendar of the court minutes, etc. of the East India company, 1644-1649 (Oxford i912).

Santen, H. W. van, De Verenigde Oost-Indische Compagnie in Gujarat en Hindustan, 1620-1660 (Leiden 1982). 
, VOC-dienaar in India : Geleynssen de Jongh in het land van de Groot-Mogol (Franeker 200I).

Schaepman, H. J. A. M., Jan Pieterszoon Coen, rede uitgesproken te Hoorn op 30 mei 1893 ('s-Gravenhage I893).

Scholten, R. L., Over makelaars in zee-assurantie (Amsterdam I879).

Schoorl, H., Isaac le Maire, koopman en bedijker (Haarlem I969).

Schumpeter, J. A., The theory of economic development. An inquiry into Profits, Capital, Credit, Interest, and the business cycle (Cambridge, Massachusetts I96I).

Schutte, G. J., 'Coolhaas, Willem Philippus (I899-I98I)', In Biografisch Woordenboek van Nederland. http://www.inghist.nl/Onderzoek/ Projecten/BWN/lemmata/bwn6/coolhaas ('s-Gravenhage, 2008).

Schutte, G. J., Het Indisch Sion, De Gereformeerde Kerk onder de Verenigde Oost-Indische Compagnie (Hilversum 2002).

Slauerhoff, J., Jan Pietersz. Coen, drama in elf taferelen met een inleiding door Ronald Brouwer ('s-Gravenhage i986).

Smit, J., De Prooi, blinde trots breekt ABN Amro (Amsterdam 2008).

Smith, A. en A. S. Skinner, The wealth of nations. Books IV-V (London I999).

Solman, P. en T. Friedman, Life and death on the corporate battlefield: how companies win, lose, survive (New York I982).

Spijker, W. van 't, De Synode van Dordrecht in 1618 en 1619 (Houten I987).

Stapel F. W., Geschiedenis Van Nederlandsch Indië 5 delen. (Amsterdam I938).

Steensgaard, N., The Asian trade revolution of the seventeenth century: the East India companies and the decline of the caravan trade (Chicago I974).

—, 'The Dutch East India Company as an institutional innovation', in: M. Aymards (ed) Dutch capitalism and world capitalism (Cambridge I982).

Steins Bisschop, B. T. M., 'De moderne NV als Compagnie', in: L. Blussé en I. Ooms (ed.) Kennis en Compagnie: De Verenigde Oost-Indische Compagnie en de moderne Wetenschap (Leiden 2002).

Stock, J. van der, Antwerpen, verhaal van een metropool in de 16de en 17de eeuw (Antwerpen i993).

Stoppelaar, J. H. de, Balthasar de Moucheron: een bladzijde uit de Nederlandsche handelsgeschiedenis tijdens den tachtig-jarigen oorlog ('sGravenhage I90I).

Tavernier, J.B. en V. Ball, Travels in India Deel 2, vertaling van de oorspronkelijke Franse editie uit I676 (London I889). 
Temminck Groll, C. L., Dutch overseas: architectural survey: mutual heritage of four centuries in three continents (Zwolle 2002).

Tex, J. den, Oldenbarnevelt Deel 2 (Haarlem i960).

Tinniswood, A., The Verneys: a true story of love, war, and madness in seventeenth-century England.(New York 2007).

Tracy, J. D., The Rise of merchant empires: long-distance trade in the early modern world, 1350-1750 (New York I990). The Political economy of merchant empires, (New York I99I).

Tuck, P. J. N., The East India Company (New York,I998).

Valentijn, F. Oud en nieuw Oost-Indiën 5 delen (Dordrecht I72I-I724).

Veen, E. van, Decay or defeat? An inquiry into the Portuguese decline in Asia, 1580-1645 (Leiden 2000).

Velius, T., Chroniick van Hoorn, daer in verhaelt werden des selven stadts eerste begin, opcomen, en gedenckweerdige geschiedenissen, tot op den jare 1630 ... / Oversien, verbetert, en eensdeels op 't nieu beschreven, deur D. Velius, Dr. in de medecロnen tot Hoorn (Hoorn I630).

Ven, A. J. van der, Het Oud archief van de Gemeente Culemborg (Utrecht I938).

Vergouwen, J. P., De geschiedenis der Makelaardij in Assurantiën hier te lande tot 1813 ('s-Gravenhage I945).

Verseput, J., De reis van Mathijs Hendriksz. Quast en Abel Jansz. Tasman ter ontdekking van de Goud- en Zilvereilanden, (1639) Uitgaven van de Linschooten Vereeniging 56 ('s-Gravenhage I954).

Vignaud, H., La lettre et la carte de Toscanelli sur la route des Indes par l'ouest, adressées en 1474 au portugais Fernam Martins et transmises plus tard à Christophe Colomb (Parijs I903).

Vink, M., 'South India and the China Seas: How the V.O.C. shifted its weight from China and Japan to India around A.D. I636', in: G. D. Winius (ed), Studies on Portuguese Asia, 1495-1689 (Aldershot 200I).

Voet van Oudheusden, A. K. W., Historische beschrijvinge van Culemborg (Utrecht I753).

Vos, W., Batavia, de herbouw van een Oostindiëvaarder Vol. I. (Almere I990).

Vreede, G. W., Lettres et négociations de Paul Choart: seigneur de Buzanval, ambassadeur ordinaire de Henri IV en Hollande, et de François d'Aerssen, agent des Provinces-Unies en France, (1598, 1599). Suives de quelques pièces diplomatiques concernant les années 15931596, et 1602-1606 (Leiden I846).

Vries, J. de en A. van der Woude, Nederland 1500-1815, De eerste ronde van moderne economische groei (Amsterdam 2005).

Wagenaar, J., Amsterdam, in zijne opkomst, aanwas, geschiedenissen, voorregten, koophandel, gebouwen, kerkenstaat, schoolen, schutterye, gil- 
den en regeeringe, beschreeven door Jan Wagenaar, hystorieschryver der stad 3 delen (Amsterdam,I760).

Waninghen van Campen, H. en J. Buinghma, Tresoor van 't Italiaens Boeckhouden (Amsterdam I629).

Warnsinck, J. C. M., De wetenschappelijke voorbereiding van onze eerste schipvaart naar Oost-Indie ('s-Gravenhage I936).

Wieder, F. C., De reis van Mahu en de Cordes door de Straat van Magalhaes naar Zuid-Amerika en Japan, 1598-160o Deel III Het eerste Hollandse Schip in Japan. Werken uitgegeven door de Linschooten-Vereeniging 24. (Den Haag I925).

Wijnaendts van Resandt, W., De gezaghebbers der Oost-Indische compagnie op hare buiten-comptoiren in Azië (Amsterdam 1944).

Witteveen, M., Een onderneming van landsbelang: de oprichting van de Verenigde Oost-Indische Compagnie in 1602 (Amsterdam 2002).

Woude, J. van der, Coen (Amsterdam I948).

Zandvliet, K., Mapping for money: maps, plans, and topographic paintings and their role in Dutch overseas expansion during the 16th and 17th centuries (Amsterdam I998).

— De Nederlandse ontmoeting met Azië, 1600-1950 (Zwolle 2002). 


\section{Index}

Adams, William I89, 229

Aelst, Arend van I3I

Agung, soesoehoenan van Mataram 247-

$$
248
$$

Ailly, Arnold Jan d' rog

Aldrich, William 52

Alphen, Simon van 276, 280, 305-306, 308

Alva, hertog van 20, 30, 3I, 82

— slag bij Jemmingen (I568) 93

Anthonisz, Meus (vader van VD) 3I-33

Ambon 64, 68, 86, I02, I05, I07, I74, I87, I9I, 2OI, 2I5-222, 254, 284-285, 322

- doodstraf Engelse kooplieden ( $\mathrm{I} 623$ ) IO7, 20I

- Zie ook kruidnagelmonopolie; Molukken

Amsterdam (eiland) I33, I34

Amsterdam, Tachtigjarige Oorlog en 37, 4I Antwerpen, Tachtigjarige Oorlog en 23-24

Armada (I588) 20, 253

- tweede (I639) 26I

Armeense kooplieden I88-189

arminianen zie remonstranten

Arminius 32

Asian Trade and European Influence in the Indonesian Archipelago between 1500 and about 1630 (Meilink-Roelofsz, I962) 8I

assuradeur van zeeschepen en lading (VD) 40-43

Atjeh (Sumatra) I9I

Australië zie Zuidland

Baäls priester over de zeden en gewoonten der Bramanen (Rogerus) 288

Bacon, Sir Francis I05

Baltische Zeehandel zie Oostzeehandel

Banda-Archipel 62, 63, 70, 72-75, 79, 84, 85 , I05, I74, I87, I9I, 216
- nootmuskaat- en foeliemonopolie 85 , IO2

Bantam (Java) 2I, 5I, 52, 62, 7I, I74, 247248

- VOC in oorlog met (I633) I40

Batavia (Java) I7, 73, 75, 82, 86 e.v., IOI, I03, I05, I08-IIO, 248-249, 277, 295$298,308,319,323$

- belegeringen door Javaans leger (i 628 ) I08; (I629) I09-IIO

— groei van 295-298

- handel met Mataram 248-249

- Kasteel van Ior

- kerkbouw 296, 297, 308

- rechtspraak 298

- slechte verhoudingen onder VOC-top I2I-I22

— stichting (I6I9) I7, 73, 75, 82, 86 e.v., 319

- wel en wee bevolking 296-298

Bataviase Statuten (I642) I8, 286-288, 324

Baticalao (Portugees fort Ceylon) 26I-263

- verovering door VOC ( $\left.\mathrm{I}_{3} 8\right)_{2} 262$

- overgave aan Singalezen 263

bedriifsstrategie VOC I6-I7

Beeldenstorm (I566) 3I, 93

begrafenis van VD (22 april I645) 305

Belonje, J. 57

Bewind en beleid bij de VOC van 1672-1702

(Gaastra, I989) 49

Blaeu, Willem 94

Bloedraad 20

Blussé, L. 225, 322

boekhouder in Batavia (VD) IOO-IOI

boekhouding VOC I64 e.v.

Bonin-eilanden 289

Bontekoe, Willem Ysbrants 96

Boreel, Pieter 269, 275

Both, Pieter, eerste gouverneur-generaal in

Azië 72-73, 84, I50-I5I, I54

- over privéhandel I25

Braudel, Fernand 24 
Breda, Spaanse herovering (I625) 2I, 22, I 27

Bredero, heer van Vianen 30

Briefboeken van VOC I47

Brieven van VD aan VOC-bestuur I3I-I32, 303-304, 333-342, 349-357

- eerste als gouverneur-generaal 343-348

- over nieuw bestand (I63I) I3I-I32

- over vrije Intra-Aziatische handel I3II32

Broekom, Jan van 275

Brouwer, Hendrick,

- dood (I643) I43

- gouverneur-generaal (I632) I28, I3I, I37, I49, I52, I54, I60, I89, 242, 247, $255,256,275,283,289,297,320-321$

- Heren Zeventien en I39-I44

- Hirado (Japan) 230, 238-240

— in dienst bij de WIC (I642) I43

- 'Memorie van Overgave' voor VD 2092I3, 2I5

- onkreukbaarheid I38-139

- sobere levensstijl I40

- strijd tegen misstanden I38 e.v.

- VD en 99-I00, I37-I38, I4I-I43, I55I56, 209-2I3

— vertrek uit Indië 276

Burg, Johan van der I22, I4I-I43, 275

- Brouwer en I4I-I43

Burke, Edmund I88, 28I

Busken Huet, Conrad 79

Caen, Antoni 2I8, 22I, 275, 276, 283

Caerden, adm. Paulus van der 69

Caertekoe, Minne Willemsz. 267

calvinisten 81, 83, 84, 93, 95, 138, 316

Cambodja 234, 236-237

Camps, opperkoopman 230

Carleton, Sir Dudley io6

Caron, Francois 235, 288

Carpentier, gouverneur generaal Pieter De (I623-'29) I03, I04, I07, IO9-IIO, II2, I3O, I5I, I54, 283

— eerste steen Kasteel van Batavia 295

- vloot I9I

carrière VD IOO-IO2, 3I9-32I

Cats, Jacob rog

Ceram 2I7-218

Ceylon 72, I80, 221, 256, 269, 307, 322

- campagnes VOC op I97, 26I-265

Chaudhuri, S. I73-I74, I88

Cheng Chih-lung 232
Chijs, J.A. van der 52, 79, 3I7

China, handel met 62, 7I, I9I, I94, 213, 225-238

- zeerovers 232

Chinese Zee I74, 225-238

Cochin 270

Coen, Jan Pieterszoon I7, 73, 75, 93, I38, I5I, I54, I73, 209, 283, 3I6, 3I9-320

- $350^{\text {ste }}$ geboortedag (I937) 80-8I, 3I6

- $400^{\text {ste }}$ geboortedag (I987) 8I-82

- affaire Sara Specx-Pieter Cortenhoeff (I629) Io8-Io9, 286, 320

- beeldvorming van 78-82

- beleg van Macao (I622) 230-23I

- carrière bij VOC 83

- Chinees-Japanse handel 230

- directeur-generaal 84-8

- dood van (20 sept. I629) IIO-II2, benoeming Vlack tot opvolger III-II2

— familieachtergrond 82-83

- gouverneur-generaal (I6I9-'23) 77, 89 e.v.; (I627-'29) I05-II2

- Heren Zeventien en 85 e.v., 9I-92, 96, I07

- intra-Aziatische handel en I03

- leerjaren 83

- lid Raad van Indië (I6I4) 84

- nootmuskaat- en foeliemonopolie I02

- ontmaskering VD en 98-IoI

— terugkeer naar de Republiek (I623) I03, 105

- VD en 98-Io2

- VD's carrière en 77

- verankeren VOC-macht in Azië en 84

— verovering Jakarta (mei I6I9) 89-90

— vierde VOC-vloot en 83-84

- vloot I90

- volkerenmoord Banda-Archipel 8I, 9I92, IO2, 2I7

- vrijgeven intra-Aziatische handel en I05, 107

Colenbrander, dr. H.T. 79-80, 82, I07

Colijn, dr. H. 8о, 8г, 3І6

Colombo (Portugees fort Ceylon) 26I, 263

Columbus, Christoffel 49

Constant, Carel 309

Contraremonstranten (versus remonstranten) $32,33,44,85,92-96$, 293, 319

convoyen en licenten 24-25

Cook, James289, 292 
Coolhaas, W.Ph. I5-I6, 38, 44, 77, 100, IO3, I2I, I49

Cooper, Jacob 258-260

Coromandelkust (India) 70, I73, I74, I9I, 254, 270

Cortenhoeff, Boudewijn 44

Couros, Martinus 309

Coxinga 24I-242

Crappe, Roland II3

Cromwell 205

Culemborg ( $\mathrm{r}^{\mathrm{e}}$ eeuw) 29 e.v.

- Tachtigjarige Oorlog en 29-30

- VD in I29

— vrijplaats 29-30, 43-44

Dam, P. van IIo, I69, I72, I97, 294, 308

Decay of Defeat (Van Veen, 200I) 254

Decima (Japan) 235, 237, 238, 242

Deense compagnie 284 ?

Demmer, Gerard 275

Dertigjarige Oorlog (I6I8-'48) 23

Descartes, René 37, I29

desolate boedelskamer, Amsterdam 44-45

Diaz, Bartolomeus 49

Diemen-Aelst, Maria van (echtgenote VD) I29, 276, 278, 297, 305, 320

- achtergrond II3

- diamanthandel 280-28I

- erfenis van VD en 308-309

- Grande Dame van Batavia 276, 323

- huwelijk met VD (jan. I630) II2-II3

- huwelijken na dood VD 309

- invloed I49

— testament 309

- vermogensverschil met echtgenoot I29

Dillen, van 50-5I

directeur-generaal, VD als (juli r633-dec. '35) I3O-I3I, I37-I 45

directeur-generaalschap (functie) 77

Discovery of India (Nehru) I88

Divesting a Myth (Blussé) 225

dividend VOC, eerste uitkering (I6II) 73

Divina Comedia (Dante, ca. I300) 47

Drake, adm. 20

Duis, zeeslag bij (I639) 26I

Dutch-Asiatic Shipping 190

East India Company (EIC) 2I, 86, I64, I69, I73, I88

- concurrentie met VOC I98, 20I-207, 22I
- forten 205

- geldgebrek 20I-202

- oprichting (I600) 53, 202

- organisatie en doelen 202 e.v.

- Raad van Defensie I03

- Van den Heuvel adviseur bij 286

— verdrag met VOC (I6I9) 90-9I, 94-95, IO6-IO7

- VOC en 88-89, I98, 20I-207, 221

eerste landvoogd Pieter Both, De

(Rietbergen) 6I

Eerste Oost-Indiëvaart (I595) 2I

EIC zie East India Company (EIC)

Elias, J.E. 94

Elizabeth I, koningin van Engeland 202

Engels, Jan 37, 39, 40, 99

Engelschen en Nederlanders in Shakespeare's tijd (Huizinga) 20I

Engelsen I7, 20, 63, 72, 85, 86, 88-89, IO3, I23, 2OI-2O7, 2II

- Bantam ro5

- handelsgeschillen met I03-I05

- kwestie-Moretti I04-I05

- kaapvaart op Portugese schepen 230

- kruidnagelhandel 2I5

- Zie ook East India Company

erfenis/erfgenamen van VD 307-3II

Estado da India (Portugal) I88, 253-27I, 322-323

- einde van 268-27I

Evertsen, adm. Johan 26I

faillissement van VD I5, I7, 42-43, 98-IOI, 256-257

familie-achtergrond van VD 3I-33, 368-376

Fernández de Quirós, Pedro 289

Firando zie Hirado

Florian, Isacq 39

Floris I, graaf van Culemborg 30-3I, 32

Floris II, , graaf van Culemborg 32, 44, IOO

foeliemonopolie 70, 176, 187, 216-217, 256, $317,319,322$

Formosa zie Taiwan

forten en handelsfactorijen VOC $55-56$, 62, 187

- Ambon 187

- Coromandelkust (India) I87

- Gamron (Perzië) I73, I95-I96

- Hirado (Japan) 230

- Pescadores-archipel 23I

- Taiwan 23I-232, 234 
- Zie ook Batavia

Fossa Eugeniana (Rijn-Maaskanaal) 22-23

Frankrijk/Fransen 63, 72

- opkomst van (vanaf I6I8) 23

Frederik Hendrik, prins 22, 37, I95, 26I

- VD bij I29

— verovering Maastricht (I632) I28

Frederik V, keurvorst van de Palts 95

Frentrop, P. 54, 55, 3I7

Fruin, R. 50

Gaastra, F.S. 50, 94, 254, 270

Galle (Portugees fort Ceylon) 26I, 269

— verovering door VOC (I640) 262-263

Gamron (Perzië) I73, I95-I96

Gardenijs, Arent 275, 278

— raad van Indië 275

Geertruidenberg, verovering door Republiek (I593) 20, 21

geld als motor van de handel 24-25

Gelria (fort, Coromandelkust) I87

genealogie van VD 368-376

generale missiven van de VOC in Indië I03, I29, I47

- door VD (I63I) II5, I22-I26, I29

Gerretson, F.C. 83

Gerritsz, Hessel 94

Geschiedenis van de VOC (Gaastra, I99I) 6I

Geschiedenis van Nederlands Indië (Stapel, I938) I5

Geuzen, keuze van de naam 30

Gijsels, Artus I05, 284, 285

Glamann, K. 3I7

Goa (Portugese vesting) 65, 83, I74, 206, 210, 226, 253, 322

- jaarlijkse blokkade door VOC (163645) I94, I97, 2IO-2II, 2I3, 257-26I, $262,264-265,283,322$

— verlies Malakka en 268-269

godsdienstvrijheid I9-20

Golconda-diamantmijn (India) 280

gomaristen zie contraremonstranten

goudmijnen, Taiwan 240-24I

gouverneur-generaal, VD als I44, I47-I62, 32I-32I

— invloed Heren Zeventien op I52 e.v.

- strategie I3I-I32

gouverneur-generaalschap (functie)I7, I5II52

Groot, Hugo de (Grotius)37, 71, 73, 74, 203
Grote Ambonse of Hoamaolese Oorlog (I65I) 222

Gruyter, Bartholomeus de I3I, 280, 308

- huwelijk met Maria Specx 3I0-3II

Gruyter, Pieter de I29, I56, 280, 304, 307, 308-309, 310

Gupta, Ashin das I88

Habsburgers 37, I27, 253

Haghen, adm. Steven van der 64-65

handelsfactorijen zie forten en handelsfactorijen VOC

Harn, Gerrit van I3I

Heijden, E.J.J. van der $3 \mathrm{I} 7$

Heijer, H.J. den 54, 55

Hein, adm. Piet 22, 83

- zilvervloot (I628) 228

Hendricksz., Annette 276

Heuvel, Anthonie van den Io8-Io9, I22I23

- aanval op VD II3-II5

- gouverneur van Ambon (I634) 285

- VD's afrekening met I42-I43, 284-286

Hidetada, shogun 227

Hideyoshi, Toyotomi 227

Hirado (Japan) I02, I75, I94, 230, 234, 235-236, 238-239

— afbraak handelsfactorij (I639) 235-236

Hitu (schiereiland van Ambon) 22I

Hoevenaer, Christina (moeder van VD) 3I33

Hoevenaer, Lambert 3I

Holland, handel met Spanje 20

Hoolck, Gijsbert van der 309

Hoorne, graaf van i9

Huizinga, Johan 3I5-3I6

Hulsebos, dominee 293

Iemitsu, shogun 227

Ieyasu, shogun 227, 230

Imhoff, van gouverneur-generaal 152

India 62, 72, I73, I74, I75-I76, I9I-I94, 307

- Coromandelkust (India) 70, I73, I74, I9I, 254, 270

- Mogolrijk 122, I87, I96

- Zie ook Suratte

indiensttreding van VOC (VD) 44-45

indigo $157, \mathrm{I} 66, \mathrm{I} 69$, I74

inpoldering van de Zijpe 57, 3I7

Intra-Aziatische zeehandel 62, 75, I64, I72 e.v., 225-244, 255-27I, 320-324 
- groei en kosten daarvan I74

- Heren Zeventien tegen openstelling van (I627) I07, 28I

- Indiase textielhandel I74

— katoenen stoffen 70-7I, I74

- Matelief over 70-72

- moessons en I73-I74

- vrije I05, I07, I25, I3I, I39-I40, 256, 303, 319, 32I, 323-324

- winstgevendheid I74 e.v.

Iquan $232-234,236$

Iseren, Willem van 32

Itinerario (Jan Huygen van Linschoten) 228

Jacobs, Pieter 38

Jafna (Portugees fort Ceylon) 26I

Jakarta 72, 77-78

- VOC-loge in 77-78

- Zie ook Batavia

Jakobsz, kpt. Leendert 97

Jamby (Sumatra) I9I

Jansz, Willem 289

Japan

- handel met 62, 72, I73, I74, I75-I76, I79-I8O, I9I, I94, 2II, 213, 225-238, $242,255,283$

- christenvervolging 227-228, 234

- katholieke missie 226-227

— zilver 226, 228, 238, 32I, 323

Japara (Java) 248

Java 70-72, 77-78, 85, 247-250

- dominicaanse missie 248

Jemmingen, slag bij (1568) 93

jeugdjaren van VD (I593-I608) 29-33

jezuïeten 226-227

Joao IV, koning van Portugal 269

Johor (vorstendom) 65, 66, 73

- VOC-beleg van Malakka en 266-267

Jonge, Jhr. Mr. J.K.J. de 79

Junius, dominee Robert 239-240

Justinus van Nassau 2I

Kaap Maria van Diemen (Nieuw-Zeeland) 29I

Kaapkolonie, stichting van (I652) 270

kaapvaart $6_{3}$

- op Indonesische schepen 257

- op Portugese schepen 230, 257

Kakiali, 'kapitan Hitu' 22I

Kamers van de VOC
- Amsterdam 39, 43, 44, 54, 62, 84, 97, II2, I28, I3I, I47, I52-I54, I64, I7I, I72, I89, 2I2, 260-26I

- Delft 54, 62, I43, I72, I89

- Enkhuizen 54, 62, I72, I89

- Hoorn 54, 62, I72, I89

- Rotterdam 54, 62, 63, 74, I72, I89

- Zeeland 54, 62, I52, I72, I89

Kandy, koninkrijk op Ceylon 262, 263

kaneelmonopolie, strijd om 26I-264, 269270

Kanton (Gwanzhou) 226

Karel I, koning van Engeland I07, 204205, 286

Karel V, keizer 57

katholieke missie 226-227, 248, 293

Keyser, Cornelis de I29

Kismis (Qesh), beleg van (I644) I96

Klucht van de Koe (Bredero, IGI2) 44

Knappert, dr. L. 80

kolonisatievraagstuk VOC 292-293

Koninklijk Paleis, Amsterdam39, 44-45

koopman, VD als (I609-'I6) 37-45

Cortenhoeff, Boudewijn I00, Io8

Cortenhoeff, Jacob Io8

Cortenhoeff, Pieter 108-109, I30, 286, 320

Koxinga 232

Kraan, A. van der I6

kruidnagelmonopolie 70, 124-I25, 210, 213, $215-222,256,317,322$

Kunst, Bartholomeus Havicksz II3

Lamey, strafexpedities VOC tegen ( $\mathrm{I}_{3} 2$, I636)240

Landwehr, J. 288

Leemhorst, burgemeester van Hoorn 80$8 \mathrm{I}$

Lemaire, Isaac 308

Levant Company (Engeland) 52-53, 202, 204

Liberer, Johan II3

Lijn, Cornelis van der I96, 24I, 275, 282283, 292, 303-305, 308

- Cambodja 237

- directeur-generaal 275, 278-280

- opvolging van VD (I645) 305-307

- gouverneur-generaal (I645-'50) 307308

— rijtocht (I648) 276

Linhares, graaf van 254

Linschoten, Jan Huygen van 5I, 96, 228

Lodensteijn, Jan Joosten van 229 
Lodesteyn, Gijsbert I43

Lodewijk XIII, koning van Frankrijk I27

Lodewijk van Nassau 93

Lowenstein, L. 56

Lucasz, Philips I7, 97, I37, I39, I75, I79, $218,264,275,276,278,283$

- directeur-generaal 275

Lusiëla (rebellenfort op Ceram) 2I7 e.v.

- verovering van $\left(\mathrm{I}_{3} 6 \mathrm{C}^{2}\right.$ 2I8-2I9

Maastricht, verovering door Republiek (I632) I28

Macao 226, 254, 257, 265

- aanval op (I622) 257

Maetsuycker, Johan 154, 278, 275, 280, $285,287,304,305-306$

- gouverneur-generaal (1653-'78) 270, 307

Makassar 70, 72, I04, I24, 22I-222

- kruidnagelmonopolie en 22I

— verovering van (I667) 222

Malabarkust 259-26I, 270

Malakka (Portugees fort) 53, 62, 63, 70-72, $83,160,180,225$

- beleg (I606) 65-68; (I640-'4I) I92I93, 265 e.v., 318

- verovering (I64I) 248-249, 264-27I, 322

Mandelslo, Johan Albrecht van 258, 260

Margareta van Parma I9

Marillac, maarschalk Louis de I27

Martapoera (Borneo) 247

Mataram (Javaans rijk) 247-250, 257

- Nederlandse gevangenen 249-250

— vrede met 307

Matelief de Jonge, adm. Cornelis 6I-76, 84, I67, I73, 217, 229, 318

- Ambon 68

- Bantam 68

- bewindhebber VOC/kamer Rotterdam 74

- Chinese Zee 229

- grafsteen 74-75, 76

- Johor 65

- Malakka-beleg (I606) 65-68, 266

- memories van 70-76

- Ternate 68-69

— verdere carrière 74

Mauritius (VOC-schip) I5, 44

- reis VD naar Indië op 96-97

Mauritius(eiland) 64, 65, I59-160
Maurits, prins 20, 37, 7I, 7I, 88, 89, 94, IOO, 317

- Twaalfjarig Bestand en 94-96

- versus Van Oldenbarnevelt 92-96

Medici, Maria de I27

Meeusen, Thonis (valse naam van VD) I5, 44, 89, 96-IoI

- ontmaskering als Van Diemen 97-IOI, IO2

Meilink-Roelofsz, M.A.P. 8I, I72

Ménagier de Paris, Le (I393) 487

Merchants and Revolution (Brenner) 205

Mestdagh, Pieter 282, 285, 305

- secretaris Raad van Indië 276

Meusz, Anthonisz (grootvader VD) 3 I

Molukken 62, 63, 68-7I, 73, 75, 83-85, I05, I9I, I94, I97,216, 2I7,

- kruidnagelmonopolie I24-I25 I24-I25

- VD op de (I638) 283

- verovering Portugese forten (1603-'06) $64-65$

monopolie zie foeliemonopolie;

kaneelmonopolie;

kruidnagelmonopolie;

nootmuskaatmonopolie

Moretti, Juan Maria IO4

Mortelet, Abbé 28I

Mozambique 83

Mun, Thomas 94

Münster, Vrede van (I648) 24

naamloze vennootschap 50,55 e.v., $28 \mathrm{I}$ 282, 3I6-3I7

- schandalen 28I-282

Nagasaki (Japan) 226

Nationale Synode (Emden, I57I) 93

Neck, Jacob Cornelisz. van 202, 228-229

- Macao 228-229

Nederland, VD terug in I27-I35

Negapatman (India) 270

Negombo (Portugees fort Ceylon) 26I, 263-264

- herovering Portugezen (8 nov. I640) 264

— verovering door VOC (mei I640) 263

Neira (Banda-Archipel) 84, 2I6

Newitt, M.D.D. 270-27I

Nieuw Hoorn (VOC-schip) 96

Nieuw-Guinea 289, 29I

Nieuw-Julfa (Perzië) I88-I89

Nieuw-Zeeland 29I

Noort, Olivier van 52 
nootmuskaatmonopolie 48, I76, I87, 2162I7, 256, 3I7, 319, 322

notenmonopolie 70

Nuyts, Pieter I22-I23, I24, 2II

- aanval op VD iız e.v.

- handel met Japan en 232

octrooi VOC (1602) 50, 53-57

— octrooiverlenging (I643) 293-295

Oldenbarnevelt, Johan van $37,53,57,88$, 3I7

- Amsterdamse kooplieden en 93-94

- doodvonnis 93-94

- versus Maurits 92-96

Olivares, graaf hertog $\mathrm{I} 28,253$

ontdekkingsreizen 49, 286, 288-292

- Abel Tasman 286, 2892-292, 324

ontmaskering VD 97-IOI

Oost-Indische Compagnie als zeemogendheid in Azië, De (MacLeod) 94

Oostzeehandel 20, 25, 83

oprichting Verenigde Oostindische Compagnie (VOC) 49 e.v., 3I7-3I8

- motieven 50-5I

Opstand zie Tachtigjarige Oorlog

opvolging van VD 305-307

Oranje (VOC-schip) 6I, 67

'Origin and Rythm of Dutch Agression angainst the Estado da India' (Bussé, Winius) 254

overlijden van VD (I9 april I645) 237, 24I, 305

Panhuysen, Luc 82

Parma, hertog van 20

Parra, gouverneur-generaal Petrus Albertus van der 288

Paulo, Antonie 250

Pauw, Adriaan I3I, I55

Pauw, Pieter 57

Pauw, Reinier 44, 55, 84, 89, 92-96, I00, I55, 3I7

- doodvonnis Van Oldenbarnevelt en 94

- Twaalfjarig Bestand en 94-96

Pekel, Jan 250

pennist in Batavia, VD als IOO-IO2

peperhandel 2I, 48, 5I, 52, 62, 70, I22, I30, I64, I66-I69, I73, I74, I97, 202, 226, 247, 253, 259-26I, 297-298, 322

Perzië I73, I74, I75-I76, I9I, I95-I96, 210 Pescadores-archipel 23I

Pessaert, Barend 284
Philips II, koning van Spanje I9-20, 5I, 53, 253

- verwerving Portugal (I580) 253

Philips III, koning van Spanje 289

Philips IV, koning van Spanje 2I, I28, 253-254

Picknick-incident (1636) I95

Plancius $5 \mathrm{I}$

Plassey, slag bij (1757) I88

poldervennootschappen 57

Pomp, Dirck Gerritsz ('Dirck China') 228, 229

Poppen, Jan 37

Portugal/Portugezen 53, II23, 232

- blokkade Goa en 257-26I

- Brazilië 270-27I

- handel China-Japan 225 e.v.

- Nagasaki 226, 227

- onafhankelijkheid van Spanje (I640) 23, 268, 269

- Spaanse overheersing (I580) 2I

- strijd tegen I7-I8, 62-68, 7I, 73, 83, IO3, I22, I96, 205, 2IO-2II, 2I3, 25327I, 284, 322-323

— v erdrag met Engeland (I635) 205

— verzwakking van I94

- wapenstilstand met (I644) I98

- zilver 228

Portugese Oost-Indische Compagnie (I629-'34) 253-254

Pozzo Toscanelli, Paolo dal 49

Prasat Thong, koning van Siam I95

privéhandel VOC-mensen in Indië II3 e.v., I22, I24, I39-I40, 278-28I, 323-324

Protestantse Unie 95

protestantse zending 293

Pruys, Dirk I53

Putmans, gouverneur van Taiwan 233

Quaeckernaeck, Jacob Jansz. 229

Quelang (Taiwan) 24I

Quitsicq 233

Raad van Defensie (VD lid van, I624) I03

Raad van Indië 84-85, 90, IO3, III, II4, II5, I4I, I43, I49, I5I-I52, I54, 2I8, 275-277, 279, 282, 287, 305, 307

- VD in 103

Raad van Justitie I08, I39, 279, 285, 287

Raad van State I9, 80

Raben, Remco 3I5

Raemburch, Johan III 
Ravenswaaij, Diederick van 308

Ravenswaeij, Johannes van 32

Reael, Laurens 79, 84-85, 92-93, I07, I30, I54, I55, 283

- Brouwer en I40-I4I

- gouverneur-generaal (I6I6-'I8) 79, 8485, 92-93, I5I

- Heren Zeventien en 92

regeerstijl VD 282-284

regering van VD I7-I8, I47, 275-299, 323324

— beleid I47, 283

- effectiviteit 283

- invloed op VOC 286-295

— kerkordening (I643) 288

- kolonisatievraagstuk 286, 292-293

- leven aan de top 275 e.v.

- luxe 276-278

- macht en geld 323-324

- onenigheid in de top 278

- ontdekkingsreizen 286, 288-292, 324

- Statuten van Batavia (I642) 286-288, 324

- vrouwen en 276

— werkwijze 282-284

Reiniersz, Carel I54, 262, 307

Remonstranten versus contraremonstranten $32,33,85,92-96$, I4O-I4I

rendez-vous I7, 7I, 73, 75, 86-92

- Matelief over noodzaak van 7I

— vestiging van 86-92

- Zie ook Batavia

retourschepen I90

retourvloot I9O; (mrt. I63I) II5, I22-I26; (I64I) 358-360

- generale missive door VD II5, I22-I26

Reynst, Gerrit, gouverneur-generaal (I6I4'I6) $84-85$, I5I, I54

Ribeiro, Joao 262

Richelieu, kard. de 23, I27-I28

Riebeeck, Jan van (neef van VD) 3I, I3I, 270

Rietbergen, P.J.A.N. 73

rijkdom van de Republiek 23

rise of commercial empires, The (Ormond, 2003) 25

Rotterdamse Historische Musea 74-75

Sao Thome (India) 254, 257

Schaepman, H.J.A.M. 79 scheepvaarten naar Oost-Indië voor VOCoprichting

— eerste (I595-'97) 5I, 53

— tweede (I598-'99) 5I-52

schooljaren van VD 32

Schouten, Justus I95, 275-276, 298

- proces tegen (I644) 298

- raad van Indië 275-276

schulden van VD, afwikkeling van II2, I29

Schumpeter, J.A. 53

Shekigahara, slag bij (I600) 227

Shimabara-opstand ( $\mathrm{I}_{37}$-' $^{\prime} 8$ 8) 227

Siam (Thailand) I95, 229, 234, 236

Singha, radja van Kindy 262-263

Slauerhoff, J.J. Io9

slavenhandel 26I

Smeekschrift der edelen (I566) 30

Smith, Adam 28I

Smithwick, Thomas 204

Sock, Martinus 23I

Sousa Coutinho, Manuel de 267

'South India and the Chinese Seas' (Vink) 255

Spaanschen Brabander (Bredero, I6I7) 4344

Spanje/Spanjaarden 53, 68-69, 73, I03, I23, 232; zie ook Frederik Hendrik; Maurits; Philips II; Portugal/ Portugezen; Tachtigjarige Oorlog; Twaalfjarig Bestand

Specerij-eilanden zie Banda-Archipel; Molukken

specerijenhandel 2I, 47-60, 6I, 70-7I; zie ook foeliemonopolie; kaneelmonopolie; kruidnagelmonoplie; nootmuskaatmonopolie

speculaties 38-40

Specx, Jacques 83, IO2, IO4, IO7, IIO-II5, I22-I2 6, I28, I30, I38, I60, I75, 228 $229,242,283,295,320$

- gouverneur-generaal (I629-) III-II5, I5I-I52

- administratieve zaken en I2I-I22

- Hirado (Japan) 230

- VD en III-II5

Specx, Sara Io8-109, 286, 320

Speelman, gouverneur-generaal Cornelis (I68I-'84) 307

Speult, gouverneur Herman van (Ambon) 86

Spilbergen, Joris van 87

Spinola, gen. Ambrosio de 2I, I27 
Spinoza, Baruch 37

Spruyt, R.J. 8I-82

St. Paul (eiland) I33, I24

Stapel, F.W. I5, 38

Statuten van Batavia zie Bataviase Statuten

Steensgaard, N. 52, 54, 55, 203

Stevin, Simon 88, 89

Staten-Generaal 53, 55, 56, 7I-74, 83, 96, 106, I07, I28, I32, I50, I91, 269, 293294, 309, 318, 319

Staten van Holland 53, 57, 96, 294

Straat Sunda 7I

Straat van Malakka, afsluiting (1636) I94, 257

Sumatra I9I

Suratte (India) I73, I74, I76, I9I-I94, I96, 210, 222, 283

Sweers, Catharina 277

Sweers, Jacob 277

Sweers, Salomon I3I, I58, 277, 278-280, 303-305, 308, 3II

synode van Delft 33

synode van Dordrecht 293

Tachtigjarige Oorlog (I568-I648) I9-27, 253 e.v.

- handel en 23-25, 37

Taiwan (Formosa) I73, I74, I80, I87, I94, 23I, 283, 32I

- goudmijnen 240-24I

- kolonisatie 238-242

- verlies van 24I-242, 307

- Zeelandia (VOC-fort) 239

Tasman, Abel 286, 289-292, 324

Tasmanië zie Van Diemensland

Tavernier, Jean Baptiste 276

Telles, Antonio, onderkoning in Goa 248

termijnhandel 38-40

Ternate (fort) 68-69

Terra Dimensis zie Van Diemensland testament van VD (I632) I29, 308, 36I; (I645) 365-367

Thailand zie Siam

Tidore (Molukken) 64-65

Tokugawa-clan 227

Tricomale (Portugees fort Ceylon) 26I

— overgave aan Singalezen 263

— verovering door VOC (I639) [Trincomale] 262

Twaalfjarig Bestand (I609-'2I) 2I, 25, 83$84,93-96,230,318-319$
Vaglienti, Piero 40

Valentijn, F. 77, 84, Iо०, IIо, I48, 280

Valle, Pietro della 253

Van Diemen Box 309, 310

Van Diemensland 290, 29I

Venlo, verovering door Republiek (1632) 22

vennootschap zie naamloze vennootschap Verenigde Oostindische Compagnie (VOC)

- bestuurlijk 53-54, 62, I47-I62

- businessplan 6I-63

- crisis en strategiewijziging (I609-'I9) 6I-76, 3I8-3I9

- doelstellingen 5I-52

— faillissement (I799) I54

- inschrijving op het kapitaal (I602) 54, 62

- octrooiverlenging (I643) 293-295

- ondernemingsvorm 54-57

- oprichting (I602) 49 e.v., 3I7-3I8

- organisatie in Azië 62, 63

- rechten investeerders 54-55, 56-57

- staat in de staat 53

- staatssteun 53, 73

Verhoeff, adm. Pieter Willemsz 83-84 vestiging van het Nederlandsch gezag over de banda-eilanden, De (Vander Chijs, I866) 79

Victoria (fort op Ambon) 220

Vieira de Figueiredo, Francisco 222

Vierde Engelse Oorlog (I78I) I8I, I98

'Viering 400 jaar VOC' 3I5

Vietnam 234, 236-238

- VD en 237-238

Vink, M. 322

Virginia Company, faillissement (I624) IO5

Vlack, Pieter Io8, III-II2, I22-I24, I37, 276

— aanval op VD (I630) II3-II4

- directeur-generaal 276

Vliet, Jeremias van I95, 277

Vliet, Simon van 288

vloot VOC onder VD I87-200

- kosten vlootacties 197

vloten van de VOC

- eerste zie Haghen, adm. Steven van der

- tweede zie Matelief de Jonge, adm. Cornelis

- derde zie Caerden, adm. Paulus van der

- vierde (I607-'II) 83-84 
VOC as Sorcerer's Apprentice (Blussé) 225

VOC-mentaliteit (begrip) I6, 3I6

Vondel, Joost van den 44

Wagenaar, J. I53

Warnsinck, J.C.M. 5 I

Warwijck, Wybrand van 229

Wealth of Nations (Smith) 28I-282

Wenen, beleg door Turken (I683) I87

Westerwold, Adam van 262

West-Indische Compagnie (WIC) 96, I53I54, I75, 26I, 265, 294

- Noord-Brazilië 26I

- El Mina (West-Afrika) 26I

- oprichting 96

'Wetenschappelijke voorbereiding van de eerste scheepvaart naar Oost-Indië, De' 5 I

Wilde, Oscar 158

Willem van Oranje I9

Wingurla, vorst rijk naast Goa 269

Winius, G.D. 322

winstgevendheid VOC onder VD I63-I85, 256, 307

- intra-Aziatische handel I72 e.v.

- retour van I64I I68-I7I
— opbouw winst I72-I8I

zedenzaak Sara Specx-Pieter Cortenhoeff (I629) I08-109, 286, 320

Zeeland, handel met Spanje 20

Zeelandia (fort, Taiwan) I87, 23I

zeereizen VD naar Indië

— eerste 96-97

- tweede 134

zorg voor bemanning schepen 134

zeeroverij 42, 49, 232-234

- Chinese Zee 232-234

Zheng He I89

ziekbed VD 303-305

zijdehandel I66, I69, I88-189, 225-226

Zijpe, inpoldering 57, 3I7

Zilver20, 22, 23, 42, I04, I69, I73 e.v., I80, I9I, 2II, 225-226, 228, 234, 238, 254, 289, 32I, 323

- intra-Aziatische handel en 238

Zilvervloot ( 1628 ) 22, 228

Zuidelijke Nederlanden 20, 22-24, I28, 32I

Zuidland (Australië) 96, 97, 289, 29I 


\section{Curriculum Vitae}

Menno Witteveen werd geboren op 26 augustus I954 te Driebergen. In I973 haalde hij het Gymnasium Bèta-diploma aan het Nederlands Lyceum in Den Haag. Vervolgens studeerde hij geschiedenis aan de Universiteit Leiden, waar hij in I98I afstudeerde op de ballingschap van de Nederlands-Indische regering tijdens de Tweede Wereldoorlog.

Hij koos na zijn studie geschiedenis voor een carrière in het bankwezen. In I989 werd hij medeoprichter van Koopman \& Witteveen NV. Politiek actief voor D66 sinds zijn studententijd is hij thans penningmeester van D66.

In 2002 schreef hij over de oprichting van de VOC in 1602 het boek Een Onderneming van Landsbelang.

Menno Witteveen is getrouwd en heeft drie dochters. 